\title{
Development and analysis of lithologically controlled regional curves of hydraulic geometry for Appalachian mountain streams, Ridge and Valley Physiographic Province, Pennsylvania
}

\author{
Matthew S. Finkenbinder \\ West Virginia University
}

Follow this and additional works at: https://researchrepository.wvu.edu/etd

\section{Recommended Citation}

Finkenbinder, Matthew S., "Development and analysis of lithologically controlled regional curves of hydraulic geometry for Appalachian mountain streams, Ridge and Valley Physiographic Province, Pennsylvania" (2008). Graduate Theses, Dissertations, and Problem Reports. 4371.

https://researchrepository.wvu.edu/etd/4371

This Thesis is protected by copyright and/or related rights. It has been brought to you by the The Research Repository @ WVU with permission from the rights-holder(s). You are free to use this Thesis in any way that is permitted by the copyright and related rights legislation that applies to your use. For other uses you must obtain permission from the rights-holder(s) directly, unless additional rights are indicated by a Creative Commons license in the record and/ or on the work itself. This Thesis has been accepted for inclusion in WVU Graduate Theses, Dissertations, and Problem Reports collection by an authorized administrator of The Research Repository @ WVU. For more information, please contact researchrepository@mail.wvu.edu. 
Development and Analysis of Lithologically Controlled Regional Curves of Hydraulic Geometry for Appalachian Mountain Streams, Ridge and Valley Physiographic Province, Pennsylvania

Matthew S. Finkenbinder

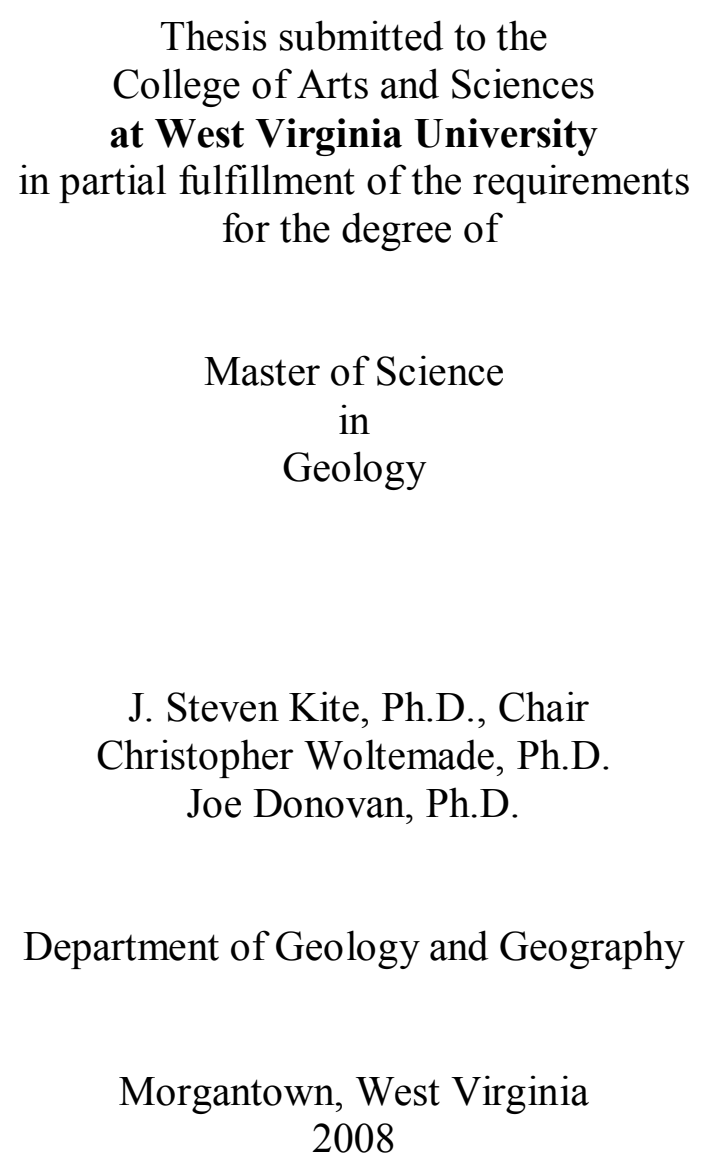

Keywords: fluvial geomorphology, regional curves of hydraulic geometry, stream restoration 


\begin{abstract}
$\underline{\text { Abstract }}$
Development and Analysis of Lithologically Controlled Regional Curves of Hydraulic Geometry for Appalachian Mountain Streams, Ridge and Valley Physiographic Province, Pennsylvania

Matthew S. Finkenbinder

Regional curves of hydraulic geometry are frequently constructed for physiographic provinces, regions that have similar geologic structure, climate, and geomorphic history. As a result, the factors controlling channel form are more alike than would be the case for streams across widespread geographic regions. However, geology can vary significantly within a physiographic province. The purpose of this study, therefore, was to determine if regional curves would be more precise predictors of hydraulic geometry if developed for geologically similar streams within a physiographic province. A total of 34 reaches on six ungauged mountain streams in the Ridge and Valley Physiographic Province of Pennsylvania were used to develop lithologically controlled regional curves for drainage area versus bankfull cross-sectional area, bankfull width, and bankfull mean depth.

The slope, $\mathrm{y}$-intercept, and $\mathrm{R}^{2}$ value of the non-carbonate lithologically controlled regional curves were compared to three distinct regional curves of varying watershed size and physiography. These comparisons reveal that lithologically controlled regional curves for bankfull cross-sectional area are consistently statistically different than the other three curves. The factors that may influence differences in the regional curves include bedrock geology, geologic structure, physiography, channel gradient, watershed size, riparian vegetation, and land use. Comparison of $\mathrm{R}^{2}$ values shows regional curves derived from a larger sample size and including a majority of larger watersheds $(>75$ $\mathrm{km}^{2}$ ) produce less variance. An additional regional curve was derived by combing hydraulic geometry data from the lithologically controlled watersheds and non-carbonate watersheds initially investigated by Chaplin (2005). Higher $\mathrm{R}^{2}$ values indicate the combined curves developed with a larger sample size and dominated by larger watersheds produce less variance compared to the lithologically controlled curves. Future regional curve investigators should include ungauged watersheds, increase sample size, and more fully constrain the variables controlling natural channel dimensions to assess if more precise hydraulic geometry relationships can be developed within physiographic provinces.
\end{abstract}




\section{$\underline{\text { Acknowledgements }}$}

I would foremost like to express my gratitude to Dr. J. Steven Kite and Dr. Christopher J. Woltemade, for their guidance, insight, and encouragement throughout the duration of this project. I would also like to thank Dr. Joseph Donovan, who served on my committee and provided assistance related to statistics and consistently encouraged an easy-going perspective during stressful times.

I am additionally indebted to Jeffrey Chaplin and Robert Jarrett of the United States Geological Survey for their technical assistance and comments related to data analysis and the subsequent research conclusions. I am also indebted to the Geological Society of America, for providing financial support in the way of a graduate student research grant, which helped offset the cost of field data collection.

I would also like to thank all of my friends and colleagues in the Department of Geology and Geography. Foremost, I would like to thank Crissy Vinciguerra, my field assistant and best friend, whose support and encouragement was especially helpful in the completion of this thesis. I also thank Yancey Strickler and Stephanie Annick for their help with lodging during a month of field work in Pennsylvania. I would also like to thank Daniel Harris and Jane Thies for their friendship; you have all made my time in Morgantown a pleasure.

I would lastly like to express my gratitude for the love and support provided by my family. I am indebted to my brother, David, for his friendship and encouragement. Most importantly, I extend my deepest gratitude to my parents, for their unending support, instilling in me their work ethic, and belief that education is the key to success in life. 
I dedicate this thesis to my father, Dewaine, who provoked my interest in the outdoors and streams at a young age, through yearly camping trips along Laurel Run, in the Ridge and Valley Physiographic Province of Perry County, Pennsylvania. 


\section{$\underline{\text { Table of Contents }}$}

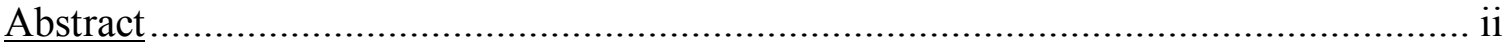

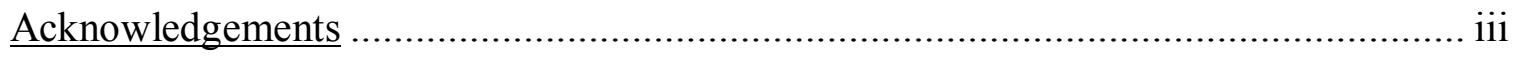

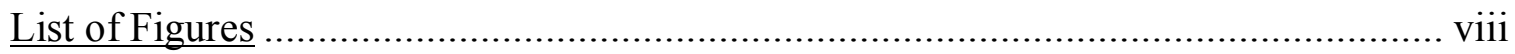

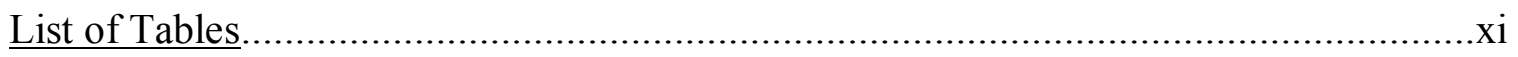

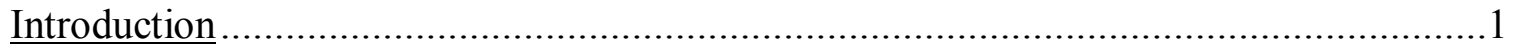

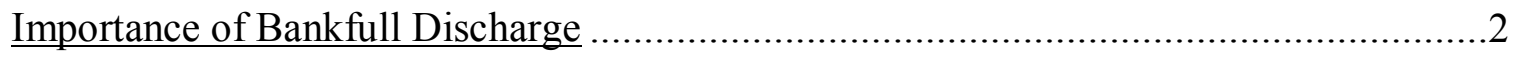

Controls on Hydraulic Geometry ..................................................................

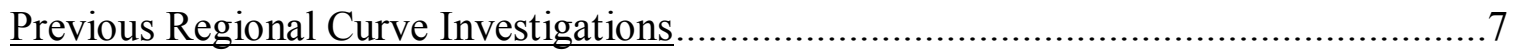

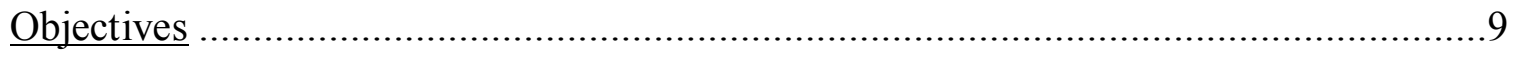

Study Area

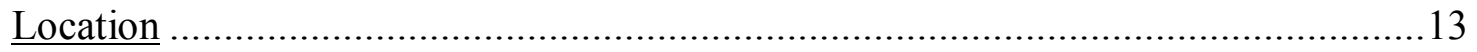

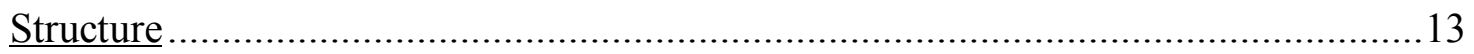

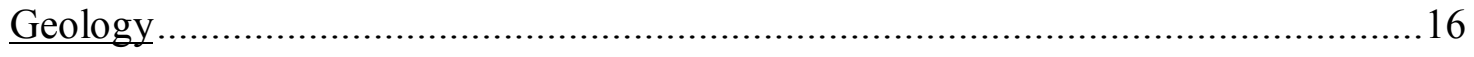

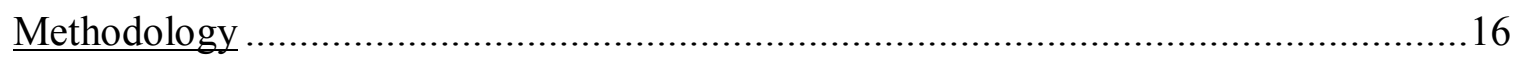

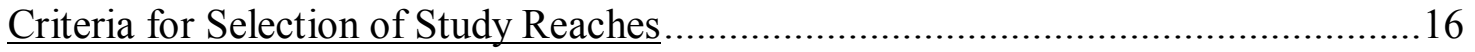

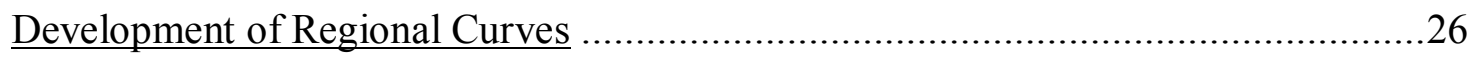

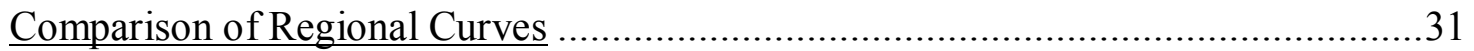

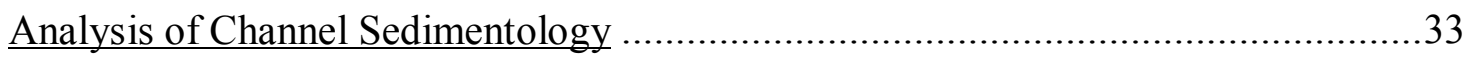

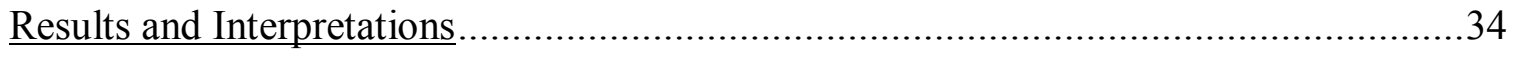

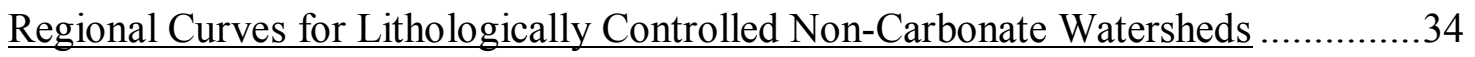

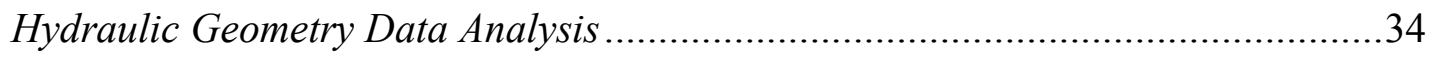

Regional Curve Development .................................................................4 
Comparison of Regional Curves.

Interpretations

$\underline{\text { Regional Curves for Non-carbonate Watersheds Draining Areas }<75 \mathrm{~km}^{2}}$

Hydraulic Geometry Data Analysis .........................................................5

Regional Curve Development ......................................................................61

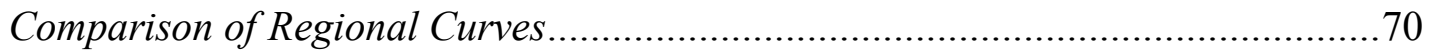

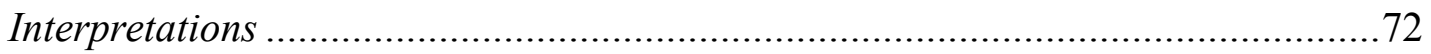

$\underline{\text { Regional Curves for Non-carbonate Watersheds in the Ridge and Valley Physiographic }}$

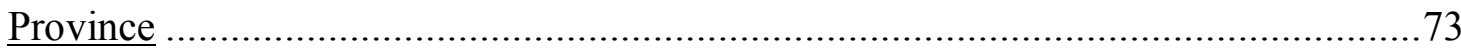

Hydraulic Geometry Data Analysis ....................................................... 73

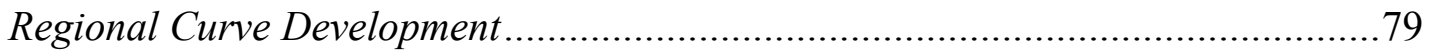

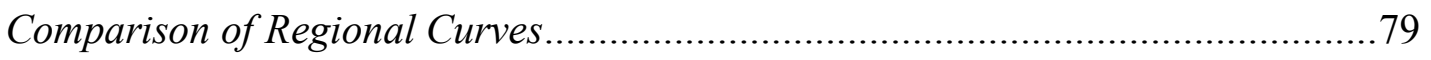

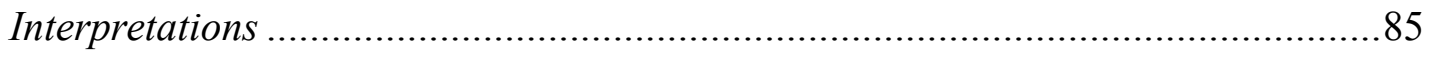

Combined Regional Curves for Non-Carbonate Watersheds ................................87

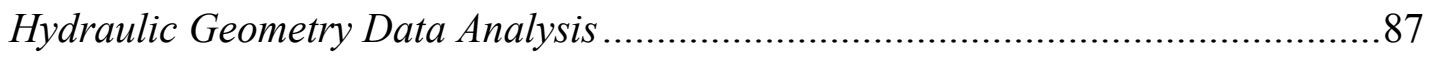

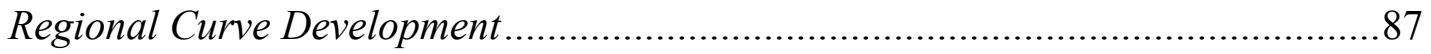

Comparison of Regional Curves............................................................... 96

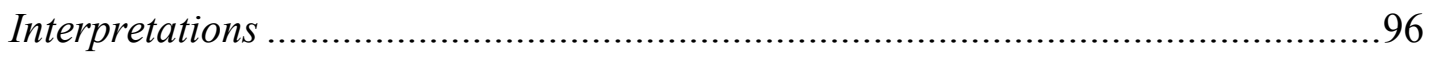

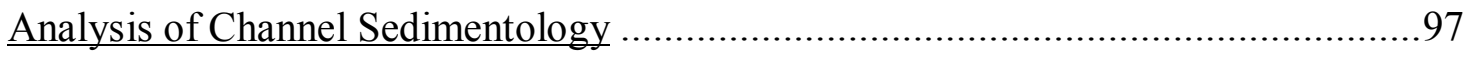

Results of Channel Bedload Sediment Investigation .........................................97

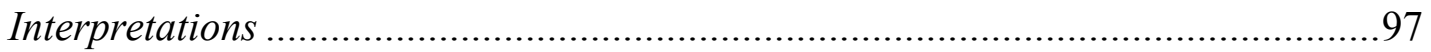

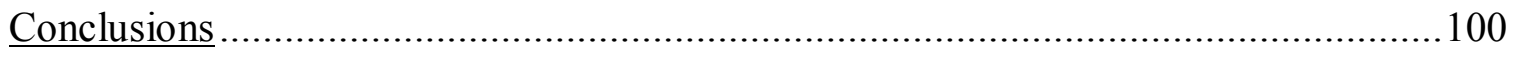


Limitations and Constraints on the Applications of Lithologically Controlled Regional

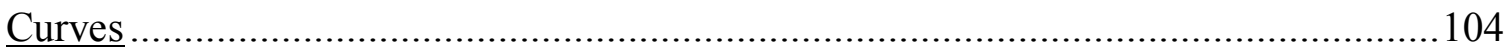

References

Appendix 1. Characteristics of the measured riffles and channel survey data for

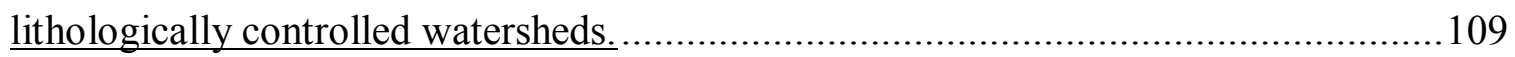

Appendix 2. Riffle bedload sediment characteristics in lithologically controlled

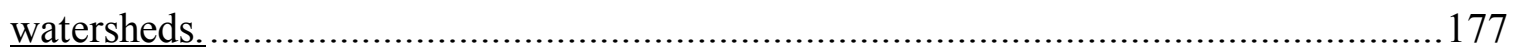

Appendix 3. Plots relating the texture of the $\mathrm{D}_{\underline{50}}$ and $\mathrm{D}_{\underline{84}}$ versus drainage area for each

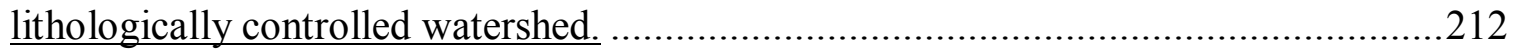




\section{$\underline{\text { List of Figures }}$}

Figure 1. Physiography and major rivers of Pennsylvania and adjacent areas...............14

Figure 2. Study area map showing physiographic provinces, counties, and hydrography.

Figure 3. Bedrock geology map of South Branch Little Aughwick Creek Watershed. ...18

Figure 4. Bedrock geology map of Laurel Run Watershed. 19

Figure 5. Bedrock geology map of West Licking Creek Watershed............................20

Figure 6. Bedrock geology map of Horse Valley Run. ...........................................21

Figure 7. Bedrock geology map of Sherman Creek..........................................22

Figure 8. Bedrock geology map of Conodoguinet Creek Watershed...........................23

Figure 9. Topographic map showing measured reaches along South Branch Little

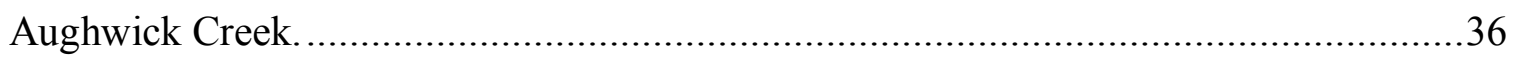

Figure 10. Topographic map showing measured reaches along Laurel Run..................37

Figure 11. Topographic map showing measured reaches along West Licking Creek.....38

Figure 12. Topographic map showing measured reaches along Horse Valley Run.........39

Figure 13. Topographic map showing measured reaches along Sherman Creek............40

Figure 14. Topographic map showing measured reaches along Conodoguinet Creek. ...41

Figure 15. Regression residuals plot for bankfull cross-sectional area for lithologically

controlled regional curves for non-carbonate watersheds.

Figure 16. Regression residuals plot for bankfull width for lithologically controlled

regional curves for non-carbonate watersheds.

Figure 17. Regression residuals plot for bankfull mean depth for lithologically controlled regional curves for non-carbonate watersheds. 
Figure 18. Lithologically controlled regional curve for non-carbonate watersheds for bankfull cross-sectional area.

Figure 19. Lithologically controlled regional curve for non-carbonate watersheds for bankfull width. .49

Figure 20. Lithologically controlled regional curve for non-carbonate watersheds for bankfull mean depth. .50

Figure 21. Regression residuals plot for bankfull cross-sectional area for regional curves for $<75 \mathrm{~km} 2$ non-carbonate watersheds. 63

Figure 22. Regression residuals plot for bankfull width for regional curves for $<75 \mathrm{~km} 2$ non-carbonate watersheds.

Figure 23. Regression residuals plot for bankfull mean depth for regional curves for $<75$ $\mathrm{km} 2$ non-carbonate watersheds.

Figure 24. Regional curve for $<75 \mathrm{~km} 2$ non-carbonate watersheds for bankfull crosssectional area.

Figure 25. Regional curve for $<75 \mathrm{~km} 2$ non-carbonate watersheds for bankfull width..67 Figure 26. Regional curve for $<75 \mathrm{~km} 2$ non-carbonate watersheds for bankfull mean depth. .68

Figure 27. Regression residuals plot for bankfull cross-sectional area for regional curves for non-carbonate watersheds for the Ridge and Valley Physiographic Province. .76

Figure 28. Regression residuals plot for bankfull width for regional curves for noncarbonate watersheds for the Ridge and Valley Physiographic Province. .77 Figure 29. Regression residuals plot for bankfull mean depth for regional curves for noncarbonate watersheds for the Ridge and Valley Physiographic Province. .78 
Figure 30. Regional curve for non-carbonate watersheds for the Ridge and Valley Physiographic Province for bankfull cross-sectional area.

Figure 31. Regional curve for non-carbonate watersheds for the Ridge and Valley Physiographic Province for bankfull width. .81

Figure 32. Regional curve for non-carbonate watersheds for the Ridge and Valley Physiographic Province for bankfull mean depth. 82

Figure 33. Regression residuals plot for bankfull cross-sectional area for combined regional curves for non-carbonate watersheds.

Figure 34. Regression residuals plot for bankfull width for combined regional curves for non-carbonate watersheds.

Figure 35. Regression residuals plot for bankfull mean depth for combined regional curves for non-carbonate watersheds.

Figure 36. Combined regional curve for non-carbonate watersheds for bankfull crosssectional area.

Figure 37. Combined regional curve for non-carbonate watersheds for bankfull width..93 Figure 38. Combined regional curve for non-carbonate watersheds for bankfull mean depth.

Figure 39. Texture of D50 and D84 of channel bedload sediments versus drainage area for all lithologically controlled watersheds. 


\section{$\underline{\text { List of Tables }}$}

Table 1. Characteristics of sites used to develop Chaplin's (2005) regional curves for non-carbonate watersheds.

Table 2. Summary of quantitative attributes for Chaplin's (2005) regional curves for non-carbonate watersheds.

Table 3. Bedrock geology units in the study area. 17

Table 4. Characteristics of sites used to develop lithologically controlled regional curves for non-carbonate watersheds .35

Table 5. Kolmogorov-Smirnov normality test statistics for lithologically controlled regional curves for non-carbonate watersheds.

Table 6. Summary of quantitative attributes for lithologically controlled regional curves

for non-carbonate watersheds.

Table 7. Statistical results from analysis of covariance comparison between lithologically controlled curves and Chaplin's (2005) curves. .51

Table 8. Central tendency statistics for watershed drainage area of regional curves.......53

Table 9. Central tendency statistics for percent watershed urbanized of regional curves.

Table 10. Central tendency statistics for percent watershed forested of regional curves..

Table 11. Characteristics of sites used to develop regional curves for non-carbonate

watersheds $<75 \mathrm{~km} 2$.

Table 12. Kolmogorov-Smirnov normality test statistics for regional curves for streams in non-carbonate watersheds $<75 \mathrm{~km} 2$.. 
Table 13. Summary of quantitative attributes for regional curves for non-carbonate watersheds $<75 \mathrm{~km} 2$.

Table 14. Statistical results from analysis of covariance comparison between lithologically controlled curves and regional curves for non-carbonate watersheds $<75$

$\mathrm{km} 2$.

Table 15. Characteristics of sites used to develop regional curves for non-carbonate watersheds for the Ridge and Valley Physiographic Province

Table 16. Kolmogorov-Smirnov normality test statistics for regional curves for noncarbonate watersheds for the Ridge and Valley Physiographic Province. .75

Table 17. Summary of quantitative attributes for regional curves for non-carbonate watersheds for the Ridge and Valley Physiographic Province. .83

Table 18. Statistical results from analysis of covariance comparison between lithologically controlled curves and regional curves for non-carbonate watersheds for the Ridge and Valley Physiographic Province.

Table 19. Kolmogorov-Smirnov normality test statistics for combined regional curves for non-carbonate watersheds.

Table 20. Summary of quantitative attributes for combined regional curves for noncarbonate watersheds.

Table 21. Summary of key results from slope and y-intercept comparisons between regional curves.. 


\section{Introduction}

Continual expansion of the human population and commercial and residential development of the natural world has led to impairment and modification of many stream channels (Swift 1984). Several anthropogenic activities result in the degradation of stream channels, including channelization for drainage and agricultural purposes, urbanization, mining, and flow regulation through dam placement (Wohl 2000). These anthropogenic activities may result in changes in the water and sediment discharge or direct changes to the morphology and geometry of channels (Wohl 2000). Direct modifications of stream channels or changes in the hydrologic or sedimentologic regime often result in instability. As anthropogenically induced instability ensues, excessive aggradation or degradation often becomes apparent, disrupting the equilibrium condition to which natural channels tend (Leopold 1994).

Stream restoration, or natural channel design, is a relatively new field that has been a useful tool to remediate impaired streams (Skidmore et al. 2001). A common natural channel design approach involves using empirical data to develop regional curves to predict the dimensions of stable design reaches (Wharton et al, 1989). A regional curve is "an ordinary least-squares regression expressed as a power function that relates drainage area to selected bankfull response variables" (Chaplin 2005). The most common bankfull response variables for which regional curves are developed include discharge, cross-sectional area, width, and depth. Accordingly, bankfull response variables can be estimated from regional curves, if the drainage area for a specified location is known. The development of such relations often involves large data sets and the derived equations display average flow or channel conditions (Skidmore et al. 2001). 
Regional curves are frequently constructed for physiographic provinces, or regions that have similar geologic structure, climate, and geomorphic history (Dunne and Leopold 1978). As a result of this physiographic restriction, the factors controlling channel form are more alike than would be the case for streams across more widespread geographic regions. However, geology can vary significantly within a given physiographic province (Sevon 2000) and this variation may be a major cause of outliers that deviate from regional curves. Regional curves have also been historically created only from stations with U.S. Geological Survey stream-flow gauges (Chaplin 2005) (Keaton et al 2005) (Dunne and Leopold 1978). However, solely relying on watersheds with stream-flow gauges limits the ability of the derived regional curve to accurately portray the spectrum of hydraulic geometry conditions within a physiographic province. The majority of stream-flow gauges have been placed on lowland rivers with drainage areas larger than most small low-order mountain streams. Therefore, it was the goal of this study to investigate whether regional curves of hydraulic geometry within the Ridge and Valley Physiographic Province of Pennsylvania should be developed for lithologically similar, ungauged mountain streams. A working hypothesis for this project was that mountain stream channels containing abundant, cobble to boulder sized alluvium will be wider and shallower than predicted by regional curves developed for whole physiographic provinces.

\section{$\underline{\text { Importance of Bankfull Discharge }}$}

The bankfull discharge is considered the most important flow event in controlling and maintaining channel form. Wolman and Miller (1960) advanced this idea in their investigation of the frequency and magnitude of flow events in relation to channel 
maintenance and sediment transport. Wolman and Miller (1960) recognized that channel form is influenced by a natural range of flow conditions. They noted that the channel and floodplain of any stream are principally constructed by the processes of lateral accretion, or point bar development (Wolman and Miller 1960). Through analysis of the transport of suspended sediment by frequent and infrequent flows, Wolman and Miller (1960) found that the overwhelming majority of total sediment removal from watersheds resulted from moderate-magnitude, moderate-frequency flows. They suggested that although catastrophic flow events have the ability to transport large quantities of sediment, they occur so infrequently that their overall importance is minimal. In humid regions, the bankfull discharge has a recurrence interval of one to two years (Wolman and Miller 1960). The bankfull discharge is commonly referred to as the effective or dominant discharge, due to its importance in controlling and maintaining channel form (Knighton 1998).

Williams (1978) investigated the recurrence interval of the bankfull discharge using recurrence frequency data from several rivers in the United States. Recurrence data were derived from annual maximum series of instantaneous discharges occurring at the elevation of the active floodplain. A frequency distribution of the bankfull discharge was constructed and yielded a mean recurrence of approximately 1.5 years, although a broad range of recurrence intervals exists, spanning from 1.01 to 32 years (Williams 1978). Only approximately a third of sampled rivers have a bankfull discharge recurrence interval near 1.5 years, so Williams (1978) concluded that the mean recurrence of 1.5 years for bankfull discharge was not reliable. Variance in the recurrence interval of the bankfull discharge was attributed to channel gradient (Williams 1978); analysis showed 
as channel gradient increased, the recurrence interval of bankfull discharge also increased (Williams 1978).

\section{Controls on Hydraulic Geometry}

The hydraulic geometry of any natural river channel is adjusted to accommodate the discharge and sediment load supplied to it (Leopold 1994). The independent variables that indirectly control hydraulic geometry include geology, climate, soils, vegetation, and basin physiography (Knighton 1998). In unglaciated terrains, channel sedimentology is controlled by the bedrock geology that underlies the drainage basin (Knighton 1998). The composition of the channel bed and banks is primarily influenced by channel sedimentology and riparian vegetation (Knighton 1998). Over time, stream channels adjust to their current climatic regime and a state of stability or equilibrium is commonly achieved. Equilibrium is attained when the magnitude of erosive forces caused by flow and the magnitude of the resisting forces of the bed and banks are equal, and neither aggradation nor degradation of the channel occurs.

The composition of bed and bank materials exerts an influence on the strength of the channel boundary, and as a result influences channel form. The strength of the channel banks is largely dependent on the cohesiveness of sediments, which is influenced by basin geology. In his investigation of alluvial channels with minimal bedload in the Great Plains, Schumm (1960) compared channel dimensions to the percentage of silt and clay $(M)$ in the channel banks for several rivers. He concluded that channel banks with a high percentage of silt and clay produce deep and narrow channels (Schumm 1960).

In an effort to distinguish between the primary means of sediment transport, Schumm (1963) subdivided natural channels into three categories, using the percentage 
silt and clay $(M)$ in the channel and the percent of bedload out of the total load. Arbitrary threshold percentages were used to distinguish three channel types: bedload, mixed load, and suspended load (Schumm 1963). Schumm characterized stable bedload channels as having width-depth ratios greater than 25 and relatively steep gradients (Schumm 1963). Stable mixed load channels were characterized as having width-depth ratios greater than 7 and less than 25 and moderate gradients (Schumm 1963). Stable suspended load channels have gentle gradients and a width-depth ratio less than 7 (Schumm 1963).

Subsequently, Osterkamp (1980) distinguished the influence of discharge and channel sedimentology on channel form whilst investigating several alluvial reaches in Kansas. Channel geometry and sedimentology data were collected for several rivers of varying hydrologic regimes. Osterkamp (1980) found that rivers transporting mostly silt and clay in suspension produced the deepest and narrowest cross-sections. More importantly, discharge was identified as the primary control on channel size, whilst sediment load was more influential in controlling channel shape (Osterkamp 1980). In an effort to further understand how drainage basin geology influences channel sedimentology and channel form, Hack (1957) studied channel sediments along the longitudinal profile of several bedrock influenced alluvial streams in Virginia and Maryland. Hack (1957) noted that as channel slope increased, the size of bedload sediments also increased. Several explanations were postulated to account for the change in size of bed load sediments, including mechanical weathering, or breakage of sediments by abrasion (Hack 1957). Resistant lithologic units, such as quartzite or sandstone, persist downstream for longer distances due to their inherent resilience against abrasion. Weaker lithologic units, such as shale and carbonate bedrock, are more susceptible to 
breakage and disintegration, and accordingly do not persist for great distances downstream from source areas.

Hack (1957) also compared the dimension of the channel cross section to varying lithologic units. He concluded that non-resistant lithologies produced deeper cross sections than those underlain by more resistant lithologies (Hack 1957). In a similar study of several streams in central Pennsylvania, analogous conclusions were drawn with respect to the resistance of underlying strata and the dimension of the channel cross section (Brush 1961).

Hack (1965) later compared channel slope to stream length for several streams located in different lithologies in the Shenandoah Valley in Virginia and West Virginia. Channel slopes were, on average, seven times greater in sandstone watersheds than in shale watersheds (Hack 1965). Streams located in carbonate rocks displayed an intermediate character, having slopes between those of sandstone and shale areas. High variance in channel slope within carbonate watersheds was attributed to some carbonate units containing significant amounts of resistant chert, which may persist in the channel and produce steep slopes (Hack 1965).

Miller (1991) investigated channel sediments and dimensions along bedrockinfluenced alluvial streams in Indiana. The study streams were categorized on the basis of the dominant underlying lithology, either as siliciclastic or carbonate strata.

Siliciclastic channels were characterized by short bedrock reaches and extensive $(>250$ $\mathrm{m}$ in length) alluvial reaches, dominated by sandstone alluvium (Miller 1991). The carbonate channels exhibited extensive bedrock reaches ( $>$ several hundred $\mathrm{m}$ in length), interspersed with short alluvial reaches dominated by thin sandstone alluvium with fewer 
carbonate clasts (Miller 1991). The pervasiveness of extensive carbonate bedrock reaches was attributed to greater storage capacity for alluvium in floodplains and long distances from the siliciclastic source area. Miller concluded that siliciclastic channel geometries appear to be sized to convey bedload of a particular size, whereas carbonate channel cross sections are adjusted to the composition of the underlying strata, not the supplied bedload.

\section{Previous Regional Curve Investigations}

The quantitative understanding of natural channels was advanced by Leopold and Maddock (1953) in their fundamental study relating discharge to a number of dependent variables, including velocity, channel width, and channel depth. Hydraulic geometry data from several streams in the central and western United States were used to assess how velocity, width and depth vary through a range of flow conditions. The independent variable of discharge was plotted versus each of the dependent variables. A powerfunction trend line was added to each of the regression plots, using ordinary least-squares regression, producing an equation containing a constant of proportionality relating discharge to the other variables and an exponent relating how discharge impacts each dependent variable. Leopold and Maddock (1953) showed that all of the dependent variables increase with the increased discharge, but velocity increases only slightly, depth increases moderately, and width increases rapidly (Leopold 1994).

The concept of regional curve equations relating drainage area to a bankfull channel variable was introduced by Dunne and Leopold (1978), while investigating the channel geometry of the Upper Green River Basin, Wyoming. Initially, the importance of the bankfull stage was realized because of its significance to flooding and 
environmental management, but identification of bankfull stage proved to be problematic where a narrow and poorly defined floodplain was present. Therefore, Dunne and Leopold (1978) collected hydraulic and channel geometry data for the bankfull stage at several reaches in the Upper Green River Basin and used univariate regression to derive equations displaying how average conditions varied with drainage area. As a result, the equations relating hydraulic geometry to a bankfull response variable could then be used to aid identification of bankfull stage in reaches where the floodplain is poorly defined. Similar drainage area vs. bankfull channel geometry data were later assembled for basins in the San Francisco Bay area and Southeastern Pennsylvania (Dunne and Leopold 1978), and the Upper Salmon River, Idaho (Emmett 1975). Combined plots of regional curves of hydraulic geometry show obvious geographic trends in the relationship between drainage area and each bankfull channel variables. Dunne and Leopold (1978) concluded that climate, along with physiography and geology, were the causes of variability in the relationships. Accordingly, the term 'regional curve' was applied to the developed equations because of their significance to areas of similar climate, geology, and geomorphic history.

Chaplin (2005) developed regional curves for non-urban, small watersheds in Pennsylvania and selected adjacent areas in Maryland. Chaplin's study area included seven physiographic provinces; Piedmont, Ridge and Valley, Appalachian Plateaus, New England, Blue Ridge, Coastal Plain, and Central Lowland. Data were collected from 66 flow gauging stations and adjacent reaches; ordinary least-squares regression techniques were used to develop curves relating drainage area to bankfull discharge, bankfull crosssectional area, bankfull width, and bankfull mean depth (Chaplin 2005). Statistical 
methods were employed to determine what factors, including physiography, percent carbonate bedrock, and percent of watershed that was glaciated, influenced the resultant regional curves (Chaplin 2005). Only percent carbonate bedrock statistically influenced the slope of the equations of the regression lines, thus the development of regional curve equations for non-carbonate $(\leq 30 \%$ carbonate) bedrock watersheds (Table 1$)$ and carbonate ( $>30 \%$ carbonate) bedrock watersheds was carried out (Chaplin 2005). Attributes of the non-carbonate regional curves, including the slope and y-intercept, coefficient of determination, and f-statistic values are presented in Table 2.

\section{$\underline{\text { Objectives }}$}

The objectives of this study are as follows:

1. To develop regional curve equations for bankfull channel width, bankfull mean depth, and bankfull cross-sectional area for lithologically controlled mountain watersheds in the Ridge and Valley Physiographic Province, Pennsylvania. In this study, the phrase lithologically controlled refers to watersheds that have a high degree of homogeneity in lithology.

2. To compare the slope and y-intercept of the lithologically controlled regional curve equations to published regional curves, in an effort to determine if lithologically separate curves should be created within physiographic provinces, and to compare $\mathrm{R}^{2}$ values from lithologically diverse and lithologically similar regional curves to determine if a decrease in variance is achieved.

3. To conduct "pebble-counts" on each measured reach to quantify the relationship between bedload texture and drainage area. 


\begin{tabular}{|c|c|c|c|c|c|c|c|}
\hline USGS Gage & Physiographic & Drainage & Bankfull & Bankfull & Bankfull & Percent & Percent \\
\hline I.D. & Province & Area & XSA & w & MD & Urban & Forested \\
\hline & & $\left(\mathrm{km}^{2}\right)$ & $\left(\mathrm{m}^{2}\right)$ & $(\mathrm{m})$ & $(\mathrm{m})$ & & \\
\hline 1449360 & v & 129.24 & 22.11 & 25.15 & 0.84 & 4.7 & 68 \\
\hline 1450500 & $\mathrm{v}$ & 198.65 & 36.33 & 44.50 & 0.83 & 1.2 & 70 \\
\hline 1451800 & $\mathrm{v}$ & 137.27 & 30.84 & 32.31 & 0.95 & 1.1 & 33 \\
\hline 1452000 & $\mathrm{v}$ & 196.32 & 28.89 & 32.31 & 0.82 & 3.7 & 34 \\
\hline 1468500 & v & 344.47 & 53.51 & 34.44 & 1.55 & --- & --- \\
\hline 1469500 & v & 111.11 & 13.47 & 16.92 & 0.79 & 2.4 & 77 \\
\hline 1470756 & v & 411.81 & 62.34 & 47.85 & 1.30 & 1.3 & 40 \\
\hline 1516500 & $a$ & 31.60 & 14.12 & 21.70 & 0.76 & 0.1 & 47 \\
\hline 1518420 & $a$ & 192.44 & 44.50 & 33.22 & 1.33 & 0.1 & 55 \\
\hline 1533250 & a & 30.56 & 7.46 & 17.80 & 0.32 & 0.2 & 63 \\
\hline 1537000 & v & 83.92 & 10.68 & 14.97 & 0.71 & --- & -- \\
\hline 1538000 & v & 113.44 & 17.65 & 21.12 & 0.84 & 5.8 & 83 \\
\hline 1542720 & $a$ & 21.60 & 4.31 & 8.56 & 0.52 & 0 & 65 \\
\hline 1542810 & a & 13.57 & 3.98 & 13.53 & 0.41 & 0 & 99 \\
\hline 1543700 & $\mathrm{a}$ & 471.38 & 69.77 & 54.56 & 1.26 & 0.1 & 93 \\
\hline 1544500 & $a$ & 352.24 & 50.54 & 48.46 & 1.05 & 0 & 96 \\
\hline 1545600 & a & 119.66 & 19.79 & 25.82 & 0.79 & 0 & 100 \\
\hline 1547700 & $\mathrm{v}$ & 114.22 & 14.86 & 19.45 & 0.78 & 0.2 & 78 \\
\hline 1549500 & a & 97.64 & 28.06 & 28.10 & 1.00 & 0.1 & 78 \\
\hline 1550000 & a & 448.07 & 72.19 & 61.57 & 1.17 & 0.1 & 80 \\
\hline 1552500 & a & 61.64 & 20.44 & 20.88 & 0.98 & 0 & 92 \\
\hline 1553700 & v & 132.87 & 28.06 & 22.71 & 1.22 & 0.5 & 31 \\
\hline 1555500 & $\mathrm{v}$ & 419.58 & 63.27 & 40.54 & 1.56 & 1 & 67 \\
\hline 1565000 & $\mathrm{v}$ & 424.76 & 50.07 & 35.36 & 1.45 & 1.2 & 63 \\
\hline 1566000 & v & 554.26 & 113.34 & 60.96 & 1.87 & 0.1 & 70 \\
\hline 1567500 & v & 38.85 & 10.03 & 13.17 & 0.77 & 0.1 & 49 \\
\hline 1568000 & $\mathrm{v}$ & 536.13 & 87.33 & 61.57 & 1.12 & 0.9 & 68 \\
\hline 1569340 & $v$ & 13.70 & 6.55 & 12.62 & 0.53 & 1.9 & 34 \\
\hline 1613050 & v & 27.71 & 6.22 & 11.09 & 0.57 & 0 & 70 \\
\hline 3011800 & a & 120.18 & 16.44 & 19.05 & 0.86 & 1 & 96 \\
\hline 3021410 & a & 135.46 & 28.99 & 19.32 & 1.53 & 0.8 & 57 \\
\hline 3022540 & $\mathrm{a}$ & 80.29 & 16.72 & 22.34 & 0.76 & 0.2 & 64 \\
\hline 3026500 & $a$ & 20.31 & 7.51 & 10.91 & 0.70 & 0.1 & 94 \\
\hline 3028000 & a & 163.17 & 29.26 & 29.63 & 0.90 & 0.6 & 91 \\
\hline 3034500 & a & 226.36 & 47.66 & 30.48 & 1.55 & 0.3 & 73 \\
\hline 3039925 & $a$ & 8.94 & 3.14 & 8.32 & 0.38 & 0.1 & 99 \\
\hline 3049000 & a & 354.83 & 49.98 & 34.14 & 1.46 & 0.5 & 50 \\
\hline 3049800 & a & 14.97 & 3.03 & 5.49 & 0.55 & 0 & 80 \\
\hline
\end{tabular}

Table 1. Characteristics of sites used to develop Chaplin's (2005) regional curves for non-carbonate watersheds. Key to symbols in table: [XSA] Cross-Sectional Area, [W] Width, [MD] Mean Depth, [v] Ridge and Valley, [a] Appalachian Plateaus, [cl] Central Lowland, [p] Piedmont, [--] missing data. 


\begin{tabular}{|c|c|c|c|c|c|c|c|}
\hline USGS Gage & Physiographic & Drainage & Bankfull Cross- & Bankfull & Bankfull & Percent & Percent \\
\hline I.D. & Province & Area & Sectional Area & Width & Mean Depth & Urban & Forested \\
\hline & & $\left(\mathrm{km}^{2}\right)$ & $\left(\mathrm{m}^{2}\right)$ & $(\mathrm{m})$ & $(\mathrm{m})$ & & \\
\hline 3072880 & a & 45.32 & 16.17 & 17.53 & 0.93 & 1.4 & 63 \\
\hline 3080000 & $\mathrm{a}$ & 313.39 & 56.30 & 49.07 & 1.15 & 0.9 & 68 \\
\hline 3102500 & a & 269.36 & 38.00 & 22.10 & 1.72 & 0.2 & 30 \\
\hline 4213075 & $\mathrm{cl}$ & 11.53 & 2.24 & 8.87 & 0.26 & --- & --- \\
\hline 1471980 & $p$ & 221.44 & 43.48 & 27.46 & 1.58 & 1.5 & 56 \\
\hline 1472157 & $p$ & 153.07 & 29.36 & 26.55 & 1.11 & 1 & 64 \\
\hline 1472198 & $p$ & 98.42 & 28.24 & 35.66 & 0.81 & 2 & 54 \\
\hline 1472199 & $p$ & 59.57 & 18.77 & 29.41 & 0.64 & 1.9 & 61 \\
\hline 1475850 & $p$ & 40.92 & 14.96 & 17.53 & 0.85 & 15 & 61 \\
\hline 1477000 & $p$ & 158.25 & 28.15 & 21.21 & 1.33 & 19 & 55 \\
\hline 1480300 & $p$ & 48.43 & 11.89 & 17.50 & 0.68 & 1.5 & 31 \\
\hline 1480500 & $p$ & 118.62 & 16.63 & 23.65 & 0.71 & 2.2 & 42 \\
\hline 1480617 & $p$ & 142.45 & 24.90 & 29.57 & 0.84 & 2.2 & 42 \\
\hline 1578200 & $p$ & 22.53 & 5.92 & 8.90 & 0.68 & 0.9 & 20 \\
\hline 1586210 & $p$ & 36.26 & 9.85 & 13.53 & 0.73 & --- & --- \\
\hline 1586610 & $p$ & 72.52 & 17.56 & 20.79 & 0.84 & --- & --- \\
\hline 1639500 & $p$ & 264.18 & 57.23 & 30.78 & 1.87 & --- & --- \\
\hline
\end{tabular}

Table 1. Characteristics of sites used to develop Chaplin's (2005) regional curves for non-carbonate watersheds - continued. Key to symbols in table: [XSA] Cross-Sectional Area, [W] Width, [MD] Mean Depth, [v] Ridge and Valley, [a] Appalachian Plateaus, [cl] Central Lowland, [p] Piedmont, [--] missing data. 


\begin{tabular}{|l|r|r|r|r|c|}
\hline \multicolumn{1}{|c|}{$\begin{array}{c}\text { Response } \\
\text { Variable }\end{array}$} & Equation & Slope & Y Intercept & $\mathbf{R}^{\mathbf{2}}$ & F-statistic \\
\hline $\begin{array}{l}\text { Cross- } \\
\text { Sectional Area }\end{array}$ & $\mathrm{CSA}=0.524 \mathrm{DA}^{0.797}$ & 0.797 & 0.524 & 0.923 & 232.73 \\
\hline Width & $\mathrm{W}=2.916 \mathrm{DA}^{0.449}$ & 0.449 & 2.916 & 0.813 & 110.29 \\
\hline Mean Depth & $\mathrm{D}=0.195 \mathrm{DA}^{0.330}$ & 0.330 & 0.195 & 0.718 & 88.13 \\
\hline
\end{tabular}

Table 2. Summary of quantitative attributes for Chaplin's (2005) regional curves for non-carbonate watersheds. 


\section{Study Area}

\section{$\underline{\text { Location }}$}

The study area is located in the Ridge and Valley Physiographic Province, SouthCentral Pennsylvania (Figure 1). The Ridge and Valley is bound to the east by the Blue Ridge Physiographic Province and to the west by the Appalachian Plateaus Physiographic Province (Fenneman 1928). Laurel Run, Horse Valley Run, Sherman Creek, South Branch Little Aughwick Creek, Conodoguinet Creek, and West Licking Creek watersheds were investigated in Fulton, Franklin, Cumberland, Perry, Juniata, Mifflin, and Huntingdon counties, Pennsylvania (Figure 2). All watersheds are characterized by a trellis to dendritic drainage pattern, an elongate shape, relatively small drainage areas $\left(<75 \mathrm{~km}^{2}\right)$, and divides underlain by resistant quartz sandstone of either the lower Silurian Tuscarora Formation or the upper Ordovician Bald Eagle Formation. The morphology of all study streams is characterized by well-developed sequences of pools and riffles. Portions of all of the study streams are located in state game lands or state forests.

\section{$\underline{\text { Structure }}$}

The Ridge and Valley Physiographic Province consists of a generally parallel sequence of northeast to southwest trending ridges and valleys (Thornbury 1965).

Topography is intimately linked to bedrock geology; ridges are capped by resistant strata and valleys underlain by weaker strata (Fenneman 1928). The western section of the greater province includes two sub-provinces, the Appalachian Mountain Section and the Susquehanna Lowland Section (Sevon 2000), both partially included in the study area. 


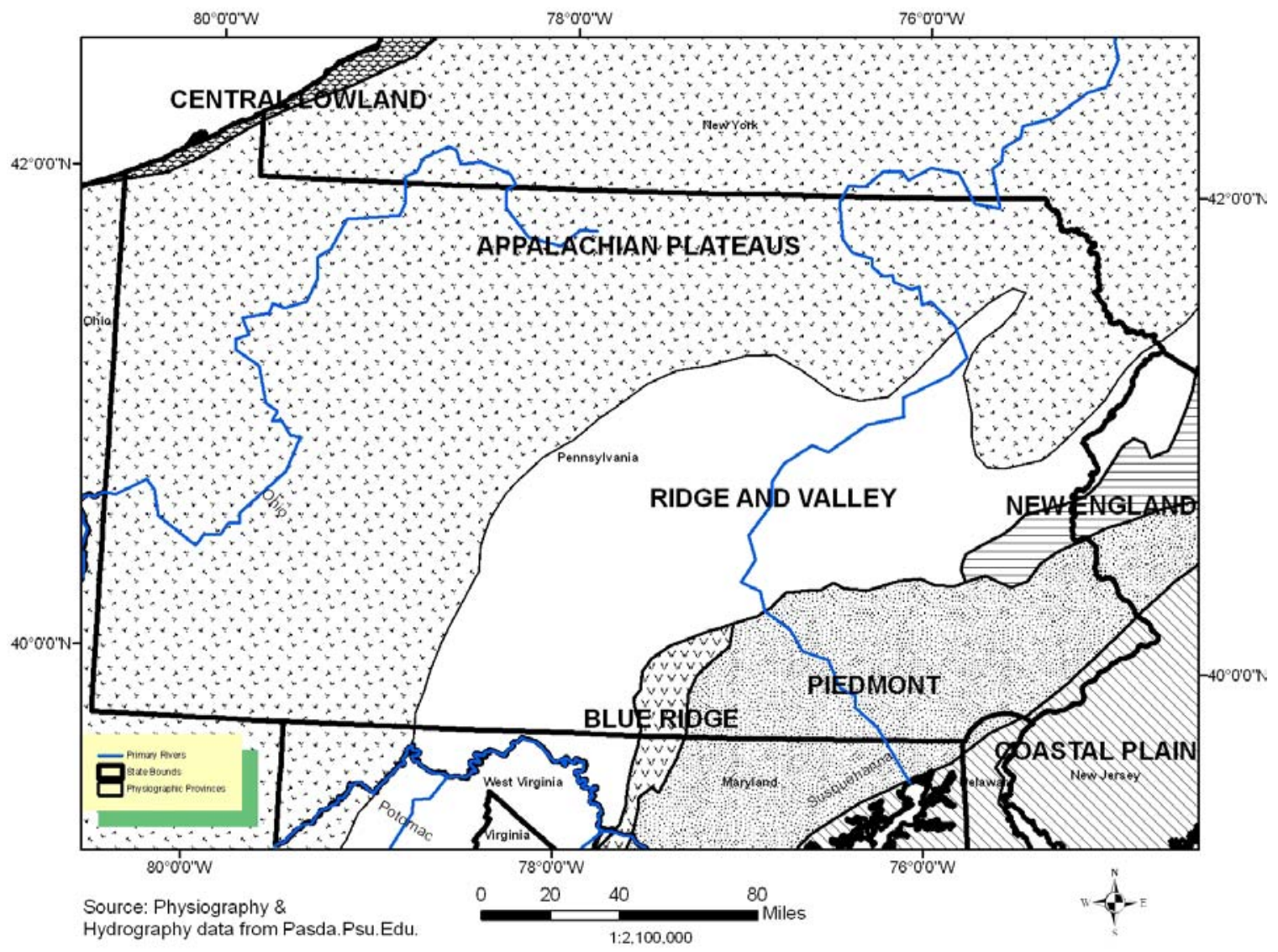

Figure 1. Physiography and major rivers of Pennsylvania and adjacent areas. 


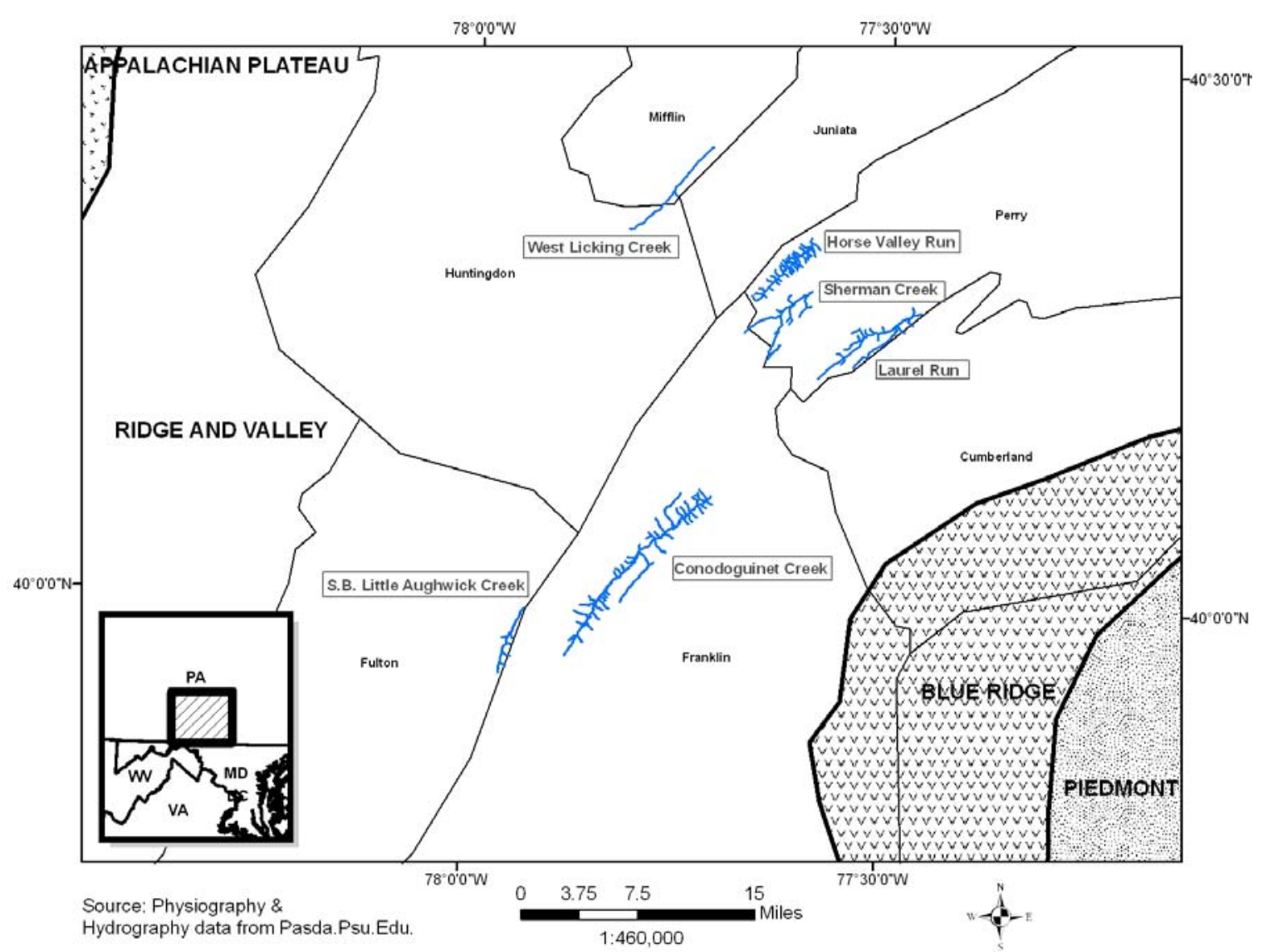

Figure 2. Study area map showing physiographic provinces, counties, and hydrography. 
The structure of the Appalachian Mountain and Susquehanna Lowland Sections consists of "open and closed plunging folds having narrow hinges and planar limbs", with minor faulting (Seven 2000). The origin of the present-day landscape is attributed to fluvial erosion, and to a lesser extent, periglacial mass wasting and solution of carbonate rocks (Sevon 2000).

Geology

The bedrock geology in the study area encompasses several units of early Paleozoic age (Guyer and Wilshusen, 1982). Descriptions of the geologic units in the study area are presented in Table 3. Geologic maps of the study watersheds were created in ArcGIS 9.1, by draping a geology layer (Berg et al., 1980) over 1:100,000 scale digital raster graphics (Figures 3-8). Reconnaissance of the study watersheds indicated the presence of extensive surficial, unconsolidated deposits. Valley bottoms display extensive alluvial deposits of sandstone cobbles and boulders, whereas slopes are mantled with colluvium dominated by angular sandstone clasts. The extent of the colluvial deposits likely increased during periglacial climatic episodes experienced in nonglaciated terrains during the Pleistocene Epoch (Mills and Delcourt 1991), when deep freeze-thaw and cryoturbation increased mechanical bedrock disintegration and sediment production (Shultz 1999).

\section{Methodology}

\section{Criteria for Selection of Study Reaches}

The criteria used to select study reaches for regional curve development include the following: 


\begin{tabular}{|c|c|c|c|c|}
\hline$\underline{\text { Formation }}$ & $\underline{\text { Age }}$ & $\underline{\text { Lithology }}$ & Max Thickness & Topography \\
\hline $\begin{array}{l}\text { Wills Creek } \\
\text { Formation }\end{array}$ & Silurian & $\begin{array}{l}\text { Greenish-gray shale containing localized } \\
\text { limestone and sandstone zones. }\end{array}$ & $200 \mathrm{~m}$ & $\begin{array}{l}\text { Undulating hills of } \\
\text { low relief. }\end{array}$ \\
\hline $\begin{array}{l}\text { Mifflintown } \\
\text { Formation }\end{array}$ & Silurian & $\begin{array}{l}\text { Greenish-gray shale interbedded with gray } \\
\text { fossiliferous limestone. }\end{array}$ & $90 \mathrm{~m}$ & $\begin{array}{l}\text { Rolling hills of } \\
\text { moderate to high } \\
\text { relief. }\end{array}$ \\
\hline $\begin{array}{l}\text { Bloomsburg } \\
\text { Formation }\end{array}$ & Silurian & $\begin{array}{l}\text { Red to grayish-red shale, siltstone, and fine } \\
\text { to coarse-grained sandstone with thin } \\
\text { impure limestone. }\end{array}$ & $150 \mathrm{~m}$ & $\begin{array}{l}\text { Rolling hills of } \\
\text { moderate relief. }\end{array}$ \\
\hline $\begin{array}{c}\text { Keefer } \\
\text { Formation }\end{array}$ & Silurian & $\begin{array}{l}\text { Gray, medium to thick bedded, fine to } \\
\text { coarse-grained, fossiliferous, quartzitic } \\
\text { sandstone and hematitic sandstone. }\end{array}$ & $20 \mathrm{~m}$ & $\begin{array}{l}\text { Hills of moderate } \\
\text { to low relief. }\end{array}$ \\
\hline $\begin{array}{l}\text { Rose Hill } \\
\text { Formation }\end{array}$ & Silurian & $\begin{array}{l}\text { Olive to medium-gray shale with } \\
\text { interbedded sandy and silty beds. }\end{array}$ & $290 \mathrm{~m}$ & $\begin{array}{l}\text { Hills of moderate } \\
\text { relief. }\end{array}$ \\
\hline $\begin{array}{l}\text { Tuscarora } \\
\text { Formation }\end{array}$ & Silurian & $\begin{array}{l}\text { White to gray, medium to thick bedded, fine } \\
\text { to coarse-grained quartzitic sandstone. }\end{array}$ & $460 \mathrm{~m}$ & $\begin{array}{l}\text { High mountainous } \\
\text { ridges and steep, } \\
\text { rough terrains. }\end{array}$ \\
\hline $\begin{array}{l}\text { Juniata } \\
\text { Formation }\end{array}$ & Ordovician & $\begin{array}{l}\text { Red, fine-grained to conglomeratic } \\
\text { sandstone and to a lesser extent, } \\
\text { interbedded red shale. }\end{array}$ & $345 \mathrm{~m}$ & $\begin{array}{l}\text { High relief, rough } \\
\text { mountainous } \\
\text { ridges. }\end{array}$ \\
\hline $\begin{array}{l}\text { Bald Eagle } \\
\text { Formation }\end{array}$ & Ordovician & $\begin{array}{l}\text { Fine to coarse-grained, friable, cross- } \\
\text { bedded sandstone and quartz pebble } \\
\text { conglomerate. }\end{array}$ & $305 \mathrm{~m}$ & $\begin{array}{l}\text { Mountain ridges } \\
\text { and rough to steep } \\
\text { topographies. }\end{array}$ \\
\hline $\begin{array}{l}\text { Martinsburg } \\
\text { Formation }\end{array}$ & Ordovician & $\begin{array}{l}\text { Thick sequence of medium to dark-gray to } \\
\text { olive-gray shale, interbedded with siltstone } \\
\text { and fine-grained sandstone. }\end{array}$ & $3960 \mathrm{~m}$ & $\begin{array}{l}\text { Dissected valleys } \\
\text { with low relief. }\end{array}$ \\
\hline
\end{tabular}

Table 3. Bedrock geology units in the study area. Descriptions from Guyer and Wilshusen (1982). 


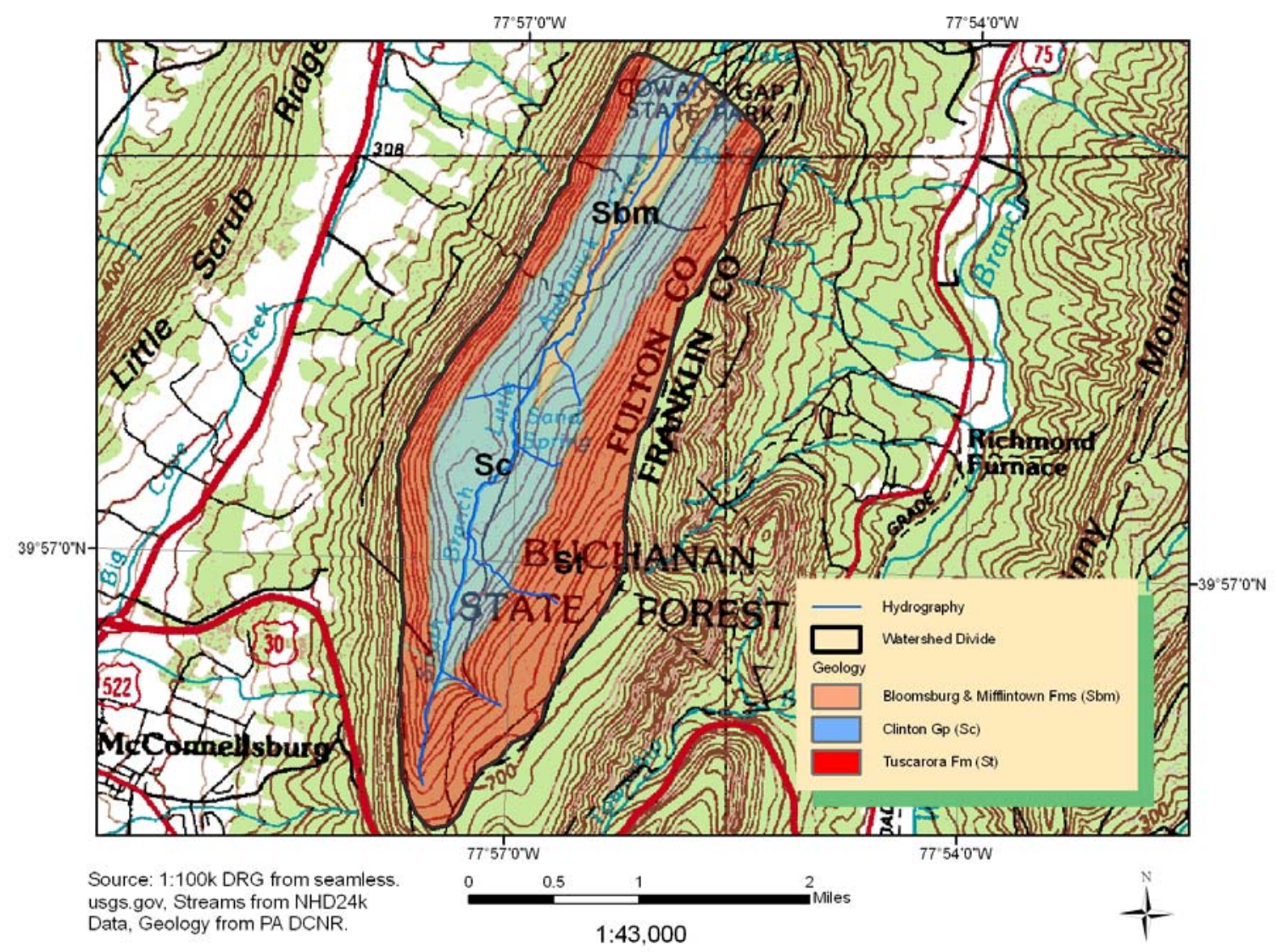

Figure 3. Bedrock geology map of South Branch Little Aughwick Creek Watershed. 


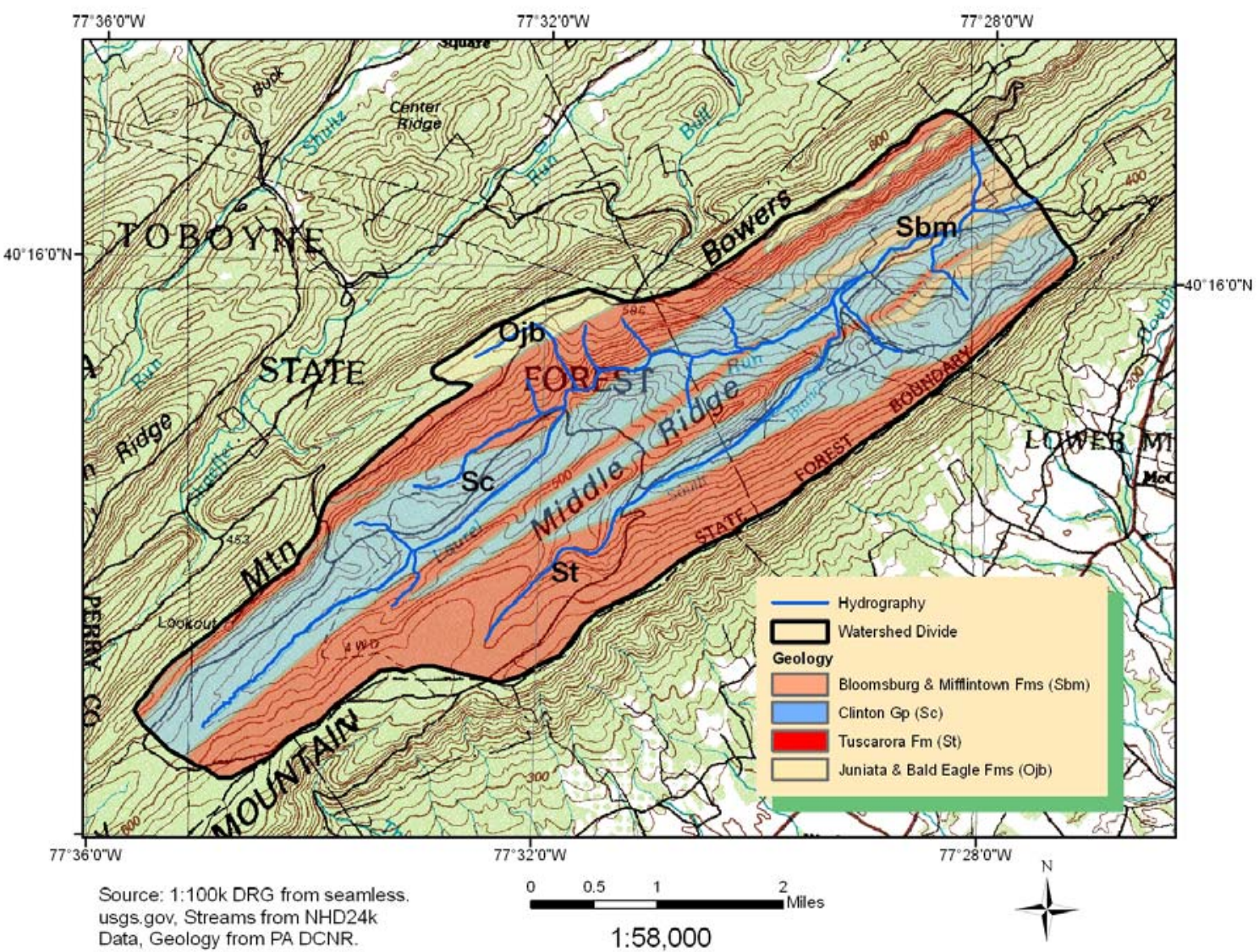

Figure 4. Bedrock geology map of Laurel Run Watershed. 


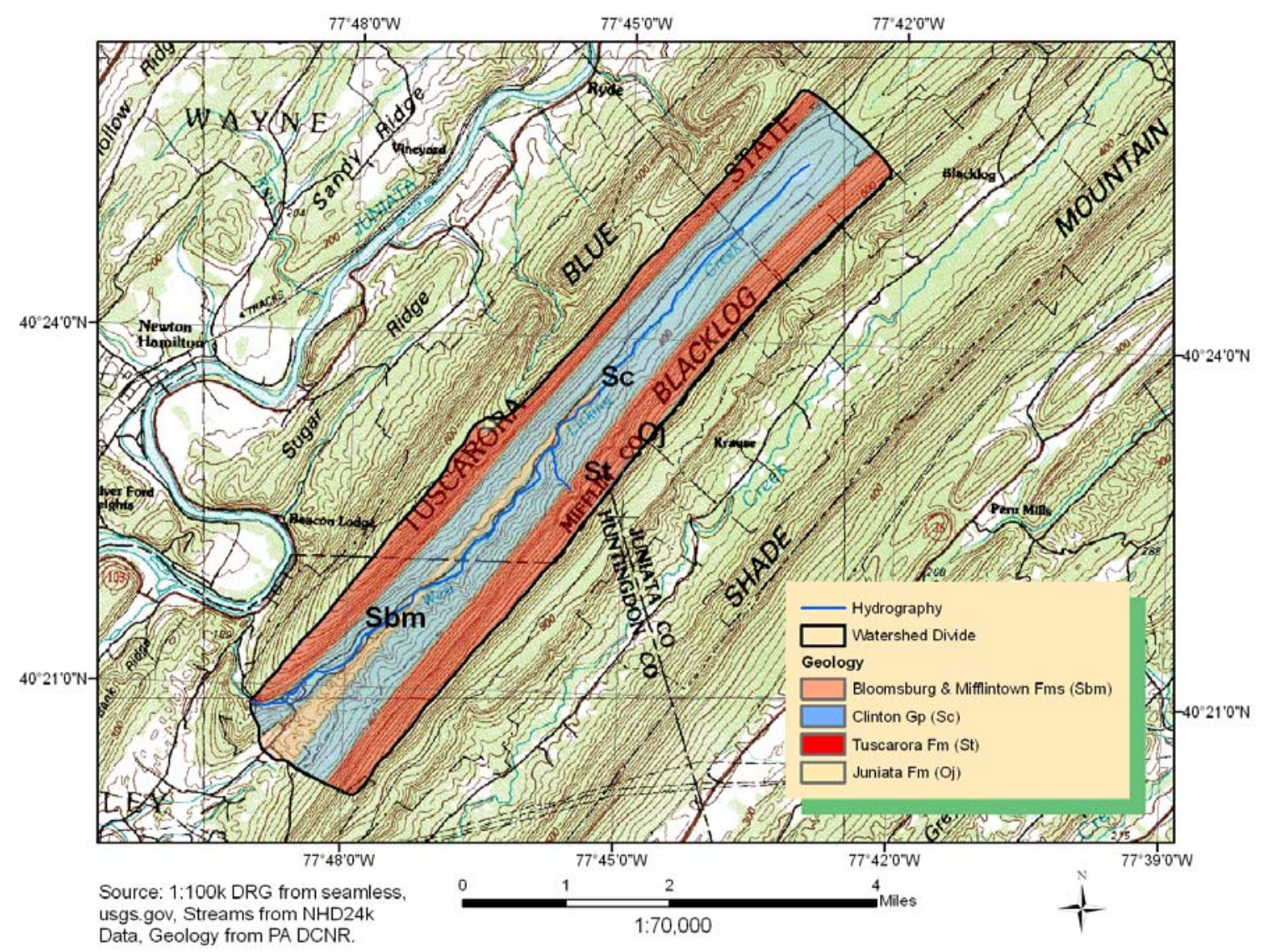

Figure 5. Bedrock geology map of West Licking Creek Watershed. 


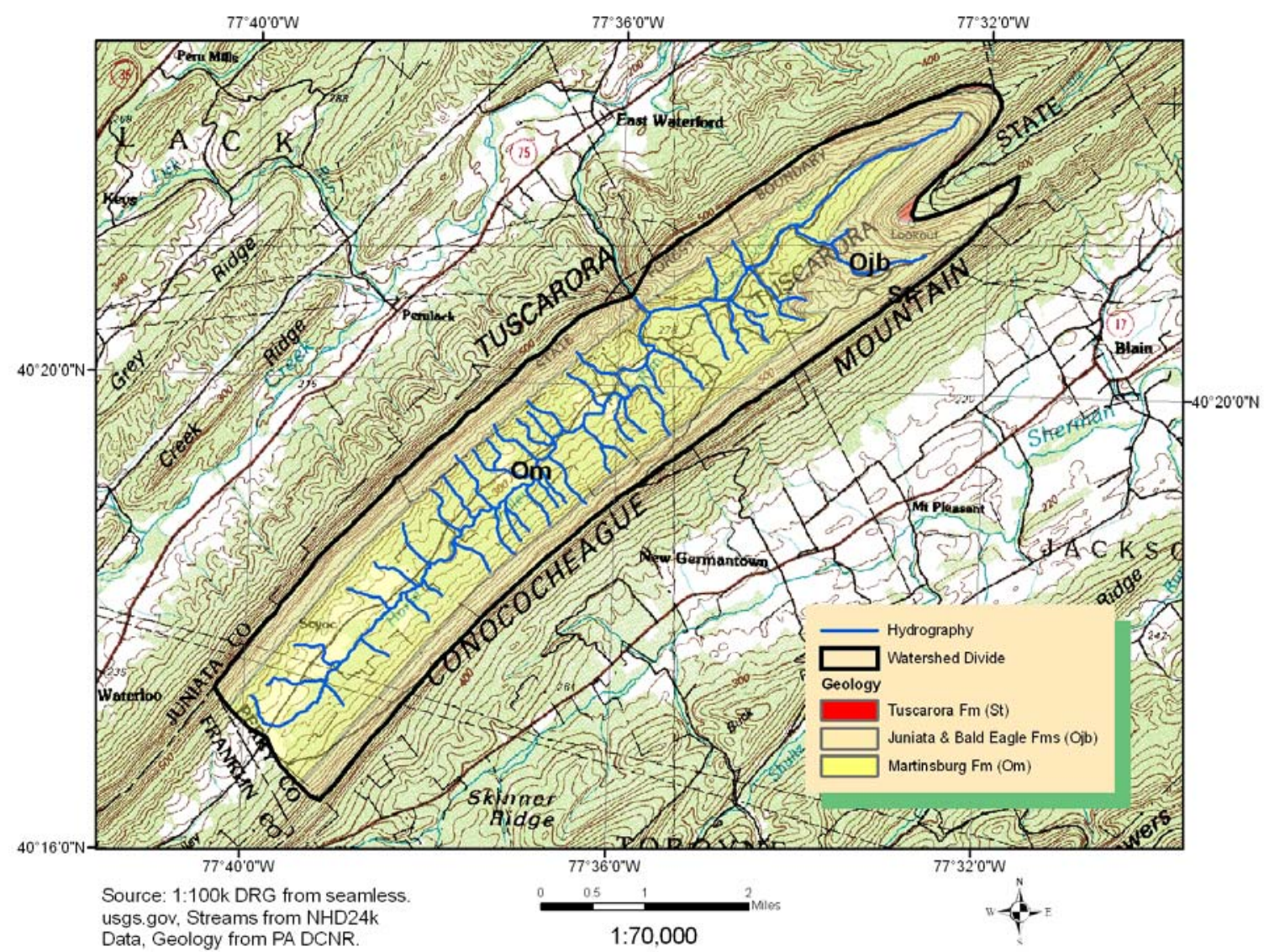

Figure 6. Bedrock geology map of Horse Valley Run. 


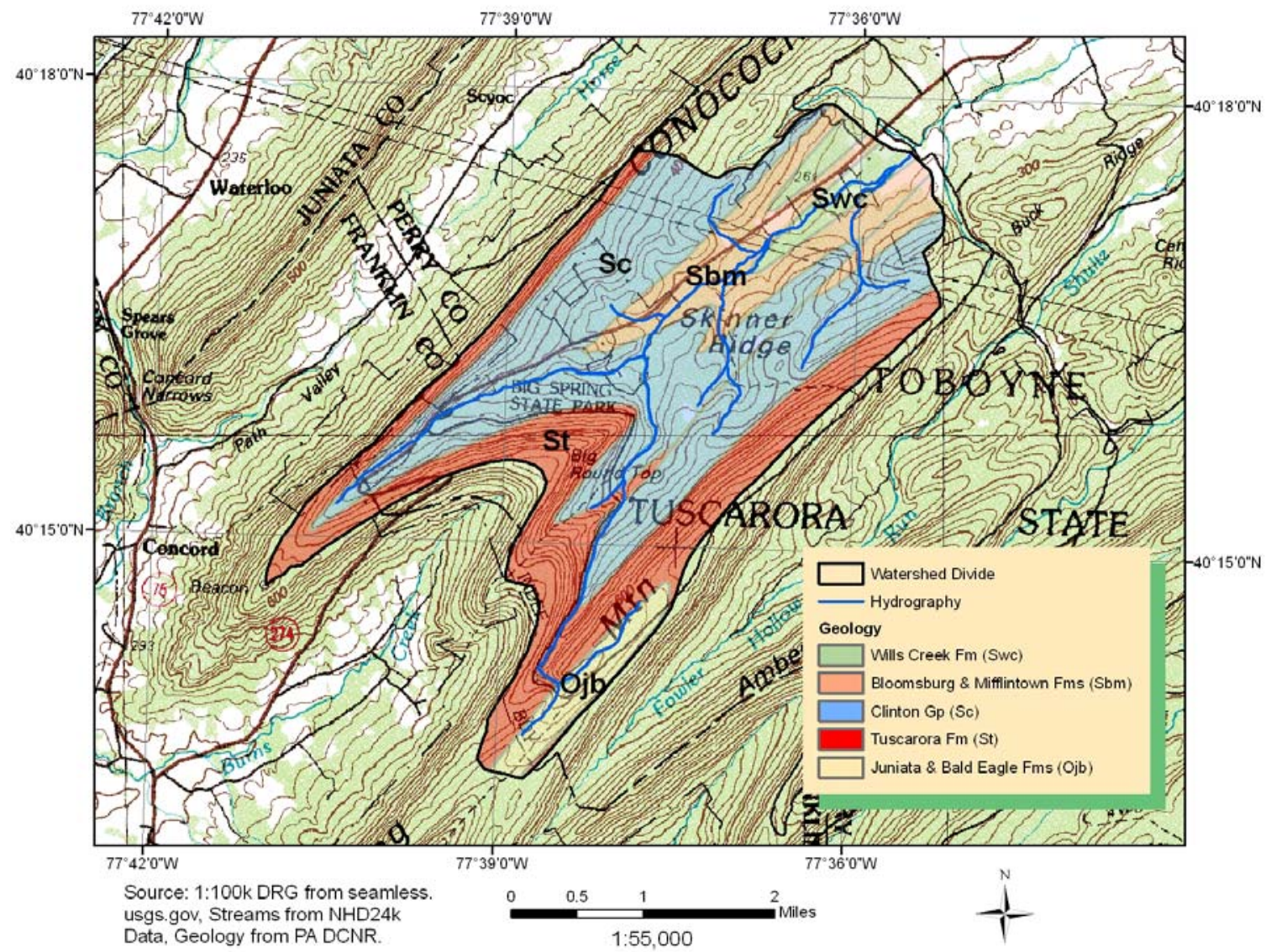

Figure 7. Bedrock geology map of Sherman Creek. 


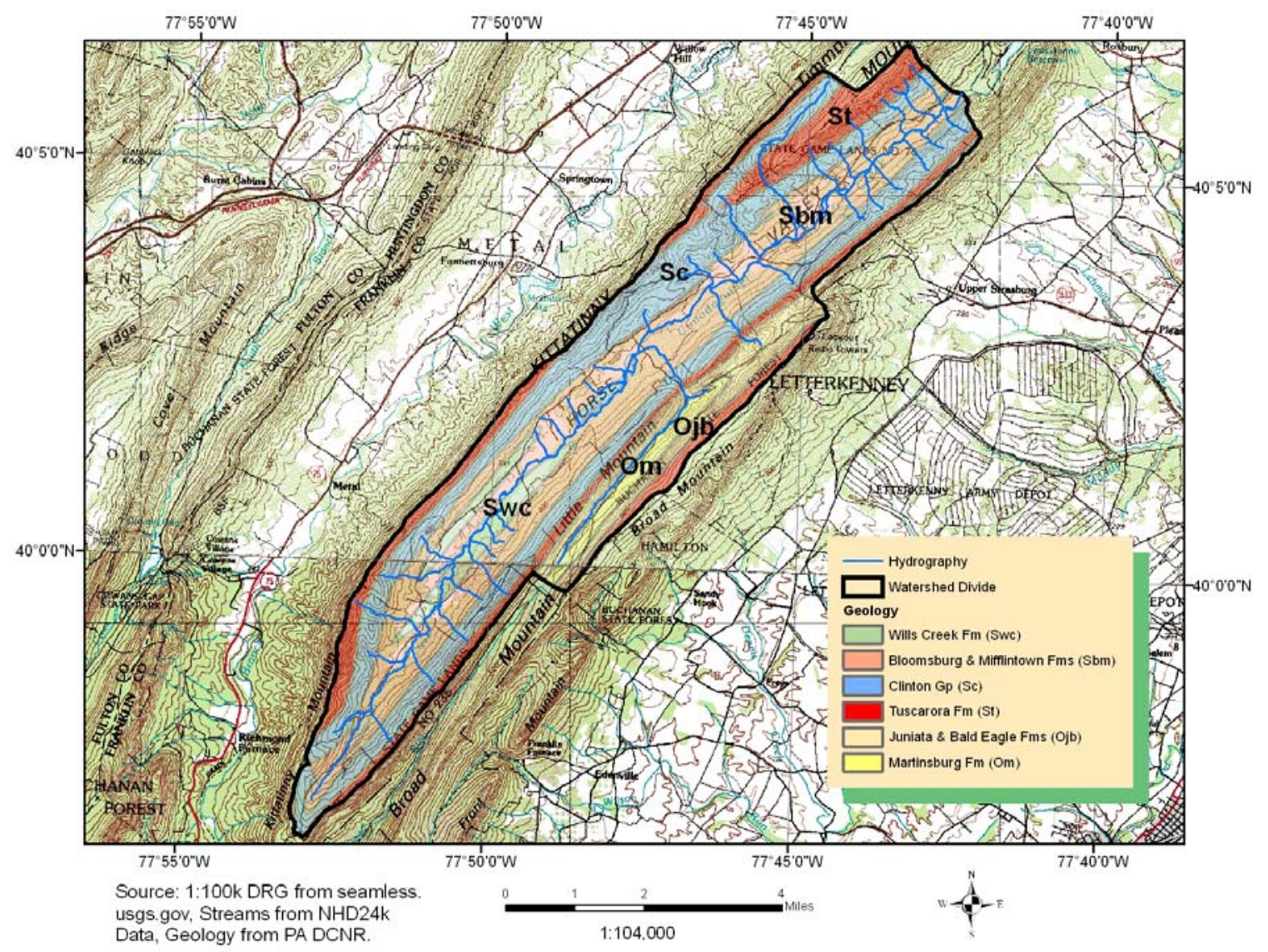

Figure 8. Bedrock geology map of Conodoguinet Creek Watershed. 
- The upland areas draining to the study reaches were entirely located within the Ridge and Valley Physiographic Province.

- Surface or sub-surface mining does not occur in the watershed.

- Urban land use was no greater than 20 percent of the total drainage area.

- No more than 20 percent of the watershed above the measured reaches was regulated by flow control structures.

- Less than 30 percent of the total drainage area was underlain by carbonate rocks (i.e. non-carbonate watersheds of Chaplin (2005)).

- The watershed divides above each site were underlain by Silurian Tuscarora or Ordovician Bald Eagle quartz sandstone.

To ensure consistency in reach selection, Chaplin's (2005) criteria were used, with the addition of the constraint on watershed divide geology. Thorough investigation of the study reaches was undertaken to ensure the selection criteria were met.

Geographic Information Systems (GIS) were utilized to verify reach selection criteria. After reaches were identified and the stream cross-section surveyed, the watershed area above each measured reach was delineated using ESRI ArcGIS 9.1 and the 7.5' digital raster graphics for each study area. A watershed polygon was manually delineating based upon interpretation of contour lines. After drainage basin polygons were created, basin area was calculated using an area code in ArcGIS 9.1.

To ensure all of the study watersheds were located entirely within the Ridge and Valley Physiographic Province, the study watershed polygons and a shapefile of the physiographic provinces of Pennsylvania were imported into ArcGIS 9.1. Visual 
inspection of the watershed polygons confirmed the study areas were confined to the Ridge and Valley.

All of the study watersheds were interpreted to have less than 30 percent of their total drainage area underlain by carbonate rocks because the dominant lithology for the geologic formations in each of the watersheds is a clastic sedimentary rock type (Table 3) (Guyer and Wilshusen, 1982). Minor amounts of limestone occur in the Silurian Bloomsburg, Mifflintown, and Wills Creek Formations; however, inspection of the 7.5' topographic maps of the study watersheds revealed no well-developed karst features.

Surface or sub-surface mining activities in the study watersheds was absent as verified by inspecting relevant 7.5 ' topographic maps and by ground reconnaissance. In addition, the lack of coal bearing strata and significant limestone units in the study watersheds reiterated the absence of any significant mining activities. Regulation of flow on the study streams also was assessed by inspection of topographic maps and ground reconnaissance. All of the study watersheds were determined to be unregulated because no significant dams are mapped above any study reaches.

Urban land use, as defined by Chaplin (2005), consists of low-intensity developed, high-intensity developed, and high-intensity commercial/industrial. Using ArcGIS 9.1, National Land Cover Data (USGS 1996) verified urban land use was less than 20 percent for each study watershed.

Forest lands consist of three unique classifications; deciduous forest, evergreen forest, and mixed forest. National Land Cover Data (USGS 1996) were used to calculate the percent of forest cover in study watersheds. As was the case in determining percent 
urbanization, the watershed polygons were used to extract land cover type for each watershed in ArcGIS 9.1.

ArcGIS 9.1 was used to verify all of the study watersheds had divides underlain by Silurian Tuscarora Formation or Ordovician Bald Eagle quartz sandstone. The study watershed polygons and a 1:250,000 digital bedrock geology map of Pennsylvania (Berg at al. 1980) were imported into ArcGIS 9.1. Visual inspection of the watersheds verified the Tuscarora or Bald Eagle formations were present along all of the divides.

\section{Development of Regional Curves}

Initially, study streams were analyzed by visually inspecting the relevant $7.5^{\text {, }}$ topographic maps. The purpose of this analysis was twofold; to identify land with public access (i.e. state game lands, state parks, or state forest), and identify reaches for later measurements. Measurement reaches displayed widely spaced bottomland contours, suggesting these reaches would display developed floodplains. A minimum of five stable reaches along each study stream was selected for measurement, each stream having two adjacent riffles. Reach stability was visually assessed in the field by ensuring neither aggradation nor degradation of the channel was apparent. Excessive erosion along channel banks, mid-channel bars creating an over-widening effect, and the presence of large woody debris within any reach resulted in exclusion from sampling. Channel crosssections were surveyed across two adjacent riffles, and values for bankfull cross-sectional area, bankfull mean depth, and bankfull width were calculated for each riffle. The bankfull response variables were calculated using the Reference Reach Spreadsheet v4.3 Level, developed by Mecklenburg (2006) at the Ohio Department of Natural Resources. Average dimensions for the bankfull response variables were calculated for each reach. 
The bankfull stage was identified at each riffle prior to survey of the channel cross-section. Riffles were selected for measurement because they are generally free to adjust laterally under the current flow regime and more consistently represent hydraulic geometry (Rosgen 1996). Criteria used to identify the bankfull stage in the field are described by Leopold (1994) and Rosgen (1996), and included the following:

- A change in slope on the channel banks.

- A change in texture of sediments on the channel banks.

- The elevation of the top of the highest depositional feature, such as point bars

- A change in riparian vegetation types and the presence of lichens along the channel banks.

Difficulty in accurately and consistently identifying the bankfull stage arose in the

field. To ensure consistency in bankfull stage identification, detailed notes on the four field criteria were made at each site. Channel bank slope breaks were identified as the interface between a surface where the investigator's shoe rested flat up on the floodplain and a surface at the edge of the channel were one's foot rested at an angle. Changes in channel-bank sediments were assessed in the field with a standard grain size comparator. The bankfull stage was identified as the interface between coarse-grained sediment in the channel proper and fine-grained vertically accreted sediments on the floodplain. Fluvial surfaces unrelated to the current hydrologic regime (i.e. terraces) were largely absent from the study reaches. In the case where benches were adjacent to the channel, crosssectional surveys extended laterally to include the terraces, which allowed for later reassessment of the field-identified bankfull stage. 
The channel cross-section was surveyed once the bankfull stage was identified. A plastic measuring tape was stretched taunt across the channel, perpendicular to the direction of flow, and secured above the bankfull stage, all within the riparian corridor. Vertical elevations were determined across the cross-section line using a Leica Rugby 100 LR laser level and a surveying rod fitted with an audible laser receiver. The Leica Rugby 100 LR uses a long range infrared beam and has a vertical accuracy of plus or minus $1.5 \mathrm{~mm}$ per $30 \mathrm{~m}$ of horizontal distance (Leica 2007).

Cross-sectional surveys were extended laterally as far as possible from the channel. However, dense riparian vegetation made survey beyond the channel margins impossible in several study reaches. Survey measurements were taken every 2.0 feet $(0.61 \mathrm{~m})$ in the horizontal direction and at any other locations where a significant change in topography occurred. Bankfull-stage indicators were recorded in surveying to allow subsequent calculation of the bankfull response variables.

Data were assessed to verify they fulfilled the requirements of regression analysis: normally distributed $\mathrm{x}$ and $\mathrm{y}$ variables, non-autocorrelated and homoscedastic regression residuals, a likely causal relationship between the variables, and a general linear relationship (Donovan 2006). Data normality was determined by performing a Kolmogorov-Smirnov test using the Minitab statistical package. The critical Kolmogorov-Smirnov value was determined at a confidence interval of $95 \%$. If the test statistic was found to be less than the critical value, the sampled data were considered to be normally distributed. As watershed size increases, stream dimensions also increase. Accordingly, a causal relationship between the independent variable, drainage area, and the dependent bankfull response variables was assumed. 
Homoscedasticity refers to the condition where residuals are scattered around the regression line in a non-clustered fashion (Donovan 2006). In the case of homoscedasticity, the "variances of the y distributions are all equal to one another" (Kachigan 1986). Homoscedasticity was assessed by visually inspecting the regression plots and observing the location of data points in relation to the best-fit line. Homoscedasticity was not assumed if data points were clustered at one end of the regression line. Non-autocorrelation refers to the condition where residuals are scattered around the regression line randomly (Donovan 2006), and was assessed visually by inspecting the regression plots to ensure data points were randomly scattered around the best-fit line. Non-autocorrelation was not assumed if the data points plotted in groups above or below the regression line.

After the requirements of regression were verified, a regional curve equation relating drainage area to bankfull cross-sectional area, bankfull width, and bankfull mean depth were developed using ordinary least-squares regression. Hydraulic geometry data were compiled in Microsoft Excel and drainage area was plotted versus each of the bankfull response variables on a log-log scale. A power function trend line and the equation describing the best-fit line were added to each of the plots. Two additional statistics were calculated in order to quantify the validity of regression analysis. The coefficient of determination, or $\mathrm{R}^{2}$ value, quantifies the magnitude of the regression relationship and the f-statistic describes the goodness of fit of the regional curve models (Kachigan 1986). As model fit increases, $\mathrm{R}^{2}$ values approach 1.0 and f-statistic values approach infinity (Kachigan 1986). 
Hydraulic geometry data from the non-carbonate watersheds sampled by Chaplin (2005) were used to develop two additional regional curves. Non-carbonate watersheds draining areas $<75 \mathrm{~km}^{2}$ and those in the Ridge and Valley Physiographic Province were grouped. The purpose of grouping non-carbonate watersheds sampled by Chaplin (2005) and subsequent regional curve development was to allow for additional comparisons to the lithologically controlled regional curves. Prior to regional curve development, hydraulic geometry data were analyzed to ensure the requirements of regression analysis were met.

Hydraulic geometry data for the lithologically controlled watersheds and all noncarbonate watersheds investigated by Chaplin (2005) were combined to create an additional regional curve. Prior to regional curve development, the hydraulic geometry data were analyzed to ensure they met the prerequisite conditions to perform regression analysis. Regional curves were developed for bankfull cross-sectional area, bankfull width, and bankfull mean depth. The purpose of combining data and subsequently developing another set of regional curves was to assess changes in $\mathrm{R}^{2}$ values, or regression validity, between the initially developed lithologically controlled regional curves.

A subtle difference in methodology for regional curve development was apparent between this study and Chaplin's (2005), and should be mentioned. Chaplin (2005) sampled several watersheds from across physiographic divides throughout Pennsylvania. In this study, a large number of samples were collected from relatively few watersheds solely in the Ridge and Valley Physiographic Province. As a result of this study's 
sampling procedure, the issue of statistical independence of the lithologically controlled measured reaches may be apparent, but is not further investigated.

\section{Comparison of Regional Curves}

The slope and y-intercept of lithologically controlled regional curve equations were compared to three regional hydraulic geometry curves; (1) regional curves for noncarbonate watersheds (Chaplin 2005), (2) regional curves for non-carbonate watersheds draining areas $<75 \mathrm{~km}^{2}$, and (3) regional curves for non-carbonate watersheds in the Ridge and Valley Physiographic Province. The equations for the combined regional curve, based on data from this study's lithologically controlled watersheds and all noncarbonate watersheds investigated by Chaplin (2005), were not compared to the lithologically controlled regional curves, due to redundancy in data used to develop both relations. Regional curves were compared using analysis of covariance (ANCOVA), specifically to determine differences in the slope and y-intercept between regional curves. The null hypothesis of the ANCOVA statistical test was that there is no difference in the mean of the slope and y-intercept of the regression equations for both regional curves. The null hypothesis was rejected if the p-value (the probability of incorrectly rejecting the null hypothesis if it is true) was $\leq 0.05$ (95\% confidence). The analysis was carried out using the Analysis Toolpak add-in for Microsoft Excel. Prior to running the analysis, two variables were created. The first variable $\left(\mathrm{X}_{2}\right)$ was given a value of 0 for the control data set and a value of 1 for the discrete data set (Grabow et al. 1998). The second variable $\left(\mathrm{X}_{1} * \mathrm{X}_{2}\right)$ was calculated by multiplying the independent variable by the $\mathrm{X}_{2}$ variable (Grabow et al. 1998). These two variables were generated to allow the regression analysis to test for differences in slope and y-intercept between the data sets. 
The ANCOVA was setup using 'before/after' procedures explained by Grabow et al. (1998) to compare unique regression lines. ANCOVA results are reported as p-values and coefficients describing the difference in magnitude between the control and discrete slopes and intercepts.

The $\mathrm{R}^{2}$ value of the lithologically controlled regional curves was compared individually to the three regional hydraulic geometry curves mentioned above and the combined regional curve, based on data from this study's lithologically controlled and Chaplin's (2005) watersheds. Results of $\mathrm{R}^{2}$ values illuminate how much variance the independent variable, drainage area, explains in the dependent bankfull response variables. If the $\mathrm{R}^{2}$ value for the lithologically controlled regional curves were larger, a decrease in variance in the bankfull response variable was apparent. On the contrary, if the $\mathrm{R}^{2}$ value for the lithologically controlled regional curves were smaller, an increase in variance in the bankfull response variable was apparent.

Bias towards watersheds with relatively small drainage areas was inevitable in this study's development of lithologically controlled regional curves. Standard statistical measures of central tendency, including mean, median, range, and standard deviation, were calculated for drainage area for all regional hydraulic geometry curves. Central tendency analysis for percent watershed urbanization and percent watershed forested for all regional hydraulic geometry curves except the combined curves were made, to assess possible land use bias in the watersheds used to construct regional curves. Any significant bias in drainage area, urbanization, and forest conditions between the lithologically controlled curves will result in constraints in the application of these curves. 


\section{Analysis of Channel Sedimentology}

Pebble counts were undertaken to illuminate the nature of downstream textural changes in channel bedload sediments in the study streams. A pebble count quantitatively describes the size distribution of bedload sediments in the channel (Rosgen 1996), and was carried out on each surveyed reach. The procedure, initially described by Wolman (1954), and later modified, involved lying a transect across the bed surface in a channel reach (Bunte et al. 2001). Each clast was selected at predetermined intervals along the transect, by blindly picking up the particle at the tip of the measurer's shoe. The intermediate axis of the particle was measured and the clast returned to the stream channel. The process was repeated until the opposite side of the channel was reached. A new transect was then established, in a zig-zag pattern, and the process was repeated until at least 100 measurements were collected. If a riffle were too small to allow 100 measurements, an adjacent riffle was used for additional data.

Pebble-count data were plotted into size classes according to Rosgen (1996). A cumulative frequency plot was constructed by inputting the sedimentology data into the Reference Reach Spreadsheet v4.3 Level (Mecklenburg 2006), and $\mathrm{D}_{50}$ and $\mathrm{D}_{84}$ particle sizes were calculated. $\mathrm{D}_{50}$ refers to a particle size equal to or larger than $50 \%$ of sampled particles (Rosgen 1996). $D_{84}$ refers to a particle size equal to or larger than $84 \%$ of sampled particles, which is the mean particle size plus one standard deviation. $\mathrm{D}_{50}$ and $\mathrm{D}_{84}$ were plotted versus drainage area for each watershed and for all watersheds. Plots were inspected to assess how particle sizes change in the downstream direction in the study streams. 


\section{$\underline{\text { Results and Interpretations }}$}

\section{$\underline{\text { Regional Curves for Lithologically Controlled Non-Carbonate Watersheds }}$}

\section{Hydraulic Geometry Data Analysis}

Characteristics of each measured riffle, including coordinate locations, descriptive location information, bankfull stage evidence, and hydraulic geometry data are given in Appendix 1. The reach average of bankfull response variables (Table 4) from 34 unique reaches from the six study watersheds (Figures 9-14), was used in development of lithologically controlled regional curves for non-carbonate watershed in the Ridge and Valley Physiographic Province.

Kolmogorov-Smirnov normality tests (Table 5) show the test statistic for drainage area, bankfull width, and bankfull mean depth are less than the critical value of 0.23 ; thus, these data sets are normally distributed. The test statistic for bankfull crosssectional area (Table 5), however, is greater than the critical value of 0.23 , so these data cannot be verified as normally distributed. Transformation of bankfull cross-sectional area data to logarithmic scale converts the sample to a normal distribution, but makes later comparison of regional curves impossible. Keaton et al. (2005) suggested in a similar case, transformation of non-normal data to logarithmic scale is not necessary if regression with drainage area provides a high $\mathrm{R}^{2}$ value and f-statistic value significantly above zero. The bankfull cross-sectional area data set does have a large $\mathrm{R}^{2}$ value and an f-statistic value significantly above zero (Table 6), and therefore remained untransformed.

Regression residuals plots for all bankfull response variables (Figures 15-17) show the dependent bankfull response variables do not have a constant variance with 


\begin{tabular}{|c|c|c|c|c|c|c|c|c|c|}
\hline Watershed & $\begin{array}{c}\text { Reach } \\
\text { I.D. }\end{array}$ & $\begin{array}{c}\text { Drainage } \\
\text { Area } \\
\left(\mathrm{km}^{2}\right) \\
\end{array}$ & $\begin{array}{c}\text { Bankfull } \\
\text { XSA } \\
\left(\mathrm{m}^{2}\right) \\
\end{array}$ & $\begin{array}{c}\text { Bankfull } \\
\text { W } \\
(\mathrm{m})\end{array}$ & $\begin{array}{c}\text { Bankfull } \\
\text { MD } \\
(\mathrm{m})\end{array}$ & $\begin{array}{l}\text { D50 } \\
(\mathrm{mm}) \\
\end{array}$ & $\begin{array}{l}\text { D84 } \\
(\mathrm{mm}) \\
\end{array}$ & $\begin{array}{c}\% \\
\text { Urban }\end{array}$ & $\begin{array}{c}\% \\
\text { Forested }\end{array}$ \\
\hline S. Branch Little Aughwick Creek & 1 & 1.91 & 0.95 & 4.54 & 0.20 & 9 & 76 & 0.00 & 99.11 \\
\hline S. Branch Little Aughwick Creek & 2 & 5.39 & 1.94 & 4.45 & 0.43 & 50 & 130 & 0.00 & 95.45 \\
\hline S. Branch Little Aughwick Creek & 3 & 8.86 & 3.82 & 7.01 & 0.56 & 45 & 130 & 0.00 & 96.88 \\
\hline S. Branch Little Aughwick Creek & 4 & 10.18 & 4.10 & 7.19 & 0.58 & 23 & 83 & 0.00 & 97.30 \\
\hline S. Branch Little Aughwick Creek & 5 & 12.07 & 5.09 & 9.46 & 0.53 & 43 & 160 & 0.00 & 97.68 \\
\hline Sherman Creek & 6 & 4.10 & 2.61 & 7.06 & 0.37 & 59 & 160 & 0.00 & 99.85 \\
\hline Sherman Creek & 7 & 15.39 & 5.27 & 10.87 & 0.49 & 78 & 170 & 0.00 & 98.58 \\
\hline Sherman Creek & 8 & 4.28 & 3.36 & 8.63 & 0.40 & 79 & 180 & 0.00 & 96.04 \\
\hline Sherman Creek & 9 & 21.36 & 5.31 & 9.94 & 0.55 & 94 & 160 & 0.00 & 98.43 \\
\hline Sherman Creek & 10 & 26.05 & 5.59 & 9.39 & 0.61 & 67 & 120 & 0.00 & 97.79 \\
\hline Sherman Creek & 11 & 2.62 & 1.37 & 3.67 & 0.37 & 13 & 84 & 0.00 & 93.70 \\
\hline Horse Valley Run & 12 & 11.34 & 3.54 & 6.77 & 0.53 & 19 & 70 & 0.00 & 88.54 \\
\hline Horse Valley Run & 13 & 36.18 & 9.88 & 16.09 & 0.61 & 42 & 130 & 0.81 & 94.91 \\
\hline Horse Valley Run & 14 & 12.90 & 3.68 & 7.62 & 0.49 & 40 & 120 & 0.20 & 99.45 \\
\hline Horse Valley Run & 15 & 10.05 & 2.96 & 6.39 & 0.47 & 39 & 90 & 0.21 & 99.41 \\
\hline Horse Valley Run & 16 & 7.54 & 2.36 & 4.75 & 0.50 & 84 & 130 & 0.16 & 99.39 \\
\hline Horse Valley Run & 17 & 3.99 & 2.18 & 6.00 & 0.37 & 76 & 140 & 0.00 & 99.39 \\
\hline Laurel Run & 18 & 3.70 & 1.87 & 5.36 & 0.35 & 90 & 210 & 0.00 & 100.00 \\
\hline Laurel Run & 19 & 13.21 & 4.89 & 10.10 & 0.49 & 77 & 180 & 0.00 & 99.32 \\
\hline Laurel Run & 20 & 1.97 & 1.54 & 4.25 & 0.37 & 59 & 130 & 0.00 & 100.00 \\
\hline Laurel Run & 21 & 5.49 & 3.13 & 5.82 & 0.53 & 93 & 210 & 0.00 & 99.79 \\
\hline Laurel Run & 22 & 19.35 & 4.53 & 7.18 & 0.62 & 93 & 210 & 0.00 & 99.21 \\
\hline Laurel Run & 23 & 28.02 & 4.93 & 7.32 & 0.69 & 90 & 210 & 0.00 & 99.37 \\
\hline Laurel Run & 24 & 36.23 & 5.76 & 12.02 & 0.46 & 97 & 180 & 0.00 & 98.63 \\
\hline Conodoguinet Creek & 25 & 73.30 & 12.11 & 17.85 & 0.67 & 62 & 120 & 0.01 & 94.99 \\
\hline Conodoguinet Creek & 26 & 65.45 & 13.03 & 13.99 & 0.94 & 58 & 120 & 0.00 & 94.62 \\
\hline Conodoguinet Creek & 27 & 52.58 & 14.03 & 16.84 & 0.85 & 87 & 150 & 0.00 & 95.04 \\
\hline Conodoguinet Creek & 28 & 41.62 & 13.37 & 15.12 & 0.88 & 44 & 97 & 0.00 & 93.31 \\
\hline Conodoguinet Creek & 29 & 12.15 & 4.93 & 8.43 & 0.59 & 48 & 93 & 0.00 & 97.93 \\
\hline West Licking Creek & 30 & 4.30 & 1.24 & 4.02 & 0.30 & 110 & 210 & 0.00 & 99.14 \\
\hline West Licking Creek & 31 & 6.97 & 2.08 & 5.43 & 0.38 & 110 & 200 & 0.00 & 99.29 \\
\hline West Licking Creek & 32 & 15.93 & 4.21 & 7.25 & 0.58 & 120 & 230 & 0.00 & 99.19 \\
\hline West Licking Creek & 33 & 19.32 & 4.66 & 8.72 & 0.53 & 94 & 170 & 0.00 & 99.25 \\
\hline West Licking Creek & 34 & 26.16 & 5.77 & 10.58 & 0.55 & 110 & 230 & 0.00 & 99.16 \\
\hline
\end{tabular}

Table 4. Characteristics of sites used to develop lithologically controlled regional curves for non-carbonate watersheds. Key to symbols in table: [XSA] Cross-Sectional Area, [W] Width, [MD] Mean Depth. 


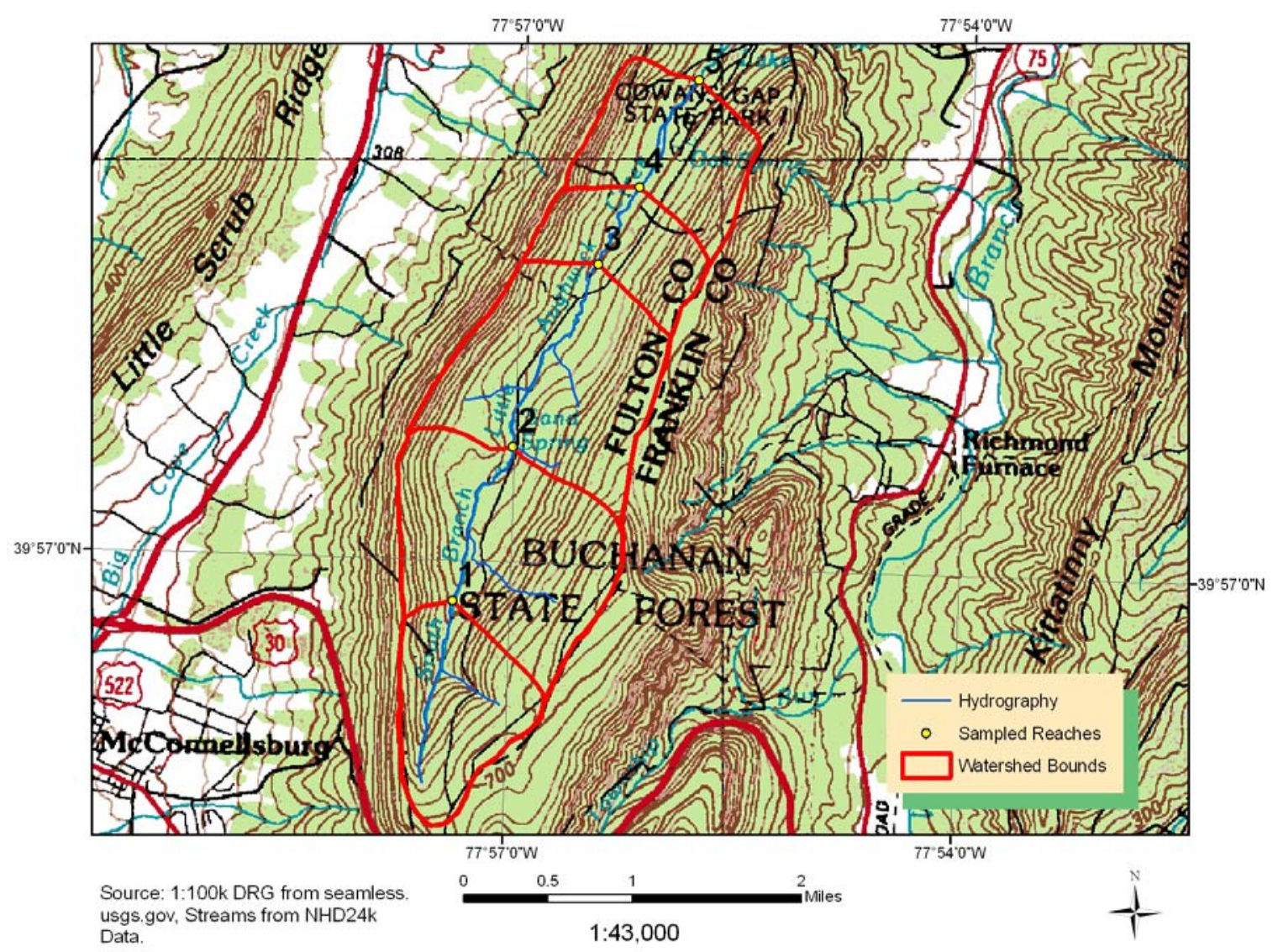

Figure 9. Topographic map showing measured reaches along South Branch Little Aughwick Creek. 


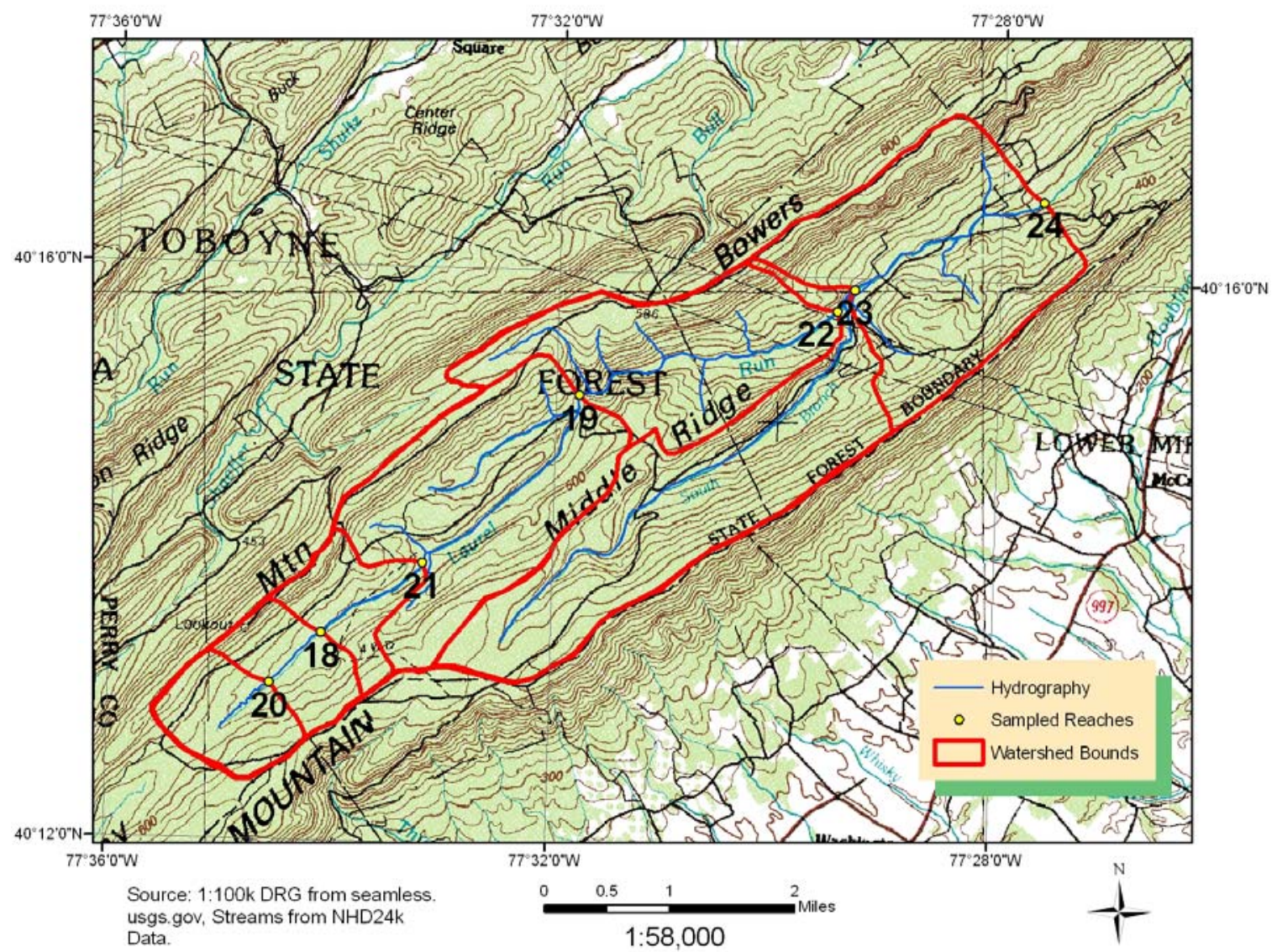

Figure 10. Topographic map showing measured reaches along Laurel Run. 


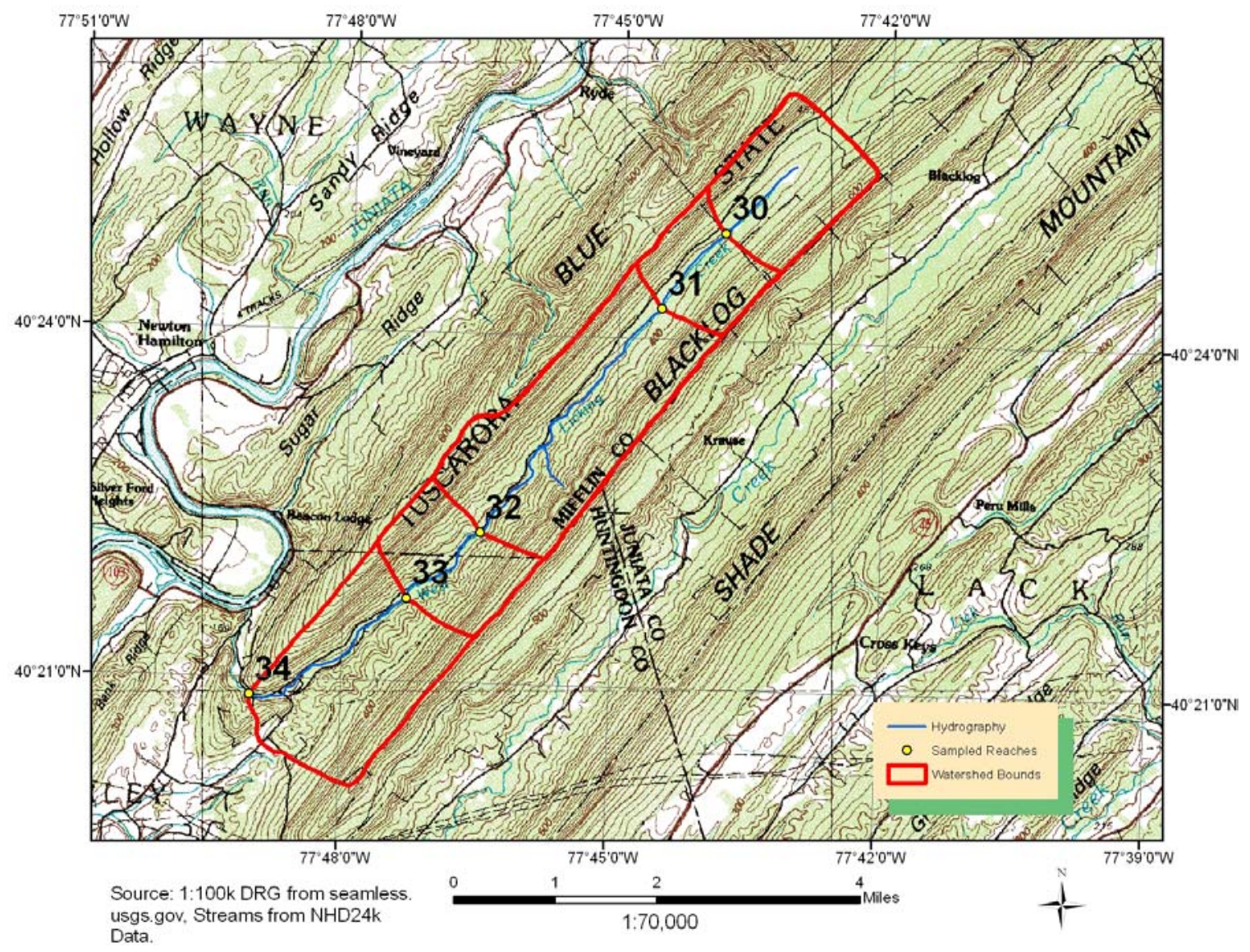

Figure 11. Topographic map showing measured reaches along West Licking Creek. 


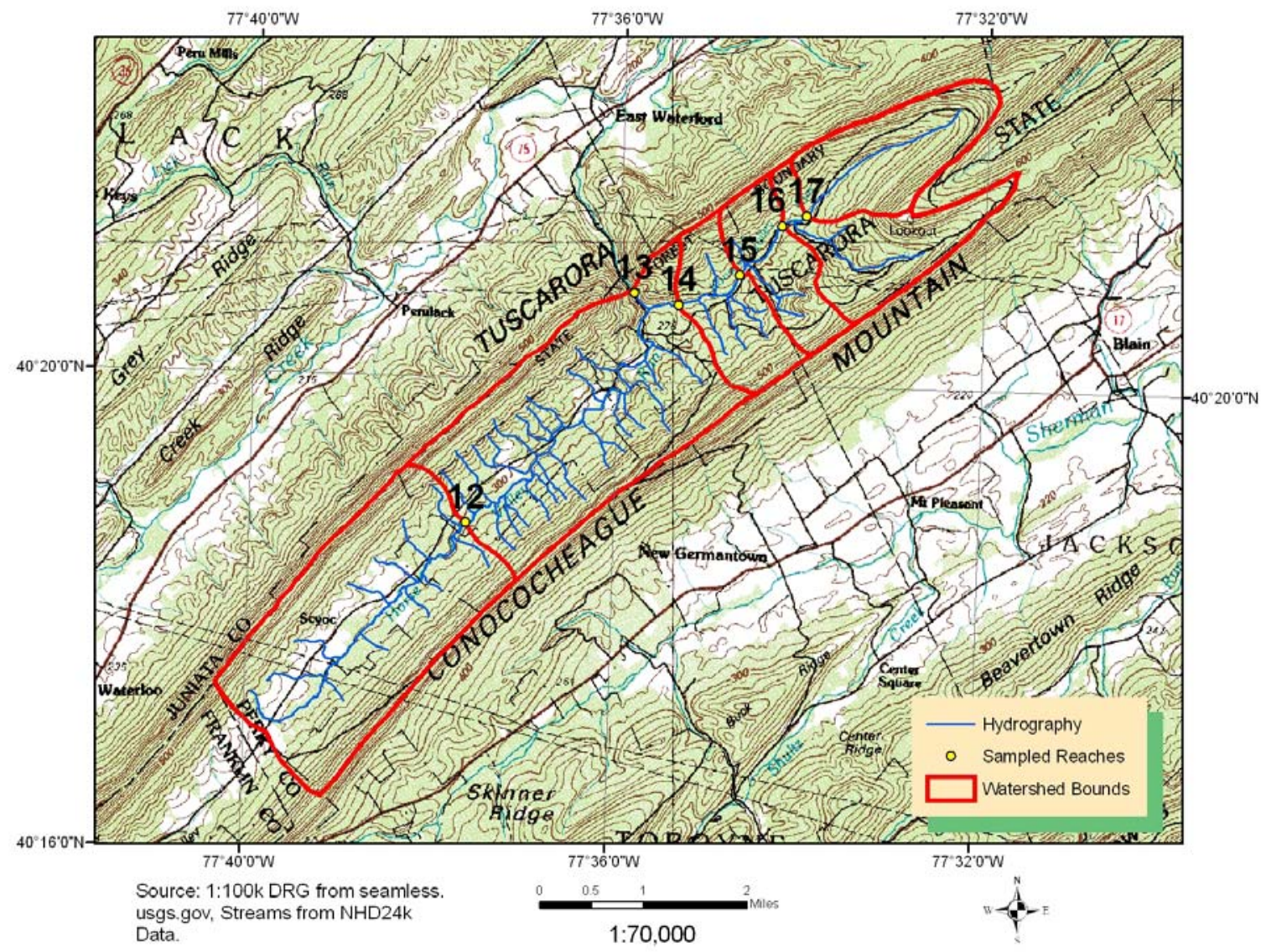

Figure 12. Topographic map showing measured reaches along Horse Valley Run. 


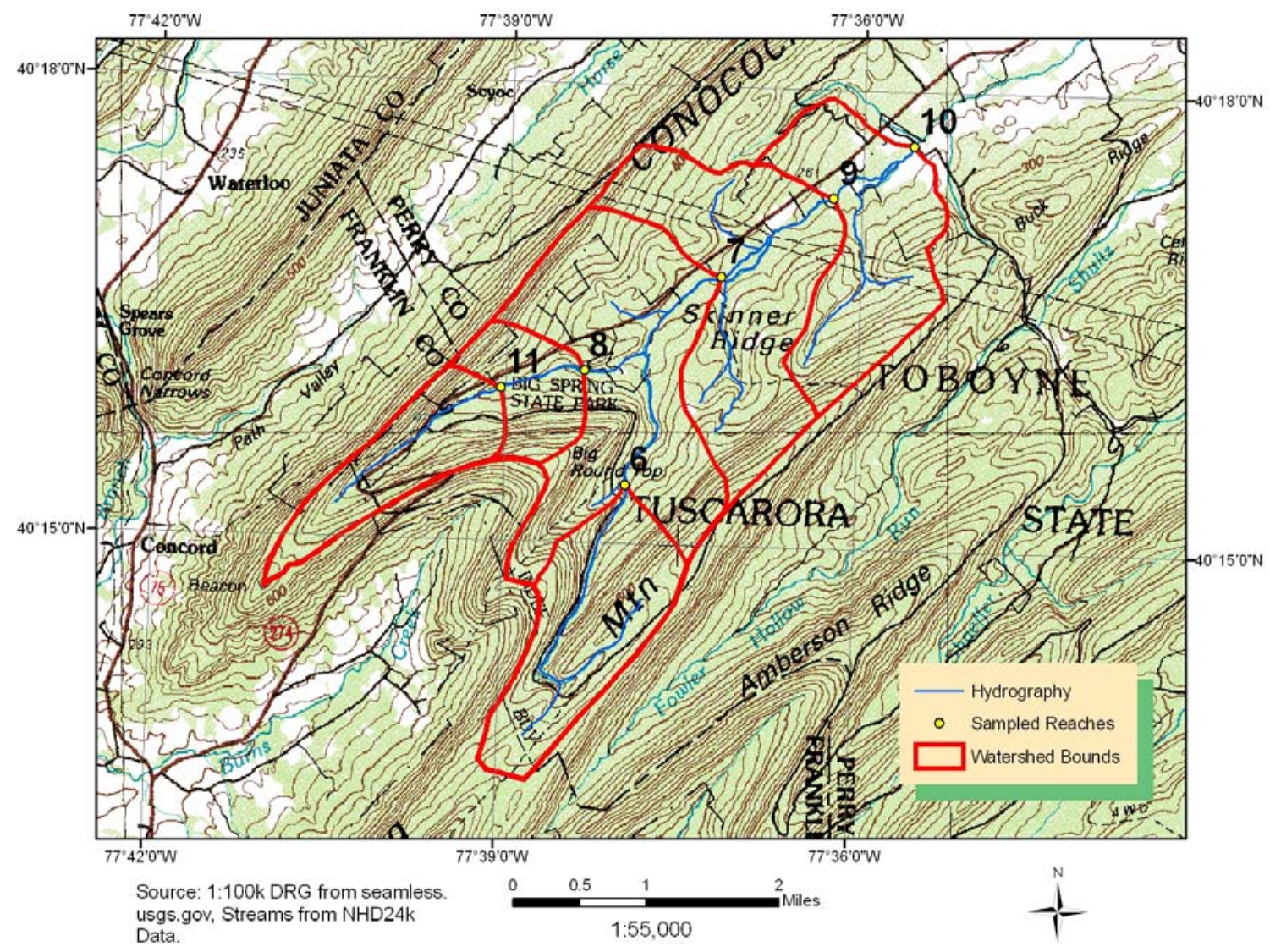

Figure 13. Topographic map showing measured reaches along Sherman Creek. 


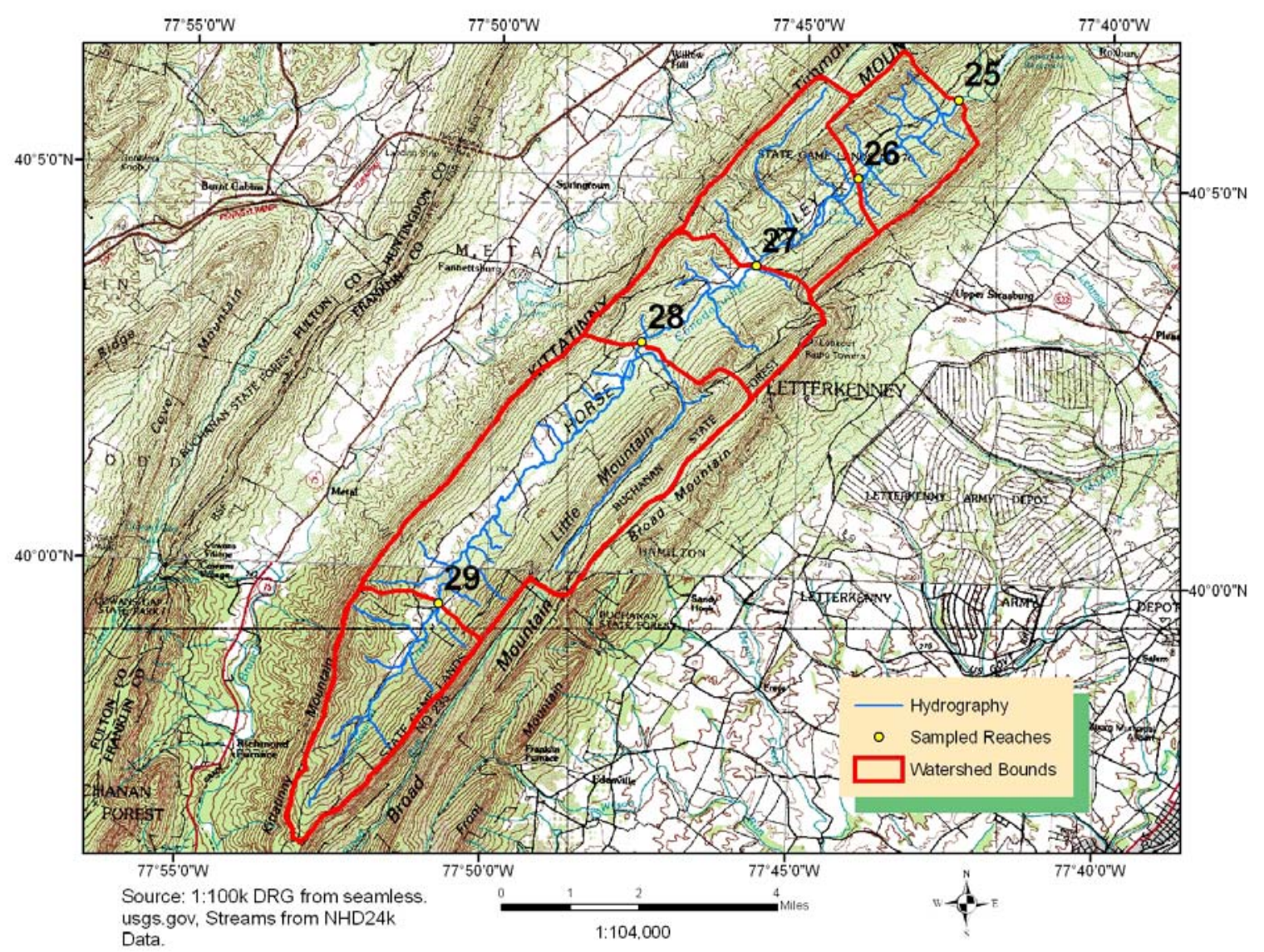

Figure 14. Topographic map showing measured reaches along Conodoguinet Creek. 


\begin{tabular}{|l|c|}
\hline \multicolumn{1}{|c|}{ Sample Description } & Kolmogorov-Smirnov Test Statistic \\
\hline Drainage Area & 0.199 \\
\hline Cross-Sectional Area & 0.254 \\
\hline Width & 0.155 \\
\hline Depth & 0.119 \\
\hline
\end{tabular}

Table 5. Kolmogorov-Smirnov normality test statistics for lithologically controlled regional curves for non-carbonate watersheds. A sample size $(n)=34$ yields a critical value of 0.23 . 


\begin{tabular}{|l|r|r|r|r|c|}
\hline \multicolumn{1}{|c|}{$\begin{array}{c}\text { Response } \\
\text { Variable }\end{array}$} & Equation & Slope & Y Intercept & $\mathbf{R}^{2}$ & F-statistic \\
\hline $\begin{array}{l}\text { Cross- } \\
\text { Sectional Area }\end{array}$ & ${\mathrm{CSA}=0.791 \mathrm{DA}^{0.649}}$ & 0.649 & 0.791 & 0.88 & 633.90 \\
\hline Width & $\mathrm{W}=3.061 \mathrm{DA}^{0.380}$ & 0.380 & 3.061 & 0.78 & 229.90 \\
\hline Mean Depth & $\mathrm{D}=0.256 \mathrm{DA}^{0.273}$ & 0.273 & 0.256 & 0.73 & 134.72 \\
\hline
\end{tabular}

Table 6. Summary of quantitative attributes for lithologically controlled regional curves for non-carbonate watersheds. 


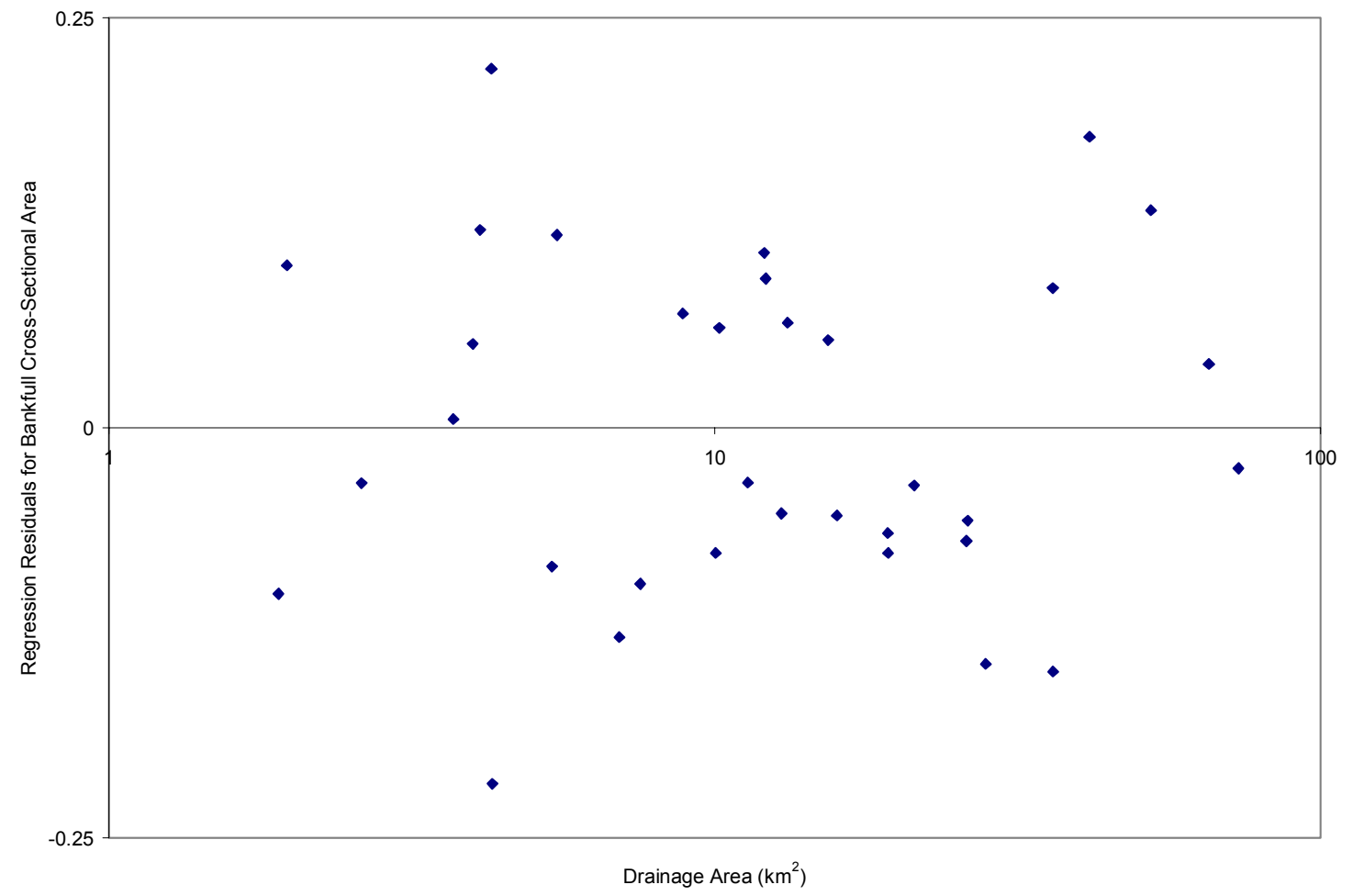

Figure 15. Regression residuals plot for bankfull cross-sectional area for lithologically controlled regional curves for non-carbonate watersheds. 


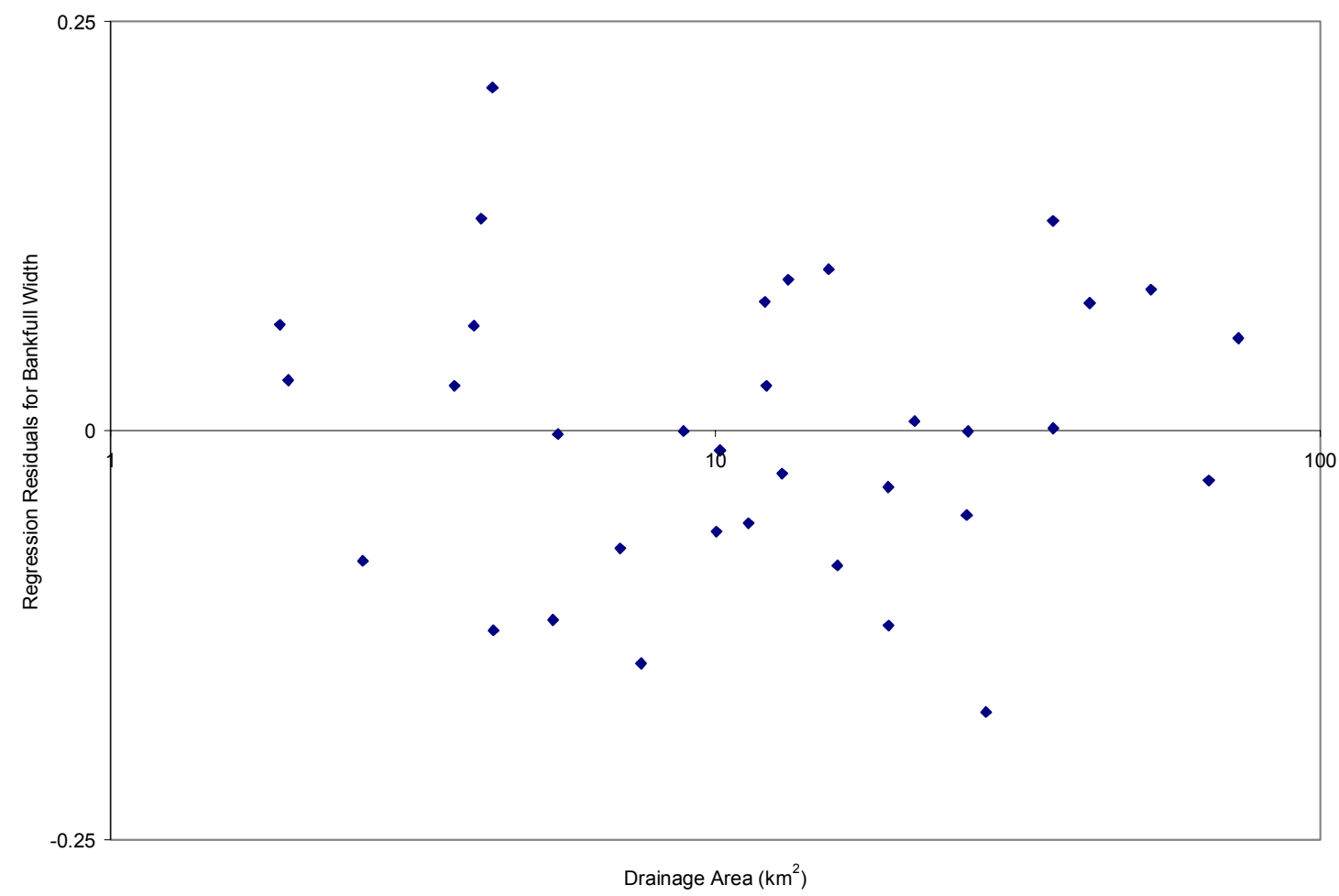

Figure 16. Regression residuals plot for bankfull width for lithologically controlled regional curves for non-carbonate watersheds. 


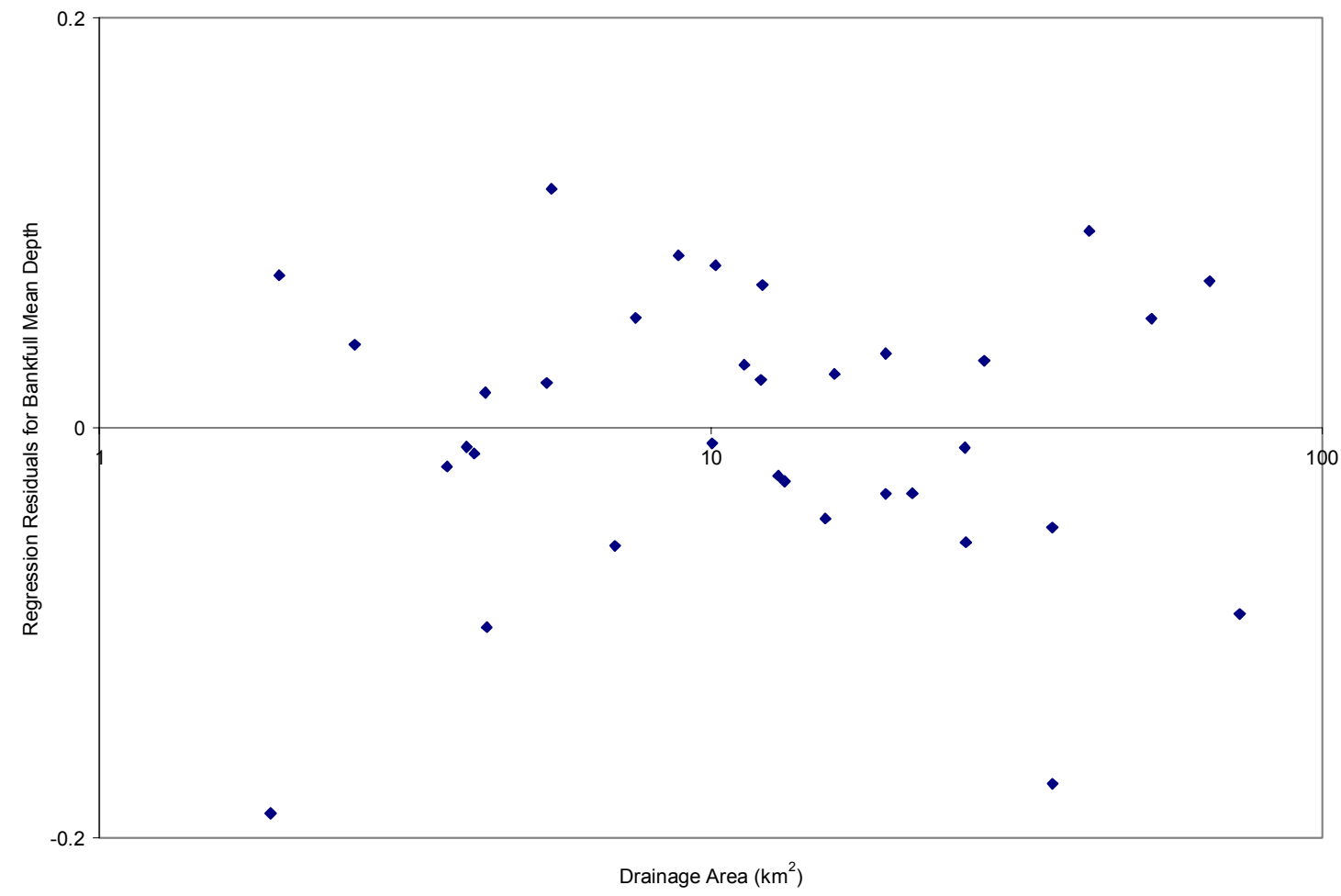

Figure 17. Regression residuals plot for bankfull mean depth for lithologically controlled regional curves for non-carbonate watersheds. 
respect to the independent variable, drainage area. This condition, referred to as heteroscedasticity, violates a requirement of regression analysis. Due to inherent variability in the hydraulic geometry of mountain streams, a constant variance of the dependent bankfull response variables is not expected. Further visual inspection of the plots shows the residuals are randomly distributed around the regression line. The lack of distinctive grouping of the residuals verifies the sampled data is non-autocorrelated. The last two requirements to perform regression analysis, a causal and linear relationship between the independent and dependent variables are assumed.

\section{Regional Curve Development}

The bankfull cross-sectional area regional curve (Figure 18) has the largest $\mathrm{R}^{2}$ value, 0.88 , followed by bankfull width (Figure 19) and bankfull mean depth (Figure 20) values of 0.78 and 0.73 , respectively (Table 6). The f-statistic value for the bankfull cross-sectional area regional curve is highest, 232.73 , followed by bankfull width and bankfull mean depth values of 110.29 and 88.13, respectively (Table 6). Thus, the bankfull cross-sectional area regional curve displays the least variance and best fit, followed by bankfull width and lastly bankfull mean depth, as evidenced by $\mathrm{R}^{2}$ and $\mathrm{f}$ statistic values (Table 6).

\section{Comparison of Regional Curves}

The p-values (Table 7) show a statistically different slope and y-intercept exists between the bankfull cross-sectional area regional curves for lithologically controlled regional curves for non-carbonate watersheds and Chaplin's (2005) curves for noncarbonate watersheds. The p-value and coefficient for $y$-intercept for bankfull 


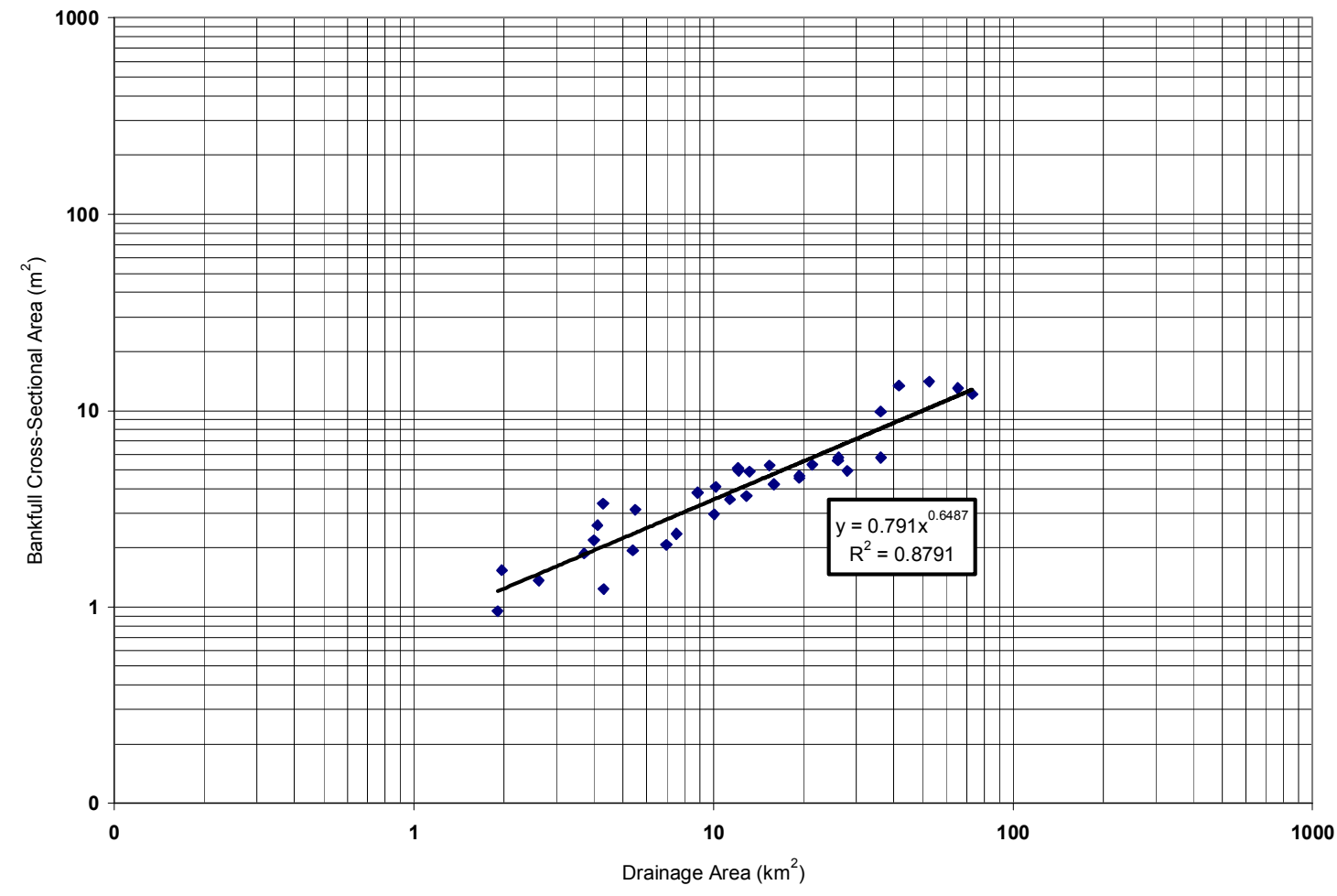

Figure 18. Lithologically controlled regional curve for non-carbonate watersheds for bankfull cross-sectional area. 


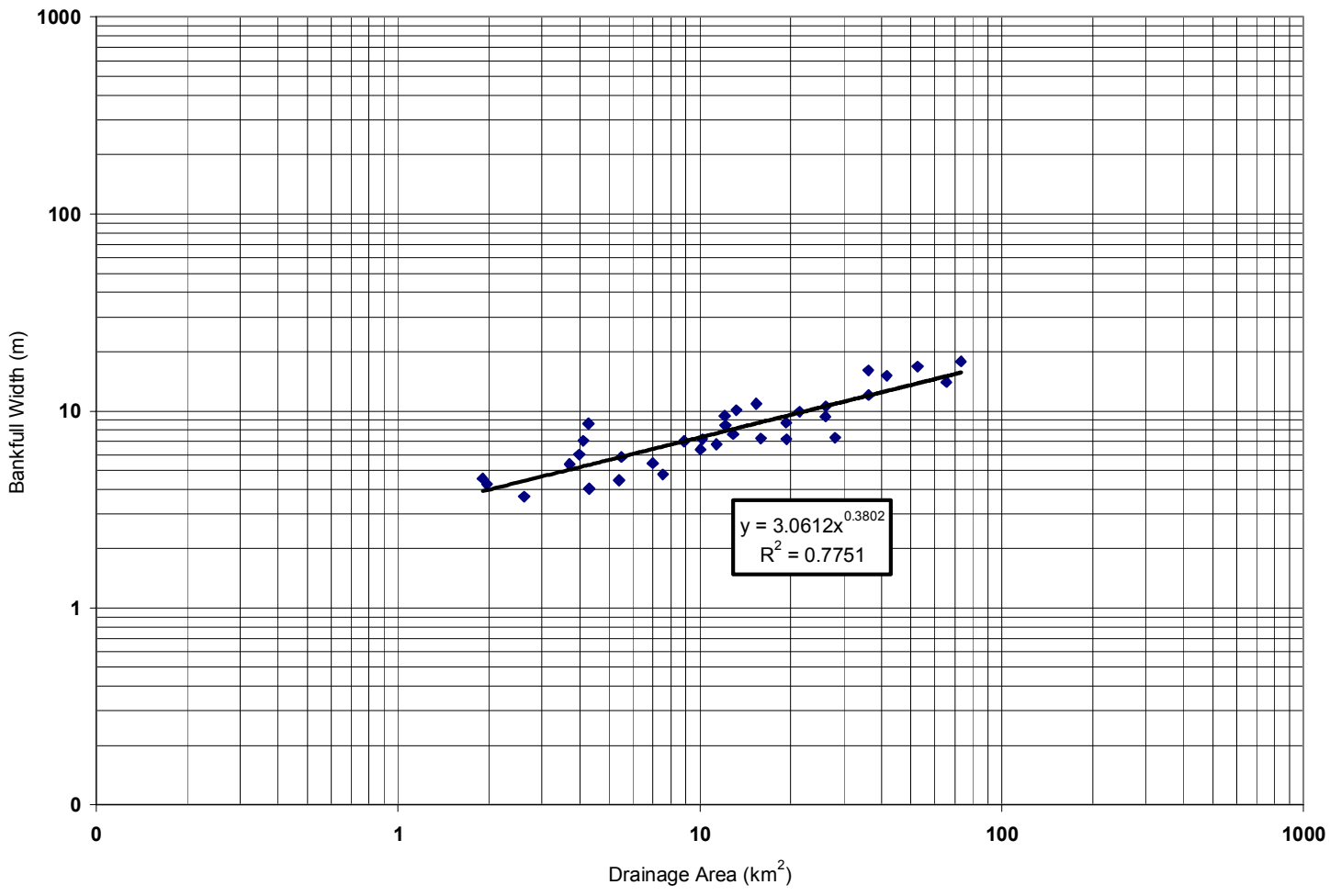

Figure 19. Lithologically controlled regional curve for non-carbonate watersheds for bankfull width. 


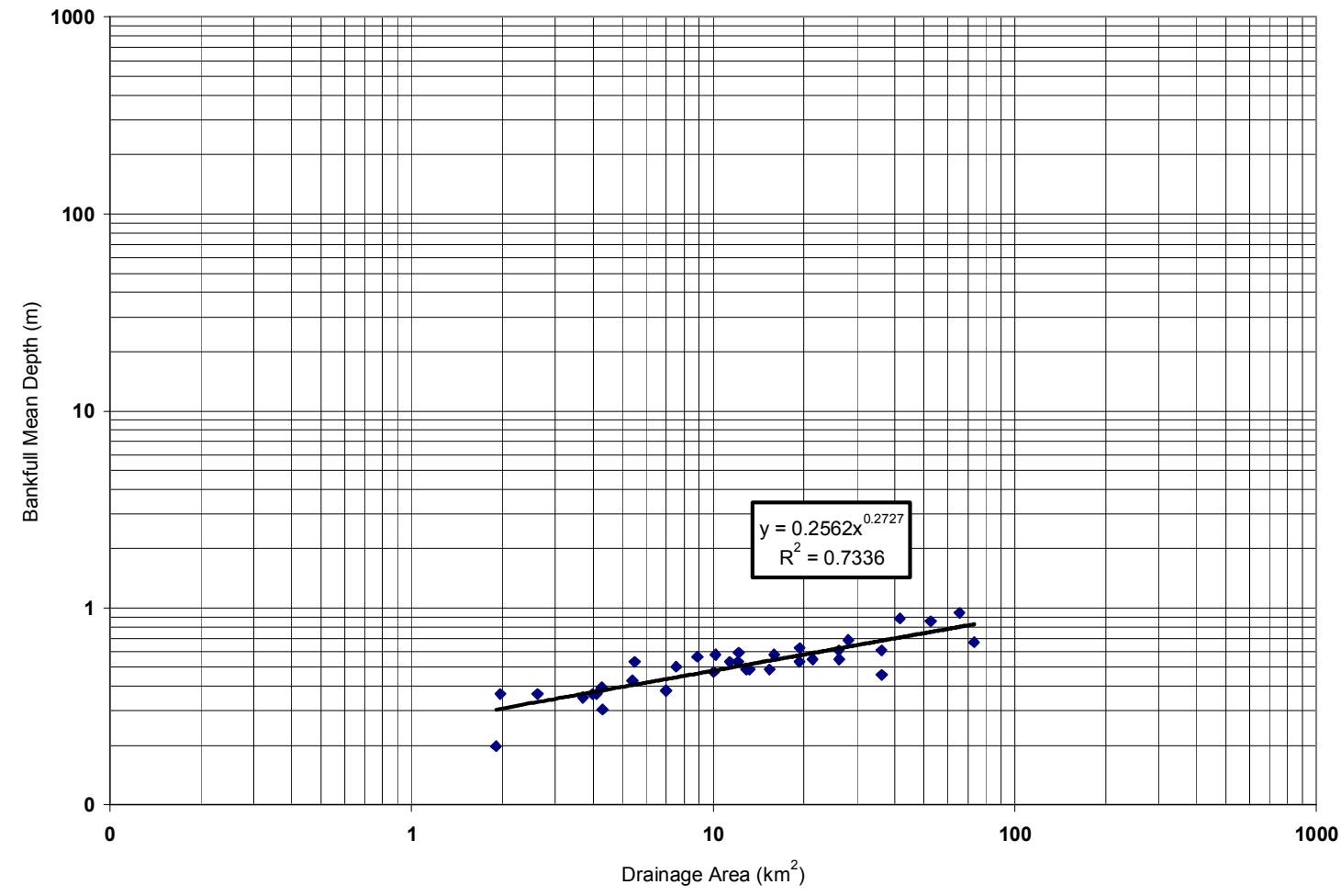

Figure 20. Lithologically controlled regional curve for non-carbonate watersheds for bankfull mean depth. 


\begin{tabular}{|c|c|c|c|c|c|c|}
\hline \multicolumn{7}{|c|}{ Bankfull Cross-Sectional Area $\left(\mathrm{m}^{2}\right)$} \\
\hline & & & Intercept & Intercept & Slope & Slope \\
\hline Data & $\mathrm{N}$ & $\mathbf{R}^{2}$ & p-value & Coefficient & $p$-value & Coefficient \\
\hline Controlled Curves & 34 & 0.88 & 0.031 & 0.179 & 0.008 & -0.148 \\
\hline Chaplin's Curves & 55 & 0.92 & --- & --- & --- & --- \\
\hline \multicolumn{7}{|l|}{ Bankfull Width $(m)$} \\
\hline & & & Intercept & Intercept & Slope & Slope \\
\hline Data & $\mathbf{N}$ & & p-value & Coefficient & $\mathrm{p}$-value & Coefficient \\
\hline Controlled Curves & 34 & 0.78 & 0.777 & 0.021 & 0.166 & -0.069 \\
\hline Chaplin's Curves & 55 & 0.81 & --- & --- & --- & --- \\
\hline \multicolumn{7}{|c|}{ Bankfull Depth (m) } \\
\hline & & & Intercept & Intercept & Slope & Slope \\
\hline Data & $\mathbf{N}$ & & p-value & Coefficient & p-value & Coefficient \\
\hline Controlled Curves & 34 & 0.73 & 0.083 & 0.119 & 0.204 & -0.058 \\
\hline Chaplin's Curves & 55 & 0.72 & --- & --- & --- & --- \\
\hline
\end{tabular}

Table 7. Statistical results from analysis of covariance comparison between lithologically controlled curves and Chaplin's (2005) curves. 
cross-sectional area is 0.031 and 0.179 (Table 7). The p-value and coefficient for slope for the bankfull cross-sectional area curve is 0.008 and -0.148 for slope (Table 7). Thus, the lithologically controlled regional curve for non-carbonate watersheds for bankfull cross-sectional area has a slightly higher y-intercept and slightly lower slope, than Chaplin's (2005) bankfull cross-sectional area curve. Bankfull width and bankfull mean depth regional curve y-intercepts and slopes have p-values greater than 0.05 , and therefore can not be shown to be statistically different. As a result, this study's hypothesis that regional curves developed for small mountain streams with abundant coarse sandstone alluvium will produce wider and shallower dimensions in comparison to curves developed for whole physiographic provinces, must be rejected.

Coefficient of determination $\left(\mathrm{R}^{2}\right)$ values for both curves (Table 7) reveal the bankfull cross-sectional area regional curves have the largest $R^{2}$ values, with a value of 0.92 for Chaplin's (2005) curves and 0.88 for the lithologically controlled curves. $\mathrm{R}^{2}$ values for the bankfull width regional curves are 0.81 for Chaplin's (2005) curves and 0.78 for the lithologically controlled curves. Accordingly, drainage area explains more variance in bankfull cross-sectional area and bankfull width for Chaplin's (2005) regional curves. The bankfull mean depth curves have $\mathrm{R}^{2}$ values of 0.73 for the lithologically controlled curves and 0.72 for Chaplin's (2005) curves. Overall, only minor differences in $\mathrm{R}^{2}$ values and, therefore, regression validity, exist between both regional curves.

Drainage area statistics (Table 8) reveals the watersheds used to construct lithologically controlled curves are on average much smaller than those used to construct Chaplin's (2005) curves. The mean drainage area for sites used to develop the lithologically controlled curves was $18.2 \mathrm{~km}^{2}$, compared to a mean of $164.2 \mathrm{~km}^{2}$ for sites 


\begin{tabular}{|c|c|c|c|c|c|}
\hline $\begin{array}{l}\text { Regional Curve } \\
\text { Description }\end{array}$ & Samples & Mean & Median & Range & $\begin{array}{l}\text { Standard } \\
\text { Deviation }\end{array}$ \\
\hline $\begin{array}{l}\text { Lithologically } \\
\text { Controlled Regional } \\
\text { Curves }\end{array}$ & 34 & 18.2 & 12.1 & $1.91-73.3$ & 17.9 \\
\hline $\begin{array}{l}\text { Chaplin's Regional } \\
\text { Curves }\end{array}$ & 55 & 164.2 & 119.7 & $8.93-554.3$ & 148.6 \\
\hline $\begin{array}{l}\text { Ridge \& Valley } \\
\text { Regional Curves }\end{array}$ & 18 & 221.6 & 135.1 & $13.7-554.3$ & 177.3 \\
\hline $\begin{array}{l}<75 \mathrm{~km}^{2} \text { Regional } \\
\text { Curves }\end{array}$ & 19 & 32.7 & 30.6 & $8.92-72.5$ & 18.5 \\
\hline $\begin{array}{l}\text { Combined Regional } \\
\text { Curves }\end{array}$ & 89 & 108.4 & 41.6 & $1.91-554.3$ & 137.0 \\
\hline
\end{tabular}

Table 8. Central tendency statistics for watershed drainage area of regional curves. Statistics calculated for lithologically controlled regional curves, Chaplin's (2005) regional curves, regional curves for watersheds $<75 \mathrm{~km} 2$, regional curves for the Ridge and Valley, and combined regional curves. Drainage area units are in $\mathrm{km}^{2}$. 
in Chaplin's (2005) curves. A greater range (Table 8) of drainage areas was sampled to construct Chaplin's (2005) curves.

Means for percent watershed urbanized for regional curves (Table 9) shows both are derived from watersheds having very minimal urban land use. The mean of percent watershed urbanized for lithologically controlled curves was $0.04 \%$, compared to $1.63 \%$ for Chaplin's (2005) curves. Watersheds with a broader range in urbanized conditions were sampled to construct Chaplin's (2005) regional curves. Lithologically controlled curves are derived from heavily forested watersheds, displaying on average $97.7 \%$ forest cover, whereas Chaplin's (2005) curves were constructed from watersheds with a mean of only $64.4 \%$ forest cover (Table 10 ).

\section{Interpretations}

Analysis shows the lithologically controlled regional curve for bankfull crosssectional area has a statistically different slope and y-intercept than Chaplin's (2005). Bedrock geology, geologic structure, physiography, channel gradient, watershed size, riparian vegetation, and land-use conditions may influence differences in the slope and yintercept of the regional curves. Bedrock geology is similar in this study's watersheds, but, in contrast, the bedrock geology of Chaplin's (2005) watersheds consists of a much broader range of lithologies (Sevon 2000).

Differences are apparent in physiography of the watersheds used to construct both regional curves. Lithologically controlled curves in this study are derived solely from watersheds in the Ridge and Valley Physiographic Province; on the contrary, Chaplin's (2005) curves come from watersheds located in several physiographic provinces. 


\begin{tabular}{|l|r|r|r|r|r|}
\hline $\begin{array}{l}\text { Regional Curve } \\
\text { Description }\end{array}$ & Samples & Mean & Median & Range & $\begin{array}{c}\text { Standard } \\
\text { Deviation }\end{array}$ \\
\hline $\begin{array}{l}\text { Lithologically } \\
\begin{array}{l}\text { Oontrolled Regional } \\
\text { Curves }\end{array}\end{array}$ & 34 & 0.04 & 0.00 & $0.00-0.81$ & 0.15 \\
\hline $\begin{array}{l}\text { Chaplin's Regional } \\
\text { Curves }\end{array}$ & 55 & 1.63 & 0.80 & $0.00-19.0$ & 3.45 \\
\hline $\begin{array}{l}\text { Ridge \& Valley } \\
\text { Regional Curves }\end{array}$ & 18 & 1.63 & 1.15 & $0.00-5.80$ & \\
\hline \\
$\begin{array}{l}<75 \mathrm{~km}^{2} \text { Regional } \\
\text { Curves }\end{array}$
\end{tabular}

Table 9. Central tendency statistics for percent watershed urbanized of regional curves. Statistics calculated for lithologically controlled regional curves, Chaplin's (2005) regional curves, regional curves for watersheds $<75 \mathrm{~km}^{2}$, and regional curves for the Ridge and Valley. Values calculated without data for six watersheds for Chaplin's (2005) curves. 


\begin{tabular}{|l|r|r|r|r|r|}
\hline $\begin{array}{l}\text { Regional Curve } \\
\text { Description }\end{array}$ & Samples & Mean & Median & Range & $\begin{array}{c}\text { Standard } \\
\text { Deviation }\end{array}$ \\
\hline $\begin{array}{l}\text { Lithologically } \\
\text { Controlled Regional } \\
\text { Curves }\end{array}$ & 34 & 97.7 & 98.9 & $88.5-100.0$ & 2.55 \\
\hline $\begin{array}{l}\text { Chaplin's Regional } \\
\text { Curves }\end{array}$ & 55 & 64.4 & 64.0 & $20.0-100.0$ & 21.1 \\
\hline $\begin{array}{l}\text { Ridge \& Valley } \\
\text { Regional Curves }\end{array}$ & 18 & 58.4 & 67.5 & $31.0-83.0$ & 18.3 \\
\hline $\begin{array}{l}<75 \mathrm{~km}^{2} \text { Regional } \\
\text { Curves }\end{array}$ & 19 & 64.3 & 63.0 & $20.0-99.0$ & 24.4 \\
\hline
\end{tabular}

Table 10. Central tendency statistics for percent watershed forested of regional curves. Statistics calculated for lithologically controlled regional curves, Chaplin's (2005) regional curves, regional curves for watersheds $<75 \mathrm{~km} 2$, and regional curves for the Ridge and Valley. Values calculated without data for six watersheds for Chaplin's (2005) curves. 
Geological structure and surface processes vary across physiographic provinces (Sevon 2000), potentially influencing the slope and y-intercept of regional curves. For instance, the Ridge and Valley Physiographic Province that hosts this study's sites is dominated by fluvial erosion and relict periglacial mass wasting (Sevon 2000), while Chaplin's (2005) study also includes areas of glacial erosion and deposition.

Based upon field observations, channel gradients are high and might be greater in the watersheds used to construct lithologically controlled curves. The lithologically controlled watersheds are located in mountainous areas characterized by high gradient riffles and lower gradient pools. Observation of adjacent riffles in the lithologically controlled watersheds suggests significant variability in slope exists. As channel gradient increases, velocity does the same, possibly resulting in significant local differences in discharge between successive riffles. Variability in discharge between riffles of differing gradient may result in different channel-forming discharges for riffle sections within a single reach, and therefore impact channel form, and the resultant regional curves. On the contrary, channel gradient is likely lower and less variable on the lowland rivers sampled by Chaplin (2005), so stream flows would be more uniform, leading to less variable channel dimensions.

Watersheds used to construct Chaplin's (2005) curves are on average much larger and consist of a wider range in drainage areas than those in this study. Accordingly, much of the difference in slope and y-intercept of the regression lines may be due to data that is not common to both studies. For instance, the smaller drainage areas of this study's lithologically controlled curves and the larger drainage area of Chaplin's (2005) curves may have a considerable influence on their respective regression lines. In 
addition, smaller watersheds are prone to a flashier hydrologic regime in comparison to larger watersheds. Rapid delivery of precipitation to stream channels in small watersheds is the result of steep slopes that transition from ridges. On the contrary, larger watersheds generally have gentler slopes and as a result, precipitation takes a longer time to be delivered to channels.

Land use, including the impacts of urbanization and deforestation, can alter runoff processes and change flood frequency (Wohl 2000). Urbanization and deforestation results in an increase in the production of hill slope sediment and a decrease in infiltration, resulting in an increase in water yield (Wohl 2000). The lithologically controlled regional curves and Chaplin's (2005) curves are both derived from dominantly rural watersheds, so the percent of urban land probably does not significantly influence the relations. However, the percent of forestation, does vary significantly between watersheds used in the two regional curves and might influence the slope and y-intercept of the curves. Lithologically controlled regional curves are derived from watersheds almost entirely forested; while watersheds used to construct Chaplin's (2005) curves are on average approximately two-thirds forested.

Riparian vegetation is an important factor in determining the strength of channel banks (Knighton 1998) and thus, influences channel dimensions. Vegetation at most lithologically controlled sites has forest cover, with a few located in grasslands or pastures. Chaplin (2005) did not mention riparian vegetation for his non-carbonate watersheds, but differences in riparian vegetation type and vegetation density between regional curves may exist and may yield differences in the attributes of curves. 
The factors influencing differences in $\mathrm{R}^{2}$ values between regional curves may include the number of sites used in curve development, watershed size, and channel gradient. Twenty-one fewer sites were used to construct the lithologically controlled regional curves than were used to construct Chaplin's (2005) curves. As sample size increases, the precision of any statistical test increases (Kachigan 1986). In this case, Chaplin's (2005) curves for bankfull cross-sectional area and bankfull width have larger $\mathrm{R}^{2}$ values and less variance versus the lithologically controlled curves, possibly in large part as a result of a larger sample size.

Channel gradient is steeper along small mountain streams and floodplains are not as well developed as they are in lowland settings. Correct identification of the bankfull stage is a prerequisite when sampling watersheds to develop regional curves. Therefore, difficulty in accurately identifying the floodplain in high-gradient mountain streams may result in hydraulic geometry relationships with more variance. Curves developed with lowland rivers, with better developed and easier to identify floodplains, likely should show less variance. Furthermore, smaller streams may be more difficult to survey precisely because the intricacies of channel form are more subtle. Thus, surveying error in small channels may result in greater relative errors in calculation of the bankfull response variables, than would occur on larger channels.

$\underline{\text { Regional Curves for Non-carbonate Watersheds Draining Areas }<75 \mathrm{~km}^{2}}$

\section{Hydraulic Geometry Data Analysis}

The characteristics of 19 streams draining non-carbonate watersheds (Table 11), initially investigated by Chaplin (2005), were used in the development of regional curves for watersheds draining areas $<75 \mathrm{~km}^{2}$ in the Piedmont, Ridge and Valley, Appalachian 


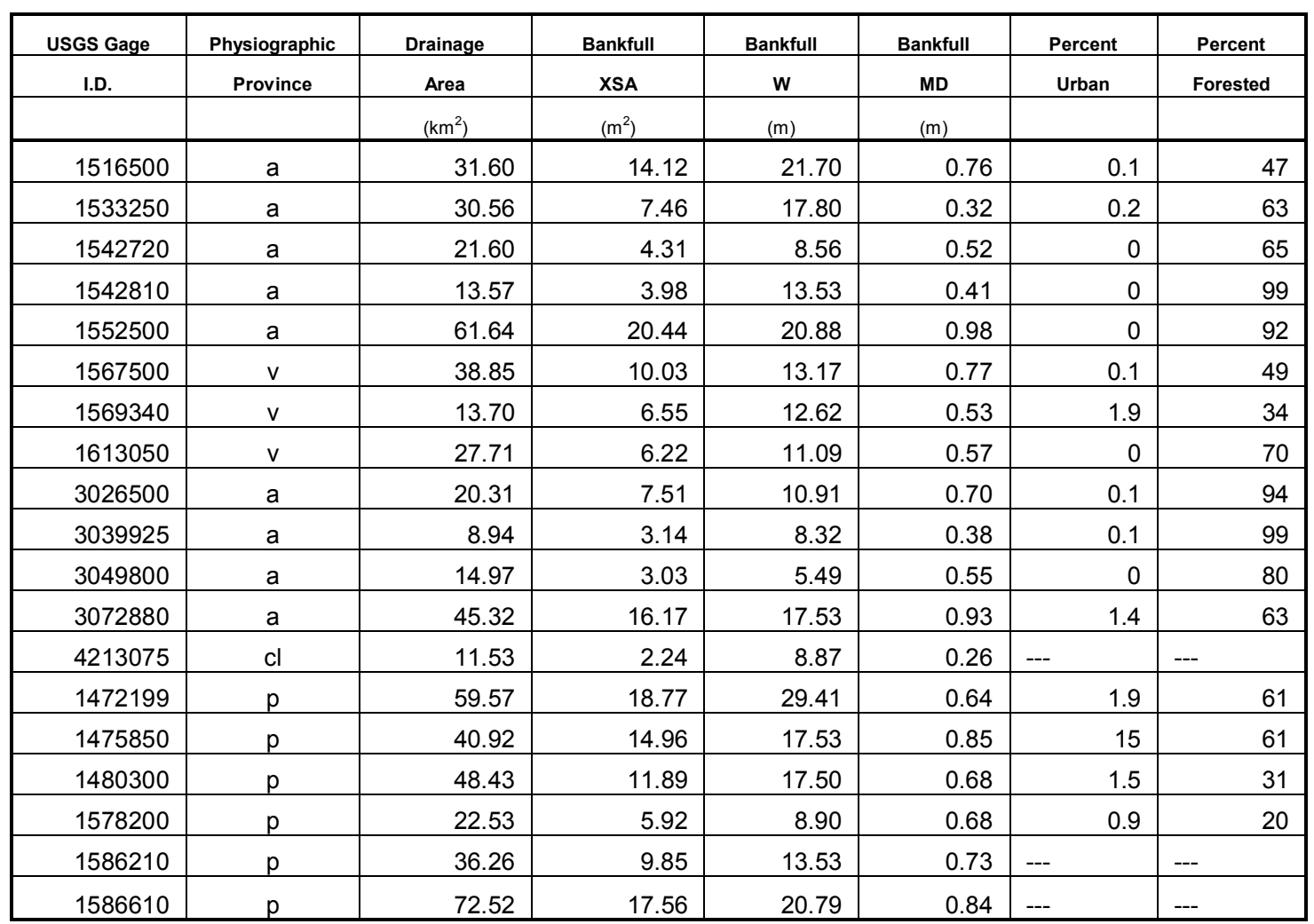

Table 11. Characteristics of sites used to develop regional curves for non-carbonate watersheds $<75 \mathrm{~km} 2$. Key to symbols in table: [XSA] Cross-Sectional Area, [W] Width, [MD] Mean Depth, [v] Ridge and Valley, [a] Appalachian Plateaus, [cl] Central Lowland, [p] Piedmont, [---] missing data. 
Plateaus, and Central Lowland Physiographic Provinces in Pennsylvania and selected areas of Maryland.

Kolmogorov-Smirnov normality tests (Table 12) for drainage area and all bankfull response variables show all test statistics are less than the critical value of 0.3 , and thus the data are normally distributed. Plots of regression residuals for bankfull response variables (Figures 21-23) reveal the variances are not all equal, resulting in heteroscedasticity. The residuals plots show no distinctive grouping above or below the regression line, suggesting the residuals are randomly distributed about the regression line, and non-autocorrelation is assumed. The last two requirements to perform regression analysis, a causal and linear relationship between the independent and dependent variables also are assumed.

\section{Regional Curve Development}

$\mathrm{R}^{2}$ values for bankfull cross-sectional area (Figure 24), bankfull width (Figure 25), and bankfull mean depth (Figure 26) are 0.846, 0.607, and 0.536, respectively (Table 13). $R^{2}$ values for bankfull width and bankfull mean depth regional curves are significantly lower than 1.0, indicating a large amount of variance is unexplained. Fstatistic values for bankfull cross-sectional area, bankfull width, and bankfull mean depth (Table 13) are rather low; confirming a large amount of variance is unexplained in these curves. The bankfull cross-sectional area regional curve displays the least variance and best fit, followed by bankfull width and, lastly, bankfull mean depth, as evidenced by $\mathrm{R}^{2}$ and f-statistic values. 


\begin{tabular}{|l|c|}
\hline \multicolumn{1}{|c|}{ Sample Description } & Kolmogorov-Smirnov Test Statistic \\
\hline Drainage Area & 0.129 \\
\hline Cross-Sectional Area & 0.173 \\
\hline Width & 0.126 \\
\hline Depth & 0.108 \\
\hline
\end{tabular}

Table 12. Kolmogorov-Smirnov normality test statistics for regional curves for streams in non-carbonate watersheds $<75 \mathrm{~km} 2$. A sample size $(\mathrm{n})=19$ yields a critical value of 0.3 . 


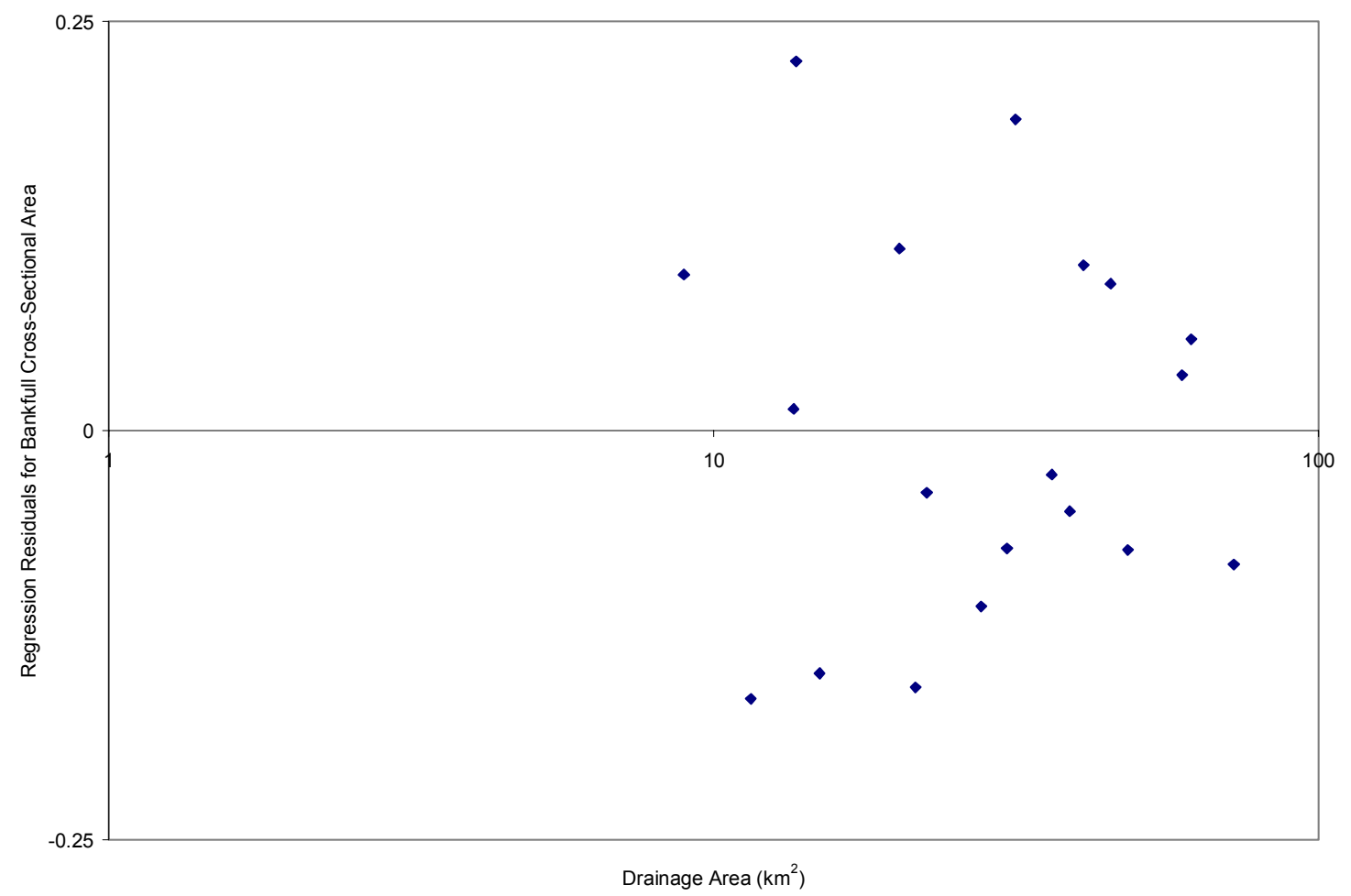

Figure 21. Regression residuals plot for bankfull cross-sectional area for regional curves for $<75 \mathrm{~km} 2$ non-carbonate watersheds. 


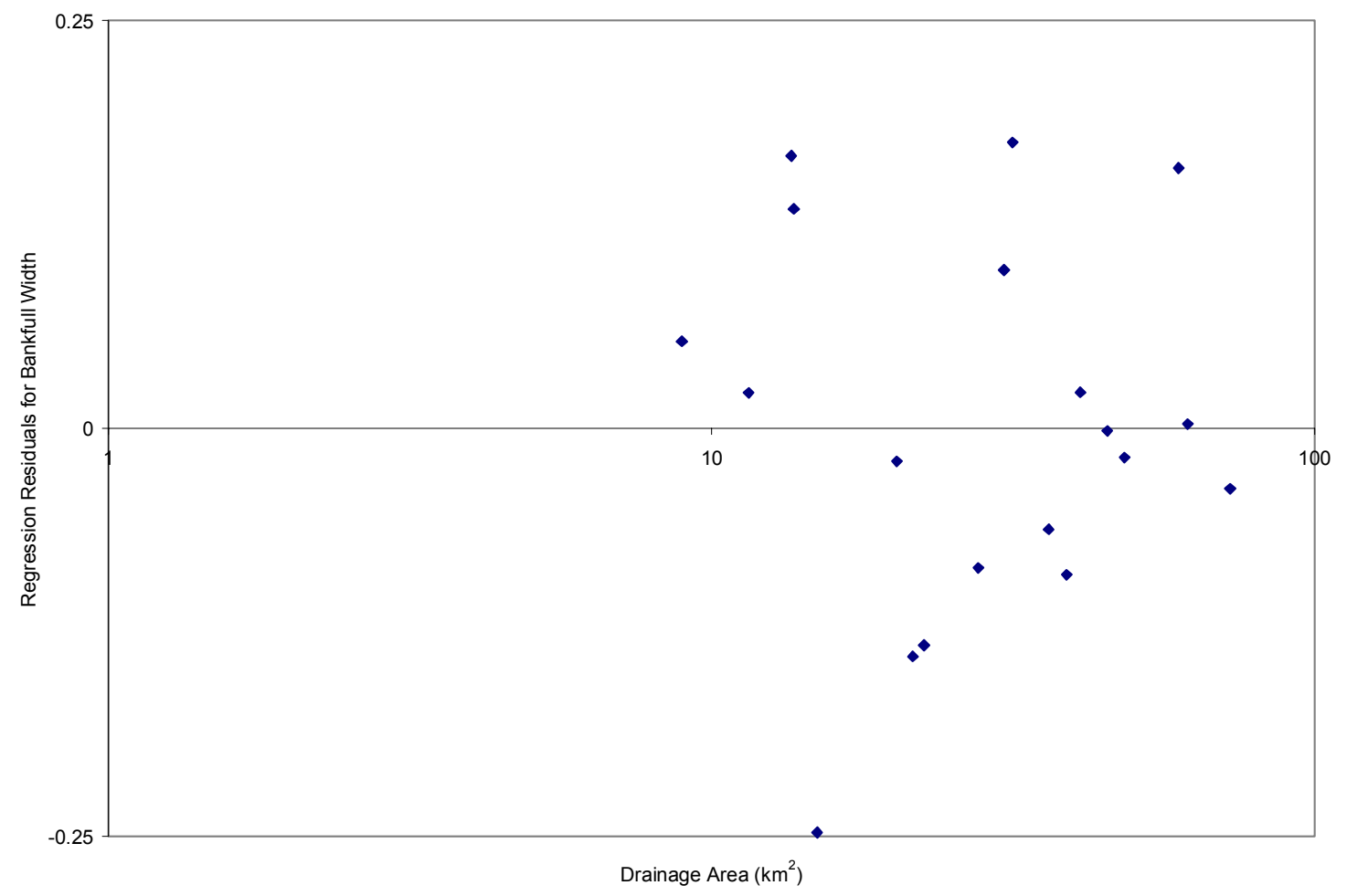

Figure 22. Regression residuals plot for bankfull width for regional curves for $<75 \mathrm{~km} 2$ non-carbonate watersheds. 


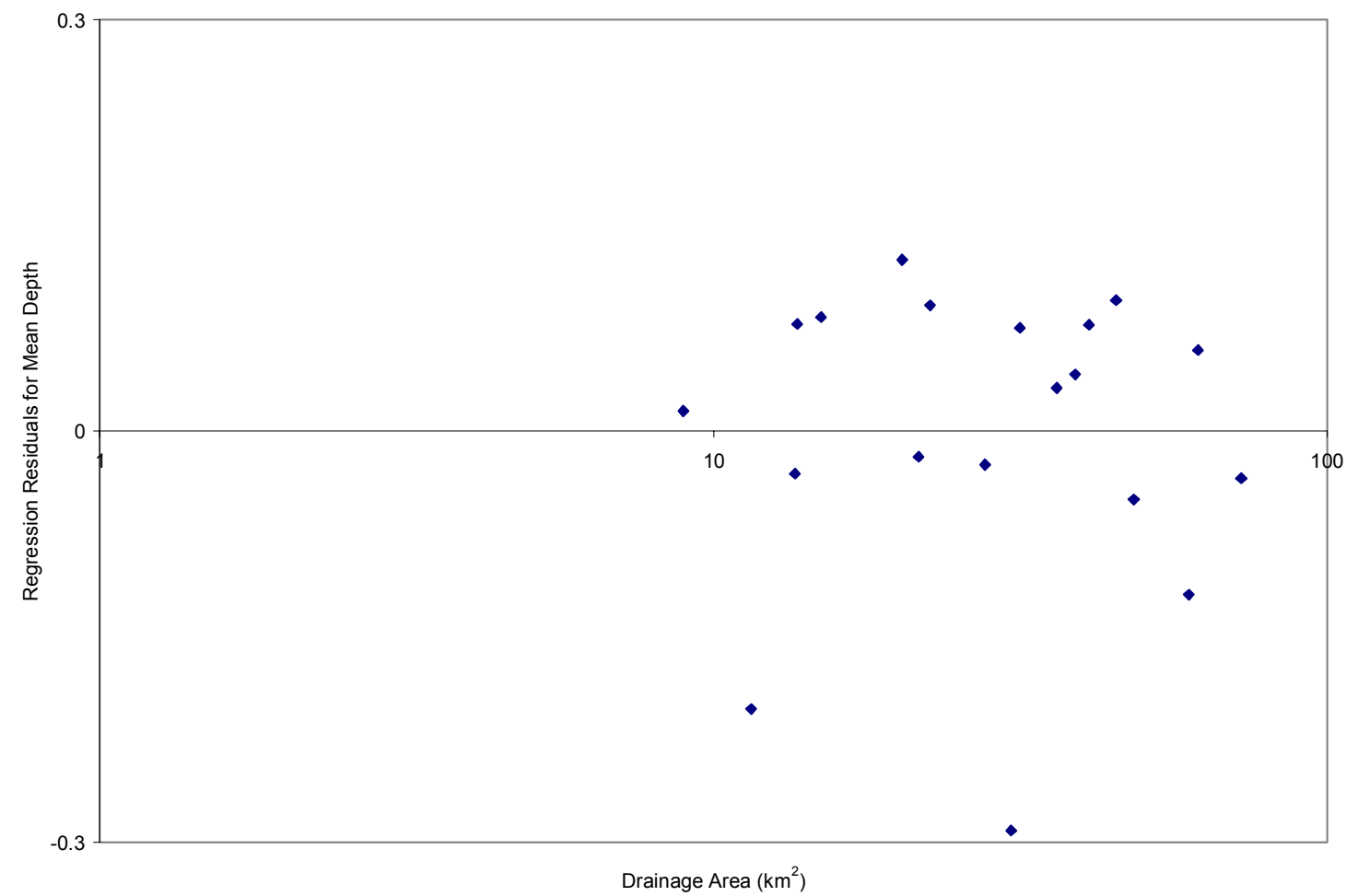

Figure 23. Regression residuals plot for bankfull mean depth for regional curves for $<$ $75 \mathrm{~km} 2$ non-carbonate watersheds. 


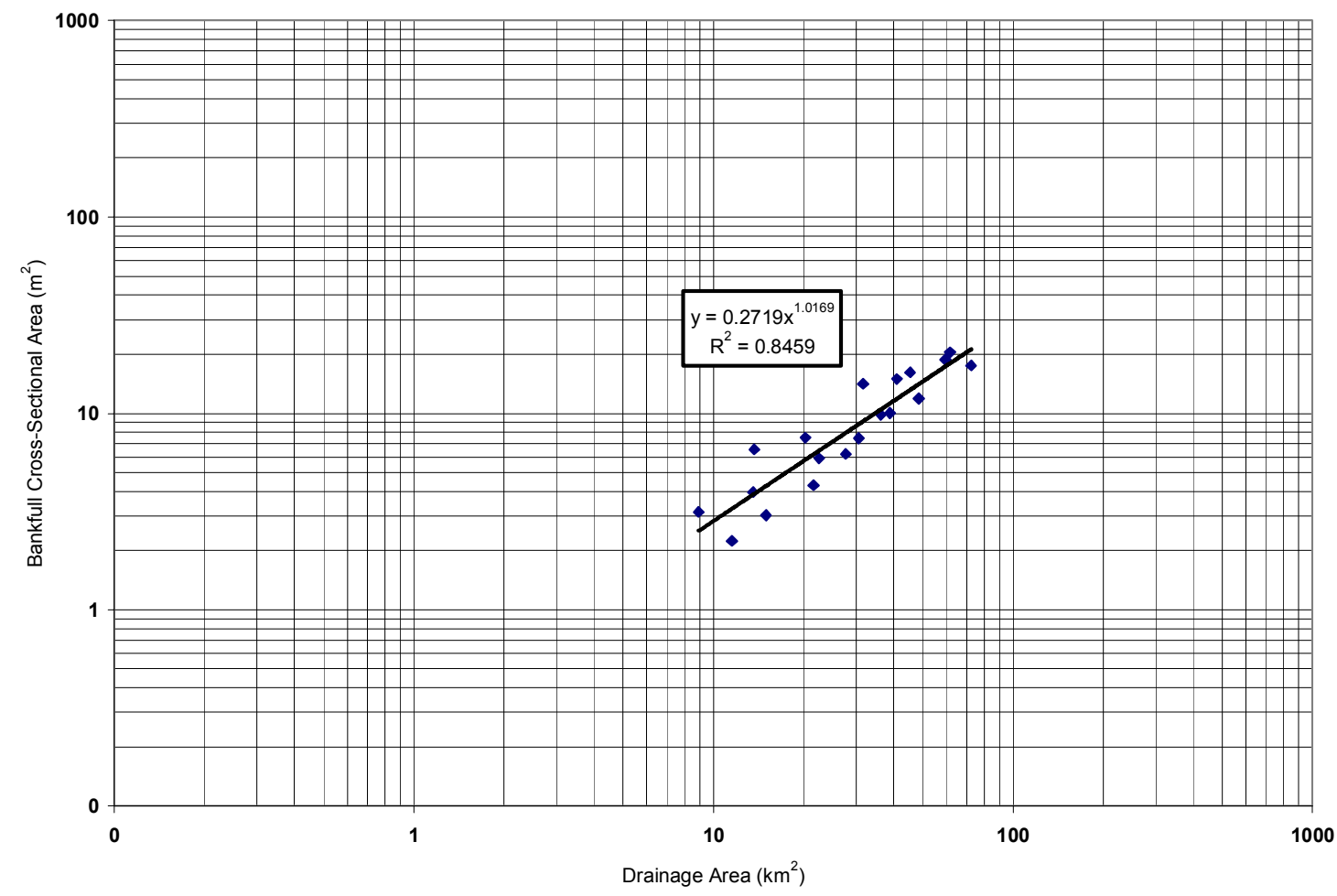

Figure 24. Regional curve for $<75 \mathrm{~km} 2$ non-carbonate watersheds for bankfull crosssectional area. 


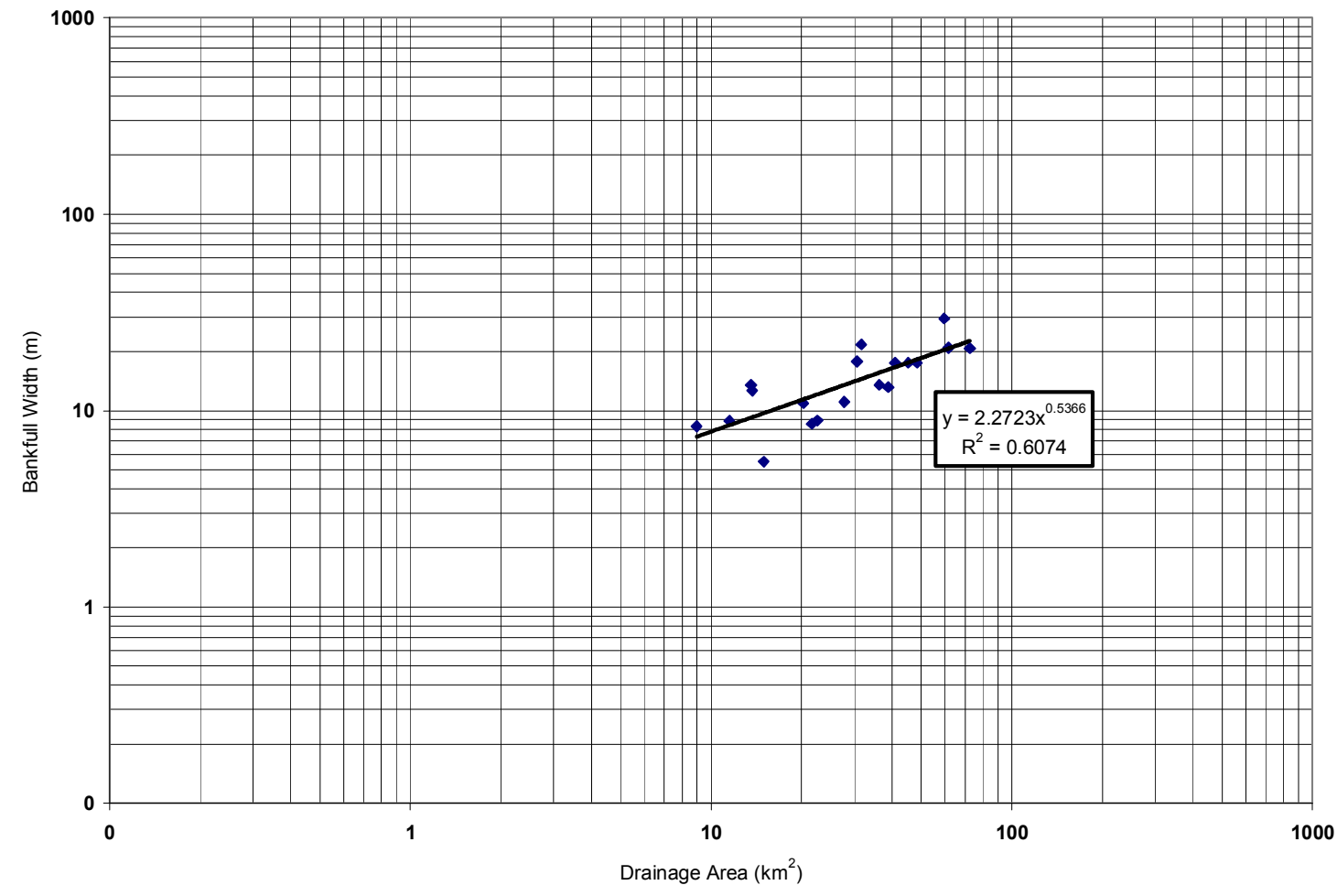

Figure 25. Regional curve for $<75 \mathrm{~km} 2$ non-carbonate watersheds for bankfull width. 


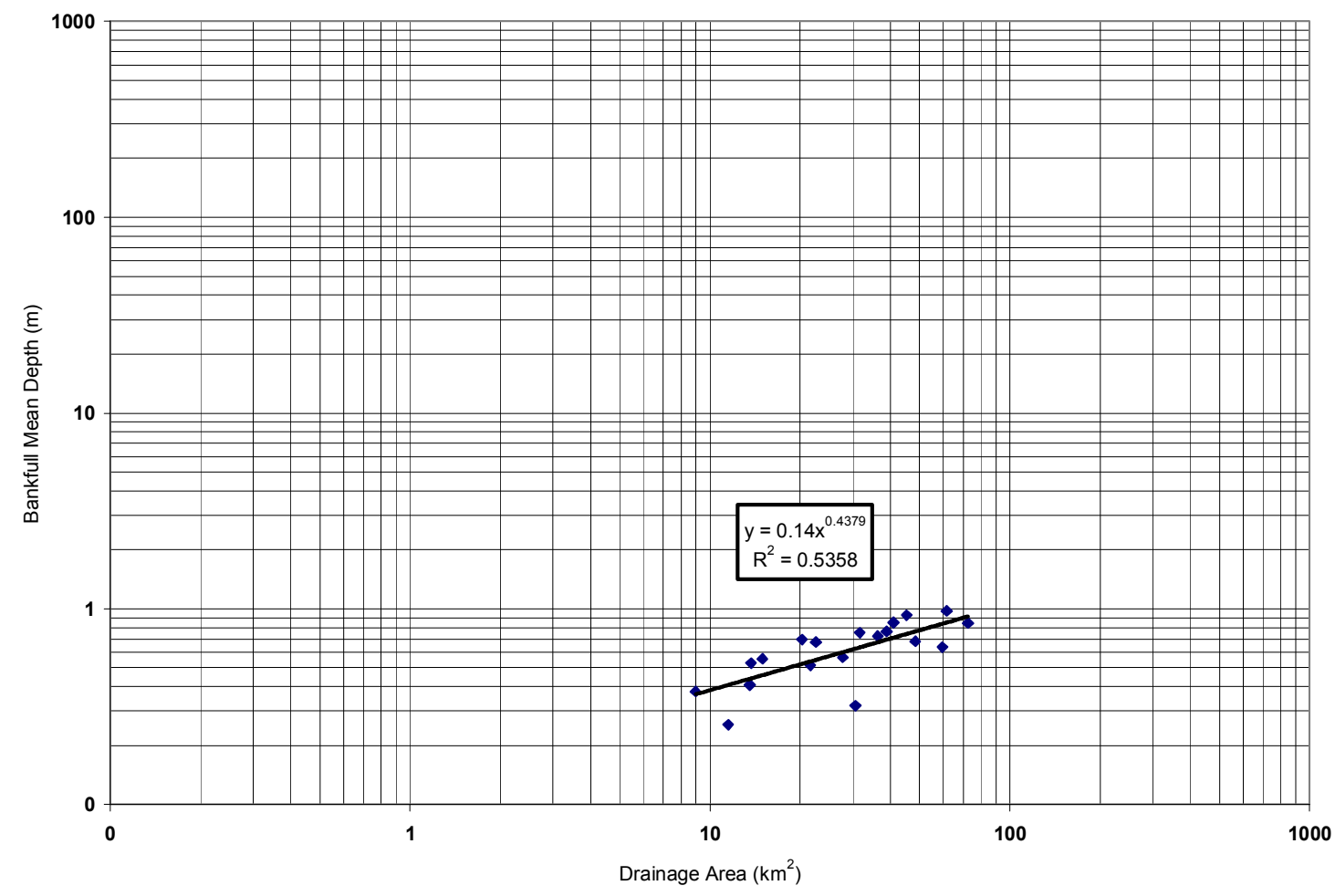

Figure 26. Regional curve for $<75 \mathrm{~km} 2$ non-carbonate watersheds for bankfull mean depth. 


\begin{tabular}{|l|r|r|r|r|r|}
\hline \multicolumn{1}{|c|}{$\begin{array}{c}\text { Response } \\
\text { Variable }\end{array}$} & Equation & Slope & Y Intercept & $\mathbf{R}^{\mathbf{2}}$ & F-statistic \\
\hline $\begin{array}{l}\text { Cross- } \\
\text { Sectional Area }\end{array}$ & $\mathrm{CSA}=0.272 \mathrm{DA}^{1.017}$ & 1.017 & 0.272 & 0.85 & 93.32 \\
\hline Width & $\mathrm{W}=2.272 \mathrm{DA}^{0.537}$ & 0.537 & 2.272 & 0.61 & 26.30 \\
\hline Mean Depth & $\mathrm{D}=0.140 \mathrm{DA}^{0.438}$ & 0.438 & 0.140 & 0.54 & 19.62 \\
\hline
\end{tabular}

Table 13. Summary of quantitative attributes for regional curves for non-carbonate watersheds $<75 \mathrm{~km} 2$. 


\section{Comparison of Regional Curves}

The p-values (Table 14) show a statistically different slope and y-intercept exists in bankfull cross-sectional area between lithologically controlled curves and the curves for $<75 \mathrm{~km}^{2}$ non-carbonate watersheds. The p-value and coefficient for $\mathrm{y}$-intercept for is 0.004 and 0.464 (Table 14) and for slope is 0.001 and -0.368 (Table 14). The lithologically controlled bankfull cross-sectional area curve thus has a greater y-intercept and lower slope than the curves for $<75 \mathrm{~km}^{2}$ non-carbonate watersheds. The p-values (Table 14) for bankfull width are above 0.05 and, thus, the two regional curves can not be considered statistically different. The p-values (Table 14) for the bankfull mean depth regional curve indicate the y-intercept is statistically different, while slope is not. The pvalue and coefficient for y-intercept for the bankfull mean depth regional curve is 0.035 and 0.262 , indicating the lithologically controlled bankfull mean depth curve has a slightly larger y-intercept than the curves for $<75 \mathrm{~km}^{2}$ non-carbonate watersheds. Comparison of regional curves reveals the hypothesis of this study must be rejected, due to a lack of significant statistical differences between the bankfull width and bankfull mean depth curves.

The lithologically controlled regional curves for all bankfull response variables have higher $\mathrm{R}^{2}$ values, and thus greater regression validity, compared to the curves for $<$ $75 \mathrm{~km}^{2}$ non-carbonate watersheds (Table 14 ). $\mathrm{R}^{2}$ values for the bankfull cross-sectional area curves are most comparable, at 0.88 for the lithologically controlled curves and 0.85 for the curves for $<75 \mathrm{~km}^{2}$ non-carbonate watersheds. Comparison of the bankfull width and bankfull mean depth regional curves reveals significant differences in curve validity. The lithologically controlled curve for bankfull width explains 17\% more variance (Table 


\begin{tabular}{|c|c|c|c|c|c|c|}
\hline \multicolumn{7}{|c|}{ Bankfull Cross-Sectional Area $\left(\mathrm{m}^{2}\right)$} \\
\hline & & & Intercept & Intercept & Slope & Slope \\
\hline Data & $\mathbf{N}$ & $\mathbf{R}^{2}$ & $p$-value & Coefficient & $\mathrm{p}$-value & Coefficient \\
\hline Controlled Curves & 34 & 0.88 & 0.004 & 0.464 & 0.001 & -0.368 \\
\hline$<\mathrm{km}^{2}$ Curves & 19 & 0.85 & --- & --- & --- & --- \\
\hline \multicolumn{7}{|c|}{ Bankfull Width (m) } \\
\hline & & & Intercept & Intercept & Slope & Slope \\
\hline Data & $\mathbf{N}$ & & $\mathrm{p}$-value & Coefficient & p-value & Coefficient \\
\hline Controlled Curves & 34 & 0.78 & 0.354 & 0.129 & 0.116 & -0.156 \\
\hline$<\mathrm{km}^{2}$ Curves & 19 & 0.61 & --- & --- & --- & --- \\
\hline \multicolumn{7}{|c|}{ Bankfull Depth (m) } \\
\hline & & & Intercept & Intercept & Slope & Slope \\
\hline Data & $\mathbf{N}$ & & $\mathrm{p}$-value & Coefficient & $\mathrm{p}$-value & Coefficient \\
\hline Controlled Curves & 34 & 0.73 & 0.035 & 0.262 & 0.059 & -0.165 \\
\hline$<\mathrm{km}^{2}$ Curves & 19 & 0.54 & --- & --- & --- & --- \\
\hline
\end{tabular}

Table 14. Statistical results from analysis of covariance comparison between lithologically controlled curves and regional curves for non-carbonate watersheds $<75$ $\mathrm{km} 2$. 
14) and the bankfull mean depth curve explains $19 \%$ more variance (Table 14) than the curves for $<75 \mathrm{~km}^{2}$ non-carbonate watersheds.

Means of drainage area (Table 8) shows lithologically controlled curves are constructed from smaller watersheds versus the curves for $<75 \mathrm{~km}^{2}$ non-carbonate watersheds. Regional curves for $<75 \mathrm{~km}^{2}$ non-carbonate watersheds are derived of watersheds with a mean drainage area that is $14.5 \mathrm{~km}^{2}$ (Table 8) greater than the lithologically controlled curves. Statistics for percent watershed urbanized for regional curves (Table 9) show both curves are constructed of largely rural watersheds. Statistics for percent watershed forested (Table 10) reveal significant differences in forest cover between the watersheds sampled to construct both curves. For instance, the lithologically controlled curves display on average $33.4 \%$ more forest cover than the curves for $<75$ $\mathrm{km}^{2}$ non-carbonate watersheds (Table 10).

\section{Interpretations}

Analysis shows the lithologically controlled bankfull cross-sectional area regional curve has a statistically different slope and y-intercept, and the bankfull mean depth regional curve has a statistically different y-intercept, than the curves for $<75 \mathrm{~km}^{2}$ noncarbonate watersheds. Bedrock geology, geologic structure, physiography, riparian vegetation, and land-use conditions may cause differences in these attributes between regional curves. The lithologically controlled curves are confined to the Ridge and Valley; whereas curves for $<75 \mathrm{~km}^{2}$ watersheds also include the Appalachian Plateaus, Central Lowland, and Piedmont Provinces.

Differences in forest cover are apparent between lithologically controlled curves and curves for $<75 \mathrm{~km}^{2}$ non-carbonate watersheds, which can result in alterations to 
runoff processes that affect hydraulic geometry. Reach scale differences in riparian vegetation may exist between watersheds used to develop both regional curves. Any significant differences in vegetation may influence channel dimensions and may result in differences in the slope and y-intercept of curves.

The most important factor influencing differences in $\mathrm{R}^{2}$ values may be the number of sites used to develop regional curves. The curves for $<75 \mathrm{~km}^{2}$ non-carbonate watersheds are developed from 19 sites, compared to 34 sites used to construct the lithologically controlled regional curves. Accordingly, the limited number of sites used to construct the curves for $<75 \mathrm{~km}^{2}$ non-carbonate watersheds results in lower $\mathrm{R}^{2}$ values, and less statistical precision.

Regional Curves for Non-carbonate Watersheds in the Ridge and Valley Physiographic Province

Hydraulic Geometry Data Analysis

The characteristics of 18 non-carbonate streams (Table 15), initially investigated by Chaplin (2005), were used to develop regional curves for watersheds solely located in the Ridge and Valley Physiographic Province in Pennsylvania and selected areas of Maryland.

Kolmogorov-Smirnov normality tests (Table 16) show the test statistic for drainage area and all bankfull response variables are less than the critical value of 0.31 , indicating these data are normally distributed. Plots of regression residuals for all bankfull response variables (Figures 27-29) show the variances of the residuals around the regression line are unequal, and are thus heteroscedastic. The residuals appear furthermore randomly distributed around the regression line, and are thus 


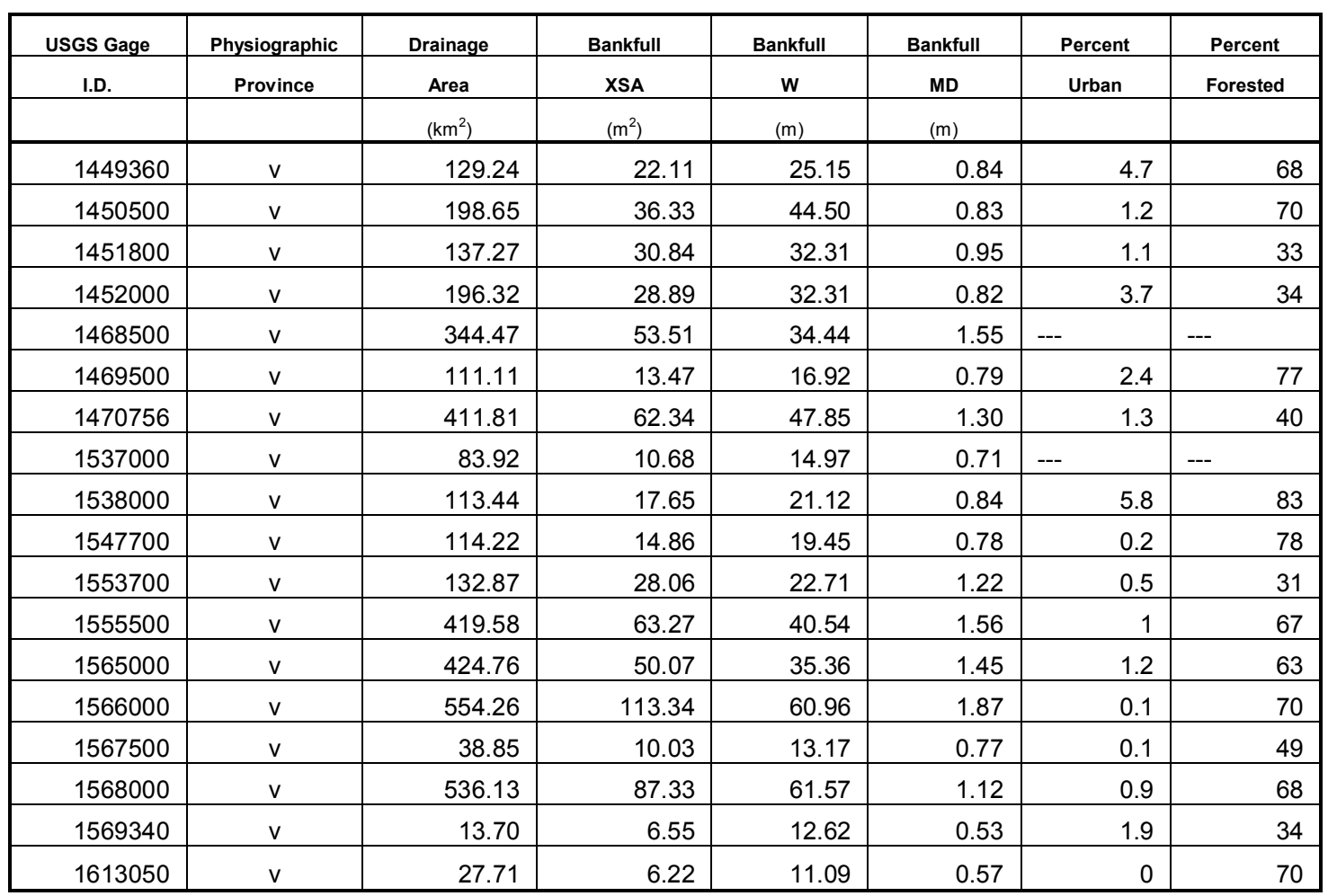

Table 15. Characteristics of sites used to develop regional curves for non-carbonate watersheds for the Ridge and Valley Physiographic Province. Key to symbols in table: [XSA] Cross-Sectional Area, [W] Width, [MD] Mean Depth, [v] Ridge and Valley, [---] missing data. 


\begin{tabular}{|l|c|}
\hline \multicolumn{1}{|c|}{ Sample Description } & Kolmogorov-Smirnov Test Statistic \\
\hline Drainage Area & 0.238 \\
\hline Cross-Sectional Area & 0.185 \\
\hline Width & 0.131 \\
\hline Depth & 0.215 \\
\hline
\end{tabular}

Table 16. Kolmogorov-Smirnov normality test statistics for regional curves for noncarbonate watersheds for the Ridge and Valley Physiographic Province. A sample size (n) $=18$ yields a critical value of 0.31 . 


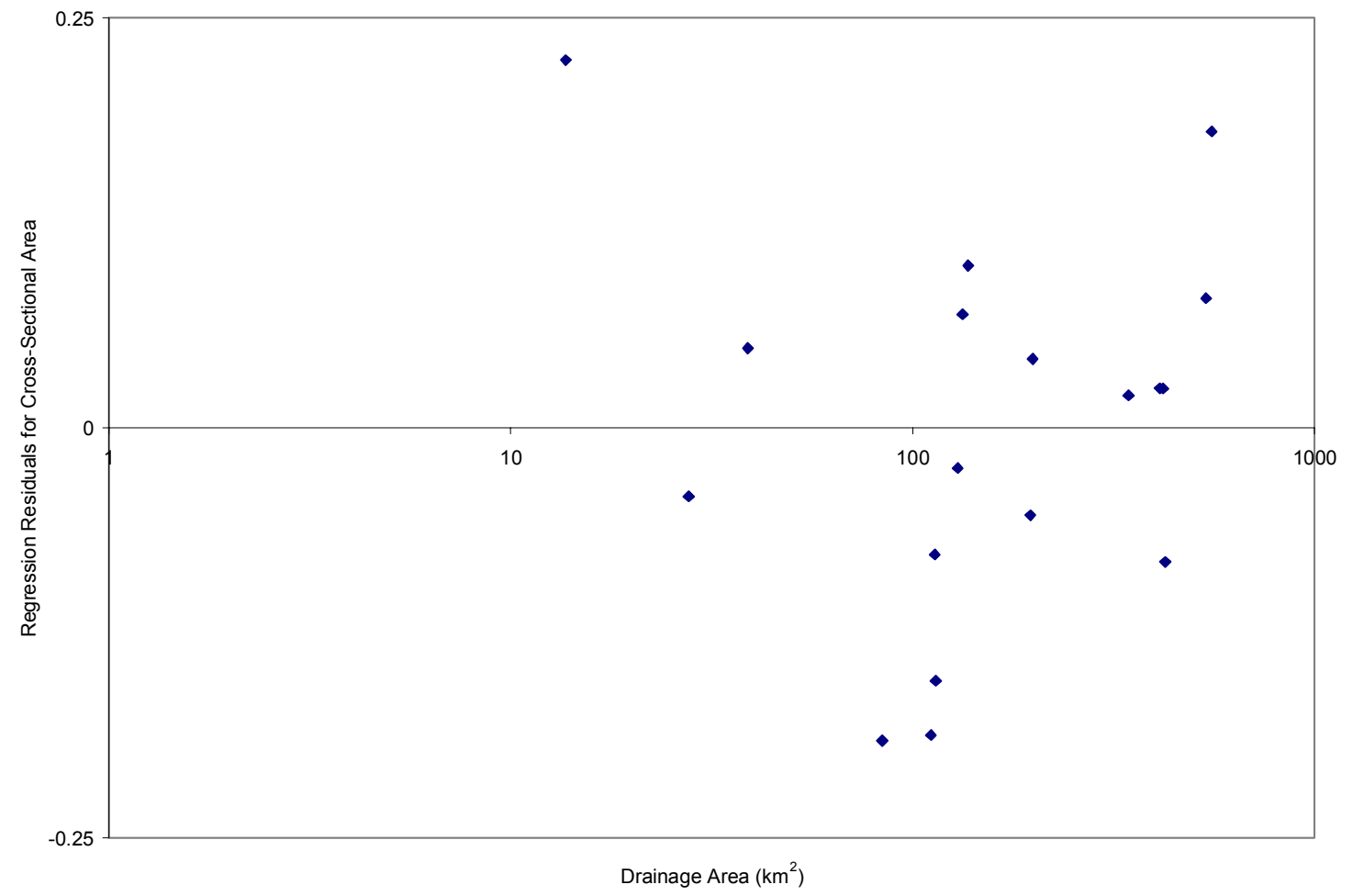

Figure 27. Regression residuals plot for bankfull cross-sectional area for regional curves for non-carbonate watersheds for the Ridge and Valley Physiographic Province. 


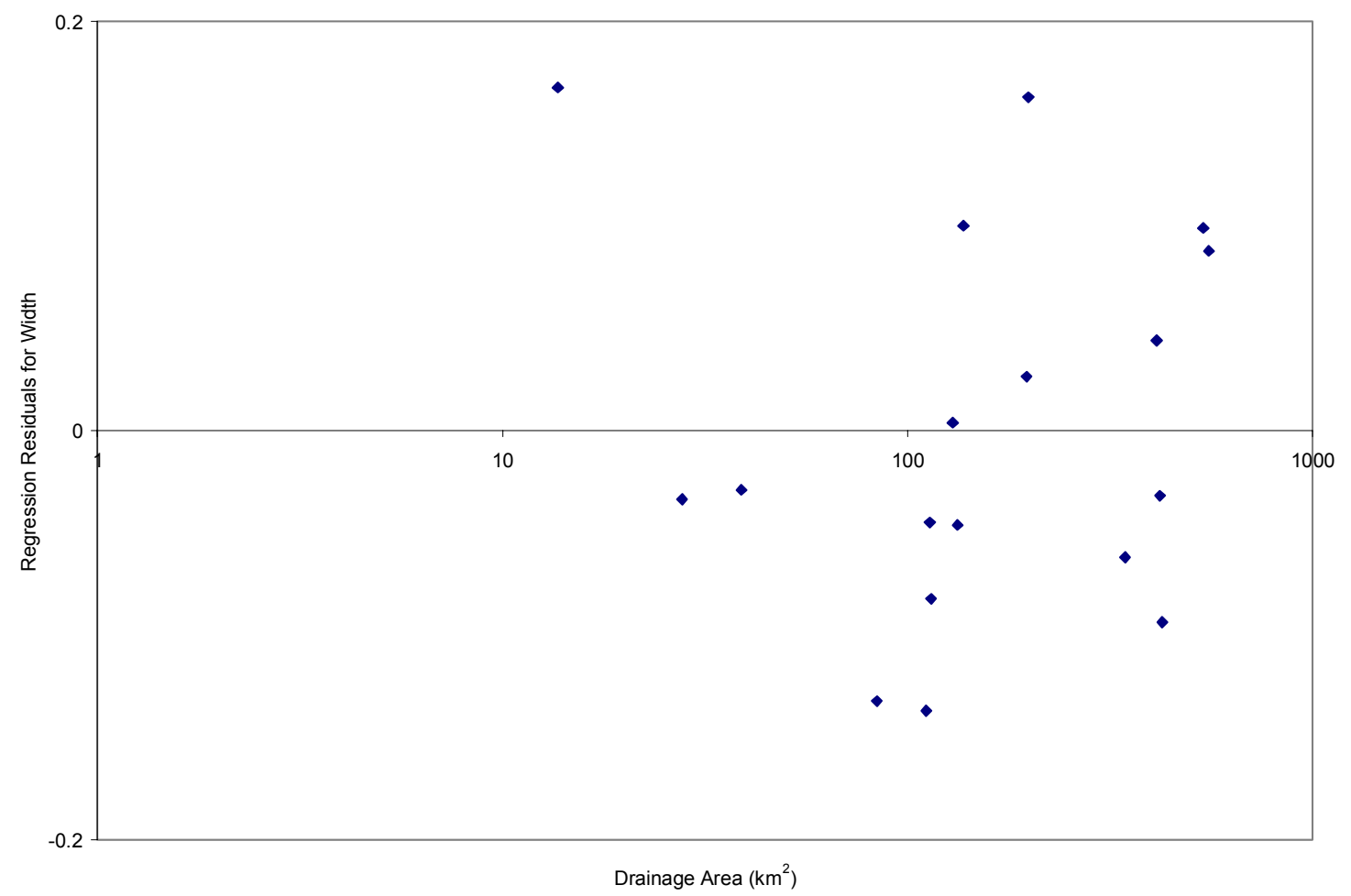

Figure 28. Regression residuals plot for bankfull width for regional curves for noncarbonate watersheds for the Ridge and Valley Physiographic Province. 


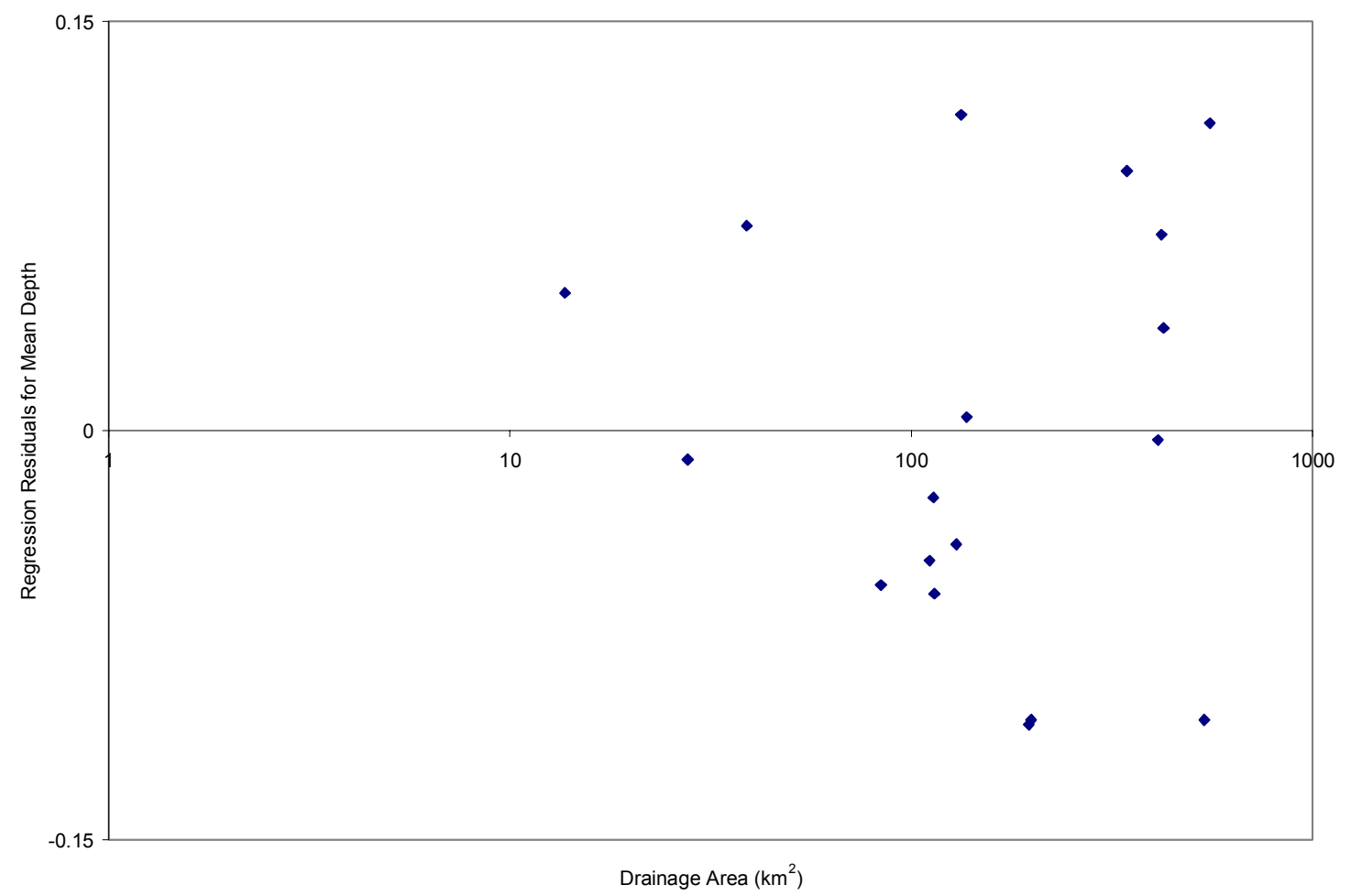

Figure 29. Regression residuals plot for bankfull mean depth for regional curves for non-carbonate watersheds for the Ridge and Valley Physiographic Province. 
non-autocorrelated. A linear and causal relationship between drainage area and all of the bankfull response variables can be assumed.

Regional Curve Development

$\mathrm{R}^{2}$ values for bankfull cross-sectional area (Figure 30, bankfull width (Figure 31), and bankfull mean depth (Figure 32) regional curves are 0.908, 0.841, and 0.768, respectively (Table 17). F-statistic values are also highest for bankfull cross-sectional area, followed by bankfull width and bankfull mean depth (Table 17). Therefore, the bankfull cross-sectional area regional curve displays the least variance and best fit, followed by bankfull width and, lastly, bankfull mean depth.

\section{Comparison of Regional Curves}

The p-values (Table 18) for the bankfull cross-sectional area regional curve indicate a statistically different slope exists between lithologically controlled curves and curves for non-carbonate Ridge and Valley watersheds. The p-value and slope coefficient for the bankfull cross-sectional area curve is 0.048 and -0.150 (Table 18). Accordingly, the lithologically controlled bankfull cross-sectional area regional curve has a slightly lower slope than the curves for non-carbonate watersheds solely located in the Ridge and Valley. The p-values for slope and y-intercept for bankfull width and bankfull mean depth curves are all above 0.05 , so the curves can not be considered statistically different, and the research hypothesis again must be rejected due to a lack of statistical differences between the bankfull width and bankfull mean depth regional curves.

The regional curves for non-carbonate Ridge and Valley watersheds for all bankfull response variables have moderately larger $\mathrm{R}^{2}$ values than the lithologically 


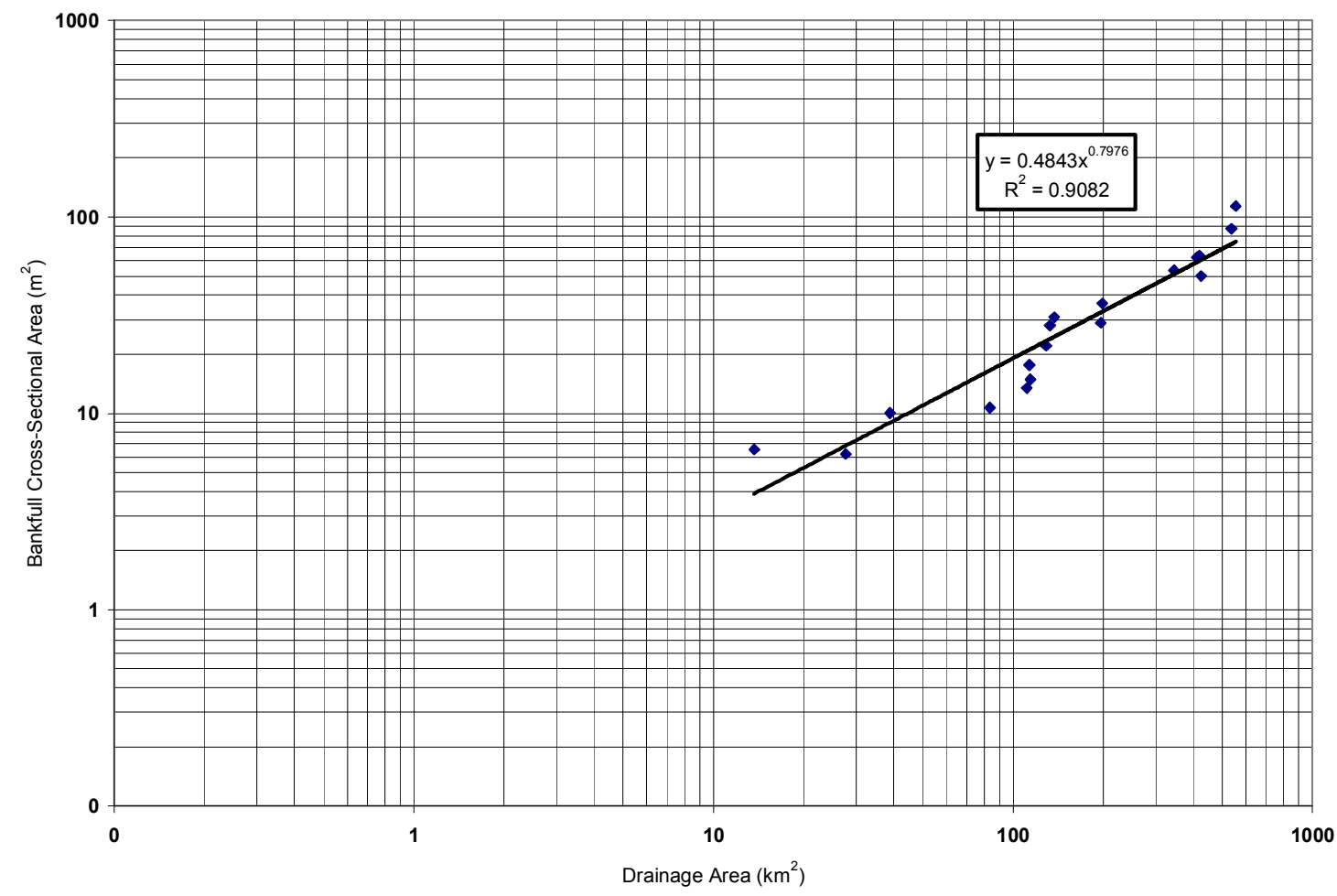

Figure 30. Regional curve for non-carbonate watersheds for the Ridge and Valley Physiographic Province for bankfull cross-sectional area. 


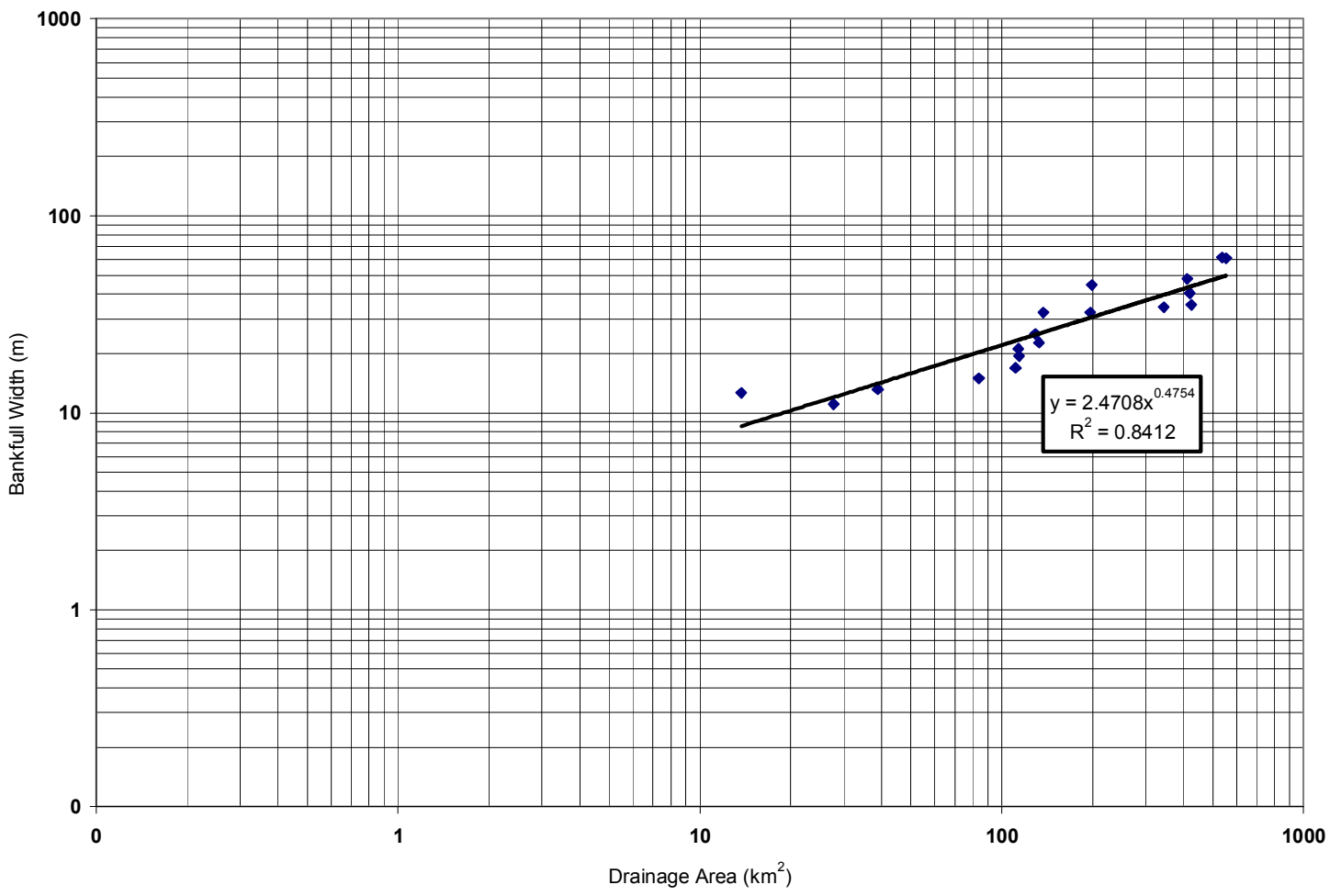

Figure 31. Regional curve for non-carbonate watersheds for the Ridge and Valley Physiographic Province for bankfull width. 


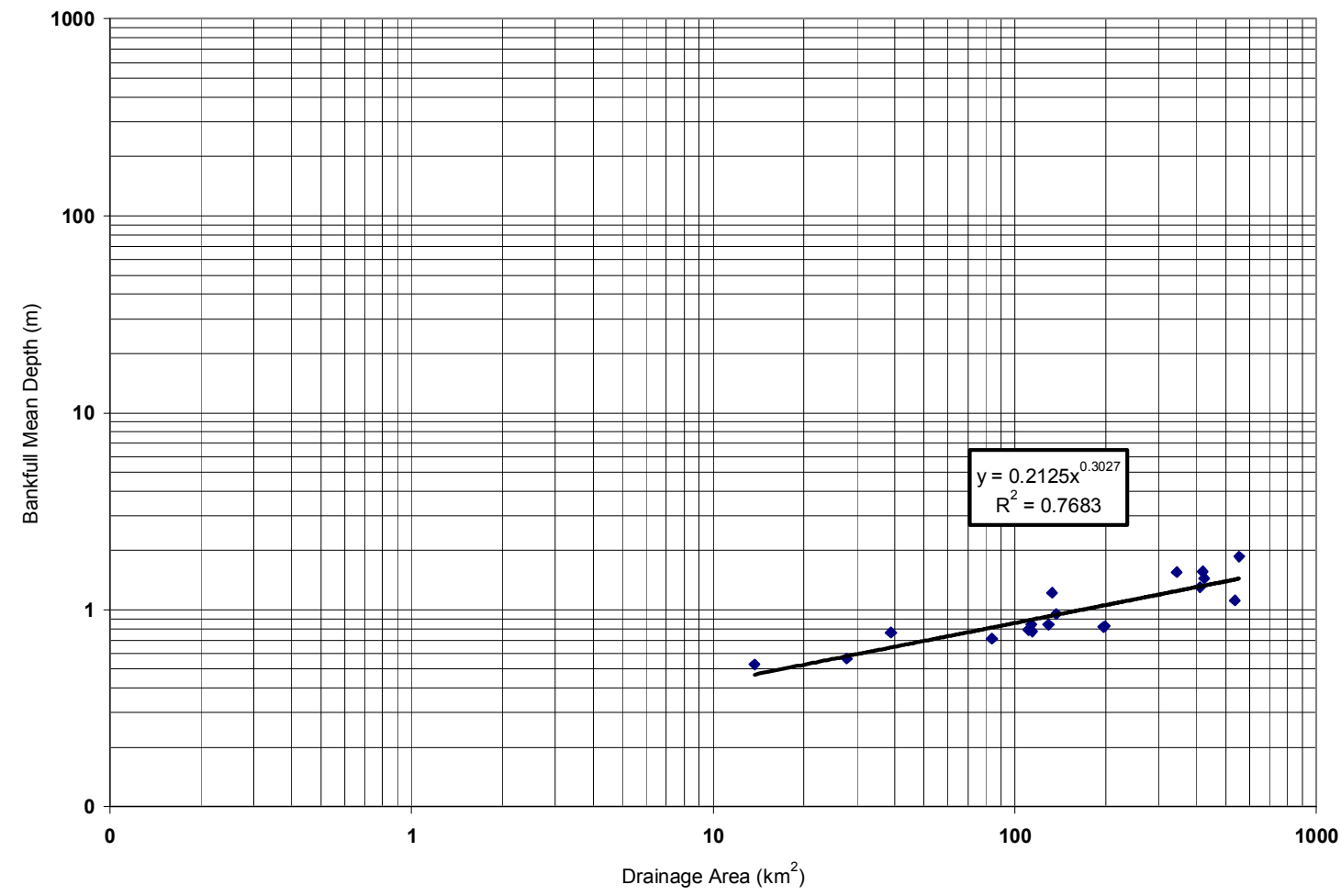

Figure 32. Regional curve for non-carbonate watersheds for the Ridge and Valley Physiographic Province for bankfull mean depth. 


\begin{tabular}{|l|r|r|r|r|c|}
\hline \multicolumn{1}{|c|}{$\begin{array}{c}\text { Response } \\
\text { Variable }\end{array}$} & \multicolumn{1}{c|}{ Equation } & Slope & Y Intercept & $\mathbf{R}^{\mathbf{2}}$ & F-statistic \\
\hline $\begin{array}{l}\text { Cross- } \\
\text { Sectional Area }\end{array}$ & $\mathrm{CSA}=0.484 \mathrm{DA}^{0.798}$ & 0.798 & 0.484 & 0.91 & 158.21 \\
\hline Width & $\mathrm{W}=2.471 \mathrm{DA}^{0.475}$ & 0.475 & 2.471 & 0.84 & 84.74 \\
\hline Mean Depth & $\mathrm{D}=0.213 \mathrm{DA}^{0.303}$ & 0.303 & 0.213 & 0.77 & 53.06 \\
\hline
\end{tabular}

Table 17. Summary of quantitative attributes for regional curves for non-carbonate watersheds for the Ridge and Valley Physiographic Province. 


\begin{tabular}{|c|c|c|c|c|c|c|}
\hline \multicolumn{7}{|c|}{ Bankfull Cross-Sectional Area $\left(\mathrm{m}^{2}\right)$} \\
\hline & & & Intercept & Intercept & Slope & Slope \\
\hline Data & $\mathbf{N}$ & $\mathbf{R}^{2}$ & p-value & Coefficient & $p$-value & Coefficient \\
\hline Controlled Curves & 34 & 0.88 & 0.133 & 0.213 & 0.048 & -0.150 \\
\hline R \& V Curves & 18 & 0.91 & --- & --- & --- & -- \\
\hline \multicolumn{7}{|l|}{ Bankfull Width (m) } \\
\hline & & & Intercept & Intercept & Slope & Slope \\
\hline Data & $\mathbf{N}$ & & $p$-value & Coefficient & $p$-value & Coefficient \\
\hline Controlled Curves & 34 & 0.78 & 0.43 & 0.093 & 0.129 & -0.095 \\
\hline R \& V Curves & 18 & 0.84 & --- & --- & --- & --- \\
\hline \multicolumn{7}{|c|}{ Bankfull Depth (m) } \\
\hline & & & Intercept & Intercept & Slope & Slope \\
\hline Data & $\mathbf{N}$ & & $p$-value & Coefficient & $p$-value & Coefficient \\
\hline Controlled Curves & 34 & 0.73 & 0.391 & 0.081 & 0.547 & -0.030 \\
\hline R \& V Curves & 18 & 0.77 & --- & --- & --- & --- \\
\hline
\end{tabular}

Table 18. Statistical results from analysis of covariance comparison between lithologically controlled curves and regional curves for non-carbonate watersheds for the Ridge and Valley Physiographic Province. 
controlled curves. Bankfull cross-sectional area regional curves are most comparable, with $R^{2}$ values of 0.91 for curves for Ridge and Valley watersheds and 0.88 for the lithologically controlled curves. $\mathrm{R}^{2}$ values for the bankfull width relations are 0.84 for Ridge and Valley watershed curves and 0.78 for lithologically controlled curves. Lastly, bankfull mean depth $\mathrm{R}^{2}$ values are 0.77 for the Ridge and Valley curves and 0.73 for the lithologically controlled curves.

Means of drainage area (Table 8) show lithologically controlled curves are derived from a mean drainage area of $18.2 \mathrm{~km}^{2}, 203.4 \mathrm{~km}^{2}$ less than the mean drainage area for the curves for non-carbonate Ridge and Valley watersheds. Standard deviation values (Table 8) show the curves for Ridge and Valley watersheds are derived from a much broader range of drainage areas than lithologically controlled curves.

Statistics for percent watershed urbanized (Table 9) shows both regional curves are derived from largely rural watersheds. Statistics shows the mean percent watershed forested for the lithologically controlled curves is $97.7 \%, 39.3 \%$ more than the mean for the curves for non-carbonate Ridge and Valley watersheds (Table 10).

\section{Interpretations}

The lithologically controlled regional curve for bankfull cross-sectional area has a statistically different slope than the curves for non-carbonate Ridge and Valley watersheds. Bedrock geology, geomorphic history, channel gradient, watershed size, riparian vegetation, and land-use may yield differences between these curves. Bedrock geology and geomorphic history vary within the Ridge and Valley Physiographic Province (Sevon 2000) and, therefore, differ between sites used to develop both regional curves. 
Channel gradients may be greater at sites included in lithologically controlled regional curves, possibly resulting in different channel forming discharges for riffles within a reach and variable channel dimensions. Mean drainage area and degree of unforested land cover for sites used to construct lithologically controlled regional curves are smaller than those used to develop curves for non-carbonate Ridge and Valley watersheds, so these watersheds almost certainly have a flashier hydrologic regime. Moreover, riparian vegetation type and density may differ between the sites used to develop both curves.

The factors that may influence differences in $\mathrm{R}^{2}$ values include the number of sites used to construct curves, channel gradient, and watershed size. The curves for noncarbonate Ridge and Valley watersheds solely were developed from 18 sites, compared to 34 used to construct lithologically controlled curves. Therefore, the regional curves developed with fewer sites have greater regression validity, or higher $\mathrm{R}^{2}$ values. This result may be in part influenced by not having a representative sample of the statistical population, yielding few outliers and higher $\mathrm{R}^{2}$ values.

Channel gradients are higher at the sites used in lithologically controlled curves, and are associated with poorly developed and difficult to identify floodplains, resulting in smaller $\mathrm{R}^{2}$ values. Survey measurement of the channel cross-section of small streams may also result in large relative errors and yield inaccurate values for bankfull response variables. Thus, as previously stated, due to measurement error, curves developed from smaller streams may result in more variance. 
Combined Regional Curves for Non-Carbonate Watersheds

\section{Hydraulic Geometry Data Analysis}

The characteristics of the 34 streams (Table 4) used in the development of lithologically controlled curves and the 55 streams (Table 1) used in the development of Chaplin's (2005) regional curves were used to develop of a combined regional curve for all non-carbonate watersheds.

Kolmogorov-Smirnov normality tests (Table 19) shows all of the bankfull response variables have test statistics less than the critical value of 0.21 , and are normally distributed; however, the drainage area data, has a test statistic value of 0.218 , very slightly above the critical value, and is non-normally distributed. Logarithmic transformation of the drainage area data to create a normal distribution would make comparison of regional curves impossible, so such transformation is not warranted.

Plots of regression residuals for all bankfull response variables (Figures 33-35) show unequal variances of the residuals about the regression line, so the data are heteroscedastic. Regression residuals are randomly distributed around each regression line, so non-autocorrelation of the variables is assumed. A linear and causal relationship between drainage area and all of the bankfull response variables can be assumed.

\section{Regional Curve Development}

The bankfull cross-sectional area regional curve (Figure 36) has the largest $\mathrm{R}^{2}$ value, 0.95 (Table 20). $\mathrm{R}^{2}$ values for bankfull width (Figure 37) and bankfull mean depth (Figure 38) regional curves are 0.90 and 0.81 , respectively (Table 20). F-statistic values are significantly high for all combined regional curves (Table 20), indicating a large 


\begin{tabular}{|l|c|}
\hline \multicolumn{1}{|c|}{ Sample Description } & Kolmogorov-Smirnov Test Statistic \\
\hline Drainage Area & 0.218 \\
\hline Cross-Sectional Area & 0.194 \\
\hline Width & 0.131 \\
\hline Depth & 0.134 \\
\hline
\end{tabular}

Table 19. Kolmogorov-Smirnov normality test statistics for combined regional curves for non-carbonate watersheds. A sample size $(n)=89$ yields a critical value of 0.21 . 


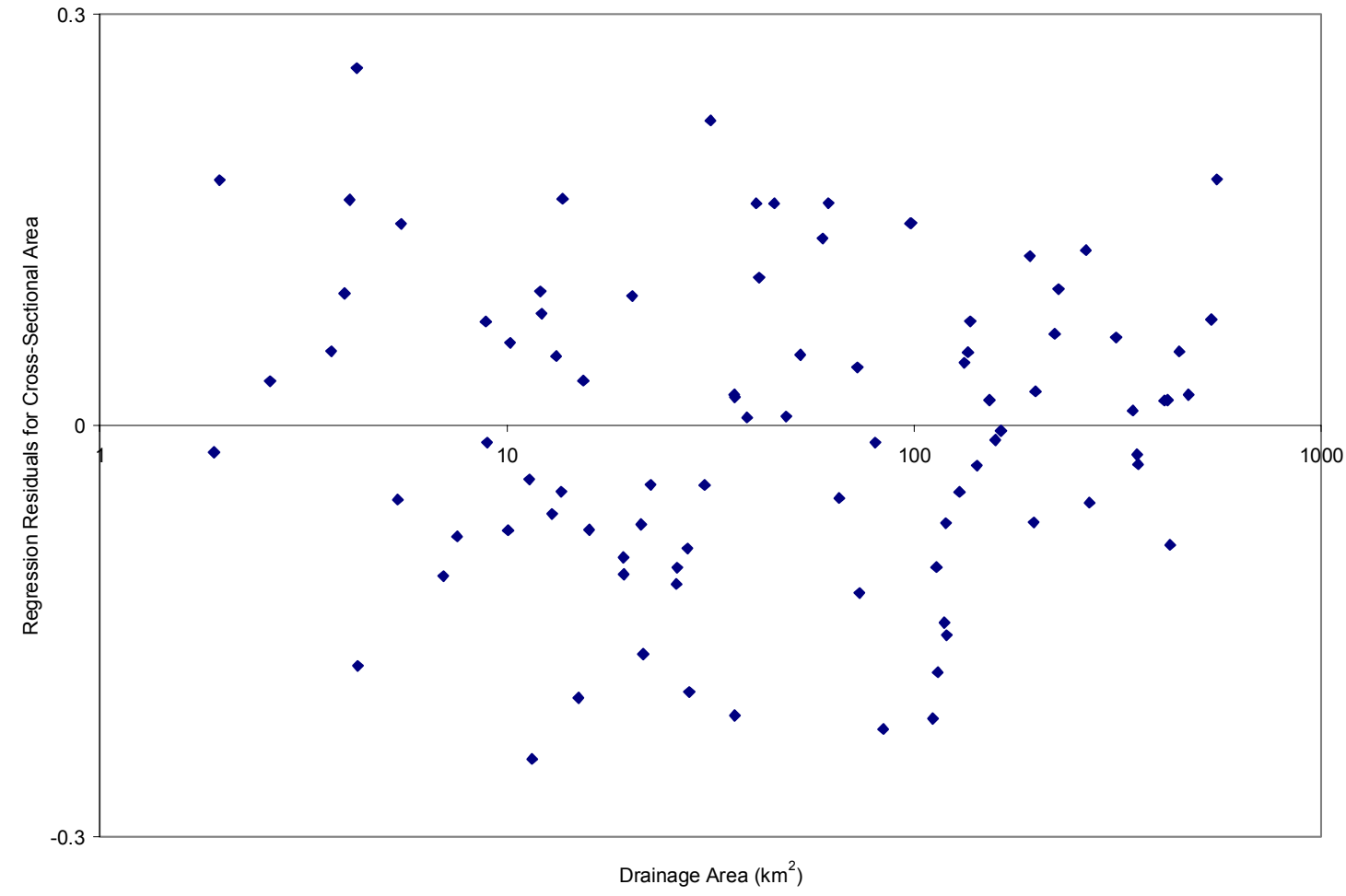

Figure 33. Regression residuals plot for bankfull cross-sectional area for combined regional curves for non-carbonate watersheds. 


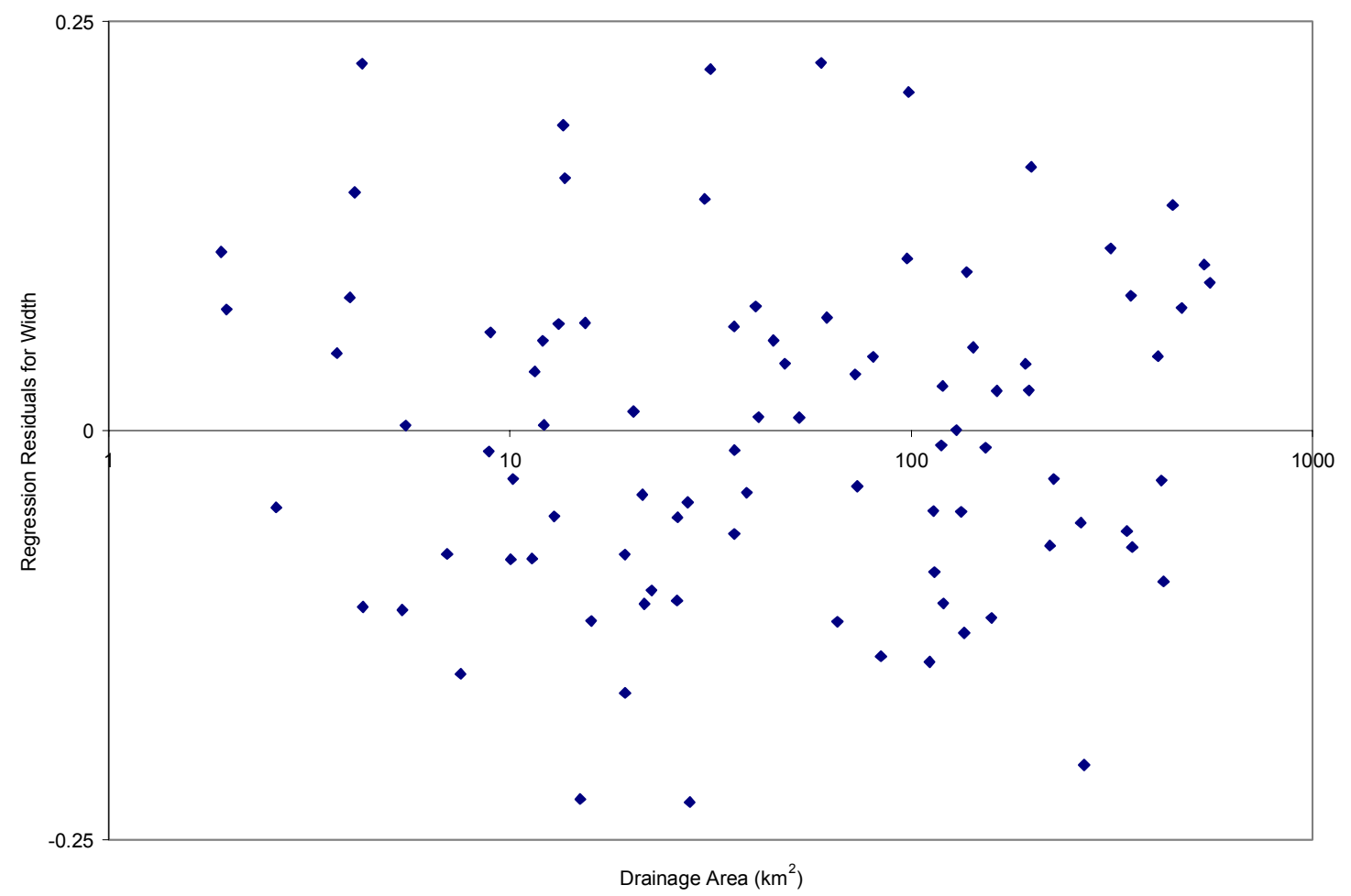

Figure 34. Regression residuals plot for bankfull width for combined regional curves for non-carbonate watersheds. 


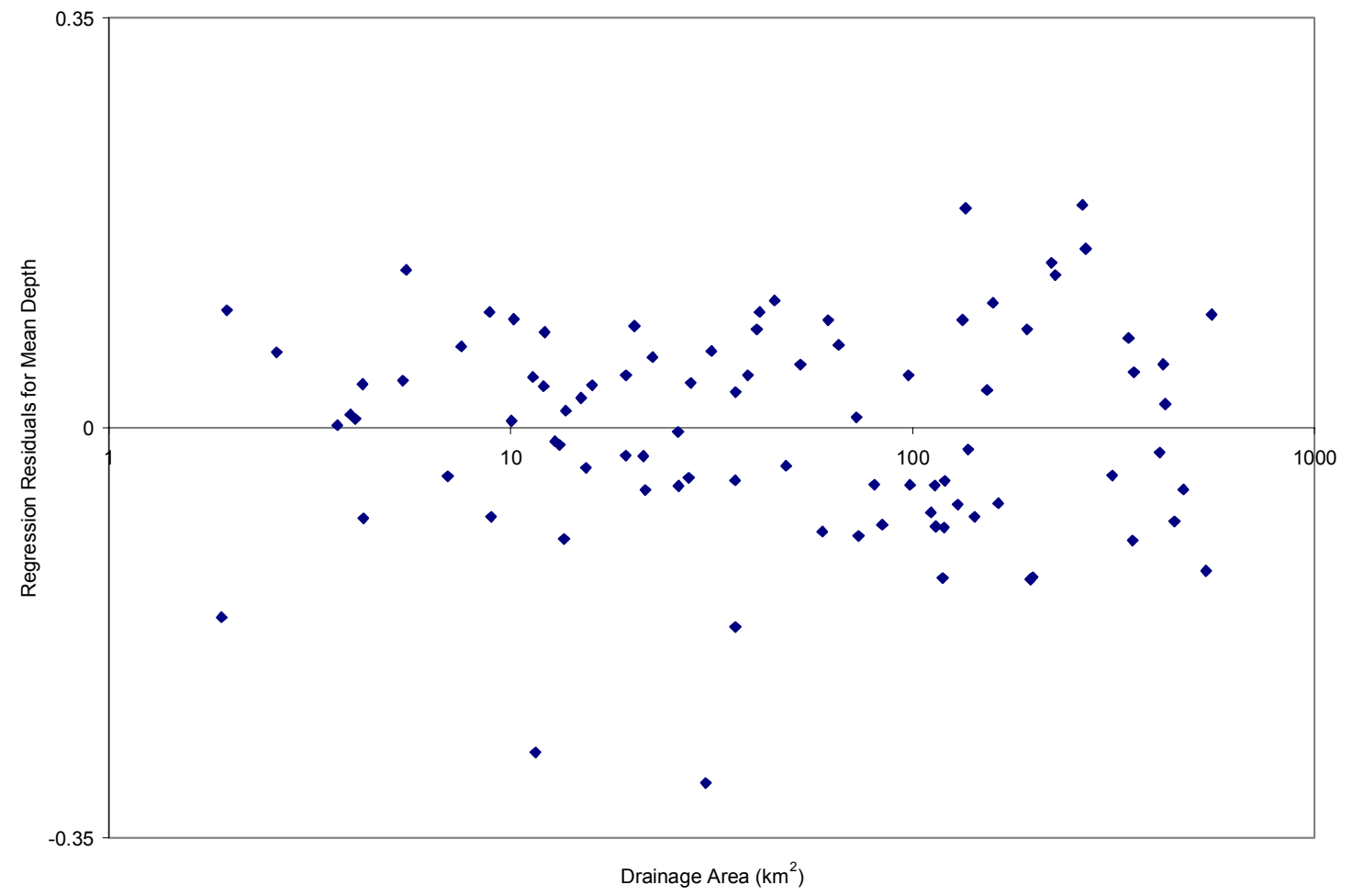

Figure 35. Regression residuals plot for bankfull mean depth for combined regional curves for non-carbonate watersheds. 


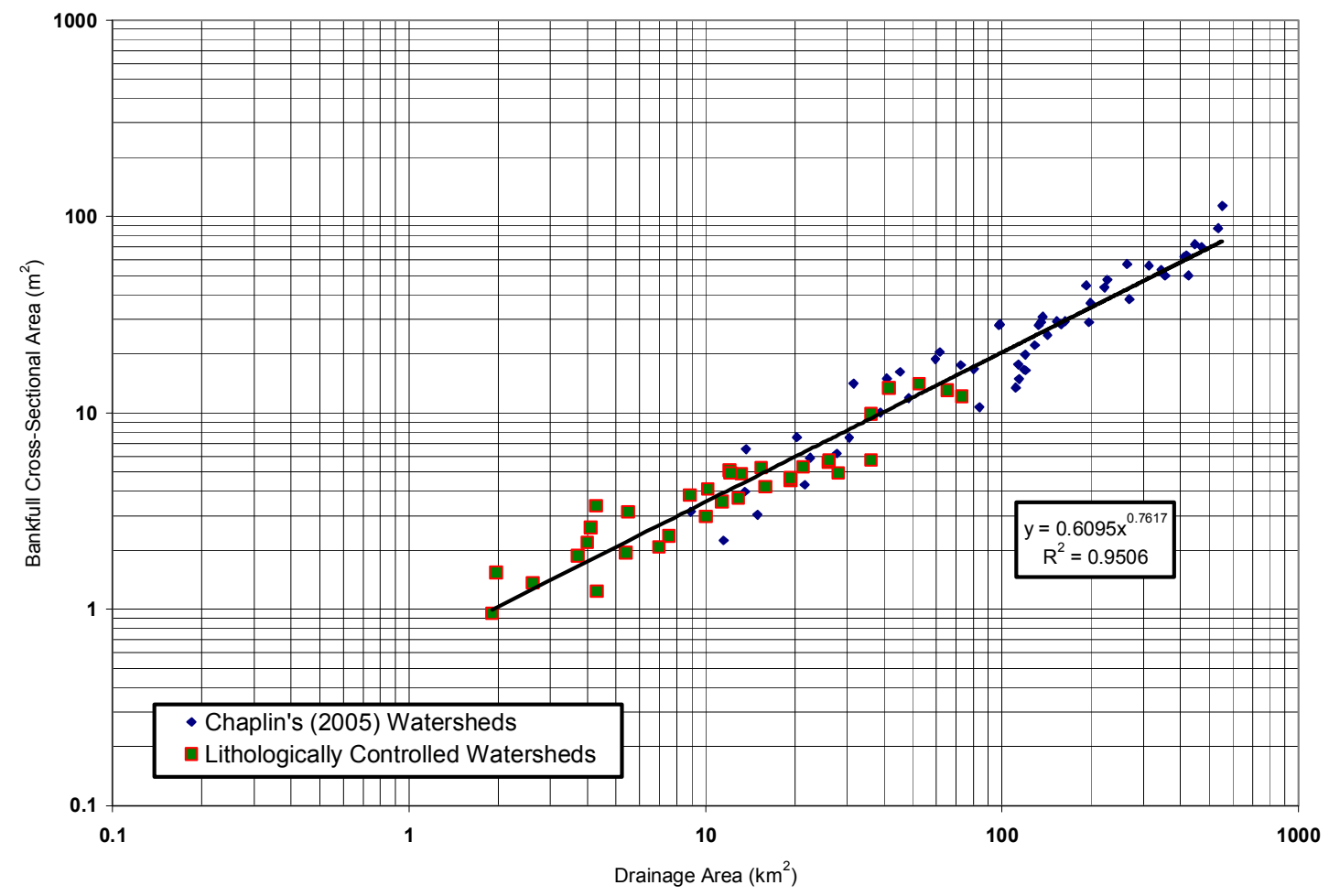

Figure 36. Combined regional curve for non-carbonate watersheds for bankfull crosssectional area. 


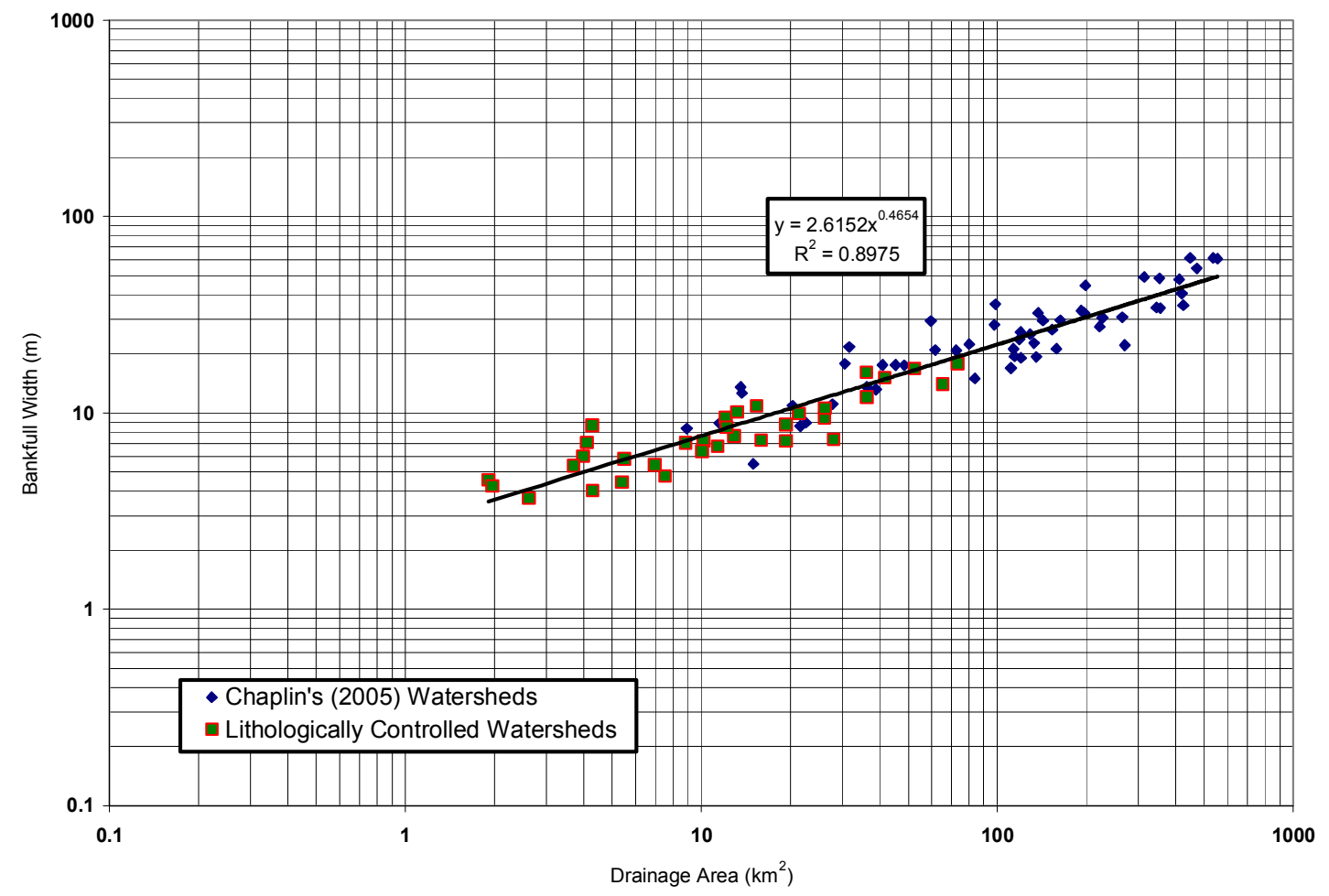

Figure 37. Combined regional curve for non-carbonate watersheds for bankfull width. 


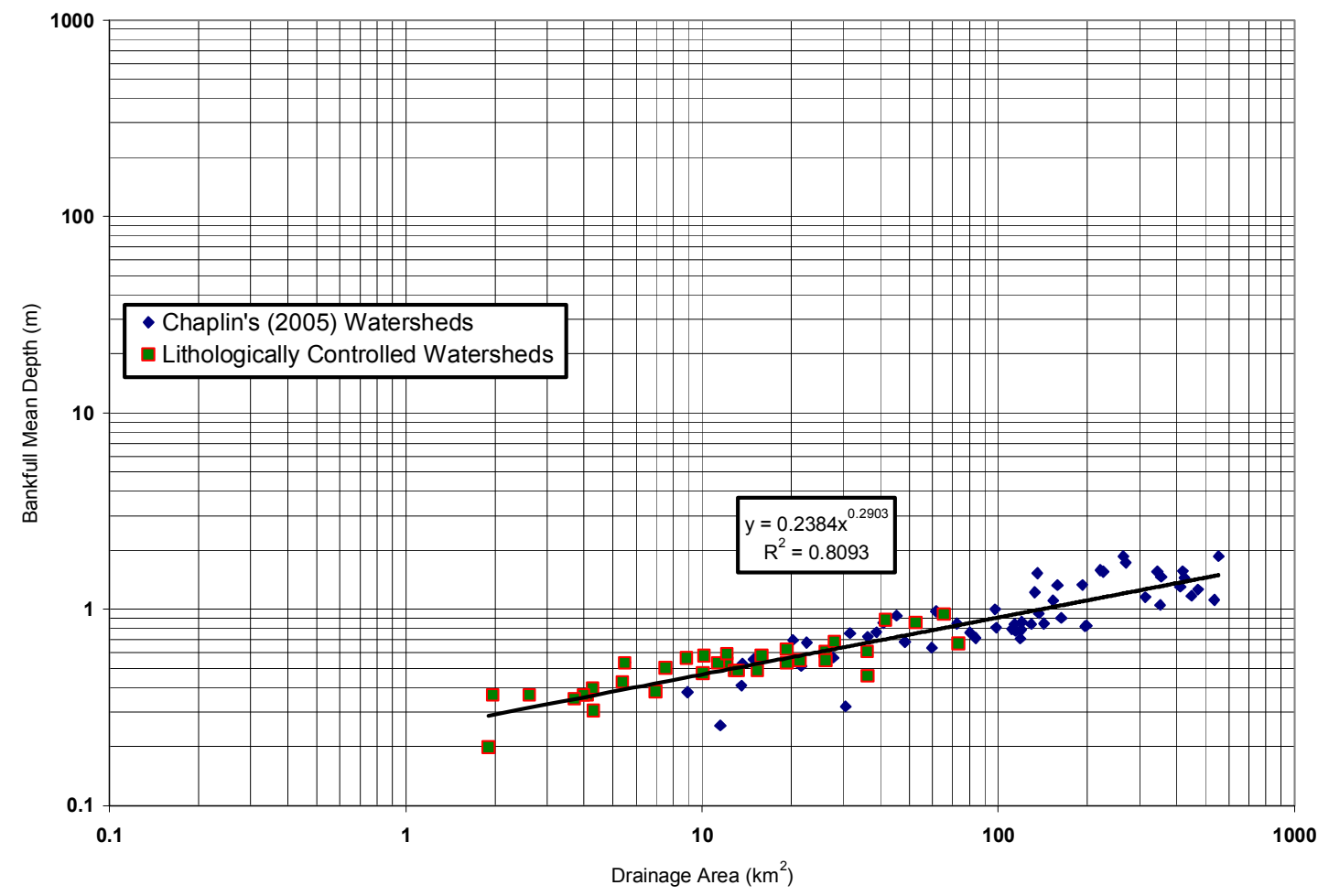

Figure 38. Combined regional curve for non-carbonate watersheds for bankfull mean depth. 


\begin{tabular}{|l|r|r|r|r|c|}
\hline \multicolumn{1}{|c|}{$\begin{array}{c}\text { Response } \\
\text { Variable }\end{array}$} & Equation & Slope & Y Intercept & $\mathbf{R}^{\mathbf{2}}$ & F-statistic \\
\hline $\begin{array}{l}\text { Cross- } \\
\text { Sectional Area }\end{array}$ & $\mathrm{CSA}=0.610 \mathrm{DA}^{0.762}$ & 0.762 & 0.610 & 0.95 & 1675.32 \\
\hline Width & $\mathrm{W}=2.615 \mathrm{DA}^{0.465}$ & 0.465 & 2.615 & 0.90 & 762.17 \\
\hline Mean Depth & $\mathrm{D}=0.238 \mathrm{DA}^{0.290}$ & 0.290 & 0.238 & 0.81 & 369.30 \\
\hline
\end{tabular}

Table 20. Summary of quantitative attributes for combined regional curves for noncarbonate watersheds. 
sample size produces better regression fit. Overall, the bankfull cross-sectional area regional curve has the least variance and best regression validity, followed by the bankfull width and lastly bankfull mean depth curves.

\section{Comparison of Regional Curves}

$\mathrm{R}^{2}$ values for the combined regional curves for non-carbonate watersheds for all bankfull response variables (Table 20) are significantly larger than values for the lithologically controlled curves (Table 6). The $\mathrm{R}^{2}$ values for the bankfull cross-sectional area regional curves are most alike, at 0.95 for the combined curves and 0.88 for the lithologically controlled curves. The $\mathrm{R}^{2}$ value for the combined bankfull width curve is 0.90 , explaining $12 \%$ more variance than the lithologically controlled curve. Lastly, the $0.81 \mathrm{R}^{2}$ value for the combined bankfull mean depth curve explains $8 \%$ more variance than the lithologically controlled curve.

\section{Interpretations}

The number of sites used to construct regional curves, channel gradient, and watershed size may influence the high $\mathrm{R}^{2}$ values of the combined regional curves. The combined regional curves are developed with 89 sites, compared to 34 used to construct the lithologically controlled regional curves. Thus, the combined curves constructed with a significantly larger sample size produce less variance and greater statistical precision.

The mean drainage area for watersheds used to construct the combined regional

curves was $108.4 \mathrm{~km}^{2}$ (Table 8), compared to $18.2 \mathrm{~km}^{2}$ (Table 8 ) for the lithologically controlled curves. In addition, small mountain streams have high gradients and greater reach scale variability between adjacent riffles, producing poorly developed floodplains 
and significant local differences in dominant discharge and as a result, channel form. Difficulty in accurately surveying smaller streams likely results in more error and greater variance from the true value of channel geometry. All of these factors combined are suspected to cause the lithologically controlled curves to have more variance than the combined curves.

\section{Analysis of Channel Sedimentology}

\section{Results of Channel Bedload Sediment Investigation}

The riffle sedimentology data and cumulative frequency distributions for each pebble-count are given in Appendix 2. A plot relating the texture of the $\mathrm{D}_{50}$ and $\mathrm{D}_{84}$ for each study reach is included in Appendix 3. Each plot shows variation in bedload texture appear random with increasing watershed area; no downstream fining or coarsening trend can be discerned in the lithologically controlled setting for either $\mathrm{D}_{50}$ or $\mathrm{D}_{84}$. The behavior of the $\mathrm{D}_{50}$ and $\mathrm{D}_{84}$ on all plots is similar, where coarsening or fining occurs in the $\mathrm{D}_{50}$, the same occurs in the $\mathrm{D}_{84}$. A best-fit line relating $\mathrm{D}_{50}$ and $\mathrm{D}_{84}$ to drainage area for all field-investigated reaches (Figure 39) yielded $R^{2}$ values for the $D_{50}$ and $D_{84}$ of only 0.0081 and 0.0034 , respectively, indicating no significant trend exists in downstream changes in the texture of bedload sediments.

\section{Interpretations}

Analysis of channel sedimentology results reveals the texture of bedload sediments is highly variable as drainage area increases. Although not quantified in the field, observation of the study streams along the longitudinal profile revealed significant changes in channel gradient between adjacent riffles. Higher channel gradients result in 


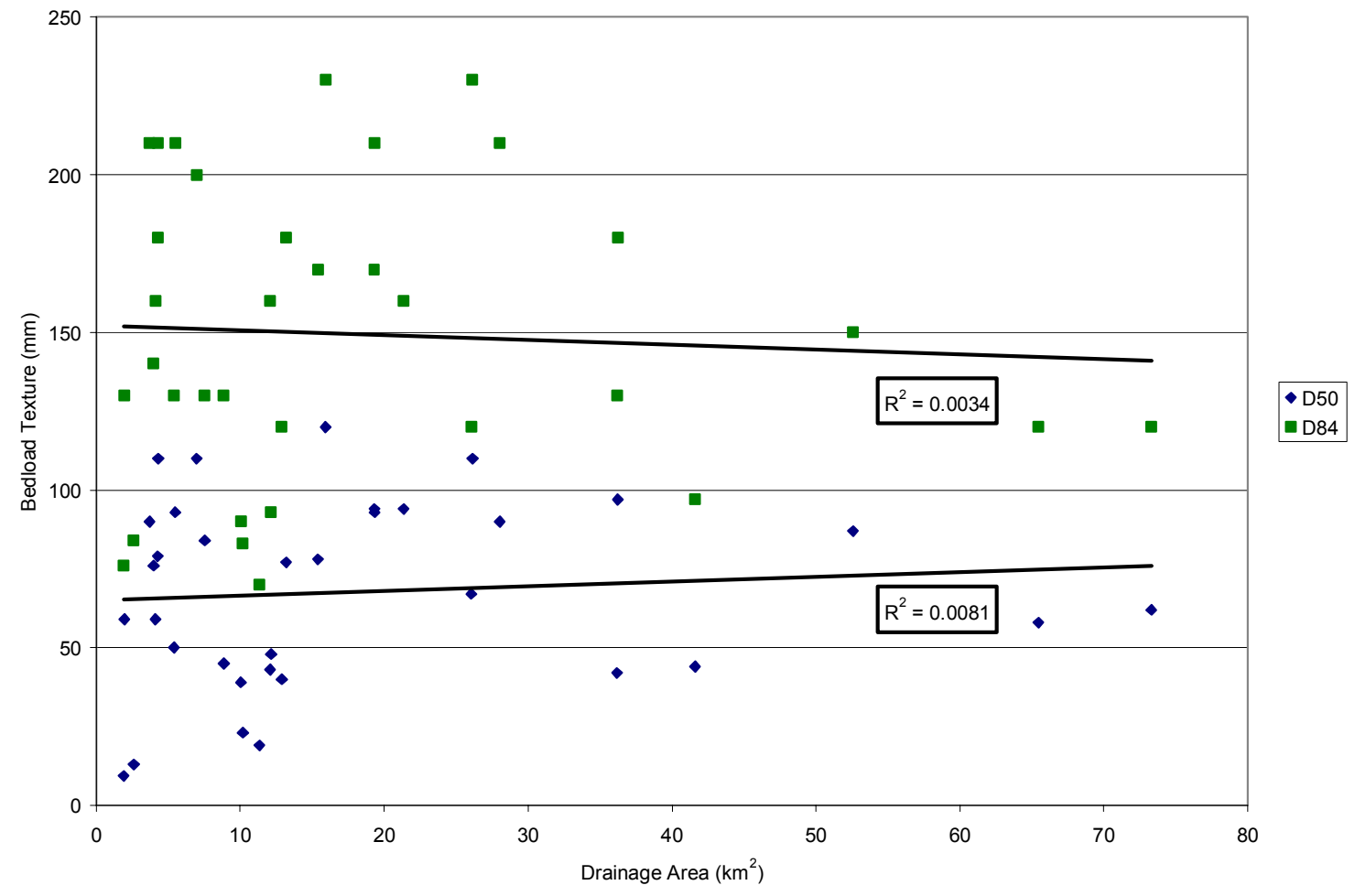

Figure 39. Texture of D50 and D84 of channel bedload sediments versus drainage area for all lithologically controlled watersheds. 
higher flow velocity and stream power than lower channel gradients. Bedload transport is related to the transporting capacity of a given flow, and therefore is related to channel gradient through velocity (Knighton 1998). Thus, local sorting of bedload in riffle sections may give rise to variability of bedload textures as watershed size increases. In validation of the influence of channel gradient on bedload textures, Jarrett (1984) found a positive correlation between the $\mathrm{D}_{84}$ and channel slope for mountain rivers in the Rocky Mountains of Colorado.

The texture of bedload sediments generally decrease in size as the distance downstream increases (Knighton 1998), in contrast to this study's findings. Mechanical disintegration of bedload sediments through abrasion and a decrease in transport capacity as distance downstream increases results in downstream fining (Leopold 1994). However, alluvial input from tributaries and mass movement input from adjacent hill slopes can re-supply stream channels and result in more complex bedload relationships. In the study area of the lithologically controlled watersheds, tributary and hill-slope input may be important sources of bedload to the master streams. Most of the lithologically controlled streams display a trellis drainage pattern, with numerous small, high gradient low-order tributaries that intermittently re-supply the master channel with coarse sediments. Therefore, tributary input might contribute to the apparently random relationship between bedload textures and drainage area.

Hill slope input to stream channels may result from mass movement of the extensive surficial deposits that blanket the slopes that transition from valleys bottoms to ridge tops in the study watersheds. Movement of these surficial deposits may occur when hill slopes are undercut by meandering streams or excessive precipitation results in slope 
instability. Other factors may influence mass wasting in the study watersheds, including historical deforestation and road construction. When colluvial sediments reach adjacent streams, channels likely become overloaded with sediment. Accordingly, the input of coarse sediment from adjacent hill slopes may intermittently resupply the study streams, resulting in the random relationship between bedload texture and drainage area.

\section{$\underline{\text { Conclusions }}$}

The variables that influence natural channel dimensions, bedrock geology, geologic structure, channel gradient, watershed size, riparian vegetation, and land use, vary significantly across and within physiographic provinces and at the reach scale. Previous regional curve investigations in the Appalachian Highlands (Chaplin 2005; Keaton et al. 2005) have considered physiography and land use, specifically urbanization, and also explored the impact of carbonate geology on drainage area-discharge relationships.

In this study, regional curves are developed for lithologically similar watersheds within the Ridge and Valley Physiographic Province. Documented statistical variations in slope and y-intercept between the lithologically controlled curves and curves for varying physiography and watershed size are summarized in Table 21 . As a result, future investigators should make an effort to constrain additional variables that influence channel dimensions within physiographic provinces, in an attempt to increase the statistical precision of regional curve equations.

Watershed size and channel gradient may be influential in causing differences in slope and y-intercept between the lithologically controlled regional curves and the three distinct regional curves derived from watersheds of varying size and physiography. 


\begin{tabular}{|c|c|c|c|c|c|c|}
\hline \multirow{3}{*}{$\begin{array}{l}\underline{\text { Regional Curve }} \\
\text { Curve Attribute }\end{array}$} & \multicolumn{6}{|c|}{$\underline{\text { Lithologically Controlled Watersheds }}$} \\
\hline & \multicolumn{2}{|c|}{$\frac{\text { Bankfull Cross- }}{\text { Sectional Area }}$} & \multicolumn{2}{|c|}{$\frac{\text { Bankfull }}{\underline{\text { Width }}}$} & \multicolumn{2}{|c|}{$\frac{\text { Bankfull }}{\text { Mean Depth }}$} \\
\hline & Slope & Intercept & Slope & Intercept & Slope & Intercept \\
\hline $\begin{array}{c}\text { Chaplin's (2005) } \\
\text { Curves }\end{array}$ & Lower & Higher & ---- & ---- & ---- & ---- \\
\hline $\begin{array}{l}\text { Curves for }<75 \\
\mathrm{~km}^{2} \text { Watersheds } \\
\text { (Chaplin's Data) }\end{array}$ & Lower & Higher & ---- & ---- & ---- & Higher \\
\hline $\begin{array}{l}\text { Curves for Ridge } \\
\text { and Valley } \\
\text { (Chaplin's Data) }\end{array}$ & Lower & ---- & ---- & ---- & ---- & ---- \\
\hline
\end{tabular}

Table 21. Summary of key results from slope and y-intercept comparisons between regional curves. Key to symbols in table: [Lower] A lower slope/intercept exists for lithologically controlled regional curves, [Higher] A higher slope/intercept exists for lithologically controlled regional curves, [----] No statistical difference exists between regional curves. 
These factors, furthermore, may be important in producing variability in $\mathrm{R}^{2}$ values, or explained variance. Specifically, regional curves derived from relatively small watersheds in mountain settings are shown to produce lower $\mathrm{R}^{2}$ values than curves developed from larger watersheds from lowland settings. As a result, future investigations could group watersheds according to drainage area and streams according to channel gradient, and develop unique relationships for each. By grouping watersheds into classes according to size and gradient, it may be possible to separate mountain rivers with a flashier hydrology from lowland rivers. Comparison of regional curve slope and $\mathrm{y}$-intercept values and of $\mathrm{R}^{2}$ values from regression analysis between the groups may reveal if this strategy is worthwhile in increasing explained variance or producing statistically unique regional curve equations.

The development of regional curves has been historically limited to stream flow gauge sites with good flood frequency records, and so the overwhelming majority of watersheds are ignored. This historic limitation is related to the development of regional curves relating drainage area to bankfull discharge. However, in stream restoration, the proper size of design channels on ungauged streams can be estimated with the assistance of a bankfull cross-sectional area, bankfull width, and bankfull mean depth regional curve (Harmon et al. 1999). If channel gradient is measured in the field at an ungauged stream reach, bankfull discharge can be estimated using the slope-conveyance or critical depth methods. Jarrett and England (2002) have shown that using either of these methods results in discharge values within twenty-five percent of actual values. Therefore, future development of regional curves should include ungauged watersheds. 
The number of sites used to develop regional curves for physiographic provinces in Pennsylvania almost always is correlated with variance, if all other independent variables remain constant. As sample size increases, the precision of curve equations increases, and variance decreases, assuming a representative sample has been collected. In this study, the combined regional curves for non-carbonate watersheds are developed from 89 sites, resulting in high explained variance for all bankfull variables. Furthermore, these curves are derived from gauged and ungauged watersheds, allowing such a large sample size in curve development. Thus, the inclusion of ungauged sites in regional curves will allow larger data sets and may yield curve equations with greater statistical precision and less variance.

A suggested methodology for future curve investigations would involve first, determining which variables controlling hydraulic geometry are to be constrained. A large number of gauged and ungauged streams should be then sampled, resulting in a data set that may potentially be sub-sampled into groups based on drainage area and channel gradient differences. To ascertain if grouping of the sampled streams is warranted, cluster analysis may be utilized. Results from cluster analysis may define thresholds to assemble the sampled streams into distinctive groups, based on similarities in drainage area and channel gradient. If clustering of data is apparent, unique regional hydraulic geometry curves should be developed for the watershed groups and the slopes and yintercepts of the curves should be compared using analysis of covariance, to assess if the curve attributes are statistically different. 


\section{Limitations and Constraints on the Applications of Lithologically Controlled}

\section{$\underline{\text { Regional Curves }}$}

The limitations associated with regional curve development relate to the fulfillment of the requirements of regression analysis. These limitations relate to a lack normally distributed and heteroscedastic residuals. Constraints on the application of existing regional curves stem from the attributes of the watersheds used to develop the relations. It is important to note that regional curves should not be the sole means to estimate bankfull channel dimensions. Additional methods, such as field-evidenced bankfull stage identification and flood-flow records, should be coupled with use of the regional curves. The lithologically controlled regional curves for non-carbonate watersheds should be used only when the following requirements are met:

- The criteria used in the selection of watersheds for regional curves must be fulfilled.

- Use of regional curves is limited to the range of watersheds sampled in the development of regional curves, between 1.91 to $73.3 \mathrm{~km}^{2}$.

- Use of regional curves from this study is limited to watersheds that did not experience glacial erosion or deposition during the Pleistocene Epoch.

- Percent urban land use must be minimal, less than $1 \%$ per watershed area.

- Percent forest cover must be the dominant land cover, with at least $85 \%$ per watershed area. 


\section{References}

Berg, T.M., Edmunds, W.E., and Geyer, A.R., 1980. Geologic Map of Pennsylvania, 2nd Edition. Pennsylvania Geological Survey.

Bloom, A.L., 1998. Geomorphology, A Systematic Analysis of Late Cenozoic Landforms ( ${ }^{\text {rd }}$ Edition). Waveland Press, Inc., Long Grove, IL.

Brush, L.M.J., 1961. Drainage Basins, Channels, and Flow Characteristics of Selected Streams in Central Pennsylvania, U.S. Geological Survey Professional Paper 282F, pp. 145-181.

Bunte, K., and Abt, S. R., 2001. Sampling Surface and Subsurface Particle-size Distributions in Wadeable Gravel-and Cobble-Bed Streams for Analyses in Sediment Transport, Hydraulics, and Streambed Monitoring, Gen. Tech. Rep. RMRS-GTR-74. U.S. Department of Agriculture, Forest Service, Rocky Mountain Research Station, Fort Collins, CO, pp. 482.

Chaplin, J.J., 2005. Development of Regional Curves Relating Bankfull-Channel Geometry and Discharge to Drainage Area for Streams in Pennsylvania and Selected Areas of Maryland, U.S. Geological Survey Water-Resources Investigation Report 2005-5147, pp. 40.

Donovan, J.J., 2006. Regression Analysis, Lecture for Geology 659, West Virginia University, Morgantown, WV.

Dunne, T., and Leopold, L.B., 1978. Water in Environmental Planning. W.H. Freeman, San Francisco.

Emmett, W.W., 1975. The Channels and Waters of the Upper Salmon River Area, Idaho, United States Geological Survey Professional Paper 870-A, pp. 115.

Fenneman, N.M., 1928. Physiographic Divisions of the United States. Annals of the Association of American Geographers, 18: 264-355.

Grabow, G.L., Spooner, J., Lombardo, L.A., Line, D.E., and Tweedy, K.L., 1998. Has Water Quality Improved?: Use of a Spreadsheet for Statistical Analysis of Paired Watershed, Upstream/Downstream, and Before/After Monitoring Designs, NCSU Water Quality Group Newsletter. North Carolina State University, Raleigh, NC.

Guyer, A.R., and Wilshusen, J.P., 1982. Engineering Characteristics of the Rocks of Pennsylvania. Pennsylvania Geological Survey, Harrisburg, PA.

Hack, J.T., 1957. Studies of Longitudinal Stream Profiles in Virginia and Maryland, United States Geological Survey Professional Paper 294-B, pp. 45-95. 
Hack, J.T., 1965. Geomorphology of the Shenandoah Valley, Virginia and West Virginia, and the Origin of the Residual Ore Deposits, U.S. Geological Survey Professional Paper 484, pp. 84.

Harman, W.H., Jennings, G.D., Patterson, J.M., Clinton, D.R., Slate, L.O., Jessup, A.G., Everhart, J.R., and Smith, R.E., 1999. Bankfull Hydraulic Geometry Relationships for North Carolina Streams. AWRA Wildland Hydrology Symposium Proceedings. American Water Resources Association, Bozeman, MT.

Jarrett, R.D., 1984. Hydraulics of High-Gradient Streams. Journal of Hydraulic Engineering, 110(11): 1519-1539.

Jarrett, R.D., and England, J.F., Jr., 2002. Reliability of Paleostage Indicators for Paleoflood Studies: American Geophysical Union Water Science and Application Series. In: P.K. House, Webb, R.H., Baker, V.R., and Levish, D.R. (Editor), Ancient Floods, Modern Hazards, Principles and Applications of Paleoflood Hydrology, pp. 91-109.

Kachigan, S.K., 1986. An Interdisciplinary Introduction to Univariate and Multivariate Methods. Radius Press, New York.

Keaton, J.N., Messinger, T., and Doheny, E.H., 2005. Development and Analysis of Regional Curves for Streams in the Non-urban Valley and Ridge Physiographic Province, Maryland, Virginia, and West Virginia, U.S. Geological Survey Scientific Investigations Report 2005-5076, pp. 115.

Knighton, D., 1998. Fluvial Forms and Processes, A New Perspective. Arnold, London, U.K.

Leica Geosystems, 2007. Rugby 100 LR Survey Laser. Loyola Spatial Systems, [online] http://www.leica.loyola.com/products/-construction_lasers/rugby1001r.html.

Leopold, L.B., and Maddock, T., 1953. The Hydraulic Geometry of Stream Channels and some Physiographic Implications, U.S. Geological Survey Professional Paper 252, pp. 57.

Leopold, L.B., 1994. A View of the River. Harvard University Press, Cambridge, MA.

Mecklenburg, D., 2006. Reference Reach Spreadsheet, Version 4.3L. Ohio Department of Natural Resources.

Miller, J.R., 1991. Controls on Channel Form along Bedrock-Influenced Alluvial Streams in South-Central Indiana. Physical Geography, 12: 167-186.

Mills, H.H., and Delcourt, P.A., 1991. Quaternary Geology of the Appalachian Highlands and Interior Low Plateaus. In: R.B. Morrison (Editor), Quaternary Non-Glacial 
Geology; Coterminous U.S.; The Geology of North America. Geological Society of America, Boulder, Colorado, pp. 611 - 628.

Osterkamp, W.R., 1980. Sediment-Morphology Relations of Alluvial Channels, Proceedings of the Symposium on Watershed Management. American Society of Civil Engineers, pp. 188-199.

Rosgen, D., 1996. Applied River Morphology. Printed Media Companies, Minneapolis, $\mathrm{MN}$.

Schumm, S.A., 1960. The Shape of Alluvial Channels in Relation to Sediment Type, U.S. Geological Survey Professional Paper 352-B, pp. 30.

Schumm, S.A., 1963. A Tentative Classification of Alluvial River Channels; An Examination of Similarities and Differences among some Great Plains Rivers, U.S. Geological Survey Professional Paper 477, pp. 10.

Sevon, W.D., 2000. Physiographic Provinces of Pennsylvania (4th ed.), Bureau of Topographic and Geologic Survey Map 13. Pennsylvania Geological Survey, Harrisburg, PA.

Shultz, C.H., 1999. The Geology of Pennsylvania. Pennsylvania Geological Survey, Harrisburg, PA.

Skidmore, P.B., Shields, F.D., Doyle, M.W., and Miller, D.E., 2001. A Categorization of Approaches to Natural Channel Design, Proceedings of the ASCE Wetlands Engineering and River Restoration Conference. American Society of Civil Engineers, pp. 12.

Swift, B.L., 1984. Status of Riparian Ecosystems in the United States. Water Resources Bulletin, 20: 223-228.

Thornbury, W.D., 1965. Regional Geomorphology of the United States. John Wiley \& Sons, Inc., New York.

U.S.G.S., 1996. National Land Cover Data, [online] http://www.pasda.su.edu/data/nlcd/nlcd_pa_tiff_dd.zip.

Wharton, G., Arnell, N.W., Gregory, K.J., and Gurnell, A.M., 1989. River Discharge Estimated from Channel Dimensions. Journal of Hydrology, 106: 365-376.

Williams, G.P., 1978. Bankfull discharge of rivers. Water Resources Research, 14(6): $1141-1154$.

Wohl, E.E., 2000. Mountain Rivers, Water Resources Monograph 14. American Geophysical Union, Washington D.C. 
Wolman, M.G., 1954. A Method of Sampling Coarse River-Bed Material. Transactions of the American Geophysical Union, 35: 951-956.

Wolman, M.G., and Miller, J.P., 1960. Magnitude and Frequency of Forces in Geomorphic Processes. Journal of Geology, 68: 54-74. 


\section{Appendix 1. Characteristics of the measured riffles and channel survey data for}

\section{lithologically controlled watersheds.}

The data collected while surveying the channel cross-section of all of the measured riffles is available in Appendix 1. The appendix also includes the coordinates of the measured riffles in the Universal Transverse Mercator system using the North American Datum of 1927, a description of the reach location, graphs of the surveyed channel cross-sections, the drainage area of the riffle watersheds, the field evidenced bankfull stage indicator, and riffle scale calculations for all of the bankfull response variables. The highest elevation measured at each riffle was later adjusted to a base level of 100 feet, for consistency in the channel cross-section graphs. A uniform scale is used on all channel cross-section graphs, to allow for visual comparison between the study watersheds. The horizontal blue line in the channel cross-section graphs indicates the elevation of the bankfull stage. The study streams were initially surveyed and the bankfull response variables were calculated in English units (feet). The bankfull stage elevation is noted by bolder text and an asterisk $(*)$ after the value. Conversion of the bankfull response variables to metric units was carried out after the reach average was calculated (Table 4). 


\section{South Branch Little Aughwick Creek}

Date of Survey: April 30, 2007

Reach \#: 1-A
Time of Survey: 9:35 am

Drainage Area: 0.74 sq. miles

UTM Coordinate Location: Zone 18, $4425801 \mathrm{~m} \mathrm{~N}, 0247456 \mathrm{~m} \mathrm{E}$

Location Information: Buchanan State Forest, parked vehicle on Aughwick Road, approximately $1 / 4$ mile north of Fore Trail.

Bankfull Indicator(s): A change in slope along the west channel bank.

Bankfull Response Variables: Cross-sectional area (11.4 square feet), width (15.5 feet), mean depth ( 0.7 feet).

\section{Graph of Channel Cross-Section}

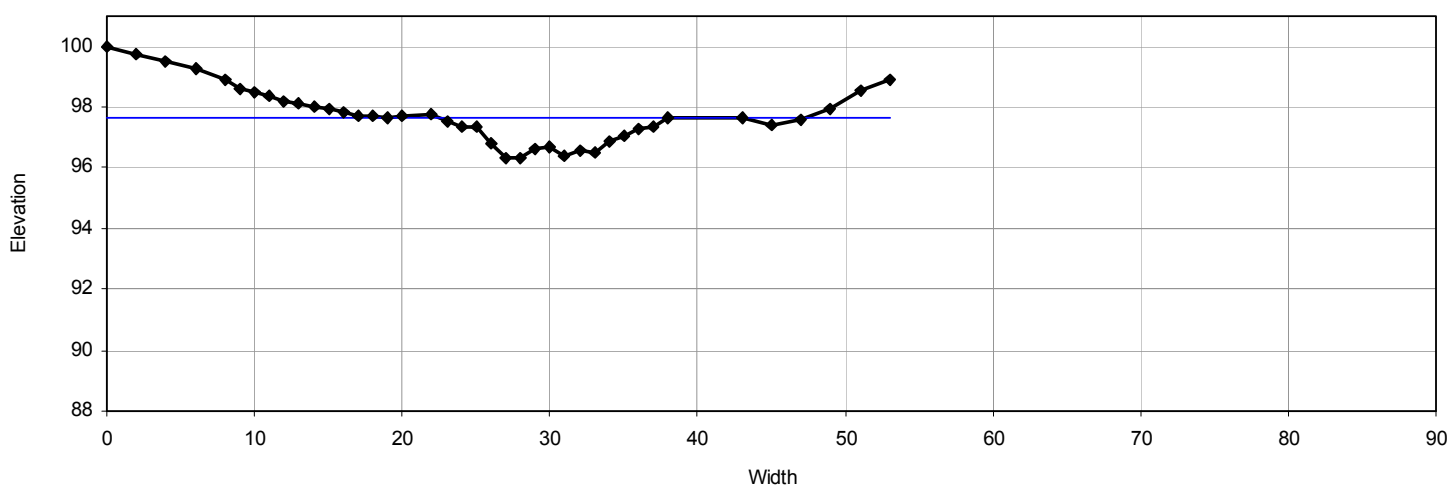

$\underline{\text { Survey Data }}$

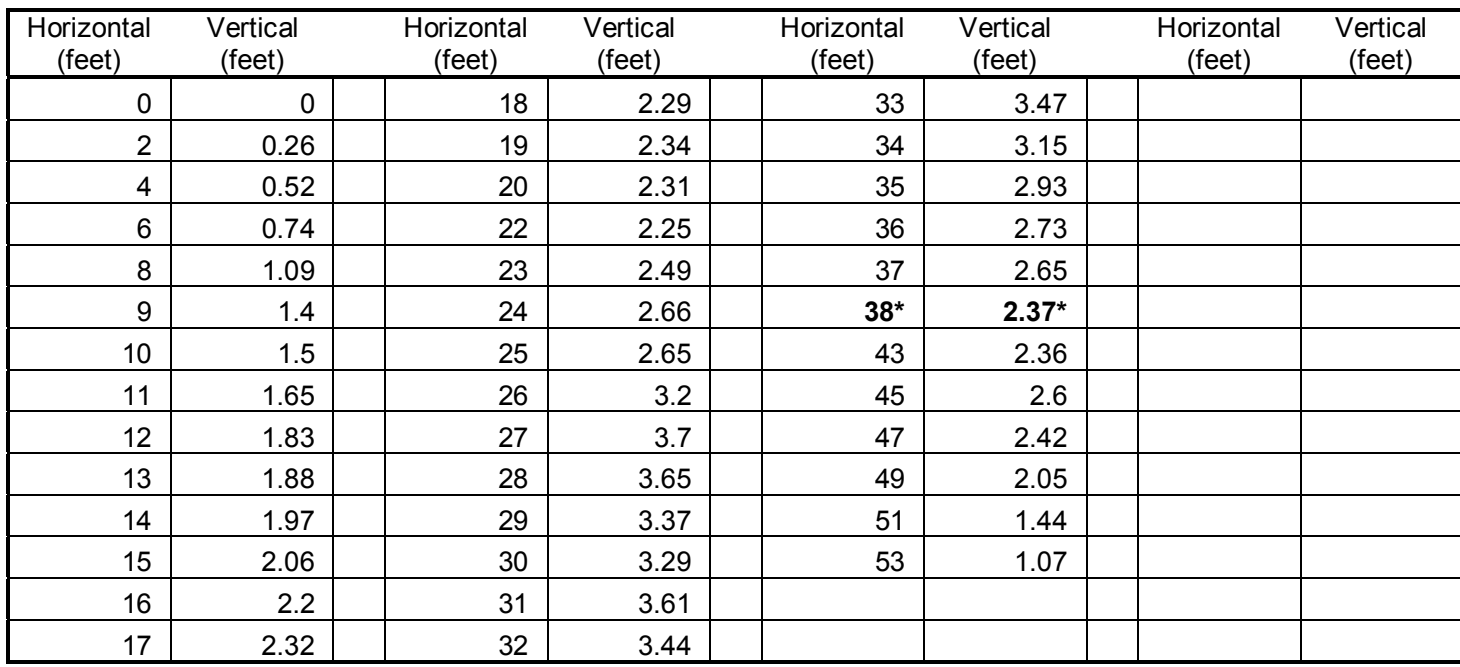




\section{South Branch Little Aughwick Creek}

Date of Survey: April 30, 2007

Reach \#: 1 -B
Time of Survey: 10:12 am

Drainage Area: 0.74 sq. miles

UTM Coordinate Location: Zone 18, $4425800 \mathrm{~m} \mathrm{~N}, 0247461 \mathrm{~m} \mathrm{E}$

Location Information: Buchanan State Forest, parked vehicle on Aughwick Road, approximately $1 / 4$ mile north of Fore Trail, upstream from survey 1-A.

Bankfull Indicator(s): A change in slope along the east channel bank.

Bankfull Response Variables: Cross-sectional area (9.1 square feet), width (14.3 feet), mean depth (0.6 feet).

\section{Graph of Channel Cross-Section}

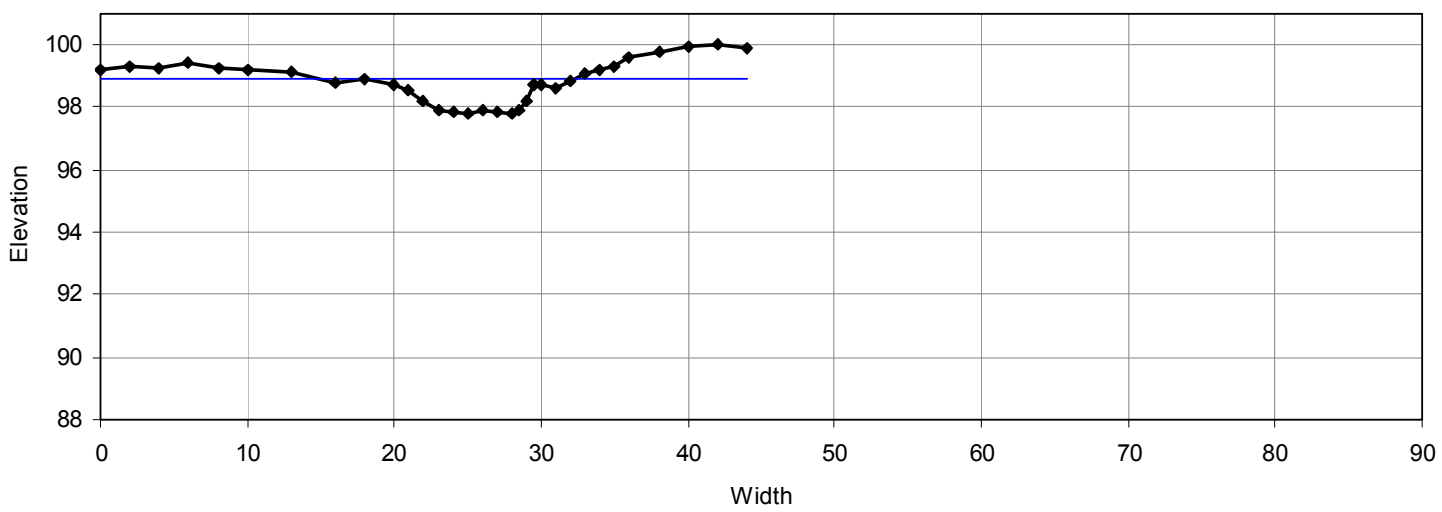

$\underline{\text { Survey Data }}$

\begin{tabular}{|c|c|c|c|c|c|c|c|}
\hline $\begin{array}{c}\text { Horizontal } \\
\text { (feet) }\end{array}$ & $\begin{array}{c}\begin{array}{l}\text { Vertical } \\
\text { (feet) }\end{array} \\
\end{array}$ & $\begin{array}{c}\text { Horizontal } \\
\text { (feet) }\end{array}$ & $\begin{array}{c}\begin{array}{c}\text { Vertical } \\
\text { (feet) }\end{array} \\
\end{array}$ & $\begin{array}{c}\text { Horizontal } \\
\text { (feet) }\end{array}$ & $\begin{array}{c}\text { Vertical } \\
\text { (feet) }\end{array}$ & $\begin{array}{c}\text { Horizontal } \\
\text { (feet) }\end{array}$ & $\begin{array}{c}\begin{array}{c}\text { Vertical } \\
\text { (feet) }\end{array} \\
\end{array}$ \\
\hline 0 & 0.78 & 25 & 2.21 & 38 & 0.2 & & \\
\hline 2 & 0.68 & 26 & 2.11 & 40 & 0.06 & & \\
\hline 4 & 0.73 & 27 & 2.16 & 42 & 0 & & \\
\hline 6 & 0.56 & 28 & 2.19 & 44 & 0.1 & & \\
\hline 8 & 0.72 & 28.5 & 2.1 & & & & \\
\hline 10 & 0.78 & 29 & 1.8 & & & & \\
\hline 13 & 0.88 & 29.5 & 1.3 & & & & \\
\hline 16 & 1.22 & 30 & 1.28 & & & & \\
\hline $18^{*}$ & $1.07^{*}$ & 31 & 1.39 & & & & \\
\hline 20 & 1.25 & 32 & 1.13 & & & & \\
\hline 21 & 1.43 & 33 & 0.9 & & & & \\
\hline 22 & 1.8 & 34 & 0.78 & & & & \\
\hline 23 & 2.1 & 35 & 0.68 & & & & \\
\hline 24 & 2.15 & 36 & 0.39 & & & & \\
\hline
\end{tabular}




\section{South Branch Little Aughwick Creek}

Date of Survey: April 30, 2007

Reach \#: 2-A
Time of Survey: 11:08 am

Drainage Area: 2.08 sq. miles

UTM Coordinate Location: Zone 18, 4427286 m N, 0247990 m E

Location Information: Buchanan State Forest, parked vehicle at intersection of Aughwick Road and King's trail, walked upstream.

Bankfull Indicator(s): A change in slope along the west channel bank.

Bankfull Response Variables: Cross-sectional area (9.3 square feet), width (17.6 feet), mean depth (0.5 feet).

\section{Graph of Channel Cross-Section}

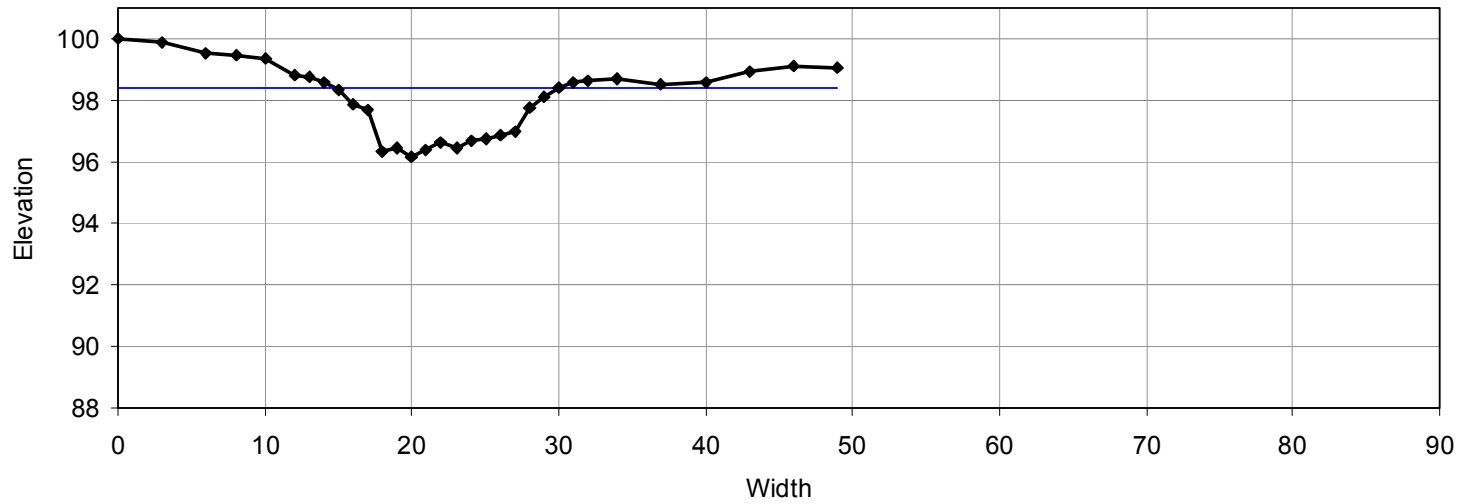

Survey Data

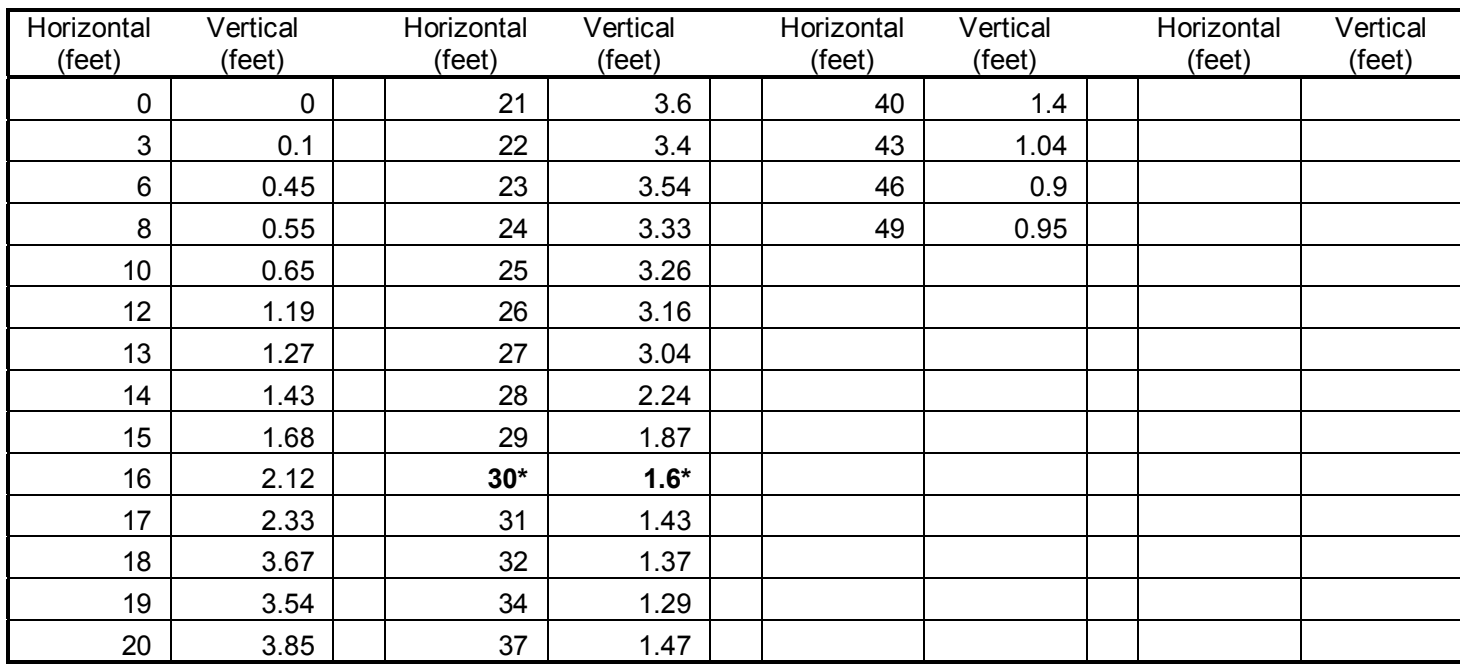




\section{South Branch Little Aughwick Creek}

Date of Survey: April 30, 2007

Time of Survey: 11:39 am

Reach \#: 2-B

Drainage Area: 2.08 sq. miles

UTM Coordinate Location: Zone 18, 4427256 m N, 0247978 m E

Location Information: Buchanan State Forest, parked vehicle at intersection of

Aughwick Road and King's trail. Located upstream from reach 2-A.

Bankfull Indicator(s): A change in slope along the west channel bank.

Bankfull Response Variables: Cross-sectional area (21.2 square feet), width (13.9 feet), mean depth (1.3 feet).

\section{Graph of Channel Cross-Section}

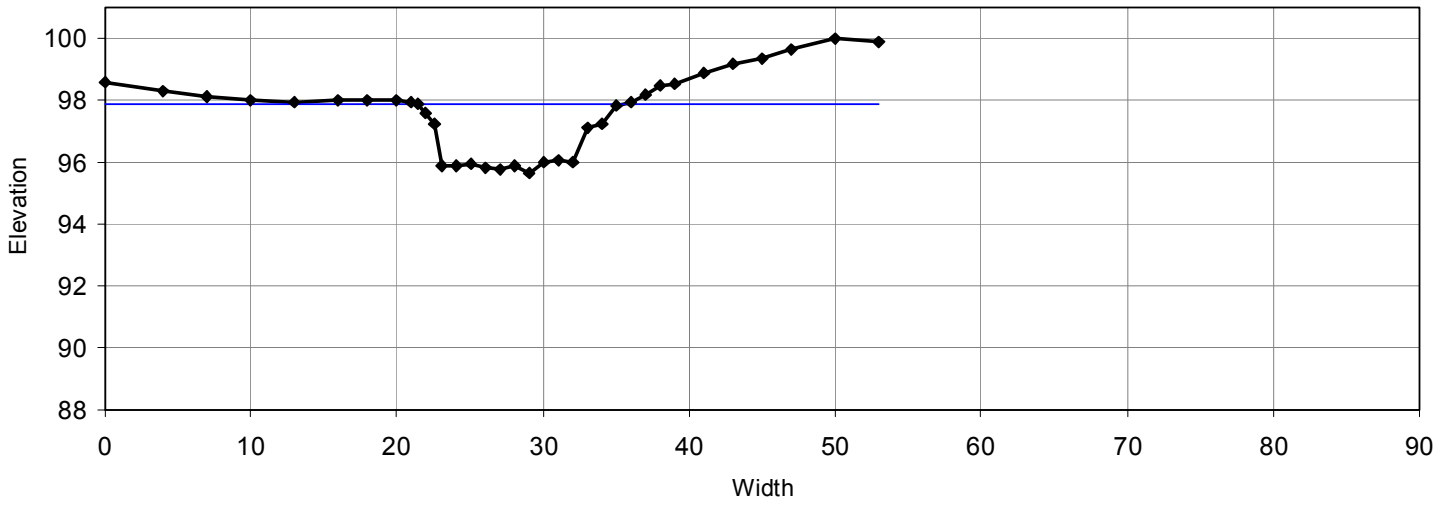

$\underline{\text { Survey Data }}$

\begin{tabular}{|c|c|c|c|c|c|c|c|}
\hline $\begin{array}{c}\text { Horizontal } \\
\text { (feet) }\end{array}$ & $\begin{array}{c}\begin{array}{c}\text { Vertical } \\
\text { (feet) }\end{array} \\
\end{array}$ & $\begin{array}{c}\text { Horizontal } \\
\text { (feet) }\end{array}$ & $\begin{array}{l}\begin{array}{l}\text { Vertical } \\
\text { (feet) }\end{array} \\
\end{array}$ & $\begin{array}{c}\text { Horizontal } \\
\text { (feet) }\end{array}$ & $\begin{array}{c}\begin{array}{c}\text { Vertical } \\
\text { (feet) }\end{array} \\
\end{array}$ & $\begin{array}{c}\text { Horizontal } \\
\text { (feet) }\end{array}$ & $\begin{array}{c}\begin{array}{c}\text { Vertical } \\
\text { (feet) }\end{array} \\
\end{array}$ \\
\hline 0 & 1.44 & 25 & 4.06 & 39 & 1.47 & & \\
\hline 4 & 1.68 & 26 & 4.2 & 41 & 1.13 & & \\
\hline 7 & 1.9 & 27 & 4.24 & 43 & 0.82 & & \\
\hline 10 & 2.02 & 28 & 4.12 & 45 & 0.65 & & \\
\hline 13 & 2.07 & 29 & 4.33 & 47 & 0.37 & & \\
\hline 16 & 2.18 & 30 & 4 & 50 & 0 & & \\
\hline 18 & 1.89 & 31 & 3.92 & 53 & 0.1 & & \\
\hline 20 & 2 & 32 & 4 & & & & \\
\hline 21 & 2.07 & 33 & 2.88 & & & & \\
\hline $21.5^{*}$ & $2.13^{*}$ & 34 & 2.76 & & & & \\
\hline 22 & 2.4 & 35 & 2.19 & & & & \\
\hline 22.5 & 2.74 & 36 & 2.03 & & & & \\
\hline 23 & 4.11 & 37 & 1.8 & & & & \\
\hline 24 & 4.13 & 38 & 1.54 & & & & \\
\hline
\end{tabular}




\section{South Branch Little Aughwick Creek}

Date of Survey: April 30, 2007

Time of Survey: 12:37 am

Reach \#: 3-A

Drainage Area: 3.42 sq. miles

UTM Coordinate Location: Zone 18, 4429045 m N, 0248757 m E

Location Information: Buchanan State Forest, parked vehicle at intersection of Aughwick Road and Crossing Creek Trail, approximately 300 yards downstream of bridge over creek.

Bankfull Indicator(s): A change in slope along the west channel bank.

Bankfull Response Variables: Cross-sectional area (40.5 square feet), width (19.5 feet), mean depth $(2.1$ feet $)$.

\section{Graph of Channel Cross-Section}

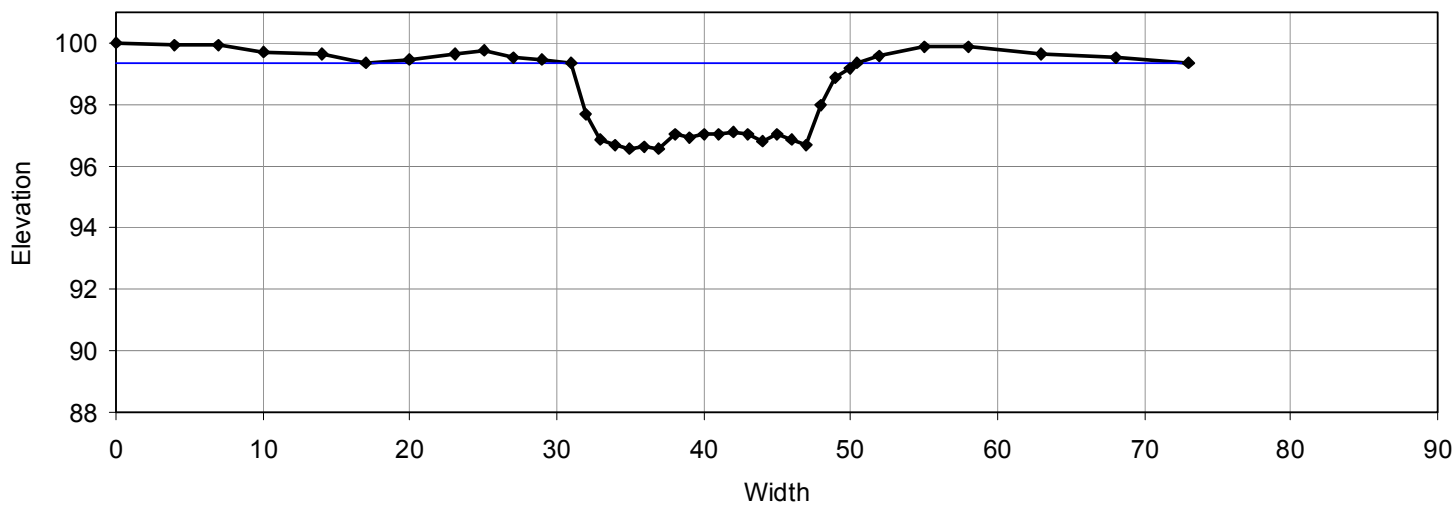

$\underline{\text { Survey Data }}$

\begin{tabular}{|c|c|c|c|c|c|c|c|}
\hline $\begin{array}{c}\text { Horizontal } \\
\text { (feet) }\end{array}$ & $\begin{array}{c}\begin{array}{c}\text { Vertical } \\
\text { (feet) }\end{array} \\
\end{array}$ & $\begin{array}{c}\text { Horizontal } \\
\text { (feet) }\end{array}$ & $\begin{array}{c}\begin{array}{c}\text { Vertical } \\
\text { (feet) }\end{array} \\
\end{array}$ & $\begin{array}{c}\text { Horizontal } \\
\text { (feet) }\end{array}$ & $\begin{array}{c}\begin{array}{l}\text { Vertical } \\
\text { (feet) }\end{array} \\
\end{array}$ & $\begin{array}{c}\text { Horizontal } \\
\text { (feet) }\end{array}$ & $\begin{array}{c}\begin{array}{c}\text { Vertical } \\
\text { (feet) }\end{array} \\
\end{array}$ \\
\hline 0 & 0 & 34 & 3.3 & 48 & 2 & & \\
\hline 4 & 0.05 & 35 & 3.42 & 49 & 1.1 & & \\
\hline 7 & 0.09 & 36 & 3.36 & 50 & 0.83 & & \\
\hline 10 & 0.3 & 37 & 3.44 & $50.5^{*}$ & $0.67^{*}$ & & \\
\hline 14 & 0.35 & 38 & 2.96 & 52 & 0.39 & & \\
\hline 17 & 0.65 & 39 & 3.05 & 55 & 0.1 & & \\
\hline 20 & 0.52 & 40 & 2.96 & 58 & 0.13 & & \\
\hline 23 & 0.35 & 41 & 2.97 & 63 & 0.35 & & \\
\hline 25 & 0.25 & 42 & 2.88 & 68 & 0.45 & & \\
\hline 27 & 0.46 & 43 & 2.95 & 73 & 0.65 & & \\
\hline 29 & 0.55 & 44 & 3.2 & & & & \\
\hline 31 & 0.67 & 45 & 2.97 & & & & \\
\hline 32 & 2.32 & 46 & 3.15 & & & & \\
\hline 33 & 3.11 & 47 & 3.33 & & & & \\
\hline
\end{tabular}




\section{South Branch Little Aughwick Creek}

Date of Survey: April 30, 2007

Reach \#: 3-B
Time of Survey: 1:05 pm

Drainage Area: 3.42 sq. miles

UTM Coordinate Location: Zone 18, 4429065 m N, 0248752 m E

Location Information: Buchanan State Forest, reach located approximately 60 feet downstream from 3-A.

Bankfull Indicator(s): A change in slope along the west channel bank.

Bankfull Response Variables: Cross-sectional area (40.5 square feet), width (19.5 feet), mean depth (2.1 feet).

\section{Graph of Channel Cross-Section}

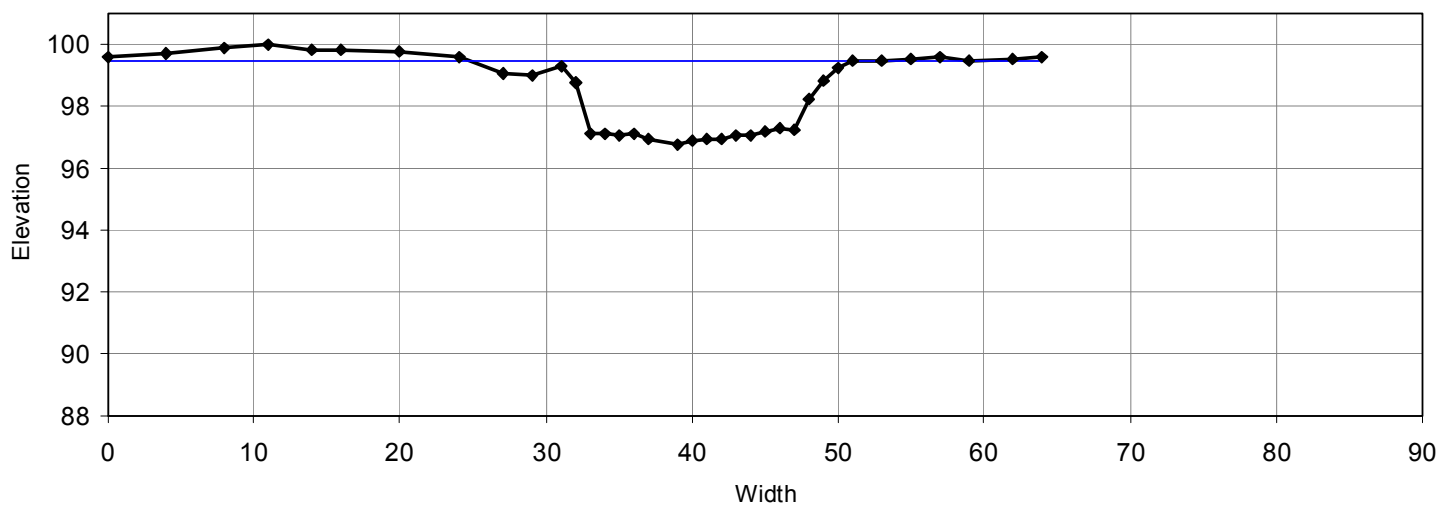

$\underline{\text { Survey Data }}$

\begin{tabular}{|c|c|c|c|c|c|c|c|}
\hline $\begin{array}{c}\text { Horizontal } \\
\text { (feet) }\end{array}$ & $\begin{array}{c}\text { Vertical } \\
\text { (feet) }\end{array}$ & $\begin{array}{c}\text { Horizontal } \\
\text { (feet) }\end{array}$ & $\begin{array}{c}\begin{array}{c}\text { Vertical } \\
\text { (feet) }\end{array} \\
\end{array}$ & $\begin{array}{c}\text { Horizontal } \\
\text { (feet) }\end{array}$ & $\begin{array}{c}\text { Vertical } \\
\text { (feet) }\end{array}$ & $\begin{array}{c}\text { Horizontal } \\
\text { (feet) }\end{array}$ & $\begin{array}{c}\begin{array}{c}\text { Vertical } \\
\text { (feet) }\end{array} \\
\end{array}$ \\
\hline 0 & 0.44 & 35 & 2.95 & 50 & 0.79 & & \\
\hline 4 & 0.32 & 36 & 2.91 & $51^{*}$ & $0.51^{*}$ & & \\
\hline 8 & 0.12 & 37 & 3.04 & 53 & 0.55 & & \\
\hline 11 & 0 & 39 & 3.24 & 55 & 0.45 & & \\
\hline 14 & 0.17 & 40 & 3.13 & 57 & 0.39 & & \\
\hline 16 & 0.19 & 41 & 3.03 & 59 & 0.52 & & \\
\hline 20 & 0.22 & 42 & 3.06 & 62 & 0.48 & & \\
\hline 24 & 0.42 & 43 & 2.96 & 64 & 0.44 & & \\
\hline 27 & 0.92 & 44 & 2.92 & 66 & 0.56 & & \\
\hline 29 & 0.99 & 45 & 2.85 & 68 & 0.37 & & \\
\hline 31 & 0.7 & 46 & 2.68 & 70 & 0.32 & & \\
\hline 32 & 1.21 & 47 & 2.76 & & & & \\
\hline 33 & 2.86 & 48 & 1.74 & & & & \\
\hline 34 & 2.87 & 49 & 1.19 & & & & \\
\hline
\end{tabular}




\section{South Branch Little Aughwick Creek}

Date of Survey: May 1, 2007

Reach \#: 4-A
Time of Survey: 10:46 am

Drainage Area: 3.93 sq. miles

UTM Coordinate Location: Zone 18, 4429787 m N, 0249149 m E

Location Information: Cowan's Gap State Park, parked vehicle at the intersection of Aughwick Road and Camron Trail.

Bankfull Indicator(s): A change in slope along the west to northwest channel bank.

Bankfull Response Variables: Cross-sectional area (44.9 square feet), width (22.7 feet), mean depth (2.0 feet).

\section{Graph of Channel Cross-Section}

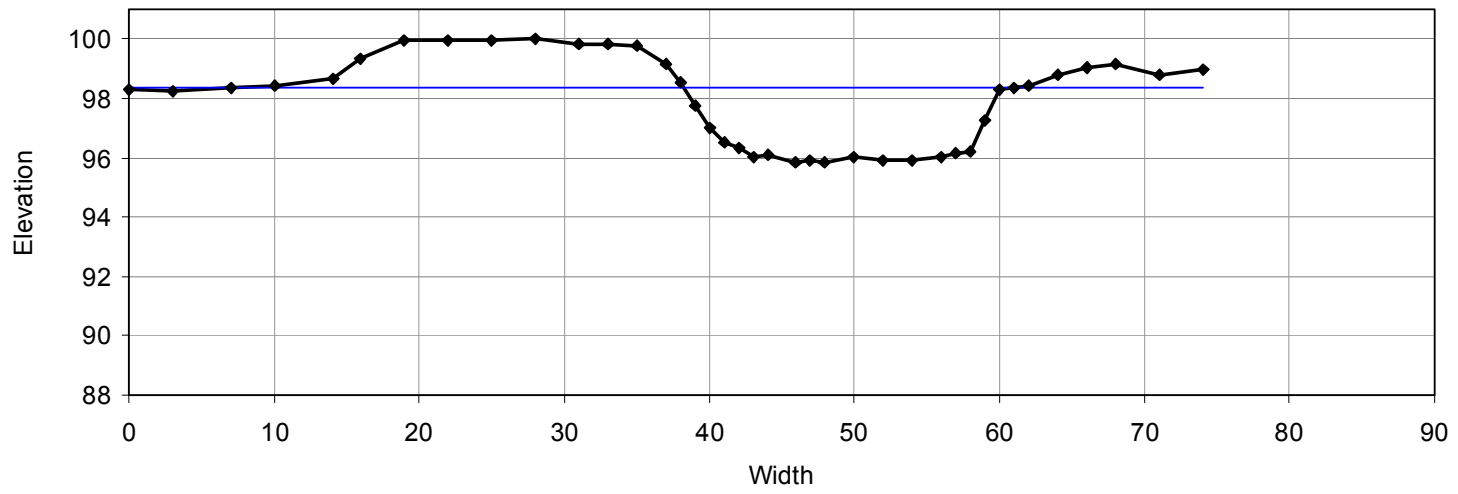

Survey Data

\begin{tabular}{|c|c|c|c|c|c|c|c|}
\hline $\begin{array}{c}\begin{array}{c}\text { Horizontal } \\
\text { (feet) }\end{array} \\
\end{array}$ & $\begin{array}{c}\begin{array}{c}\text { Vertical } \\
\text { (feet) }\end{array} \\
\end{array}$ & $\begin{array}{c}\begin{array}{c}\text { Horizontal } \\
\text { (feet) }\end{array} \\
\end{array}$ & $\begin{array}{l}\text { Vertical } \\
\text { (feet) }\end{array}$ & $\begin{array}{c}\begin{array}{c}\text { Horizontal } \\
\text { (feet) }\end{array} \\
\end{array}$ & $\begin{array}{c}\begin{array}{c}\text { Vertical } \\
\text { (feet) }\end{array} \\
\end{array}$ & $\begin{array}{c}\text { Horizontal } \\
\text { (feet) }\end{array}$ & $\begin{array}{c}\begin{array}{c}\text { Vertical } \\
\text { (feet) }\end{array} \\
\end{array}$ \\
\hline 0 & 1.71 & 38 & 1.43 & 57 & 3.82 & & \\
\hline 3 & 1.73 & 39 & 2.22 & 58 & 3.76 & & \\
\hline 7 & 1.65 & 40 & 2.98 & 59 & 2.72 & & \\
\hline 10 & 1.58 & 41 & 3.48 & 60 & 1.71 & & \\
\hline 14 & 1.36 & 42 & 3.67 & $61^{*}$ & $1.63^{*}$ & & \\
\hline 16 & 0.65 & 43 & 3.94 & 62 & 1.58 & & \\
\hline 19 & 0.06 & 44 & 3.9 & 64 & 1.23 & & \\
\hline 22 & 0.02 & 46 & 4.14 & 66 & 0.95 & & \\
\hline 25 & 0.06 & 47 & 4.06 & 68 & 0.82 & & \\
\hline 28 & 0 & 48 & 4.13 & 71 & 1.18 & & \\
\hline 31 & 0.15 & 50 & 3.97 & 74 & 1.01 & & \\
\hline 33 & 0.17 & 52 & 4.07 & & & & \\
\hline 35 & 0.22 & 54 & 4.11 & & & & \\
\hline 37 & 0.85 & 56 & 3.95 & & & & \\
\hline
\end{tabular}




\section{South Branch Little Aughwick Creek}

Date of Survey: May 1, 2007

Reach \#: 4-B
Time of Survey: 11:24 am

Drainage Area: 3.93 sq. miles

UTM Coordinate Location: Zone 18, 4429825 m N, $0249153 \mathrm{~m} \mathrm{E}$

Location Information: Cowan's Gap State Park, parked vehicle at the intersection of Aughwick Road and Camron Trail. Reach located downstream from 4-A.

Bankfull Indicator(s): A change in slope along the east to southeast channel bank.

Bankfull Response Variables: Cross-sectional area (43.4 square feet), width (24.5 feet), mean depth (1.8 feet).

\section{Graph of Channel Cross-Section}

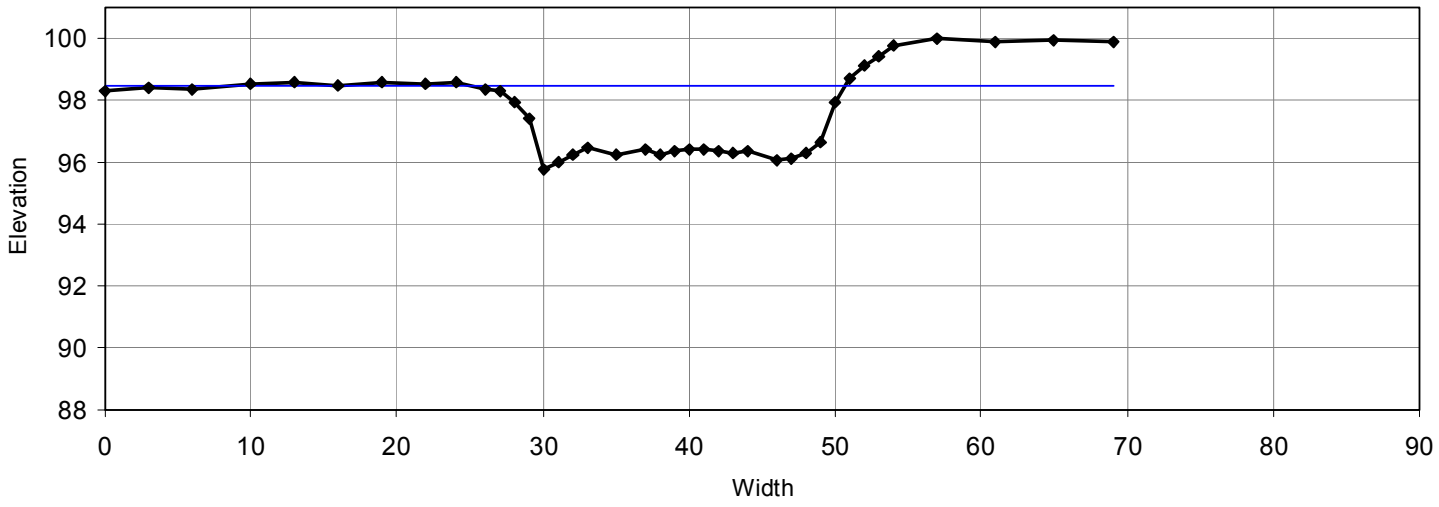

Survey Data

\begin{tabular}{|c|c|c|c|c|c|c|c|}
\hline $\begin{array}{c}\text { Horizontal } \\
\text { (feet) }\end{array}$ & $\begin{array}{c}\begin{array}{l}\text { Vertical } \\
\text { (feet) }\end{array} \\
\end{array}$ & $\begin{array}{c}\text { Horizontal } \\
\text { (feet) }\end{array}$ & $\begin{array}{c}\text { Vertical } \\
\text { (feet) }\end{array}$ & $\begin{array}{c}\text { Horizontal } \\
\text { (feet) }\end{array}$ & $\begin{array}{c}\text { Vertical } \\
\text { (feet) }\end{array}$ & $\begin{array}{c}\text { Horizontal } \\
\text { (feet) }\end{array}$ & $\begin{array}{c}\begin{array}{c}\text { Vertical } \\
\text { (feet) }\end{array} \\
\end{array}$ \\
\hline 0 & 1.68 & 31 & 4 & 48 & 3.68 & & \\
\hline 3 & 1.61 & 32 & 3.78 & 49 & 3.35 & & \\
\hline 6 & 1.66 & 33 & 3.55 & 50 & 2.04 & & \\
\hline 10 & 1.47 & 35 & 3.78 & 51 & 1.27 & & \\
\hline 13 & 1.41 & 37 & 3.58 & 52 & 0.91 & & \\
\hline 16 & 1.53 & 38 & 3.77 & 53 & 0.61 & & \\
\hline 19 & 1.39 & 39 & 3.66 & 54 & 0.26 & & \\
\hline 22 & 1.47 & 40 & 3.6 & 57 & 0 & & \\
\hline 24 & 1.43 & 41 & 3.6 & 61 & 0.12 & & \\
\hline $26^{*}$ & $1.64^{*}$ & 42 & 3.66 & 65 & 0.08 & & \\
\hline 27 & 1.69 & 43 & 3.71 & 69 & 0.14 & & \\
\hline 28 & 2.08 & 44 & 3.64 & & & & \\
\hline 29 & 2.58 & 46 & 3.93 & & & & \\
\hline 30 & 4.21 & 47 & 3.87 & & & & \\
\hline
\end{tabular}




\section{South Branch Little Aughwick Creek}

Date of Survey: May 1, 2007

Reach \#: 5-A
Time of Survey: $12: 37$ am

Drainage Area: 4.66 sq. miles

UTM Coordinate Location: Zone 18, 4430894 m N, 0249774 m E

Location Information: Cowan's Gap State Park, parked vehicle in lot near Cabin F, located approximately 1,500 feet upstream of Cowan's Gap Lake.

Bankfull Indicator(s): A change in slope along the west to northwest channel bank.

Bankfull Response Variables: Cross-sectional area (53.4 square feet), width (31.6 feet), mean depth (1.7 feet).

\section{Graph of Channel Cross-Section}

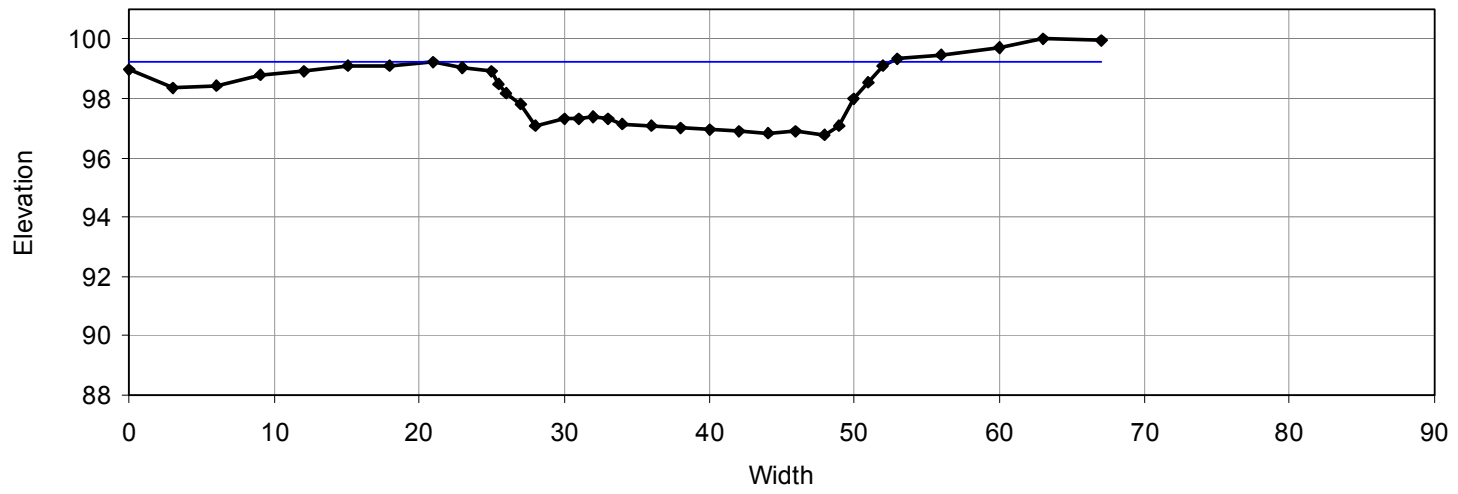

Survey Data

\begin{tabular}{|c|c|c|c|c|c|c|c|}
\hline $\begin{array}{c}\begin{array}{c}\text { Horizontal } \\
\text { (feet) }\end{array} \\
\end{array}$ & $\begin{array}{c}\begin{array}{c}\text { Vertical } \\
\text { (feet) }\end{array} \\
\end{array}$ & $\begin{array}{c}\begin{array}{c}\text { Horizontal } \\
\text { (feet) }\end{array} \\
\end{array}$ & $\begin{array}{l}\text { Vertical } \\
\text { (feet) }\end{array}$ & $\begin{array}{c}\text { Horizontal } \\
\text { (feet) }\end{array}$ & $\begin{array}{c}\begin{array}{c}\text { Vertical } \\
\text { (feet) }\end{array} \\
\end{array}$ & $\begin{array}{c}\text { Horizontal } \\
\text { (feet) }\end{array}$ & $\begin{array}{c}\begin{array}{c}\text { Vertical } \\
\text { (feet) }\end{array} \\
\end{array}$ \\
\hline 0 & 1.03 & 30 & 2.65 & 51 & 1.43 & & \\
\hline 3 & 1.64 & 31 & 2.7 & 52 & 0.89 & & \\
\hline 6 & 1.57 & 32 & 2.62 & 53 & 0.68 & & \\
\hline 9 & 1.19 & 33 & 2.69 & 56 & 0.55 & & \\
\hline 12 & 1.08 & 34 & 2.84 & 60 & 0.27 & & \\
\hline 15 & 0.9 & 36 & 2.94 & 63 & 0 & & \\
\hline 18 & 0.88 & 38 & 3 & 67 & 0.06 & & \\
\hline 21 & 0.77 & 40 & 3.04 & & & & \\
\hline 23 & 0.96 & 42 & 3.13 & & & & \\
\hline $25^{*}$ & $1.08^{*}$ & 44 & 3.14 & & & & \\
\hline 25.5 & 1.51 & 46 & 3.09 & & & & \\
\hline 26 & 1.83 & 48 & 3.23 & & & & \\
\hline 27 & 2.2 & 49 & 2.9 & & & & \\
\hline 28 & 2.91 & 50 & 1.98 & & & & \\
\hline
\end{tabular}




\section{South Branch Little Aughwick Creek}

Date of Survey: May 1, 2007

Reach \#: 5-B
Time of Survey: 1:01 pm

Drainage Area: 4.66 sq. miles

UTM Coordinate Location: Zone 18, 4430706 m N, 0249706 m E

Location Information: Cowan's Gap State Park, parked vehicle in lot near Cabin F, located upstream from reach 5-A.

Bankfull Indicator(s): A change in slope along the west to northwest channel bank.

Bankfull Response Variables: Cross-sectional area (53.4 square feet), width (31.6 feet), mean depth (1.7 feet).

\section{Graph of Channel Cross-Section}

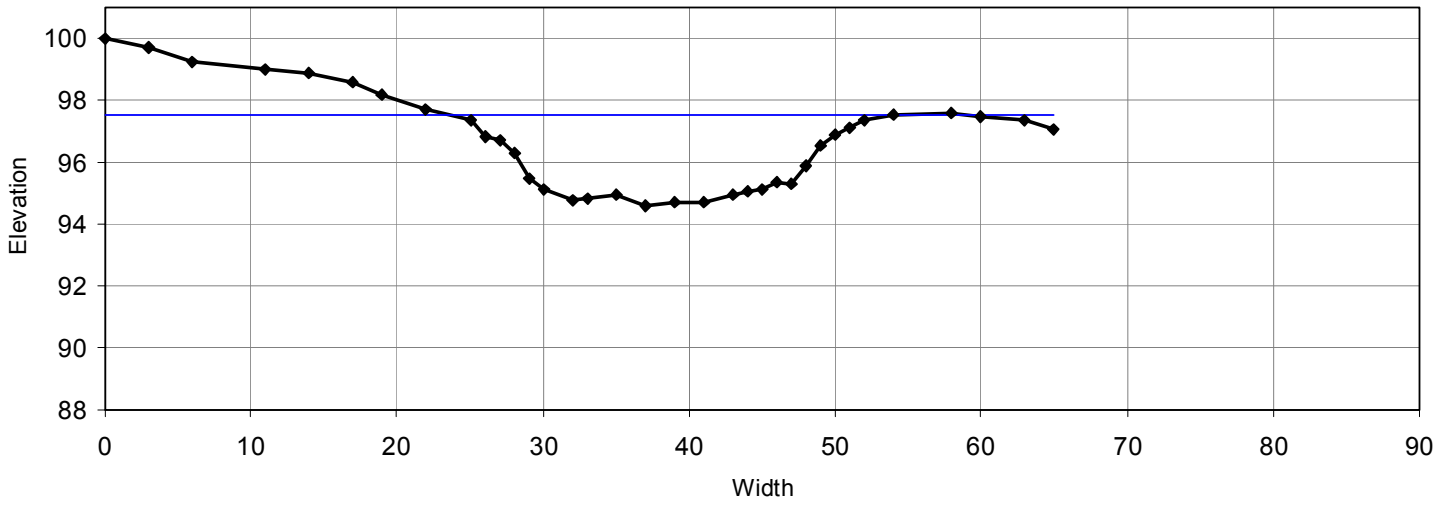

$\underline{\text { Survey Data }}$

\begin{tabular}{|c|c|c|c|c|c|c|c|}
\hline $\begin{array}{c}\text { Horizontal } \\
\text { (feet) }\end{array}$ & $\begin{array}{c}\text { Vertical } \\
\text { (feet) }\end{array}$ & $\begin{array}{c}\text { Horizontal } \\
\text { (feet) }\end{array}$ & $\begin{array}{c}\begin{array}{c}\text { Vertical } \\
\text { (feet) }\end{array} \\
\end{array}$ & $\begin{array}{c}\text { Horizontal } \\
\text { (feet) }\end{array}$ & $\begin{array}{c}\text { Vertical } \\
\text { (feet) }\end{array}$ & $\begin{array}{c}\text { Horizontal } \\
\text { (feet) }\end{array}$ & $\begin{array}{c}\begin{array}{c}\text { Vertical } \\
\text { (feet) }\end{array} \\
\end{array}$ \\
\hline 0 & 0 & 32 & 5.23 & 51 & 2.91 & & \\
\hline 3 & 0.29 & 33 & 5.16 & 52 & 2.63 & & \\
\hline 6 & 0.76 & 35 & 5.03 & $54^{*}$ & $2.48^{*}$ & & \\
\hline 11 & 0.98 & 37 & 5.44 & 58 & 2.41 & & \\
\hline 14 & 1.12 & 39 & 5.31 & 60 & 2.52 & & \\
\hline 17 & 1.44 & 41 & 5.31 & 63 & 2.67 & & \\
\hline 19 & 1.8 & 43 & 5.08 & 65 & 2.94 & & \\
\hline 22 & 2.28 & 44 & 4.97 & & & & \\
\hline 25 & 2.67 & 45 & 4.89 & & & & \\
\hline 26 & 3.2 & 46 & 4.67 & & & & \\
\hline 27 & 3.29 & 47 & 4.69 & & & & \\
\hline 28 & 3.7 & 48 & 4.13 & & & & \\
\hline 29 & 4.5 & 49 & 3.45 & & & & \\
\hline 30 & 4.9 & 50 & 3.1 & & & & \\
\hline
\end{tabular}




\section{Sherman Creek}

Date of Survey: May 2, 2007

Reach \#: 6-A
Time of Survey: 11:59 am

Drainage Area: 1.58 sq. miles

UTM Coordinate Location: Zone 18, 4459394 m N, 0276143 m E

Location Information: Tuscarora State Forest, parked vehicle on Hemlock Road at intersection of Patterson Run Trail. Reach located on Patterson Run in Hemlocks Natural Area.

Bankfull Indicator(s): A change in slope along the west channel bank.

Bankfull Response Variables: Cross-sectional area (21.2 square feet), width (22.4 feet), mean depth $(0.9$ feet $)$.

\section{Graph of Channel Cross-Section}

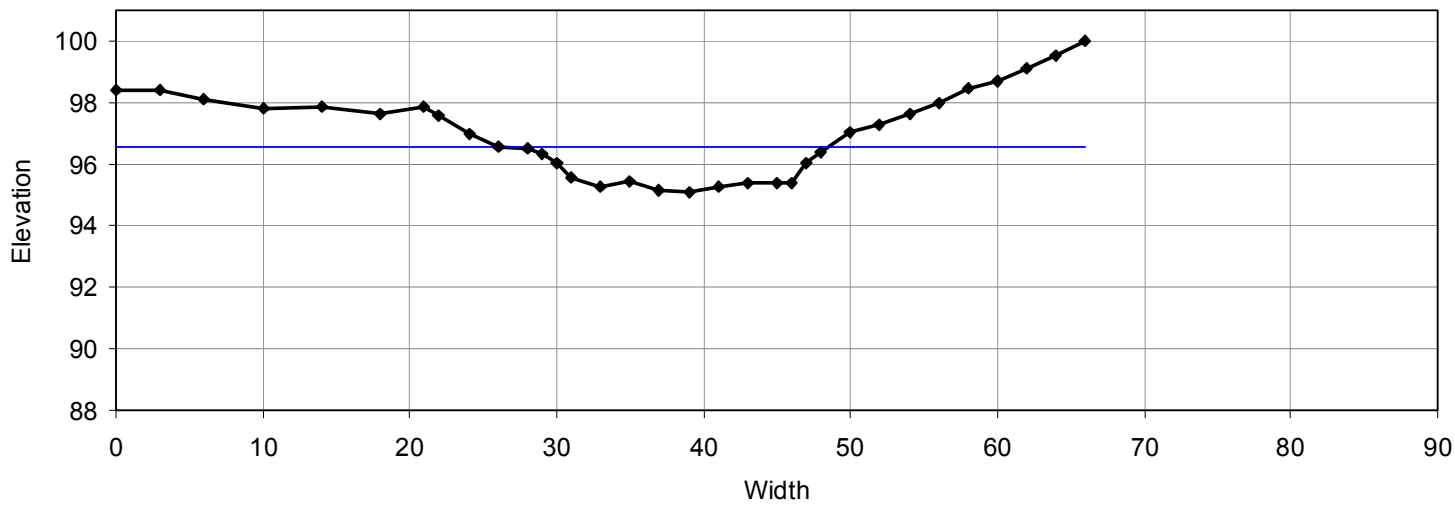

$\underline{\text { Survey Data }}$

\begin{tabular}{|c|c|c|c|c|c|c|c|}
\hline $\begin{array}{c}\text { Horizontal } \\
\text { (feet) }\end{array}$ & $\begin{array}{c}\text { Vertical } \\
\text { (feet) }\end{array}$ & $\begin{array}{c}\text { Horizontal } \\
\text { (feet) }\end{array}$ & $\begin{array}{c}\text { Vertical } \\
\text { (feet) }\end{array}$ & $\begin{array}{c}\text { Horizontal } \\
\text { (feet) }\end{array}$ & $\begin{array}{c}\begin{array}{c}\text { Vertical } \\
\text { (feet) }\end{array} \\
\end{array}$ & $\begin{array}{c}\text { Horizontal } \\
\text { (feet) }\end{array}$ & $\begin{array}{c}\begin{array}{c}\text { Vertical } \\
\text { (feet) }\end{array} \\
\end{array}$ \\
\hline 0 & 1.62 & 33 & 4.72 & 58 & 1.52 & & \\
\hline 3 & 1.59 & 35 & 4.57 & 60 & 1.31 & & \\
\hline 6 & 1.89 & 37 & 4.86 & 62 & 0.88 & & \\
\hline 10 & 2.18 & 39 & 4.89 & 64 & 0.48 & & \\
\hline 14 & 2.14 & 41 & 4.73 & 66 & 0 & & \\
\hline 18 & 2.36 & 43 & 4.62 & & & & \\
\hline 21 & 2.16 & 45 & 4.61 & & & & \\
\hline 22 & 2.4 & 46 & 4.61 & & & & \\
\hline 24 & 3 & 47 & 3.94 & & & & \\
\hline $26^{*}$ & $3.45^{*}$ & 48 & 3.59 & & & & \\
\hline 28 & 3.51 & 50 & 2.95 & & & & \\
\hline 29 & 3.68 & 52 & 2.75 & & & & \\
\hline 30 & 3.99 & 54 & 2.35 & & & & \\
\hline 31 & 4.45 & 56 & 2.01 & & & & \\
\hline
\end{tabular}




\section{Sherman Creek}

Date of Survey: May 2, 2007

Reach \#: 6-B
Time of Survey: $12: 38$ am

Drainage Area: 1.58 sq. miles

UTM Coordinate Location: Zone 18, 4459397 m N, 0276106 m E

Location Information: Tuscarora State Forest, parked vehicle on Hemlock Road at intersection of Patterson Run Trail. Reach located downstream of 6-A.

Bankfull Indicator(s): A change in slope along the west channel bank.

Bankfull Response Variables: Cross-sectional area (35 square feet), width (23.9 feet), mean depth (1.5 feet).

\section{Graph of Channel Cross-Section}

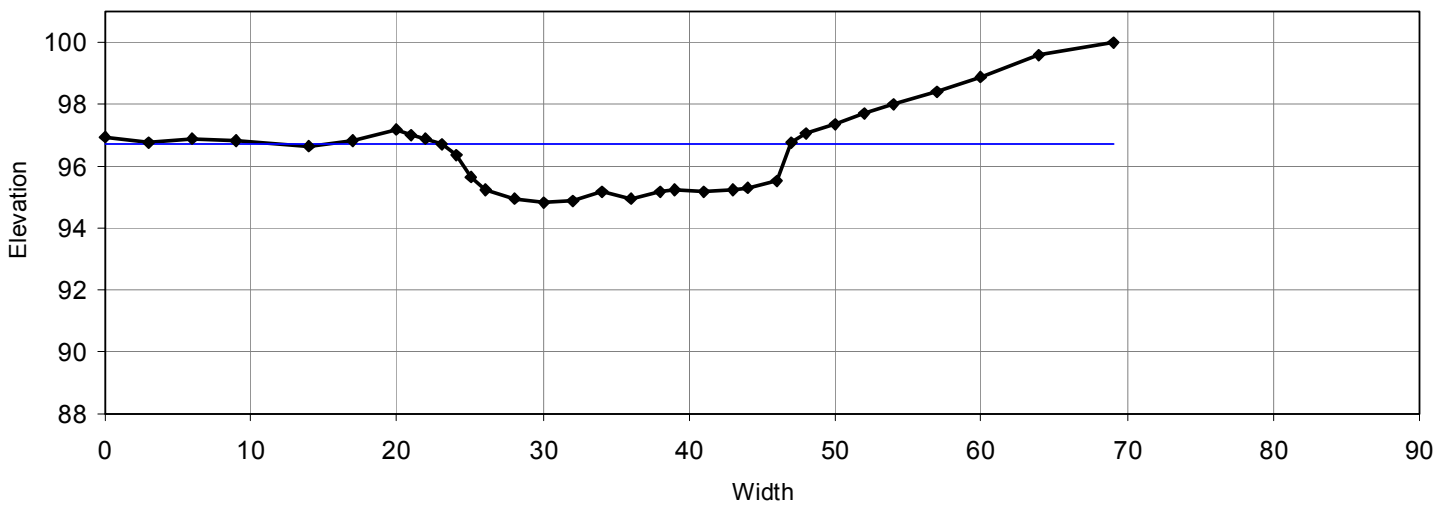

$\underline{\text { Survey Data }}$

\begin{tabular}{|c|c|c|c|c|c|c|c|}
\hline $\begin{array}{c}\text { Horizontal } \\
\text { (feet) }\end{array}$ & $\begin{array}{c}\begin{array}{c}\text { Vertical } \\
\text { (feet) }\end{array} \\
\end{array}$ & $\begin{array}{l}\text { Horizontal } \\
\text { (feet) }\end{array}$ & $\begin{array}{c}\begin{array}{c}\text { Vertical } \\
\text { (feet) }\end{array} \\
\end{array}$ & $\begin{array}{c}\text { Horizontal } \\
\text { (feet) }\end{array}$ & $\begin{array}{c}\begin{array}{l}\text { Vertical } \\
\text { (feet) }\end{array} \\
\end{array}$ & $\begin{array}{c}\text { Horizontal } \\
\text { (feet) }\end{array}$ & $\begin{array}{c}\begin{array}{c}\text { Vertical } \\
\text { (feet) }\end{array} \\
\end{array}$ \\
\hline 0 & 3.03 & 30 & 5.2 & 54 & 2.01 & & \\
\hline 3 & 3.24 & 32 & 5.14 & 57 & 1.6 & & \\
\hline 6 & 3.11 & 34 & 4.84 & 60 & 1.1 & & \\
\hline 9 & 3.18 & 36 & 5.06 & 64 & 0.41 & & \\
\hline 14 & 3.35 & 38 & 4.83 & 69 & 0 & & \\
\hline 17 & 3.17 & 39 & 4.77 & & & & \\
\hline 20 & 2.81 & 41 & 4.81 & & & & \\
\hline 21 & 2.98 & 43 & 4.78 & & & & \\
\hline 22 & 3.14 & 44 & 4.71 & & & & \\
\hline $23^{*}$ & $3.29^{*}$ & 46 & 4.45 & & & & \\
\hline 24 & 3.65 & 47 & 3.21 & & & & \\
\hline 25 & 4.34 & 48 & 2.94 & & & & \\
\hline 26 & 4.78 & 50 & 2.65 & & & & \\
\hline 28 & 5.08 & 52 & 2.27 & & & & \\
\hline
\end{tabular}




\section{Sherman Creek}

Date of Survey: May 2, 2007

Reach \#: 7-A
Time of Survey: 1:44 pm

Drainage Area: 5.94 sq. miles

UTM Coordinate Location: Zone 18, 4462068 m N, 0277339 m E

Location Information: Tuscarora State Forest, parked vehicle at bridge on Shearer Doug Road, located off Route 274.

Bankfull Indicator(s): A change in slope along the north channel bank.

Bankfull Response Variables: Cross-sectional area (59.9 square feet), width (41.3 feet), mean depth (1.4 feet).

\section{Graph of Channel Cross-Section}

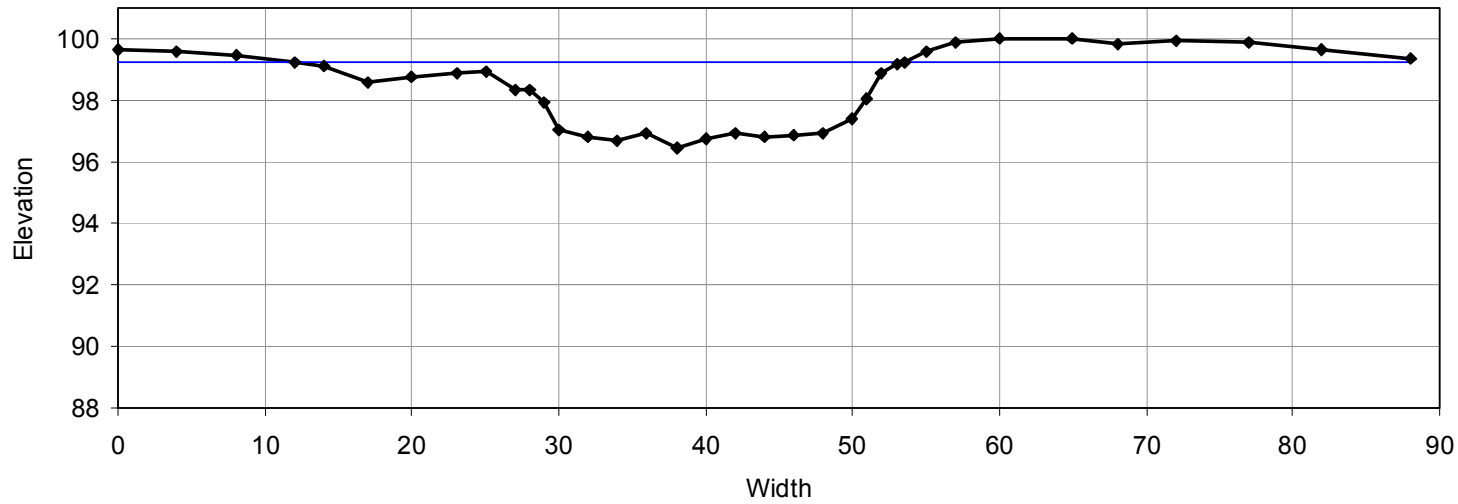

Survey Data

\begin{tabular}{|c|c|c|c|c|c|c|c|}
\hline $\begin{array}{l}\text { Horizontal } \\
\text { (feet) }\end{array}$ & $\begin{array}{c}\text { Vertical } \\
\text { (feet) }\end{array}$ & $\begin{array}{l}\text { Horizontal } \\
\text { (feet) }\end{array}$ & $\begin{array}{c}\begin{array}{c}\text { Vertical } \\
\text { (feet) }\end{array} \\
\end{array}$ & $\begin{array}{c}\text { Horizontal } \\
\text { (feet) }\end{array}$ & $\begin{array}{c}\begin{array}{c}\text { Vertical } \\
\text { (feet) }\end{array} \\
\end{array}$ & $\begin{array}{c}\text { Horizontal } \\
\text { (feet) }\end{array}$ & $\begin{array}{c}\begin{array}{c}\text { Vertical } \\
\text { (feet) }\end{array} \\
\end{array}$ \\
\hline 0 & 0.36 & 34 & 3.29 & 57 & 0.12 & & \\
\hline 4 & 0.4 & 36 & 3.08 & 60 & 0.02 & & \\
\hline 8 & 0.55 & 38 & 3.54 & 65 & 0 & & \\
\hline 12 & 0.76 & 40 & 3.25 & 68 & 0.21 & & \\
\hline 14 & 0.88 & 42 & 3.05 & 72 & 0.06 & & \\
\hline 17 & 1.41 & 44 & 3.2 & 77 & 0.12 & & \\
\hline 20 & 1.26 & 46 & 3.13 & 82 & 0.33 & & \\
\hline 23 & 1.13 & 48 & 3.05 & 88 & 0.63 & & \\
\hline 25 & 1.05 & 50 & 2.58 & & & & \\
\hline 27 & 1.63 & 51 & 1.98 & & & & \\
\hline 28 & 1.65 & 52 & 1.14 & & & & \\
\hline 29 & 2.06 & 53 & 0.85 & & & & \\
\hline 30 & 2.97 & $53.5^{*}$ & $0.77^{*}$ & & & & \\
\hline 32 & 3.17 & 55 & 0.42 & & & & \\
\hline
\end{tabular}




\section{Sherman Creek}

Date of Survey: May 2, 2007

Reach \#: 7-B
Time of Survey: $2: 15 \mathrm{pm}$

Drainage Area: 5.94 sq. miles

UTM Coordinate Location: Zone 18, 4462075 m N, $0277372 \mathrm{~m} \mathrm{E}$

Location Information: Tuscarora State Forest, parked vehicle at bridge on Shearer Doug Road, located off Route 274 . Reach located approximately 50 feet downstream of 7-A.

Bankfull Indicator(s): A change in slope along the north channel bank.

Bankfull Response Variables: Cross-sectional area - (53.6 square feet), width - (30 feet), mean depth (1.8 feet).

\section{Graph of Channel Cross-Section}

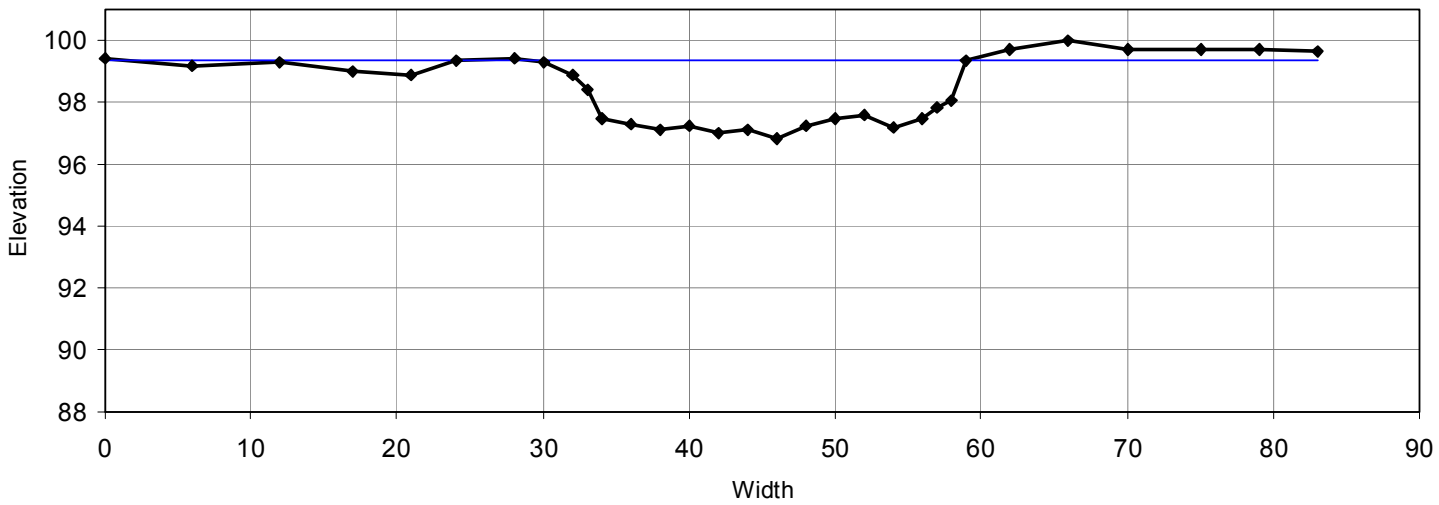

$\underline{\text { Survey Data }}$

\begin{tabular}{|c|c|c|c|c|c|c|c|}
\hline $\begin{array}{c}\text { Horizontal } \\
\text { (feet) }\end{array}$ & $\begin{array}{c}\begin{array}{c}\text { Vertical } \\
\text { (feet) }\end{array} \\
\end{array}$ & $\begin{array}{l}\text { Horizontal } \\
\text { (feet) }\end{array}$ & $\begin{array}{c}\begin{array}{l}\text { Vertical } \\
\text { (feet) }\end{array} \\
\end{array}$ & $\begin{array}{c}\text { Horizontal } \\
\text { (feet) }\end{array}$ & $\begin{array}{c}\begin{array}{l}\text { Vertical } \\
\text { (feet) }\end{array} \\
\end{array}$ & $\begin{array}{c}\text { Horizontal } \\
\text { (feet) }\end{array}$ & $\begin{array}{c}\begin{array}{c}\text { Vertical } \\
\text { (feet) }\end{array} \\
\end{array}$ \\
\hline 0 & 0.56 & 42 & 2.98 & 75 & 0.31 & & \\
\hline 6 & 0.82 & 44 & 2.88 & 79 & 0.28 & & \\
\hline 12 & 0.68 & 46 & 3.15 & 83 & 0.33 & & \\
\hline 17 & 0.98 & 48 & 2.76 & & & & \\
\hline 21 & 1.11 & 50 & 2.55 & & & & \\
\hline 24 & 0.67 & 52 & 2.41 & & & & \\
\hline 28 & 0.56 & 54 & 2.8 & & & & \\
\hline 30 & 0.68 & 56 & 2.53 & & & & \\
\hline 32 & 1.1 & 57 & 2.16 & & & & \\
\hline 33 & 1.56 & 58 & 1.94 & & & & \\
\hline 34 & 2.53 & $59^{*}$ & $0.62^{*}$ & & & & \\
\hline 36 & 2.71 & 62 & 0.29 & & & & \\
\hline 38 & 2.86 & 66 & 0 & & & & \\
\hline 40 & 2.74 & 70 & 0.32 & & & & \\
\hline
\end{tabular}




\section{Sherman Creek}

Date of Survey: May 3, 2007

Reach \#: 8-A
Time of Survey: $8: 55 \mathrm{am}$

Drainage Area: 1.65 sq. miles

UTM Coordinate Location: Zone 18, 4460998 m N, $0275361 \mathrm{~m} \mathrm{E}$

Location Information: Tuscarora State Forest, parked vehicle on Route 274 at a shale pit adjacent to road, at the crest of a small hill. Reach located on Big Spring Run.

Bankfull Indicator(s): A change in slope along the south to southeast channel bank.

Bankfull Response Variables: Cross-sectional area (35.4 square feet), width (27.9 feet), mean depth (1.3 feet).

\section{Graph of Channel Cross-Section}

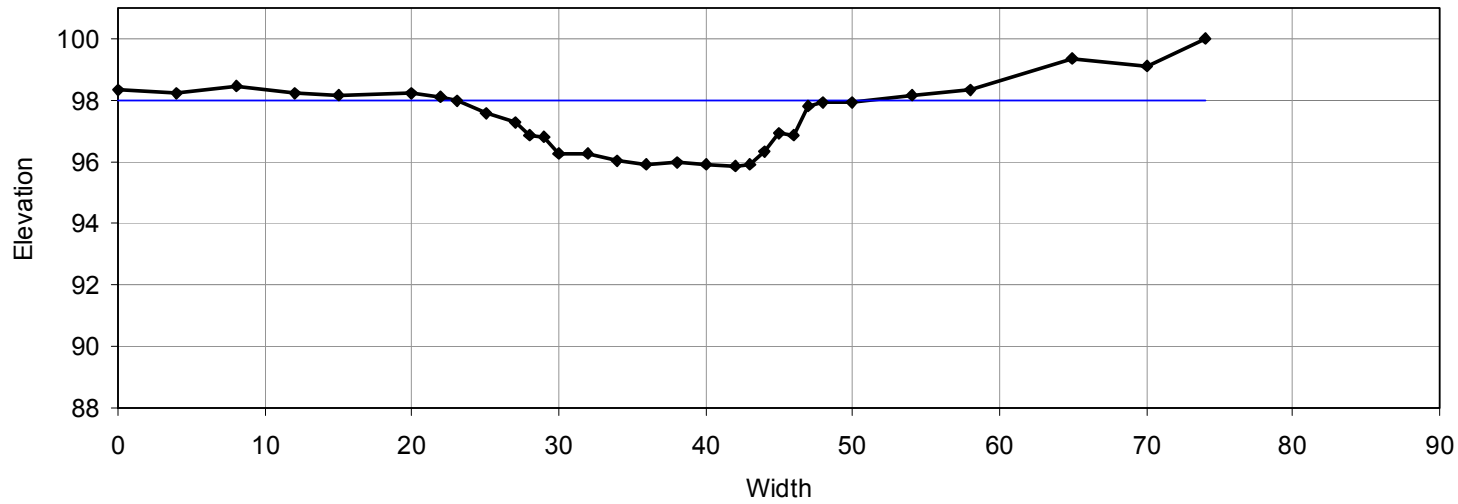

$\underline{\text { Survey Data }}$

\begin{tabular}{|c|c|c|c|c|c|c|c|}
\hline $\begin{array}{l}\text { Horizontal } \\
\text { (feet) }\end{array}$ & $\begin{array}{c}\text { Vertical } \\
\text { (feet) }\end{array}$ & $\begin{array}{c}\text { Horizontal } \\
\text { (feet) }\end{array}$ & $\begin{array}{c}\text { Vertical } \\
\text { (feet) }\end{array}$ & $\begin{array}{l}\text { Horizontal } \\
\text { (feet) }\end{array}$ & $\begin{array}{c}\text { Vertical } \\
\text { (feet) }\end{array}$ & $\begin{array}{c}\text { Horizontal } \\
\text { (feet) }\end{array}$ & $\begin{array}{c}\text { Vertical } \\
\text { (feet) }\end{array}$ \\
\hline 0 & 1.67 & 34 & 3.94 & 65 & 0.67 & & \\
\hline 8 & 1.57 & 38 & 4.02 & 74 & 0 & & \\
\hline 12 & 1.78 & 40 & 4.06 & & & & \\
\hline 20 & 1.76 & 43 & 4.11 & & & & \\
\hline 22 & 1.9 & 44 & 3.69 & & & & \\
\hline $23^{*}$ & $2.03^{*}$ & 45 & 3.07 & & & & \\
\hline 25 & 2.4 & 46 & 3.15 & & & & \\
\hline 27 & 2.75 & 47 & 2.21 & & & & \\
\hline 30 & 3.73 & 54 & 1.83 & & & & \\
\hline 32 & 3.75 & 58 & 1.65 & & & & \\
\hline
\end{tabular}




\section{Sherman Creek}

Date of Survey: May 3, 2007

Reach \#: 8-B
Time of Survey: 9:45 am

Drainage Area: 1.65 sq. miles

UTM Coordinate Location: Zone 18, $4460977 \mathrm{~m} \mathrm{~N}, 0275361 \mathrm{~m} \mathrm{E}$

Location Information: Tuscarora State Forest, parked vehicle on Route 274 at a shale pit adjacent to road, at the crest of a small hill. Reach located approximately 100 feet upstream of 8-A.

Bankfull Indicator(s): A change in slope along the south to southeast channel bank.

Bankfull Response Variables: Cross-sectional area (37 square feet), width (28.7 feet), mean depth (1.3 feet).

\section{Graph of Channel Cross-Section}

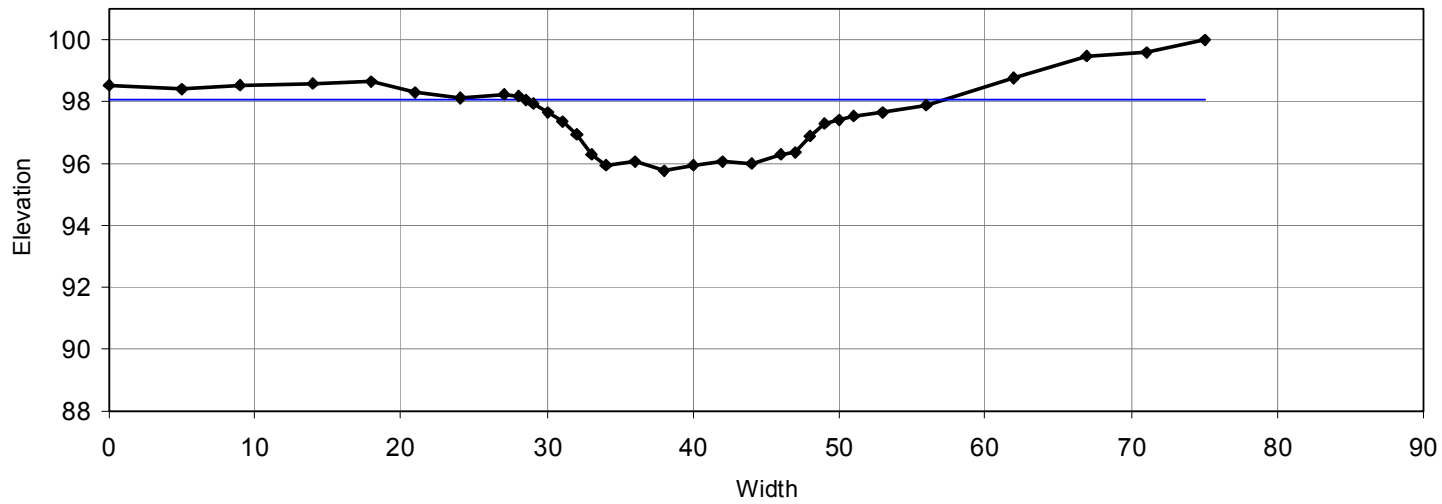

\section{$\underline{\text { Survey Data }}$}

\begin{tabular}{|c|c|c|c|c|c|c|c|}
\hline $\begin{array}{c}\text { Horizontal } \\
\text { (feet) }\end{array}$ & $\begin{array}{c}\text { Vertical } \\
\text { (feet) }\end{array}$ & $\begin{array}{c}\text { Horizontal } \\
\text { (feet) }\end{array}$ & $\begin{array}{c}\text { Vertical } \\
\text { (feet) }\end{array}$ & $\begin{array}{c}\text { Horizontal } \\
\text { (feet) }\end{array}$ & $\begin{array}{c}\text { Vertical } \\
\text { (feet) }\end{array}$ & $\begin{array}{c}\text { Horizontal } \\
\text { (feet) }\end{array}$ & $\begin{array}{c}\text { Vertical } \\
\text { (feet) }\end{array}$ \\
\hline 0 & 1.45 & 33 & 3.7 & 56 & 2.12 & & \\
\hline 9 & 1.46 & 36 & 3.96 & 67 & 0.55 & & \\
\hline 14 & 1.39 & 38 & 4.21 & 71 & 0.41 & & \\
\hline 24 & 1.91 & 44 & 3.98 & & & & \\
\hline 27 & 1.74 & 46 & 3.72 & & & & \\
\hline 28 & 1.82 & 47 & 3.64 & & & & \\
\hline $28.5^{\star}$ & $1.95^{*}$ & 48 & 3.09 & & & & \\
\hline 31 & 2.65 & 51 & 2.45 & & & & \\
\hline 32 & 3.08 & 53 & 2.33 & & & & \\
\hline
\end{tabular}




\section{Sherman Creek}

Date of Survey: May 3, 2007

Reach \#: 9-A
Time of Survey: 10:35 am

Drainage Area: 8.25 sq. miles

UTM Coordinate Location: Zone 18, $4463005 \mathrm{~m} \mathrm{~N}, 0278571 \mathrm{~m} \mathrm{E}$

Location Information: Tuscarora State Forest, parked vehicle on Route 274, approximately $1 / 4$ mile north of Fairview Church at the intersection of Iron Horse Trail.

Bankfull Indicator(s): A change in slope along the south channel bank.

Bankfull Response Variables: Cross-sectional area (60.8 square feet), width (36.3 feet), mean depth (1.7 feet).

\section{Graph of Channel Cross-Section}

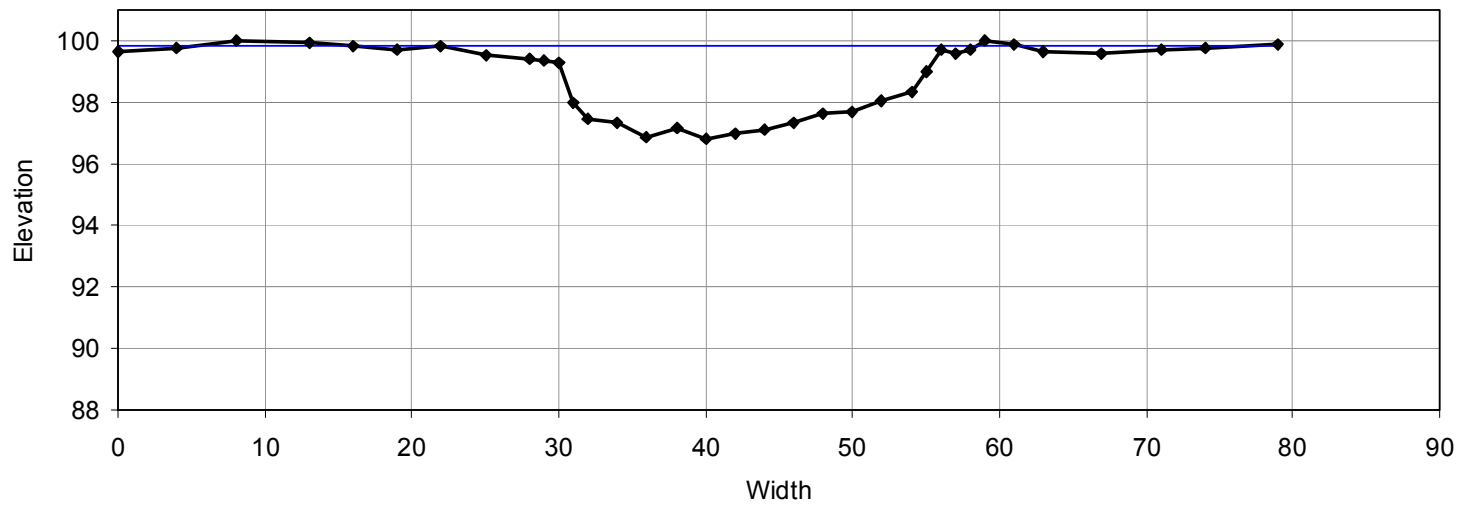

$\underline{\text { Survey Data }}$

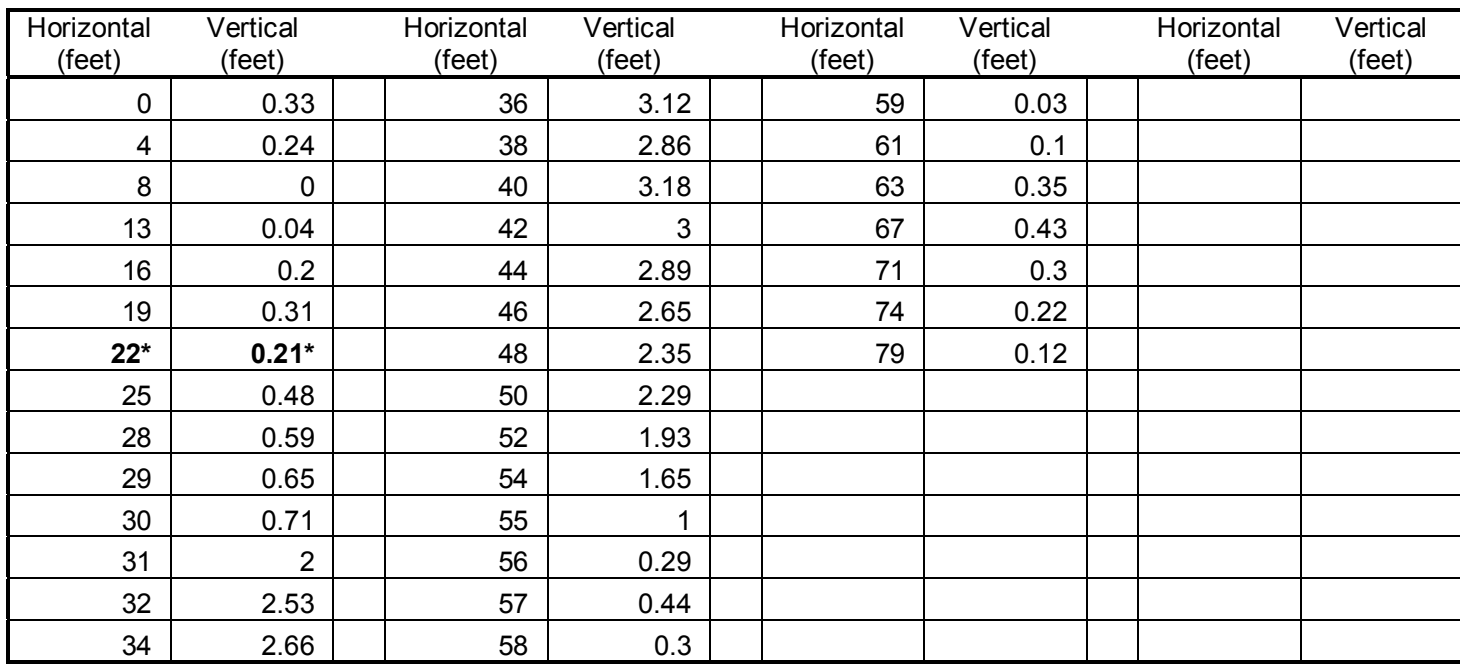




\section{Sherman Creek}

Date of Survey: May 3, 2007

Reach \#: 9-B
Time of Survey: 11:08 am

Drainage Area: 8.25 sq. miles

UTM Coordinate Location: Zone 18, $4463007 \mathrm{~m} \mathrm{~N}, 0278568 \mathrm{~m} \mathrm{E}$

Location Information: Tuscarora State Forest, parked vehicle on Route 274, approximately $1 / 4$ mile north of Fairview Church at the intersection of Iron Horse Trail. Reach located upstream of 9-A.

Bankfull Indicator(s): A change in slope along the south channel bank.

Bankfull Response Variables: Cross-sectional area (53.6 square feet), width (28.9 feet), mean depth (1.9 feet).

\section{Graph of Channel Cross-Section}

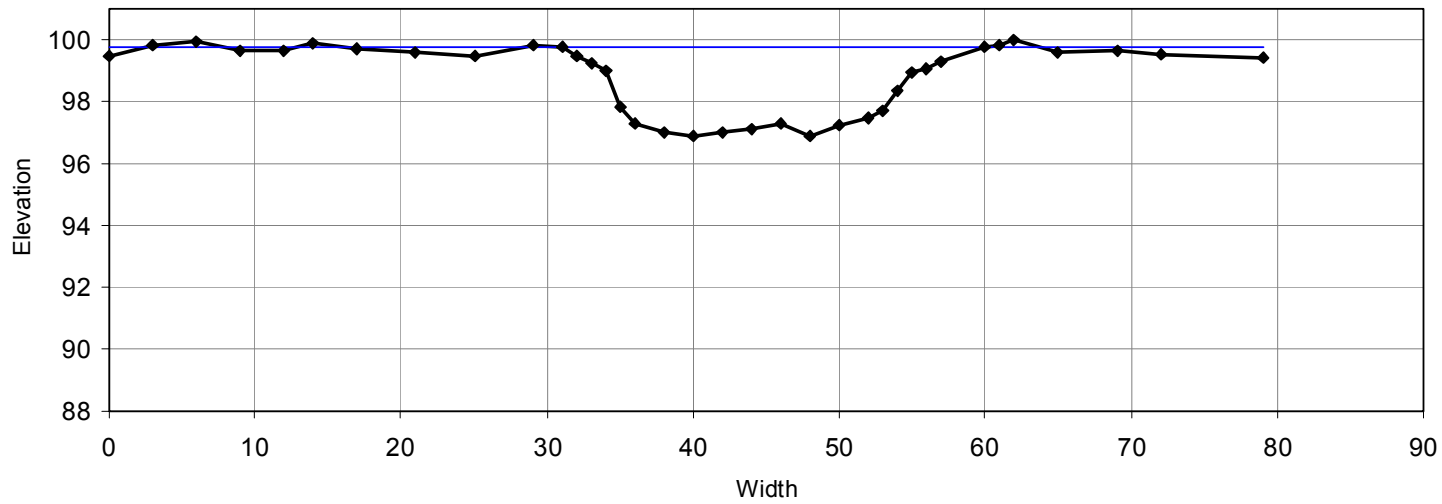

\section{$\underline{\text { Survey Data }}$}

\begin{tabular}{|c|c|c|c|c|c|c|c|}
\hline $\begin{array}{c}\text { Horizontal } \\
\text { (feet) }\end{array}$ & $\begin{array}{c}\text { Vertical } \\
\text { (feet) }\end{array}$ & $\begin{array}{c}\text { Horizontal } \\
\text { (feet) }\end{array}$ & $\begin{array}{c}\text { Vertical } \\
\text { (feet) }\end{array}$ & $\begin{array}{c}\text { Horizontal } \\
\text { (feet) }\end{array}$ & $\begin{array}{c}\text { Vertical } \\
\text { (feet) }\end{array}$ & $\begin{array}{c}\text { Horizontal } \\
\text { (feet) }\end{array}$ & $\begin{array}{c}\text { Vertical } \\
\text { (feet) }\end{array}$ \\
\hline 0 & 0.51 & 35 & 2.17 & 57 & 0.71 & & \\
\hline 6 & 0.04 & 38 & 3 & 61 & 0.17 & & \\
\hline 9 & 0.34 & 40 & 3.1 & 62 & 0 & & \\
\hline 14 & 0.14 & 44 & 2.87 & 69 & 0.38 & & \\
\hline 17 & 0.28 & 46 & 2.72 & 72 & 0.48 & & \\
\hline 21 & 0.39 & 48 & 3.1 & 79 & 0.57 & & \\
\hline 25 & 0.51 & 50 & 2.77 & & & & \\
\hline 29 & 0.19 & 52 & 2.53 & & & & \\
\hline 33 & 0.77 & 55 & 1.05 & & & & \\
\hline 34 & 0.98 & 56 & 0.97 & & & & \\
\hline
\end{tabular}




\section{Sherman Creek}

Date of Survey: May 3, 2007

Reach \#: $10-\mathrm{A}$ miles
Time of Survey: 12:07 am

Drainage Area: 10.06 sq.

UTM Coordinate Location: Zone 18, $4463007 \mathrm{~m} \mathrm{~N}, 0278568 \mathrm{~m} \mathrm{E}$

Location Information: Located on private property with public fishing access, on Buck Ridge Road, off of Route 274.

Bankfull Indicator(s): A change in slope along the south channel bank.

Bankfull Response Variables: Cross-sectional area (60.2 square feet), width (30.8 feet), mean depth (2.0 feet).

\section{Graph of Channel Cross-Section}

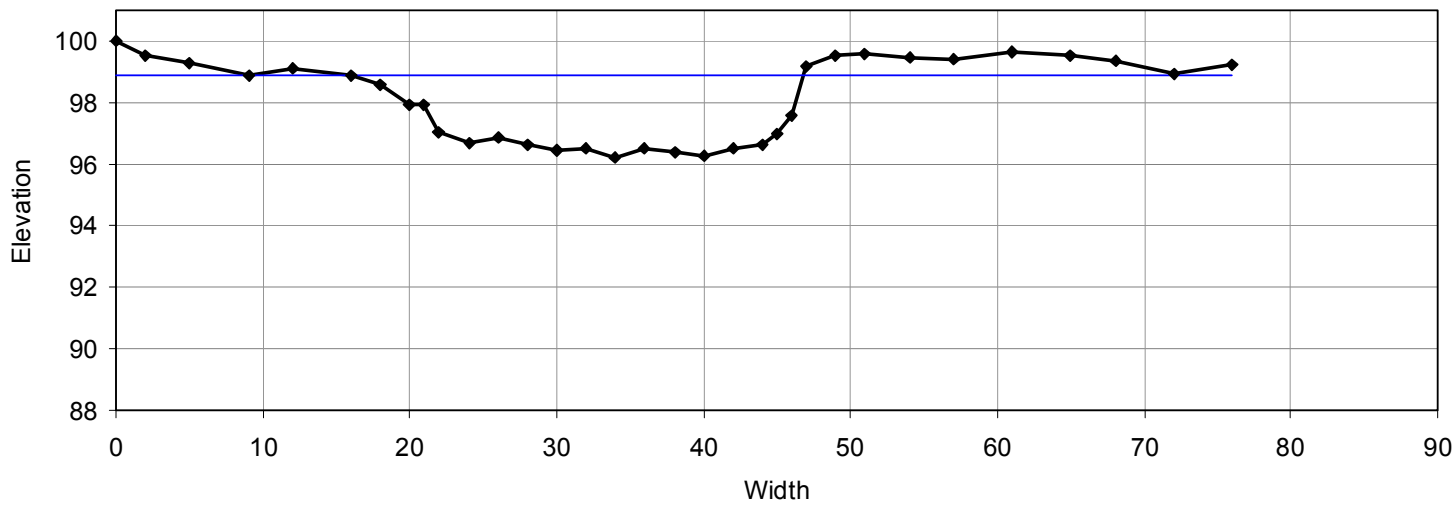

\section{$\underline{\text { Survey Data }}$}

\begin{tabular}{|c|c|c|c|c|c|c|c|}
\hline $\begin{array}{l}\text { Horizontal } \\
\text { (feet) }\end{array}$ & $\begin{array}{l}\text { Vertical } \\
\text { (feet) }\end{array}$ & $\begin{array}{l}\text { Horizontal } \\
\text { (feet) }\end{array}$ & $\begin{array}{c}\text { Vertical } \\
\text { (feet) }\end{array}$ & $\begin{array}{c}\text { Horizontal } \\
\text { (feet) }\end{array}$ & $\begin{array}{c}\text { Vertical } \\
\text { (feet) }\end{array}$ & $\begin{array}{c}\text { Horizontal } \\
\text { (feet) }\end{array}$ & $\begin{array}{c}\begin{array}{c}\text { Vertical } \\
\text { (feet) }\end{array} \\
\end{array}$ \\
\hline 0 & 0 & 32 & 3.48 & 61 & 0.37 & & \\
\hline 2 & 0.48 & 34 & 3.81 & 65 & 0.46 & & \\
\hline 5 & 0.72 & 36 & 3.51 & 68 & 0.65 & & \\
\hline 9 & 1.15 & 38 & 3.59 & 72 & 1.07 & & \\
\hline 12 & 0.89 & 40 & 3.72 & 76 & 0.76 & & \\
\hline $16^{*}$ & $1.11^{*}$ & 42 & 3.52 & & & & \\
\hline 18 & 1.44 & 44 & 3.35 & & & & \\
\hline 20 & 2.09 & 45 & 3 & & & & \\
\hline 21 & 2.08 & 46 & 2.4 & & & & \\
\hline 22 & 2.97 & 47 & 0.82 & & & & \\
\hline 24 & 3.31 & 49 & 0.48 & & & & \\
\hline 26 & 3.14 & 51 & 0.41 & & & & \\
\hline 28 & 3.39 & 54 & 0.53 & & & & \\
\hline 30 & 3.55 & 57 & 0.59 & & & & \\
\hline
\end{tabular}




\section{Sherman Creek}

Date of Survey: May 9, 2007

Reach \#: 11-A
Time of Survey: 3:19 pm

Drainage Area: 1.01 sq. miles

UTM Coordinate Location: Zone 18, $4460667 \mathrm{~m} \mathrm{~N}, 0274457 \mathrm{~m} \mathrm{E}$

Location Information: Tuscarora State Forest, east of Big Spring State Park. Reach located on Big Spring Run

Bankfull Indicator(s): A change in slope along the north channel bank.

Bankfull Response Variables: Cross-sectional area (14 square feet), width (12.6 feet), mean depth (1.1 feet).

\section{Graph of Channel Cross-Section}

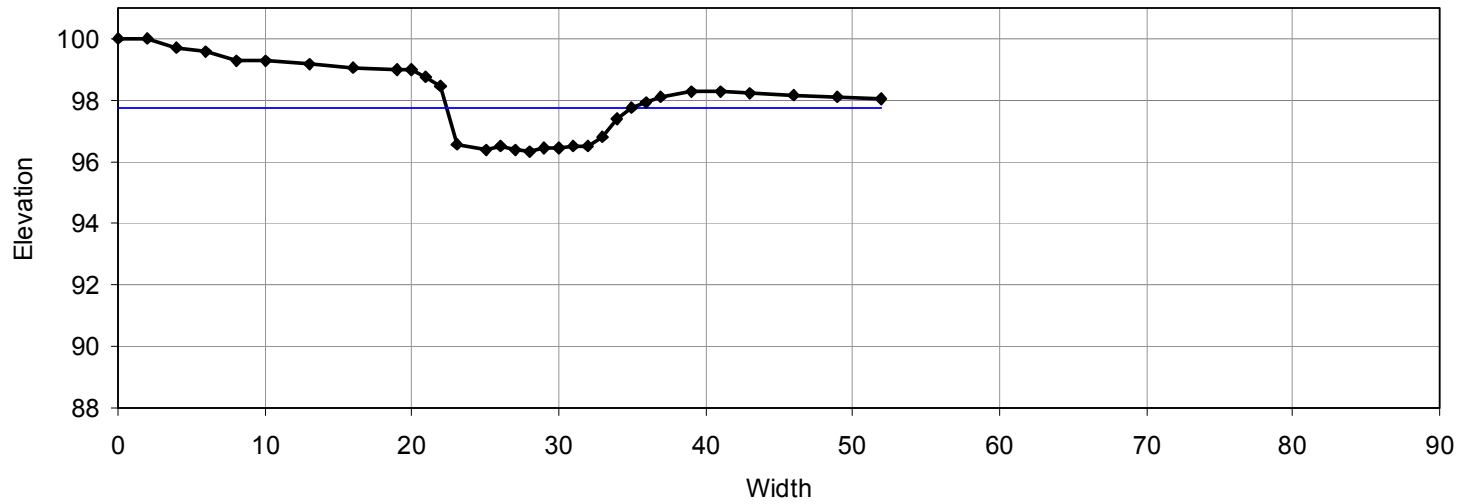

Survey Data

\begin{tabular}{|c|c|c|c|c|c|c|c|}
\hline $\begin{array}{c}\text { Horizontal } \\
\text { (feet) }\end{array}$ & $\begin{array}{c}\text { Vertical } \\
\text { (feet) }\end{array}$ & $\begin{array}{c}\text { Horizontal } \\
\text { (feet) }\end{array}$ & $\begin{array}{c}\text { Vertical } \\
\text { (feet) }\end{array}$ & $\begin{array}{c}\text { Horizontal } \\
\text { (feet) }\end{array}$ & $\begin{array}{l}\text { Vertical } \\
\text { (feet) }\end{array}$ & $\begin{array}{c}\text { Horizontal } \\
\text { (feet) }\end{array}$ & $\begin{array}{c}\text { Vertical } \\
\text { (feet) }\end{array}$ \\
\hline 0 & 0 & 26 & 3.49 & 43 & 1.79 & & \\
\hline 4 & 0.3 & 28 & 3.64 & 49 & 1.9 & & \\
\hline 6 & 0.39 & 29 & 3.56 & 52 & 1.94 & & \\
\hline 10 & 0.71 & 31 & 3.49 & & & & \\
\hline 13 & 0.86 & 32 & 3.47 & & & & \\
\hline 16 & 0.95 & 33 & 3.22 & & & & \\
\hline 19 & 0.98 & 34 & 2.6 & & & & \\
\hline 20 & 1.02 & $35^{*}$ & $2.25^{*}$ & & & & \\
\hline 23 & 3.45 & 39 & 1.74 & & & & \\
\hline 25 & 3.63 & 41 & 1.72 & & & & \\
\hline
\end{tabular}




\section{Sherman Creek}

Date of Survey: May 9, 2007

Reach \#: $11-B$
Time of Survey: $3: 47 \mathrm{pm}$

Drainage Area: 1.01 sq. miles

UTM Coordinate Location: Zone 18, $4460667 \mathrm{~m} \mathrm{~N}, 0274457 \mathrm{~m} \mathrm{E}$

Location Information: Tuscarora State Forest, east of Big Spring State Park. Reach located on Big Spring Run, downstream approximately 25 feet from 11-A.

Bankfull Indicator(s): A change in slope along the north channel bank.

Bankfull Response Variables: Cross-sectional area (15.4 square feet), width (11.5 feet), mean depth (1.3 feet).

\section{Graph of Channel Cross-Section}

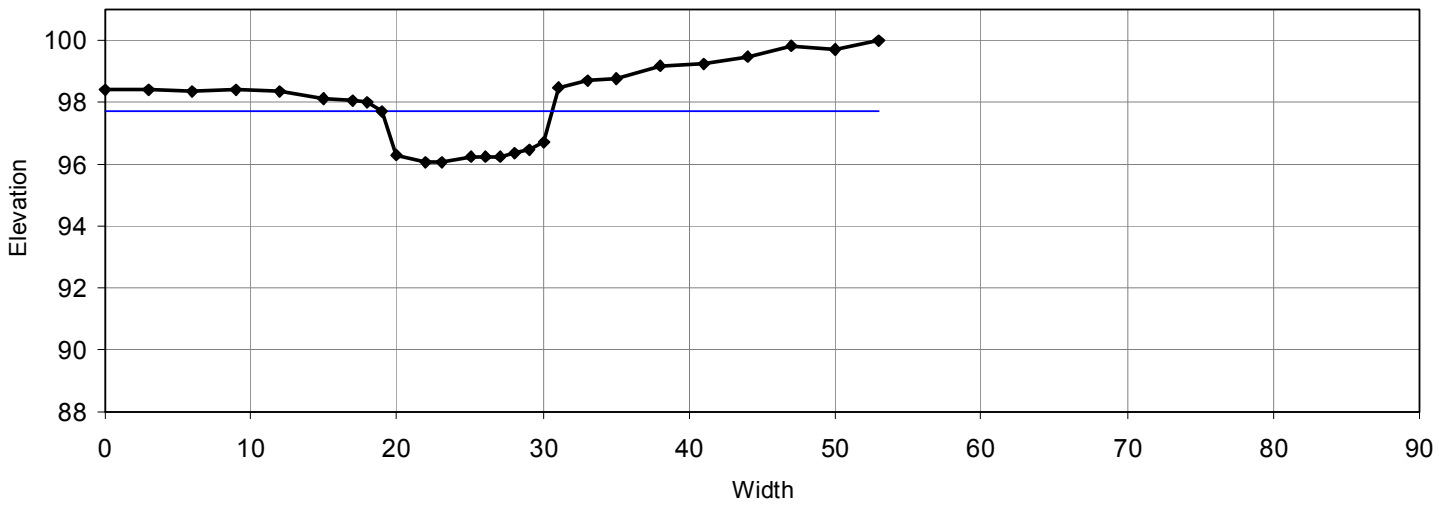

$\underline{\text { Survey Data }}$

\begin{tabular}{|c|c|c|c|c|c|c|c|}
\hline $\begin{array}{c}\text { Horizontal } \\
\text { (feet) }\end{array}$ & $\begin{array}{c}\text { Vertical } \\
\text { (feet) }\end{array}$ & $\begin{array}{c}\text { Horizontal } \\
\text { (feet) }\end{array}$ & $\begin{array}{c}\begin{array}{c}\text { Vertical } \\
\text { (feet) }\end{array} \\
\end{array}$ & $\begin{array}{c}\text { Horizontal } \\
\text { (feet) }\end{array}$ & $\begin{array}{c}\begin{array}{c}\text { Vertical } \\
\text { (feet) }\end{array} \\
\end{array}$ & $\begin{array}{c}\text { Horizontal } \\
\text { (feet) }\end{array}$ & $\begin{array}{c}\begin{array}{c}\text { Vertical } \\
\text { (feet) }\end{array} \\
\end{array}$ \\
\hline 0 & 1.6 & 27 & 3.77 & & & & \\
\hline 3 & 1.59 & 28 & 3.65 & & & & \\
\hline 6 & 1.67 & 29 & 3.54 & & & & \\
\hline 9 & 1.61 & 30 & 3.29 & & & & \\
\hline 12 & 1.65 & 31 & 1.5 & & & & \\
\hline 15 & 1.86 & 33 & 1.31 & & & & \\
\hline 17 & 1.94 & 35 & 1.25 & & & & \\
\hline 18 & 2 & 38 & 0.8 & & & & \\
\hline $19^{*}$ & $2.32^{*}$ & 41 & 0.79 & & & & \\
\hline 20 & 3.71 & 44 & 0.55 & & & & \\
\hline 22 & 3.94 & 47 & 0.2 & & & & \\
\hline 23 & 3.97 & 50 & 0.29 & & & & \\
\hline 25 & 3.79 & 53 & 0 & & & & \\
\hline 26 & 3.79 & & & & & & \\
\hline
\end{tabular}




\section{Horse Valley Run}

Date of Survey: May 10, 2007

Reach \#: $12-\mathrm{A}$
Time of Survey: 9:52 am

Drainage Area: 4.38 sq. miles

UTM Coordinate Location: Zone 18, $4465254 \mathrm{~m} \mathrm{~N}, 0276218 \mathrm{~m} \mathrm{E}$

Location Information: Tuscarora State Forest, parked vehicle on Horse Valley Road.

Bankfull Indicator(s): A change in slope along the west channel bank.

Bankfull Response Variables: Cross-sectional area (53.4 square feet), width (31.6 feet), mean depth (1.7 feet).

\section{Graph of Channel Cross-Section}

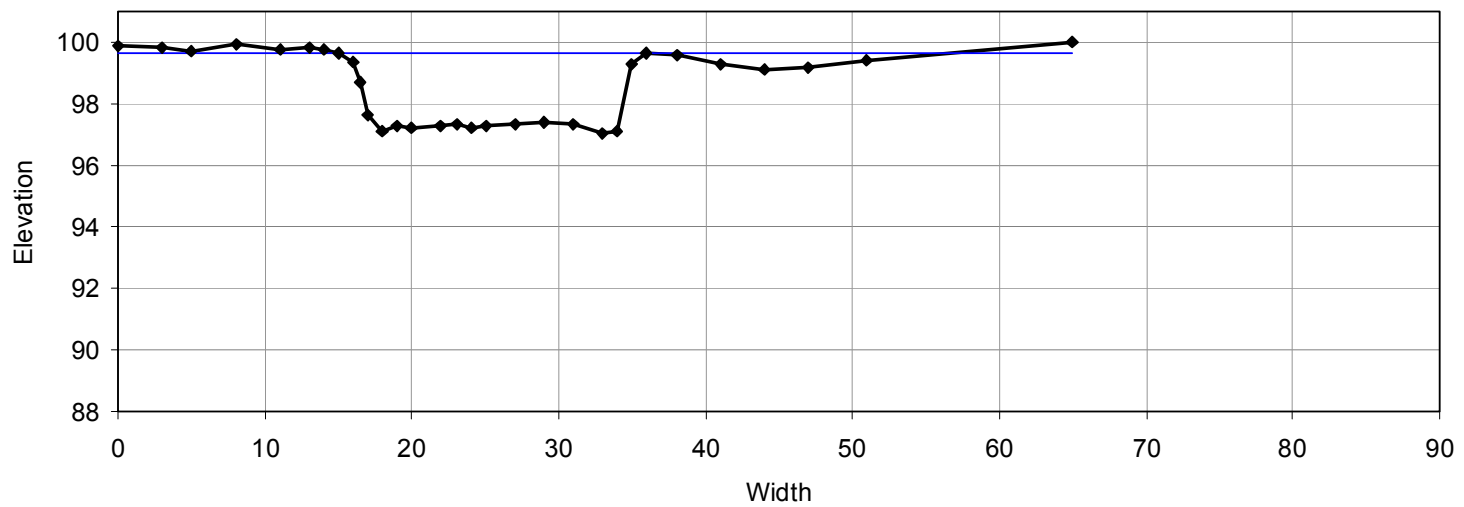

$\underline{\text { Survey Data }}$

\begin{tabular}{|c|c|c|c|c|c|c|c|}
\hline $\begin{array}{c}\begin{array}{c}\text { Horizontal } \\
\text { (feet) }\end{array} \\
\end{array}$ & $\begin{array}{c}\begin{array}{c}\text { Vertical } \\
\text { (feet) }\end{array} \\
\end{array}$ & $\begin{array}{c}\text { Horizontal } \\
\text { (feet) }\end{array}$ & $\begin{array}{l}\text { Vertical } \\
\text { (feet) }\end{array}$ & $\begin{array}{c}\text { Horizontal } \\
\text { (feet) }\end{array}$ & $\begin{array}{c}\text { Vertical } \\
\text { (feet) }\end{array}$ & $\begin{array}{c}\text { Horizontal } \\
\text { (feet) }\end{array}$ & $\begin{array}{c}\begin{array}{c}\text { Vertical } \\
\text { (feet) }\end{array} \\
\end{array}$ \\
\hline 0 & 0.1 & 22 & 2.7 & 47 & 0.86 & & \\
\hline 3 & 0.2 & 23 & 2.65 & 51 & 0.58 & & \\
\hline 5 & 0.3 & 24 & 2.78 & 65 & 0 & & \\
\hline 8 & 0.05 & 25 & 2.71 & & & & \\
\hline 11 & 0.23 & 27 & 2.64 & & & & \\
\hline 13 & 0.18 & 29 & 2.58 & & & & \\
\hline 14 & 0.23 & 31 & 2.66 & & & & \\
\hline $15^{*}$ & $0.35^{*}$ & 33 & 2.93 & & & & \\
\hline 16 & 0.68 & 34 & 2.92 & & & & \\
\hline 16.5 & 1.33 & 35 & 0.74 & & & & \\
\hline 17 & 2.39 & 36 & 0.36 & & & & \\
\hline 18 & 2.89 & 38 & 0.43 & & & & \\
\hline 19 & 2.71 & 41 & 0.71 & & & & \\
\hline 20 & 2.81 & 44 & 0.87 & & & & \\
\hline
\end{tabular}




\section{Horse Valley Run}

Date of Survey: May 10, 2007

Time of Survey: 10:03 am

Reach \#: $12-B$

Drainage Area: 4.38 sq. miles

UTM Coordinate Location: Zone 18, $4465262 \mathrm{~m} \mathrm{~N}, 0276227 \mathrm{~m} \mathrm{E}$

Location Information: Tuscarora State Forest, parked vehicle on Horse Valley Road.

Reach located downstream from survey 12-A.

Bankfull Indicator(s): A change in slope along the west channel bank.

Bankfull Response Variables: Cross-sectional area (33.1 square feet), width (23.4 feet), mean depth (1.4 feet).

\section{Graph of Channel Cross-Section}

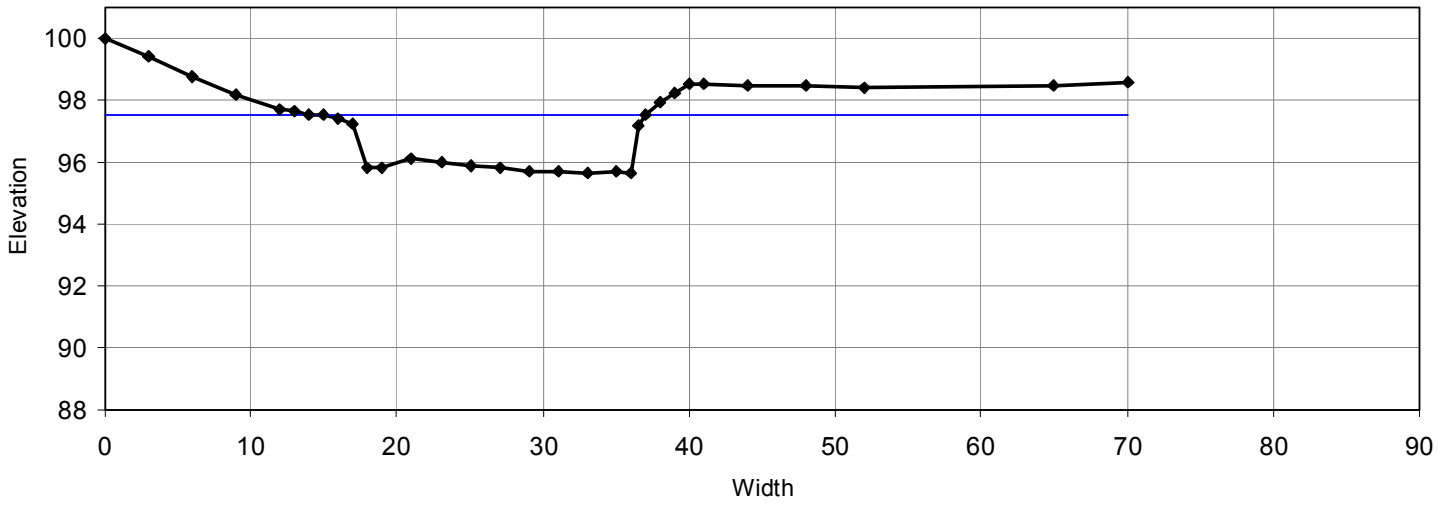

$\underline{\text { Survey Data }}$

\begin{tabular}{|c|c|c|c|c|c|c|c|}
\hline $\begin{array}{l}\text { Horizontal } \\
\text { (feet) }\end{array}$ & $\begin{array}{c}\text { Vertical } \\
\text { (feet) }\end{array}$ & $\begin{array}{c}\text { Horizontal } \\
\text { (feet) }\end{array}$ & $\begin{array}{l}\text { Vertical } \\
\text { (feet) }\end{array}$ & $\begin{array}{c}\text { Horizontal } \\
\text { (feet) }\end{array}$ & $\begin{array}{c}\text { Vertical } \\
\text { (feet) }\end{array}$ & $\begin{array}{c}\text { Horizontal } \\
\text { (feet) }\end{array}$ & $\begin{array}{c}\text { Vertical } \\
\text { (feet) }\end{array}$ \\
\hline 0 & 0 & 25 & 4.11 & 48 & 1.54 & & \\
\hline 3 & 0.61 & 27 & 4.15 & 52 & 1.56 & & \\
\hline 6 & 1.25 & 29 & 4.3 & 65 & 1.53 & & \\
\hline 9 & 1.83 & 31 & 4.31 & 70 & 1.44 & & \\
\hline 12 & 2.29 & 33 & 4.33 & & & & \\
\hline 13 & 2.37 & 35 & 4.29 & & & & \\
\hline 14 & 2.48 & 36 & 4.38 & & & & \\
\hline $15^{*}$ & $2.45^{\star}$ & 36.5 & 2.81 & & & & \\
\hline 16 & 2.56 & 37 & 2.49 & & & & \\
\hline 17 & 2.78 & 38 & 2.08 & & & & \\
\hline 18 & 4.19 & 39 & 1.77 & & & & \\
\hline 19 & 4.18 & 40 & 1.49 & & & & \\
\hline 21 & 3.87 & 41 & 1.45 & & & & \\
\hline 23 & 4.01 & 44 & 1.52 & & & & \\
\hline
\end{tabular}




\section{Horse Valley Run}

Date of Survey: May 10, 2007

Time of Survey: 11:28 am

Reach \#: 13-A

Drainage Area: 13.9 sq. miles

UTM Coordinate Location: Zone 18, 4469394 m N, 0279428 m E

Location Information: Tuscarora State Forest, parked vehicle on Horse Valley Road, located at the water gap.

Bankfull Indicator(s): A change in slope along the south channel bank.

Bankfull Response Variables: Cross-sectional area (116.9 square feet), width (52.6 feet), mean depth (2.2 feet).

\section{Graph of Channel Cross-Section}

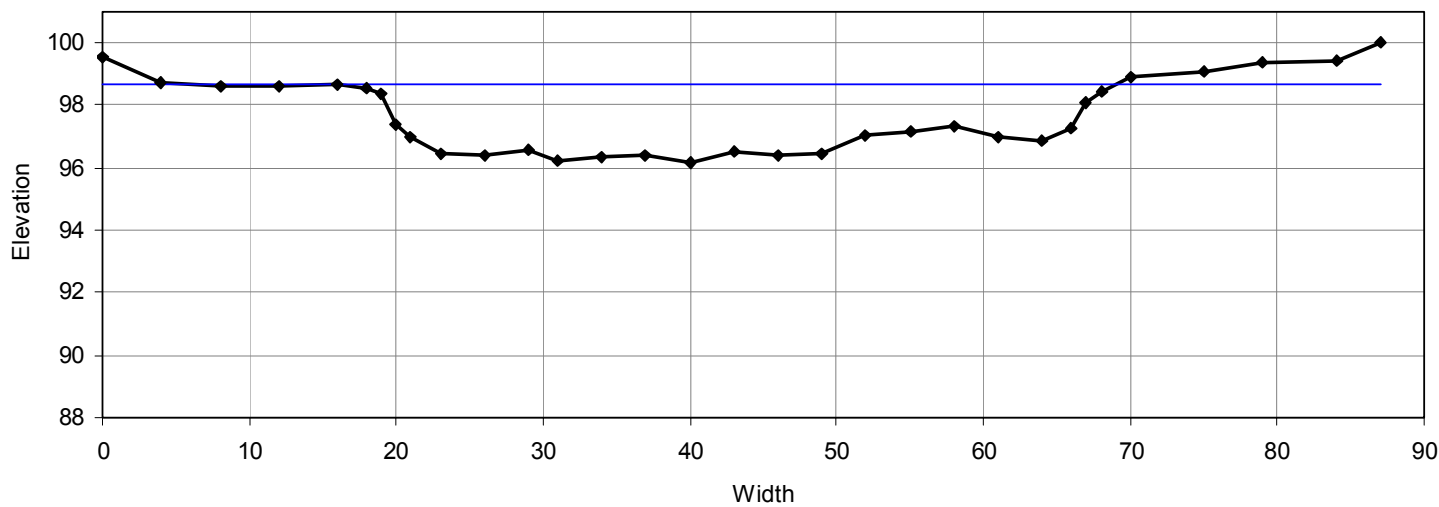

$\underline{\text { Survey Data }}$

\begin{tabular}{|c|c|c|c|c|c|c|c|}
\hline $\begin{array}{c}\text { Horizontal } \\
\text { (feet) }\end{array}$ & $\begin{array}{c}\text { Vertical } \\
\text { (feet) }\end{array}$ & $\begin{array}{c}\text { Horizontal } \\
\text { (feet) }\end{array}$ & $\begin{array}{l}\text { Vertical } \\
\text { (feet) }\end{array}$ & $\begin{array}{c}\text { Horizontal } \\
\text { (feet) }\end{array}$ & $\begin{array}{c}\text { Vertical } \\
\text { (feet) }\end{array}$ & $\begin{array}{c}\text { Horizontal } \\
\text { (feet) }\end{array}$ & $\begin{array}{c}\begin{array}{c}\text { Vertical } \\
\text { (feet) }\end{array} \\
\end{array}$ \\
\hline 0 & 1.5 & 43 & 5.9 & 74 & 2.76 & & \\
\hline 4 & 1.52 & 46 & 5.66 & 76 & 2.61 & & \\
\hline 9 & 1.69 & 48 & 5.53 & 79 & 2.28 & & \\
\hline 12 & 2.52 & 51 & 5.31 & 82 & 1.68 & & \\
\hline 15 & 2.71 & 53 & 5.32 & 86 & 1.3 & & \\
\hline 19 & 2.7 & 56 & 4.96 & 90 & 1.06 & & \\
\hline $21^{*}$ & $2.93^{*}$ & 59 & 4.87 & 94 & 0.53 & & \\
\hline 23 & 3.56 & 62 & 4.93 & 98 & 0 & & \\
\hline 25 & 4.81 & 65 & 5.24 & & & & \\
\hline 27 & 5.53 & 68 & 5.15 & & & & \\
\hline 30 & 5.55 & 70 & 5.08 & & & & \\
\hline 34 & 5.56 & 71 & 4.58 & & & & \\
\hline 37 & 5.63 & 72 & 3.87 & & & & \\
\hline 40 & 5.71 & 73 & 3.2 & & & & \\
\hline
\end{tabular}




\section{Horse Valley Run}

Date of Survey: May 10, 2007

Reach \#: $13-B$
Time of Survey: 12:00 am

Drainage Area: 13.9 sq. miles

UTM Coordinate Location: Zone 18, 4469406 m N, $0279414 \mathrm{~m} \mathrm{E}$

Location Information: Tuscarora State Forest, reach located approximately 100 feet downstream from survey 2 -A.

Bankfull Indicator(s): A change in slope along the south channel bank.

Bankfull Response Variables: Cross-sectional area (95.7 square feet), width (53 feet), mean depth (1.8 feet).

\section{Graph of Channel Cross-Section}

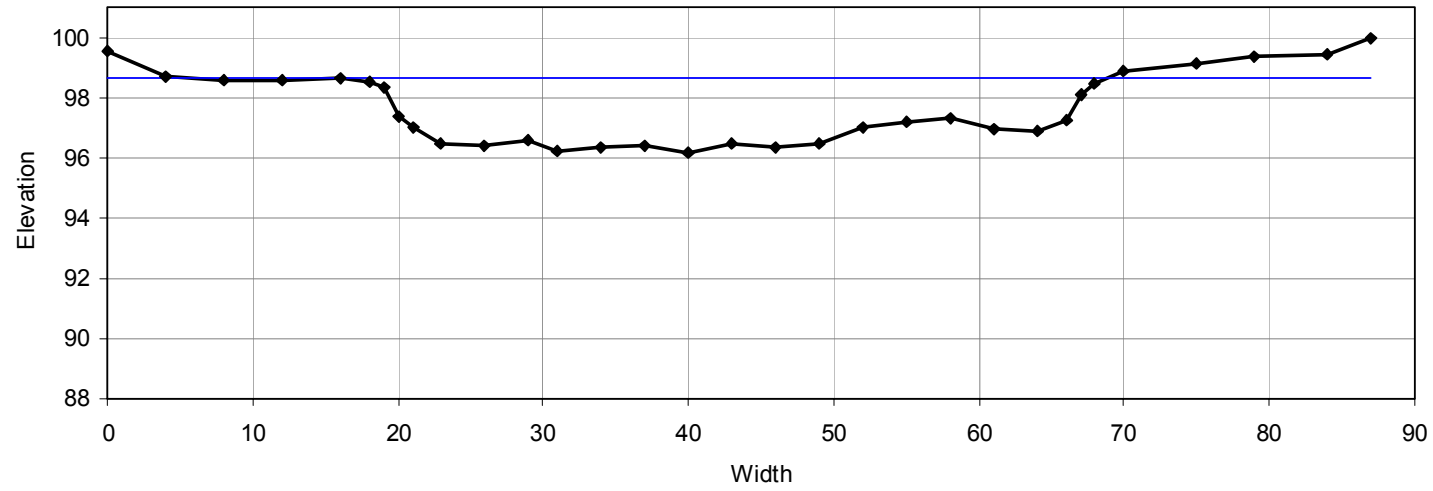

$\underline{\text { Survey Data }}$

\begin{tabular}{|c|c|c|c|c|c|c|c|}
\hline $\begin{array}{c}\text { Horizontal } \\
\text { (feet) }\end{array}$ & $\begin{array}{c}\begin{array}{c}\text { Vertical } \\
\text { (feet) }\end{array} \\
\end{array}$ & $\begin{array}{l}\text { Horizontal } \\
\text { (feet) }\end{array}$ & $\begin{array}{c}\begin{array}{l}\text { Vertical } \\
\text { (feet) }\end{array} \\
\end{array}$ & $\begin{array}{c}\text { Horizontal } \\
\text { (feet) }\end{array}$ & $\begin{array}{c}\begin{array}{l}\text { Vertical } \\
\text { (feet) }\end{array} \\
\end{array}$ & $\begin{array}{c}\text { Horizontal } \\
\text { (feet) }\end{array}$ & $\begin{array}{c}\begin{array}{c}\text { Vertical } \\
\text { (feet) }\end{array} \\
\end{array}$ \\
\hline 0 & 0.45 & 37 & 3.61 & 75 & 0.9 & & \\
\hline 4 & 1.27 & 40 & 3.86 & 79 & 0.65 & & \\
\hline 8 & 1.4 & 43 & 3.51 & 84 & 0.58 & & \\
\hline 12 & 1.41 & 46 & 3.63 & 87 & 0 & & \\
\hline 16 & 1.33 & 49 & 3.55 & & & & \\
\hline 18 & 1.45 & 52 & 2.97 & & & & \\
\hline $19^{*}$ & $1.65^{*}$ & 55 & 2.83 & & & & \\
\hline 20 & 2.6 & 58 & 2.69 & & & & \\
\hline 21 & 3.02 & 61 & 3.05 & & & & \\
\hline 23 & 3.56 & 64 & 3.11 & & & & \\
\hline 26 & 3.59 & 66 & 2.76 & & & & \\
\hline 29 & 3.41 & 67 & 1.92 & & & & \\
\hline 31 & 3.8 & 68 & 1.55 & & & & \\
\hline 34 & 3.68 & 70 & 1.1 & & & & \\
\hline
\end{tabular}




\section{Horse Valley Run}

Date of Survey: May 10, 2007

Reach \#: $14-\mathrm{A}$
Time of Survey: 1:04 pm

Drainage Area: 4.98 sq. miles

UTM Coordinate Location: Zone 18, $4469188 \mathrm{~m} \mathrm{~N}, 0280073 \mathrm{~m} \mathrm{E}$

Location Information: Tuscarora State Forest, parked vehicle on Horse Valley Road near confluence of Horse Valley Run and Kansas Valley Run. Measured reach on Kansas Valley Run.

Bankfull Indicator(s): A change in slope along the south channel bank.

Bankfull Response Variables: Cross-sectional area (41.3 square feet), width (26.3 feet), mean depth (1.6 feet).

\section{Graph of Channel Cross-Section}

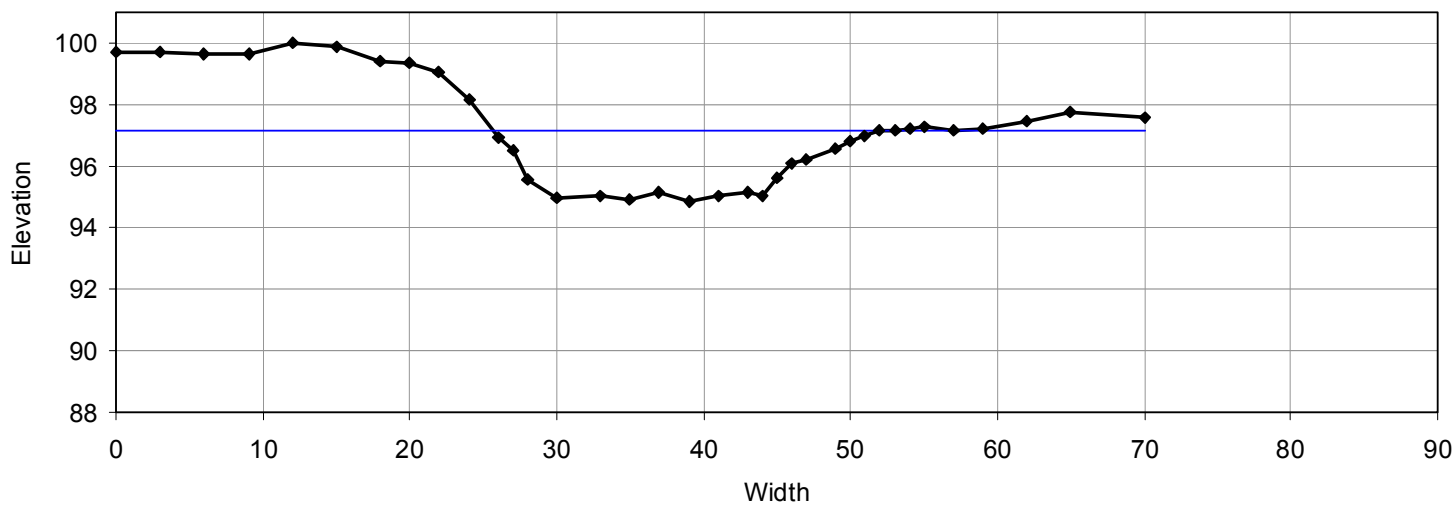

\section{$\underline{\text { Survey Data }}$}

\begin{tabular}{|c|c|c|c|c|c|c|c|}
\hline $\begin{array}{l}\text { Horizontal } \\
\text { (feet) }\end{array}$ & $\begin{array}{c}\begin{array}{l}\text { Vertical } \\
\text { (feet) }\end{array} \\
\end{array}$ & $\begin{array}{l}\text { Horizontal } \\
\text { (feet) }\end{array}$ & $\begin{array}{c}\begin{array}{l}\text { Vertical } \\
\text { (feet) }\end{array} \\
\end{array}$ & $\begin{array}{c}\text { Horizontal } \\
\text { (feet) }\end{array}$ & $\begin{array}{c}\begin{array}{l}\text { Vertical } \\
\text { (feet) }\end{array} \\
\end{array}$ & $\begin{array}{c}\text { Horizontal } \\
\text { (feet) }\end{array}$ & $\begin{array}{c}\text { Vertical } \\
\text { (feet) }\end{array}$ \\
\hline 0 & 0.31 & 33 & 4.95 & 53 & 2.83 & & \\
\hline 3 & 0.31 & 35 & 5.08 & 54 & 2.78 & & \\
\hline 6 & 0.33 & 37 & 4.85 & 55 & 2.74 & & \\
\hline 9 & 0.34 & 39 & 5.13 & 57 & 2.85 & & \\
\hline 12 & 0 & 41 & 4.97 & 59 & 2.81 & & \\
\hline 15 & 0.15 & 43 & 4.87 & 62 & 2.55 & & \\
\hline 18 & 0.62 & 44 & 4.95 & 65 & 2.27 & & \\
\hline 20 & 0.68 & 45 & 4.39 & 70 & 2.4 & & \\
\hline 22 & 0.93 & 46 & 3.9 & & & & \\
\hline 24 & 1.83 & 47 & 3.76 & & & & \\
\hline 26 & 3.06 & 49 & 3.44 & & & & \\
\hline 27 & 3.47 & 50 & 3.2 & & & & \\
\hline 28 & 4.43 & 51 & 3.03 & & & & \\
\hline 30 & 5 & $52^{*}$ & $2.86^{*}$ & & & & \\
\hline
\end{tabular}




\section{Horse Valley Run}

Date of Survey: May 10, 2007

Reach \#: $14-B$
Time of Survey: 1:32 pm

Drainage Area: 4.98 sq. miles

UTM Coordinate Location: Zone 18, 4469183 m N, $0280067 \mathrm{~m} \mathrm{E}$

Location Information: Tuscarora State Forest, parked vehicle on Horse Valley Road near confluence of Horse Valley Run and Kansas Valley Run. Reach located downstream of survey $14-\mathrm{B}$.

Bankfull Indicator(s): A change in slope along the south channel bank.

Bankfull Response Variables: Cross-sectional area (38 square feet), width (23.7 feet), mean depth (1.6 feet).

\section{Graph of Channel Cross-Section}

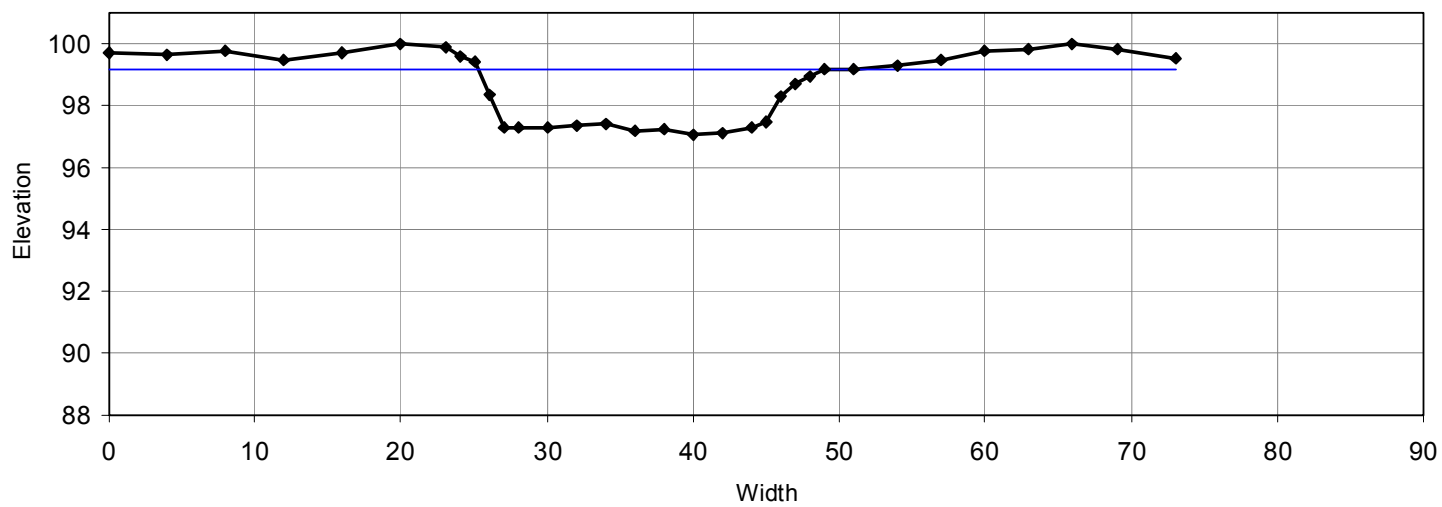

\section{$\underline{\text { Survey Data }}$}

\begin{tabular}{|c|c|c|c|c|c|c|c|}
\hline $\begin{array}{c}\text { Horizontal } \\
\text { (feet) }\end{array}$ & $\begin{array}{c}\text { Vertical } \\
\text { (feet) }\end{array}$ & $\begin{array}{c}\text { Horizontal } \\
\text { (feet) }\end{array}$ & $\begin{array}{c}\text { Vertical } \\
\text { (feet) }\end{array}$ & $\begin{array}{c}\text { Horizontal } \\
\text { (feet) }\end{array}$ & $\begin{array}{c}\text { Vertical } \\
\text { (feet) }\end{array}$ & $\begin{array}{c}\text { Horizontal } \\
\text { (feet) }\end{array}$ & $\begin{array}{c}\text { Vertical } \\
\text { (feet) }\end{array}$ \\
\hline 0 & 0.32 & 34 & 2.6 & 60 & 0.21 & & \\
\hline 8 & 0.21 & 38 & 2.77 & 66 & 0.01 & & \\
\hline 12 & 0.52 & 40 & 2.93 & 69 & 0.16 & & \\
\hline 23 & 0.13 & 45 & 2.54 & & & & \\
\hline 24 & 0.41 & 46 & 1.71 & & & & \\
\hline 25 & 0.57 & 47 & 1.28 & & & & \\
\hline 26 & 1.67 & 48 & 1.05 & & & & \\
\hline 30 & 2.68 & 54 & 0.72 & & & & \\
\hline 32 & 2.62 & 57 & 0.54 & & & & \\
\hline
\end{tabular}




\section{Horse Valley Run}

Date of Survey: May 10, 2007

Reach \#: $15-\mathrm{A}$
Time of Survey: 2:26 pm

Drainage Area: 3.88 sq. miles

UTM Coordinate Location: Zone 18, $4469481 \mathrm{~m} \mathrm{~N}, 0280978 \mathrm{~m} \mathrm{E}$

Location Information: Tuscarora State Forest, parked vehicle on Kansas Valley Road. Reach located on Kansas Valley Run.

Bankfull Indicator(s): A change in slope along the northwest channel bank.

Bankfull Response Variables: Cross-sectional area (27.7 square feet), width (19 feet), mean depth (1.5 feet).

\section{Graph of Channel Cross-Section}

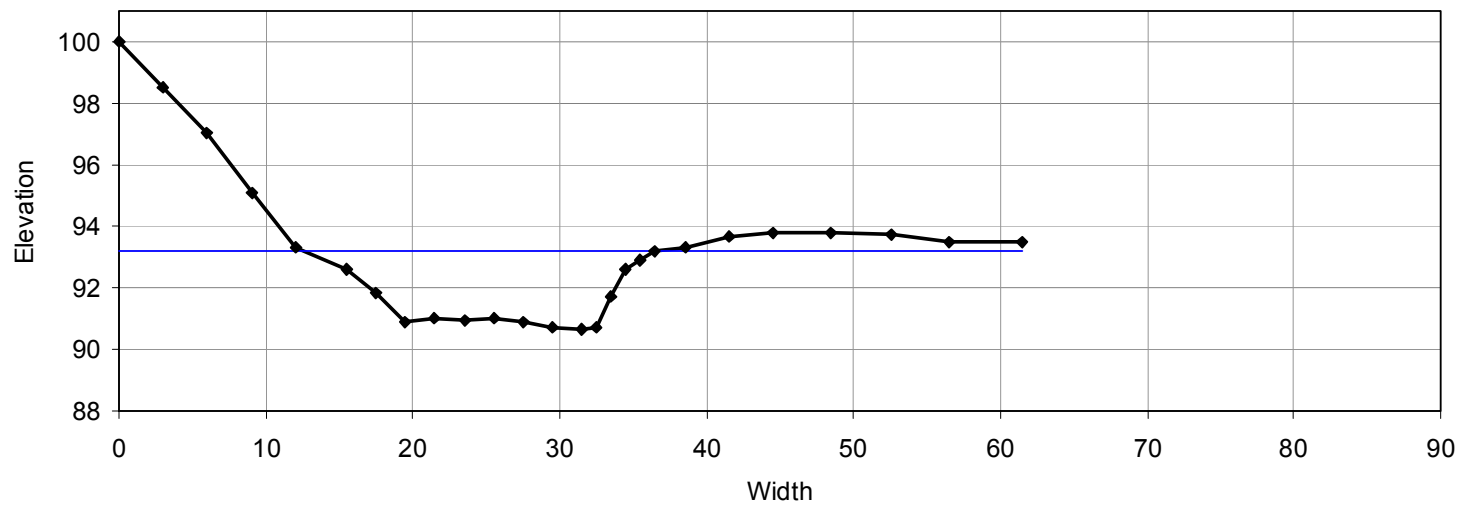

\section{Survey Data}

\begin{tabular}{|c|c|c|c|c|c|c|c|}
\hline $\begin{array}{c}\text { Horizontal } \\
\text { (feet) }\end{array}$ & $\begin{array}{c}\begin{array}{c}\text { Vertical } \\
\text { (feet) }\end{array} \\
\end{array}$ & $\begin{array}{c}\text { Horizontal } \\
\text { (feet) }\end{array}$ & $\begin{array}{l}\begin{array}{l}\text { Vertical } \\
\text { (feet) }\end{array} \\
\end{array}$ & $\begin{array}{c}\text { Horizontal } \\
\text { (feet) }\end{array}$ & $\begin{array}{c}\begin{array}{c}\text { Vertical } \\
\text { (feet) }\end{array} \\
\end{array}$ & $\begin{array}{c}\text { Horizontal } \\
\text { (feet) }\end{array}$ & $\begin{array}{c}\begin{array}{c}\text { Vertical } \\
\text { (feet) }\end{array} \\
\end{array}$ \\
\hline 0 & 0 & 32.5 & 9.29 & & & & \\
\hline 3 & 1.47 & 33.5 & 8.29 & & & & \\
\hline 6 & 2.96 & 34.5 & 7.39 & & & & \\
\hline 9 & 4.88 & 35.5 & 7.11 & & & & \\
\hline 12 & 6.67 & $36.5^{*}$ & $6.81^{*}$ & & & & \\
\hline 15.5 & 7.38 & 38.5 & 6.69 & & & & \\
\hline 17.5 & 8.16 & 41.5 & 6.31 & & & & \\
\hline 19.5 & 9.1 & 44.5 & 6.2 & & & & \\
\hline 21.5 & 8.99 & 48.5 & 6.23 & & & & \\
\hline 23.5 & 9.05 & 52.5 & 6.24 & & & & \\
\hline 25.5 & 9 & 56.5 & 6.5 & & & & \\
\hline 27.5 & 9.11 & 61.5 & 6.51 & & & & \\
\hline 29.5 & 9.28 & & & & & & \\
\hline 31.5 & 9.37 & & & & & & \\
\hline
\end{tabular}




\section{Horse Valley Run}

Date of Survey: May 10, 2007

Reach \#: $15-B$
Time of Survey: 2:41 pm

Drainage Area: 3.88 sq. miles

UTM Coordinate Location: Zone 18, $4469562 \mathrm{~m} \mathrm{~N}, 0281022 \mathrm{~m} \mathrm{E}$

Location Information: Tuscarora State Forest, parked vehicle on Kansas Valley Road.

Reach located on Kansas Valley Run. Reach located downstream from 15-A.

Bankfull Indicator(s): A change in slope along the northwest channel bank.

Bankfull Response Variables: Cross-sectional area (36.1 square feet), width (22.9 feet), mean depth (1.6 feet).

\section{Graph of Channel Cross-Section}

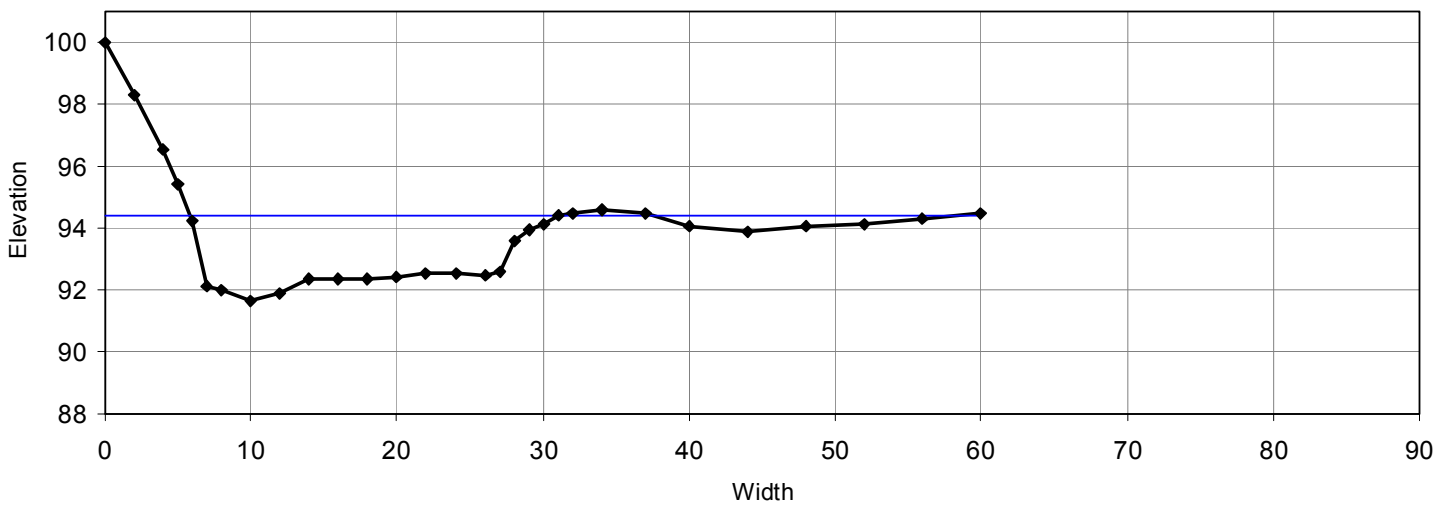

$\underline{\text { Survey Data }}$

\begin{tabular}{|c|c|c|c|c|c|c|c|}
\hline $\begin{array}{c}\text { Horizontal } \\
\text { (feet) }\end{array}$ & $\begin{array}{c}\text { Vertical } \\
\text { (feet) }\end{array}$ & $\begin{array}{c}\text { Horizontal } \\
\text { (feet) }\end{array}$ & $\begin{array}{c}\begin{array}{c}\text { Vertical } \\
\text { (feet) }\end{array} \\
\end{array}$ & $\begin{array}{c}\text { Horizontal } \\
\text { (feet) }\end{array}$ & $\begin{array}{c}\text { Vertical } \\
\text { (feet) }\end{array}$ & $\begin{array}{c}\text { Horizontal } \\
\text { (feet) }\end{array}$ & $\begin{array}{c}\begin{array}{c}\text { Vertical } \\
\text { (feet) }\end{array} \\
\end{array}$ \\
\hline 0 & 0 & 24 & 7.47 & 56 & 5.7 & & \\
\hline 2 & 1.73 & 26 & 7.54 & 60 & 5.53 & & \\
\hline 4 & 3.45 & 27 & 7.43 & & & & \\
\hline 5 & 4.61 & 28 & 6.42 & & & & \\
\hline 6 & 5.74 & $29 *$ & $6.03^{*}$ & & & & \\
\hline 7 & 7.89 & 30 & 5.87 & & & & \\
\hline 8 & 8.02 & 31 & 5.59 & & & & \\
\hline 10 & 8.33 & 32 & 5.55 & & & & \\
\hline 12 & 8.11 & 34 & 5.43 & & & & \\
\hline 14 & 7.64 & 37 & 5.54 & & & & \\
\hline 16 & 7.66 & 40 & 5.97 & & & & \\
\hline 18 & 7.62 & 44 & 6.1 & & & & \\
\hline 20 & 7.58 & 48 & 5.96 & & & & \\
\hline 22 & 7.48 & 52 & 5.88 & & & & \\
\hline
\end{tabular}




\section{Horse Valley Run}

Date of Survey: May 11, 2007

Reach \#: $16-A$
Time of Survey: 2:19 pm

Drainage Area: 2.91 sq. miles

UTM Coordinate Location: Zone 18, $4470293 \mathrm{~m} \mathrm{~N}, 0281655 \mathrm{~m} \mathrm{E}$

Location Information: Tuscarora State Forest, parked vehicle on Kansas Valley Road. Reach located on Kansas Valley Run, upstream from active forest clearing operation.

Bankfull Indicator(s): A change in slope along the west channel bank.

Bankfull Response Variables: Cross-sectional area (23 square feet), width (14.8 feet), mean depth (1.6 feet).

\section{Graph of Channel Cross-Section}

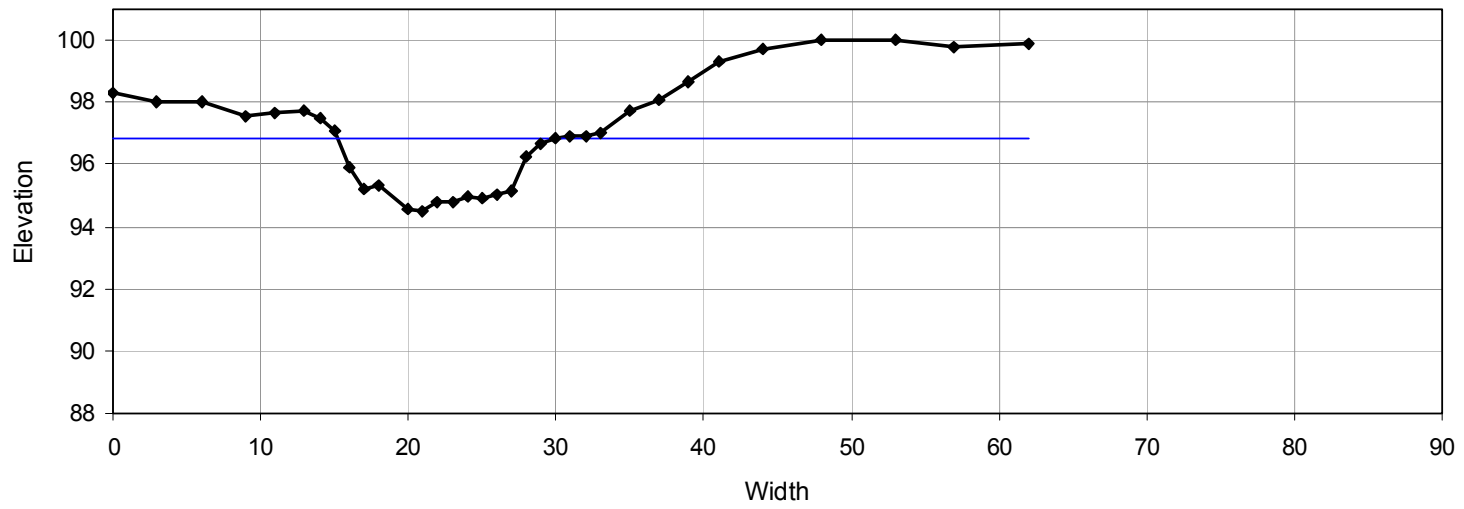

\section{Survey Data}

\begin{tabular}{|c|c|c|c|c|c|c|c|}
\hline $\begin{array}{c}\begin{array}{c}\text { Horizontal } \\
\text { (feet) }\end{array} \\
\end{array}$ & $\begin{array}{c}\begin{array}{c}\text { Vertical } \\
\text { (feet) }\end{array} \\
\end{array}$ & $\begin{array}{c}\begin{array}{c}\text { Horizontal } \\
\text { (feet) }\end{array} \\
\end{array}$ & $\begin{array}{l}\text { Vertical } \\
\text { (feet) }\end{array}$ & $\begin{array}{c}\text { Horizontal } \\
\text { (feet) }\end{array}$ & $\begin{array}{c}\begin{array}{c}\text { Vertical } \\
\text { (feet) }\end{array} \\
\end{array}$ & $\begin{array}{c}\text { Horizontal } \\
\text { (feet) }\end{array}$ & $\begin{array}{c}\begin{array}{c}\text { Vertical } \\
\text { (feet) }\end{array} \\
\end{array}$ \\
\hline 0 & 1.71 & 23 & 5.18 & 41 & 0.68 & & \\
\hline 3 & 1.96 & 24 & 5.03 & 44 & 0.28 & & \\
\hline 6 & 2 & 25 & 5.07 & 48 & 0 & & \\
\hline 9 & 2.43 & 26 & 4.97 & 53 & 0 & & \\
\hline 11 & 2.32 & 27 & 4.85 & 57 & 0.22 & & \\
\hline 13 & 2.25 & 28 & 3.76 & 62 & 0.1 & & \\
\hline 14 & 2.52 & 29 & 3.33 & & & & \\
\hline 15 & 2.9 & $30 *$ & $3.13^{*}$ & & & & \\
\hline 16 & 4.07 & 31 & 3.12 & & & & \\
\hline 17 & 4.77 & 32 & 3.12 & & & & \\
\hline 18 & 4.69 & 33 & 3 & & & & \\
\hline 20 & 5.46 & 35 & 2.28 & & & & \\
\hline 21 & 5.49 & 37 & 1.91 & & & & \\
\hline 22 & 5.21 & 39 & 1.32 & & & & \\
\hline
\end{tabular}




\section{Horse Valley Run}

Date of Survey: May 11, 2007

Reach \#: $16-B$
Time of Survey: 2:34 pm

Drainage Area: 2.91 sq. miles

UTM Coordinate Location: Zone 18, 4470266 m N, 0281647 m E

Location Information: Tuscarora State Forest, parked vehicle on Kansas Valley Road.

Reach located on Kansas Valley Run, approximately 150 feet downstream from reach 16A.

Bankfull Indicator(s): A change in slope along the east channel bank.

Bankfull Response Variables: Cross-sectional area (27.7 square feet), width (16.4 feet), mean depth (1.7 feet).

\section{Graph of Channel Cross-Section}

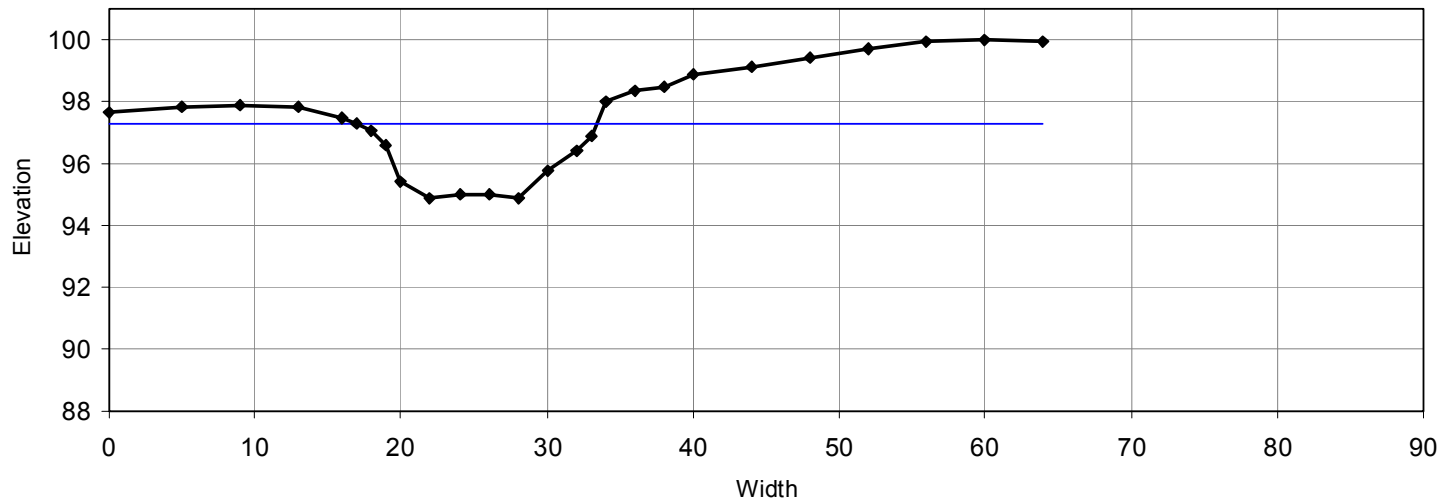

\section{$\underline{\text { Survey Data }}$}

\begin{tabular}{|c|c|c|c|c|c|c|c|}
\hline $\begin{array}{l}\text { Horizontal } \\
\text { (feet) }\end{array}$ & $\begin{array}{c}\begin{array}{c}\text { Vertical } \\
\text { (feet) }\end{array} \\
\end{array}$ & $\begin{array}{c}\text { Horizontal } \\
\text { (feet) }\end{array}$ & $\begin{array}{c}\begin{array}{c}\text { Vertical } \\
\text { (feet) }\end{array} \\
\end{array}$ & $\begin{array}{c}\text { Horizontal } \\
\text { (feet) }\end{array}$ & $\begin{array}{c}\begin{array}{l}\text { Vertical } \\
\text { (feet) }\end{array} \\
\end{array}$ & $\begin{array}{c}\text { Horizontal } \\
\text { (feet) }\end{array}$ & $\begin{array}{c}\text { Vertical } \\
\text { (feet) }\end{array}$ \\
\hline 0 & 2.34 & 32 & 3.58 & & & & \\
\hline 5 & 2.15 & 33 & 3.13 & & & & \\
\hline 9 & 2.09 & 34 & 2.01 & & & & \\
\hline 13 & 2.18 & 36 & 1.62 & & & & \\
\hline 16 & 2.5 & 38 & 1.54 & & & & \\
\hline $17^{*}$ & $2.68^{*}$ & 40 & 1.14 & & & & \\
\hline 18 & 2.97 & 44 & 0.9 & & & & \\
\hline 19 & 3.44 & 48 & 0.59 & & & & \\
\hline 20 & 4.57 & 52 & 0.32 & & & & \\
\hline 22 & 5.11 & 56 & 0.03 & & & & \\
\hline 24 & 4.99 & 60 & 0 & & & & \\
\hline 26 & 5 & 64 & 0.06 & & & & \\
\hline 28 & 5.11 & & & & & & \\
\hline 30 & 4.26 & & & & & & \\
\hline
\end{tabular}




\section{Horse Valley Run}

Date of Survey: May 11, 2007

Reach \#: $17-\mathrm{A}$
Time of Survey: $3: 37 \mathrm{pm}$

Drainage Area: 1.54 sq. miles

UTM Coordinate Location: Zone 18, $4470482 \mathrm{~m} \mathrm{~N}, 0282011 \mathrm{~m} \mathrm{E}$

Location Information: Tuscarora State Forest, parked vehicle on Kansas Valley Road near intersection with Kansas Loop Road. Reach located on Kansas Valley Run.

Bankfull Indicator(s): A change in slope along the northwest channel bank.

Bankfull Response Variables: Cross-sectional area (20.3 square feet), width (18.2 feet), mean depth (1.1 feet).

\section{Graph of Channel Cross-Section}

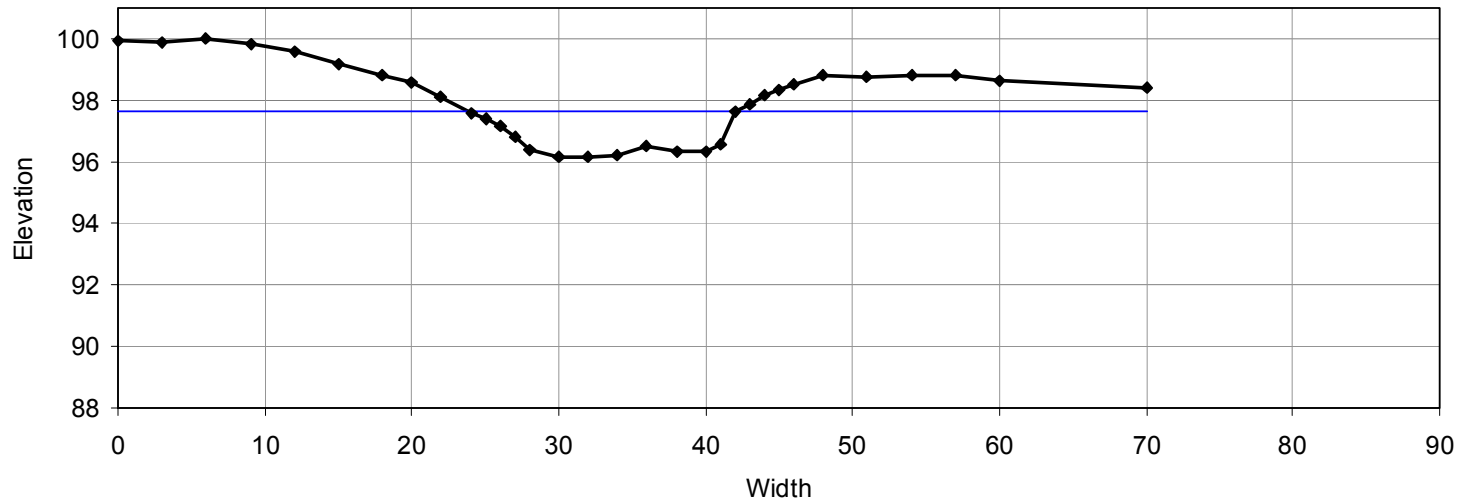

\section{Survey Data}

\begin{tabular}{|c|c|c|c|c|c|c|c|}
\hline $\begin{array}{c}\begin{array}{c}\text { Horizontal } \\
\text { (feet) }\end{array} \\
\end{array}$ & $\begin{array}{c}\begin{array}{c}\text { Vertical } \\
\text { (feet) }\end{array} \\
\end{array}$ & $\begin{array}{c}\begin{array}{c}\text { Horizontal } \\
\text { (feet) }\end{array} \\
\end{array}$ & $\begin{array}{l}\text { Vertical } \\
\text { (feet) }\end{array}$ & $\begin{array}{c}\begin{array}{c}\text { Horizontal } \\
\text { (feet) }\end{array} \\
\end{array}$ & $\begin{array}{c}\begin{array}{l}\text { Vertical } \\
\text { (feet) }\end{array} \\
\end{array}$ & $\begin{array}{c}\text { Horizontal } \\
\text { (feet) }\end{array}$ & $\begin{array}{c}\begin{array}{c}\text { Vertical } \\
\text { (feet) }\end{array} \\
\end{array}$ \\
\hline 0 & 0.05 & 30 & 3.87 & 54 & 1.2 & & \\
\hline 3 & 0.12 & 32 & 3.86 & 57 & 1.17 & & \\
\hline 6 & 0 & 34 & 3.79 & 60 & 1.37 & & \\
\hline 9 & 0.2 & 36 & 3.5 & 70 & 1.59 & & \\
\hline 12 & 0.42 & 38 & 3.69 & & & & \\
\hline 15 & 0.81 & 40 & 3.65 & & & & \\
\hline 18 & 1.16 & 41 & 3.43 & & & & \\
\hline 20 & 1.44 & $42^{*}$ & $2.36^{*}$ & & & & \\
\hline 22 & 1.88 & 43 & 2.13 & & & & \\
\hline 24 & 2.4 & 44 & 1.86 & & & & \\
\hline 25 & 2.61 & 45 & 1.63 & & & & \\
\hline 26 & 2.85 & 46 & 1.48 & & & & \\
\hline 27 & 3.22 & 48 & 1.21 & & & & \\
\hline 28 & 3.59 & 51 & 1.24 & & & & \\
\hline
\end{tabular}




\section{Horse Valley Run}

Date of Survey: May 11, 2007

Reach \#: $17-B$
Time of Survey: 3:55 pm

Drainage Area: 1.54 sq. miles

UTM Coordinate Location: Zone 18, $4470482 \mathrm{~m} \mathrm{~N}, 0282011 \mathrm{~m} \mathrm{E}$

Location Information: Tuscarora State Forest, parked vehicle on Kansas Valley Road near intersection with Kansas Loop Road. Reach located approximately 50 feet downstream of 17-A.

Bankfull Indicator(s): A change in slope along the northwest channel bank.

Bankfull Response Variables: Cross-sectional area (26.7 square feet), width (21.2 feet), mean depth (1.3 feet).

\section{Graph of Channel Cross-Section}

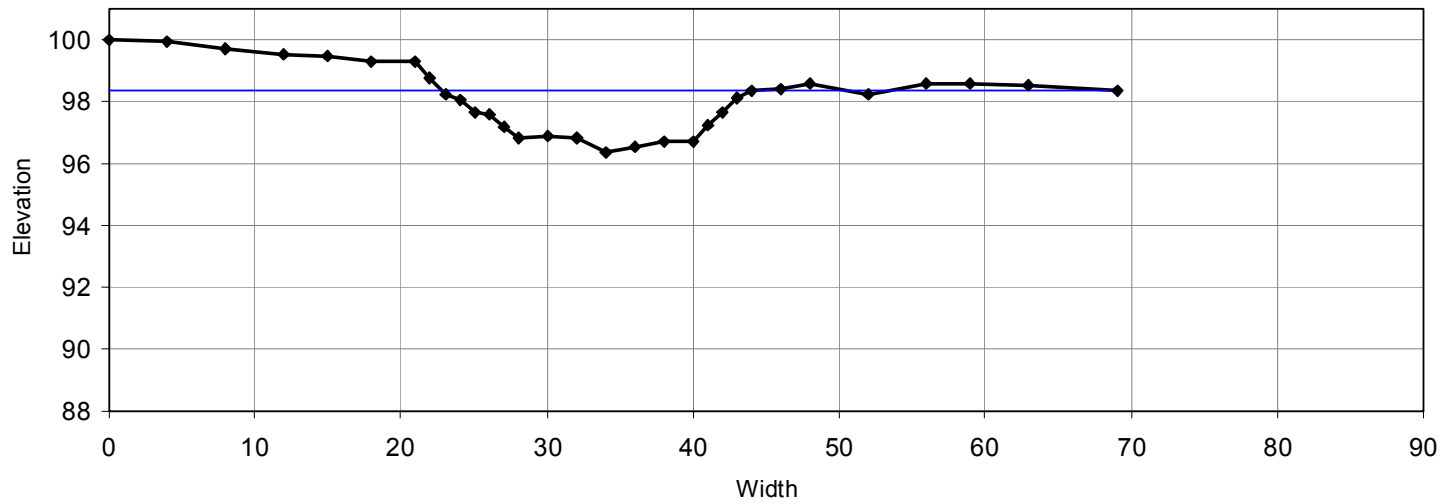

\section{$\underline{\text { Survey Data }}$}

\begin{tabular}{|c|c|c|c|c|c|c|c|}
\hline $\begin{array}{l}\text { Horizontal } \\
\text { (feet) }\end{array}$ & $\begin{array}{l}\text { Vertical } \\
\text { (feet) }\end{array}$ & $\begin{array}{c}\text { Horizontal } \\
\text { (feet) }\end{array}$ & $\begin{array}{c}\text { Vertical } \\
\text { (feet) }\end{array}$ & $\begin{array}{l}\text { Horizontal } \\
\text { (feet) }\end{array}$ & $\begin{array}{l}\text { Vertical } \\
\text { (feet) }\end{array}$ & $\begin{array}{c}\text { Horizontal } \\
\text { (feet) }\end{array}$ & $\begin{array}{c}\text { Vertical } \\
\text { (feet) }\end{array}$ \\
\hline 0 & 0 & 30 & 3.13 & 59 & 1.4 & & \\
\hline 4 & 0.03 & 32 & 3.2 & 63 & 1.47 & & \\
\hline 8 & 0.27 & 34 & 3.64 & 69 & 1.66 & & \\
\hline 12 & 0.49 & 36 & 3.45 & & & & \\
\hline 15 & 0.52 & 38 & 3.31 & & & & \\
\hline 18 & 0.68 & 40 & 3.28 & & & & \\
\hline 21 & 0.73 & 41 & 2.75 & & & & \\
\hline 22 & 1.23 & 42 & 2.36 & & & & \\
\hline 23 & 1.74 & 43 & 1.88 & & & & \\
\hline 24 & 1.94 & $44^{*}$ & $1.65^{*}$ & & & & \\
\hline 25 & 2.35 & 46 & 1.58 & & & & \\
\hline 26 & 2.4 & 48 & 1.41 & & & & \\
\hline 27 & 2.84 & 52 & 1.76 & & & & \\
\hline 28 & 3.18 & 56 & 1.42 & & & & \\
\hline
\end{tabular}




\section{Laurel Run}

Date of Survey: May 12, 2007

Time of Survey: 11:07 am

Reach \#: $18-\mathrm{A}$

Drainage Area: 1.43 sq. miles

UTM Coordinate Location: Zone 18, 4455788 m N, 0281538 m E

Location Information: Tuscarora State Forest, parked vehicle along Three Square Hollow Road at the intersection of Tuscarora Trail.

Bankfull Indicator(s): A change in slope along the south channel bank.

Bankfull Response Variables: Cross-sectional area (22.3 square feet), width (19.2 feet), mean depth (1.2 feet).

\section{Graph of Channel Cross-Section}

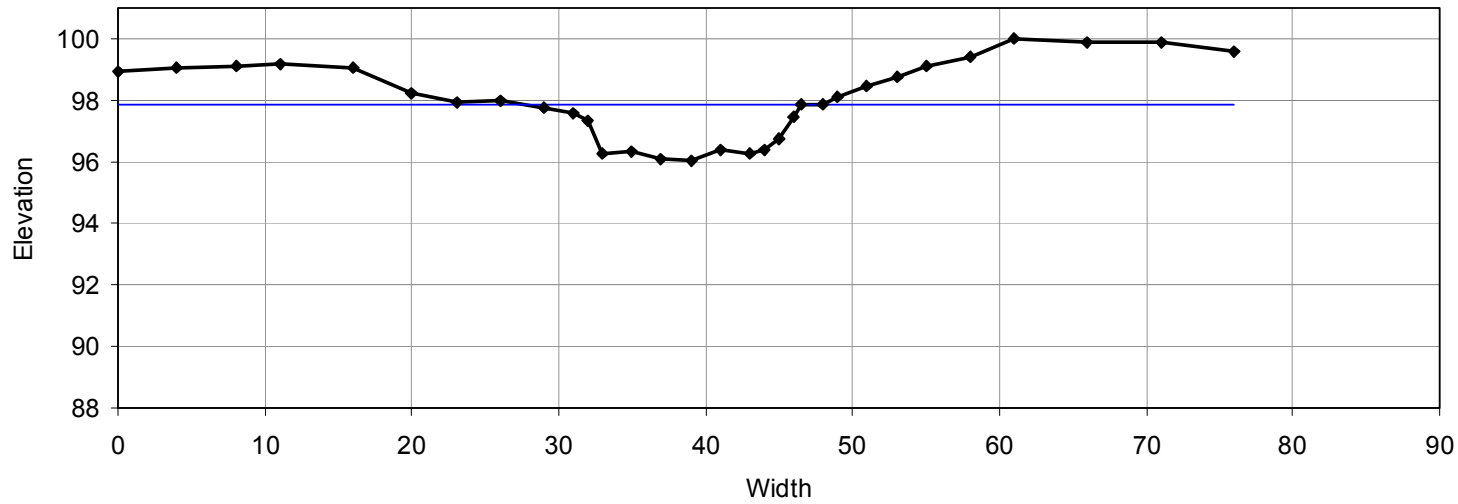

Survey Data

\begin{tabular}{|c|c|c|c|c|c|c|c|}
\hline $\begin{array}{c}\begin{array}{c}\text { Horizontal } \\
\text { (feet) }\end{array} \\
\end{array}$ & $\begin{array}{c}\begin{array}{c}\text { Vertical } \\
\text { (feet) }\end{array} \\
\end{array}$ & $\begin{array}{c}\begin{array}{c}\text { Horizontal } \\
\text { (feet) }\end{array} \\
\end{array}$ & $\begin{array}{l}\text { Vertical } \\
\text { (feet) }\end{array}$ & $\begin{array}{c}\begin{array}{c}\text { Horizontal } \\
\text { (feet) }\end{array} \\
\end{array}$ & $\begin{array}{l}\text { Vertical } \\
\text { (feet) }\end{array}$ & $\begin{array}{c}\text { Horizontal } \\
\text { (feet) }\end{array}$ & $\begin{array}{c}\begin{array}{c}\text { Vertical } \\
\text { (feet) }\end{array} \\
\end{array}$ \\
\hline 0 & 1.07 & 39 & 3.96 & 66 & 0.14 & & \\
\hline 4 & 0.96 & 41 & 3.62 & 71 & 0.1 & & \\
\hline 8 & 0.87 & 43 & 3.75 & 76 & 0.4 & & \\
\hline 11 & 0.83 & 44 & 3.58 & & & & \\
\hline 16 & 0.96 & 45 & 3.26 & & & & \\
\hline 20 & 1.79 & 46 & 2.57 & & & & \\
\hline 23 & 2.08 & $46.5^{*}$ & $2.13^{*}$ & & & & \\
\hline 26 & 2.02 & 48 & 2.12 & & & & \\
\hline 29 & 2.27 & 49 & 1.91 & & & & \\
\hline 31 & 2.42 & 51 & 1.56 & & & & \\
\hline 32 & 2.64 & 53 & 1.24 & & & & \\
\hline 33 & 3.75 & 55 & 0.92 & & & & \\
\hline 35 & 3.67 & 58 & 0.61 & & & & \\
\hline 37 & 3.91 & 61 & 0 & & & & \\
\hline
\end{tabular}




\section{Laurel Run}

Date of Survey: May 12, 2007

Time of Survey: 11:23 am

Reach \#: $18-B$

Drainage Area: 1.43 sq. miles

UTM Coordinate Location: Zone 18, $4455800 \mathrm{~m} \mathrm{~N}, 0281525 \mathrm{~m} \mathrm{E}$

Location Information: Tuscarora State Forest, parked vehicle along Three Square

Hollow Road at the intersection of Tuscarora Trail. Reach located approximately 50 feet downstream of 18 -A.

Bankfull Indicator(s): A change in slope along the south channel bank.

Bankfull Response Variables: Cross-sectional area (18.0 square feet), width (16.0 feet), mean depth (1.1 feet).

\section{Graph of Channel Cross-Section}

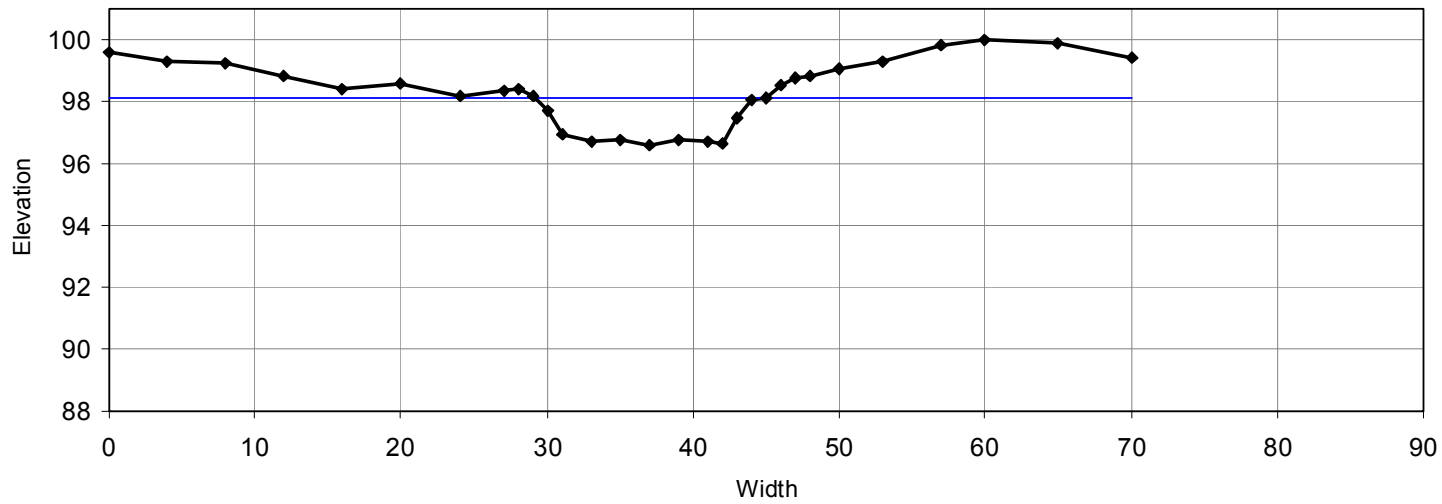

\section{$\underline{\text { Survey Data }}$}

\begin{tabular}{|c|c|c|c|c|c|c|c|}
\hline $\begin{array}{l}\text { Horizontal } \\
\text { (feet) }\end{array}$ & $\begin{array}{l}\text { Vertical } \\
\text { (feet) }\end{array}$ & $\begin{array}{l}\text { Horizontal } \\
\text { (feet) }\end{array}$ & $\begin{array}{c}\text { Vertical } \\
\text { (feet) }\end{array}$ & $\begin{array}{l}\text { Horizontal } \\
\text { (feet) }\end{array}$ & $\begin{array}{c}\text { Vertical } \\
\text { (feet) }\end{array}$ & $\begin{array}{l}\text { Horizontal } \\
\text { (feet) }\end{array}$ & $\begin{array}{c}\text { Vertical } \\
\text { (feet) }\end{array}$ \\
\hline 0 & 0.44 & 37 & 3.41 & 65 & 0.11 & & \\
\hline 4 & 0.7 & 39 & 3.25 & 70 & 0.59 & & \\
\hline 8 & 0.76 & 41 & 3.31 & & & & \\
\hline 12 & 1.17 & 42 & 3.35 & & & & \\
\hline 16 & 1.57 & 43 & 2.52 & & & & \\
\hline 20 & 1.41 & 44 & 1.93 & & & & \\
\hline 24 & 1.8 & $45^{*}$ & $1.86^{*}$ & & & & \\
\hline 27 & 1.66 & 46 & 1.48 & & & & \\
\hline 28 & 1.58 & 47 & 1.21 & & & & \\
\hline 29 & 1.84 & 48 & 1.18 & & & & \\
\hline 30 & 2.28 & 50 & 0.96 & & & & \\
\hline 31 & 3.04 & 53 & 0.68 & & & & \\
\hline 33 & 3.29 & 57 & 0.17 & & & & \\
\hline 35 & 3.22 & 60 & 0 & & & & \\
\hline
\end{tabular}




\section{Laurel Run}

Date of Survey: May 12, 2007

Time of Survey: $12: 37$ am

Reach \#: $19-A$

Drainage Area: 5.1 sq. miles

UTM Coordinate Location: Zone 18, 4458794 m N, 0284863 m E

Location Information: Tuscarora State Forest, parked vehicle at intersection of Laurel Run Road and North Fork Trail.

Bankfull Indicator(s): A change in slope along the east channel bank, extrapolated from 30 feet upstream.

Bankfull Response Variables: Cross-sectional area (58.7 square feet), width (35.1 feet), mean depth (1.7 feet)

\section{Graph of Channel Cross-Section}

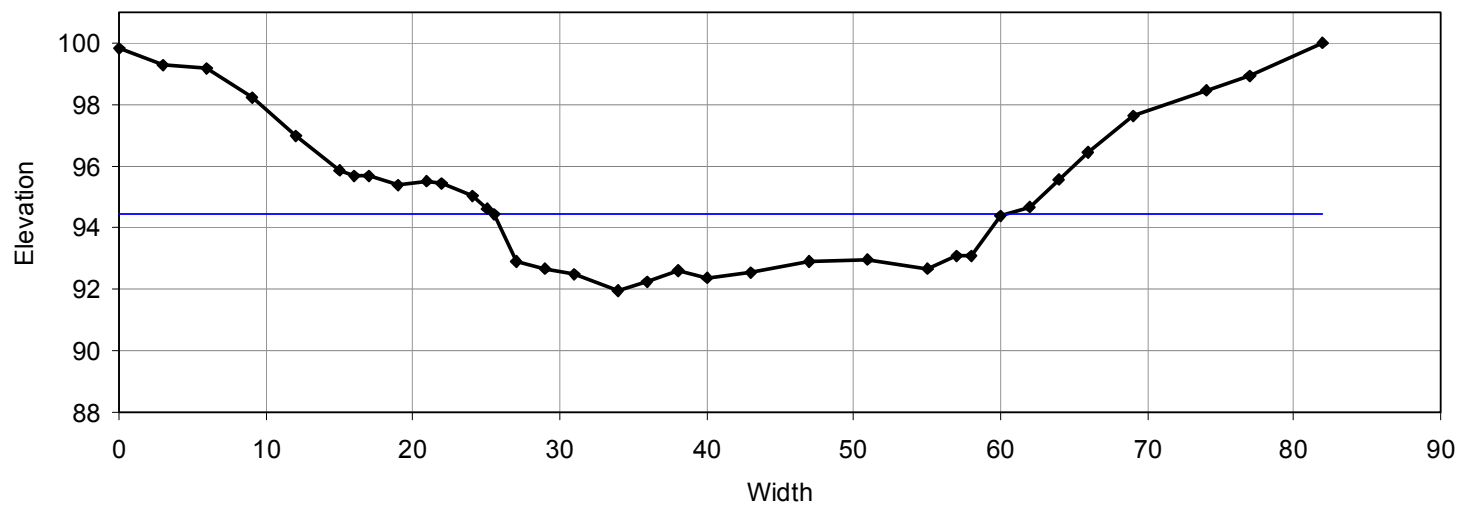

\section{$\underline{\text { Survey Data }}$}

\begin{tabular}{|c|c|c|c|c|c|c|c|}
\hline $\begin{array}{l}\text { Horizontal } \\
\text { (feet) }\end{array}$ & $\begin{array}{c}\begin{array}{l}\text { Vertical } \\
\text { (feet) }\end{array} \\
\end{array}$ & $\begin{array}{c}\text { Horizontal } \\
\text { (feet) }\end{array}$ & $\begin{array}{c}\begin{array}{l}\text { Vertical } \\
\text { (feet) }\end{array} \\
\end{array}$ & $\begin{array}{c}\text { Horizontal } \\
\text { (feet) }\end{array}$ & $\begin{array}{c}\begin{array}{l}\text { Vertical } \\
\text { (feet) }\end{array} \\
\end{array}$ & $\begin{array}{c}\text { Horizontal } \\
\text { (feet) }\end{array}$ & $\begin{array}{c}\text { Vertical } \\
\text { (feet) }\end{array}$ \\
\hline 0 & 0.17 & 27 & 7.09 & 62 & 5.34 & & \\
\hline 3 & 0.71 & 29 & 7.33 & 64 & 4.41 & & \\
\hline 6 & 0.86 & 31 & 7.51 & 66 & 3.53 & & \\
\hline 9 & 1.77 & 34 & 8.04 & 69 & 2.37 & & \\
\hline 12 & 3.02 & 36 & 7.73 & 74 & 1.55 & & \\
\hline 15 & 4.15 & 38 & 7.39 & 77 & 1.08 & & \\
\hline 16 & 4.32 & 40 & 7.63 & 82 & 0 & & \\
\hline 17 & 4.29 & 43 & 7.44 & & & & \\
\hline 19 & 4.61 & 47 & 7.08 & & & & \\
\hline 21 & 4.49 & 51 & 7.01 & & & & \\
\hline 22 & 4.54 & 55 & 7.31 & & & & \\
\hline 24 & 4.99 & 57 & 6.89 & & & & \\
\hline 25 & 5.37 & 58 & 6.93 & & & & \\
\hline $25.5^{*}$ & $5.55^{*}$ & 60 & 5.64 & & & & \\
\hline
\end{tabular}




\section{Laurel Run}

Date of Survey: May 12, 2007

Reach \#: $19-B$
Time of Survey: 1:00 pm

Drainage Area: 5.1 sq. miles

UTM Coordinate Location: Zone 18, $4458793 \mathrm{~m} \mathrm{~N}, 0284851 \mathrm{~m} \mathrm{E}$

Location Information: Tuscarora State Forest, reach located approximately 100 feet downstream of $19-\mathrm{A}$.

Bankfull Indicator(s): A change in slope along the east channel bank.

Bankfull Response Variables: Cross-sectional area (46.6 square feet), width (31.2 feet), mean depth (1.5 feet).

\section{Graph of Channel Cross-Section}

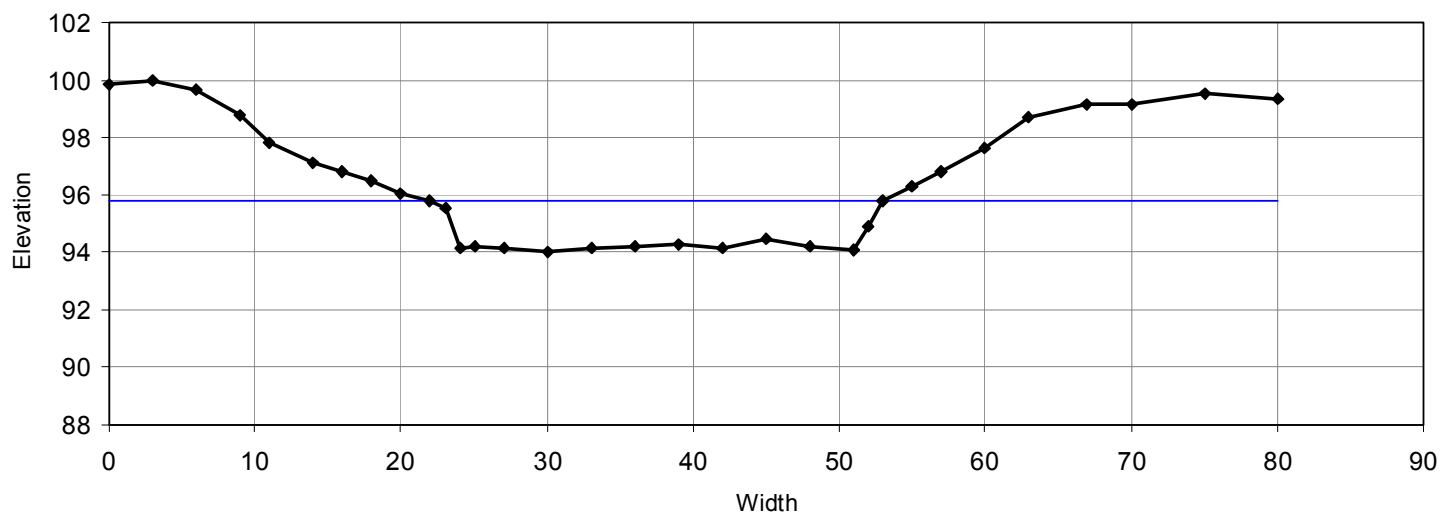

$\underline{\text { Survey Data }}$

\begin{tabular}{|c|c|c|c|c|c|c|c|}
\hline $\begin{array}{c}\text { Horizontal } \\
\text { (feet) }\end{array}$ & $\begin{array}{c}\begin{array}{l}\text { Vertical } \\
\text { (feet) }\end{array} \\
\end{array}$ & $\begin{array}{c}\text { Horizontal } \\
\text { (feet) }\end{array}$ & $\begin{array}{c}\begin{array}{c}\text { Vertical } \\
\text { (feet) }\end{array} \\
\end{array}$ & $\begin{array}{c}\text { Horizontal } \\
\text { (feet) }\end{array}$ & $\begin{array}{c}\text { Vertical } \\
\text { (feet) }\end{array}$ & $\begin{array}{c}\text { Horizontal } \\
\text { (feet) }\end{array}$ & $\begin{array}{c}\begin{array}{c}\text { Vertical } \\
\text { (feet) }\end{array} \\
\end{array}$ \\
\hline 0 & 0.15 & 30 & 5.99 & 67 & 0.84 & & \\
\hline 3 & 0 & 33 & 5.83 & 70 & 0.86 & & \\
\hline 6 & 0.37 & 36 & 5.82 & 75 & 0.46 & & \\
\hline 9 & 1.22 & 39 & 5.72 & 80 & 0.63 & & \\
\hline 11 & 2.16 & 42 & 5.86 & & & & \\
\hline 14 & 2.9 & 45 & 5.57 & & & & \\
\hline 16 & 3.18 & 48 & 5.81 & & & & \\
\hline 18 & 3.48 & 51 & 5.89 & & & & \\
\hline 20 & 3.93 & 52 & 5.1 & & & & \\
\hline $22^{*}$ & $4.22^{*}$ & 53 & 4.19 & & & & \\
\hline 23 & 4.47 & 55 & 3.69 & & & & \\
\hline 24 & 5.84 & 57 & 3.22 & & & & \\
\hline 25 & 5.8 & 60 & 2.37 & & & & \\
\hline 27 & 5.84 & 63 & 1.27 & & & & \\
\hline
\end{tabular}




\section{Laurel Run}

Date of Survey: May 14, 2007

Reach \#: 20-A
Time of Survey: 9:26 am

Drainage Area: 0.76 sq. miles

UTM Coordinate Location: Zone 18, 4455295 m N, 0281016 m E

Location Information: Tuscarora State Forest, parked vehicle at intersection of Laurel Run Road and College Trail.

Bankfull Indicator(s): A change in slope along the northwest channel bank.

Bankfull Response Variables: Cross-sectional area (16.7 square feet), width (13.1 feet), mean depth (1.3 feet).

\section{Graph of Channel Cross-Section}

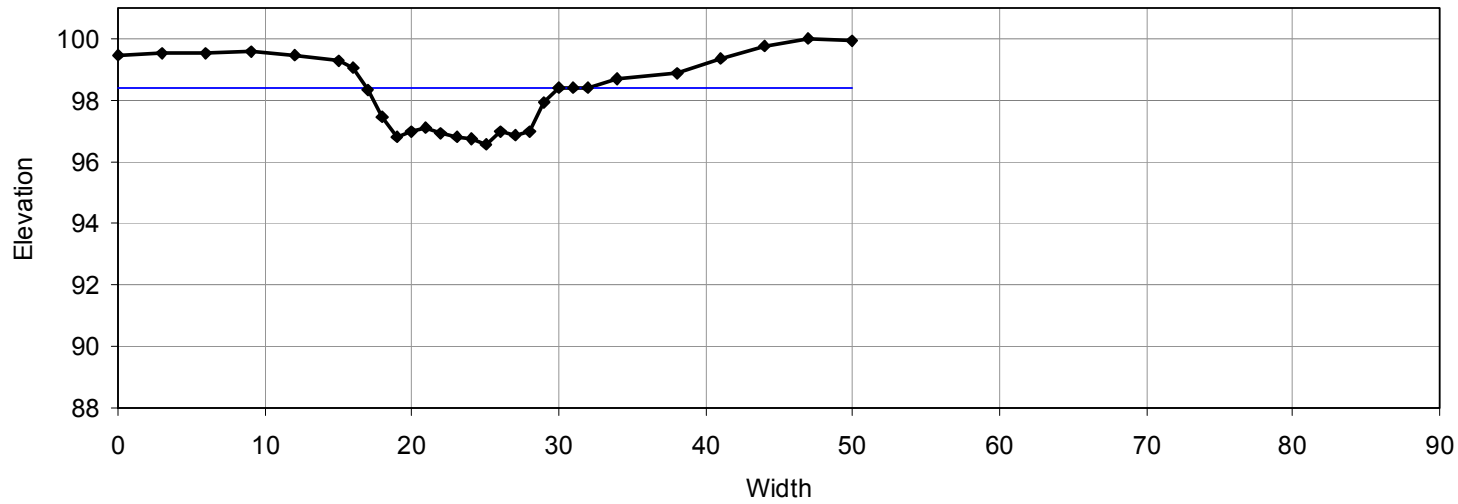

\section{Survey Data}

\begin{tabular}{|c|c|c|c|c|c|c|c|}
\hline $\begin{array}{c}\begin{array}{c}\text { Horizontal } \\
\text { (feet) }\end{array} \\
\end{array}$ & $\begin{array}{c}\begin{array}{c}\text { Vertical } \\
\text { (feet) }\end{array} \\
\end{array}$ & $\begin{array}{c}\begin{array}{c}\text { Horizontal } \\
\text { (feet) }\end{array} \\
\end{array}$ & $\begin{array}{l}\text { Vertical } \\
\text { (feet) }\end{array}$ & $\begin{array}{c}\begin{array}{c}\text { Horizontal } \\
\text { (feet) }\end{array} \\
\end{array}$ & $\begin{array}{c}\begin{array}{l}\text { Vertical } \\
\text { (feet) }\end{array} \\
\end{array}$ & $\begin{array}{c}\text { Horizontal } \\
\text { (feet) }\end{array}$ & $\begin{array}{c}\begin{array}{c}\text { Vertical } \\
\text { (feet) }\end{array} \\
\end{array}$ \\
\hline 0 & 0.53 & 24 & 3.23 & 50 & 0.08 & & \\
\hline 3 & 0.49 & 25 & 3.45 & & & & \\
\hline 6 & 0.48 & 26 & 3.04 & & & & \\
\hline 9 & 0.43 & 27 & 3.11 & & & & \\
\hline 12 & 0.51 & 28 & 2.99 & & & & \\
\hline 15 & 0.71 & 29 & 2.07 & & & & \\
\hline 16 & 0.97 & $30^{*}$ & $1.6^{*}$ & & & & \\
\hline 17 & 1.66 & 31 & 1.66 & & & & \\
\hline 18 & 2.55 & 32 & 1.59 & & & & \\
\hline 19 & 3.21 & 34 & 1.31 & & & & \\
\hline 20 & 3.04 & 38 & 1.12 & & & & \\
\hline 21 & 2.91 & 41 & 0.64 & & & & \\
\hline 22 & 3.1 & 44 & 0.23 & & & & \\
\hline 23 & 3.18 & 47 & 0 & & & & \\
\hline
\end{tabular}




\section{Laurel Run}

Date of Survey: May 14, 2007

Reach \#: $20-B$
Time of Survey: 9:41 am

Drainage Area: 0.76 sq. miles

UTM Coordinate Location: Zone 18, 4455305 m N, 0281027 m E

Location Information: Tuscarora State Forest, reach located approximately 100 feet downstream of $20-\mathrm{A}$.

Bankfull Indicator(s): A change in slope along the northwest channel bank, extrapolated 10 feet upstream.

Bankfull Response Variables: Cross-sectional area (16.7 square feet), width (13.1 feet), mean depth (1.3 feet).

\section{Graph of Channel Cross-Section}

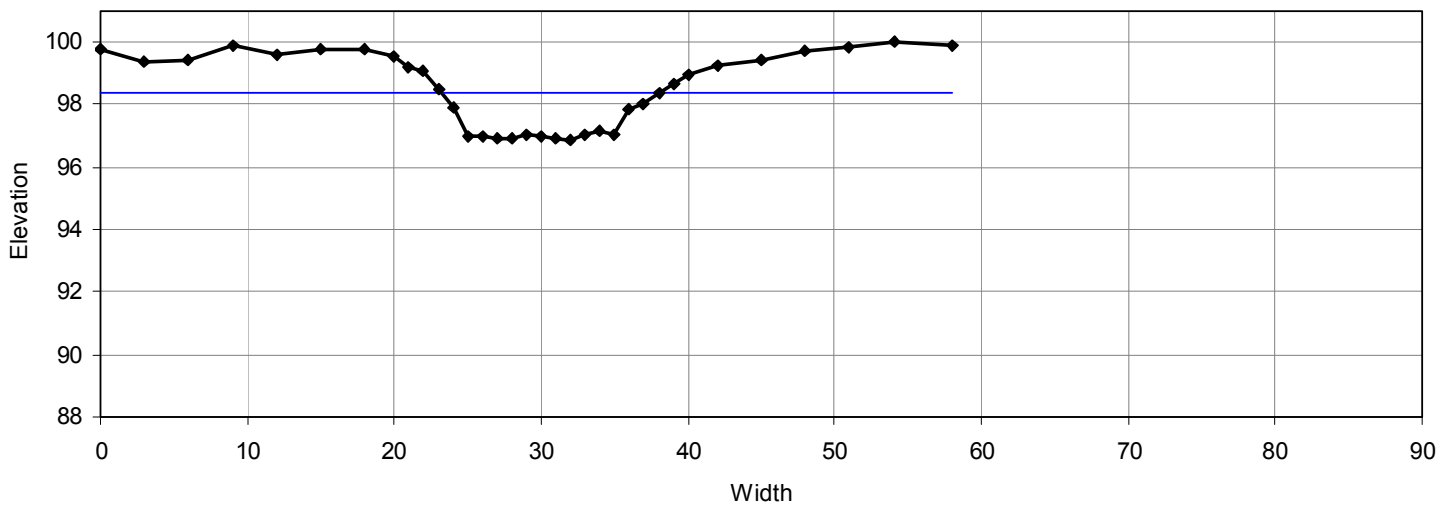

\section{$\underline{\text { Survey Data }}$}

\begin{tabular}{|c|c|c|c|c|c|c|c|}
\hline $\begin{array}{l}\text { Horizontal } \\
\text { (feet) }\end{array}$ & $\begin{array}{c}\begin{array}{c}\text { Vertical } \\
\text { (feet) }\end{array} \\
\end{array}$ & $\begin{array}{c}\text { Horizontal } \\
\text { (feet) }\end{array}$ & $\begin{array}{c}\begin{array}{l}\text { Vertical } \\
\text { (feet) }\end{array} \\
\end{array}$ & $\begin{array}{c}\text { Horizontal } \\
\text { (feet) }\end{array}$ & $\begin{array}{c}\begin{array}{l}\text { Vertical } \\
\text { (feet) }\end{array} \\
\end{array}$ & $\begin{array}{c}\text { Horizontal } \\
\text { (feet) }\end{array}$ & $\begin{array}{c}\text { Vertical } \\
\text { (feet) }\end{array}$ \\
\hline 0 & 0.24 & 27 & 3.07 & 42 & 0.74 & & \\
\hline 3 & 0.66 & 28 & 3.09 & 45 & 0.55 & & \\
\hline 6 & 0.55 & 29 & 2.98 & 48 & 0.31 & & \\
\hline 9 & 0.11 & 30 & 3.01 & 51 & 0.14 & & \\
\hline 12 & 0.38 & 31 & 3.06 & 54 & 0 & & \\
\hline 15 & 0.25 & 32 & 3.12 & 58 & 0.11 & & \\
\hline 18 & 0.2 & 33 & 2.94 & & & & \\
\hline 20 & 0.43 & 34 & 2.82 & & & & \\
\hline 21 & 0.79 & 35 & 2.96 & & & & \\
\hline 22 & 0.93 & 36 & 2.15 & & & & \\
\hline 23 & 1.53 & 37 & 1.98 & & & & \\
\hline 24 & 2.1 & $38^{*}$ & $1.63^{*}$ & & & & \\
\hline 25 & 3.05 & 39 & 1.36 & & & & \\
\hline 26 & 3.04 & 40 & 1.05 & & & & \\
\hline
\end{tabular}




\section{Laurel Run}

Date of Survey: May 14, 2007

Reach \#: 21-A
Time of Survey: 10:42 am

Drainage Area: 2.12 sq. miles

UTM Coordinate Location: Zone 18, $4456154 \mathrm{~m} \mathrm{~N}, 0282025 \mathrm{~m} \mathrm{E}$

Location Information: Tuscarora State Forest, parked vehicle on Ant Hill Trail.

Bankfull Indicator(s): A change in slope along the south channel bank.

Bankfull Response Variables: Cross-sectional area (37.8 square feet), width (20.6 feet), mean depth (1.8 feet).

\section{Graph of Channel Cross-Section}

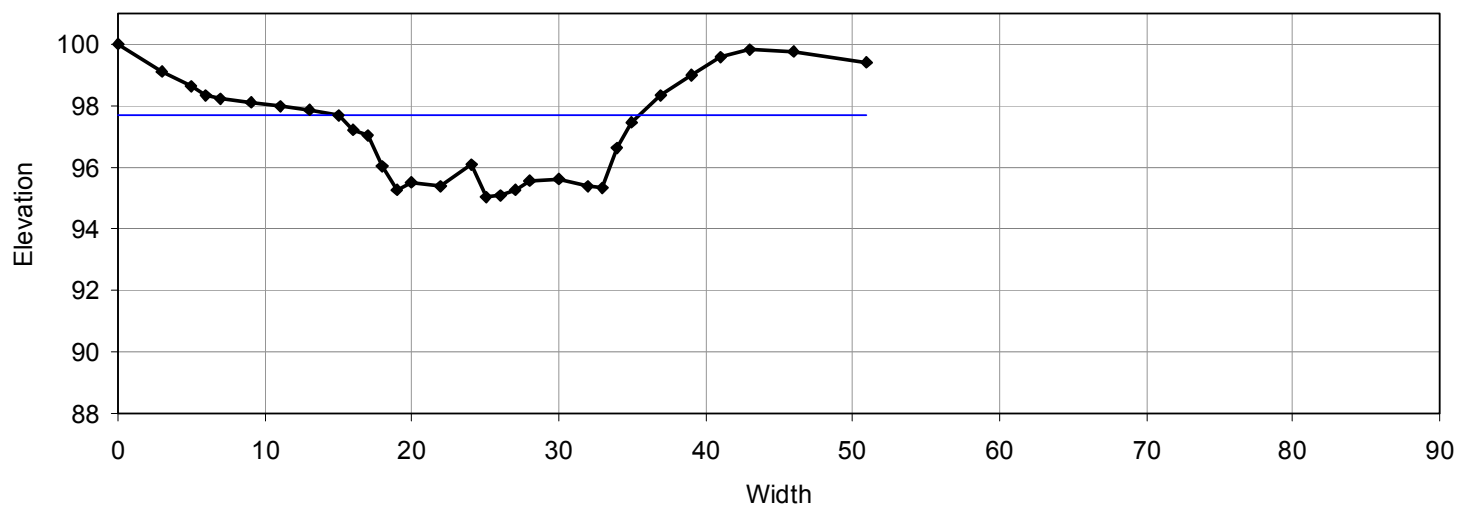

Survey Data

\begin{tabular}{|c|c|c|c|c|c|c|c|}
\hline $\begin{array}{c}\text { Horizontal } \\
\text { (feet) }\end{array}$ & $\begin{array}{c}\text { Vertical } \\
\text { (feet) }\end{array}$ & $\begin{array}{c}\text { Horizontal } \\
\text { (feet) }\end{array}$ & $\begin{array}{l}\text { Vertical } \\
\text { (feet) }\end{array}$ & $\begin{array}{c}\text { Horizontal } \\
\text { (feet) }\end{array}$ & $\begin{array}{c}\text { Vertical } \\
\text { (feet) }\end{array}$ & $\begin{array}{c}\text { Horizontal } \\
\text { (feet) }\end{array}$ & $\begin{array}{c}\begin{array}{c}\text { Vertical } \\
\text { (feet) }\end{array} \\
\end{array}$ \\
\hline 0 & 0 & 22 & 4.6 & 43 & 0.17 & & \\
\hline 3 & 0.92 & 24 & 3.89 & 46 & 0.24 & & \\
\hline 5 & 1.37 & 25 & 4.96 & 51 & 0.57 & & \\
\hline 6 & 1.64 & 26 & 4.92 & & & & \\
\hline 7 & 1.75 & 27 & 4.74 & & & & \\
\hline 9 & 1.92 & 28 & 4.43 & & & & \\
\hline 11 & 2 & 30 & 4.35 & & & & \\
\hline 13 & 2.14 & 32 & 4.63 & & & & \\
\hline $15^{*}$ & $2.29^{\star}$ & 33 & 4.68 & & & & \\
\hline 16 & 2.78 & 34 & 3.36 & & & & \\
\hline 17 & 2.94 & 35 & 2.55 & & & & \\
\hline 18 & 3.97 & 37 & 1.63 & & & & \\
\hline 19 & 4.71 & 39 & 0.99 & & & & \\
\hline 20 & 4.49 & 41 & 0.43 & & & & \\
\hline
\end{tabular}




\section{Laurel Run}

Date of Survey: May 14, 2007

Time of Survey: 10:59 am

Reach \#: $21-B$

Drainage Area: 2.12 sq. miles

UTM Coordinate Location: Zone 18, 4456176 m N, 0281989 m E

Location Information: Tuscarora State Forest, parked vehicle on Ant Hill Trail. Reach located approximately 100 feet upstream of 21-A.

Bankfull Indicator(s): A change in slope along the south channel bank.

Bankfull Response Variables: Cross-sectional area (29.6 square feet), width (17.6 feet), mean depth (1.7 feet).

\section{Graph of Channel Cross-Section}

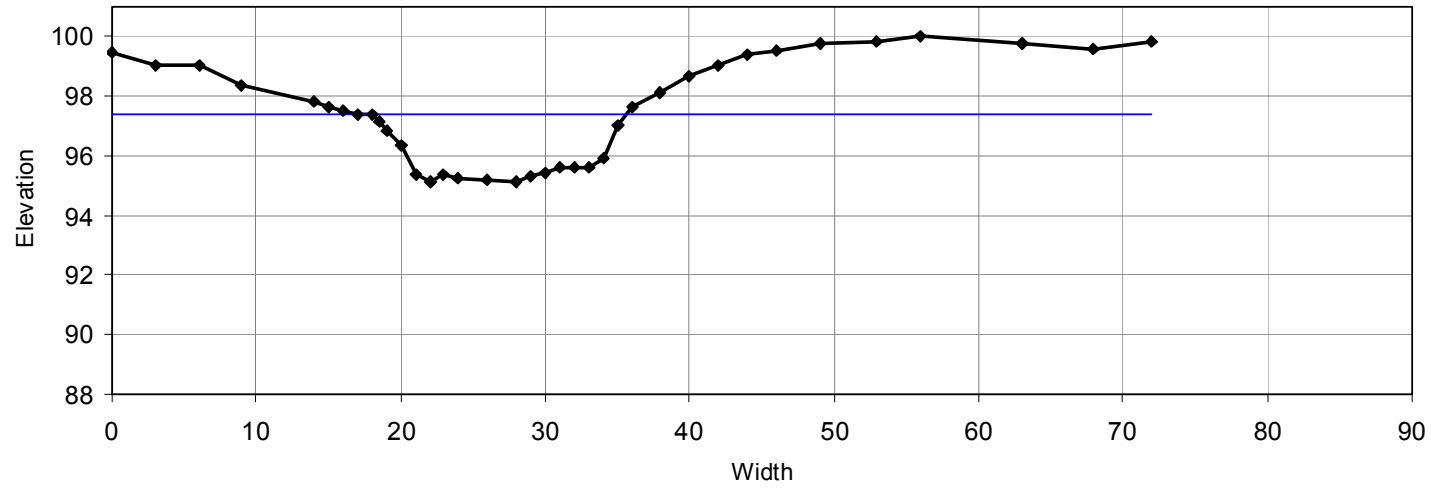

$\underline{\text { Survey Data }}$

\begin{tabular}{|c|c|c|c|c|c|c|c|}
\hline $\begin{array}{c}\text { Horizontal } \\
\text { (feet) }\end{array}$ & $\begin{array}{c}\text { Vertical } \\
\text { (feet) }\end{array}$ & $\begin{array}{c}\text { Horizontal } \\
\text { (feet) }\end{array}$ & $\begin{array}{l}\text { Vertical } \\
\text { (feet) }\end{array}$ & $\begin{array}{c}\text { Horizontal } \\
\text { (feet) }\end{array}$ & $\begin{array}{c}\text { Vertical } \\
\text { (feet) }\end{array}$ & $\begin{array}{c}\text { Horizontal } \\
\text { (feet) }\end{array}$ & $\begin{array}{c}\text { Vertical } \\
\text { (feet) }\end{array}$ \\
\hline 0 & 0.55 & 23 & 4.62 & 42 & 0.93 & & \\
\hline 3 & 0.97 & 24 & 4.73 & 44 & 0.61 & & \\
\hline 6 & 0.95 & 26 & 4.82 & 46 & 0.47 & & \\
\hline 9 & 1.61 & 28 & 4.87 & 49 & 0.21 & & \\
\hline 14 & 2.2 & 29 & 4.67 & 53 & 0.18 & & \\
\hline 15 & 2.35 & 30 & 4.55 & 56 & 0 & & \\
\hline 16 & 2.47 & 31 & 4.39 & 63 & 0.22 & & \\
\hline 17 & 2.61 & 32 & 4.35 & 68 & 0.42 & & \\
\hline 18 & 2.62 & 33 & 4.37 & 72 & 0.15 & & \\
\hline $18.5^{*}$ & $2.84^{*}$ & 34 & 4.06 & & & & \\
\hline 19 & 3.16 & 35 & 2.94 & & & & \\
\hline 20 & 3.64 & 36 & 2.38 & & & & \\
\hline 21 & 4.63 & 38 & 1.84 & & & & \\
\hline 22 & 4.84 & 40 & 1.32 & & & & \\
\hline
\end{tabular}




\section{Laurel Run}

Date of Survey: May 14, 2007

Reach \#: 22-A
Time of Survey: $12: 37$ am

Drainage Area: 7.47 sq. miles

UTM Coordinate Location: Zone 18, 4459957 m N, 0288247 m E

Location Information: Tuscarora State Forest, parked vehicle at the intersection of Laurel Run Road and Meadow Road. Reach located upstream of confluence.

Bankfull Indicator(s): A change in slope along the south to southeast channel bank and change in vegetation from moss (inside channel) to fern (outside channel).

Bankfull Response Variables: Cross-sectional area (52.4 square feet), width (24.7 feet), mean depth $(2.1$ feet $)$.

\section{Graph of Channel Cross-Section}

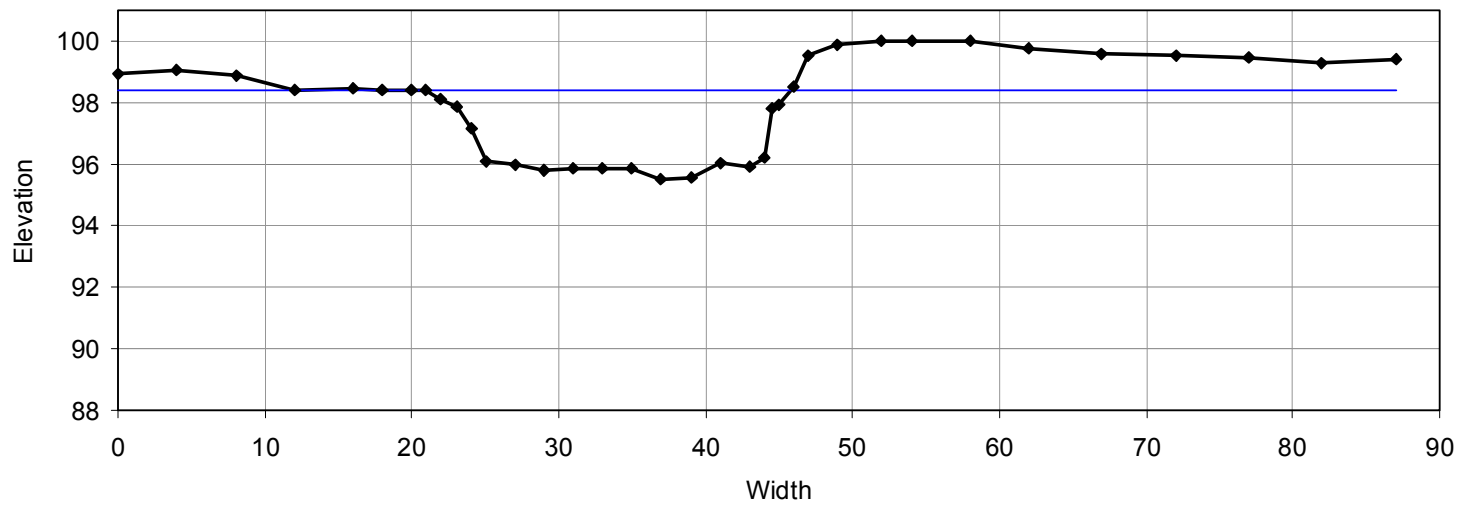

\section{$\underline{\text { Survey Data }}$}

\begin{tabular}{|c|c|c|c|c|c|c|c|}
\hline $\begin{array}{l}\text { Horizontal } \\
\text { (feet) }\end{array}$ & $\begin{array}{c}\begin{array}{l}\text { Vertical } \\
\text { (feet) }\end{array} \\
\end{array}$ & $\begin{array}{c}\text { Horizontal } \\
\text { (feet) }\end{array}$ & $\begin{array}{c}\begin{array}{l}\text { Vertical } \\
\text { (feet) }\end{array} \\
\end{array}$ & $\begin{array}{c}\text { Horizontal } \\
\text { (feet) }\end{array}$ & $\begin{array}{c}\begin{array}{l}\text { Vertical } \\
\text { (feet) }\end{array} \\
\end{array}$ & $\begin{array}{c}\text { Horizontal } \\
\text { (feet) }\end{array}$ & $\begin{array}{c}\text { Vertical } \\
\text { (feet) }\end{array}$ \\
\hline 0 & 1.06 & 31 & 4.13 & 54 & 0 & & \\
\hline 4 & 0.94 & 33 & 4.17 & 58 & 0.02 & & \\
\hline 8 & 1.15 & 35 & 4.13 & 62 & 0.24 & & \\
\hline 12 & 1.6 & 37 & 4.47 & 67 & 0.42 & & \\
\hline 16 & 1.54 & 39 & 4.46 & 72 & 0.47 & & \\
\hline 18 & 1.58 & 41 & 3.97 & 77 & 0.53 & & \\
\hline 20 & 1.59 & 43 & 4.06 & 82 & 0.74 & & \\
\hline $21^{*}$ & $1.62^{*}$ & 44 & 3.81 & 87 & 0.6 & & \\
\hline 22 & 1.92 & 44.5 & 2.18 & & & & \\
\hline 23 & 2.14 & 45 & 2.05 & & & & \\
\hline 24 & 2.86 & 46 & 1.46 & & & & \\
\hline 25 & 3.88 & 47 & 0.49 & & & & \\
\hline 27 & 4 & 49 & 0.1 & & & & \\
\hline 29 & 4.18 & 52 & 0.01 & & & & \\
\hline
\end{tabular}




\section{Laurel Run}

Date of Survey: May 14, 2007

Reach \#: 22-B
Time of Survey: 1:18 pm

Drainage Area: 7.47 sq. miles

UTM Coordinate Location: Zone 18, 4459949 m N, 0288256 m E

Location Information: Tuscarora State Forest, parked vehicle at the intersection of Laurel Run Road and Meadow Road. Reach located 50 feet downstream of 22-A.

Bankfull Indicator(s): A change in slope along the south to southeast channel bank and change in vegetation from moss (inside channel) to fern (outside channel).

Bankfull Response Variables: Cross-sectional area (45.2 square feet), width (22.4 feet), mean depth (2.0 feet).

\section{Graph of Channel Cross-Section}

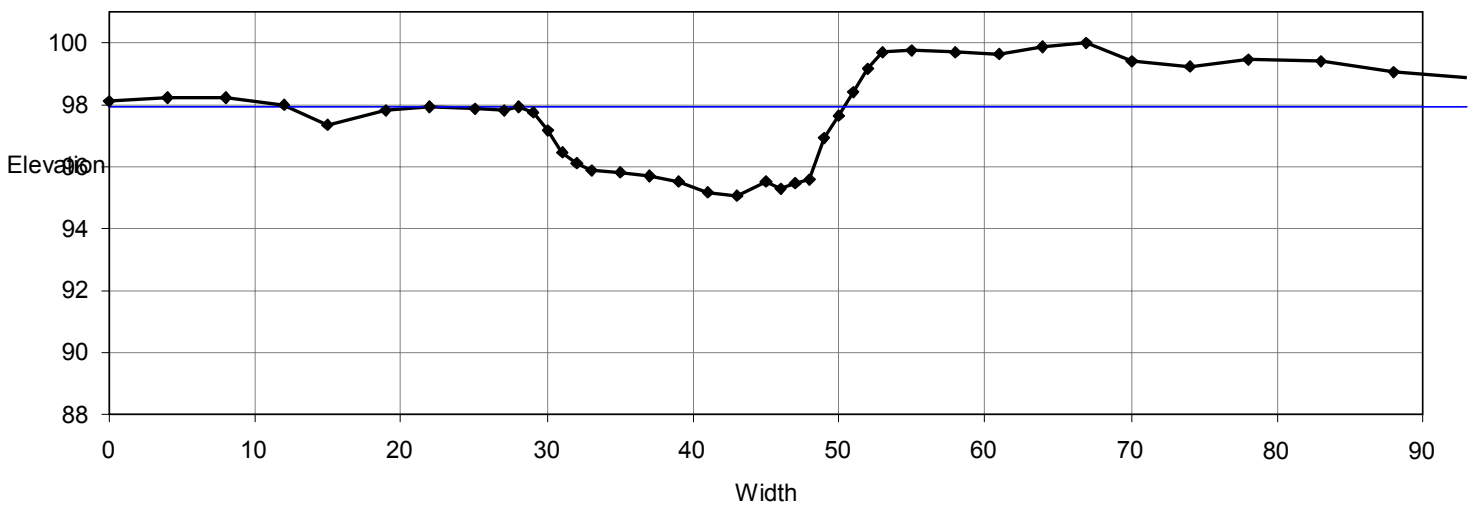

Survey Data

\begin{tabular}{|c|c|c|c|c|c|c|c|}
\hline $\begin{array}{c}\begin{array}{c}\text { Horizontal } \\
\text { (feet) }\end{array} \\
\end{array}$ & $\begin{array}{c}\begin{array}{c}\text { Vertical } \\
\text { (feet) }\end{array} \\
\end{array}$ & $\begin{array}{c}\begin{array}{c}\text { Horizontal } \\
\text { (feet) }\end{array} \\
\end{array}$ & $\begin{array}{c}\begin{array}{c}\text { Vertical } \\
\text { (feet) }\end{array} \\
\end{array}$ & $\begin{array}{c}\begin{array}{c}\text { Horizontal } \\
\text { (feet) }\end{array} \\
\end{array}$ & $\begin{array}{c}\begin{array}{c}\text { Vertical } \\
\text { (feet) }\end{array} \\
\end{array}$ & $\begin{array}{c}\begin{array}{c}\text { Horizontal } \\
\text { (feet) }\end{array} \\
\end{array}$ & $\begin{array}{c}\begin{array}{c}\text { Vertical } \\
\text { (feet) }\end{array} \\
\end{array}$ \\
\hline 0 & 1.87 & 33 & 4.14 & 53 & 0.32 & & \\
\hline 4 & 1.75 & 35 & 4.18 & 55 & 0.22 & & \\
\hline 8 & 1.79 & 37 & 4.31 & 58 & 0.3 & & \\
\hline 12 & 2.02 & 39 & 4.45 & 61 & 0.33 & & \\
\hline 15 & 2.62 & 41 & 4.84 & 64 & 0.1 & & \\
\hline 19 & 2.2 & 43 & 4.94 & 67 & 0 & & \\
\hline 22 & 2.07 & 45 & 4.45 & 70 & 0.56 & & \\
\hline 25 & 2.11 & 46 & 4.7 & 74 & 0.78 & & \\
\hline 27 & 2.17 & 47 & 4.52 & 78 & 0.53 & & \\
\hline $28^{*}$ & $2.03^{*}$ & 48 & 4.42 & 83 & 0.57 & & \\
\hline 29 & 2.25 & 49 & 3.07 & 88 & 0.92 & & \\
\hline 30 & 2.82 & 50 & 2.36 & 93 & 1.13 & & \\
\hline 31 & 3.54 & 51 & 1.6 & & & & \\
\hline 32 & 3.91 & 52 & 0.82 & & & & \\
\hline
\end{tabular}




\section{Laurel Run}

Date of Survey: May 14, 2007

Reach \#: 23-A
Time of Survey: 2:03 pm

Drainage Area: 10.8 sq. miles

UTM Coordinate Location: Zone 18, 4460026 m N, 0288292 m E

Location Information: Tuscarora State Forest, parked vehicle at the intersection of Laurel Run Road and Meadow Road. Reach located downstream of confluence.

Bankfull Indicator(s): A change in slope along the east channel bank.

Bankfull Response Variables: Cross-sectional area (53.0 square feet), width (25.4 feet), mean depth (2.1 feet).

\section{Graph of Channel Cross-Section}

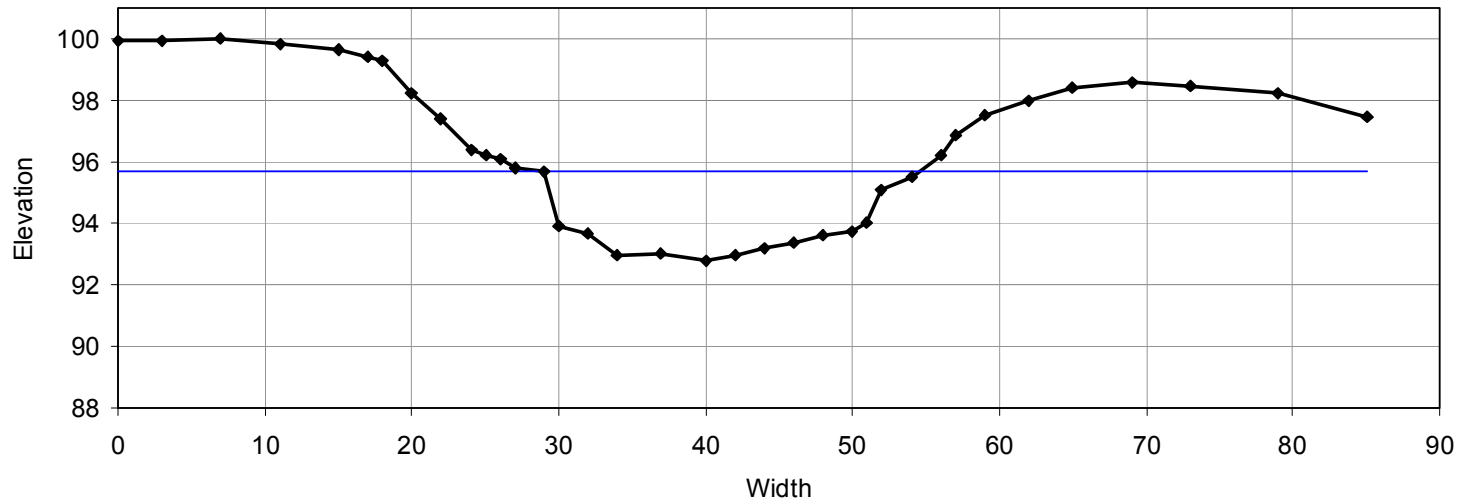

\section{Survey Data}

\begin{tabular}{|c|c|c|c|c|c|c|c|}
\hline $\begin{array}{c}\text { Horizontal } \\
\text { (feet) }\end{array}$ & $\begin{array}{c}\begin{array}{c}\text { Vertical } \\
\text { (feet) }\end{array} \\
\end{array}$ & $\begin{array}{c}\text { Horizontal } \\
\text { (feet) }\end{array}$ & $\begin{array}{c}\begin{array}{c}\text { Vertical } \\
\text { (feet) }\end{array} \\
\end{array}$ & $\begin{array}{c}\text { Horizontal } \\
\text { (feet) }\end{array}$ & $\begin{array}{c}\begin{array}{c}\text { Vertical } \\
\text { (feet) }\end{array} \\
\end{array}$ & $\begin{array}{c}\text { Horizontal } \\
\text { (feet) }\end{array}$ & $\begin{array}{c}\text { Vertical } \\
\text { (feet) }\end{array}$ \\
\hline 0 & 0.06 & 30 & 6.08 & 57 & 3.12 & & \\
\hline 3 & 0.05 & 32 & 6.3 & 59 & 2.48 & & \\
\hline 7 & 0 & 34 & 7.03 & 62 & 2 & & \\
\hline 11 & 0.16 & 37 & 6.99 & 65 & 1.6 & & \\
\hline 15 & 0.38 & 40 & 7.24 & 69 & 1.44 & & \\
\hline 17 & 0.6 & 42 & 7.06 & 73 & 1.57 & & \\
\hline 18 & 0.73 & 44 & 6.82 & 79 & 1.8 & & \\
\hline 20 & 1.76 & 46 & 6.63 & 85 & 2.56 & & \\
\hline 22 & 2.63 & 48 & 6.36 & & & & \\
\hline 24 & 3.59 & 50 & 6.26 & & & & \\
\hline 25 & 3.8 & 51 & 5.95 & & & & \\
\hline 26 & 3.93 & 52 & 4.88 & & & & \\
\hline 27 & 4.18 & 54 & 4.5 & & & & \\
\hline $29^{*}$ & $4.34^{*}$ & 56 & 3.77 & & & & \\
\hline
\end{tabular}




\section{Laurel Run}

Date of Survey: May 14, 2007

Reach \#: 23-B
Time of Survey: 2:25 pm

Drainage Area: 10.8 sq. miles

UTM Coordinate Location: Zone 18, $4460052 \mathrm{~m} \mathrm{~N}, 0288305 \mathrm{~m} \mathrm{E}$

Location Information: Tuscarora State Forest, parked vehicle at the intersection of Laurel Run Road and Meadow Road. Reach located 50 feet downstream of 23-A.

Bankfull Indicator(s): A change in slope along the west to northwest channel bank, consistent with the highest elevation of a point bar in the adjacent upstream riffle.

Bankfull Response Variables: Cross-sectional area (53.2 square feet), width (22.6 feet), mean depth (2.4 feet).

\section{Graph of Channel Cross-Section}

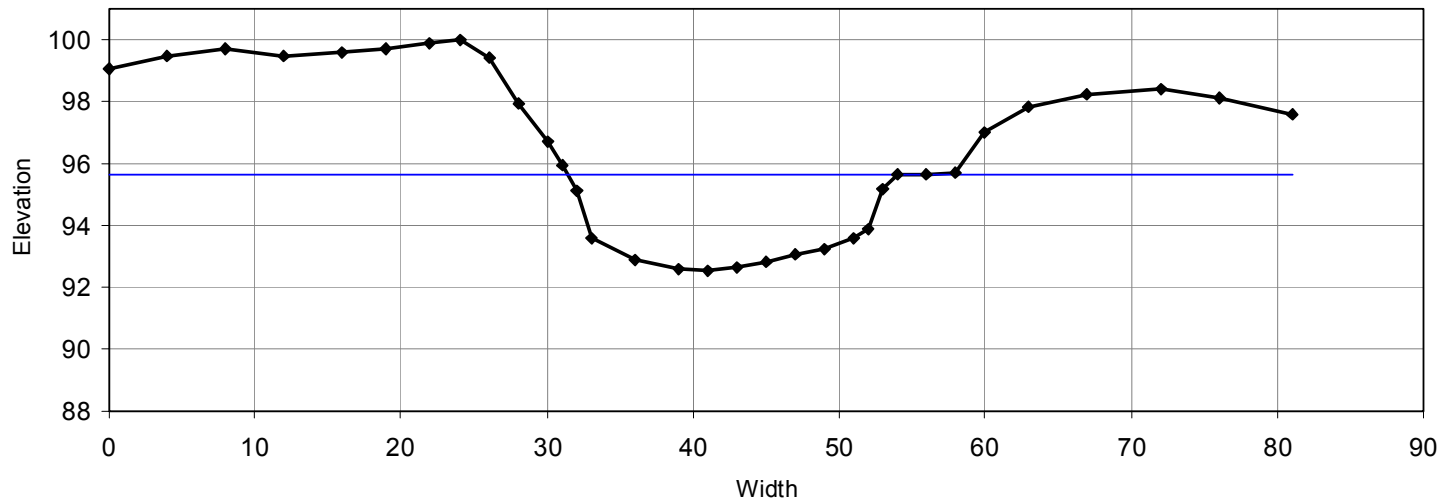

\section{$\underline{\text { Survey Data }}$}

\begin{tabular}{|c|c|c|c|c|c|c|c|}
\hline $\begin{array}{l}\text { Horizontal } \\
\text { (feet) }\end{array}$ & $\begin{array}{l}\text { Vertical } \\
\text { (feet) }\end{array}$ & $\begin{array}{c}\text { Horizontal } \\
\text { (feet) }\end{array}$ & $\begin{array}{c}\text { Vertical } \\
\text { (feet) }\end{array}$ & $\begin{array}{l}\text { Horizontal } \\
\text { (feet) }\end{array}$ & $\begin{array}{l}\text { Vertical } \\
\text { (feet) }\end{array}$ & $\begin{array}{l}\text { Horizontal } \\
\text { (feet) }\end{array}$ & $\begin{array}{c}\text { Vertical } \\
\text { (feet) }\end{array}$ \\
\hline 0 & 0.96 & 36 & 7.14 & 63 & 2.18 & & \\
\hline 4 & 0.53 & 39 & 7.4 & 67 & 1.76 & & \\
\hline 8 & 0.3 & 41 & 7.45 & 72 & 1.6 & & \\
\hline 12 & 0.54 & 43 & 7.38 & 76 & 1.87 & & \\
\hline 16 & 0.43 & 45 & 7.16 & 81 & 2.39 & & \\
\hline 19 & 0.27 & 47 & 6.93 & & & & \\
\hline 22 & 0.1 & 49 & 6.74 & & & & \\
\hline 24 & 0 & 51 & 6.41 & & & & \\
\hline 26 & 0.58 & 52 & 6.13 & & & & \\
\hline 28 & 2.07 & 53 & 4.82 & & & & \\
\hline 30 & 3.32 & $54^{*}$ & $4.37^{*}$ & & & & \\
\hline 31 & 4.07 & 56 & 4.46 & & & & \\
\hline 32 & 4.86 & 58 & 4.28 & & & & \\
\hline 33 & 6.39 & 60 & 2.99 & & & & \\
\hline
\end{tabular}




\section{Laurel Run}

Date of Survey: May 15, 2007

Reach \#: $24-\mathrm{A}$
Time of Survey: 9:26 am

Drainage Area: 13.9 sq. miles

UTM Coordinate Location: Zone 18, 4461110 m N, $0290814 \mathrm{~m} \mathrm{E}$

Location Information: Tuscarora State Forest, parked vehicle on Meadow Road at bridge over Laurel Run.

Bankfull Indicator(s): A change in slope along the northwest channel bank.

Bankfull Response Variables: Cross-sectional area (52.0 square feet), width (38.6 feet), mean depth (1.3 feet).

\section{Graph of Channel Cross-Section}

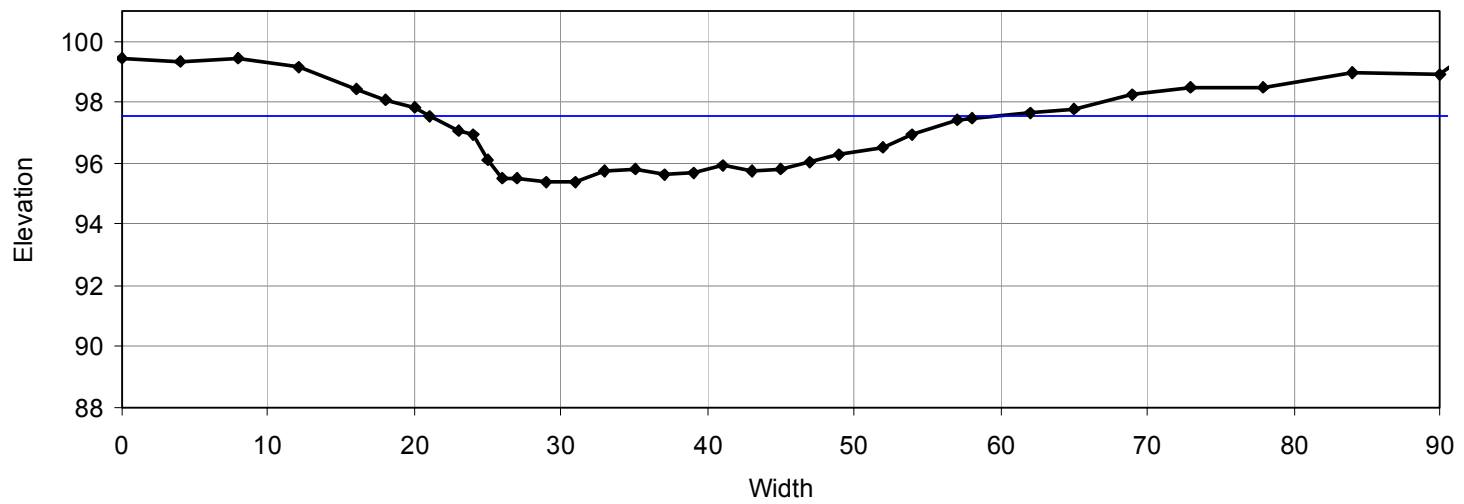

$\underline{\text { Survey Data }}$

\begin{tabular}{|c|c|c|c|c|c|c|c|}
\hline $\begin{array}{c}\text { Horizontal } \\
\text { (feet) }\end{array}$ & $\begin{array}{c}\text { Vertical } \\
\text { (feet) }\end{array}$ & $\begin{array}{c}\text { Horizontal } \\
\text { (feet) }\end{array}$ & $\begin{array}{l}\text { Vertical } \\
\text { (feet) }\end{array}$ & $\begin{array}{c}\text { Horizontal } \\
\text { (feet) }\end{array}$ & $\begin{array}{l}\text { Vertical } \\
\text { (feet) }\end{array}$ & $\begin{array}{c}\text { Horizontal } \\
\text { (feet) }\end{array}$ & $\begin{array}{c}\text { Vertical } \\
\text { (feet) }\end{array}$ \\
\hline 0 & 0.54 & 31 & 4.61 & 62 & 2.31 & & \\
\hline 8 & 0.53 & 35 & 4.2 & 69 & 1.77 & & \\
\hline 12 & 0.83 & 37 & 4.35 & 73 & 1.48 & & \\
\hline 18 & 1.95 & 41 & 4.08 & 84 & 1 & & \\
\hline 20 & 2.14 & 43 & 4.25 & 90 & 1.09 & & \\
\hline $21^{*}$ & $2.45^{\star}$ & 45 & 4.19 & 93 & 0 & & \\
\hline 23 & 2.91 & 47 & 3.94 & & & & \\
\hline 24 & 3.06 & 49 & 3.7 & & & & \\
\hline 27 & 4.48 & 57 & 2.58 & & & & \\
\hline 29 & 4.61 & 58 & 2.54 & & & & \\
\hline
\end{tabular}




\section{Laurel Run}

Date of Survey: May 15, 2007

Reach \#: $24-B$
Time of Survey: 9:50 am

Drainage Area: 13.9 sq. miles

UTM Coordinate Location: Zone 18, 4461174 m N, 0290828 m E

Location Information: Tuscarora State Forest, parked vehicle on Meadow Road at bridge over Laurel Run. Reach located upstream of 24-A approximately 100 feet.

Bankfull Indicator(s): A change in slope along the southeast channel bank.

Bankfull Response Variables: Cross-sectional area (72.1 square feet), width (40.3 feet), mean depth (1.8 feet).

\section{Graph of Channel Cross-Section}

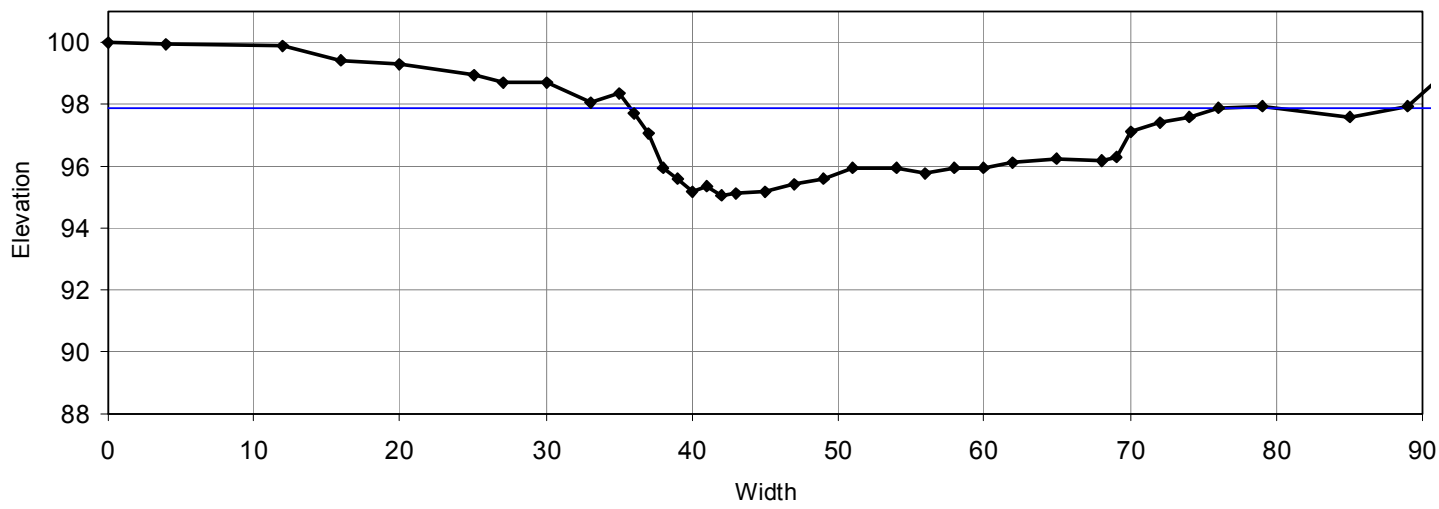

$\underline{\text { Survey Data }}$

\begin{tabular}{|c|c|c|c|c|c|c|c|}
\hline $\begin{array}{c}\text { Horizontal } \\
\text { (feet) }\end{array}$ & $\begin{array}{c}\text { Vertical } \\
\text { (feet) }\end{array}$ & $\begin{array}{c}\text { Horizontal } \\
\text { (feet) }\end{array}$ & $\begin{array}{c}\begin{array}{c}\text { Vertical } \\
\text { (feet) }\end{array} \\
\end{array}$ & $\begin{array}{c}\text { Horizontal } \\
\text { (feet) }\end{array}$ & $\begin{array}{c}\text { Vertical } \\
\text { (feet) }\end{array}$ & $\begin{array}{c}\text { Horizontal } \\
\text { (feet) }\end{array}$ & $\begin{array}{c}\begin{array}{c}\text { Vertical } \\
\text { (feet) }\end{array} \\
\end{array}$ \\
\hline 0 & 0 & 40 & 4.81 & 68 & 3.84 & & \\
\hline 4 & 0.04 & 41 & 4.65 & 69 & 3.69 & & \\
\hline 12 & 0.09 & 42 & 4.94 & 70 & 2.87 & & \\
\hline 16 & 0.58 & 43 & 4.9 & 72 & 2.61 & & \\
\hline 20 & 0.73 & 45 & 4.82 & 74 & 2.43 & & \\
\hline 25 & 1.03 & 47 & 4.58 & $76^{*}$ & $2.09^{*}$ & & \\
\hline 27 & 1.29 & 49 & 4.39 & 79 & 2.06 & & \\
\hline 30 & 1.29 & 51 & 4.04 & 85 & 2.4 & & \\
\hline 33 & 1.92 & 54 & 4.03 & 89 & 2.03 & & \\
\hline 35 & 1.67 & 56 & 4.22 & 91 & 1.21 & & \\
\hline 36 & 2.3 & 58 & 4.08 & 96 & 0.86 & & \\
\hline 37 & 2.92 & 60 & 4.04 & & & & \\
\hline 38 & 4.05 & 62 & 3.89 & & & & \\
\hline 39 & 4.42 & 65 & 3.79 & & & & \\
\hline
\end{tabular}




\section{Conodoguinet Creek}

Date of Survey: April 28, 2007

Reach \#: $25-A$
Time of Survey: 10:09 am

Drainage Area: 28.3 sq. miles

UTM Coordinate Location: Zone 18, $4442243 \mathrm{~m} \mathrm{~N}, 0268850 \mathrm{~m} \mathrm{E}$

Location Information: Private Property, adjacent to GIS Hunting Club land. Parked vehicle off Horse Valley Road, near cabin with u-shaped driveway.

Bankfull Indicator(s): A change in slope along the south channel bank.

Bankfull Response Variables: Cross-sectional area (150.3 square feet), width (59.1 feet), mean depth (2.5 feet).

\section{Graph of Channel Cross-Section}

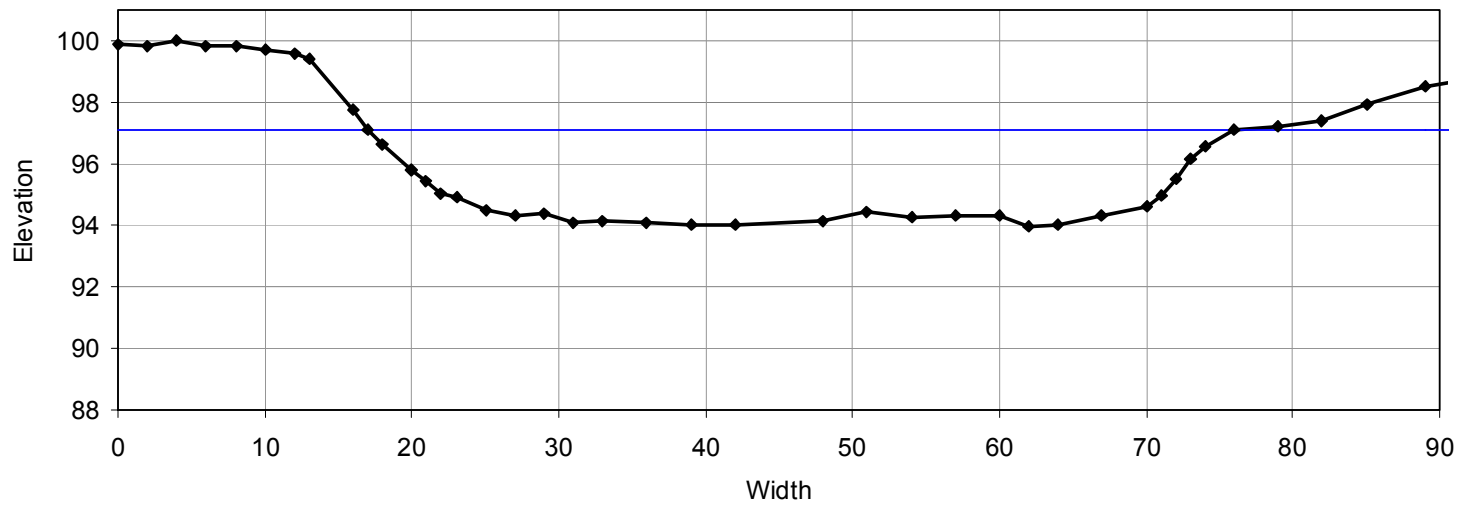

\section{Survey Data}

\begin{tabular}{|c|c|c|c|c|c|c|c|}
\hline $\begin{array}{c}\begin{array}{c}\text { Horizontal } \\
\text { (feet) }\end{array} \\
\end{array}$ & $\begin{array}{c}\begin{array}{c}\text { Vertical } \\
\text { (feet) }\end{array} \\
\end{array}$ & $\begin{array}{c}\text { Horizontal } \\
\text { (feet) }\end{array}$ & $\begin{array}{l}\begin{array}{l}\text { Vertical } \\
\text { (feet) }\end{array} \\
\end{array}$ & $\begin{array}{c}\begin{array}{c}\text { Horizontal } \\
\text { (feet) }\end{array} \\
\end{array}$ & $\begin{array}{c}\begin{array}{c}\text { Vertical } \\
\text { (feet) }\end{array} \\
\end{array}$ & $\begin{array}{c}\begin{array}{c}\text { Horizontal } \\
\text { (feet) }\end{array} \\
\end{array}$ & $\begin{array}{c}\begin{array}{c}\text { Vertical } \\
\text { (feet) }\end{array} \\
\end{array}$ \\
\hline 0 & 0.1 & 23 & 5.11 & 62 & 6.02 & & \\
\hline 2 & 0.16 & 25 & 5.51 & 64 & 5.97 & & \\
\hline 4 & 0 & 27 & 5.67 & 67 & 5.7 & & \\
\hline 6 & 0.2 & 29 & 5.63 & 70 & 5.36 & & \\
\hline 8 & 0.16 & 31 & 5.89 & 71 & 5.05 & & \\
\hline 10 & 0.3 & 33 & 5.87 & 72 & 4.51 & & \\
\hline 12 & 0.44 & 36 & 5.91 & 73 & 3.82 & & \\
\hline 13 & 0.61 & 39 & 5.96 & 74 & 3.44 & & \\
\hline 16 & 2.27 & 42 & 5.97 & $76^{*}$ & $2.88^{*}$ & & \\
\hline 17 & 2.92 & 48 & 5.83 & 79 & 2.8 & & \\
\hline 18 & 3.35 & 51 & 5.57 & 82 & 2.62 & & \\
\hline 20 & 4.22 & 54 & 5.75 & 85 & 2.07 & & \\
\hline 21 & 4.57 & 57 & 5.68 & 89 & 1.47 & & \\
\hline 22 & 4.97 & 60 & 5.67 & 95 & 1 & & \\
\hline
\end{tabular}




\section{Conodoguinet Creek}

Date of Survey: April 28, 2007

Reach \#: $25-B$
Time of Survey: 10:51 am

Drainage Area: 28.3 sq. miles

UTM Coordinate Location: Zone 18, 4442218 m N, $0268887 \mathrm{~m} \mathrm{E}$

Location Information: Private Property, adjacent to GIS Hunting Club land. Reach located downstream of 25-A.

Bankfull Indicator(s): A change in slope along the south channel bank, highest elevation of point bar is consistent with bankfull stage elevation.

Bankfull Response Variables: Cross-sectional area (110.5 square feet), width (58.0 feet), mean depth (1.9 feet).

\section{Graph of Channel Cross-Section}

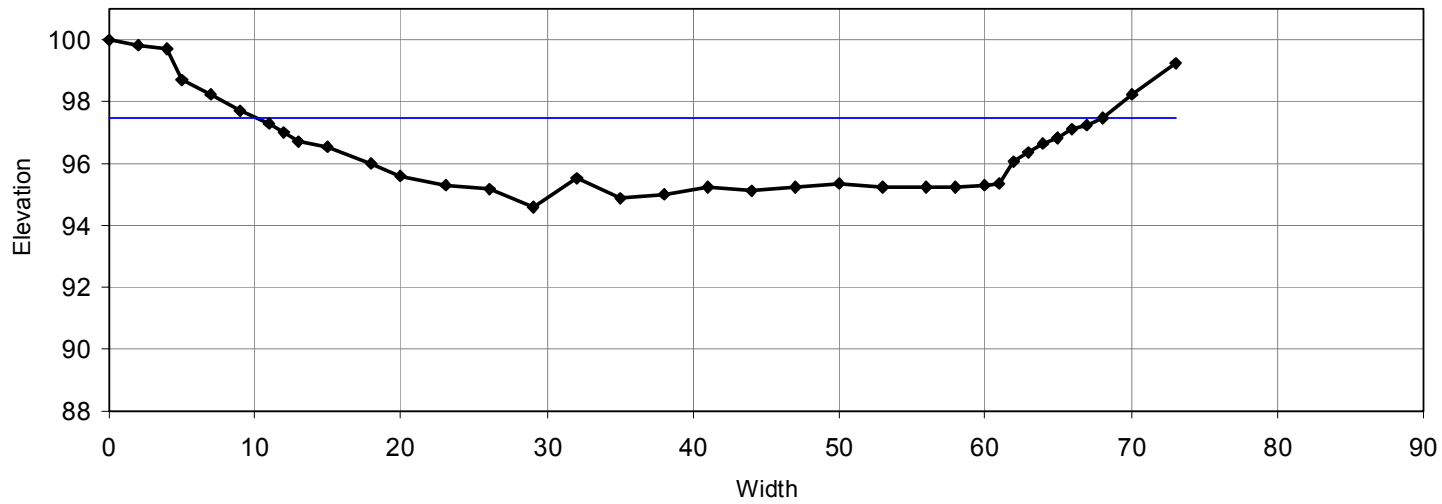

\section{$\underline{\text { Survey Data }}$}

\begin{tabular}{|c|c|c|c|c|c|c|c|}
\hline $\begin{array}{l}\text { Horizontal } \\
\text { (feet) }\end{array}$ & $\begin{array}{l}\text { Vertical } \\
\text { (feet) }\end{array}$ & $\begin{array}{l}\text { Horizontal } \\
\text { (feet) }\end{array}$ & $\begin{array}{c}\text { Vertical } \\
\text { (feet) }\end{array}$ & $\begin{array}{l}\text { Horizontal } \\
\text { (feet) }\end{array}$ & $\begin{array}{c}\text { Vertical } \\
\text { (feet) }\end{array}$ & $\begin{array}{l}\text { Horizontal } \\
\text { (feet) }\end{array}$ & $\begin{array}{c}\text { Vertical } \\
\text { (feet) }\end{array}$ \\
\hline 0 & 0 & 29 & 5.39 & 63 & 3.67 & & \\
\hline 2 & 0.16 & 32 & 4.49 & 64 & 3.38 & & \\
\hline 4 & 0.27 & 35 & 5.13 & 65 & 3.16 & & \\
\hline 5 & 1.27 & 38 & 5 & 66 & 2.91 & & \\
\hline 7 & 1.75 & 41 & 4.77 & 67 & 2.76 & & \\
\hline 9 & 2.27 & 44 & 4.9 & $68^{*}$ & $2.51^{*}$ & & \\
\hline 11 & 2.73 & 47 & 4.77 & 70 & 1.77 & & \\
\hline 12 & 2.98 & 50 & 4.64 & 73 & 0.75 & & \\
\hline 13 & 3.27 & 53 & 4.78 & & & & \\
\hline 15 & 3.49 & 56 & 4.77 & & & & \\
\hline 18 & 4.01 & 58 & 4.76 & & & & \\
\hline 20 & 4.39 & 60 & 4.72 & & & & \\
\hline 23 & 4.7 & 61 & 4.62 & & & & \\
\hline 26 & 4.84 & 62 & 3.94 & & & & \\
\hline
\end{tabular}




\section{Conodoguinet Creek}

Date of Survey: April 28, 2007

Reach \#: 26-A
Time of Survey: 12:41 am

Drainage Area: 25.3 sq. miles

UTM Coordinate Location: Zone 18, $4440697 \mathrm{~m} \mathrm{~N}, 0266759 \mathrm{~m} \mathrm{E}$

Location Information: Pennsylvania State Game Lands \# 76, parked at power line on Horse Valley Road.

Bankfull Indicator(s): A change in slope along the south channel bank.

Bankfull Response Variables: Cross-sectional area (149.1 square feet), width (47.3 feet), mean depth (3.2 feet).

\section{Graph of Channel Cross-Section}

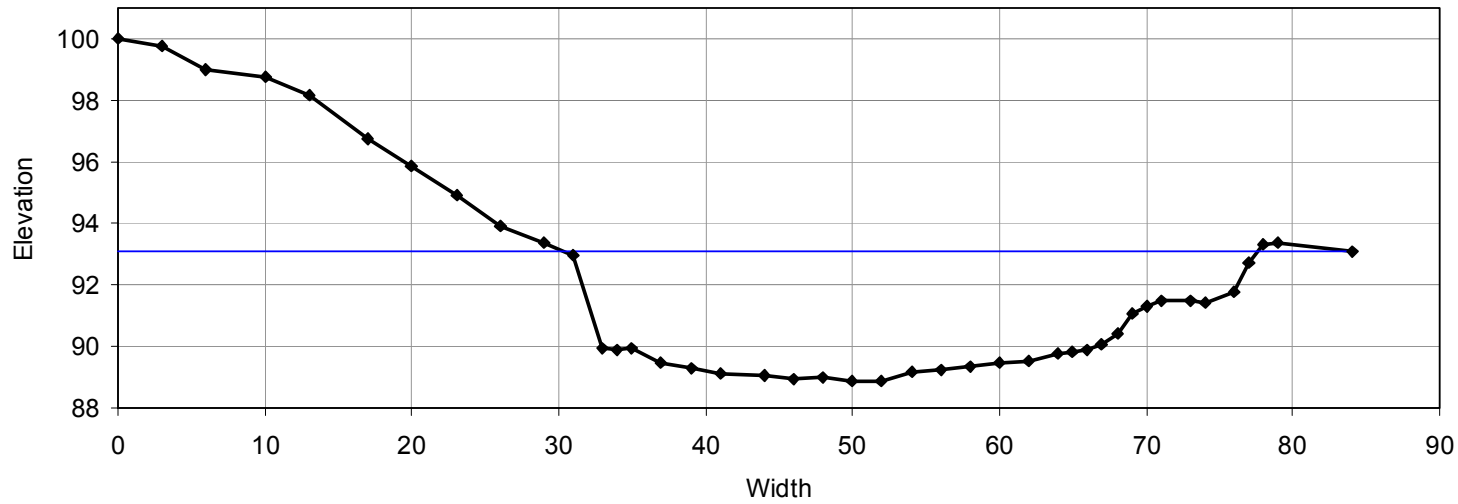

\section{Survey Data}

\begin{tabular}{|c|c|c|c|c|c|c|c|}
\hline $\begin{array}{c}\begin{array}{c}\text { Horizontal } \\
\text { (feet) }\end{array} \\
\end{array}$ & $\begin{array}{l}\text { Vertical } \\
\text { (feet) }\end{array}$ & $\begin{array}{c}\begin{array}{c}\text { Horizontal } \\
\text { (feet) }\end{array} \\
\end{array}$ & $\begin{array}{c}\begin{array}{c}\text { Vertical } \\
\text { (feet) }\end{array} \\
\end{array}$ & $\begin{array}{c}\text { Horizontal } \\
\text { (feet) }\end{array}$ & $\begin{array}{c}\begin{array}{c}\text { Vertical } \\
\text { (feet) }\end{array} \\
\end{array}$ & $\begin{array}{c}\begin{array}{c}\text { Horizontal } \\
\text { (feet) }\end{array} \\
\end{array}$ & $\begin{array}{c}\begin{array}{c}\text { Vertical } \\
\text { (feet) }\end{array} \\
\end{array}$ \\
\hline 0 & 0 & 37 & 10.55 & 65 & 10.15 & & \\
\hline 3 & 0.24 & 39 & 10.7 & 66 & 10.09 & & \\
\hline 6 & 1.02 & 41 & 10.89 & 67 & 9.95 & & \\
\hline 10 & 1.24 & 44 & 10.94 & 68 & 9.59 & & \\
\hline 13 & 1.83 & 46 & 11.07 & 69 & 8.93 & & \\
\hline 17 & 3.23 & 48 & 11 & 70 & 8.69 & & \\
\hline 20 & 4.16 & 50 & 11.11 & 71 & 8.51 & & \\
\hline 23 & 5.09 & 52 & 11.11 & 73 & 8.52 & & \\
\hline 26 & 6.1 & 54 & 10.79 & 74 & 8.55 & & \\
\hline 29 & 6.63 & 56 & 10.78 & 76 & 8.21 & & \\
\hline 31 & 7.05 & 58 & 10.67 & $77^{*}$ & $7.26^{*}$ & & \\
\hline 33 & 10.03 & 60 & 10.51 & 78 & 6.66 & & \\
\hline 34 & 10.1 & 62 & 10.45 & 79 & 6.61 & & \\
\hline 35 & 10.03 & 64 & 10.24 & 84 & 6.89 & & \\
\hline
\end{tabular}




\section{Conodoguinet Creek}

Date of Survey: April 28, 2007

Reach \#: 26-B
Time of Survey: 1:33 pm

Drainage Area: 25.3 sq. miles

UTM Coordinate Location: Zone 18, $4440721 \mathrm{~m} \mathrm{~N}, 0266815 \mathrm{~m} \mathrm{E}$

Location Information: Pennsylvania State Game Lands \# 76, parked at power line on Horse Valley Road. Reach located downstream of 26-A.

Bankfull Indicator(s): A change in slope along the south channel bank.

Bankfull Response Variables: Cross-sectional area (131.5 square feet), width (44.5 feet), mean depth (3.0 feet).

\section{Graph of Channel Cross-Section}

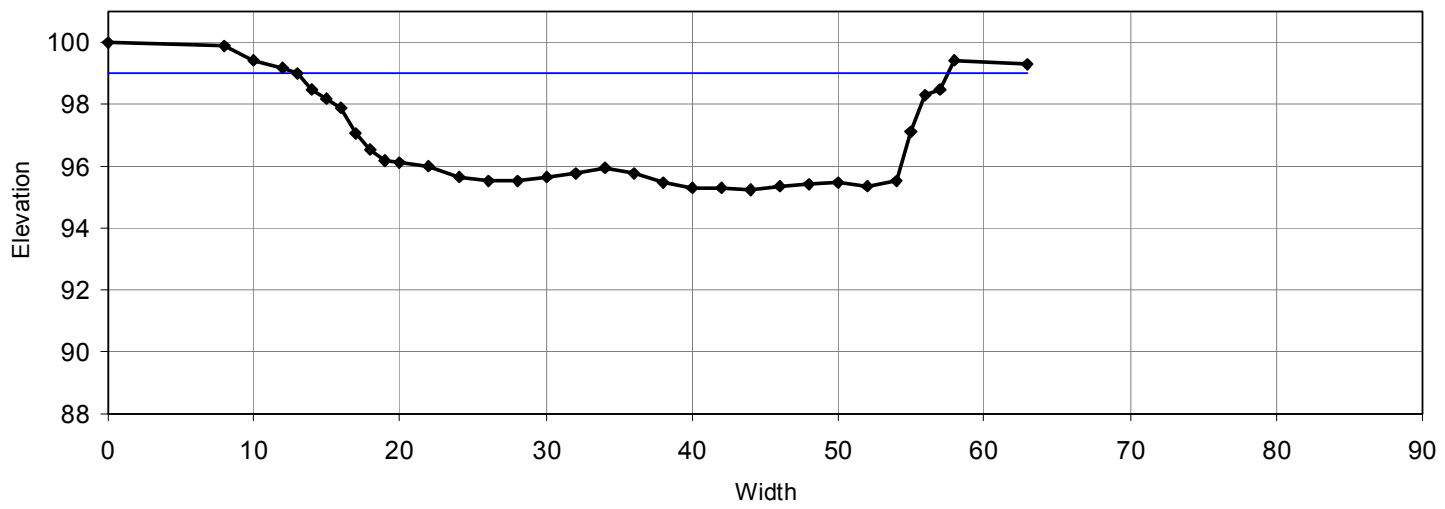

Survey Data

\begin{tabular}{|c|c|c|c|c|c|c|c|}
\hline $\begin{array}{c}\text { Horizontal } \\
\text { (feet) }\end{array}$ & $\begin{array}{c}\begin{array}{c}\text { Vertical } \\
\text { (feet) }\end{array} \\
\end{array}$ & $\begin{array}{l}\text { Horizontal } \\
\text { (feet) }\end{array}$ & $\begin{array}{l}\text { Vertical } \\
\text { (feet) }\end{array}$ & $\begin{array}{c}\text { Horizontal } \\
\text { (feet) }\end{array}$ & $\begin{array}{c}\begin{array}{l}\text { Vertical } \\
\text { (feet) }\end{array} \\
\end{array}$ & $\begin{array}{c}\text { Horizontal } \\
\text { (feet) }\end{array}$ & $\begin{array}{c}\begin{array}{c}\text { Vertical } \\
\text { (feet) }\end{array} \\
\end{array}$ \\
\hline 0 & 0 & 26 & 4.45 & 54 & 4.45 & & \\
\hline 8 & 0.12 & 28 & 4.47 & 55 & 2.86 & & \\
\hline 10 & 0.58 & 30 & 4.35 & 56 & 1.69 & & \\
\hline 12 & 0.83 & 32 & 4.21 & 57 & 1.5 & & \\
\hline $13^{*}$ & $1.02^{*}$ & 34 & 4.03 & 58 & 0.6 & & \\
\hline 14 & 1.53 & 36 & 4.21 & 63 & 0.69 & & \\
\hline 15 & 1.83 & 38 & 4.55 & & & & \\
\hline 16 & 2.09 & 40 & 4.7 & & & & \\
\hline 17 & 2.96 & 42 & 4.73 & & & & \\
\hline 18 & 3.47 & 44 & 4.75 & & & & \\
\hline 19 & 3.83 & 46 & 4.62 & & & & \\
\hline 20 & 3.88 & 48 & 4.57 & & & & \\
\hline 22 & 4.01 & 50 & 4.51 & & & & \\
\hline 24 & 4.33 & 52 & 4.63 & & & & \\
\hline
\end{tabular}




\section{Conodoguinet Creek}

Date of Survey: April 29, 2007

Reach \#: $27-A$
Time of Survey: 9:43 am

Drainage Area: 20.3 sq. miles

UTM Coordinate Location: Zone 18, $4438715 \mathrm{~m} \mathrm{~N}, 0264460 \mathrm{~m} \mathrm{E}$

Location Information: Private land with public fishing access, located upstream of sandstone bridge over creek. Reach located at intersection of Upper Strasburg Road and Horse Valley Road.

Bankfull Indicator(s): A change in slope along the north to northwest channel bank.

Bankfull Response Variables: Cross-sectional area (152.0 square feet), width (64.7 feet), mean depth (2.3 feet).

\section{Graph of Channel Cross-Section}

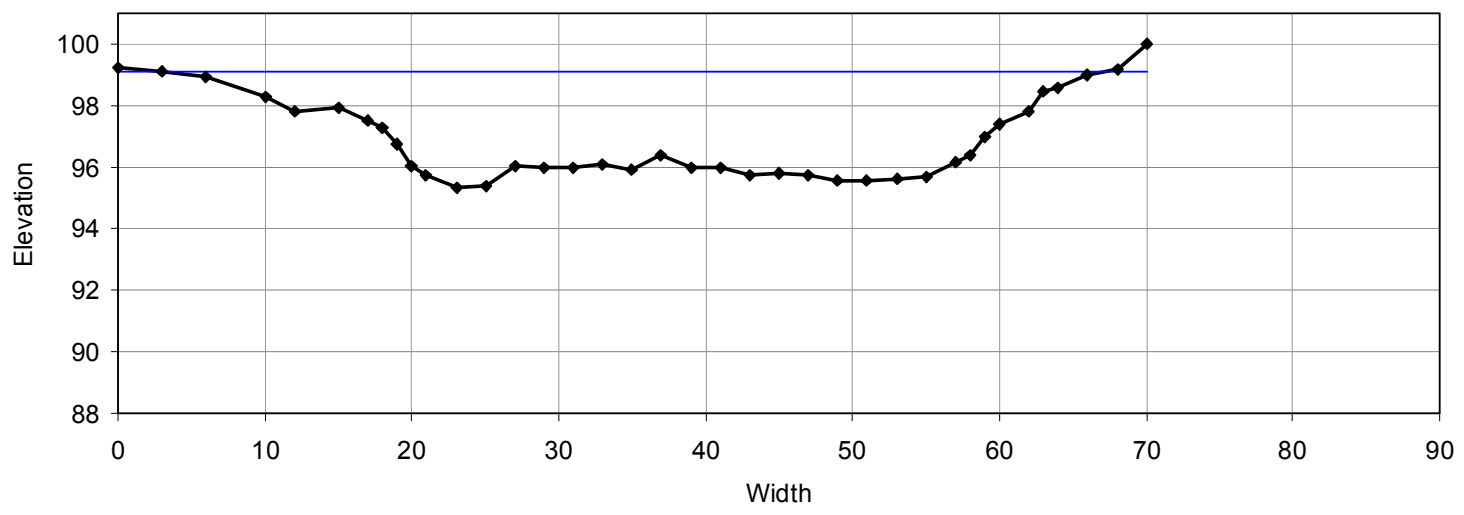

\section{$\underline{\text { Survey Data }}$}

\begin{tabular}{|c|c|c|c|c|c|c|c|}
\hline $\begin{array}{l}\text { Horizontal } \\
\text { (feet) }\end{array}$ & $\begin{array}{c}\begin{array}{l}\text { Vertical } \\
\text { (feet) }\end{array} \\
\end{array}$ & $\begin{array}{l}\text { Horizontal } \\
\text { (feet) }\end{array}$ & $\begin{array}{c}\begin{array}{l}\text { Vertical } \\
\text { (feet) }\end{array} \\
\end{array}$ & $\begin{array}{c}\text { Horizontal } \\
\text { (feet) }\end{array}$ & $\begin{array}{c}\begin{array}{l}\text { Vertical } \\
\text { (feet) }\end{array} \\
\end{array}$ & $\begin{array}{c}\text { Horizontal } \\
\text { (feet) }\end{array}$ & $\begin{array}{c}\text { Vertical } \\
\text { (feet) }\end{array}$ \\
\hline 0 & 0.76 & 29 & 4 & 57 & 3.82 & & \\
\hline $3^{*}$ & $0.88^{*}$ & 31 & 4.02 & 58 & 3.6 & & \\
\hline 6 & 1.08 & 33 & 3.93 & 59 & 2.99 & & \\
\hline 10 & 1.73 & 35 & 4.06 & 60 & 2.59 & & \\
\hline 12 & 2.18 & 37 & 3.63 & 62 & 2.18 & & \\
\hline 15 & 2.08 & 39 & 4 & 63 & 1.55 & & \\
\hline 17 & 2.49 & 41 & 4.04 & 64 & 1.41 & & \\
\hline 18 & 2.75 & 43 & 4.23 & 66 & 0.99 & & \\
\hline 19 & 3.23 & 45 & 4.2 & 68 & 0.86 & & \\
\hline 20 & 3.96 & 47 & 4.25 & 70 & 0 & & \\
\hline 21 & 4.24 & 49 & 4.42 & & & & \\
\hline 23 & 4.66 & 51 & 4.46 & & & & \\
\hline 25 & 4.6 & 53 & 4.36 & & & & \\
\hline 27 & 3.96 & 55 & 4.29 & & & & \\
\hline
\end{tabular}




\section{Conodoguinet Creek}

Date of Survey: April 29, 2007

Reach \#: 27-B
Time of Survey: 10:23 am

Drainage Area: 20.3 sq. miles

UTM Coordinate Location: Zone 18, $4438731 \mathrm{~m} \mathrm{~N}, 0264445 \mathrm{~m} \mathrm{E}$

Location Information: Private land with public fishing access, located upstream of sandstone bridge over creek. Reach located downstream of27-A, approximately 150 upstream of bridge.

Bankfull Indicator(s): A change in slope along the north to northwest channel bank.

Bankfull Response Variables: Cross-sectional area (150.1 square feet), width (45.8 feet), mean depth (3.3 feet).

\section{Graph of Channel Cross-Section}

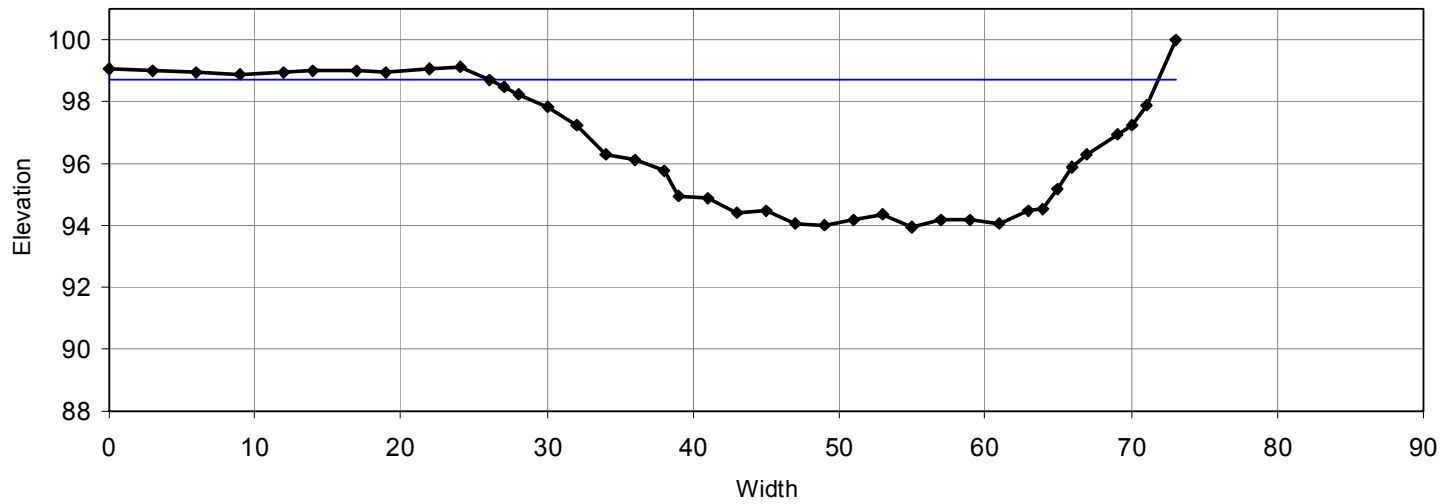

Survey Data

\begin{tabular}{|c|c|c|c|c|c|c|c|}
\hline $\begin{array}{c}\text { Horizontal } \\
\text { (feet) }\end{array}$ & $\begin{array}{c}\begin{array}{c}\text { Vertical } \\
\text { (feet) }\end{array} \\
\end{array}$ & $\begin{array}{c}\text { Horizontal } \\
\text { (feet) }\end{array}$ & $\begin{array}{c}\text { Vertical } \\
\text { (feet) }\end{array}$ & $\begin{array}{c}\begin{array}{c}\text { Horizontal } \\
\text { (feet) }\end{array} \\
\end{array}$ & $\begin{array}{c}\begin{array}{c}\text { Vertical } \\
\text { (feet) }\end{array} \\
\end{array}$ & $\begin{array}{c}\text { Horizontal } \\
\text { (feet) }\end{array}$ & $\begin{array}{c}\begin{array}{c}\text { Vertical } \\
\text { (feet) }\end{array} \\
\end{array}$ \\
\hline 0 & 0.96 & 32 & 2.79 & 59 & 5.85 & & \\
\hline 3 & 0.98 & 34 & 3.69 & 61 & 5.94 & & \\
\hline 6 & 1.07 & 36 & 3.89 & 63 & 5.52 & & \\
\hline 9 & 1.12 & 38 & 4.25 & 64 & 5.45 & & \\
\hline 12 & 1.04 & 39 & 5.05 & 65 & 4.81 & & \\
\hline 14 & 1.01 & 41 & 5.1 & 66 & 4.09 & & \\
\hline 17 & 1 & 43 & 5.58 & 67 & 3.72 & & \\
\hline 19 & 1.06 & 45 & 5.5 & 69 & 3.05 & & \\
\hline 22 & 0.93 & 47 & 5.93 & 70 & 2.75 & & \\
\hline 24 & 0.91 & 49 & 5.99 & 71 & 2.11 & & \\
\hline $26^{*}$ & $1.27^{*}$ & 51 & 5.81 & 73 & 0 & & \\
\hline 27 & 1.51 & 53 & 5.64 & & & & \\
\hline 28 & 1.79 & 55 & 6.03 & & & & \\
\hline 30 & 2.16 & 57 & 5.85 & & & & \\
\hline
\end{tabular}




\section{Conodoguinet Creek}

Date of Survey: April 29, 2007

Reach \#: 28-A
Time of Survey: 11:39 am

Drainage Area: 16.1 sq. miles

UTM Coordinate Location: Zone 18, $4436834 \mathrm{~m} \mathrm{~N}, 0261706 \mathrm{~m} \mathrm{E}$

Location Information: Private land with public fishing access, located on Keefer Road at the bridge over the creek.

Bankfull Indicator(s): A change in slope along the north to northwest channel bank.

Bankfull Response Variables: Cross-sectional area (159.1 square feet), width (49.7 feet), mean depth (3.2 feet).

\section{Graph of Channel Cross-Section}

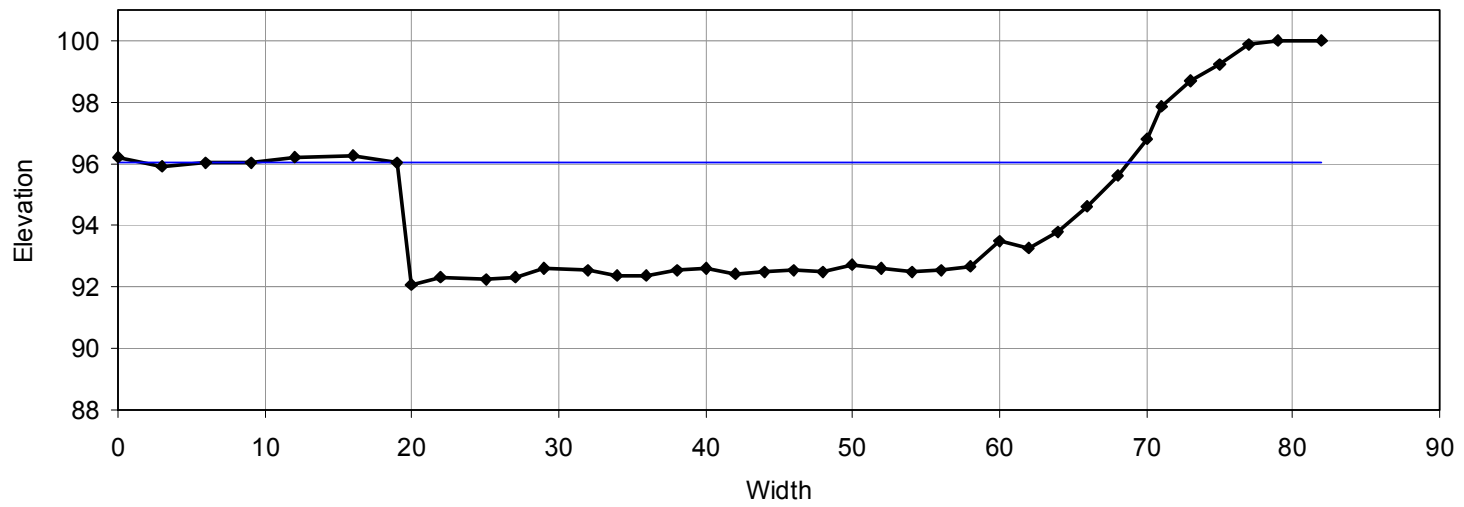

Survey Data

\begin{tabular}{|c|c|c|c|c|c|c|c|}
\hline $\begin{array}{c}\text { Horizontal } \\
\text { (feet) }\end{array}$ & $\begin{array}{c}\begin{array}{c}\text { Vertical } \\
\text { (feet) }\end{array} \\
\end{array}$ & $\begin{array}{c}\text { Horizontal } \\
\text { (feet) }\end{array}$ & $\begin{array}{l}\begin{array}{l}\text { Vertical } \\
\text { (feet) }\end{array} \\
\end{array}$ & $\begin{array}{c}\text { Horizontal } \\
\text { (feet) }\end{array}$ & $\begin{array}{c}\begin{array}{c}\text { Vertical } \\
\text { (feet) }\end{array} \\
\end{array}$ & $\begin{array}{c}\text { Horizontal } \\
\text { (feet) }\end{array}$ & $\begin{array}{c}\begin{array}{c}\text { Vertical } \\
\text { (feet) }\end{array} \\
\end{array}$ \\
\hline 0 & 3.77 & 36 & 7.6 & 64 & 6.23 & & \\
\hline 3 & 4.1 & 38 & 7.47 & 66 & 5.39 & & \\
\hline 6 & 3.99 & 40 & 7.4 & 68 & 4.35 & & \\
\hline 9 & 3.98 & 42 & 7.55 & 70 & 3.18 & & \\
\hline 12 & 3.77 & 44 & 7.53 & 71 & 2.12 & & \\
\hline 16 & 3.7 & 46 & 7.43 & 73 & 1.29 & & \\
\hline $19 *$ & $3.96^{*}$ & 48 & 7.53 & 75 & 0.8 & & \\
\hline 20 & 7.95 & 50 & 7.28 & 77 & 0.15 & & \\
\hline 22 & 7.68 & 52 & 7.38 & 79 & 0.02 & & \\
\hline 25 & 7.77 & 54 & 7.52 & 82 & 0 & & \\
\hline 27 & 7.68 & 56 & 7.45 & & & & \\
\hline 29 & 7.37 & 58 & 7.31 & & & & \\
\hline 32 & 7.44 & 60 & 6.49 & & & & \\
\hline 34 & 7.6 & 62 & 6.73 & & & & \\
\hline
\end{tabular}




\section{Conodoguinet Creek}

Date of Survey: April 29, 2007

Reach \#: $28-B$
Time of Survey: $12: 11$ am

Drainage Area: 16.1 sq. miles

UTM Coordinate Location: Zone 18, 4436899 m N, 0261738 m E

Location Information: Private land with public fishing access, located on Keefer Road at the bridge over the creek. Reach located downstream of 28-A.

Bankfull Indicator(s): A change in slope along the north to northwest channel bank.

Bankfull Response Variables: Cross-sectional area (128.8 square feet), width (49.5 feet), mean depth (2.6 feet).

\section{Graph of Channel Cross-Section}

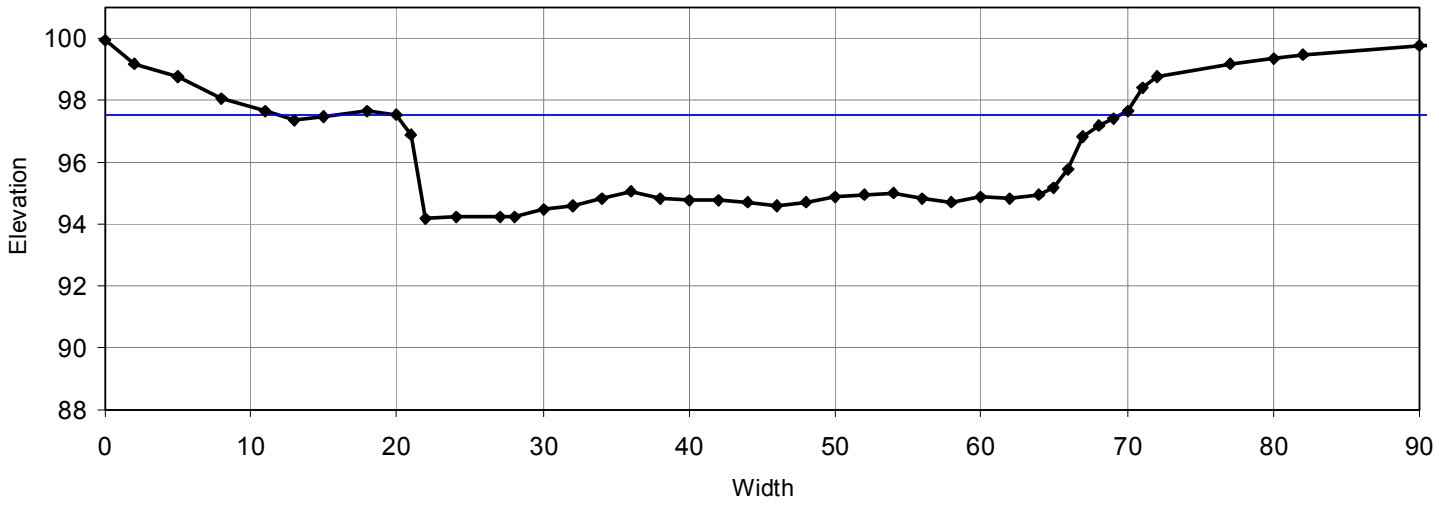

Survey Data

\begin{tabular}{|c|c|c|c|c|c|c|c|}
\hline $\begin{array}{c}\text { Horizontal } \\
\text { (feet) }\end{array}$ & $\begin{array}{c}\text { Vertical } \\
\text { (feet) }\end{array}$ & $\begin{array}{c}\text { Horizontal } \\
\text { (feet) }\end{array}$ & $\begin{array}{l}\text { Vertical } \\
\text { (feet) }\end{array}$ & $\begin{array}{c}\text { Horizontal } \\
\text { (feet) }\end{array}$ & $\begin{array}{c}\text { Vertical } \\
\text { (feet) }\end{array}$ & $\begin{array}{c}\text { Horizontal } \\
\text { (feet) }\end{array}$ & $\begin{array}{c}\text { Vertical } \\
\text { (feet) }\end{array}$ \\
\hline 0 & 0.06 & 30 & 5.52 & 58 & 5.28 & 82 & 0.5 \\
\hline 2 & 0.8 & 32 & 5.43 & 60 & 5.12 & 90 & 0.24 \\
\hline 5 & 1.26 & 34 & 5.16 & 62 & 5.19 & 100 & 0 \\
\hline 8 & 1.92 & 36 & 4.96 & 64 & 5.07 & & \\
\hline 11 & 2.33 & 38 & 5.15 & 65 & 4.83 & & \\
\hline 13 & 2.65 & 40 & 5.24 & 66 & 4.24 & & \\
\hline 15 & 2.55 & 42 & 5.22 & 67 & 3.15 & & \\
\hline 18 & 2.35 & 44 & 5.29 & 68 & 2.82 & & \\
\hline $20^{*}$ & $2.45^{*}$ & 46 & 5.39 & 69 & 2.56 & & \\
\hline 21 & 3.12 & 48 & 5.3 & 70 & 2.33 & & \\
\hline 22 & 5.8 & 50 & 5.1 & 71 & 1.6 & & \\
\hline 24 & 5.79 & 52 & 5.08 & 72 & 1.24 & & \\
\hline 27 & 5.78 & 54 & 5 & 77 & 0.8 & & \\
\hline 28 & 5.74 & 56 & 5.17 & 80 & 0.65 & & \\
\hline
\end{tabular}




\section{Conodoguinet Creek}

Date of Survey: April 29, 2007

Reach \#: 29-A
Time of Survey: 1:56 pm

Drainage Area: 4.69 sq. miles

UTM Coordinate Location: Zone 18, 4430466 m N, 0256799 m E

Location Information: Pennsylvania State Game Lands \# 235, located at the end of Upper Horse Valley Road.

Bankfull Indicator(s): A change in slope along the east to southeast channel bank.

Bankfull Response Variables: Cross-sectional area (67.9 square feet), width (25.7 feet), mean depth (2.6 feet).

\section{Graph of Channel Cross-Section}

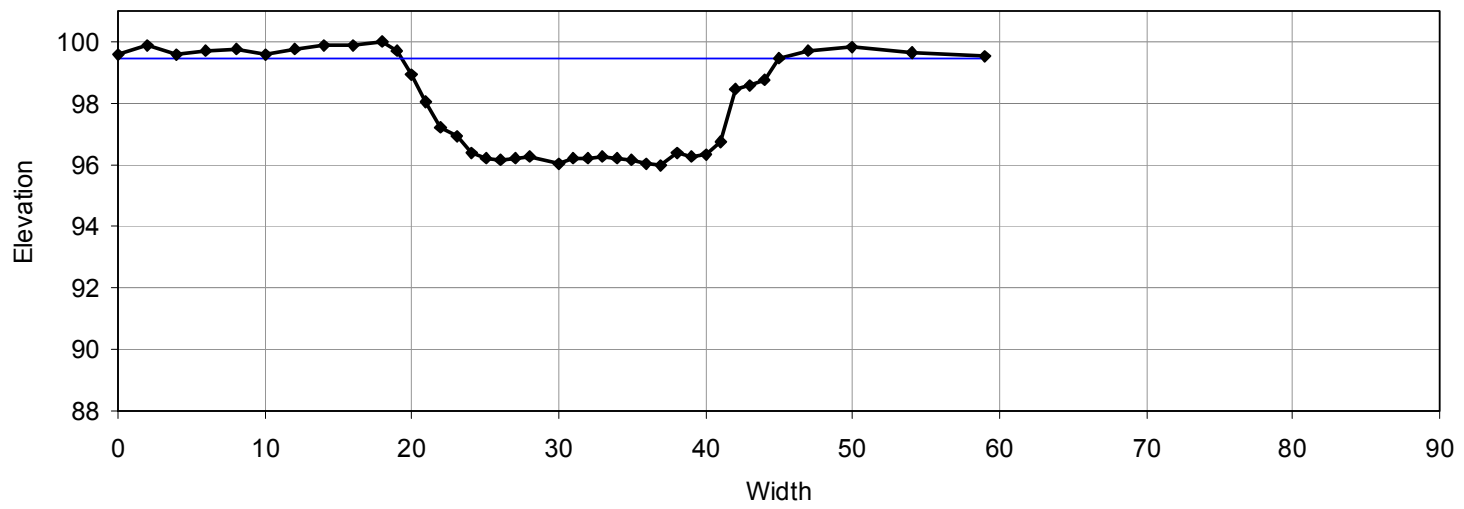

Survey Data

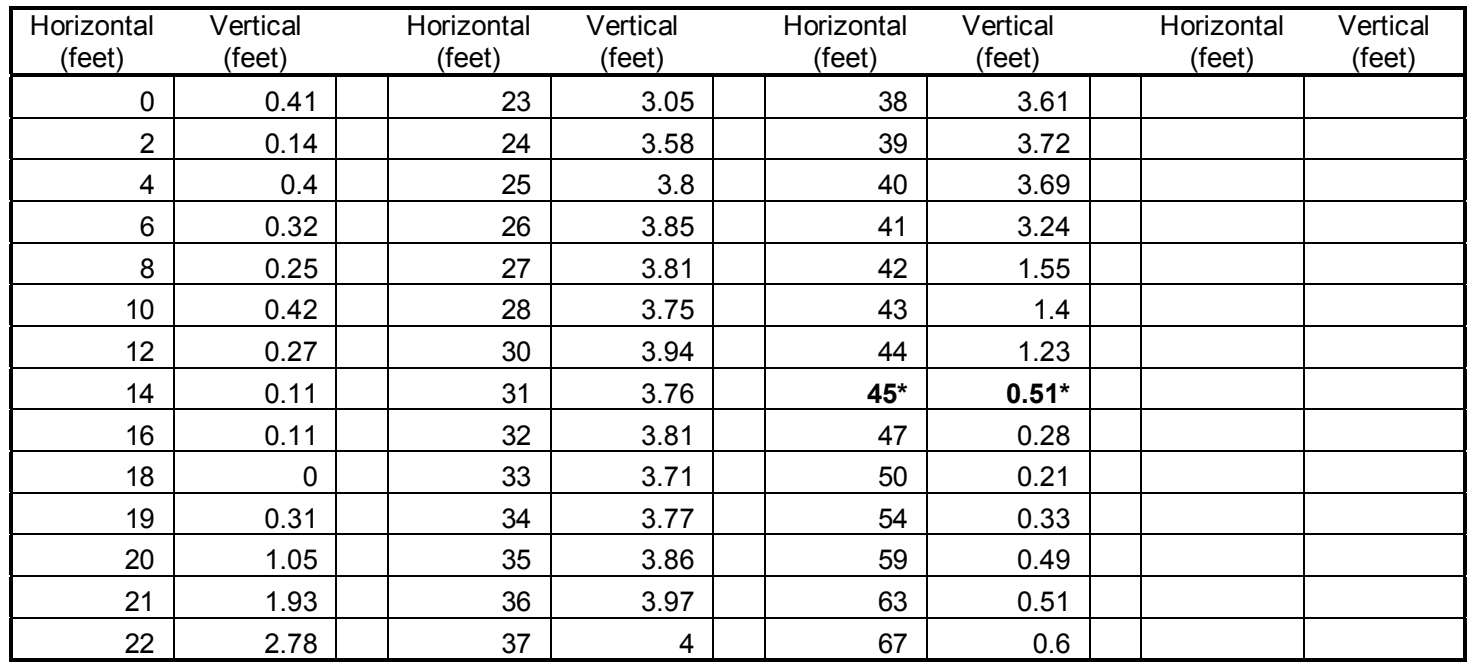




\section{Conodoguinet Creek}

Date of Survey: April 29, 2007

Reach \#: 29-B
Time of Survey: $2: 26 \mathrm{pm}$

Drainage Area: 4.69 sq. miles

UTM Coordinate Location: Zone 18, $4430391 \mathrm{~m} \mathrm{~N}, 0256741 \mathrm{~m} \mathrm{E}$

Location Information: Pennsylvania State Game Lands \# 235, located at the end of Upper Horse Valley Road. Reach located upstream of 29-A.

Bankfull Indicator(s): A change in slope along the north to northwest channel bank.

Bankfull Response Variables: Cross-sectional area (38.2 square feet), width (29.6 feet), mean depth (1.3 feet).

\section{Graph of Channel Cross-Section}

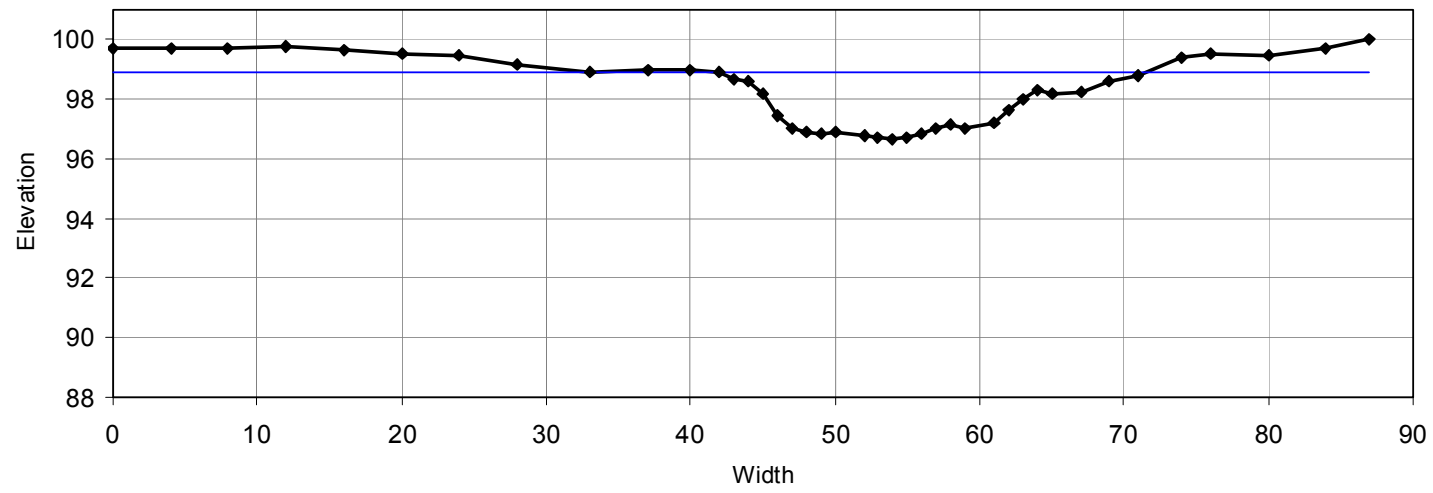

$\underline{\text { Survey Data }}$

\begin{tabular}{|c|c|c|c|c|c|c|c|}
\hline $\begin{array}{c}\text { Horizontal } \\
\text { (feet) }\end{array}$ & $\begin{array}{c}\text { Vertical } \\
\text { (feet) }\end{array}$ & $\begin{array}{c}\text { Horizontal } \\
\text { (feet) }\end{array}$ & $\begin{array}{c}\begin{array}{c}\text { Vertical } \\
\text { (feet) }\end{array} \\
\end{array}$ & $\begin{array}{c}\text { Horizontal } \\
\text { (feet) }\end{array}$ & $\begin{array}{c}\begin{array}{l}\text { Vertical } \\
\text { (feet) }\end{array} \\
\end{array}$ & $\begin{array}{c}\text { Horizontal } \\
\text { (feet) }\end{array}$ & $\begin{array}{c}\begin{array}{c}\text { Vertical } \\
\text { (feet) }\end{array} \\
\end{array}$ \\
\hline 0 & 0.27 & 45 & 1.78 & 61 & 2.8 & & \\
\hline 4 & 0.29 & 46 & 2.54 & 62 & 2.33 & & \\
\hline 8 & 0.26 & 47 & 2.98 & 63 & 2.02 & & \\
\hline 12 & 0.24 & 48 & 3.06 & 64 & 1.71 & & \\
\hline 16 & 0.32 & 49 & 3.14 & 65 & 1.83 & & \\
\hline 20 & 0.49 & 50 & 3.06 & 67 & 1.76 & & \\
\hline 24 & 0.54 & 52 & 3.23 & 69 & 1.41 & & \\
\hline 28 & 0.81 & 53 & 3.28 & 71 & 1.22 & & \\
\hline 33 & 1.05 & 54 & 3.36 & 74 & 0.59 & & \\
\hline 37 & 1.02 & 55 & 3.3 & 76 & 0.49 & & \\
\hline 40 & 1.02 & 56 & 3.18 & 80 & 0.51 & & \\
\hline $42^{*}$ & $1.1^{*}$ & 57 & 2.98 & 84 & 0.27 & & \\
\hline 43 & 1.31 & 58 & 2.82 & 87 & 0 & & \\
\hline 44 & 1.38 & 59 & 2.96 & & & & \\
\hline
\end{tabular}




\section{West Licking Creek}

Date of Survey: May 18, 2007

Reach \#: 30-A
Time of Survey: 1:09 pm

Drainage Area: 1.66 sq. miles

UTM Coordinate Location: Zone 18, 4477248 m N, 0268316 m E

Location Information: Tuscarora State Forest, parked vehicle along Licking Creek Drive near campsite \# 17.

Bankfull Indicator(s): A change in slope along the north channel bank.

Bankfull Response Variables: Cross-sectional area (13.6 square feet), width (12.2 feet), mean depth (1.1 feet).

\section{Graph of Channel Cross-Section}

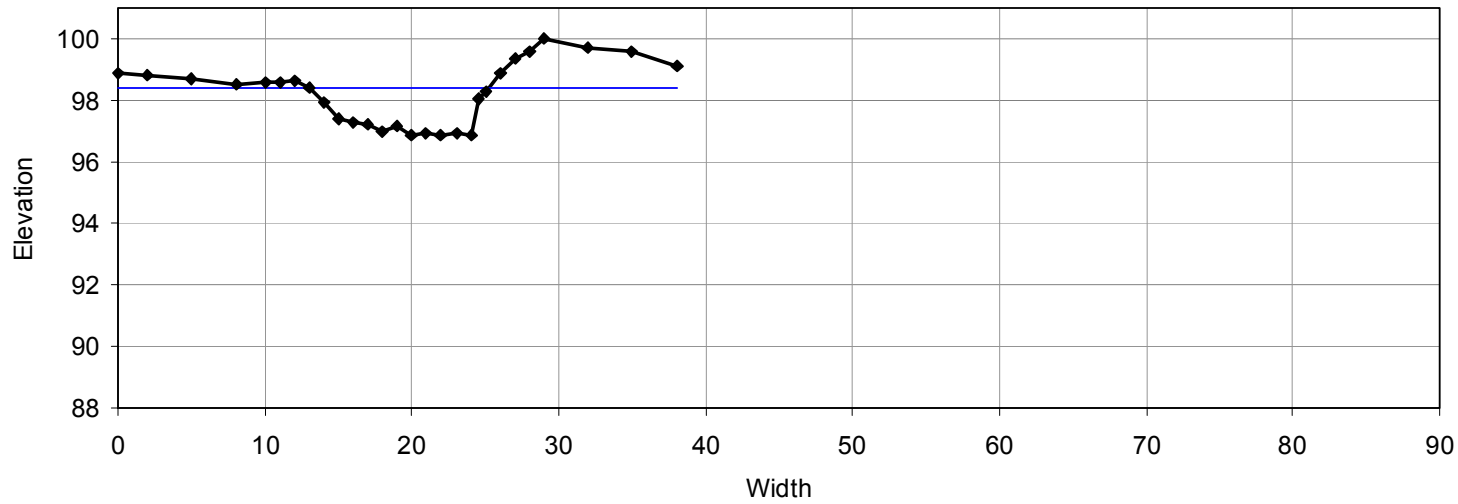

Survey Data

\begin{tabular}{|c|c|c|c|c|c|c|c|}
\hline $\begin{array}{c}\text { Horizontal } \\
\text { (feet) }\end{array}$ & $\begin{array}{c}\begin{array}{c}\text { Vertical } \\
\text { (feet) }\end{array} \\
\end{array}$ & $\begin{array}{c}\text { Horizontal } \\
\text { (feet) }\end{array}$ & $\begin{array}{c}\begin{array}{c}\text { Vertical } \\
\text { (feet) }\end{array} \\
\end{array}$ & $\begin{array}{c}\text { Horizontal } \\
\text { (feet) }\end{array}$ & $\begin{array}{c}\begin{array}{c}\text { Vertical } \\
\text { (feet) }\end{array} \\
\end{array}$ & $\begin{array}{c}\text { Horizontal } \\
\text { (feet) }\end{array}$ & $\begin{array}{c}\text { Vertical } \\
\text { (feet) }\end{array}$ \\
\hline 0 & 1.13 & 20 & 3.11 & & & & \\
\hline 2 & 1.21 & 21 & 3.07 & & & & \\
\hline 5 & 1.28 & 22 & 3.14 & & & & \\
\hline 8 & 1.49 & 23 & 3.05 & & & & \\
\hline 10 & 1.42 & 24 & 3.14 & & & & \\
\hline 11 & 1.45 & 24.5 & 1.98 & & & & \\
\hline 12 & 1.37 & 25 & 1.71 & & & & \\
\hline $13^{*}$ & $1.62^{*}$ & 26 & 1.13 & & & & \\
\hline 14 & 2.1 & 27 & 0.68 & & & & \\
\hline 15 & 2.6 & 28 & 0.39 & & & & \\
\hline 16 & 2.74 & 29 & 0 & & & & \\
\hline 17 & 2.81 & 32 & 0.28 & & & & \\
\hline 18 & 3.04 & 35 & 0.43 & & & & \\
\hline 19 & 2.82 & 38 & 0.92 & & & & \\
\hline
\end{tabular}




\section{West Licking Creek}

Date of Survey: May 18, 2007

Reach \#: $30-B$
Time of Survey: 1:23 pm

Drainage Area: 1.66 sq. miles

UTM Coordinate Location: Zone 18, 4477243 m N, 0268316 m E

Location Information: Tuscarora State Forest, parked vehicle along Licking Creek Drive near campsite \# 17. Reach located approximately 150 feet upstream of 30-A.

Bankfull Indicator(s): A change in slope along the south channel bank.

Bankfull Response Variables: Cross-sectional area (13.0 square feet), width (14.2 feet), mean depth (0.9 feet).

\section{Graph of Channel Cross-Section}

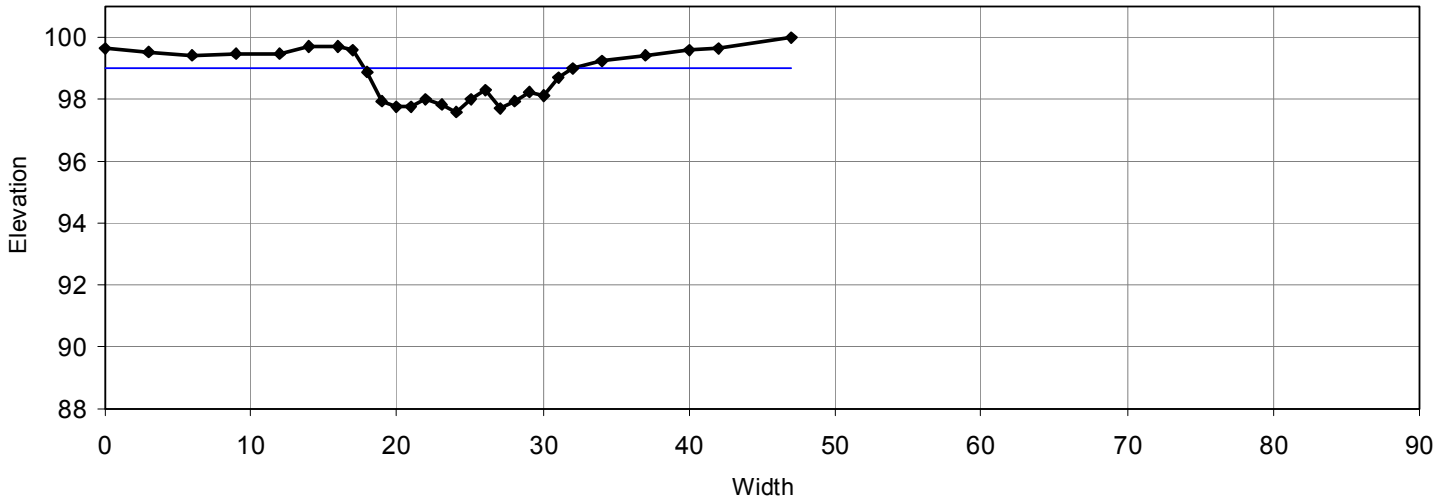

Survey Data

\begin{tabular}{|c|c|c|c|c|c|c|c|}
\hline $\begin{array}{c}\text { Horizontal } \\
\text { (feet) }\end{array}$ & $\begin{array}{c}\text { Vertical } \\
\text { (feet) }\end{array}$ & $\begin{array}{c}\text { Horizontal } \\
\text { (feet) }\end{array}$ & $\begin{array}{l}\text { Vertical } \\
\text { (feet) }\end{array}$ & $\begin{array}{c}\text { Horizontal } \\
\text { (feet) }\end{array}$ & $\begin{array}{c}\begin{array}{c}\text { Vertical } \\
\text { (feet) }\end{array} \\
\end{array}$ & $\begin{array}{c}\text { Horizontal } \\
\text { (feet) }\end{array}$ & $\begin{array}{c}\begin{array}{c}\text { Vertical } \\
\text { (feet) }\end{array} \\
\end{array}$ \\
\hline 0 & 0.38 & 24 & 2.41 & & & & \\
\hline 3 & 0.46 & 25 & 2.02 & & & & \\
\hline 6 & 0.58 & 26 & 1.71 & & & & \\
\hline 9 & 0.54 & 27 & 2.29 & & & & \\
\hline 12 & 0.53 & 28 & 2.07 & & & & \\
\hline 14 & 0.31 & 29 & 1.77 & & & & \\
\hline 16 & 0.28 & 30 & 1.86 & & & & \\
\hline 17 & 0.41 & 31 & 1.32 & & & & \\
\hline 18 & 1.14 & $32^{*}$ & $1.02^{*}$ & & & & \\
\hline 19 & 2.05 & 34 & 0.78 & & & & \\
\hline 20 & 2.25 & 37 & 0.6 & & & & \\
\hline 21 & 2.26 & 40 & 0.42 & & & & \\
\hline 22 & 2.02 & 42 & 0.35 & & & & \\
\hline 23 & 2.18 & 47 & 0 & & & & \\
\hline
\end{tabular}




\section{West Licking Creek}

Date of Survey: May 18, 2007

Reach \#: 31-A
Time of Survey: 2:10 pm

Drainage Area: 2.69 sq. miles

UTM Coordinate Location: Zone 18, 4476066 m N, 0267300 m E

Location Information: Tuscarora State Forest, parked vehicle along an un-named service road off Licking Creek Drive.

Bankfull Indicator(s): A change in slope along the east to southeast channel bank.

Bankfull Response Variables: Cross-sectional area (18.5 square feet), width (16.8 feet), mean depth (1.1 feet).

\section{Graph of Channel Cross-Section}

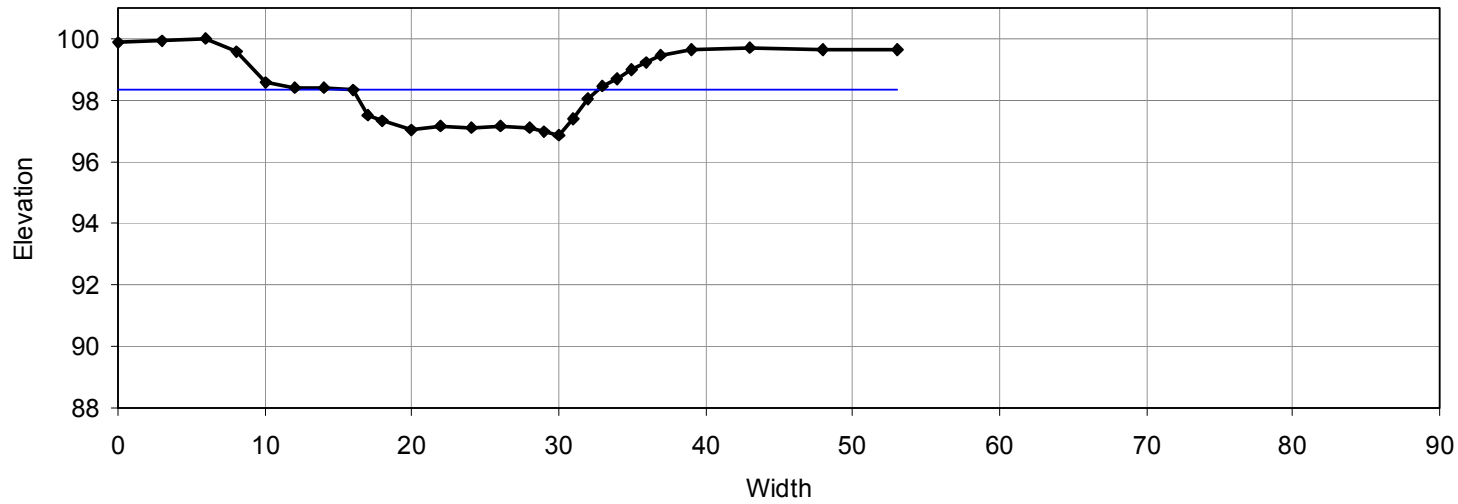

Survey Data

\begin{tabular}{|c|c|c|c|c|c|c|c|}
\hline $\begin{array}{c}\text { Horizontal } \\
\text { (feet) }\end{array}$ & $\begin{array}{c}\begin{array}{c}\text { Vertical } \\
\text { (feet) }\end{array} \\
\end{array}$ & $\begin{array}{c}\text { Horizontal } \\
\text { (feet) }\end{array}$ & $\begin{array}{c}\begin{array}{c}\text { Vertical } \\
\text { (feet) }\end{array} \\
\end{array}$ & $\begin{array}{c}\text { Horizontal } \\
\text { (feet) }\end{array}$ & $\begin{array}{c}\begin{array}{c}\text { Vertical } \\
\text { (feet) }\end{array} \\
\end{array}$ & $\begin{array}{c}\text { Horizontal } \\
\text { (feet) }\end{array}$ & $\begin{array}{c}\text { Vertical } \\
\text { (feet) }\end{array}$ \\
\hline 0 & 0.15 & 28 & 2.88 & & & & \\
\hline 3 & 0.05 & 29 & 3.03 & & & & \\
\hline 6 & 0 & 30 & 3.13 & & & & \\
\hline 8 & 0.44 & 31 & 2.61 & & & & \\
\hline 10 & 1.4 & 32 & 1.93 & & & & \\
\hline 12 & 1.66 & $33^{*}$ & $1.56^{*}$ & & & & \\
\hline 14 & 1.79 & 34 & 1.33 & & & & \\
\hline 16 & 1.63 & 35 & 1 & & & & \\
\hline 17 & 2.5 & 36 & 0.79 & & & & \\
\hline 18 & 2.67 & 37 & 0.55 & & & & \\
\hline 20 & 2.94 & 39 & 0.33 & & & & \\
\hline 22 & 2.83 & 43 & 0.3 & & & & \\
\hline 24 & 2.92 & 48 & 0.37 & & & & \\
\hline 26 & 2.85 & 53 & 0.34 & & & & \\
\hline
\end{tabular}




\section{West Licking Creek}

Date of Survey: May 18, 2007

Reach \#: $31-B$
Time of Survey: 2:30 pm

Drainage Area: 2.69 sq. miles

UTM Coordinate Location: Zone 18, $4476114 \mathrm{~m} \mathrm{~N}, 0267321 \mathrm{~m} \mathrm{E}$

Location Information: Tuscarora State Forest, parked vehicle along an un-named service road off Licking Creek Drive. Reach located approximately 150 feet upstream of 31-A.

Bankfull Indicator(s): A change in slope along the west to southwest channel bank.

Bankfull Response Variables: Cross-sectional area (26.2 square feet), width (18.8 feet), mean depth (1.4 feet).

\section{Graph of Channel Cross-Section}

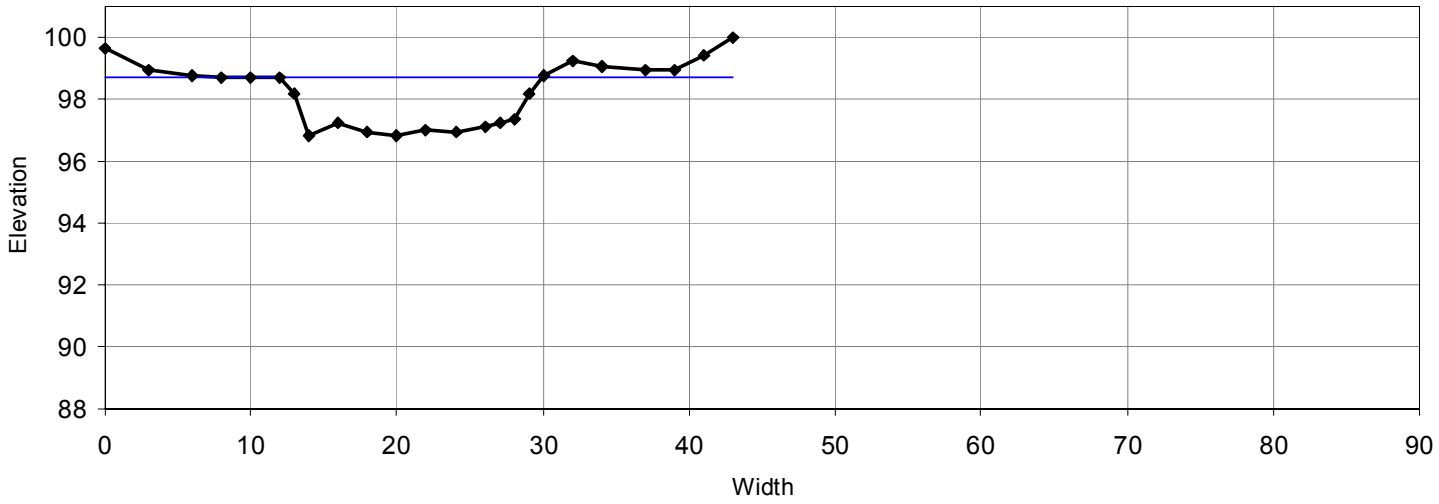

$\underline{\text { Survey Data }}$

\begin{tabular}{|c|c|c|c|c|c|c|c|}
\hline $\begin{array}{c}\text { Horizontal } \\
\text { (feet) }\end{array}$ & $\begin{array}{c}\begin{array}{l}\text { Vertical } \\
\text { (feet) }\end{array} \\
\end{array}$ & $\begin{array}{c}\text { Horizontal } \\
\text { (feet) }\end{array}$ & $\begin{array}{l}\text { Vertical } \\
\text { (feet) }\end{array}$ & $\begin{array}{c}\text { Horizontal } \\
\text { (feet) }\end{array}$ & $\begin{array}{c}\begin{array}{c}\text { Vertical } \\
\text { (feet) }\end{array} \\
\end{array}$ & $\begin{array}{c}\text { Horizontal } \\
\text { (feet) }\end{array}$ & $\begin{array}{c}\begin{array}{c}\text { Vertical } \\
\text { (feet) }\end{array} \\
\end{array}$ \\
\hline 0 & 0.37 & 27 & 2.77 & & & & \\
\hline 3 & 1.03 & 28 & 2.66 & & & & \\
\hline 6 & 1.22 & 29 & 1.85 & & & & \\
\hline 8 & 1.31 & 30 & 1.23 & & & & \\
\hline 10 & 1.28 & 32 & 0.77 & & & & \\
\hline $12^{*}$ & $1.3^{*}$ & 34 & 0.93 & & & & \\
\hline 13 & 1.8 & 37 & 1.03 & & & & \\
\hline 14 & 3.2 & 39 & 1.07 & & & & \\
\hline 16 & 2.78 & 41 & 0.61 & & & & \\
\hline 18 & 3.04 & 43 & 0 & & & & \\
\hline 20 & 3.18 & & & & & & \\
\hline 22 & 2.98 & & & & & & \\
\hline 24 & 3.08 & & & & & & \\
\hline 26 & 2.88 & & & & & & \\
\hline
\end{tabular}




\section{West Licking Creek}

Date of Survey: May 18, 2007

Reach \#: 32-A
Time of Survey: 4:18 pm

Drainage Area: 6:15 sq. miles

UTM Coordinate Location: Zone 18, 4472487 m N, 0264406 m E

Location Information: Tuscarora State Forest, parked vehicle on Licking Creek Drive.

Bankfull Indicator(s): A change in slope along the north channel bank.

Bankfull Response Variables: Cross-sectional area (41.9 square feet), width (23.0 feet), mean depth (1.8 feet).

\section{Graph of Channel Cross-Section}

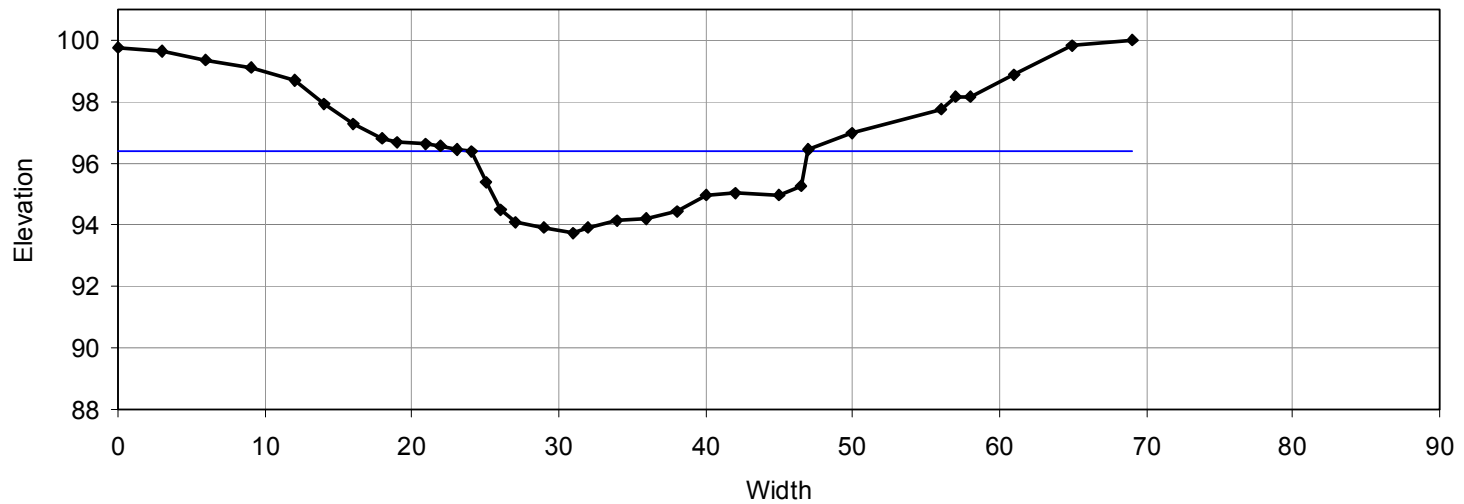

Survey Data

\begin{tabular}{|c|c|c|c|c|c|c|c|}
\hline $\begin{array}{c}\text { Horizontal } \\
\text { (feet) }\end{array}$ & $\begin{array}{c}\text { Vertical } \\
\text { (feet) }\end{array}$ & $\begin{array}{c}\text { Horizontal } \\
\text { (feet) }\end{array}$ & $\begin{array}{l}\begin{array}{l}\text { Vertical } \\
\text { (feet) }\end{array} \\
\end{array}$ & $\begin{array}{c}\text { Horizontal } \\
\text { (feet) }\end{array}$ & $\begin{array}{c}\text { Vertical } \\
\text { (feet) }\end{array}$ & $\begin{array}{c}\text { Horizontal } \\
\text { (feet) }\end{array}$ & $\begin{array}{c}\begin{array}{c}\text { Vertical } \\
\text { (feet) }\end{array} \\
\end{array}$ \\
\hline 0 & 0.22 & 26 & 5.49 & 56 & 2.25 & & \\
\hline 3 & 0.35 & 27 & 5.92 & 57 & 1.84 & & \\
\hline 6 & 0.63 & 29 & 6.07 & 58 & 1.84 & & \\
\hline 9 & 0.88 & 31 & 6.28 & 61 & 1.1 & & \\
\hline 12 & 1.32 & 32 & 6.09 & 65 & 0.2 & & \\
\hline 14 & 2.06 & 34 & 5.87 & 69 & 0 & & \\
\hline 16 & 2.72 & 36 & 5.82 & & & & \\
\hline 18 & 3.19 & 38 & 5.55 & & & & \\
\hline 19 & 3.31 & 40 & 5.01 & & & & \\
\hline 21 & 3.35 & 42 & 4.99 & & & & \\
\hline 22 & 3.41 & 45 & 5.01 & & & & \\
\hline 23 & 3.53 & 46.5 & 4.73 & & & & \\
\hline $24^{*}$ & $3.63^{*}$ & 47 & 3.57 & & & & \\
\hline 25 & 4.6 & 50 & 2.99 & & & & \\
\hline
\end{tabular}




\section{West Licking Creek}

Date of Survey: May 18, 2007

Reach \#: 32-B
Time of Survey: 4:32 pm

Drainage Area: 6:15 sq. miles

UTM Coordinate Location: Zone 18, 4472488 m N, 0264386 m E

Location Information: Tuscarora State Forest, parked vehicle on Licking Creek Drive. Reach located downstream of 32-A.

Bankfull Indicator(s): A change in slope along the south channel bank.

Bankfull Response Variables: Cross-sectional area (48.8 square feet), width (24.6 feet), mean depth (2.0 feet).

\section{Graph of Channel Cross-Section}

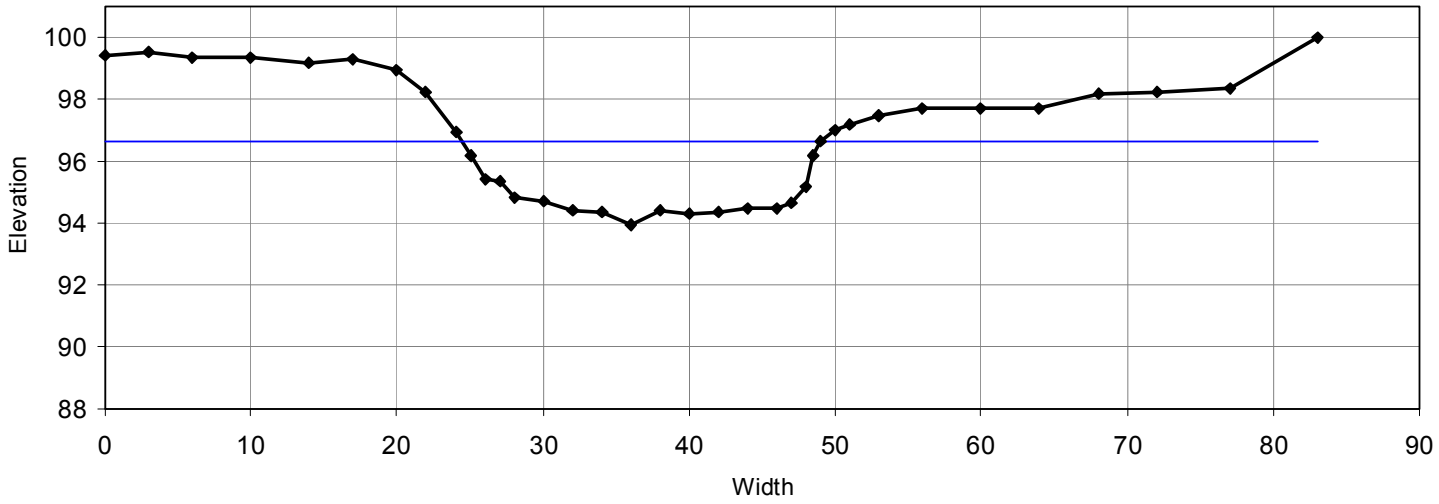

$\underline{\text { Survey Data }}$

\begin{tabular}{|c|c|c|c|c|c|c|c|}
\hline $\begin{array}{c}\text { Horizontal } \\
\text { (feet) }\end{array}$ & $\begin{array}{c}\text { Vertical } \\
\text { (feet) }\end{array}$ & $\begin{array}{c}\text { Horizontal } \\
\text { (feet) }\end{array}$ & $\begin{array}{l}\text { Vertical } \\
\text { (feet) }\end{array}$ & $\begin{array}{c}\text { Horizontal } \\
\text { (feet) }\end{array}$ & $\begin{array}{c}\text { Vertical } \\
\text { (feet) }\end{array}$ & $\begin{array}{c}\text { Horizontal } \\
\text { (feet) }\end{array}$ & $\begin{array}{c}\text { Vertical } \\
\text { (feet) }\end{array}$ \\
\hline 0 & 0.6 & 32 & 5.59 & 53 & 2.51 & & \\
\hline 3 & 0.48 & 34 & 5.67 & 56 & 2.28 & & \\
\hline 6 & 0.67 & 36 & 6.03 & 60 & 2.31 & & \\
\hline 10 & 0.65 & 38 & 5.61 & 64 & 2.29 & & \\
\hline 14 & 0.8 & 40 & 5.69 & 68 & 1.83 & & \\
\hline 17 & 0.69 & 42 & 5.63 & 72 & 1.78 & & \\
\hline 20 & 1.07 & 44 & 5.52 & 77 & 1.63 & & \\
\hline 22 & 1.78 & 46 & 5.55 & 83 & 0 & & \\
\hline 24 & 3.04 & 47 & 5.38 & & & & \\
\hline 25 & 3.81 & 48 & 4.85 & & & & \\
\hline 26 & 4.58 & 48.5 & 3.83 & & & & \\
\hline 27 & 4.64 & $49^{*}$ & $3.35^{*}$ & & & & \\
\hline 28 & 5.19 & 50 & 3.01 & & & & \\
\hline 30 & 5.28 & 51 & 2.84 & & & & \\
\hline
\end{tabular}




\section{West Licking Creek}

Date of Survey: May 19, 2007

Reach \#: 33-A
Time of Survey: 10:05 am

Drainage Area: 7.46 sq. miles

UTM Coordinate Location: Zone 18, 4471458 m N, 0263238 m E

Location Information: Tuscarora State Forest, parked vehicle on Licking Creek Drive.

Bankfull Indicator(s): A change in slope along the west channel bank.

Bankfull Response Variables: Cross-sectional area (45.5 square feet), width (26.9 feet), mean depth (1.7 feet).

\section{Graph of Channel Cross-Section}

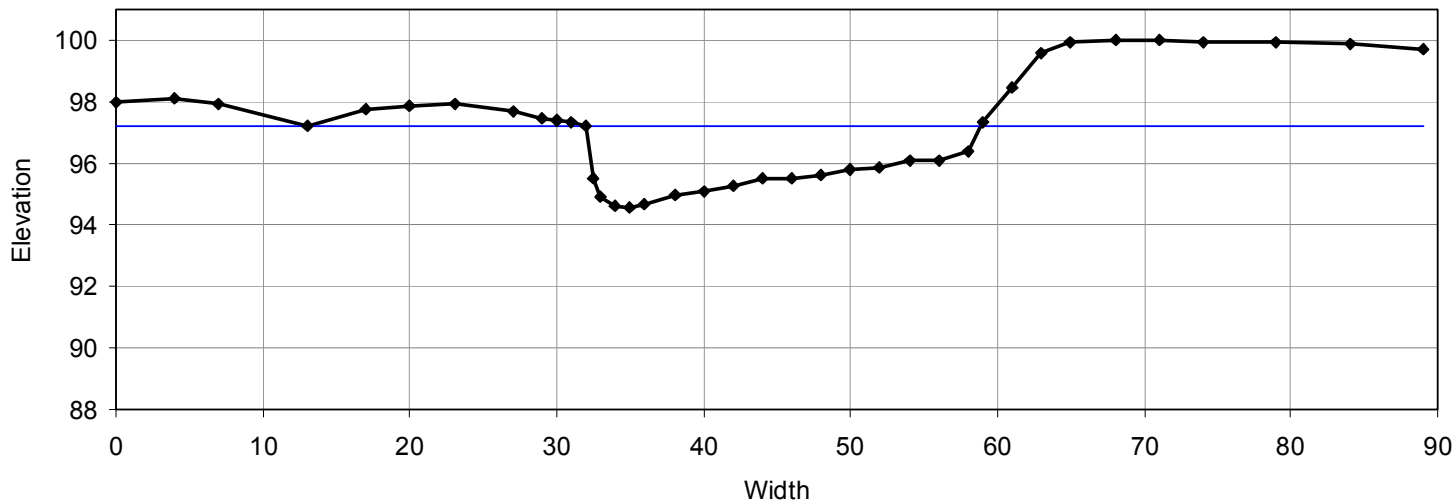

$\underline{\text { Survey Data }}$

\begin{tabular}{|c|c|c|c|c|c|c|c|}
\hline $\begin{array}{c}\text { Horizontal } \\
\text { (feet) }\end{array}$ & $\begin{array}{c}\text { Vertical } \\
\text { (feet) }\end{array}$ & $\begin{array}{c}\text { Horizontal } \\
\text { (feet) }\end{array}$ & $\begin{array}{l}\begin{array}{l}\text { Vertical } \\
\text { (feet) }\end{array} \\
\end{array}$ & $\begin{array}{c}\text { Horizontal } \\
\text { (feet) }\end{array}$ & $\begin{array}{c}\text { Vertical } \\
\text { (feet) }\end{array}$ & $\begin{array}{c}\text { Horizontal } \\
\text { (feet) }\end{array}$ & $\begin{array}{c}\begin{array}{c}\text { Vertical } \\
\text { (feet) }\end{array} \\
\end{array}$ \\
\hline 0 & 2.04 & 34 & 5.41 & 59 & 2.68 & & \\
\hline 4 & 1.87 & 35 & 5.43 & 61 & 1.53 & & \\
\hline 7 & 2.06 & 36 & 5.35 & 63 & 0.42 & & \\
\hline 13 & 2.81 & 38 & 5.04 & 65 & 0.04 & & \\
\hline 17 & 2.27 & 40 & 4.93 & 68 & 0.03 & & \\
\hline 20 & 2.14 & 42 & 4.71 & 71 & 0 & & \\
\hline 23 & 2.08 & 44 & 4.49 & 74 & 0.06 & & \\
\hline 27 & 2.31 & 46 & 4.47 & 79 & 0.08 & & \\
\hline 29 & 2.55 & 48 & 4.39 & 84 & 0.13 & & \\
\hline 30 & 2.61 & 50 & 4.19 & 89 & 0.32 & & \\
\hline 31 & 2.68 & 52 & 4.16 & & & & \\
\hline $32^{*}$ & 2.79* & 54 & 3.93 & & & & \\
\hline 32.5 & 4.47 & 56 & 3.92 & & & & \\
\hline 33 & 5.11 & 58 & 3.59 & & & & \\
\hline
\end{tabular}




\section{West Licking Creek}

Date of Survey: May 19, 2007

Reach \#: 33-B
Time of Survey: 10:19 am

Drainage Area: 7.46 sq. miles

UTM Coordinate Location: Zone 18, $4471472 \mathrm{~m} \mathrm{~N}, 0263238 \mathrm{~m} \mathrm{E}$

Location Information: Tuscarora State Forest, parked vehicle on Licking Creek Drive. Reach located approximately 100 feet upstream of 33-A.

Bankfull Indicator(s): A change in slope along the west channel bank.

Bankfull Response Variables: Cross-sectional area (54.8 square feet), width (30.3 feet), mean depth (1.8 feet).

\section{Graph of Channel Cross-Section}

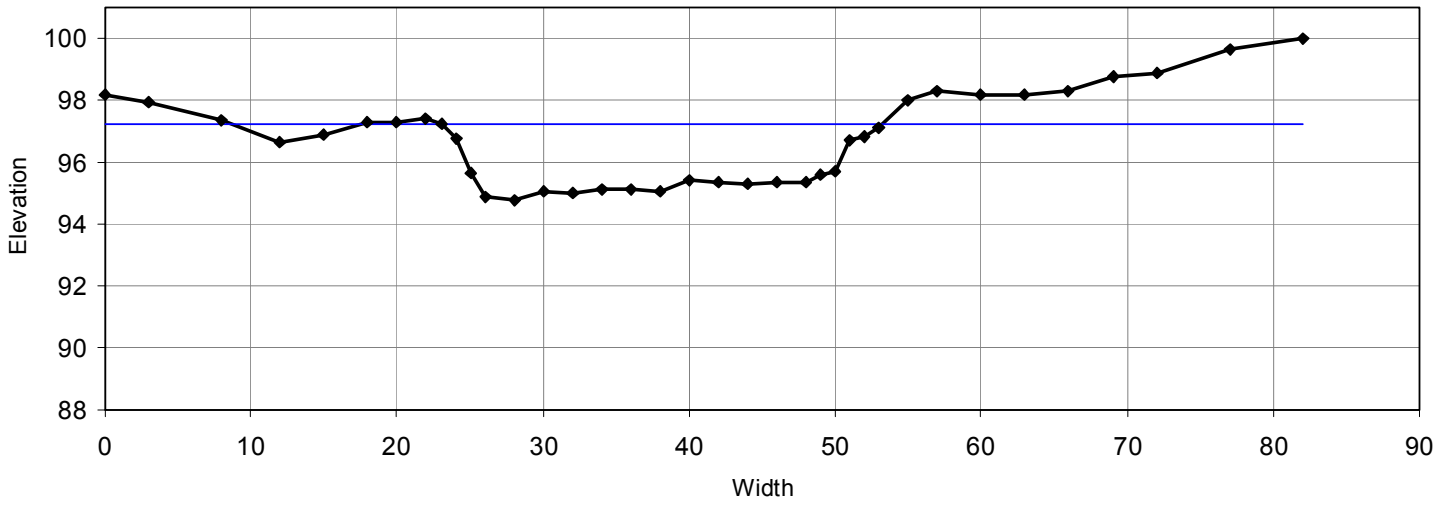

Survey Data

\begin{tabular}{|c|c|c|c|c|c|c|c|}
\hline $\begin{array}{c}\text { Horizontal } \\
\text { (feet) }\end{array}$ & $\begin{array}{c}\text { Vertical } \\
\text { (feet) }\end{array}$ & $\begin{array}{c}\text { Horizontal } \\
\text { (feet) }\end{array}$ & $\begin{array}{c}\begin{array}{c}\text { Vertical } \\
\text { (feet) }\end{array} \\
\end{array}$ & $\begin{array}{c}\text { Horizontal } \\
\text { (feet) }\end{array}$ & $\begin{array}{c}\text { Vertical } \\
\text { (feet) }\end{array}$ & $\begin{array}{c}\text { Horizontal } \\
\text { (feet) }\end{array}$ & $\begin{array}{c}\begin{array}{c}\text { Vertical } \\
\text { (feet) }\end{array} \\
\end{array}$ \\
\hline 0 & 1.8 & 32 & 5.02 & 55 & 2 & & \\
\hline 3 & 2.07 & 34 & 4.87 & 57 & 1.71 & & \\
\hline 8 & 2.63 & 36 & 4.87 & 60 & 1.8 & & \\
\hline 12 & 3.34 & 38 & 4.94 & 63 & 1.84 & & \\
\hline 15 & 3.13 & 40 & 4.59 & 66 & 1.72 & & \\
\hline 18 & 2.71 & 42 & 4.65 & 69 & 1.24 & & \\
\hline 20 & 2.69 & 44 & 4.71 & 72 & 1.13 & & \\
\hline 22 & 2.56 & 46 & 4.64 & 77 & 0.36 & & \\
\hline $23^{*}$ & $2.75^{*}$ & 48 & 4.66 & 82 & 0 & & \\
\hline 24 & 3.22 & 49 & 4.44 & & & & \\
\hline 25 & 4.34 & 50 & 4.31 & & & & \\
\hline 26 & 5.11 & 51 & 3.29 & & & & \\
\hline 28 & 5.26 & 52 & 3.2 & & & & \\
\hline 30 & 4.94 & 53 & 2.88 & & & & \\
\hline
\end{tabular}




\section{West Licking Creek}

Date of Survey: May 19, 2007

Reach \#: 34-A
Time of Survey: 11:43 am

Drainage Area: 10.1 sq. miles

UTM Coordinate Location: Zone 18, 4469927 m N, 0260738 m E

Location Information: Tuscarora State Forest, parked vehicle on Black Log Road.

Bankfull Indicator(s): A change in slope along the east to southeast channel bank.

Bankfull Response Variables: Cross-sectional area (71.3 square feet), width (26.5 feet), mean depth (2.0 feet).

\section{Graph of Channel Cross-Section}

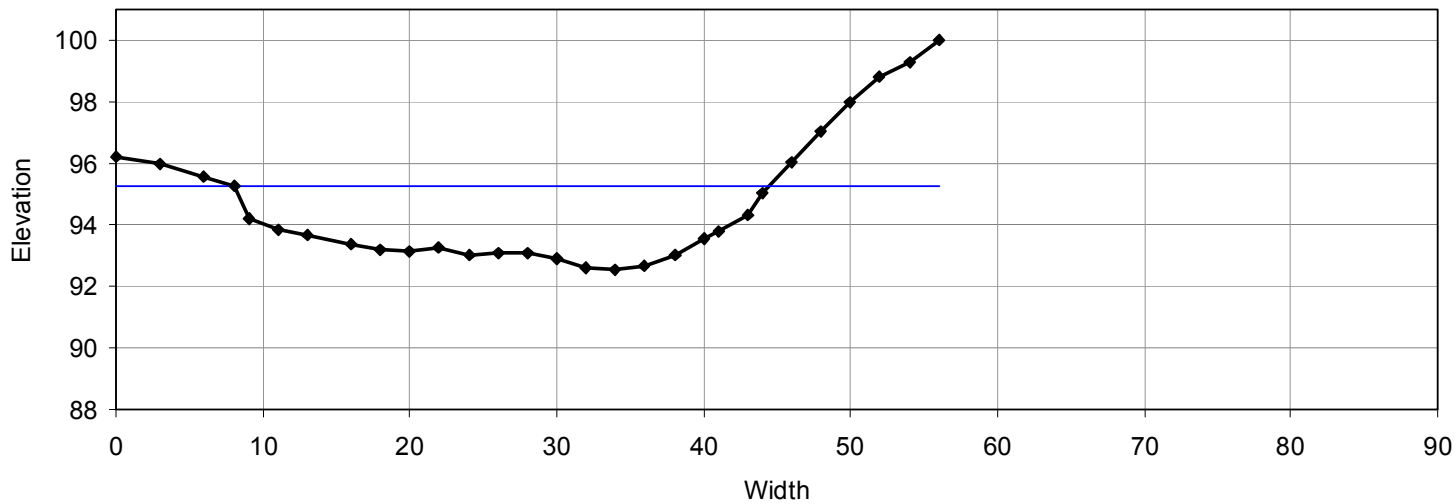

Survey Data

\begin{tabular}{|c|c|c|c|c|c|c|c|}
\hline $\begin{array}{c}\text { Horizontal } \\
\text { (feet) }\end{array}$ & $\begin{array}{c}\text { Vertical } \\
\text { (feet) }\end{array}$ & $\begin{array}{c}\text { Horizontal } \\
\text { (feet) }\end{array}$ & $\begin{array}{l}\begin{array}{l}\text { Vertical } \\
\text { (feet) }\end{array} \\
\end{array}$ & $\begin{array}{c}\text { Horizontal } \\
\text { (feet) }\end{array}$ & $\begin{array}{c}\text { Vertical } \\
\text { (feet) }\end{array}$ & $\begin{array}{c}\text { Horizontal } \\
\text { (feet) }\end{array}$ & $\begin{array}{c}\begin{array}{c}\text { Vertical } \\
\text { (feet) }\end{array} \\
\end{array}$ \\
\hline 0 & 3.77 & 30 & 7.12 & 56 & 0 & & \\
\hline 3 & 4.01 & 32 & 7.4 & & & & \\
\hline 6 & 4.45 & 34 & 7.45 & & & & \\
\hline $8^{*}$ & $4.71^{*}$ & 36 & 7.36 & & & & \\
\hline 9 & 5.77 & 38 & 6.96 & & & & \\
\hline 11 & 6.16 & 40 & 6.45 & & & & \\
\hline 13 & 6.32 & 41 & 6.23 & & & & \\
\hline 16 & 6.64 & 43 & 5.69 & & & & \\
\hline 18 & 6.82 & 44 & 4.99 & & & & \\
\hline 20 & 6.87 & 46 & 3.95 & & & & \\
\hline 22 & 6.77 & 48 & 2.96 & & & & \\
\hline 24 & 6.96 & 50 & 2.02 & & & & \\
\hline 26 & 6.89 & 52 & 1.16 & & & & \\
\hline 28 & 6.91 & 54 & 0.7 & & & & \\
\hline
\end{tabular}




\section{West Licking Creek}

Date of Survey: May 19, 2007

Reach \#: $34-B$
Time of Survey: 11:57 am

Drainage Area: 10.1 sq. miles

UTM Coordinate Location: Zone 18, 4469916 m N, $0260751 \mathrm{~m} \mathrm{E}$

Location Information: Tuscarora State Forest, parked vehicle on Black Log Road.

Reach located approximately 150 feet upstream of 34-A.

Bankfull Indicator(s): A change in slope along the east to southeast channel bank.

Bankfull Response Variables: Cross-sectional area (52.9 square feet), width (32.9 feet), mean depth (1.6 feet).

\section{Graph of Channel Cross-Section}

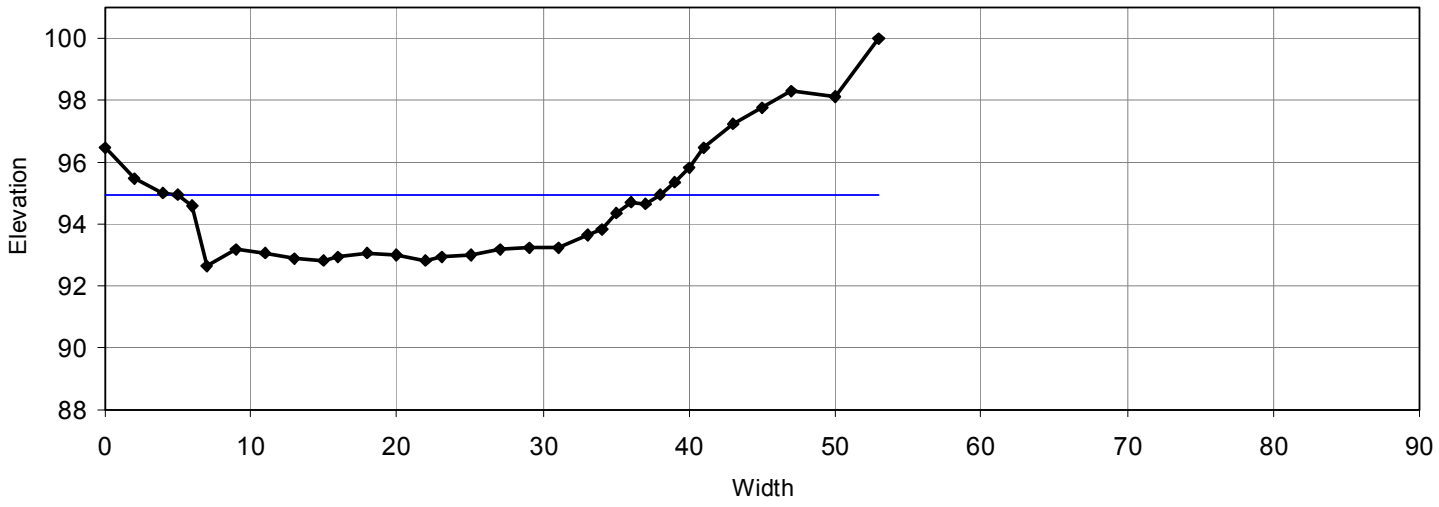

$\underline{\text { Survey Data }}$

\begin{tabular}{|c|c|c|c|c|c|c|c|}
\hline $\begin{array}{c}\text { Horizontal } \\
\text { (feet) }\end{array}$ & $\begin{array}{c}\text { Vertical } \\
\text { (feet) }\end{array}$ & $\begin{array}{c}\text { Horizontal } \\
\text { (feet) }\end{array}$ & $\begin{array}{c}\begin{array}{l}\text { Vertical } \\
\text { (feet) }\end{array} \\
\end{array}$ & $\begin{array}{c}\text { Horizontal } \\
\text { (feet) }\end{array}$ & $\begin{array}{c}\text { Vertical } \\
\text { (feet) }\end{array}$ & $\begin{array}{c}\text { Horizontal } \\
\text { (feet) }\end{array}$ & $\begin{array}{c}\begin{array}{c}\text { Vertical } \\
\text { (feet) }\end{array} \\
\end{array}$ \\
\hline 0 & 3.51 & 23 & 7.07 & 43 & 2.75 & & \\
\hline 2 & 4.55 & 25 & 7 & 45 & 2.21 & & \\
\hline 4 & 5.02 & 27 & 6.82 & 47 & 1.71 & & \\
\hline $5^{*}$ & $5.08^{*}$ & 29 & 6.75 & 50 & 1.91 & & \\
\hline 6 & 5.44 & 31 & 6.76 & 53 & 0 & & \\
\hline 7 & 7.37 & 33 & 6.34 & & & & \\
\hline 9 & 6.84 & 34 & 6.15 & & & & \\
\hline 11 & 6.97 & 35 & 5.67 & & & & \\
\hline 13 & 7.1 & 36 & 5.29 & & & & \\
\hline 15 & 7.16 & 37 & 5.34 & & & & \\
\hline 16 & 7.08 & 38 & 5.05 & & & & \\
\hline 18 & 6.94 & 39 & 4.67 & & & & \\
\hline 20 & 6.98 & 40 & 4.2 & & & & \\
\hline 22 & 7.16 & 41 & 3.52 & & & & \\
\hline
\end{tabular}




\section{Appendix 2. Riffle bedload sediment characteristics in lithologically controlled}

watersheds.

Bedload pebble-counts data are shown below, along with brief descriptions of bedload sediments, including the dominant lithology in the measured riffle and the dominant clast geometry. Cumulative frequency distribution data for each riffle were used to calculate mean particle size (D50) and mean particle size plus one standard deviation (D84). 


\section{South Branch Little Aughwick Creek}

Reach \#: $1 \quad$ UTM Location: Zone 18, $4425800 \mathrm{~m} \mathrm{~N}, 0247461 \mathrm{~m} \mathrm{E}$

Composition of Bedload: Consists largely of sub-rounded clasts of sandstone and sand grains. Sandstone is very clean, likely a quartz arenite.

Bedload Textures: D50 $=9.0 \mathrm{~mm}, \mathrm{D} 84=76.0 \mathrm{~mm}$

Cumulative Frequency Distribution

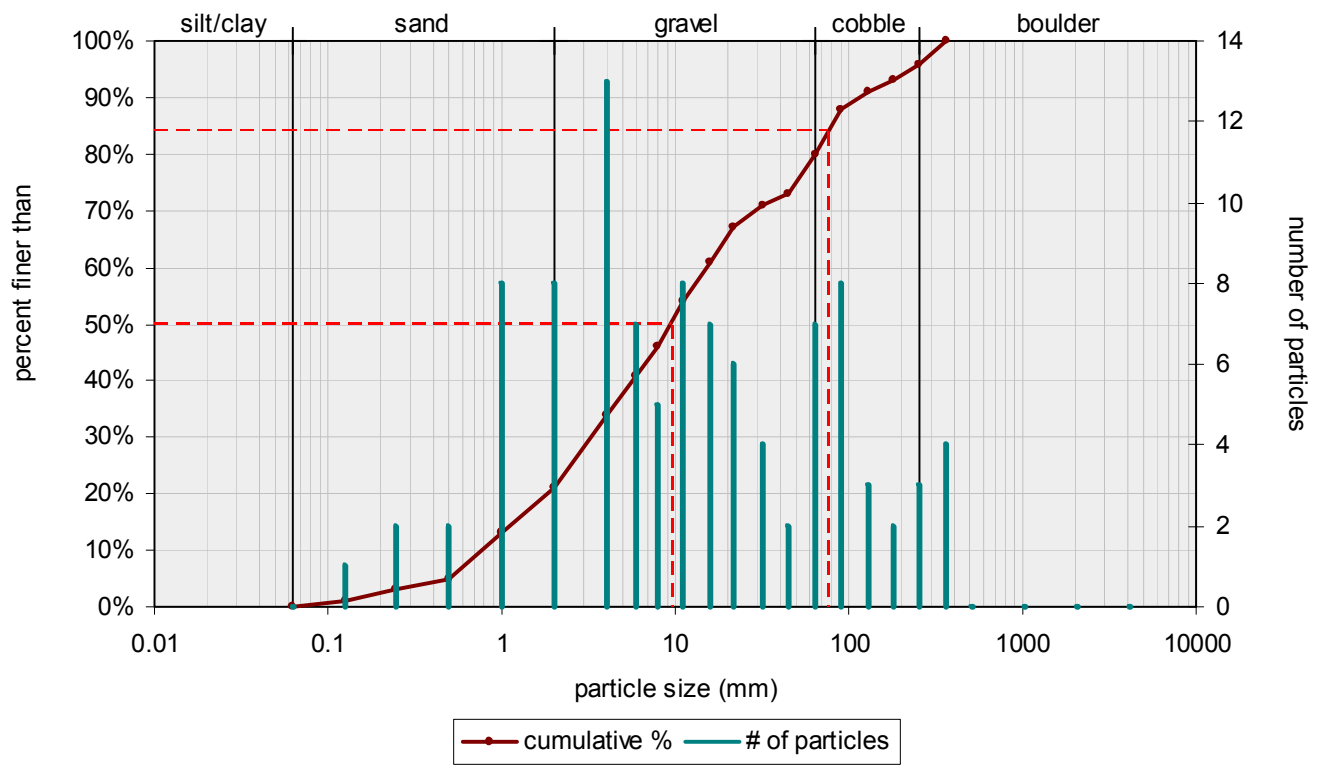

Pebble Count Data

\begin{tabular}{|c|c|c|c|c|c|c|c|c|c|c|c|}
\hline \# & Texture & \# & Texture & \# & Texture & \# & Texture & \# & Texture & \# & Texture \\
\hline 1 & 6 & 18 & 65 & 35 & 5 & 52 & 0.5 & 69 & 8 & 86 & 1 \\
\hline 2 & 16 & 19 & 320 & 36 & 13 & 53 & 87 & 70 & 5 & 87 & 194 \\
\hline 3 & 9 & 20 & 1 & 37 & 0.125 & 54 & 0.5 & 71 & 11 & 88 & 8 \\
\hline 4 & 9 & 21 & 65 & 38 & 58 & 55 & 27 & 72 & 2 & 89 & 0.5 \\
\hline 5 & 3 & 22 & 11 & 39 & 73 & 56 & 78 & 73 & 1 & 90 & 0.5 \\
\hline 6 & 0.062 & 23 & 2 & 40 & 1 & 57 & 1 & 74 & 14 & 91 & 0.25 \\
\hline 7 & 4 & 24 & 3 & 41 & 143 & 58 & 73 & 75 & 20 & 92 & 1 \\
\hline 8 & 2 & 25 & 9 & 42 & 143 & 59 & 63 & 76 & 10 & 93 & 37 \\
\hline 9 & 74 & 26 & 0.5 & 43 & 47 & 60 & 190 & 77 & 6 & 94 & 25 \\
\hline 10 & 63 & 27 & 101 & 44 & 3 & 61 & 8 & 78 & 5 & 95 & 23 \\
\hline 11 & 20 & 28 & 98 & 45 & 2 & 62 & 15 & 79 & 3 & 96 & 210 \\
\hline 12 & 37 & 29 & 2 & 46 & 3 & 63 & 0.5 & 80 & 0.5 & 97 & 310 \\
\hline 13 & 62 & 30 & 320 & 47 & 1 & 64 & 23 & 81 & 73 & 98 & 350 \\
\hline 14 & 7 & 31 & 122 & 48 & 0.5 & 65 & 4 & 82 & 13 & 99 & 3 \\
\hline 15 & 17 & 32 & 16 & 49 & 0.125 & 66 & 9 & 83 & 5 & 100 & 2 \\
\hline 16 & 54 & 33 & 1 & 50 & 0.25 & 67 & 13 & 84 & 6 & & \\
\hline 17 & 54 & 34 & 6 & 51 & 5 & 68 & 16 & 85 & 2 & & \\
\hline
\end{tabular}




\section{South Branch Little Aughwick Creek}

Reach \#: 2 UTM Location: Zone 18, $4427256 \mathrm{~m} \mathrm{~N}, 0247978 \mathrm{~m} \mathrm{E}$

Composition of Bedload: Consists largely of sub-rounded clasts of quartz sandstone, point bar composed of sand grains developing in riffle.

Bedload Textures: D50 $=50.0 \mathrm{~mm}, \mathrm{D} 84=130.0 \mathrm{~mm}$

Cumulative Frequency Distribution

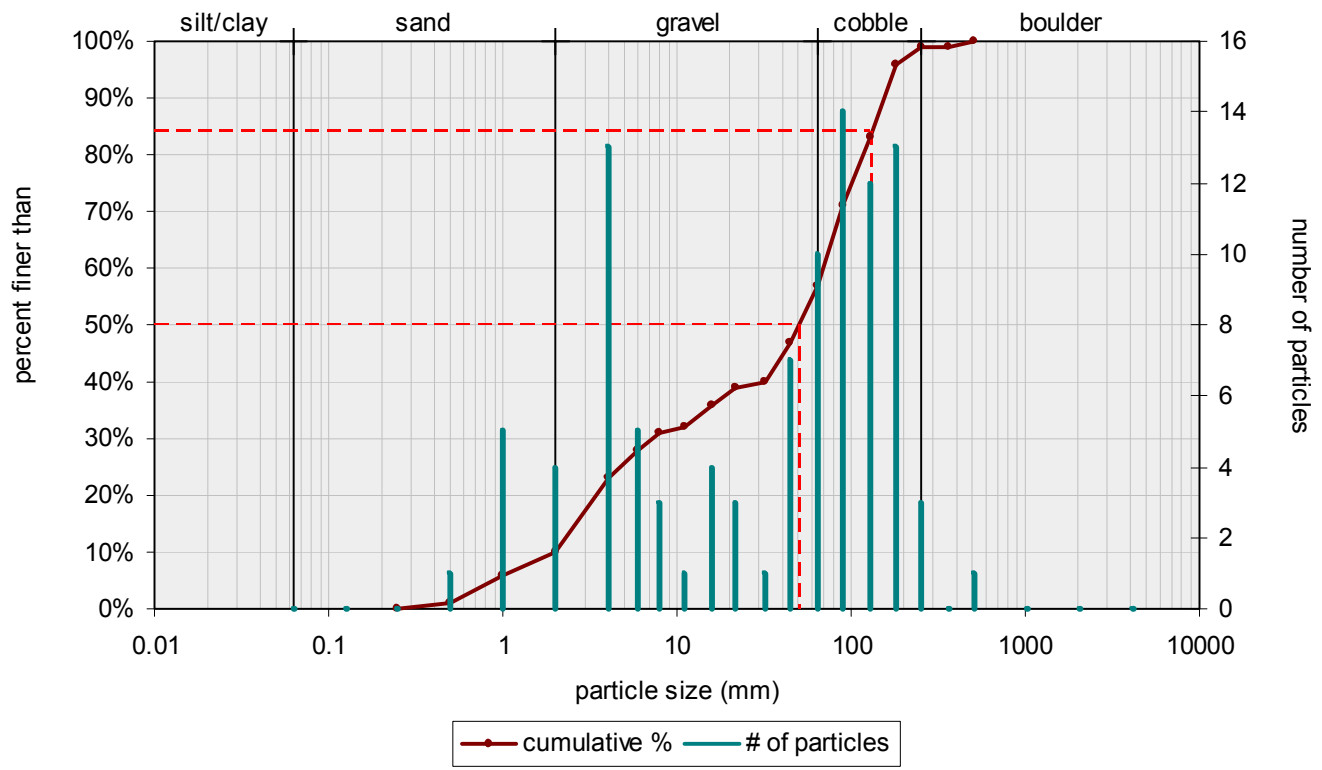

Pebble Count Data

\begin{tabular}{|c|c|c|c|c|c|c|c|c|c|c|c|}
\hline \# & Texture & $\#$ & Texture & $\#$ & Texture & $\#$ & Texture & $\#$ & Texture & \# & Texture \\
\hline 1 & 142 & 18 & 93 & 35 & 430 & 52 & 2 & 69 & 141 & 86 & 71 \\
\hline 2 & 81 & 19 & 2 & 36 & 86 & 53 & 70 & 70 & 172 & 87 & 233 \\
\hline 3 & 6 & 20 & 127 & 37 & 2 & 54 & 123 & 71 & 61 & 88 & 47 \\
\hline 4 & 2 & 21 & 61 & 38 & 145 & 55 & 128 & 72 & 57 & 89 & 161 \\
\hline 5 & 11 & 22 & 112 & 39 & 110 & 56 & 130 & 73 & 6 & 90 & 5 \\
\hline 6 & 33 & 23 & 66 & 40 & 127 & 57 & 2 & 74 & 3 & 91 & 90 \\
\hline 7 & 0.5 & 24 & 145 & 41 & 97 & 58 & 1 & 75 & 1 & 92 & 4 \\
\hline 8 & 0.25 & 25 & 79 & 42 & 49 & 59 & 3 & 76 & 46 & 93 & 12 \\
\hline 9 & 0.5 & 26 & 2 & 43 & 34 & 60 & 4 & 77 & 86 & 94 & 13 \\
\hline 10 & 0.5 & 27 & 39 & 44 & 4 & 61 & 79 & 78 & 181 & 95 & 190 \\
\hline 11 & 133 & 28 & 17 & 45 & 7 & 62 & 5 & 79 & 83 & 96 & 137 \\
\hline 12 & 2 & 29 & 2 & 46 & 36 & 63 & 67 & 80 & 1 & 97 & 19 \\
\hline 13 & 3 & 30 & 39 & 47 & 11 & 64 & 0.5 & 81 & 0.5 & 98 & 2 \\
\hline 14 & 146 & 31 & 66 & 48 & 88 & 65 & 52 & 82 & 1 & 99 & 59 \\
\hline 15 & 46 & 32 & 115 & 49 & 9 & 66 & 2 & 83 & 64 & 100 & 33 \\
\hline 16 & 16 & 33 & 130 & 50 & 52 & 67 & 155 & 84 & 83 & & \\
\hline 17 & 102 & 34 & 117 & 51 & 99 & 68 & 27 & 85 & 40 & & \\
\hline
\end{tabular}




\section{South Branch Little Aughwick Creek}

Reach \#: $3 \quad$ UTM Location: Zone 18, $4429065 \mathrm{~m} \mathrm{~N}, 0248752 \mathrm{~m} \mathrm{E}$

\section{Composition of Bedload: N/A}

Bedload Textures: D50 $=45.0 \mathrm{~mm}, \mathrm{D} 84=130.0 \mathrm{~mm}$

\section{Cumulative Frequency Distribution}

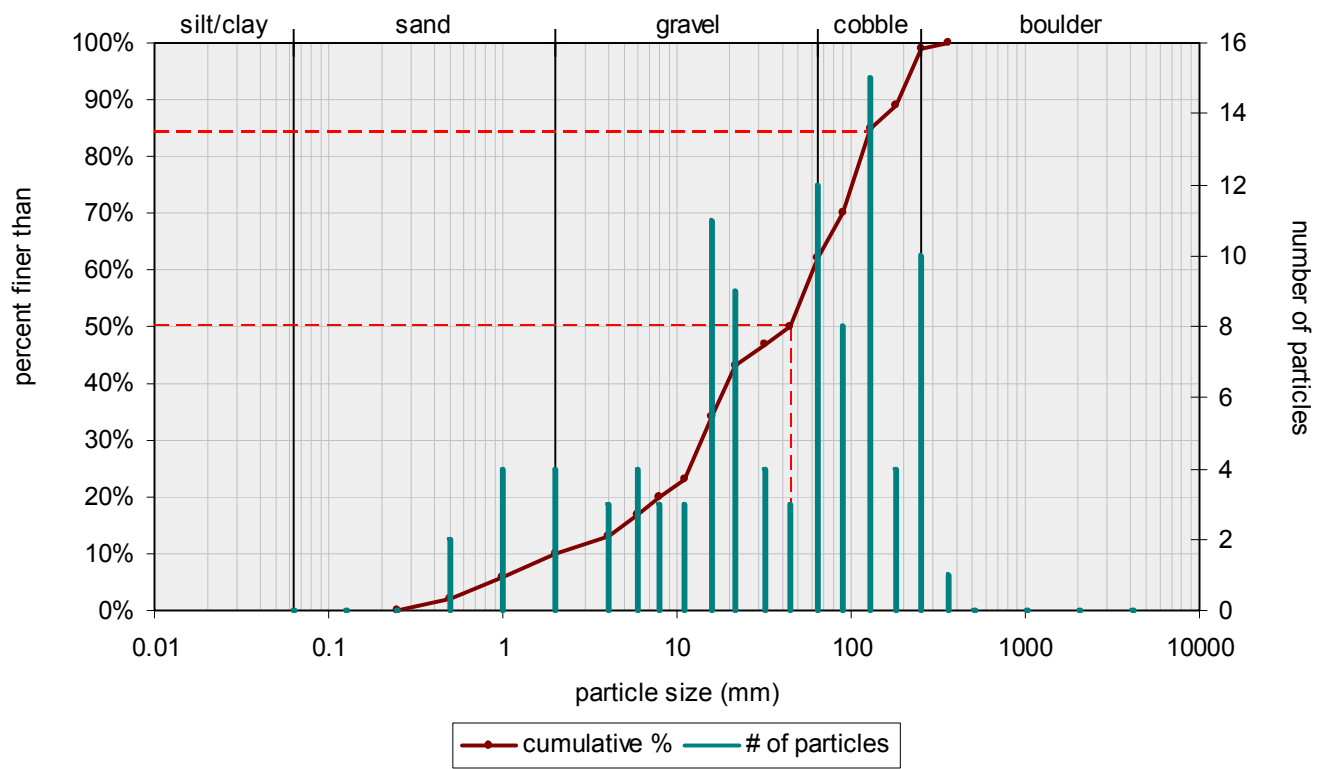

\section{Pebble Count Data}

\begin{tabular}{|c|c|c|c|c|c|c|c|c|c|c|c|}
\hline \# & Texture & $\#$ & Texture & \# & Texture & \# & Texture & \# & Texture & $\#$ & Texture \\
\hline 1 & 1 & 18 & 54 & 35 & 116 & 52 & 13 & 69 & 11 & 86 & 21 \\
\hline 2 & 110 & 19 & 107 & 36 & 2 & 53 & 12 & 70 & 111 & 87 & 225 \\
\hline 3 & 72 & 20 & 0.5 & 37 & 14 & 54 & 199 & 71 & 116 & 88 & 54 \\
\hline 4 & 7 & 21 & 77 & 38 & 46 & 55 & 0.5 & 72 & 47 & 89 & 20 \\
\hline 5 & 4 & 22 & 92 & 39 & 5 & 56 & 63 & 73 & 78 & 90 & 76 \\
\hline 6 & 14 & 23 & 192 & 40 & 49 & 57 & 13 & 74 & 9 & 91 & 171 \\
\hline 7 & 24 & 24 & 122 & 41 & 91 & 58 & 5 & 75 & 7 & 92 & 80 \\
\hline 8 & 11 & 25 & 6 & 42 & 1 & 59 & 29 & 76 & 208 & 93 & 114 \\
\hline 9 & 46 & 26 & 17 & 43 & 1 & 60 & 17 & 77 & 92 & 94 & 55 \\
\hline 10 & 72 & 27 & 11 & 44 & 66 & 61 & 3 & 78 & 182 & 95 & 163 \\
\hline 11 & 0.5 & 28 & 14 & 45 & 74 & 62 & 97 & 79 & 19 & 96 & 44 \\
\hline 12 & 44 & 29 & 8 & 46 & 106 & 63 & 196 & 80 & 14 & 97 & 19 \\
\hline 13 & 189 & 30 & 17 & 47 & 120 & 64 & 62 & 81 & 144 & 98 & 0.5 \\
\hline 14 & 19 & 31 & 215 & 48 & 59 & 65 & 118 & 82 & 12 & 99 & 243 \\
\hline 15 & 39 & 32 & 3 & 49 & 133 & 66 & 1 & 83 & 8 & 100 & 0.25 \\
\hline 16 & 121 & 33 & 0.25 & 50 & 262 & 67 & 55 & 84 & 19 & & \\
\hline 17 & 52 & 34 & 215 & 51 & 26 & 68 & 5 & 85 & 22 & & \\
\hline
\end{tabular}




\section{South Branch Little Aughwick Creek}

Reach \#: $4 \quad$ UTM Location: Zone 18, 4429825 m N, $0249153 \mathrm{~m} \mathrm{E}$

Composition of Bedload: Consists of tan to red sub-rounded clasts of quartz sandstone, some clasts have a tabular geometry.

Bedload Textures: D50 $=23.0 \mathrm{~mm}, \mathrm{D} 84=83.0 \mathrm{~mm}$

Cumulative Frequency Distribution

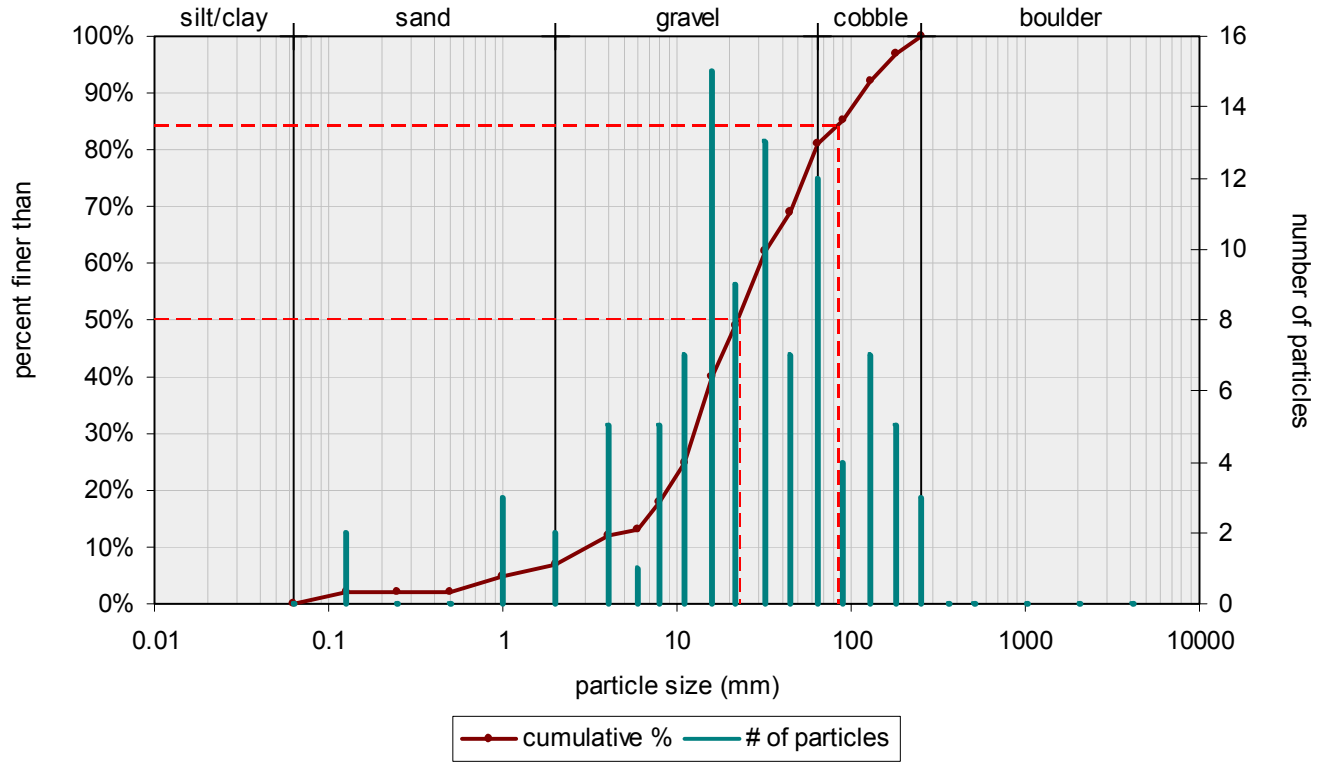

Pebble Count Data

\begin{tabular}{|c|c|c|c|c|c|c|c|c|c|c|c|}
\hline \# & Texture & $\#$ & Texture & $\#$ & Texture & \# & Texture & \# & Texture & $\#$ & Texture \\
\hline 1 & 14 & 18 & 14 & 35 & 0.062 & 52 & 16 & 69 & 0.5 & 86 & 17 \\
\hline 2 & 115 & 19 & 36 & 36 & 20 & 53 & 15 & 70 & 52 & 87 & 16 \\
\hline 3 & 43 & 20 & 102 & 37 & 14 & 54 & 11 & 71 & 34 & 88 & 68 \\
\hline 4 & 142 & 21 & 12 & 38 & 6 & 55 & 94 & 72 & 49 & 89 & 22 \\
\hline 5 & 7 & 22 & 33 & 39 & 8 & 56 & 81 & 73 & 45 & 90 & 98 \\
\hline 6 & 26 & 23 & 36 & 40 & 27 & 57 & 24 & 74 & 141 & 91 & 19 \\
\hline 7 & 27 & 24 & 11 & 41 & 6 & 58 & 0.062 & 75 & 112 & 92 & 23 \\
\hline 8 & 21 & 25 & 21 & 42 & 9 & 59 & 2 & 76 & 152 & 93 & 47 \\
\hline 9 & 9 & 26 & 192 & 43 & 12 & 60 & 48 & 77 & 55 & 94 & 17 \\
\hline 10 & 22 & 27 & 49 & 44 & 109 & 61 & 47 & 78 & 2 & 95 & 8 \\
\hline 11 & 237 & 28 & 13 & 45 & 152 & 62 & 9 & 79 & 2 & 96 & 1 \\
\hline 12 & 0.5 & 29 & 8 & 46 & 23 & 63 & 7 & 80 & 13 & 97 & 37 \\
\hline 13 & 15 & 30 & 24 & 47 & 172 & 64 & 1 & 81 & 12 & 98 & 121 \\
\hline 14 & 79 & 31 & 77 & 48 & 36 & 65 & 58 & 82 & 11 & 99 & 2 \\
\hline 15 & 28 & 32 & 33 & 49 & 31 & 66 & 27 & 83 & 3 & 100 & 5 \\
\hline 16 & 45 & 33 & 7 & 50 & 11 & 67 & 17 & 84 & 0.5 & & \\
\hline 17 & 8 & 34 & 24 & 51 & 49 & 68 & 11 & 85 & 191 & & \\
\hline
\end{tabular}




\section{South Branch Little Aughwick Creek}

Reach \#: $5 \quad$ UTM Location: Zone 18, $4430706 \mathrm{~m} \mathrm{~N}, 0249706 \mathrm{~m} \mathrm{E}$

Composition of Bedload: Consists of tan to red sub-rounded clasts of quartz sandstone, some clasts have a tabular geometry.

Bedload Textures: D50 $=43.0 \mathrm{~mm}, \mathrm{D} 84=160.0 \mathrm{~mm}$

Cumulative Frequency Distribution

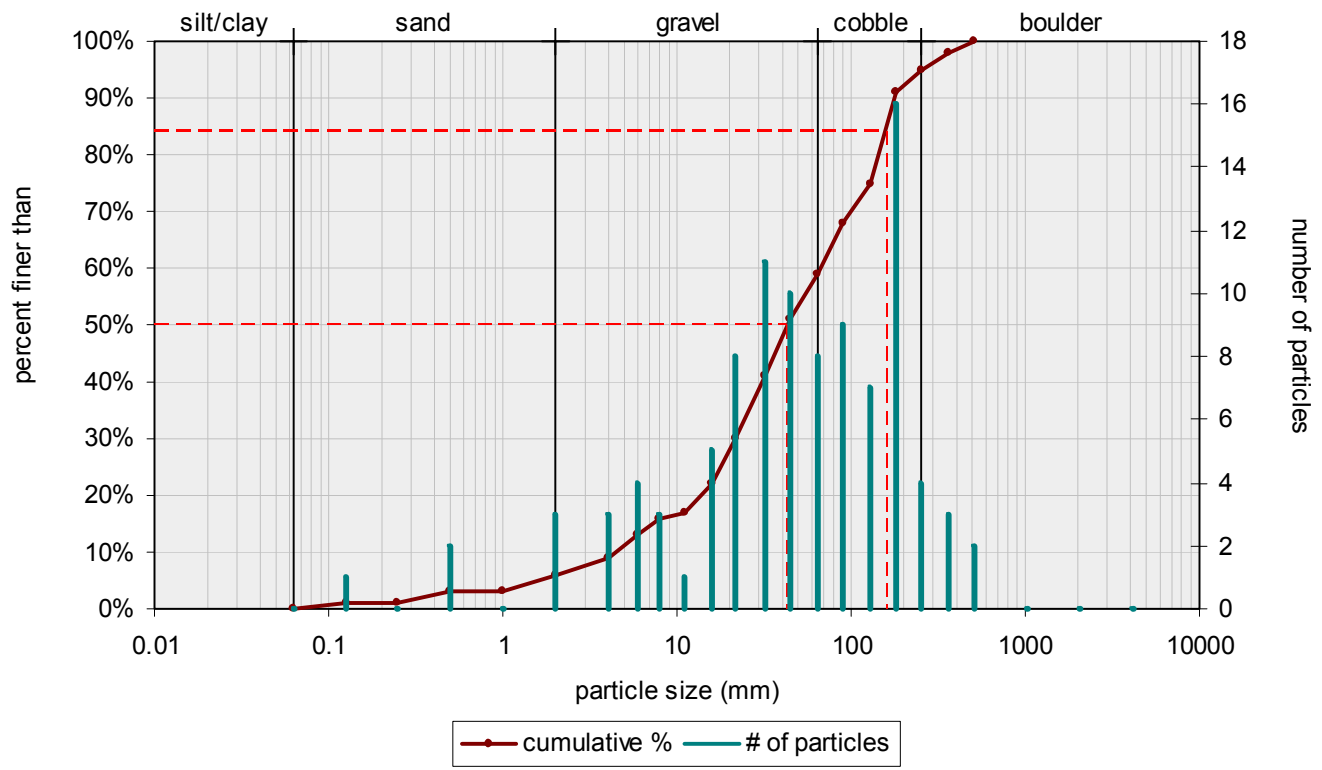

Pebble Count Data

\begin{tabular}{|c|c|c|c|c|c|c|c|c|c|c|c|}
\hline \# & Texture & $\#$ & Texture & $\#$ & Texture & \# & Texture & \# & Texture & $\#$ & Texture \\
\hline 1 & 135 & 18 & 122 & 35 & 117 & 52 & 141 & 69 & 7 & 86 & 44 \\
\hline 2 & 33 & 19 & 138 & 36 & 217 & 53 & 72 & 70 & 62 & 87 & 89 \\
\hline 3 & 19 & 20 & 145 & 37 & 178 & 54 & 364 & 71 & 71 & 88 & 3 \\
\hline 4 & 21 & 21 & 6 & 38 & 98 & 55 & 221 & 72 & 151 & 89 & 107 \\
\hline 5 & 39 & 22 & 36 & 39 & 0.25 & 56 & 168 & 73 & 0.25 & 90 & 143 \\
\hline 6 & 26 & 23 & 12 & 40 & 391 & 57 & 142 & 74 & 89 & 91 & 229 \\
\hline 7 & 25 & 24 & 4 & 41 & 274 & 58 & 140 & 75 & 326 & 92 & 96 \\
\hline 8 & 45 & 25 & 49 & 42 & 23 & 59 & 14 & 76 & 122 & 93 & 77 \\
\hline 9 & 10 & 26 & 29 & 43 & 21 & 60 & 16 & 77 & 28 & 94 & 261 \\
\hline 10 & 18 & 27 & 49 & 44 & 32 & 61 & 11 & 78 & 170 & 95 & 1 \\
\hline 11 & 22 & 28 & 34 & 45 & 129 & 62 & 69 & 79 & 71 & 96 & 4 \\
\hline 12 & 1 & 29 & 41 & 46 & 89 & 63 & 39 & 80 & 19 & 97 & 132 \\
\hline 13 & 16 & 30 & 3 & 47 & 0.062 & 64 & 24 & 81 & 184 & 98 & 144 \\
\hline 14 & 39 & 31 & 4 & 48 & 24 & 65 & 4 & 82 & 27 & 99 & 133 \\
\hline 15 & 11 & 32 & 12 & 49 & 61 & 66 & 61 & 83 & 2 & 100 & 42 \\
\hline 16 & 147 & 33 & 29 & 50 & 47 & 67 & 19 & 84 & 1 & & \\
\hline 17 & 88 & 34 & 54 & 51 & 99 & 68 & 3 & 85 & 27 & & \\
\hline
\end{tabular}




\section{Sherman Creek}

Reach \#: $6 \quad$ UTM Location: Zone 18, $4459394 \mathrm{~m} \mathrm{~N}, 0276143 \mathrm{~m} \mathrm{E}$

Composition of Bedload: Consists of tan to brownish to orange sub-rounded clasts of sandstone.

Bedload Textures: D50 $=59.0 \mathrm{~mm}, \mathrm{D} 84=160.0 \mathrm{~mm}$

Cumulative Frequency Distribution

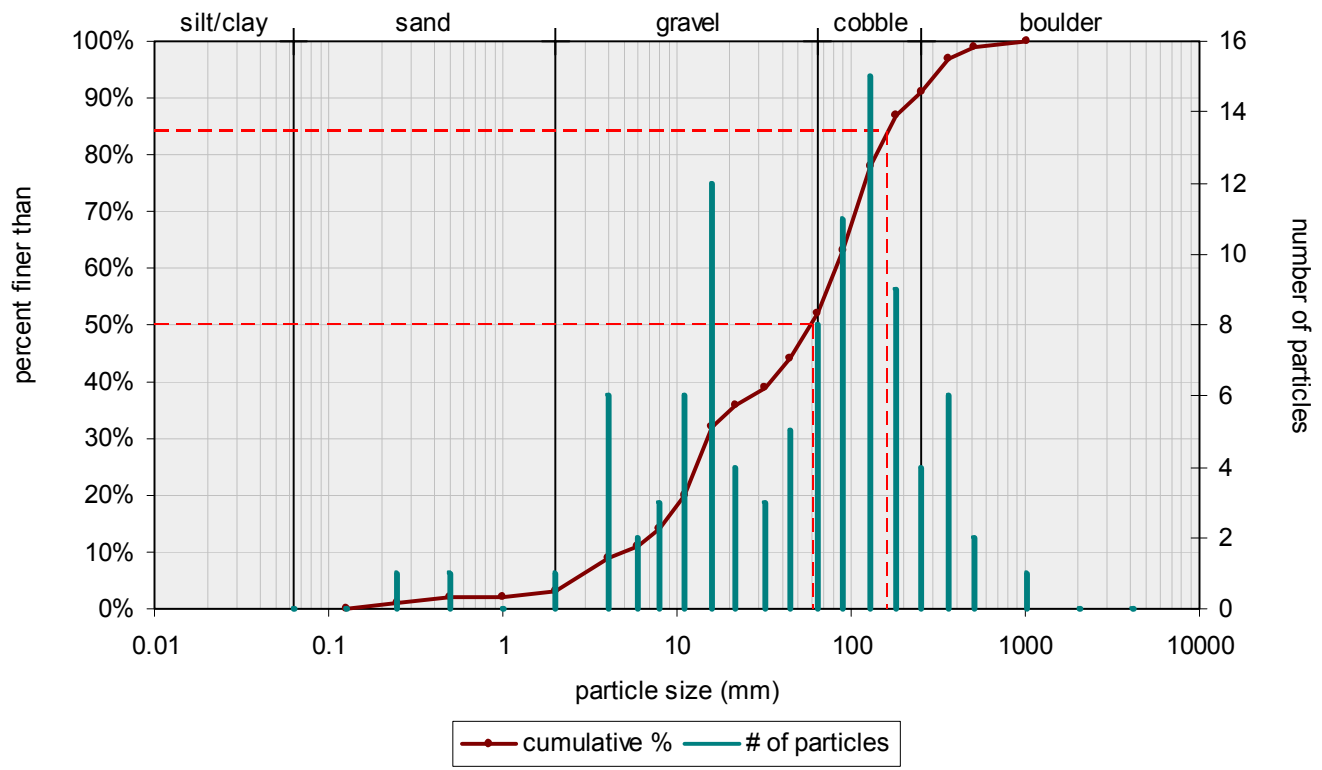

Pebble Count Data

\begin{tabular}{|c|c|c|c|c|c|c|c|c|c|c|c|}
\hline \# & Texture & $\#$ & Texture & $\#$ & Texture & \# & Texture & \# & Texture & $\#$ & Texture \\
\hline 1 & 63 & 18 & 91 & 35 & 12 & 52 & 175 & 69 & 33 & 86 & 49 \\
\hline 2 & 11 & 19 & 122 & 36 & 2 & 53 & 603 & 70 & 10 & 87 & 14 \\
\hline 3 & 152 & 20 & 118 & 37 & 89 & 54 & 138 & 71 & 207 & 88 & 87 \\
\hline 4 & 6 & 21 & 11 & 38 & 2 & 55 & 68 & 72 & 8 & 89 & 22 \\
\hline 5 & 310 & 22 & 58 & 39 & 2 & 56 & 244 & 73 & 15 & 90 & 99 \\
\hline 6 & 19 & 23 & 72 & 40 & 5 & 57 & 17 & 74 & 53 & 91 & 91 \\
\hline 7 & 7 & 24 & 51 & 41 & 12 & 58 & 68 & 75 & 51 & 92 & 41 \\
\hline 8 & 492 & 25 & 154 & 42 & 8 & 59 & 112 & 76 & 91 & 93 & 73 \\
\hline 9 & 317 & 26 & 133 & 43 & 2 & 60 & 0.125 & 77 & 87 & 94 & 134 \\
\hline 10 & 12 & 27 & 198 & 44 & 4 & 61 & 12 & 78 & 68 & 95 & 71 \\
\hline 11 & 102 & 28 & 22 & 45 & 16 & 62 & 1 & 79 & 10 & 96 & 29 \\
\hline 12 & 13 & 29 & 76 & 46 & 122 & 63 & 58 & 80 & 8 & 97 & 256 \\
\hline 13 & 0.25 & 30 & 295 & 47 & 491 & 64 & 124 & 81 & 272 & 98 & 14 \\
\hline 14 & 103 & 31 & 119 & 48 & 129 & 65 & 183 & 82 & 61 & 99 & 45 \\
\hline 15 & 168 & 32 & 122 & 49 & 40 & 66 & 84 & 83 & 91 & 100 & 2 \\
\hline 16 & 295 & 33 & 119 & 50 & 106 & 67 & 15 & 84 & 6 & & \\
\hline 17 & 14 & 34 & 18 & 51 & 2 & 68 & 9 & 85 & 34 & & \\
\hline
\end{tabular}




\section{Sherman Creek}

Reach \#: $7 \quad$ UTM Location: Zone 18, $4462068 \mathrm{~m} \mathrm{~N}, 0277339 \mathrm{~m} \mathrm{E}$

Composition of Bedload: Consists of tan to brownish sub-rounded clasts of sandstone.

Bedload Textures: D50 $=78.0 \mathrm{~mm}, \mathrm{D} 84=170.0 \mathrm{~mm}$

Cumulative Frequency Distribution

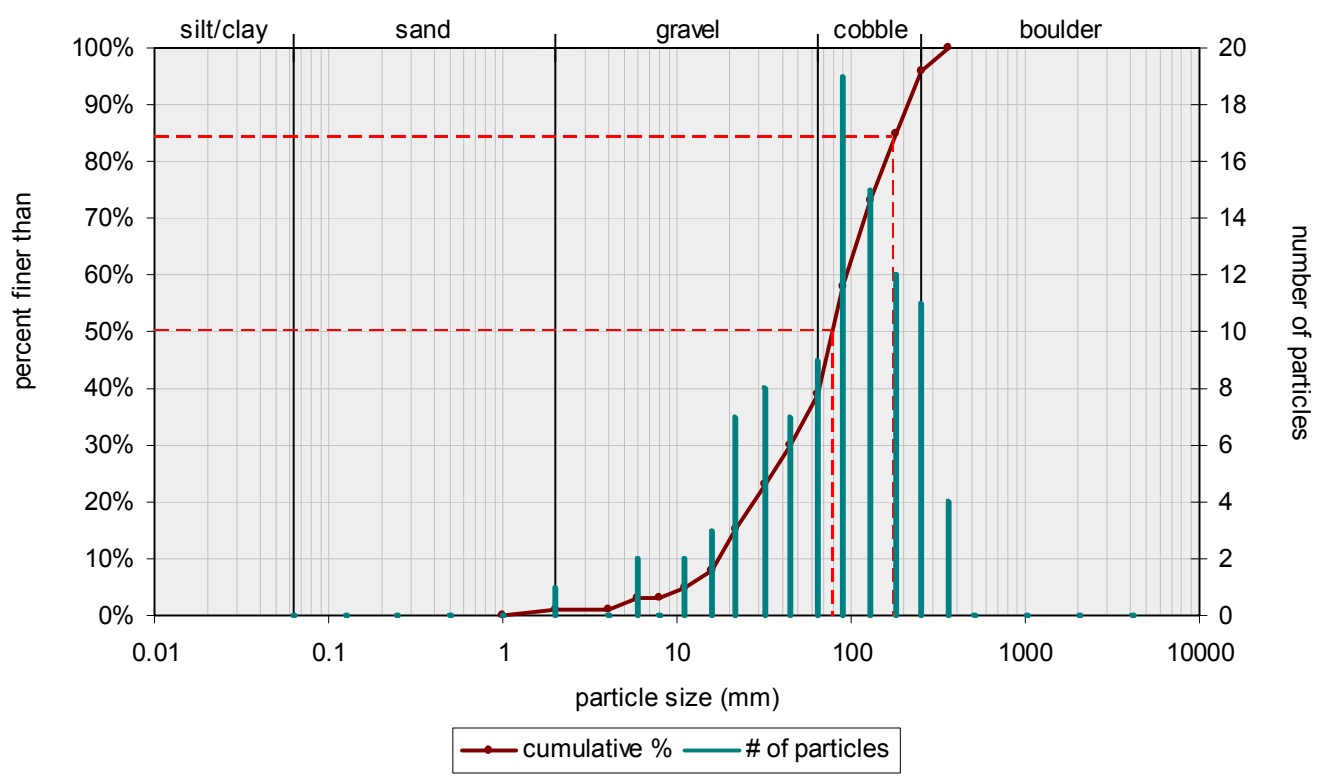

Pebble Count Data

\begin{tabular}{|c|c|c|c|c|c|c|c|c|c|c|c|}
\hline \# & Texture & \# & Texture & \# & Texture & $\#$ & Texture & $\#$ & Texture & \# & Texture \\
\hline 1 & 317 & 18 & 16 & 35 & 162 & 52 & 70 & 69 & 110 & 86 & 51 \\
\hline 2 & 30 & 19 & 237 & 36 & 27 & 53 & 361 & 70 & 150 & 87 & 49 \\
\hline 3 & 66 & 20 & 59 & 37 & 341 & 54 & 293 & 71 & 119 & 88 & 1 \\
\hline 4 & 52 & 21 & 61 & 38 & 21 & 55 & 86 & 72 & 66 & 89 & 79 \\
\hline 5 & 71 & 22 & 97 & 39 & 24 & 56 & 51 & 73 & 63 & 90 & 5 \\
\hline 6 & 142 & 23 & 128 & 40 & 82 & 57 & 129 & 74 & 87 & 91 & 142 \\
\hline 7 & 101 & 24 & 68 & 41 & 227 & 58 & 25 & 75 & 185 & 92 & 4 \\
\hline 8 & 95 & 25 & 56 & 42 & 119 & 59 & 127 & 76 & 101 & 93 & 10 \\
\hline 9 & 34 & 26 & 175 & 43 & 125 & 60 & 64 & 77 & 170 & 94 & 36 \\
\hline 10 & 15 & 27 & 79 & 44 & 191 & 61 & 40 & 78 & 80 & 95 & 207 \\
\hline 11 & 28 & 28 & 199 & 45 & 131 & 62 & 14 & 79 & 10 & 96 & 78 \\
\hline 12 & 22 & 29 & 95 & 46 & 229 & 63 & 29 & 80 & 118 & 97 & 12 \\
\hline 13 & 216 & 30 & 78 & 47 & 21 & 64 & 224 & 81 & 19 & 98 & 43 \\
\hline 14 & 49 & 31 & 85 & 48 & 38 & 65 & 87 & 82 & 22 & 99 & 44 \\
\hline 15 & 79 & 32 & 142 & 49 & 169 & 66 & 19 & 83 & 69 & 100 & 32 \\
\hline 16 & 115 & 33 & 94 & 50 & 68 & 67 & 199 & 84 & 19 & & \\
\hline 17 & 19 & 34 & 129 & 51 & 246 & 68 & 98 & 85 & 106 & & \\
\hline
\end{tabular}




\section{Sherman Creek}

Reach \#: $8 \quad$ UTM Location: Zone 18, $4460977 \mathrm{~m} \mathrm{~N}, 0275361 \mathrm{~m} \mathrm{E}$

Composition of Bedload: Consists of tan sub-rounded to sub-angular clasts of sandstone.

Some boulders appear to have a colluvial origin because of their great size.

Bedload Textures: D50 $=79.0 \mathrm{~mm}, \mathrm{D} 84=180.0 \mathrm{~mm}$

Cumulative Frequency Distribution

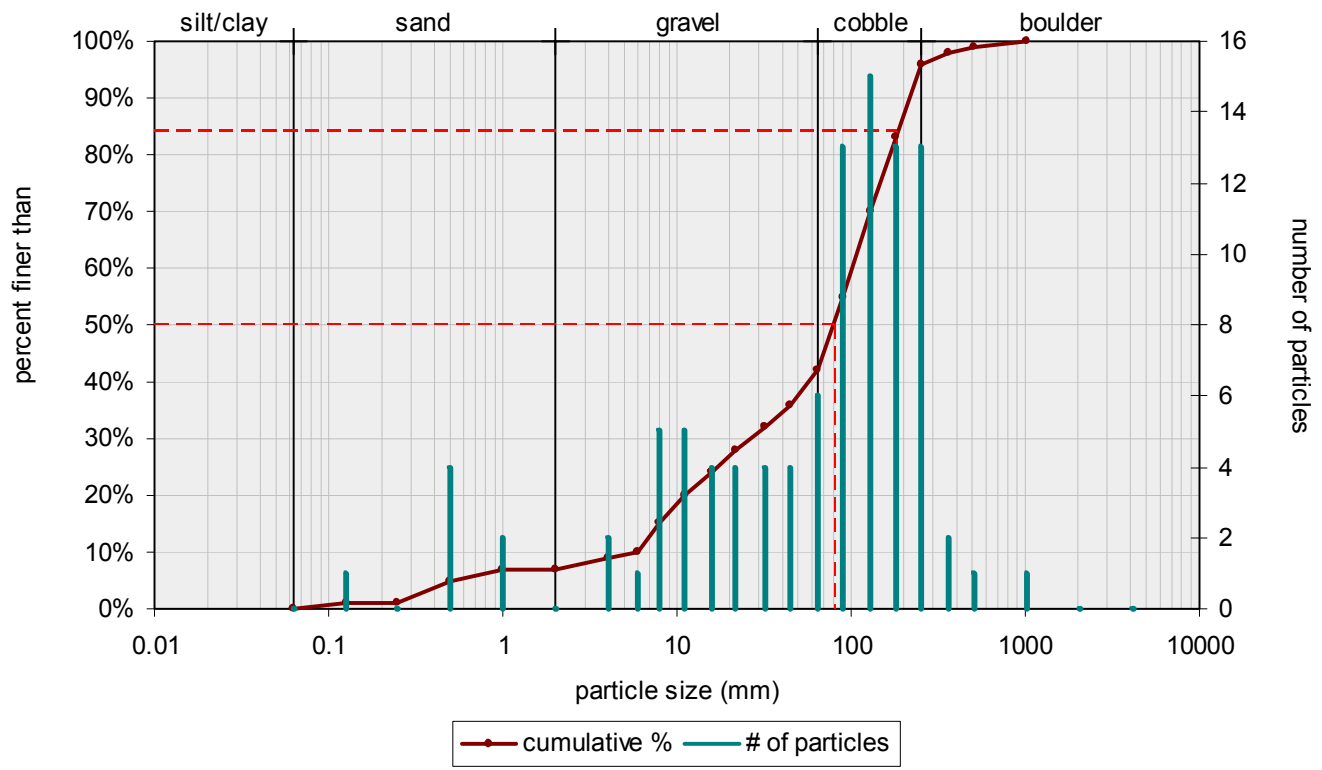

$\underline{\text { Pebble Count Data }}$

\begin{tabular}{|c|c|c|c|c|c|c|c|c|c|c|c|}
\hline$\#$ & Texture & $\#$ & Texture & $\#$ & Texture & $\#$ & Texture & \# & Texture & $\#$ & Texture \\
\hline 1 & 231 & 18 & 210 & 35 & 6 & 52 & 77 & 69 & 134 & 86 & 279 \\
\hline 2 & 9 & 19 & 91 & 36 & 74 & 53 & 98 & 70 & 156 & 87 & 7 \\
\hline 3 & 14 & 20 & 0.062 & 37 & 0.25 & 54 & 192 & 71 & 91 & 88 & 3 \\
\hline 4 & 10 & 21 & 96 & 38 & 196 & 55 & 123 & 72 & 144 & 89 & 62 \\
\hline 5 & 112 & 22 & 12 & 39 & 70 & 56 & 53 & 73 & 84 & 90 & 234 \\
\hline 6 & 17 & 23 & 29 & 40 & 0.25 & 57 & 106 & 74 & 7 & 91 & 6 \\
\hline 7 & 163 & 24 & 66 & 41 & 89 & 58 & 13 & 75 & 92 & 92 & 109 \\
\hline 8 & 87 & 25 & 69 & 42 & 9 & 59 & 10 & 76 & 188 & 93 & 137 \\
\hline 9 & 176 & 26 & 75 & 43 & 0.25 & 60 & 92 & 77 & 19 & 94 & 122 \\
\hline 10 & 0.25 & 27 & 212 & 44 & 39 & 61 & 0.5 & 78 & 39 & 95 & 118 \\
\hline 11 & 137 & 28 & 13 & 45 & 49 & 62 & 232 & 79 & 201 & 96 & 94 \\
\hline 12 & 84 & 29 & 69 & 46 & 46 & 63 & 20 & 80 & 219 & 97 & 222 \\
\hline 13 & 46 & 30 & 154 & 47 & 153 & 64 & 89 & 81 & 23 & 98 & 17 \\
\hline 14 & 134 & 31 & 261 & 48 & 27 & 65 & 2 & 82 & 204 & 99 & 19 \\
\hline 15 & 429 & 32 & 765 & 49 & 187 & 66 & 9 & 83 & 142 & 100 & 33 \\
\hline 16 & 140 & 33 & 43 & 50 & 7 & 67 & 87 & 84 & 99 & & \\
\hline 17 & 4 & 34 & 0.5 & 51 & 173 & 68 & 51 & 85 & 96 & & \\
\hline
\end{tabular}




\section{Sherman Creek}

Reach \#: $9 \quad$ UTM Location: Zone 18, $4463007 \mathrm{~m} \mathrm{~N}, 0278568 \mathrm{~m} \mathrm{E}$

Composition of Bedload: Consists of tan to red sub-rounded to rounded clasts of clean sandstone.

Bedload Textures: D50 $=94.0 \mathrm{~mm}, \mathrm{D} 84=160.0 \mathrm{~mm}$

Cumulative Frequency Distribution

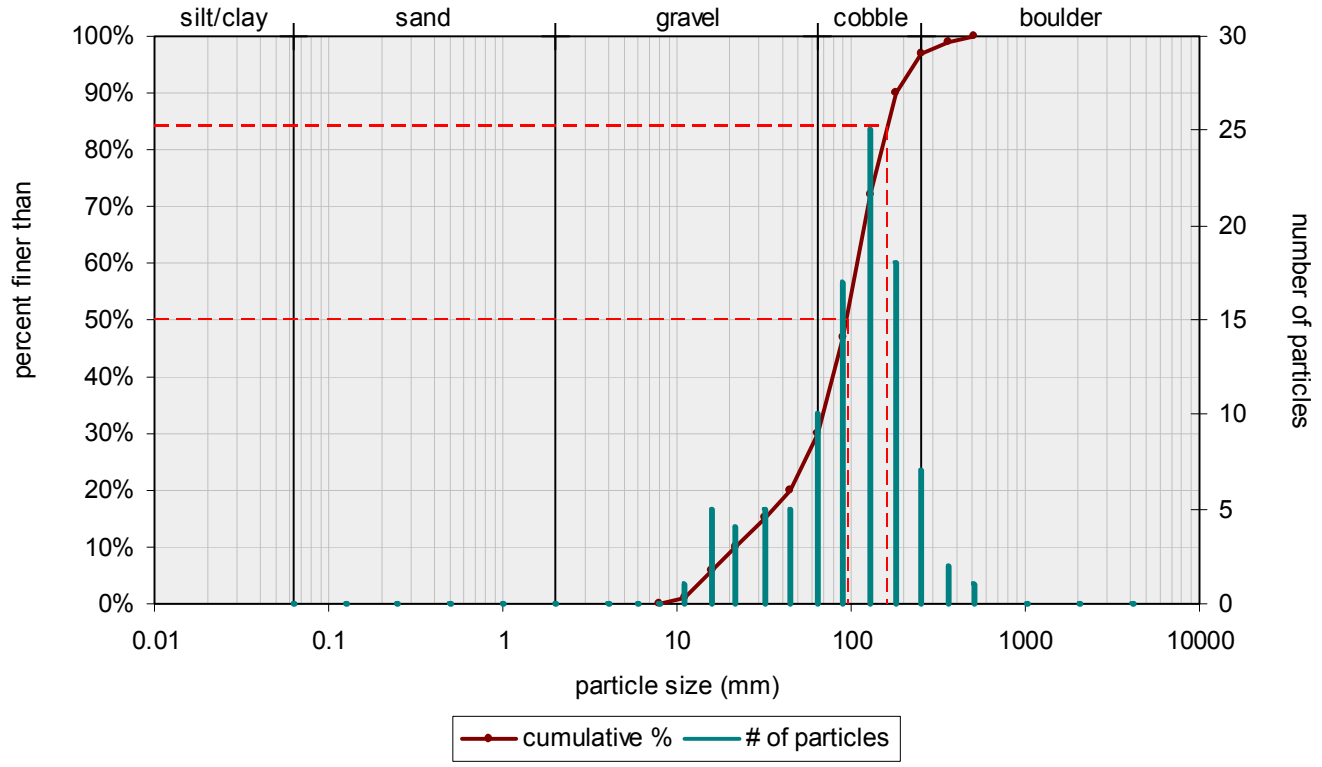

$\underline{\text { Pebble Count Data }}$

\begin{tabular}{|c|c|c|c|c|c|c|c|c|c|c|c|}
\hline \# & Texture & $\#$ & Texture & $\#$ & Texture & $\#$ & Texture & $\#$ & Texture & \# & Texture \\
\hline 1 & 15 & 18 & 63 & 35 & 102 & 52 & 27 & 69 & 119 & 86 & 230 \\
\hline 2 & 76 & 19 & 103 & 36 & 87 & 53 & 71 & 70 & 138 & 87 & 93 \\
\hline 3 & 154 & 20 & 124 & 37 & 74 & 54 & 78 & 71 & 100 & 88 & 114 \\
\hline 4 & 17 & 21 & 111 & 38 & 58 & 55 & 77 & 72 & 97 & 89 & 109 \\
\hline 5 & 149 & 22 & 59 & 39 & 57 & 56 & 99 & 73 & 19 & 90 & 112 \\
\hline 6 & 91 & 23 & 112 & 40 & 104 & 57 & 81 & 74 & 29 & 91 & 184 \\
\hline 7 & 186 & 24 & 164 & 41 & 113 & 58 & 113 & 75 & 132 & 92 & 19 \\
\hline 8 & 158 & 25 & 82 & 42 & 85 & 59 & 33 & 76 & 77 & 93 & 112 \\
\hline 9 & 18 & 26 & 49 & 43 & 38 & 60 & 230 & 77 & 212 & 94 & 118 \\
\hline 10 & 109 & 27 & 12 & 44 & 81 & 61 & 159 & 78 & 24 & 95 & 10 \\
\hline 11 & 151 & 28 & 166 & 45 & 92 & 62 & 26 & 79 & 65 & 96 & 281 \\
\hline 12 & 124 & 29 & 144 & 46 & 49 & 63 & 162 & 80 & 136 & 97 & 24 \\
\hline 13 & 142 & 30 & 61 & 47 & 13 & 64 & 96 & 81 & 53 & 98 & 68 \\
\hline 14 & 207 & 31 & 83 & 48 & 14 & 65 & 147 & 82 & 171 & 99 & 37 \\
\hline 15 & 102 & 32 & 11 & 49 & 131 & 66 & 42 & 83 & 59 & 100 & 39 \\
\hline 16 & 106 & 33 & 58 & 50 & 475 & 67 & 76 & 84 & 76 & & \\
\hline 17 & 132 & 34 & 352 & 51 & 142 & 68 & 190 & 85 & 68 & & \\
\hline
\end{tabular}




\section{Sherman Creek}

Reach \#: $10 \quad$ UTM Location: Zone 18, $4463657 \mathrm{~m} \mathrm{~N}, 0279647 \mathrm{~m} \mathrm{E}$

Composition of Bedload: Consists of rounded to sub-rounded clasts of sandstone.

Bedload Textures: D50 $=67.0 \mathrm{~mm}, \mathrm{D} 84=120.0 \mathrm{~mm}$

Cumulative Frequency Distribution

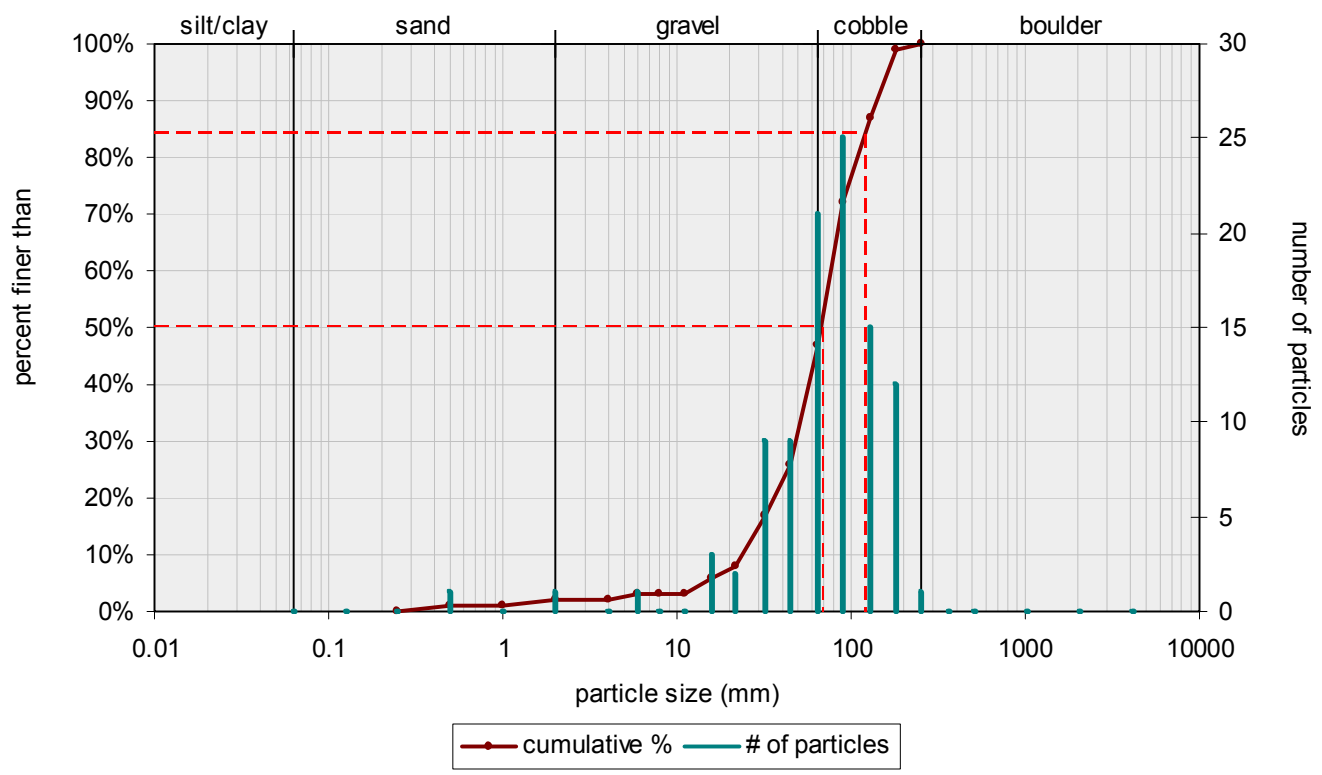

\section{Pebble Count Data}

\begin{tabular}{|c|c|c|c|c|c|c|c|c|c|c|c|}
\hline \# & Texture & \# & Texture & \# & Texture & \# & Texture & \# & Texture & \# & Texture \\
\hline 1 & 54 & 18 & 72 & 35 & 82 & 52 & 101 & 69 & 16 & 86 & 34 \\
\hline 2 & 79 & 19 & 61 & 36 & 69 & 53 & 154 & 70 & 93 & 87 & 84 \\
\hline 3 & 22 & 20 & 55 & 37 & 47 & 54 & 47 & 71 & 52 & 88 & 136 \\
\hline 4 & 67 & 21 & 138 & 38 & 82 & 55 & 24 & 72 & 193 & 89 & 86 \\
\hline 5 & 81 & 22 & 44 & 39 & 12 & 56 & 96 & 73 & 127 & 90 & 33 \\
\hline 6 & 102 & 23 & 36 & 40 & 82 & 57 & 27 & 74 & 121 & 91 & 74 \\
\hline 7 & 49 & 24 & 129 & 41 & 100 & 58 & 45 & 75 & 71 & 92 & 109 \\
\hline 8 & 72 & 25 & 62 & 42 & 66 & 59 & 39 & 76 & 64 & 93 & 241 \\
\hline 9 & 51 & 26 & 59 & 43 & 71 & 60 & 29 & 77 & 82 & 94 & 27 \\
\hline 10 & 55 & 27 & 58 & 44 & 101 & 61 & 48 & 78 & 98 & 95 & 39 \\
\hline 11 & 89 & 28 & 57 & 45 & 157 & 62 & 15 & 79 & 49 & 96 & 26 \\
\hline 12 & 91 & 29 & 31 & 46 & 78 & 63 & 140 & 80 & 22 & 97 & 4 \\
\hline 13 & 83 & 30 & 51 & 47 & 64 & 64 & 142 & 81 & 11 & 98 & 0.25 \\
\hline 14 & 71 & 31 & 32 & 48 & 86 & 65 & 44 & 82 & 1 & 99 & 26 \\
\hline 15 & 179 & 32 & 118 & 49 & 141 & 66 & 36 & 83 & 107 & 100 & 68 \\
\hline 16 & 133 & 33 & 21 & 50 & 55 & 67 & 47 & 84 & 49 & & \\
\hline 17 & 178 & 34 & 119 & 51 & 113 & 68 & 159 & 85 & 54 & & \\
\hline
\end{tabular}




\section{Sherman Creek}

Reach \#: $11 \quad$ UTM Location: Zone 18, $4460667 \mathrm{~m} \mathrm{~N}, 0274457 \mathrm{~m} \mathrm{E}$

\section{Composition of Bedload: N/A}

Bedload Textures: D50 $=13.0 \mathrm{~mm}, \mathrm{D} 84=84.0 \mathrm{~mm}$

\section{Cumulative Frequency Distribution}

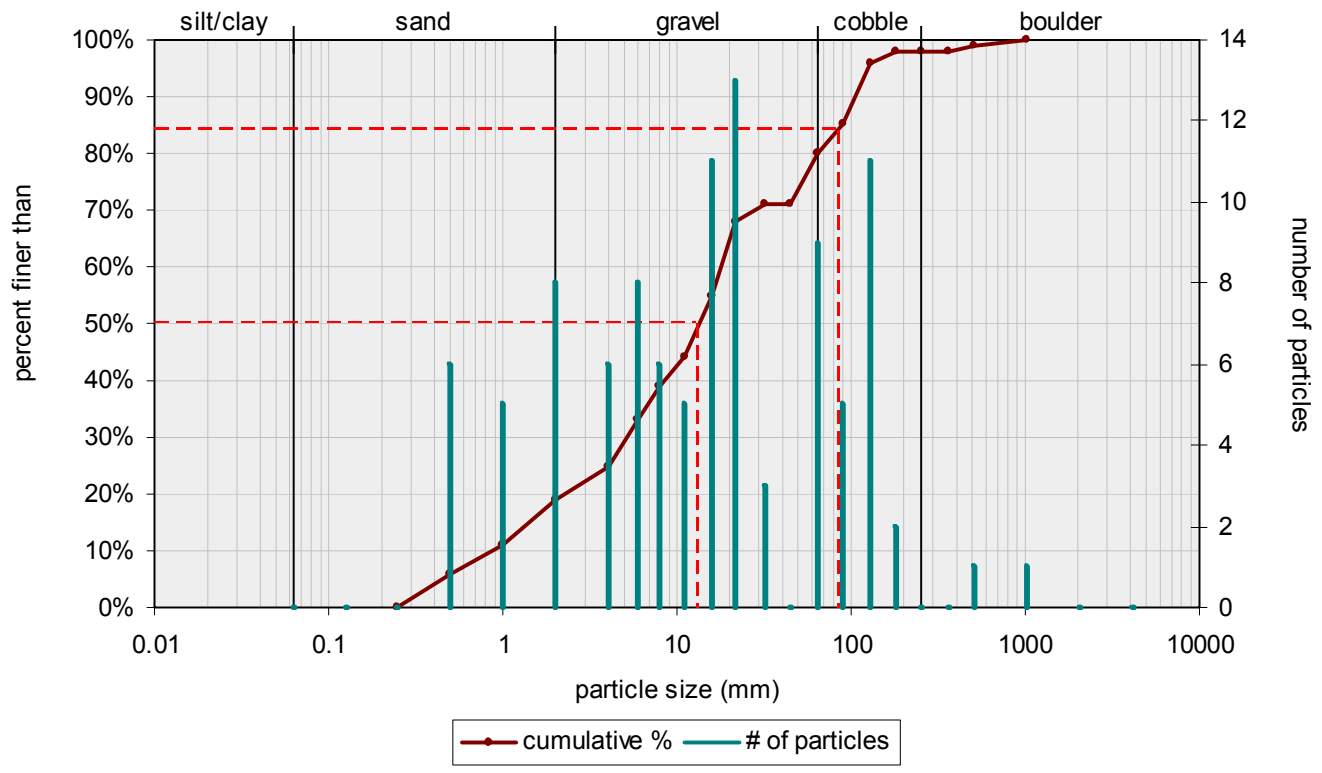

\section{Pebble Count Data}

\begin{tabular}{|c|c|c|c|c|c|c|c|c|c|c|c|}
\hline \# & Texture & $\#$ & Texture & $\#$ & Texture & \# & Texture & $\#$ & Texture & $\#$ & Texture \\
\hline 1 & 5 & 18 & 114 & 35 & 14 & 52 & 16 & 69 & 19 & 86 & 5 \\
\hline 2 & 4 & 19 & 0.5 & 36 & 4 & 53 & 8 & 70 & 49 & 87 & 1 \\
\hline 3 & 56 & 20 & 12 & 37 & 464 & 54 & 1 & 71 & 27 & 88 & 12 \\
\hline 4 & 113 & 21 & 58 & 38 & 12 & 55 & 2 & 72 & 17 & 89 & 9 \\
\hline 5 & 121 & 22 & 7 & 39 & 69 & 56 & 4 & 73 & 7 & 90 & 81 \\
\hline 6 & 17 & 23 & 5 & 40 & 109 & 57 & 104 & 74 & 905 & 91 & 0.5 \\
\hline 7 & 89 & 24 & 13 & 41 & 16 & 58 & 0.25 & 75 & 16 & 92 & 0.25 \\
\hline 8 & 116 & 25 & 49 & 42 & 24 & 59 & 69 & 76 & 7 & 93 & 7 \\
\hline 9 & 0.25 & 26 & 111 & 43 & 3 & 60 & 18 & 77 & 52 & 94 & 11 \\
\hline 10 & 0.5 & 27 & 54 & 44 & 8 & 61 & 26 & 78 & 101 & 95 & 0.25 \\
\hline 11 & 7 & 28 & 19 & 45 & 4 & 62 & 11 & 79 & 19 & 96 & 0.5 \\
\hline 12 & 1 & 29 & 56 & 46 & 3 & 63 & 5 & 80 & 8 & 97 & 1 \\
\hline 13 & 13 & 30 & 131 & 47 & 69 & 64 & 3 & 81 & 0.35 & 98 & 1 \\
\hline 14 & 11 & 31 & 9 & 48 & 16 & 65 & 0.71 & 82 & 12 & 99 & 139 \\
\hline 15 & 62 & 32 & 2 & 49 & 1 & 66 & 7 & 83 & 16 & 100 & 13 \\
\hline 16 & 96 & 33 & 17 & 50 & 2 & 67 & 1 & 84 & 119 & & \\
\hline 17 & 17 & 34 & 0.25 & 51 & 106 & 68 & 1 & 85 & 47 & & \\
\hline
\end{tabular}




\section{Horse Valley Run}

Reach \#: 12 UTM Location: Zone 18, $4465262 \mathrm{~m} \mathrm{~N}, 0276227 \mathrm{~m} \mathrm{E}$

Composition of Bedload: Consists of clasts of sandstone, covered with slimy layer of silt and clay..

Bedload Textures: D50 $=19.0 \mathrm{~mm}, \mathrm{D} 84=70.0 \mathrm{~mm}$

Cumulative Frequency Distribution

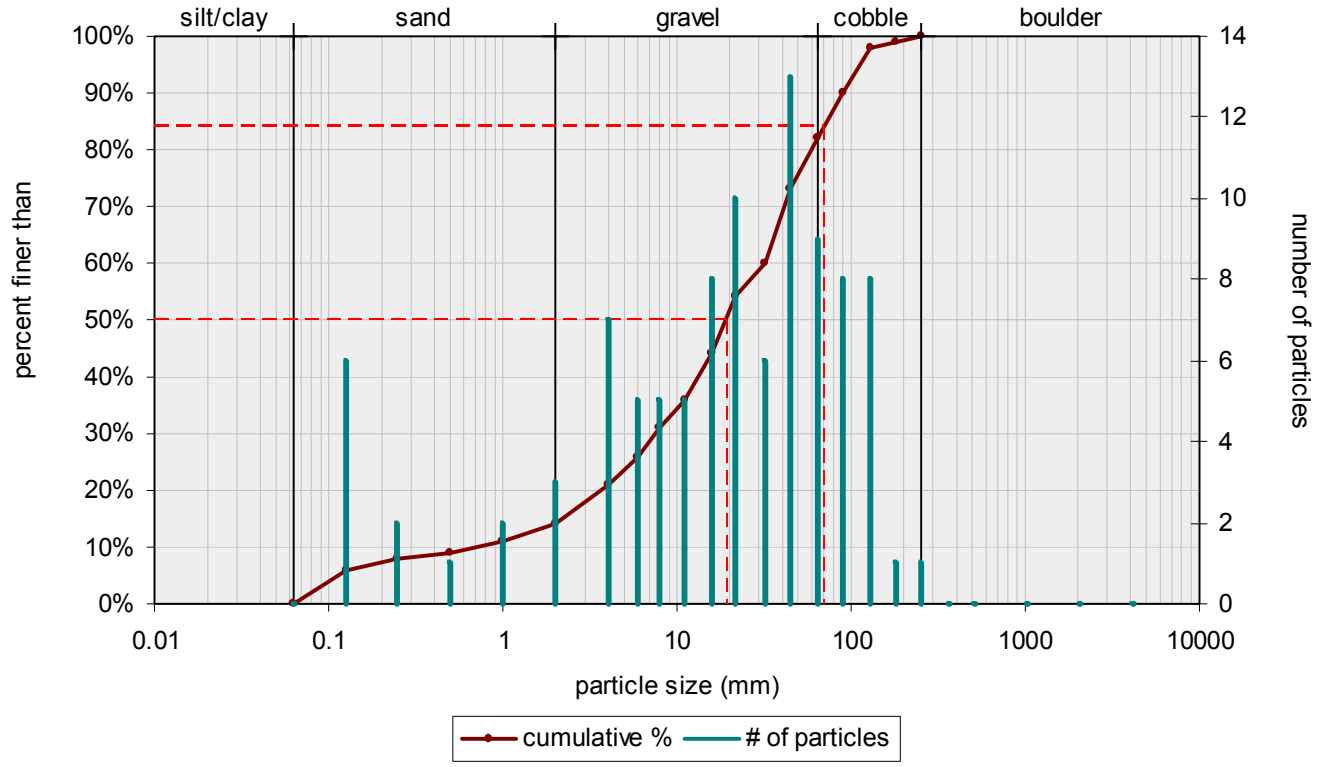

$\underline{\text { Pebble Count Data }}$

\begin{tabular}{|c|c|c|c|c|c|c|c|c|c|c|c|}
\hline$\#$ & Texture & $\#$ & Texture & $\#$ & Texture & \# & Texture & \# & Texture & $\#$ & Texture \\
\hline 1 & 72 & 18 & 5 & 35 & 109 & 52 & 85 & 69 & 10 & 86 & 7 \\
\hline 2 & 104 & 19 & 9 & 36 & 36 & 53 & 21 & 70 & 121 & 87 & 9 \\
\hline 3 & 32 & 20 & 6 & 37 & 14 & 54 & 34 & 71 & 16 & 88 & 107 \\
\hline 4 & 12 & 21 & 9 & 38 & 31 & 55 & 32 & 72 & 10 & 89 & 0.062 \\
\hline 5 & 88 & 22 & 2 & 39 & 16 & 56 & 19 & 73 & 4 & 90 & 0.5 \\
\hline 6 & 22 & 23 & 44 & 40 & 4 & 57 & 42 & 74 & 2 & 91 & 2 \\
\hline 7 & 31 & 24 & 38 & 41 & 3 & 58 & 36 & 75 & 14 & 92 & 3 \\
\hline 8 & 24 & 25 & 19 & 42 & 16 & 59 & 0.125 & 76 & 3 & 93 & 33 \\
\hline 9 & 6 & 26 & 77 & 43 & 7 & 60 & 81 & 77 & 46 & 94 & 37 \\
\hline 10 & 15 & 27 & 18 & 44 & 3 & 61 & 0.062 & 78 & 55 & 95 & 63 \\
\hline 11 & 0.062 & 28 & 62 & 45 & 1 & 62 & 34 & 79 & 29 & 96 & 11 \\
\hline 12 & 11 & 29 & 36 & 46 & 52 & 63 & 13 & 80 & 88 & 97 & 1 \\
\hline 13 & 0.062 & 30 & 0.125 & 47 & 70 & 64 & 52 & 81 & 19 & 98 & 4 \\
\hline 14 & 54 & 31 & 0.25 & 48 & 48 & 65 & 68 & 82 & 24 & 99 & 6 \\
\hline 15 & 36 & 32 & 0.062 & 49 & 17 & 66 & 125 & 83 & 0.062 & 100 & 1 \\
\hline 16 & 140 & 33 & 0.5 & 50 & 113 & 67 & 118 & 84 & 20 & & \\
\hline 17 & 4 & 34 & 60 & 51 & 98 & 68 & 206 & 85 & 12 & & \\
\hline
\end{tabular}




\section{Horse Valley Run}

Reach \#: $13 \quad$ UTM Location: Zone 18, $4469394 \mathrm{~m} \mathrm{~N}, 0279428 \mathrm{~m} \mathrm{E}$

Composition of Bedload: Consists of sub-rounded to rounded clasts of sandstone, covered with silt and clay.

Bedload Textures: D50 $=42.0 \mathrm{~mm}, \mathrm{D} 84=130.0 \mathrm{~mm}$

Cumulative Frequency Distribution

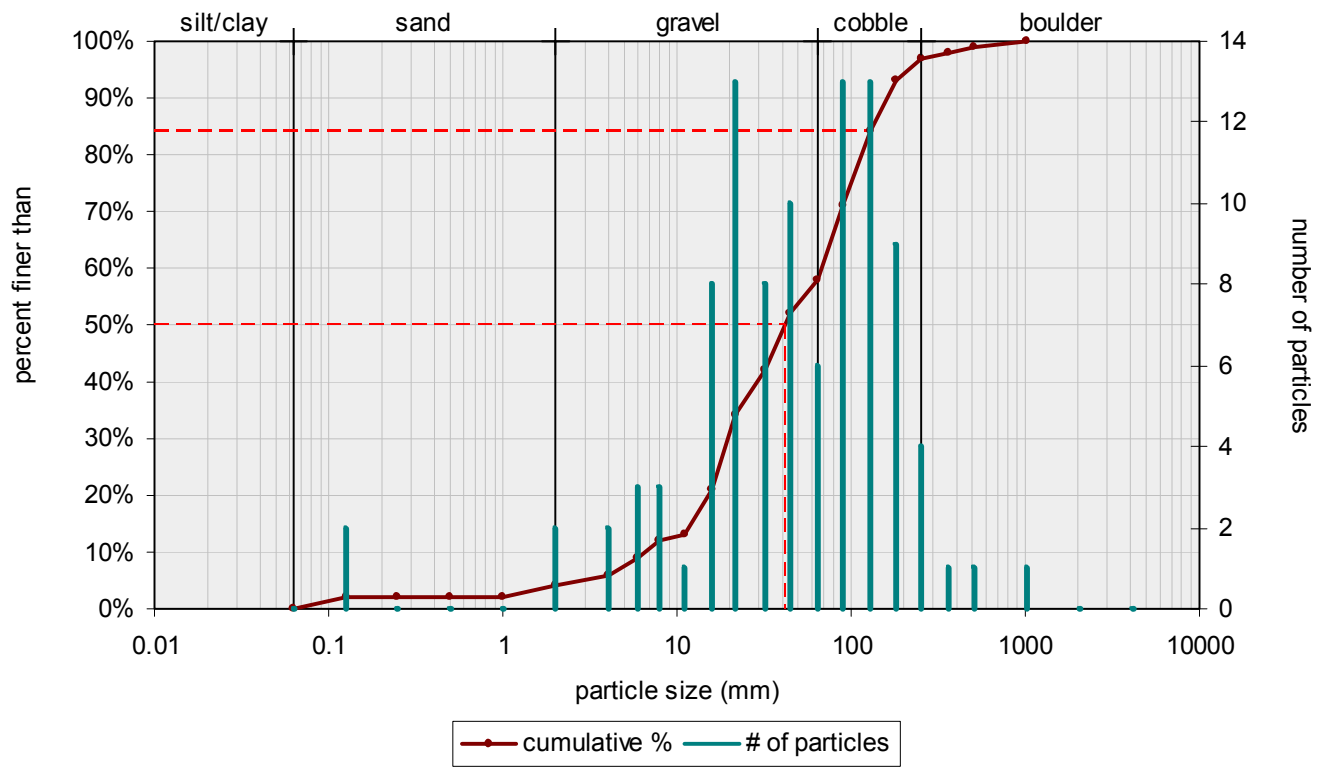

$\underline{\text { Pebble Count Data }}$

\begin{tabular}{|c|c|c|c|c|c|c|c|c|c|c|c|}
\hline$\#$ & Texture & $\#$ & Texture & $\#$ & Texture & $\#$ & Texture & \# & Texture & $\#$ & Texture \\
\hline 1 & 13 & 18 & 20 & 35 & 88 & 52 & 209 & 69 & 119 & 86 & 61 \\
\hline 2 & 14 & 19 & 16 & 36 & 1 & 53 & 46 & 70 & 437 & 87 & 38 \\
\hline 3 & 69 & 20 & 6 & 37 & 2 & 54 & 775 & 71 & 118 & 88 & 21 \\
\hline 4 & 124 & 21 & 18 & 38 & 4 & 55 & 82 & 72 & 5 & 89 & 0.062 \\
\hline 5 & 152 & 22 & 12 & 39 & 79 & 56 & 112 & 73 & 101 & 90 & 35 \\
\hline 6 & 42 & 23 & 7 & 40 & 23 & 57 & 29 & 74 & 166 & 91 & 61 \\
\hline 7 & 29 & 24 & 152 & 41 & 21 & 58 & 334 & 75 & 121 & 92 & 42 \\
\hline 8 & 123 & 25 & 69 & 42 & 84 & 59 & 18 & 76 & 4 & 93 & 22 \\
\hline 9 & 21 & 26 & 119 & 43 & 11 & 60 & 19 & 77 & 7 & 94 & 34 \\
\hline 10 & 103 & 27 & 131 & 44 & 17 & 61 & 78 & 78 & 21 & 95 & 12 \\
\hline 11 & 43 & 28 & 86 & 45 & 29 & 62 & 67 & 79 & 30 & 96 & 24 \\
\hline 12 & 46 & 29 & 173 & 46 & 178 & 63 & 91 & 80 & 12 & 97 & 171 \\
\hline 13 & 16 & 30 & 22 & 47 & 91 & 64 & 122 & 81 & 35 & 98 & 14 \\
\hline 14 & 36 & 31 & 238 & 48 & 233 & 65 & 14 & 82 & 21 & 99 & 1 \\
\hline 15 & 21 & 32 & 0.062 & 49 & 44 & 66 & 243 & 83 & 69 & 100 & 69 \\
\hline 16 & 47 & 33 & 92 & 50 & 162 & 67 & 9 & 84 & 86 & & \\
\hline 17 & 32 & 34 & 78 & 51 & 49 & 68 & 2 & 85 & 174 & & \\
\hline
\end{tabular}




\section{Horse Valley Run}

Reach \#: $14 \quad$ UTM Location: Zone 18, $4469188 \mathrm{~m} \mathrm{~N}, 0280073 \mathrm{~m} \mathrm{E}$

Composition of Bedload: Consists of sub-rounded to sub-angular clasts of sandstone.

Bedload Textures: D50 $=40.0 \mathrm{~mm}, \mathrm{D} 84=120.0 \mathrm{~mm}$

Cumulative Frequency Distribution

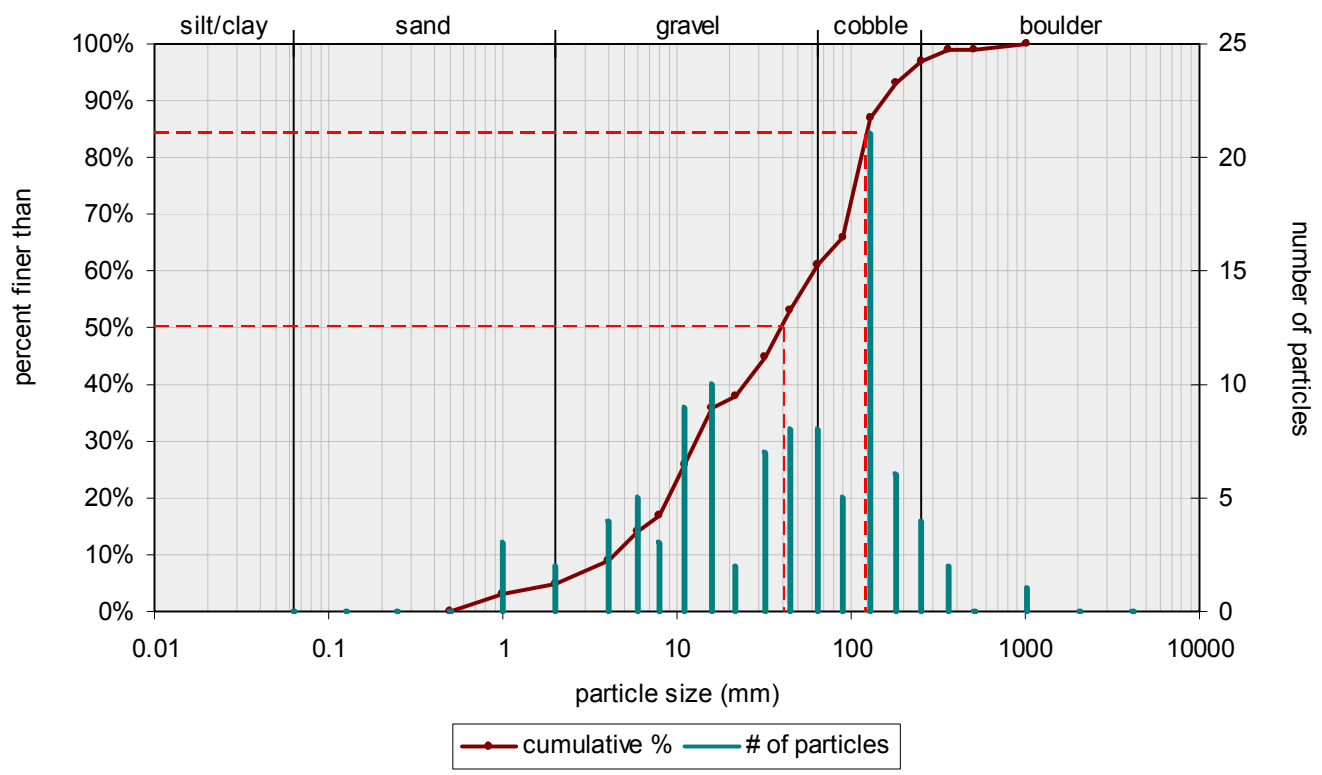

\section{Pebble Count Data}

\begin{tabular}{|r|r|r|r|r|r|r|r|r|r|r|r|r|r|r|r|}
\hline \multicolumn{1}{|r|}{ \# } & \multicolumn{1}{l}{ Texture } \\
\hline 1 & 173 & 18 & 14 & 35 & 153 & 52 & 6 & 69 & 8 & 86 & 0.5 \\
\hline 2 & 9 & 19 & 8 & 36 & 92 & 53 & 2 & 70 & 4 & 87 & 102 \\
\hline 3 & 91 & 20 & 125 & 37 & 96 & 54 & 7 & 71 & 107 & 88 & 110 \\
\hline 4 & 34 & 21 & 116 & 38 & 93 & 55 & 37 & 72 & 128 & 89 & 31 \\
\hline 5 & 41 & 22 & 8 & 39 & 127 & 56 & 0.5 & 73 & 84 & 90 & 93 \\
\hline 6 & 92 & 23 & 33 & 40 & 96 & 57 & 56 & 74 & 105 & 91 & 13 \\
\hline 7 & 182 & 24 & 10 & 41 & 5 & 58 & 9 & 75 & 49 & 92 & 14 \\
\hline 8 & 307 & 25 & 25 & 42 & 24 & 59 & 101 & 76 & 19 & 93 & 11 \\
\hline 9 & 54 & 26 & 13 & 43 & 8 & 60 & 19 & 77 & 43 & 94 & 74 \\
\hline 10 & 60 & 27 & 7 & 44 & 125 & 61 & 4 & 78 & 11 & 95 & 141 \\
\hline 11 & 29 & 28 & 18 & 45 & 3 & 62 & 36 & 79 & 100 & 96 & 22 \\
\hline 12 & 57 & 29 & 44 & 46 & 0.5 & 63 & 22 & 80 & 67 & 97 & 134 \\
\hline 13 & 77 & 30 & 8 & 47 & 4 & 64 & 12 & 81 & 202 & 98 & 1 \\
\hline 14 & 28 & 31 & 107 & 48 & 11 & 65 & 36 & 82 & 54 & 99 & \\
\hline 15 & 596 & 32 & 72 & 49 & 3 & 66 & 14 & 83 & 141 & 100 & \\
\hline 16 & 109 & 33 & 204 & 50 & 62 & 67 & 1 & 84 & 119 & & \\
\hline 17 & 107 & 34 & 11 & 51 & 55 & 68 & 274 & 85 & 8 & & \\
\hline
\end{tabular}




\section{Horse Valley Run}

Reach \#: $15 \quad$ UTM Location: Zone 18, $4469562 \mathrm{~m} \mathrm{~N}, 0281022 \mathrm{~m} \mathrm{E}$

\section{Composition of Bedload: N/A}

Bedload Textures: D50 $=39.0 \mathrm{~mm}, \mathrm{D} 84=90.0 \mathrm{~mm}$

\section{Cumulative Frequency Distribution}

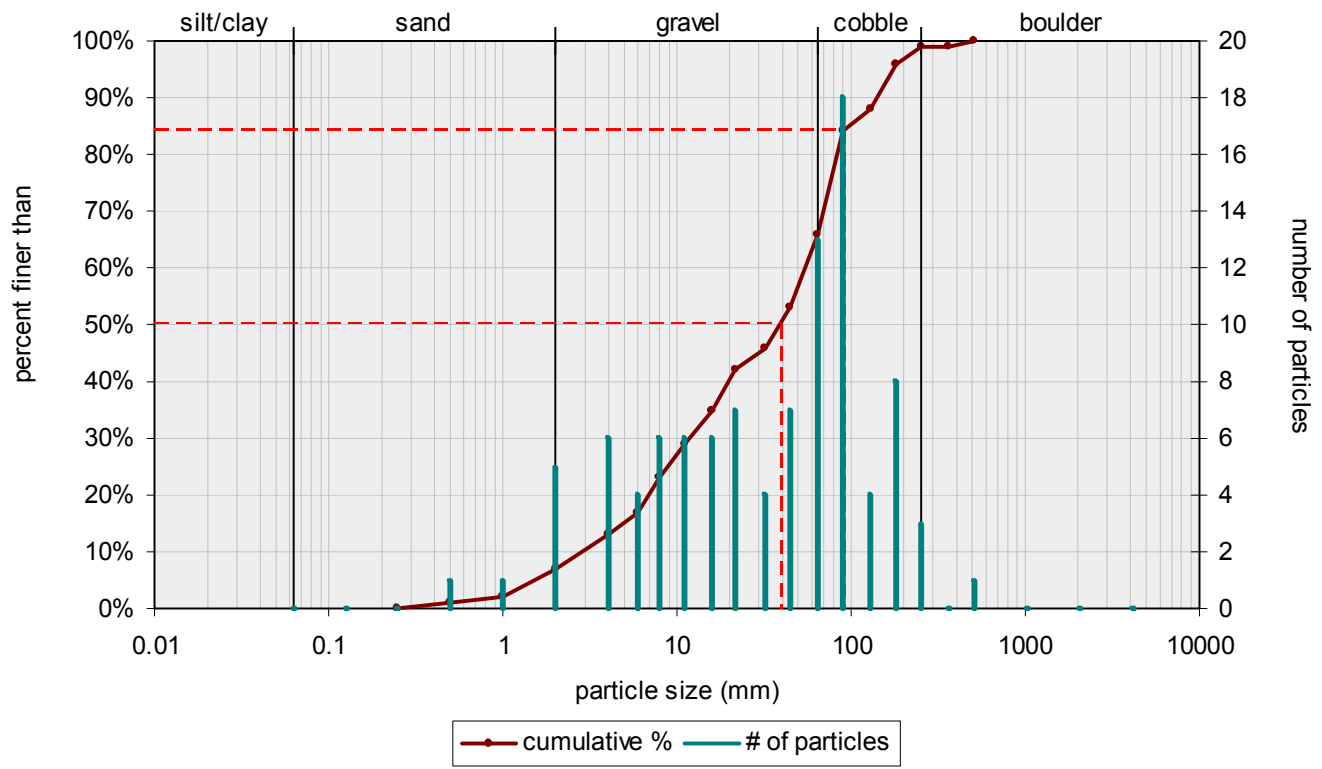

\section{$\underline{\text { Pebble Count Data }}$}

\begin{tabular}{|c|c|c|c|c|c|c|c|c|c|c|c|}
\hline \# & Texture & $\#$ & Texture & $\#$ & Texture & \# & Texture & $\#$ & Texture & $\#$ & Texture \\
\hline 1 & 142 & 18 & 39 & 35 & 117 & 52 & 17 & 69 & 3 & 86 & 192 \\
\hline 2 & 36 & 19 & 17 & 36 & 109 & 53 & 136 & 70 & 91 & 87 & 144 \\
\hline 3 & 66 & 20 & 3 & 37 & 4 & 54 & 61 & 71 & 17 & 88 & 0.25 \\
\hline 4 & 9 & 21 & 2 & 38 & 86 & 55 & 89 & 72 & 21 & 89 & 69 \\
\hline 5 & 64 & 22 & 1 & 39 & 12 & 56 & 3 & 73 & 6 & 90 & 43 \\
\hline 6 & 88 & 23 & 4 & 40 & 87 & 57 & 1 & 74 & 37 & 91 & 49 \\
\hline 7 & 27 & 24 & 62 & 41 & 79 & 58 & 71 & 75 & 37 & 92 & 67 \\
\hline 8 & 134 & 25 & 37 & 42 & 166 & 59 & 4 & 76 & 54 & 93 & 121 \\
\hline 9 & 54 & 26 & 79 & 43 & 13 & 60 & 21 & 77 & 49 & 94 & 10 \\
\hline 10 & 138 & 27 & 62 & 44 & 72 & 61 & 54 & 78 & 13 & 95 & 7 \\
\hline 11 & 129 & 28 & 3 & 45 & 51 & 62 & 6 & 79 & 1 & 96 & 1 \\
\hline 12 & 14 & 29 & 36 & 46 & 57 & 63 & 8 & 80 & 10 & 97 & 198 \\
\hline 13 & 77 & 30 & 47 & 47 & 27 & 64 & 7 & 81 & 3 & 98 & 66 \\
\hline 14 & 206 & 31 & 28 & 48 & 7 & 65 & 29 & 82 & 16 & 99 & 7 \\
\hline 15 & 161 & 32 & 84 & 49 & 78 & 66 & 17 & 83 & 5 & 100 & 0.5 \\
\hline 16 & 378 & 33 & 67 & 50 & 13 & 67 & 10 & 84 & 11 & & \\
\hline 17 & 66 & 34 & 49 & 51 & 9 & 68 & 1 & 85 & 45 & & \\
\hline
\end{tabular}




\section{Horse Valley Run}

Reach \#: $16 \quad$ UTM Location: Zone 18, $4470266 \mathrm{~m} \mathrm{~N}, 0281647 \mathrm{~m} \mathrm{E}$

Composition of Bedload: Consists of sub-rounded clasts of tan to red sandstone.

Bedload Textures: D50 $=84.0 \mathrm{~mm}, \mathrm{D} 84=130.0 \mathrm{~mm}$

\section{Cumulative Frequency Distribution}

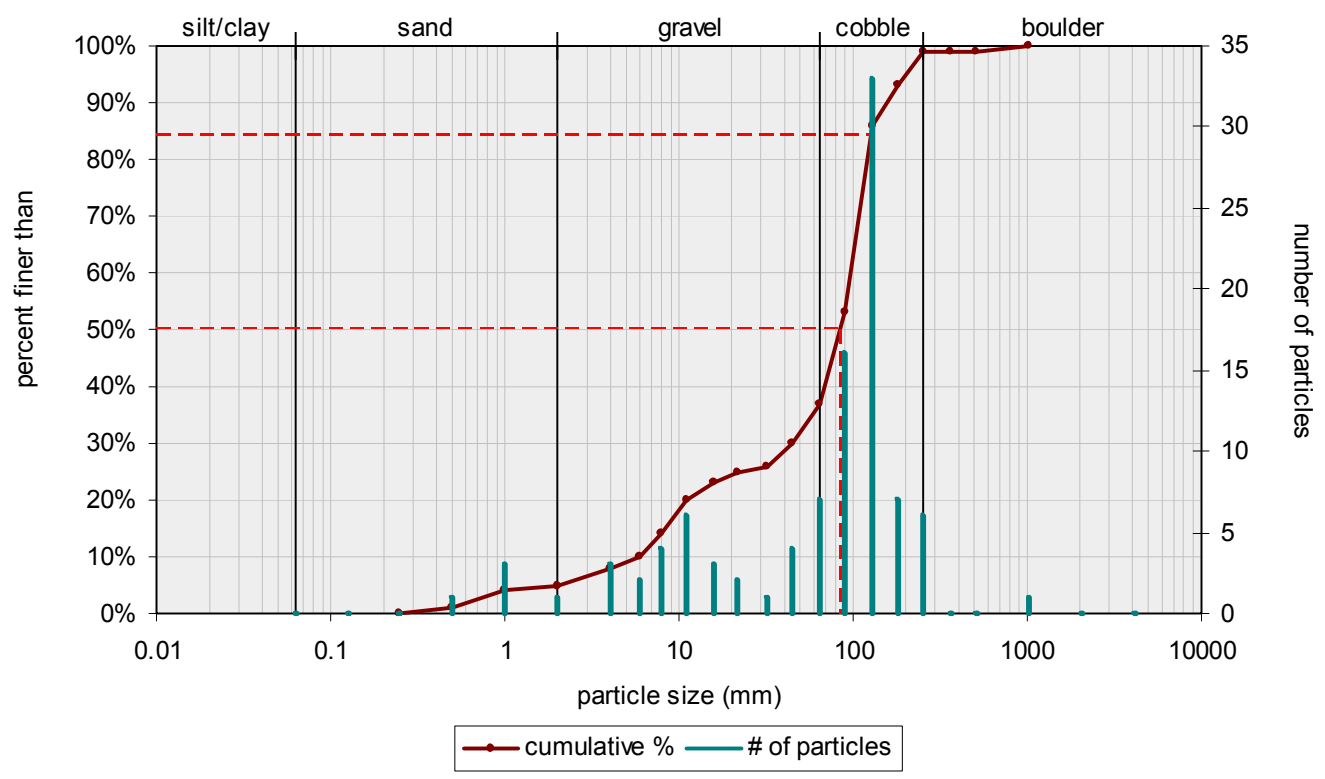

\section{$\underline{\text { Pebble Count Data }}$}

\begin{tabular}{|c|c|c|c|c|c|c|c|c|c|c|c|}
\hline \# & Texture & $\#$ & Texture & \# & Texture & \# & Texture & \# & Texture & \# & Texture \\
\hline 1 & 106 & 18 & 3 & 35 & 10 & 52 & 0.25 & 69 & 0.5 & 86 & 111 \\
\hline 2 & 84 & 19 & 17 & 36 & 81 & 53 & 86 & 70 & 0.9 & 87 & 127 \\
\hline 3 & 216 & 20 & 6 & 37 & 5 & 54 & 113 & 71 & 36 & 88 & 153 \\
\hline 4 & 96 & 21 & 1 & 38 & 135 & 55 & 109 & 72 & 6 & 89 & 75 \\
\hline 5 & 13 & 22 & 185 & 39 & 107 & 56 & 68 & 73 & 3 & 90 & 119 \\
\hline 6 & 165 & 23 & 107 & 40 & 249 & 57 & 145 & 74 & 79 & 91 & 0.5 \\
\hline 7 & 51 & 24 & 12 & 41 & 8 & 58 & 642 & 75 & 97 & 92 & 118 \\
\hline 8 & 234 & 25 & 5 & 42 & 101 & 59 & 101 & 76 & 102 & 93 & 96 \\
\hline 9 & 91 & 26 & 8 & 43 & 35 & 60 & 122 & 77 & 98 & 94 & 68 \\
\hline 10 & 100 & 27 & 66 & 44 & 121 & 61 & 96 & 78 & 87 & 95 & 54 \\
\hline 11 & 95 & 28 & 237 & 45 & 82 & 62 & 101 & 79 & 103 & 96 & 101 \\
\hline 12 & 37 & 29 & 158 & 46 & 87 & 63 & 181 & 80 & 118 & 97 & 9 \\
\hline 13 & 56 & 30 & 68 & 47 & 10 & 64 & 49 & 81 & 112 & 98 & 68 \\
\hline 14 & 93 & 31 & 26 & 48 & 169 & 65 & 111 & 82 & 121 & 99 & 130 \\
\hline 15 & 57 & 32 & 51 & 49 & 7 & 66 & 81 & 83 & 79 & 100 & 127 \\
\hline 16 & 32 & 33 & 6 & 50 & 21 & 67 & 114 & 84 & 3 & & \\
\hline 17 & 70 & 34 & 15 & 51 & 97 & 68 & 49 & 85 & 9 & & \\
\hline
\end{tabular}




\section{Horse Valley Run}

Reach \#: 17 UTM Location: Zone 18, $4470482 \mathrm{~m} \mathrm{~N}, 0282011 \mathrm{~m} \mathrm{E}$

Composition of Bedload: Consists of sub-angular to sub-rounded clasts of sandstone and abundant sand size grains.

Bedload Textures: D50 $=76.0 \mathrm{~mm}, \mathrm{D} 84=140.0 \mathrm{~mm}$

Cumulative Frequency Distribution

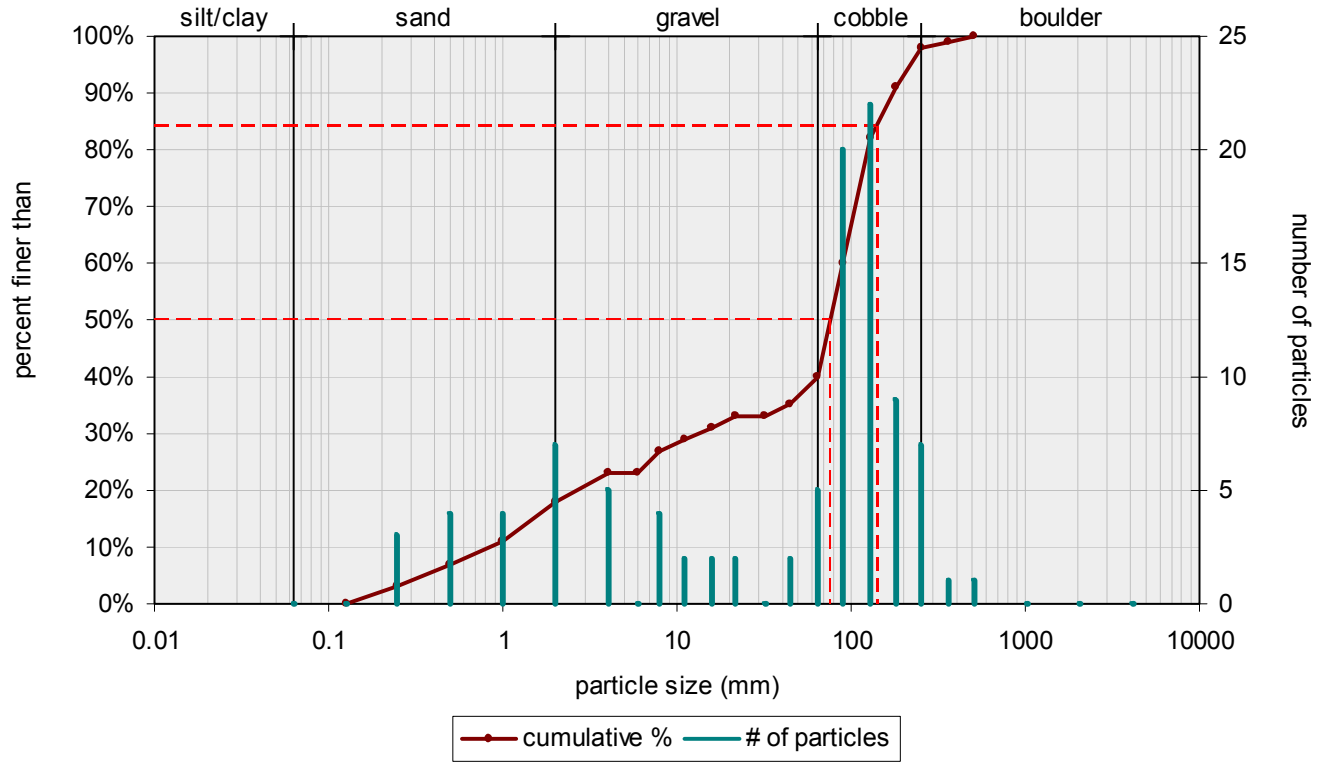

$\underline{\text { Pebble Count Data }}$

\begin{tabular}{|c|c|c|c|c|c|c|c|c|c|c|c|}
\hline$\#$ & Texture & $\#$ & Texture & $\#$ & Texture & $\#$ & Texture & $\#$ & Texture & \# & Texture \\
\hline 1 & 74 & 18 & 2 & 35 & 174 & 52 & 0.125 & 69 & 1 & 86 & 2 \\
\hline 2 & 0.25 & 19 & 97 & 36 & 68 & 53 & 117 & 70 & 74 & 87 & 53 \\
\hline 3 & 94 & 20 & 160 & 37 & 155 & 54 & 0.25 & 71 & 8 & 88 & 1 \\
\hline 4 & 111 & 21 & 97 & 38 & 84 & 55 & 57 & 72 & 127 & 89 & 242 \\
\hline 5 & 79 & 22 & 180 & 39 & 1 & 56 & 2 & 73 & 138 & 90 & 96 \\
\hline 6 & 256 & 23 & 0.125 & 40 & 72 & 57 & 93 & 74 & 82 & 91 & 7 \\
\hline 7 & 127 & 24 & 64 & 41 & 0.5 & 58 & 84 & 75 & 91 & 92 & 6 \\
\hline 8 & 1 & 25 & 91 & 42 & 224 & 59 & 61 & 76 & 1 & 93 & 109 \\
\hline 9 & 14 & 26 & 79 & 43 & 9 & 60 & 124 & 77 & 116 & 94 & 221 \\
\hline 10 & 0.5 & 27 & 88 & 44 & 2 & 61 & 0.5 & 78 & 79 & 95 & 201 \\
\hline 11 & 0.5 & 28 & 36 & 45 & 153 & 62 & 380 & 79 & 119 & 96 & 62 \\
\hline 12 & 129 & 29 & 74 & 46 & 94 & 63 & 86 & 80 & 44 & 97 & 66 \\
\hline 13 & 127 & 30 & 109 & 47 & 15 & 64 & 0.25 & 81 & 54 & 98 & 112 \\
\hline 14 & 83 & 31 & 204 & 48 & 158 & 65 & 87 & 82 & 129 & 99 & 131 \\
\hline 15 & 114 & 32 & 0.25 & 49 & 16 & 66 & 86 & 83 & 1 & 100 & 1 \\
\hline 16 & 17 & 33 & 0.125 & 50 & 79 & 67 & 2 & 84 & 7 & & \\
\hline 17 & 122 & 34 & 7 & 51 & 109 & 68 & 220 & 85 & 73 & & \\
\hline
\end{tabular}




\section{Laurel Run}

Reach \#: $18 \quad$ UTM Location: Zone 18, $4455800 \mathrm{~m} \mathrm{~N}, 0281525 \mathrm{~m} \mathrm{E}$

Composition of Bedload: Consists of tan, tabular, sub-rounded clasts of sandstone and sand size grains.

Bedload Textures: D50 $=90.0 \mathrm{~mm}, \mathrm{D} 84=210.0 \mathrm{~mm}$

Cumulative Frequency Distribution

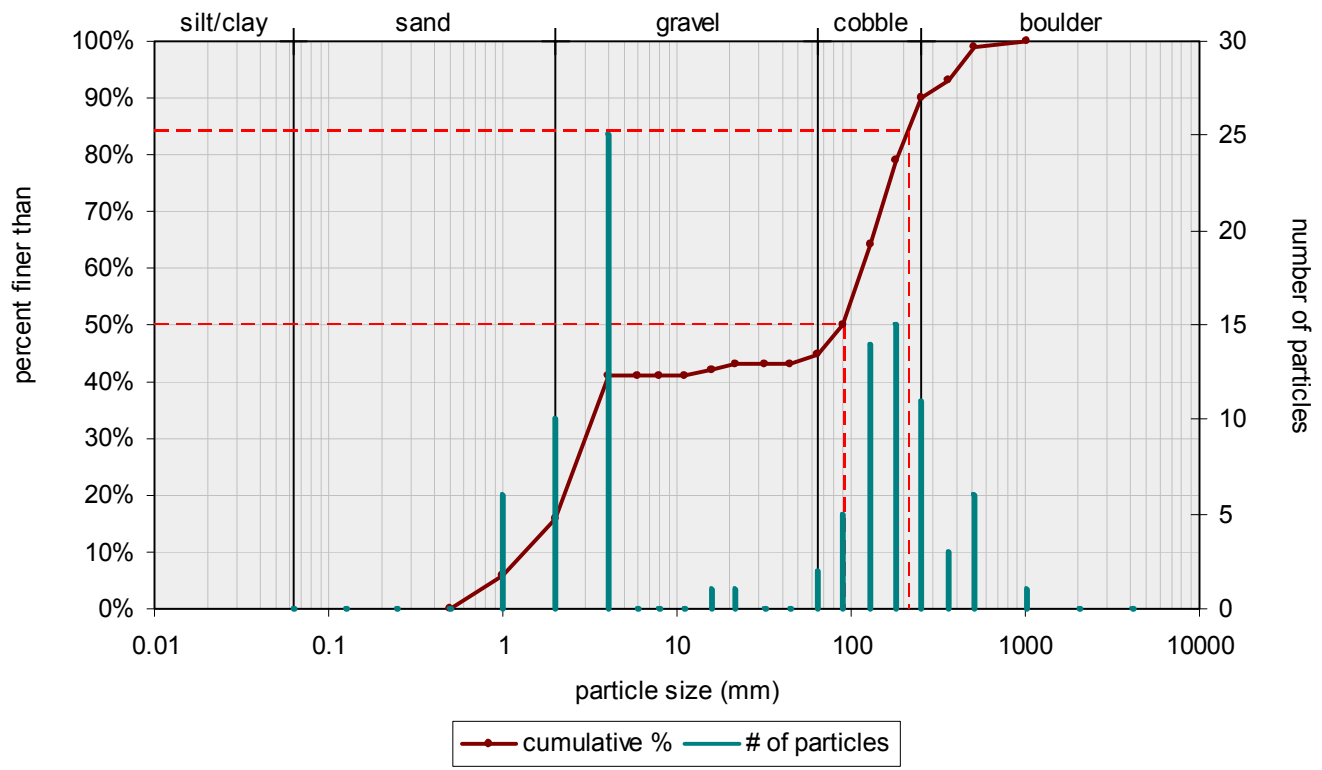

$\underline{\text { Pebble Count Data }}$

\begin{tabular}{|c|c|c|c|c|c|c|c|c|c|c|c|}
\hline \# & Texture & $\#$ & Texture & $\#$ & Texture & \# & Texture & \# & Texture & $\#$ & Texture \\
\hline 1 & 119 & 18 & 203 & 35 & 1 & 52 & 101 & 69 & 0.5 & 86 & 1 \\
\hline 2 & 647 & 19 & 2 & 36 & 101 & 53 & 1 & 70 & 130 & 87 & 2 \\
\hline 3 & 196 & 20 & 2 & 37 & 0.5 & 54 & 94 & 71 & 99 & 88 & 1 \\
\hline 4 & 134 & 21 & 136 & 38 & 2 & 55 & 182 & 72 & 2 & 89 & 79 \\
\hline 5 & 375 & 22 & 278 & 39 & 139 & 56 & 274 & 73 & 93 & 90 & 55 \\
\hline 6 & 2 & 23 & 2 & 40 & 97 & 57 & 0.5 & 74 & 2 & 91 & 1 \\
\hline 7 & 195 & 24 & 113 & 41 & 402 & 58 & 181 & 75 & 1 & 92 & 164 \\
\hline 8 & 12 & 25 & 2 & 42 & 2 & 59 & 222 & 76 & 0.5 & 93 & 223 \\
\hline 9 & 3 & 26 & 3 & 43 & 56 & 60 & 2 & 77 & 112 & 94 & 82 \\
\hline 10 & 1 & 27 & 1 & 44 & 133 & 61 & 142 & 78 & 1 & 95 & 99 \\
\hline 11 & 2 & 28 & 129 & 45 & 0.5 & 62 & 78 & 79 & 2 & 96 & 140 \\
\hline 12 & 3 & 29 & 142 & 46 & 2 & 63 & 153 & 80 & 489 & 97 & 19 \\
\hline 13 & 158 & 30 & 2 & 47 & 2 & 64 & 3 & 81 & 173 & 98 & 351 \\
\hline 14 & 209 & 31 & 97 & 48 & 2 & 65 & 2 & 82 & 132 & 99 & 2 \\
\hline 15 & 79 & 32 & 187 & 49 & 224 & 66 & 241 & 83 & 120 & 100 & 0.5 \\
\hline 16 & 368 & 33 & 1 & 50 & 2 & 67 & 104 & 84 & 461 & & \\
\hline 17 & 2 & 34 & 146 & 51 & 492 & 68 & 87 & 85 & 109 & & \\
\hline
\end{tabular}




\section{Laurel Run}

Reach \#: $19 \quad$ UTM Location: Zone 18, $4455793 \mathrm{~m} \mathrm{~N}, 0284851 \mathrm{~m} \mathrm{E}$

Composition of Bedload: Consists of sub-rounded, tan to red, clasts of sandstone.

Bedload Textures: D50 $=77.0 \mathrm{~mm}, \mathrm{D} 84=180.0 \mathrm{~mm}$

Cumulative Frequency Distribution

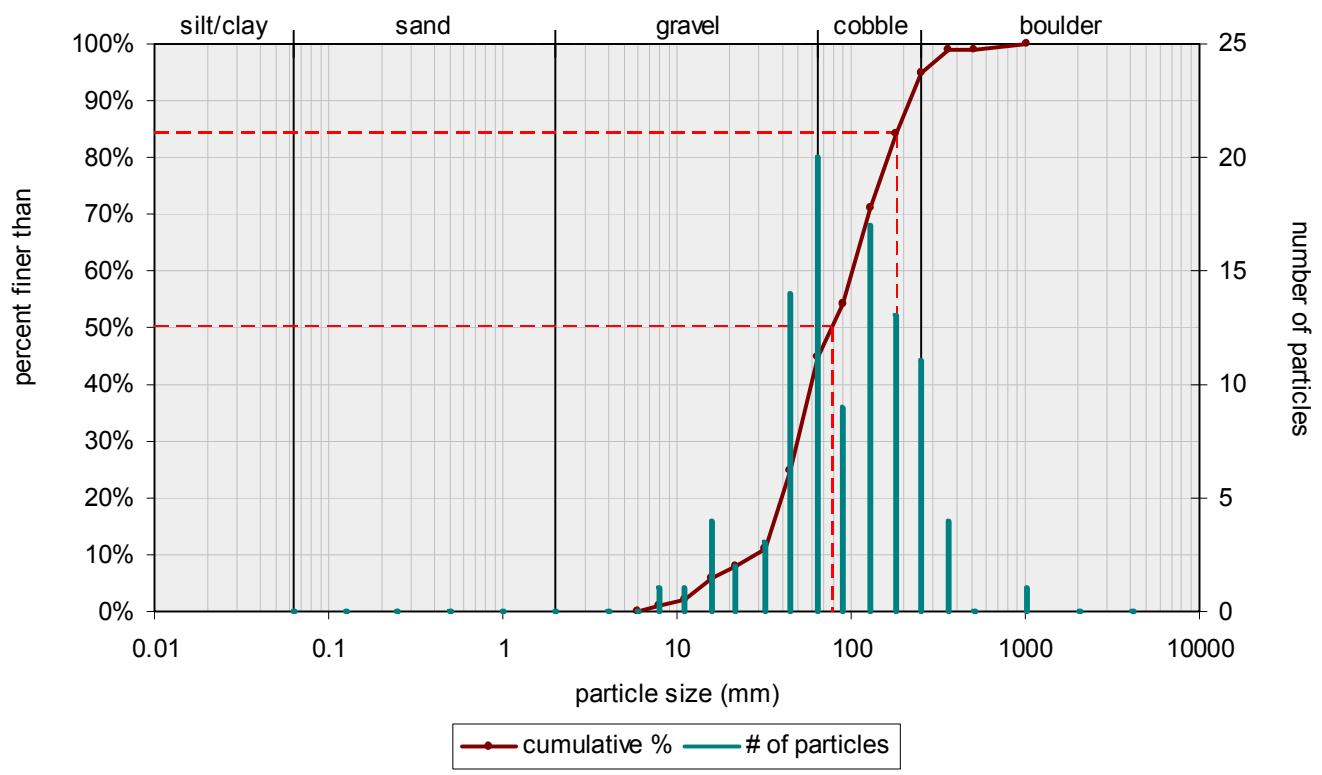

\section{$\underline{\text { Pebble Count Data }}$}

\begin{tabular}{|c|c|c|c|c|c|c|c|c|c|c|c|}
\hline \# & Texture & \# & Texture & \# & Texture & \# & Texture & \# & Texture & \# & Texture \\
\hline 1 & 104 & 18 & 106 & 35 & 333 & 52 & 48 & 69 & 62 & 86 & 69 \\
\hline 2 & 10 & 19 & 619 & 36 & 136 & 53 & 7 & 70 & 53 & 87 & 113 \\
\hline 3 & 250 & 20 & 59 & 37 & 96 & 54 & 163 & 71 & 202 & 88 & 11 \\
\hline 4 & 42 & 21 & 32 & 38 & 169 & 55 & 58 & 72 & 260 & 89 & 68 \\
\hline 5 & 43 & 22 & 311 & 39 & 58 & 56 & 74 & 73 & 31 & 90 & 196 \\
\hline 6 & 21 & 23 & 26 & 40 & 59 & 57 & 112 & 74 & 38 & 91 & 13 \\
\hline 7 & 89 & 24 & 189 & 41 & 47 & 58 & 143 & 75 & 126 & 92 & 99 \\
\hline 8 & 112 & 25 & 116 & 42 & 63 & 59 & 115 & 76 & 74 & 93 & 100 \\
\hline 9 & 54 & 26 & 58 & 43 & 61 & 60 & 134 & 77 & 273 & 94 & 48 \\
\hline 10 & 134 & 27 & 37 & 44 & 142 & 61 & 131 & 78 & 121 & 95 & 71 \\
\hline 11 & 183 & 28 & 36 & 45 & 184 & 62 & 39 & 79 & 71 & 96 & 37 \\
\hline 12 & 42 & 29 & 34 & 46 & 146 & 63 & 77 & 80 & 63 & 97 & 31 \\
\hline 13 & 139 & 30 & 105 & 47 & 37 & 64 & 61 & 81 & 61 & 98 & 210 \\
\hline 14 & 13 & 31 & 89 & 48 & 34 & 65 & 152 & 82 & 151 & 99 & 131 \\
\hline 15 & 216 & 32 & 17 & 49 & 202 & 66 & 61 & 83 & 54 & 100 & 91 \\
\hline 16 & 43 & 33 & 105 & 50 & 99 & 67 & 11 & 84 & 47 & & \\
\hline 17 & 96 & 34 & 55 & 51 & 208 & 68 & 39 & 85 & 255 & & \\
\hline
\end{tabular}




\section{Laurel Run}

Reach \#: $20 \quad$ UTM Location: Zone 18, $4455305 \mathrm{~m} \mathrm{~N}, 0281027 \mathrm{~m} \mathrm{E}$

Composition of Bedload: Consists of sub-angular to sub-rounded tan clasts of sandstone, abundant sand size grains.

Bedload Textures: D50 $=59.0 \mathrm{~mm}, \mathrm{D} 84=130.0 \mathrm{~mm}$

Cumulative Frequency Distribution

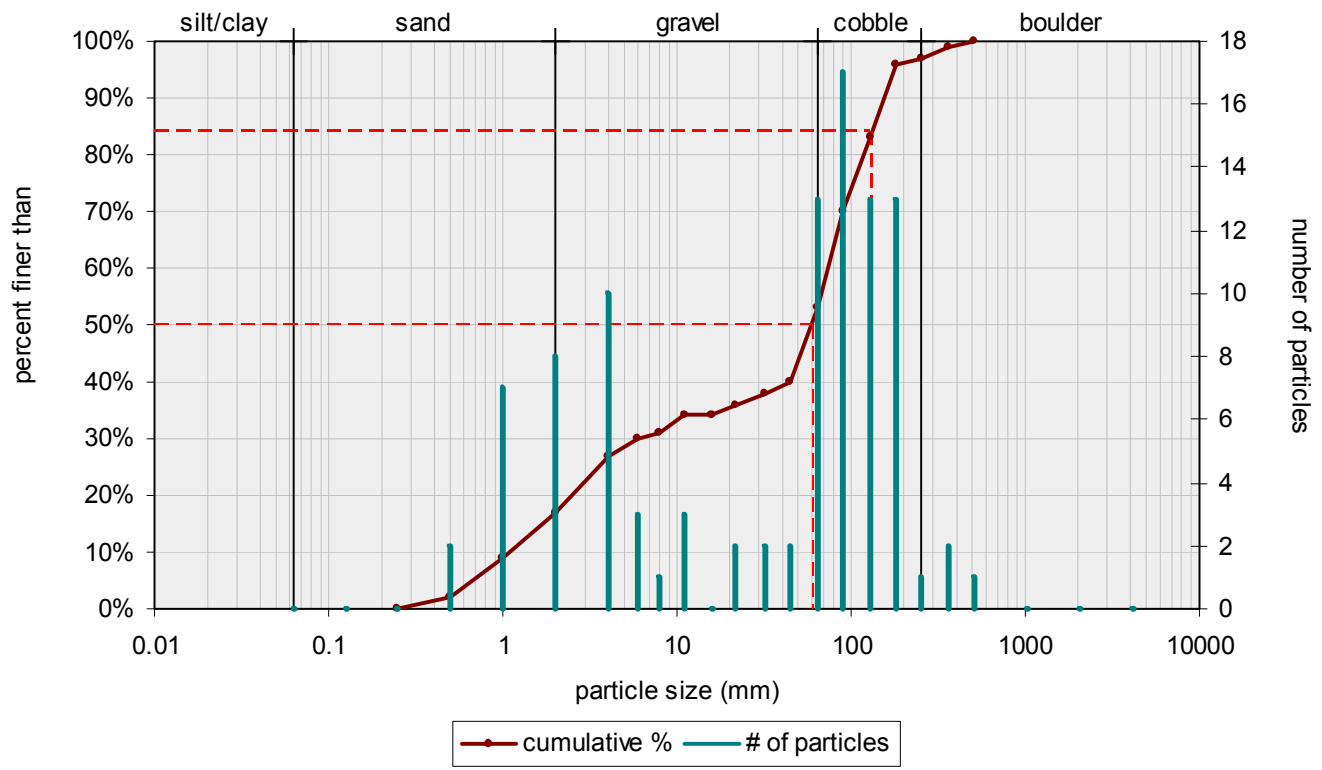

$\underline{\text { Pebble Count Data }}$

\begin{tabular}{|c|c|c|c|c|c|c|c|c|c|c|c|}
\hline$\#$ & Texture & $\#$ & Texture & $\#$ & Texture & $\#$ & Texture & \# & Texture & $\#$ & Texture \\
\hline 1 & 64 & 18 & 88 & 35 & 48 & 52 & 2 & 69 & 77 & 86 & 29 \\
\hline 2 & 129 & 19 & 65 & 36 & 59 & 53 & 51 & 70 & 100 & 87 & 7 \\
\hline 3 & 99 & 20 & 1 & 37 & 62 & 54 & 2 & 71 & 55 & 88 & 68 \\
\hline 4 & 164 & 21 & 2 & 38 & 1 & 55 & 113 & 72 & 71 & 89 & 81 \\
\hline 5 & 76 & 22 & 0.25 & 39 & 1 & 56 & 57 & 73 & 88 & 90 & 215 \\
\hline 6 & 79 & 23 & 0.25 & 40 & 2 & 57 & 3 & 74 & 1 & 91 & 38 \\
\hline 7 & 141 & 24 & 5 & 41 & 261 & 58 & 350 & 75 & 89 & 92 & 57 \\
\hline 8 & 0.5 & 25 & 147 & 42 & 16 & 59 & 61 & 76 & 173 & 93 & 81 \\
\hline 9 & 83 & 26 & 58 & 43 & 2 & 60 & 2 & 77 & 138 & 94 & 3 \\
\hline 10 & 489 & 27 & 1 & 44 & 63 & 61 & 52 & 78 & 78 & 95 & 0.5 \\
\hline 11 & 0.5 & 28 & 4 & 45 & 9 & 62 & 133 & 79 & 0.5 & 96 & 124 \\
\hline 12 & 87 & 29 & 142 & 46 & 10 & 63 & 49 & 80 & 140 & 97 & 1 \\
\hline 13 & 172 & 30 & 4 & 47 & 140 & 64 & 0.5 & 81 & 61 & 98 & 69 \\
\hline 14 & 111 & 31 & 42 & 48 & 20 & 65 & 27 & 82 & 0.5 & 99 & 2 \\
\hline 15 & 148 & 32 & 1 & 49 & 94 & 66 & 107 & 83 & 124 & 100 & 101 \\
\hline 16 & 98 & 33 & 69 & 50 & 104 & 67 & 4 & 84 & 108 & & \\
\hline 17 & 111 & 34 & 2 & 51 & 0.5 & 68 & 9 & 85 & 163 & & \\
\hline
\end{tabular}




\section{Laurel Run}

Reach \#: $21 \quad$ UTM Location: Zone 18, $4456176 \mathrm{~m} \mathrm{~N}, 0281989 \mathrm{~m} \mathrm{E}$

Composition of Bedload: Consists of tabular, sub-angular to sub-rounded clasts of clean quartz sandstone.

Bedload Textures: D50 $=93.0 \mathrm{~mm}, \mathrm{D} 84=210.0 \mathrm{~mm}$

Cumulative Frequency Distribution

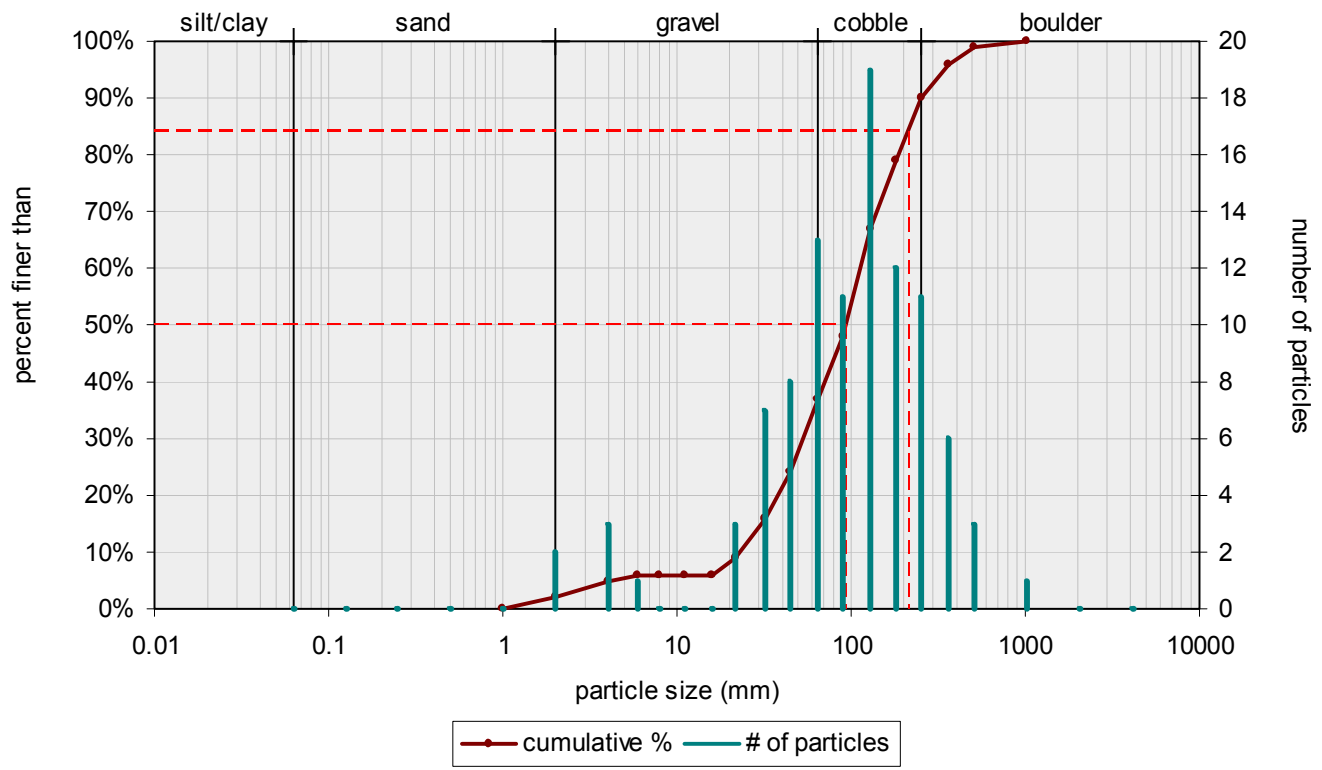

$\underline{\text { Pebble Count Data }}$

\begin{tabular}{|c|c|c|c|c|c|c|c|c|c|c|c|}
\hline \# & Texture & $\#$ & Texture & $\#$ & Texture & \# & Texture & \# & Texture & $\#$ & Texture \\
\hline 1 & 43 & 18 & 51 & 35 & 135 & 52 & 161 & 69 & 44 & 86 & 118 \\
\hline 2 & 45 & 19 & 63 & 36 & 216 & 53 & 92 & 70 & 594 & 87 & 154 \\
\hline 3 & 22 & 20 & 118 & 37 & 1 & 54 & 69 & 71 & 46 & 88 & 219 \\
\hline 4 & 25 & 21 & 102 & 38 & 129 & 55 & 150 & 72 & 180 & 89 & 77 \\
\hline 5 & 47 & 22 & 100 & 39 & 243 & 56 & 33 & 73 & 157 & 90 & 420 \\
\hline 6 & 70 & 23 & 350 & 40 & 321 & 57 & 39 & 74 & 193 & 91 & 102 \\
\hline 7 & 119 & 24 & 14 & 41 & 66 & 58 & 42 & 75 & 24 & 92 & 29 \\
\hline 8 & 112 & 25 & 22 & 42 & 28 & 59 & 41 & 76 & 98 & 93 & 91 \\
\hline 9 & 20 & 26 & 133 & 43 & 91 & 60 & 2 & 77 & 2 & 94 & 305 \\
\hline 10 & 44 & 27 & 19 & 44 & 55 & 61 & 4 & 78 & 59 & 95 & 71 \\
\hline 11 & 181 & 28 & 331 & 45 & 78 & 62 & 80 & 79 & 93 & 96 & 22 \\
\hline 12 & 2 & 29 & 89 & 46 & 91 & 63 & 169 & 80 & 138 & 97 & 183 \\
\hline 13 & 491 & 30 & 193 & 47 & 155 & 64 & 180 & 81 & 54 & 98 & 111 \\
\hline 14 & 221 & 31 & 41 & 48 & 119 & 65 & 93 & 82 & 237 & 99 & 127 \\
\hline 15 & 165 & 32 & 397 & 49 & 67 & 66 & 47 & 83 & 79 & 100 & 104 \\
\hline 16 & 49 & 33 & 59 & 50 & 51 & 67 & 142 & 84 & 1 & & \\
\hline 17 & 48 & 34 & 109 & 51 & 285 & 68 & 300 & 85 & 68 & & \\
\hline
\end{tabular}




\section{Laurel Run}

Reach \#: $22 \quad$ UTM Location: Zone 18, $4459957 \mathrm{~m} \mathrm{~N}, 0288247 \mathrm{~m} \mathrm{E}$

Composition of Bedload: Consists of tan sub-angular to sub-rounded clasts of sandstone.

Bedload Textures: D50 $=93.0 \mathrm{~mm}, \mathrm{D} 84=210.0 \mathrm{~mm}$

Cumulative Frequency Distribution

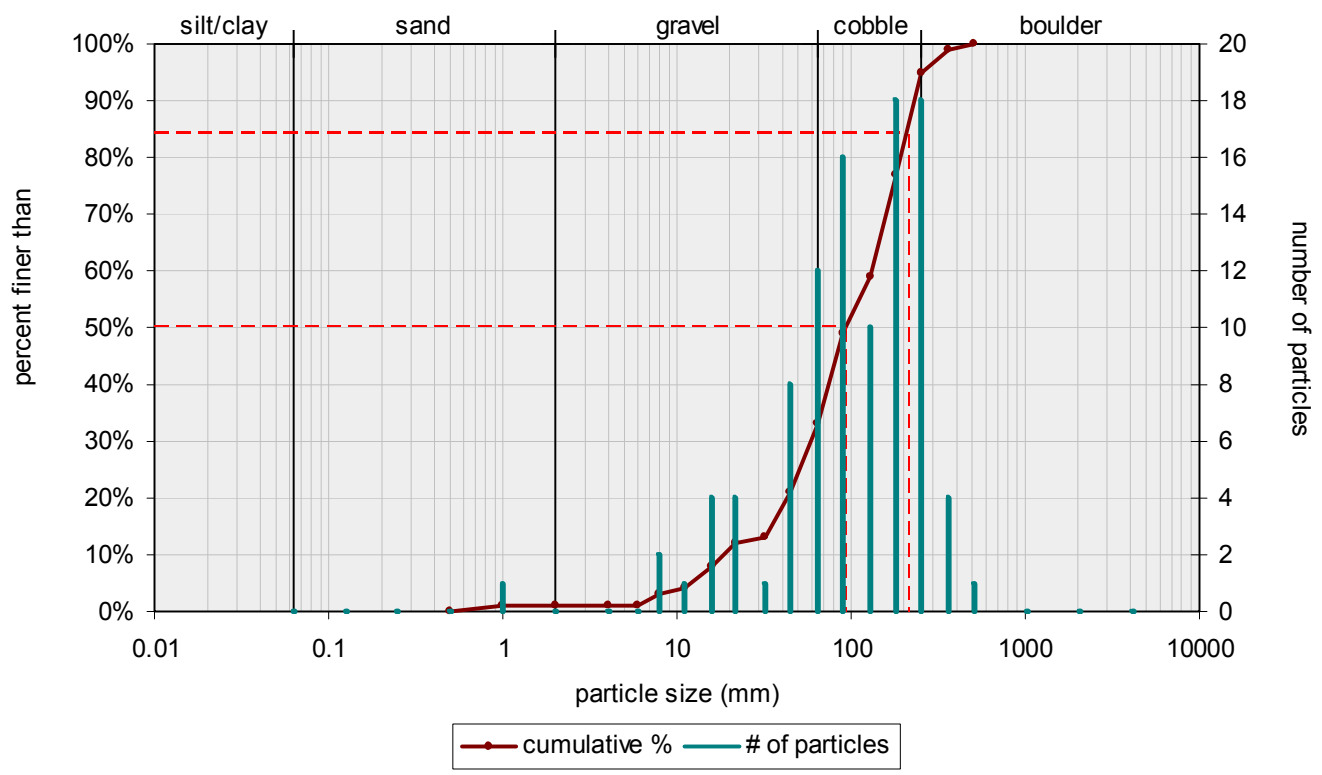

\section{$\underline{\text { Pebble Count Data }}$}

\begin{tabular}{|c|c|c|c|c|c|c|c|c|c|c|c|}
\hline \# & Texture & \# & Texture & \# & Texture & \# & Texture & \# & Texture & \# & Texture \\
\hline 1 & 192 & 18 & 211 & 35 & 114 & 52 & 60 & 69 & 337 & 86 & 66 \\
\hline 2 & 72 & 19 & 113 & 36 & 14 & 53 & 29 & 70 & 181 & 87 & 37 \\
\hline 3 & 889 & 20 & 76 & 37 & 13 & 54 & 80 & 71 & 181 & 88 & 63 \\
\hline 4 & 155 & 21 & 143 & 38 & 17 & 55 & 11 & 72 & 139 & 89 & 229 \\
\hline 5 & 163 & 22 & 185 & 39 & 129 & 56 & 0.5 & 73 & 231 & 90 & 49 \\
\hline 6 & 110 & 23 & 291 & 40 & 49 & 57 & 83 & 74 & 185 & 91 & 96 \\
\hline 7 & 247 & 24 & 148 & 41 & 128 & 58 & 6 & 75 & 83 & 92 & 71 \\
\hline 8 & 140 & 25 & 135 & 42 & 234 & 59 & 20 & 76 & 42 & 93 & 44 \\
\hline 9 & 204 & 26 & 59 & 43 & 119 & 60 & 51 & 77 & 68 & 94 & 7 \\
\hline 10 & 191 & 27 & 176 & 44 & 281 & 61 & 61 & 78 & 37 & 95 & 111 \\
\hline 11 & 39 & 28 & 82 & 45 & 198 & 62 & 106 & 79 & 14 & 96 & 20 \\
\hline 12 & 109 & 29 & 19 & 46 & 42 & 63 & 129 & 80 & 82 & 97 & 136 \\
\hline 13 & 141 & 30 & 38 & 47 & 303 & 64 & 47 & 81 & 129 & 98 & 51 \\
\hline 14 & 91 & 31 & 64 & 48 & 32 & 65 & 84 & 82 & 193 & 99 & 231 \\
\hline 15 & 50 & 32 & 9 & 49 & 81 & 66 & 63 & 83 & 189 & 100 & 104 \\
\hline 16 & 71 & 33 & 207 & 50 & 72 & 67 & 158 & 84 & 135 & & \\
\hline 17 & 49 & 34 & 168 & 51 & 221 & 68 & 201 & 85 & 416 & & \\
\hline
\end{tabular}




\section{Laurel Run}

Reach \#: $23 \quad$ UTM Location: Zone 18, $4460052 \mathrm{~m} \mathrm{~N}, 0288307 \mathrm{~m} \mathrm{E}$

Composition of Bedload: Consists of elongate, tabular, sub-angular to sub-rounded clasts of sandstone.

Bedload Textures: D50 $=90.0 \mathrm{~mm}, \mathrm{D} 84=210.0 \mathrm{~mm}$

Cumulative Frequency Distribution

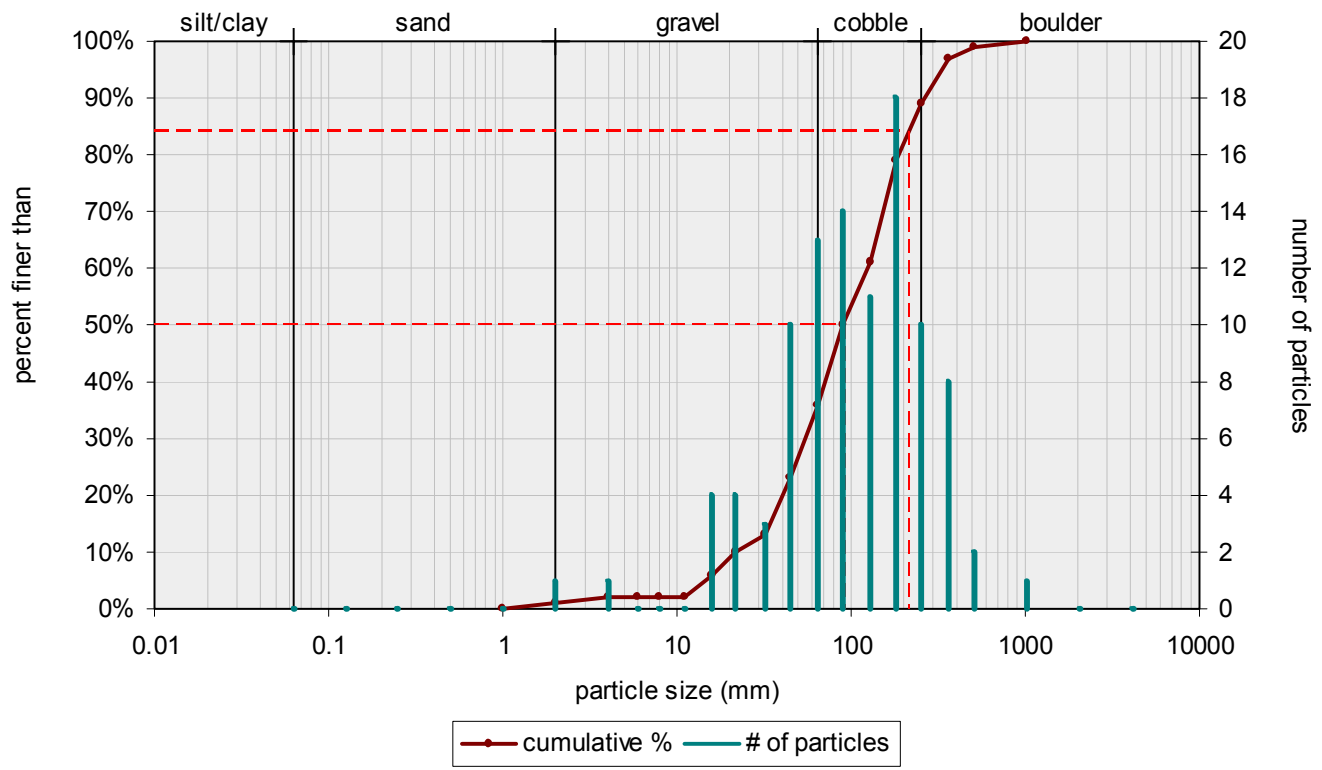

$\underline{\text { Pebble Count Data }}$

\begin{tabular}{|c|c|c|c|c|c|c|c|c|c|c|c|}
\hline$\#$ & Texture & $\#$ & Texture & $\#$ & Texture & $\#$ & Texture & \# & Texture & $\#$ & Texture \\
\hline 1 & 123 & 18 & 143 & 35 & 113 & 52 & 78 & 69 & 46 & 86 & 27 \\
\hline 2 & 36 & 19 & 63 & 36 & 160 & 53 & 359 & 70 & 68 & 87 & 173 \\
\hline 3 & 17 & 20 & 140 & 37 & 47 & 54 & 43 & 71 & 395 & 88 & 161 \\
\hline 4 & 332 & 21 & 90 & 38 & 3 & 55 & 593 & 72 & 104 & 89 & 66 \\
\hline 5 & 55 & 22 & 1 & 39 & 61 & 56 & 188 & 73 & 45 & 90 & 177 \\
\hline 6 & 15 & 23 & 144 & 40 & 66 & 57 & 11 & 74 & 113 & 91 & 24 \\
\hline 7 & 20 & 24 & 211 & 41 & 49 & 58 & 37 & 75 & 378 & 92 & 11 \\
\hline 8 & 27 & 25 & 195 & 42 & 179 & 59 & 66 & 76 & 133 & 93 & 41 \\
\hline 9 & 40 & 26 & 342 & 43 & 130 & 60 & 288 & 77 & 34 & 94 & 47 \\
\hline 10 & 20 & 27 & 86 & 44 & 361 & 61 & 36 & 78 & 192 & 95 & 41 \\
\hline 11 & 53 & 28 & 149 & 45 & 68 & 62 & 289 & 79 & 194 & 96 & 83 \\
\hline 12 & 111 & 29 & 171 & 46 & 147 & 63 & 109 & 80 & 84 & 97 & 151 \\
\hline 13 & 60 & 30 & 59 & 47 & 143 & 64 & 47 & 81 & 110 & 98 & 103 \\
\hline 14 & 131 & 31 & 247 & 48 & 82 & 65 & 43 & 82 & 209 & 99 & 130 \\
\hline 15 & 295 & 32 & 259 & 49 & 51 & 66 & 79 & 83 & 344 & 100 & 19 \\
\hline 16 & 40 & 33 & 88 & 50 & 211 & 67 & 74 & 84 & 241 & & \\
\hline 17 & 75 & 34 & 99 & 51 & 126 & 68 & 177 & 85 & 14 & & \\
\hline
\end{tabular}




\section{Laurel Run}

Reach \#: $24 \quad$ UTM Location: Zone 18, $4461110 \mathrm{~m} \mathrm{~N}, 0290814 \mathrm{~m} \mathrm{E}$

Composition of Bedload: Consists of red and tan sub-angular to sub-rounded clasts of sandstone.

Bedload Textures: D50 $=97.0 \mathrm{~mm}, \mathrm{D} 84=180.0 \mathrm{~mm}$

Cumulative Frequency Distribution

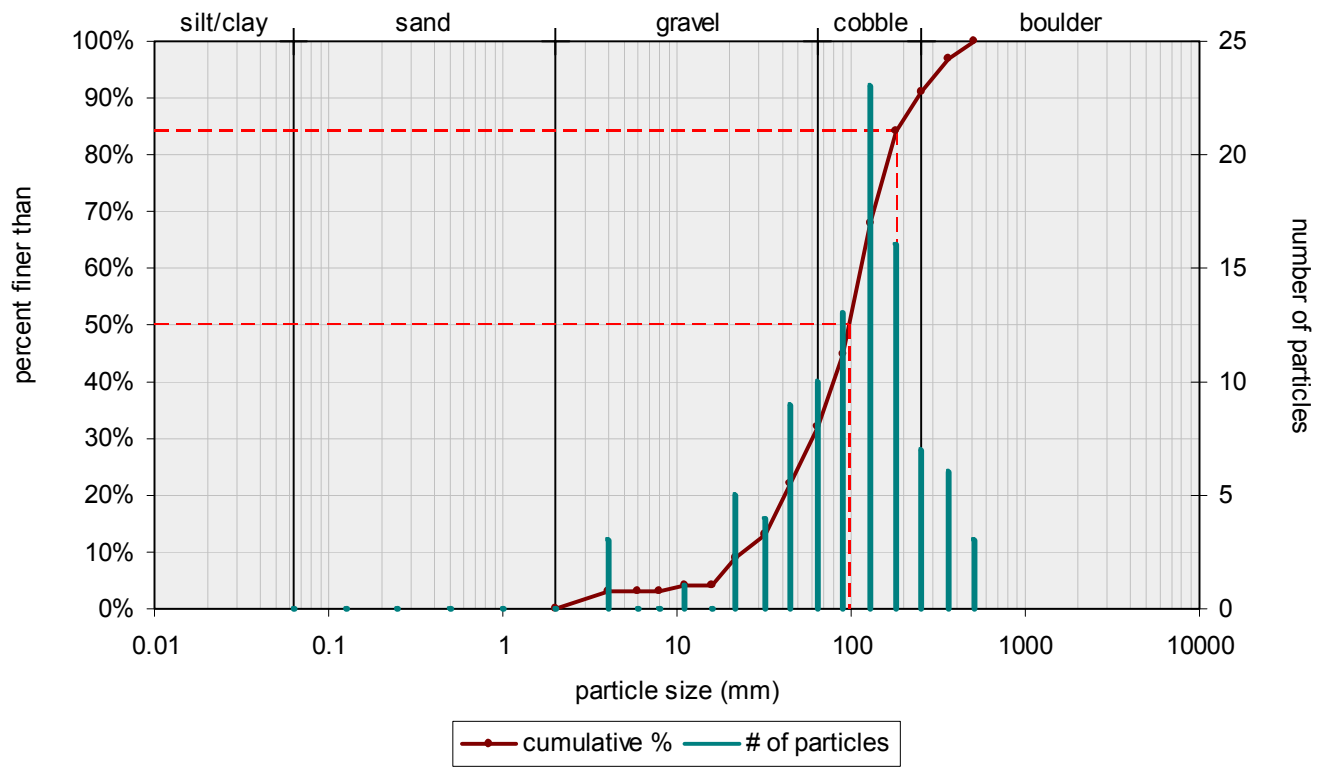

$\underline{\text { Pebble Count Data }}$

\begin{tabular}{|c|c|c|c|c|c|c|c|c|c|c|c|}
\hline \# & Texture & $\#$ & Texture & $\#$ & Texture & $\#$ & Texture & $\#$ & Texture & \# & Texture \\
\hline 1 & 21 & 18 & 61 & 35 & 101 & 52 & 135 & 69 & 85 & 86 & 87 \\
\hline 2 & 90 & 19 & 65 & 36 & 134 & 53 & 94 & 70 & 59 & 87 & 201 \\
\hline 3 & 141 & 20 & 151 & 37 & 21 & 54 & 115 & 71 & 187 & 88 & 94 \\
\hline 4 & 208 & 21 & 143 & 38 & 120 & 55 & 284 & 72 & 56 & 89 & 73 \\
\hline 5 & 277 & 22 & 423 & 39 & 106 & 56 & 104 & 73 & 173 & 90 & 79 \\
\hline 6 & 121 & 23 & 32 & 40 & 103 & 57 & 48 & 74 & 62 & 91 & 44 \\
\hline 7 & 93 & 24 & 81 & 41 & 8 & 58 & 49 & 75 & 49 & 92 & 18 \\
\hline 8 & 58 & 25 & 39 & 42 & 122 & 59 & 287 & 76 & 77 & 93 & 111 \\
\hline 9 & 113 & 26 & 72 & 43 & 44 & 60 & 121 & 77 & 419 & 94 & 17 \\
\hline 10 & 149 & 27 & 104 & 44 & 123 & 61 & 2 & 78 & 104 & 95 & 93 \\
\hline 11 & 146 & 28 & 186 & 45 & 19 & 62 & 73 & 79 & 132 & 96 & 86 \\
\hline 12 & 191 & 29 & 155 & 46 & 25 & 63 & 24 & 80 & 52 & 97 & 341 \\
\hline 13 & 35 & 30 & 364 & 47 & 102 & 64 & 140 & 81 & 321 & 98 & 150 \\
\hline 14 & 139 & 31 & 131 & 48 & 39 & 65 & 38 & 82 & 36 & 99 & 3 \\
\hline 15 & 22 & 32 & 116 & 49 & 144 & 66 & 76 & 83 & 69 & 100 & 210 \\
\hline 16 & 98 & 33 & 27 & 50 & 77 & 67 & 165 & 84 & 191 & & \\
\hline 17 & 56 & 34 & 115 & 51 & 3 & 68 & 44 & 85 & 292 & & \\
\hline
\end{tabular}




\section{Conodoguinet Creek}

Reach \#: $25 \quad$ UTM Location: Zone 18, $4442218 \mathrm{~m} \mathrm{~N}, 0268887 \mathrm{~m} \mathrm{E}$

Composition of Bedload: Consists of tan, tabular to elongate, sub-angular to sub-rounded clasts of sandstone.

Bedload Textures: D50 $=62.0 \mathrm{~mm}, \mathrm{D} 84=120.0 \mathrm{~mm}$

Cumulative Frequency Distribution

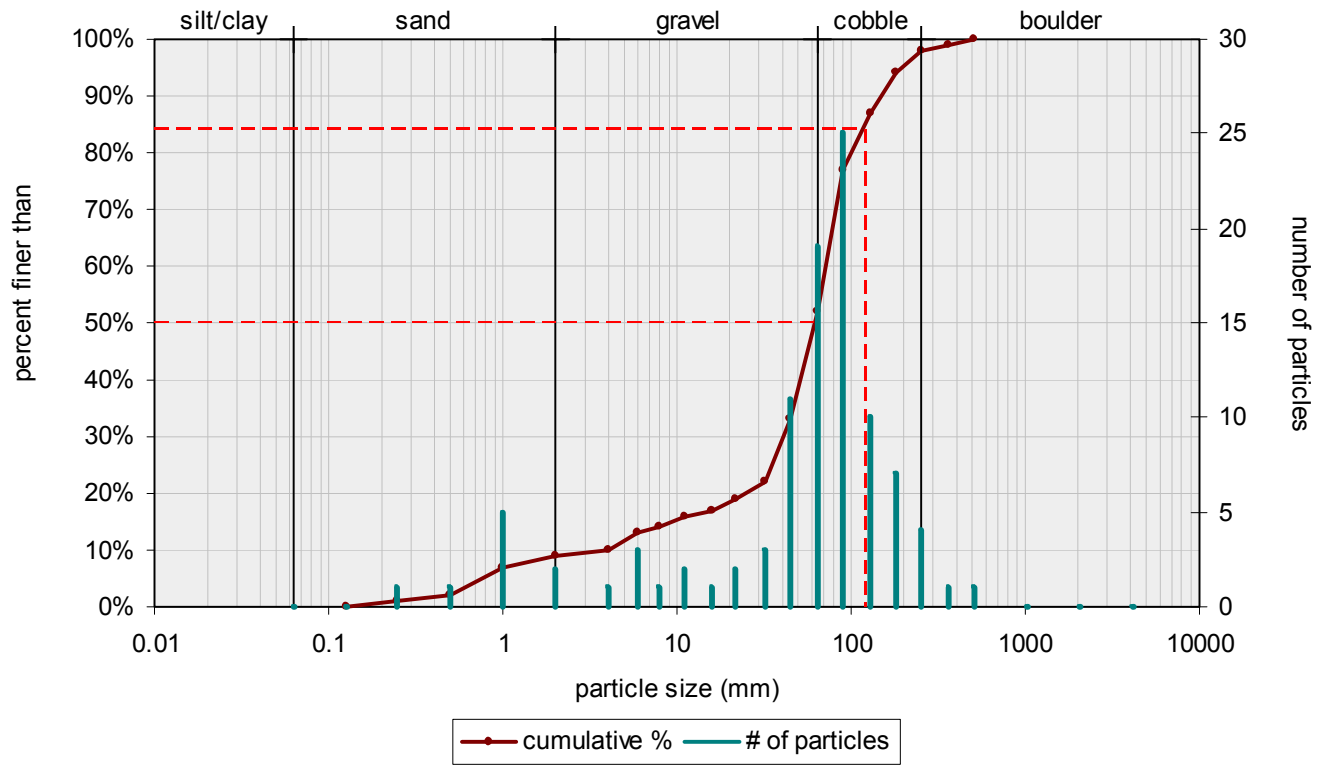

$\underline{\text { Pebble Count Data }}$

\begin{tabular}{|c|c|c|c|c|c|c|c|c|c|c|c|}
\hline \# & Texture & $\#$ & Texture & $\#$ & Texture & $\#$ & Texture & $\#$ & Texture & \# & Texture \\
\hline 1 & 1 & 18 & 69 & 35 & 55 & 52 & 44 & 69 & 380 & 86 & 53 \\
\hline 2 & 210 & 19 & 58 & 36 & 61 & 53 & 47 & 70 & 235 & 87 & 44 \\
\hline 3 & 105 & 20 & 65 & 37 & 89 & 54 & 70 & 71 & 240 & 88 & 94 \\
\hline 4 & 8 & 21 & 115 & 38 & 43 & 55 & 120 & 72 & 83 & 89 & 80 \\
\hline 5 & 57 & 22 & 70 & 39 & 22 & 56 & 105 & 73 & 58 & 90 & 79 \\
\hline 6 & 66 & 23 & 0.25 & 40 & 34 & 57 & 89 & 74 & 62 & 91 & 74 \\
\hline 7 & 77 & 24 & 150 & 41 & 0.5 & 58 & 160 & 75 & 66 & 92 & 16 \\
\hline 8 & 0.5 & 25 & 100 & 42 & 62 & 59 & 85 & 76 & 80 & 93 & 79 \\
\hline 9 & 72 & 26 & 85 & 43 & 40 & 60 & 85 & 77 & 28 & 94 & 63 \\
\hline 10 & 33 & 27 & 33 & 44 & 93 & 61 & 46 & 78 & 44 & 95 & 153 \\
\hline 11 & 85 & 28 & 46 & 45 & 53 & 62 & 0.5 & 79 & 61 & 96 & 69 \\
\hline 12 & 150 & 29 & 185 & 46 & 160 & 63 & 2.6 & 80 & 130 & 97 & 32 \\
\hline 13 & 145 & 30 & 69 & 47 & 265 & 64 & 5.2 & 81 & 0.71 & 98 & 14 \\
\hline 14 & 46 & 31 & 0.125 & 48 & 43 & 65 & 5.2 & 82 & 31 & 99 & 75 \\
\hline 15 & 1 & 32 & 53 & 49 & 95 & 66 & 5.2 & 83 & 57 & 100 & 0.5 \\
\hline 16 & 111 & 33 & 39 & 50 & 65 & 67 & 9.6 & 84 & 54 & & \\
\hline 17 & 80 & 34 & 60 & 51 & 100 & 68 & 6.3 & 85 & 21 & & \\
\hline
\end{tabular}




\section{Conodoguinet Creek}

Reach \#: 26 UTM Location: Zone 18, $4440721 \mathrm{~m} \mathrm{~N}, 0266815 \mathrm{~m} \mathrm{E}$

\section{Composition of Bedload: N/A}

Bedload Textures: D50 $=58.0 \mathrm{~mm}, \mathrm{D} 84=120.0 \mathrm{~mm}$

\section{Cumulative Frequency Distribution}

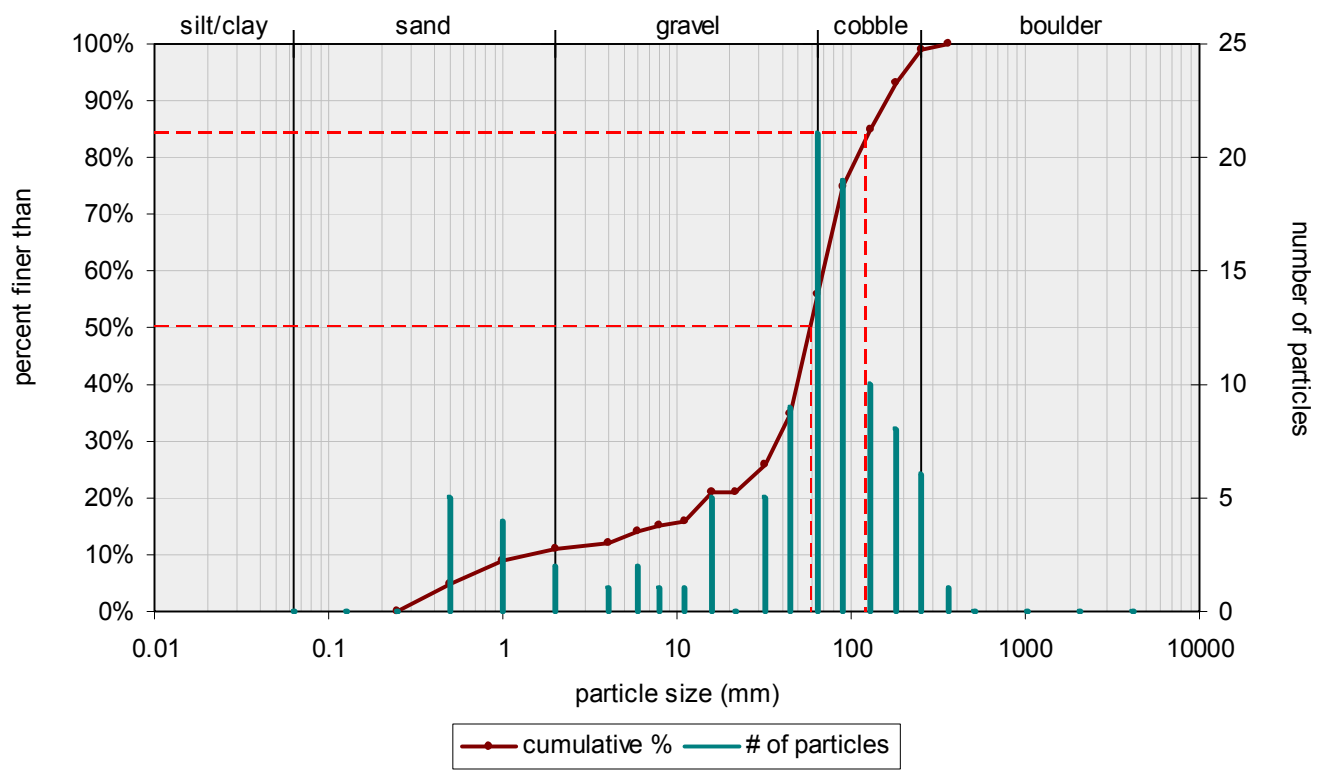

\section{Pebble Count Data}

\begin{tabular}{|c|c|c|c|c|c|c|c|c|c|c|c|}
\hline \# & Texture & $\#$ & Texture & $\#$ & Texture & \# & Texture & $\#$ & Texture & $\#$ & Texture \\
\hline 1 & 28 & 18 & 47 & 35 & 0.25 & 52 & 44 & 69 & 193 & 86 & 110 \\
\hline 2 & 9 & 19 & 50 & 36 & 178 & 53 & 74 & 70 & 4 & 87 & 193 \\
\hline 3 & 14 & 20 & 51 & 37 & 132 & 54 & 110 & 71 & 63 & 88 & 100 \\
\hline 4 & 195 & 21 & 65 & 38 & 31 & 55 & 86 & 72 & 59 & 89 & 46 \\
\hline 5 & 22 & 22 & 29 & 39 & 85 & 56 & 149 & 73 & 81 & 90 & 81 \\
\hline 6 & 12 & 23 & 40 & 40 & 115 & 57 & 183 & 74 & 73 & 91 & 36 \\
\hline 7 & 66 & 24 & 69 & 41 & 47 & 58 & 0.71 & 75 & 65 & 92 & 125 \\
\hline 8 & 0.25 & 25 & 58 & 42 & 112 & 59 & 0.5 & 76 & 205 & 93 & 1 \\
\hline 9 & 110 & 26 & 35 & 43 & 54 & 60 & 1 & 77 & 84 & 94 & 29 \\
\hline 10 & 37 & 27 & 56 & 44 & 0.5 & 61 & 263 & 78 & 63 & 95 & 51 \\
\hline 11 & 96 & 28 & 6 & 45 & 0.25 & 62 & 0.5 & 79 & 61 & 96 & 31 \\
\hline 12 & 51 & 29 & 68 & 46 & 77 & 63 & 46 & 80 & 12 & 97 & 36 \\
\hline 13 & 155 & 30 & 43 & 47 & 46 & 64 & 90 & 81 & 0.35 & 98 & 49 \\
\hline 14 & 75 & 31 & 150 & 48 & 53 & 65 & 33 & 82 & 15 & 99 & 156 \\
\hline 15 & 44 & 32 & 13 & 49 & 71 & 66 & 35 & 83 & 167 & 100 & 2 \\
\hline 16 & 46 & 33 & 135 & 50 & 190 & 67 & 56 & 84 & 46 & & \\
\hline 17 & 97 & 34 & 70 & 51 & 64 & 68 & 69 & 85 & 4 & & \\
\hline
\end{tabular}




\section{Conodoguinet Creek}

Reach \#: $27 \quad$ UTM Location: Zone 18, $4438731 \mathrm{~m} \mathrm{~N}, 0264445 \mathrm{~m} \mathrm{E}$

Composition of Bedload: Consists of tan sub-rounded clasts of quartz sandstone.

Bedload Textures: $\mathrm{D} 50=87.0 \mathrm{~mm}, \mathrm{D} 84=150.0 \mathrm{~mm}$

Cumulative Frequency Distribution

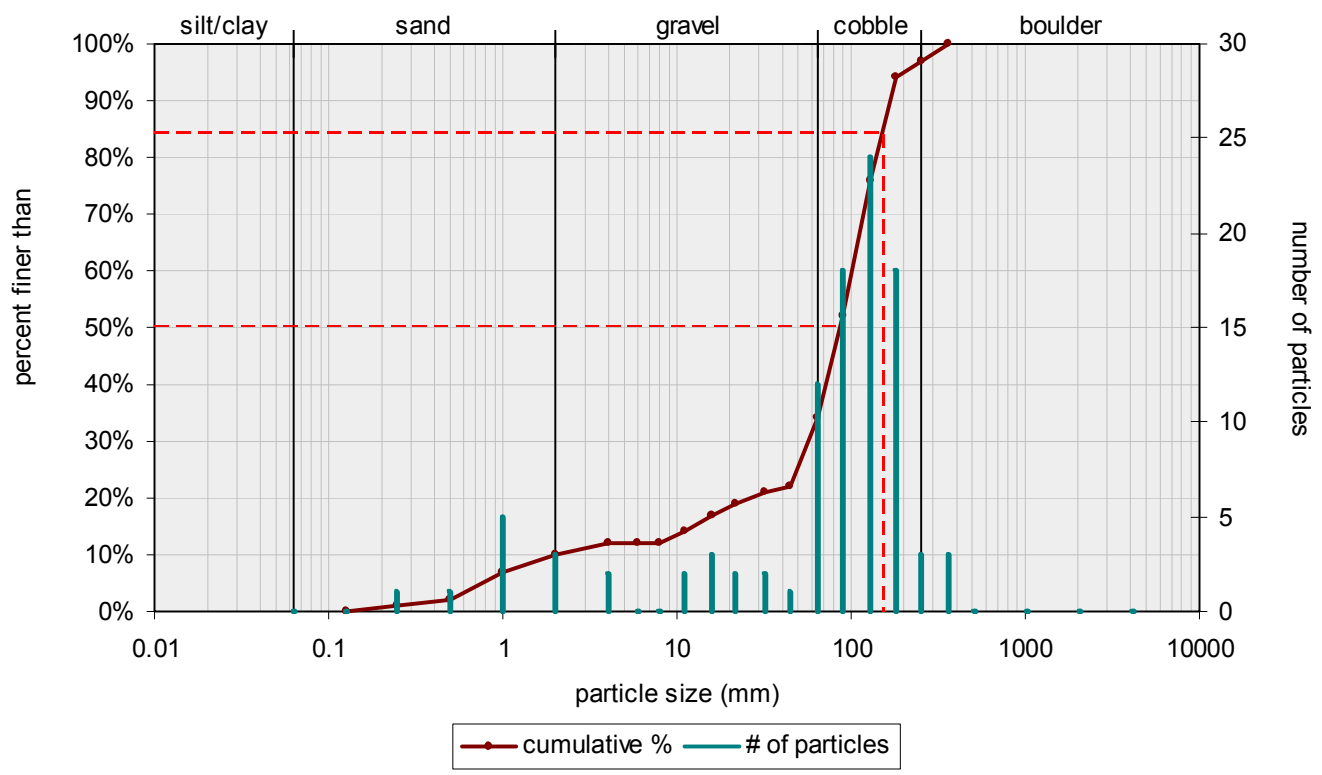

\section{$\underline{\text { Pebble Count Data }}$}

\begin{tabular}{|c|c|c|c|c|c|c|c|c|c|c|c|}
\hline \# & Texture & \# & Texture & \# & Texture & \# & Texture & \# & Texture & \# & Texture \\
\hline 1 & 53 & 18 & 80 & 35 & 91 & 52 & 310 & 69 & 100 & 86 & 63 \\
\hline 2 & 12 & 19 & 120 & 36 & 123 & 53 & 69 & 70 & 270 & 87 & 81 \\
\hline 3 & 150 & 20 & 140 & 37 & 111 & 54 & 90 & 71 & 322 & 88 & 251 \\
\hline 4 & 10 & 21 & 210 & 38 & 162 & 55 & 74 & 72 & 77 & 89 & 82 \\
\hline 5 & 130 & 22 & 127 & 39 & 55 & 56 & 0.5 & 73 & 73 & 90 & 0.5 \\
\hline 6 & 110 & 23 & 107 & 40 & 80 & 57 & 120 & 74 & 19 & 91 & 9 \\
\hline 7 & 47 & 24 & 13 & 41 & 26 & 58 & 60 & 75 & 1 & 92 & 138 \\
\hline 8 & 130 & 25 & 49 & 42 & 63 & 59 & 91 & 76 & 68 & 93 & 24 \\
\hline 9 & 116 & 26 & 53 & 43 & 1 & 60 & 130 & 77 & 77 & 94 & 164 \\
\hline 10 & 120 & 27 & 0.5 & 44 & 48 & 61 & 79 & 78 & 64 & 95 & 1 \\
\hline 11 & 2 & 28 & 0.25 & 45 & 0.125 & 62 & 143 & 79 & 161 & 96 & 138 \\
\hline 12 & 89 & 29 & 147 & 46 & 142 & 63 & 97 & 80 & 2 & 97 & 98 \\
\hline 13 & 0.5 & 30 & 45 & 47 & 112 & 64 & 128 & 81 & 174 & 98 & 113 \\
\hline 14 & 0.5 & 31 & 71 & 48 & 60 & 65 & 114 & 82 & 151 & 99 & 107 \\
\hline 15 & 43 & 32 & 143 & 49 & 67 & 66 & 113 & 83 & 21 & 100 & 151 \\
\hline 16 & 12 & 33 & 105 & 50 & 65 & 67 & 119 & 84 & 28 & & \\
\hline 17 & 74 & 34 & 107 & 51 & 58 & 68 & 103 & 85 & 69 & & \\
\hline
\end{tabular}




\section{Conodoguinet Creek}

Reach \#: 28 UTM Location: Zone 18, $4436899 \mathrm{~m} \mathrm{~N}, 0261738 \mathrm{~m} \mathrm{E}$

Composition of Bedload: Consists of elongate to tabular, sun-rounded clasts of sandstone.

Bedload Textures: D50 $=44.0 \mathrm{~mm}, \mathrm{D} 84=97.0 \mathrm{~mm}$

Cumulative Frequency Distribution

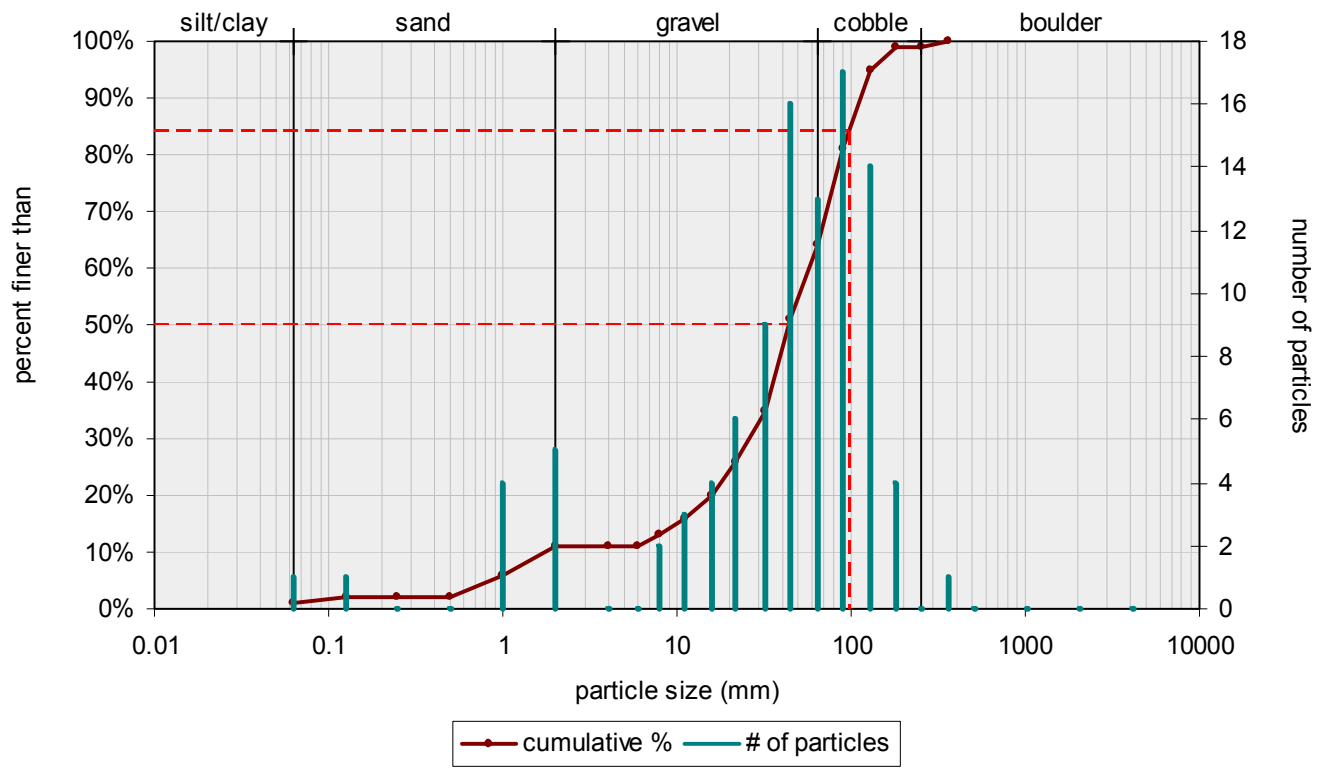

Pebble Count Data

\begin{tabular}{|c|c|c|c|c|c|c|c|c|c|c|c|}
\hline \# & Texture & $\#$ & Texture & $\#$ & Texture & $\#$ & Texture & $\#$ & Texture & \# & Texture \\
\hline 1 & 65 & 18 & 52 & 35 & 12 & 52 & 329 & 69 & 34 & 86 & 16 \\
\hline 2 & 117 & 19 & 138 & 36 & 12 & 53 & 104 & 70 & 0.062 & 87 & 26 \\
\hline 3 & 34 & 20 & 107 & 37 & 64 & 54 & 52 & 71 & 91 & 88 & 37 \\
\hline 4 & 46 & 21 & 86 & 38 & 33 & 55 & 19 & 72 & 17 & 89 & 125 \\
\hline 5 & 42 & 22 & 116 & 39 & 1 & 56 & 48 & 73 & 93 & 90 & 0.5 \\
\hline 6 & 17 & 23 & 0.5 & 40 & 38 & 57 & 1 & 74 & 78 & 91 & 164 \\
\hline 7 & 53 & 24 & 83 & 41 & 53 & 58 & 12 & 75 & 22 & 92 & 35 \\
\hline 8 & 19 & 25 & 29 & 42 & 84 & 59 & 30 & 76 & 31 & 93 & 130 \\
\hline 9 & 26 & 26 & 45 & 43 & 25 & 60 & 47 & 77 & 1 & 94 & 54 \\
\hline 10 & 1 & 27 & 79 & 44 & 0.5 & 61 & 53 & 78 & 77 & 95 & 77 \\
\hline 11 & 22 & 28 & 44 & 45 & 124 & 62 & 6 & 79 & 14 & 96 & 8 \\
\hline 12 & 44 & 29 & 91 & 46 & 101 & 63 & 38 & 80 & 68 & 97 & 68 \\
\hline 13 & 121 & 30 & 84 & 47 & 77 & 64 & 33 & 81 & 9 & 98 & 48 \\
\hline 14 & 23 & 31 & 61 & 48 & 66 & 65 & 44 & 82 & 45 & 99 & 117 \\
\hline 15 & 37 & 32 & 6 & 49 & 36 & 66 & 105 & 83 & 44 & 100 & 42 \\
\hline 16 & 9 & 33 & 0.125 & 50 & 113 & 67 & 85 & 84 & 70 & & \\
\hline 17 & 76 & 34 & 0.5 & 51 & 17 & 68 & 144 & 85 & 1 & & \\
\hline
\end{tabular}




\section{Conodoguinet Creek}

Reach \#: $29 \quad$ UTM Location: Zone 18, $4430391 \mathrm{~m} \mathrm{~N}, 0256741 \mathrm{~m} \mathrm{E}$

Composition of Bedload: Consists of elongate to tabular, sun-rounded clasts of sandstone.

Bedload Textures: D50 $=48.0 \mathrm{~mm}, \mathrm{D} 84=93.0 \mathrm{~mm}$

Cumulative Frequency Distribution

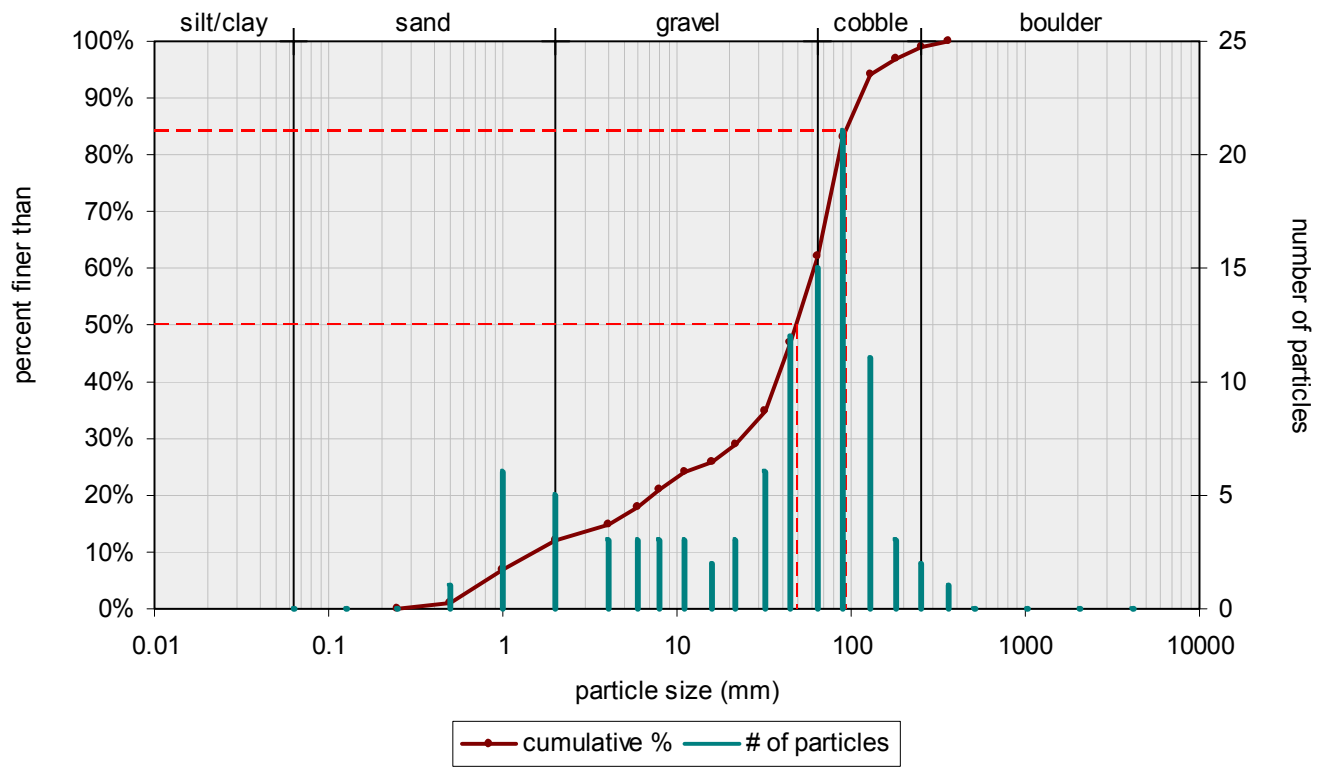

$\underline{\text { Pebble Count Data }}$

\begin{tabular}{|c|c|c|c|c|c|c|c|c|c|c|c|}
\hline$\#$ & Texture & $\#$ & Texture & \# & Texture & \# & Texture & \# & Texture & $\#$ & Texture \\
\hline 1 & 83 & 18 & 17 & 35 & 49 & 52 & 9 & 69 & 61 & 86 & 0.5 \\
\hline 2 & 140 & 19 & 38 & 36 & 26 & 53 & 7 & 70 & 29 & 87 & 43 \\
\hline 3 & 39 & 20 & 58 & 37 & 3 & 54 & 70 & 71 & 38 & 88 & 111 \\
\hline 4 & 56 & 21 & 23 & 38 & 1 & 55 & 86 & 72 & 100 & 89 & 46 \\
\hline 5 & 14 & 22 & 6 & 39 & 2 & 56 & 1 & 73 & 82 & 90 & 94 \\
\hline 6 & 77 & 23 & 77 & 40 & 1 & 57 & 81 & 74 & 41 & 91 & 38 \\
\hline 7 & 74 & 24 & 8 & 41 & 85 & 58 & 49 & 75 & 182 & 92 & 67 \\
\hline 8 & 0.25 & 25 & 75 & 42 & 0.5 & 59 & 0.5 & 76 & 0.5 & 93 & 0.5 \\
\hline 9 & 82 & 26 & 9 & 43 & 157 & 60 & 111 & 77 & 5 & 94 & 0.5 \\
\hline 10 & 51 & 27 & 61 & 44 & 74 & 61 & 88 & 78 & 159 & 95 & 53 \\
\hline 11 & 51 & 28 & 75 & 45 & 4 & 62 & 191 & 79 & 5 & 96 & 1 \\
\hline 12 & 26 & 29 & 81 & 46 & 66 & 63 & 93 & 80 & 7 & 97 & 2 \\
\hline 13 & 18 & 30 & 97 & 47 & 63 & 64 & 61 & 81 & 39 & 98 & 290 \\
\hline 14 & 31 & 31 & 16 & 48 & 1 & 65 & 81 & 82 & 47 & 99 & 111 \\
\hline 15 & 107 & 32 & 42 & 49 & 73 & 66 & 15 & 83 & 103 & 100 & 28 \\
\hline 16 & 40 & 33 & 51 & 50 & 33 & 67 & 115 & 84 & 40 & & \\
\hline 17 & 34 & 34 & 73 & 51 & 96 & 68 & 73 & 85 & 61 & & \\
\hline
\end{tabular}




\section{West Licking Creek}

Reach \#: 30 UTM Location: Zone 18, $4477248 \mathrm{~m} \mathrm{~N}, 0268316 \mathrm{~m} \mathrm{E}$

Composition of Bedload: Consists of sub-angular clasts of sandstone.

Bedload Textures: D50 $=110.0 \mathrm{~mm}, \mathrm{D} 84=210.0 \mathrm{~mm}$

Cumulative Frequency Distribution

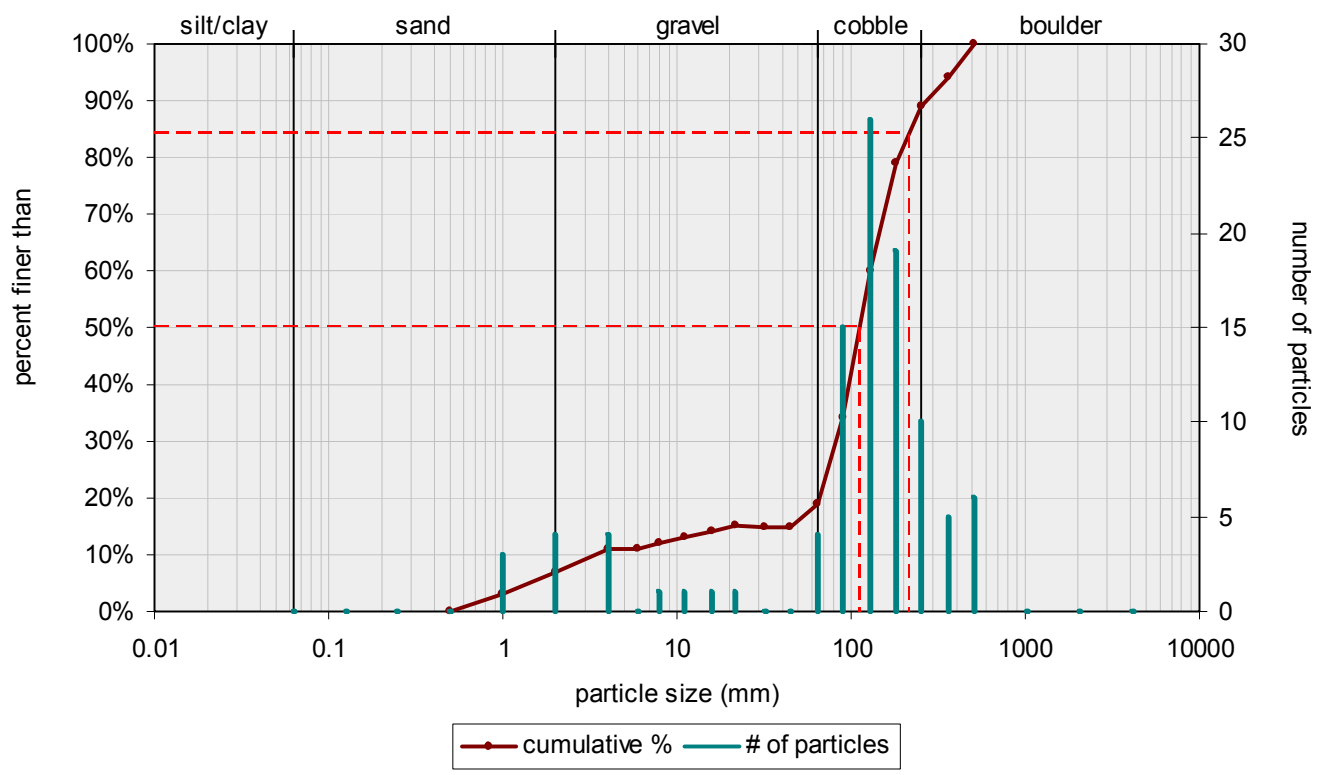

\section{Pebble Count Data}

\begin{tabular}{|c|c|c|c|c|c|c|c|c|c|c|c|}
\hline \# & Texture & \# & Texture & $\#$ & Texture & $\#$ & Texture & \# & Texture & $\#$ & Texture \\
\hline 1 & 190 & 18 & 104 & 35 & 174 & 52 & 70 & 69 & 114 & 86 & 141 \\
\hline 2 & 1 & 19 & 482 & 36 & 2 & 53 & 118 & 70 & 139 & 87 & 109 \\
\hline 3 & 323 & 20 & 70 & 37 & 107 & 54 & 78 & 71 & 81 & 88 & 81 \\
\hline 4 & 147 & 21 & 0.5 & 38 & 124 & 55 & 294 & 72 & 114 & 89 & 111 \\
\hline 5 & 391 & 22 & 131 & 39 & 66 & 56 & 283 & 73 & 0.5 & 90 & 164 \\
\hline 6 & 7 & 23 & 172 & 40 & 102 & 57 & 1 & 74 & 87 & 91 & 2 \\
\hline 7 & 201 & 24 & 453 & 41 & 91 & 58 & 70 & 75 & 1 & 92 & 3 \\
\hline 8 & 174 & 25 & 381 & 42 & 0.5 & 59 & 13 & 76 & 105 & 93 & 78 \\
\hline 9 & 125 & 26 & 146 & 43 & 194 & 60 & 72 & 77 & 126 & 94 & 62 \\
\hline 10 & 49 & 27 & 149 & 44 & 151 & 61 & 48 & 78 & 94 & 95 & 71 \\
\hline 11 & 427 & 28 & 98 & 45 & 122 & 62 & 78 & 79 & 170 & 96 & 161 \\
\hline 12 & 238 & 29 & 358 & 46 & 160 & 63 & 119 & 80 & 1 & 97 & 141 \\
\hline 13 & 466 & 30 & 62 & 47 & 128 & 64 & 84 & 81 & 126 & 98 & 107 \\
\hline 14 & 202 & 31 & 70 & 48 & 112 & 65 & 72 & 82 & 113 & 99 & 2 \\
\hline 15 & 197 & 32 & 151 & 49 & 106 & 66 & 137 & 83 & 248 & 100 & 113 \\
\hline 16 & 16 & 33 & 204 & 50 & 360 & 67 & 101 & 84 & 242 & & \\
\hline 17 & 9 & 34 & 217 & 51 & 98 & 68 & 128 & 85 & 98 & & \\
\hline
\end{tabular}




\section{West Licking Creek}

Reach \#: $31 \quad$ UTM Location: Zone 18, $4476066 \mathrm{~m} \mathrm{~N}, 0267300 \mathrm{~m} \mathrm{E}$

Composition of Bedload: Consists of sub-angular clasts of sandstone.

Bedload Textures: D50 $=110.0 \mathrm{~mm}, \mathrm{D} 84=200.0 \mathrm{~mm}$

\section{Cumulative Frequency Distribution}

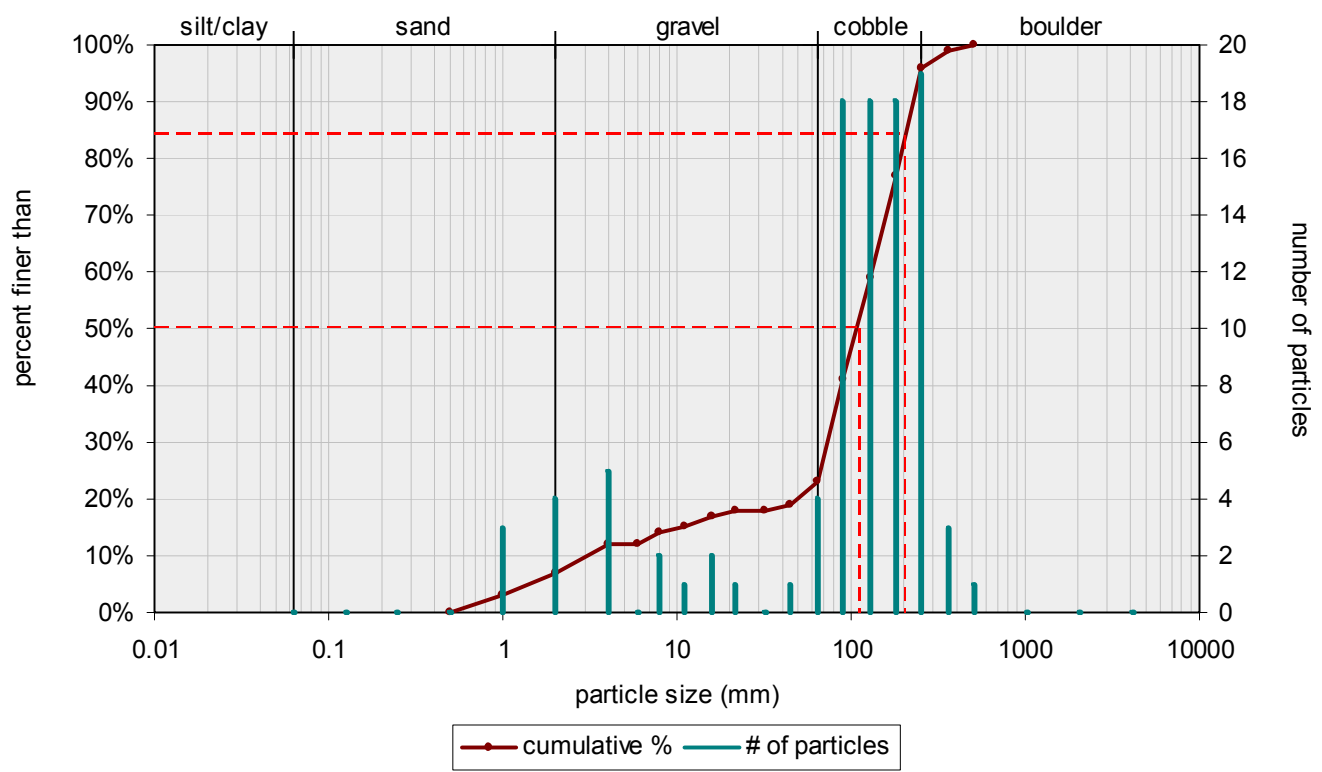

\section{$\underline{\text { Pebble Count Data }}$}

\begin{tabular}{|c|c|c|c|c|c|c|c|c|c|c|c|}
\hline \# & Texture & $\#$ & Texture & \# & Texture & \# & Texture & \# & Texture & $\#$ & Texture \\
\hline 1 & 94 & 18 & 246 & 35 & 85 & 52 & 100 & 69 & 181 & 86 & 9 \\
\hline 2 & 11 & 19 & 160 & 36 & 1 & 53 & 1 & 70 & 75 & 87 & 51 \\
\hline 3 & 171 & 20 & 224 & 37 & 1889 & 54 & 33 & 71 & 191 & 88 & 2 \\
\hline 4 & 126 & 21 & 7 & 38 & 120 & 55 & 232 & 72 & 167 & 89 & 137 \\
\hline 5 & 175 & 22 & 205 & 39 & 131 & 56 & 81 & 73 & 241 & 90 & 109 \\
\hline 6 & 184 & 23 & 2 & 40 & 354 & 57 & 73 & 74 & 191 & 91 & 113 \\
\hline 7 & 105 & 24 & 17 & 41 & 0.5 & 58 & 371 & 75 & 352 & 92 & 0.5 \\
\hline 8 & 99 & 25 & 71 & 42 & 91 & 59 & 90 & 76 & 0.5 & 93 & 1 \\
\hline 9 & 174 & 26 & 71 & 43 & 197 & 60 & 7 & 77 & 196 & 94 & 123 \\
\hline 10 & 71 & 27 & 167 & 44 & 91 & 61 & 84 & 78 & 204 & 95 & 1 \\
\hline 11 & 270 & 28 & 69 & 45 & 94 & 62 & 62 & 79 & 97 & 96 & 2 \\
\hline 12 & 141 & 29 & 164 & 46 & 81 & 63 & 71 & 80 & 238 & 97 & 96 \\
\hline 13 & 139 & 30 & 119 & 47 & 142 & 64 & 248 & 81 & 74 & 98 & 2 \\
\hline 14 & 122 & 31 & 75 & 48 & 141 & 65 & 142 & 82 & 53 & 99 & 2 \\
\hline 15 & 246 & 32 & 173 & 49 & 209 & 66 & 78 & 83 & 101 & 100 & 73 \\
\hline 16 & 128 & 33 & 168 & 50 & 68 & 67 & 64 & 84 & 128 & & \\
\hline 17 & 228 & 34 & 218 & 51 & 14 & 68 & 77 & 85 & 47 & & \\
\hline
\end{tabular}




\section{West Licking Creek}

Reach \#: 32 UTM Location: Zone 18, $4472488 \mathrm{~m} \mathrm{~N}, 0264386 \mathrm{~m} \mathrm{E}$

Composition of Bedload: Consists of sub-angular to sub-rounded clasts of sandstone, with black stains.

Bedload Textures: D50 $=120.0 \mathrm{~mm}, \mathrm{D} 84=230.0 \mathrm{~mm}$

Cumulative Frequency Distribution

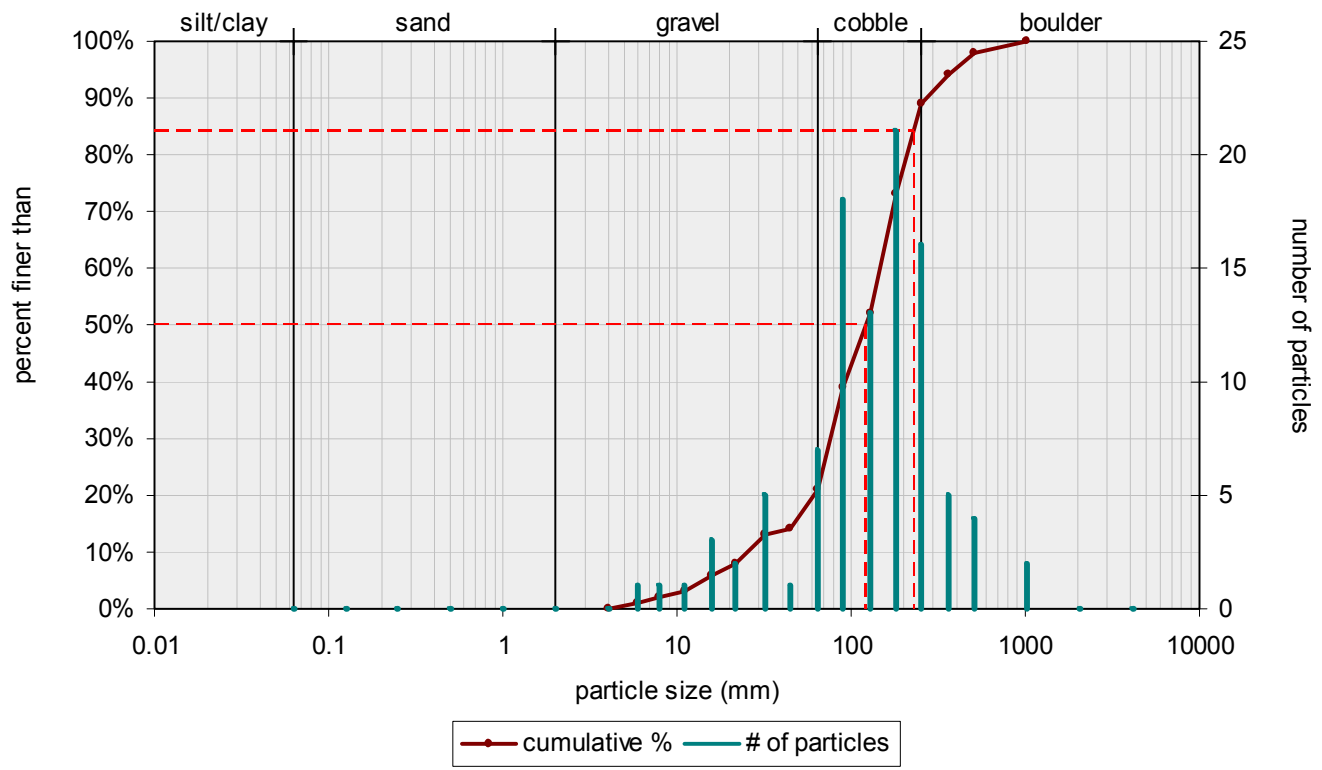

$\underline{\text { Pebble Count Data }}$

\begin{tabular}{|c|c|c|c|c|c|c|c|c|c|c|c|}
\hline \# & Texture & \# & Texture & \# & Texture & \# & Texture & \# & Texture & $\#$ & Texture \\
\hline 1 & 153 & 18 & 173 & 35 & 231 & 52 & 68 & 69 & 68 & 86 & 111 \\
\hline 2 & 181 & 19 & 191 & 36 & 96 & 53 & 71 & 70 & 49 & 87 & 202 \\
\hline 3 & 397 & 20 & 209 & 37 & 278 & 54 & 69 & 71 & 610 & 88 & 53 \\
\hline 4 & 76 & 21 & 65 & 38 & 231 & 55 & 60 & 72 & 166 & 89 & 28 \\
\hline 5 & 24 & 22 & 425 & 39 & 58 & 56 & 177 & 73 & 185 & 90 & 146 \\
\hline 6 & 9 & 23 & 124 & 40 & 5 & 57 & 122 & 74 & 79 & 91 & 143 \\
\hline 7 & 82 & 24 & 730 & 41 & 72 & 58 & 219 & 75 & 153 & 92 & 125 \\
\hline 8 & 124 & 25 & 56 & 42 & 111 & 59 & 155 & 76 & 139 & 93 & 98 \\
\hline 9 & 106 & 26 & 143 & 43 & 63 & 60 & 154 & 77 & 199 & 94 & 17 \\
\hline 10 & 89 & 27 & 61 & 44 & 99 & 61 & 213 & 78 & 420 & 95 & 30 \\
\hline 11 & 162 & 28 & 31 & 45 & 12 & 62 & 41 & 79 & 228 & 96 & 13 \\
\hline 12 & 199 & 29 & 88 & 46 & 66 & 63 & 212 & 80 & 135 & 97 & 177 \\
\hline 13 & 102 & 30 & 82 & 47 & 11 & 64 & 168 & 81 & 316 & 98 & 71 \\
\hline 14 & 73 & 31 & 271 & 48 & 205 & 65 & 143 & 82 & 77 & 99 & 70 \\
\hline 15 & 149 & 32 & 162 & 49 & 219 & 66 & 170 & 83 & 29 & 100 & 16 \\
\hline 16 & 286 & 33 & 607 & 50 & 113 & 67 & 120 & 84 & 7 & & \\
\hline 17 & 153 & 34 & 182 & 51 & 262 & 68 & 135 & 85 & 89 & & \\
\hline
\end{tabular}




\section{West Licking Creek}

Reach \#: $33 \quad$ UTM Location: Zone 18, $4471472 \mathrm{~m} \mathrm{~N}, 0263238 \mathrm{~m} \mathrm{E}$

\section{Composition of Bedload: N/A}

Bedload Textures: D50 $=94.0 \mathrm{~mm}, \mathrm{D} 84=170.0 \mathrm{~mm}$

\section{Cumulative Frequency Distribution}

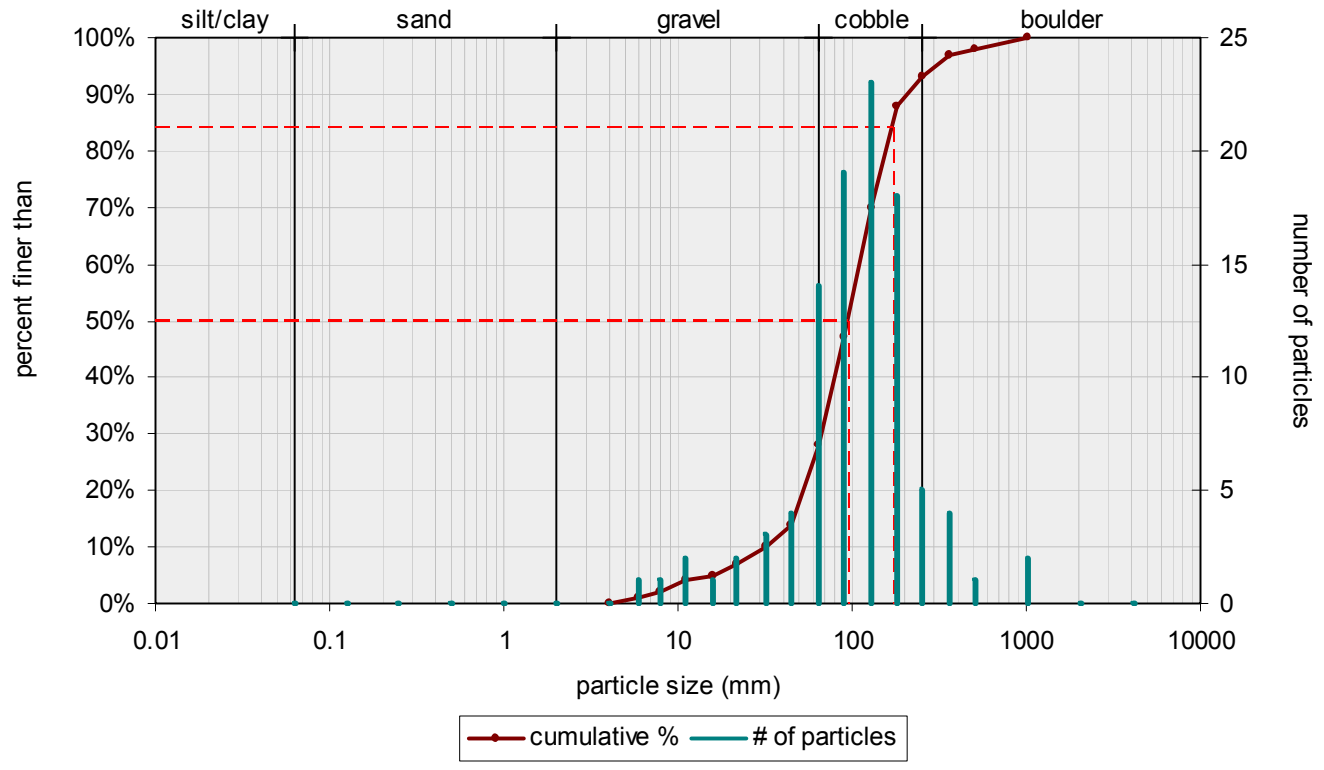

\section{Pebble Count Data}

\begin{tabular}{|c|c|c|c|c|c|c|c|c|c|c|c|}
\hline \# & Texture & $\#$ & Texture & $\#$ & Texture & \# & Texture & $\#$ & Texture & $\#$ & Texture \\
\hline 1 & 65 & 18 & 7 & 35 & 161 & 52 & 521 & 69 & 71 & 86 & 84 \\
\hline 2 & 88 & 19 & 154 & 36 & 66 & 53 & 253 & 70 & 53 & 87 & 195 \\
\hline 3 & 171 & 20 & 103 & 37 & 57 & 54 & 41 & 71 & 51 & 88 & 79 \\
\hline 4 & 106 & 21 & 71 & 38 & 90 & 55 & 91 & 72 & 55 & 89 & 155 \\
\hline 5 & 90 & 22 & 133 & 39 & 34 & 56 & 81 & 73 & 102 & 90 & 111 \\
\hline 6 & 161 & 23 & 142 & 40 & 10 & 57 & 13 & 74 & 524 & 91 & 26 \\
\hline 7 & 317 & 24 & 58 & 41 & 66 & 58 & 54 & 75 & 19 & 92 & 56 \\
\hline 8 & 112 & 25 & 156 & 42 & 57 & 59 & 63 & 76 & 101 & 93 & 54 \\
\hline 9 & 70 & 26 & 144 & 43 & 27 & 60 & 107 & 77 & 46 & 94 & 129 \\
\hline 10 & 107 & 27 & 128 & 44 & 141 & 61 & 166 & 78 & 116 & 95 & 68 \\
\hline 11 & 312 & 28 & 95 & 45 & 126 & 62 & 272 & 79 & 98 & 96 & 39 \\
\hline 12 & 16 & 29 & 41 & 46 & 69 & 63 & 147 & 80 & 150 & 97 & 61 \\
\hline 13 & 8 & 30 & 134 & 47 & 98 & 64 & 207 & 81 & 101 & 98 & 58 \\
\hline 14 & 285 & 31 & 131 & 48 & 4 & 65 & 71 & 82 & 91 & 99 & 112 \\
\hline 15 & 61 & 32 & 141 & 49 & 207 & 66 & 83 & 83 & 102 & 100 & 71 \\
\hline 16 & 224 & 33 & 72 & 50 & 119 & 67 & 77 & 84 & 95 & & \\
\hline 17 & 65 & 34 & 494 & 51 & 28 & 68 & 84 & 85 & 107 & & \\
\hline
\end{tabular}




\section{West Licking Creek}

Reach \#: 34 UTM Location: Zone 18, 4469916 m N, $0260751 \mathrm{~m} \mathrm{E}$

\section{Composition of Bedload: N/A}

Bedload Textures: D50 $=110.0 \mathrm{~mm}, \mathrm{D} 84=230.0 \mathrm{~mm}$

\section{Cumulative Frequency Distribution}

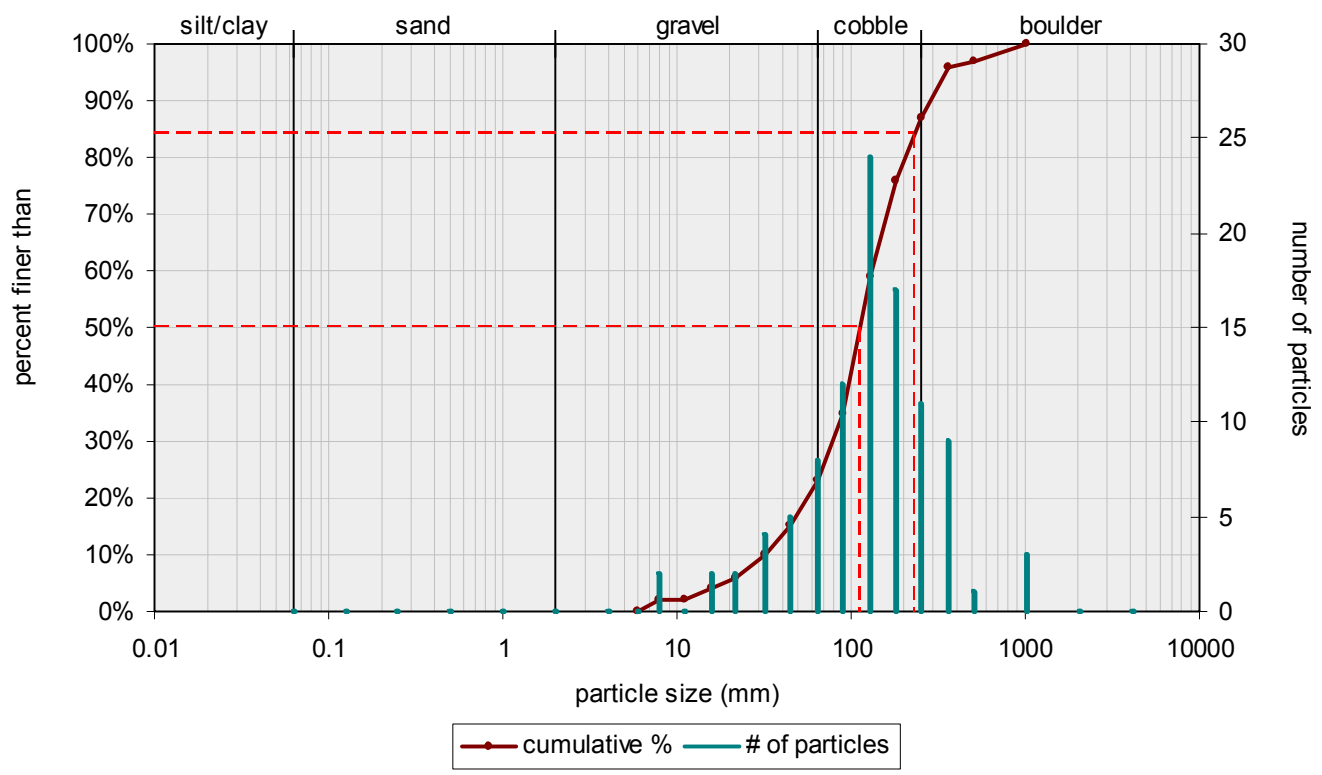

\section{Pebble Count Data}

\begin{tabular}{|c|c|c|c|c|c|c|c|c|c|c|c|}
\hline \# & Texture & \# & Texture & \# & Texture & \# & Texture & \# & Texture & \# & Texture \\
\hline 1 & 126 & 18 & 280 & 35 & 439 & 52 & 125 & 69 & 273 & 86 & 42 \\
\hline 2 & 94 & 19 & 160 & 36 & 79 & 53 & 22 & 70 & 132 & 87 & 231 \\
\hline 3 & 131 & 20 & 211 & 37 & 117 & 54 & 76 & 71 & 25 & 88 & 162 \\
\hline 4 & 103 & 21 & 275 & 38 & 231 & 55 & 191 & 72 & 14 & 89 & 96 \\
\hline 5 & 107 & 22 & 116 & 39 & 68 & 56 & 122 & 73 & 51 & 90 & 25 \\
\hline 6 & 642 & 23 & 69 & 40 & 153 & 57 & 49 & 74 & 112 & 91 & 130 \\
\hline 7 & 165 & 24 & 206 & 41 & 121 & 58 & 222 & 75 & 34 & 92 & 70 \\
\hline 8 & 332 & 25 & 179 & 42 & 147 & 59 & 178 & 76 & 85 & 93 & 24 \\
\hline 9 & 57 & 26 & 54 & 43 & 79 & 60 & 146 & 77 & 111 & 94 & 81 \\
\hline 10 & 105 & 27 & 16 & 44 & 168 & 61 & 63 & 78 & 98 & 95 & 97 \\
\hline 11 & 136 & 28 & 146 & 45 & 115 & 62 & 104 & 79 & 96 & 96 & 32 \\
\hline 12 & 7 & 29 & 280 & 46 & 124 & 63 & 305 & 80 & 321 & 97 & 64 \\
\hline 13 & 114 & 30 & 169 & 47 & 743 & 64 & 21 & 81 & 254 & 98 & 521 \\
\hline 14 & 151 & 31 & 309 & 48 & 33 & 65 & 49 & 82 & 211 & 99 & 115 \\
\hline 15 & 8 & 32 & 185 & 49 & 82 & 66 & 191 & 83 & 76 & 100 & 116 \\
\hline 16 & 185 & 33 & 11 & 50 & 144 & 67 & 96 & 84 & 109 & & \\
\hline 17 & 368 & 34 & 62 & 51 & 33 & 68 & 50 & 85 & 77 & & \\
\hline
\end{tabular}


Appendix 3. Plots relating the texture of the $\mathbf{D}_{\underline{50}}$ and $\underline{D}_{\underline{4}}$ versus drainage area for each lithologically controlled watershed.

The texture of the $\mathrm{D}_{50}$ and $\mathrm{D}_{84}$ (Table 4) are plotted versus drainage area individually for each lithologically controlled watershed. Two plots are presented for Sherman Creek Watershed, because two individual headwater tributaries along with the main stem Sherman Creek were measured. These plots are distinguished by referencing which tributary to Sherman Creek is used. A uniform scale is used on all plots to allow comparison between watersheds of varying drainage areas. Data points are labeled with the attributes of the texture of the bedload sediment (y-axis) and drainage area (x-axis). 


\section{South Branch Little Aughwick Creek}

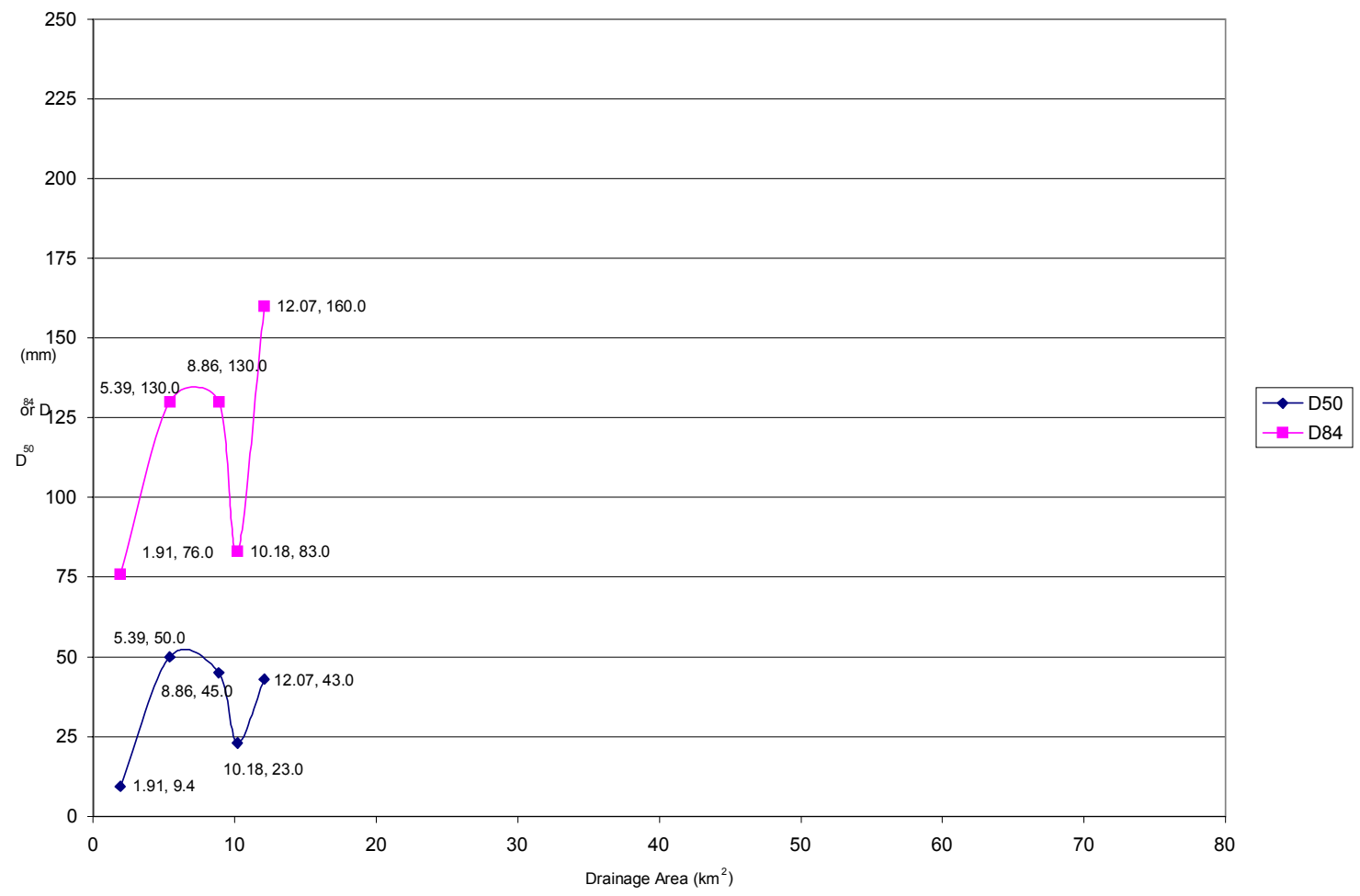




\section{West Licking Creek}

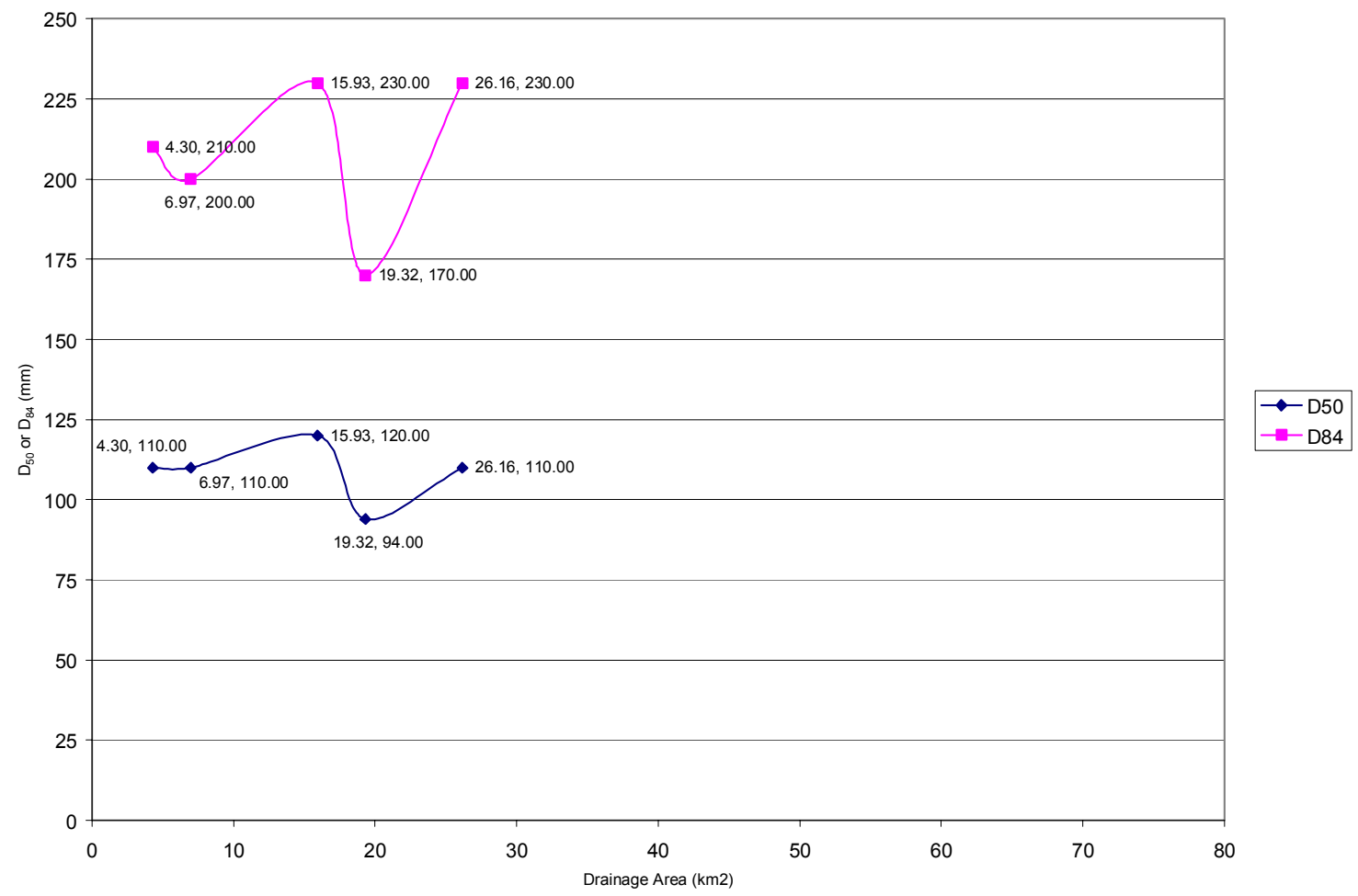




\section{Conodoguinet Creek}

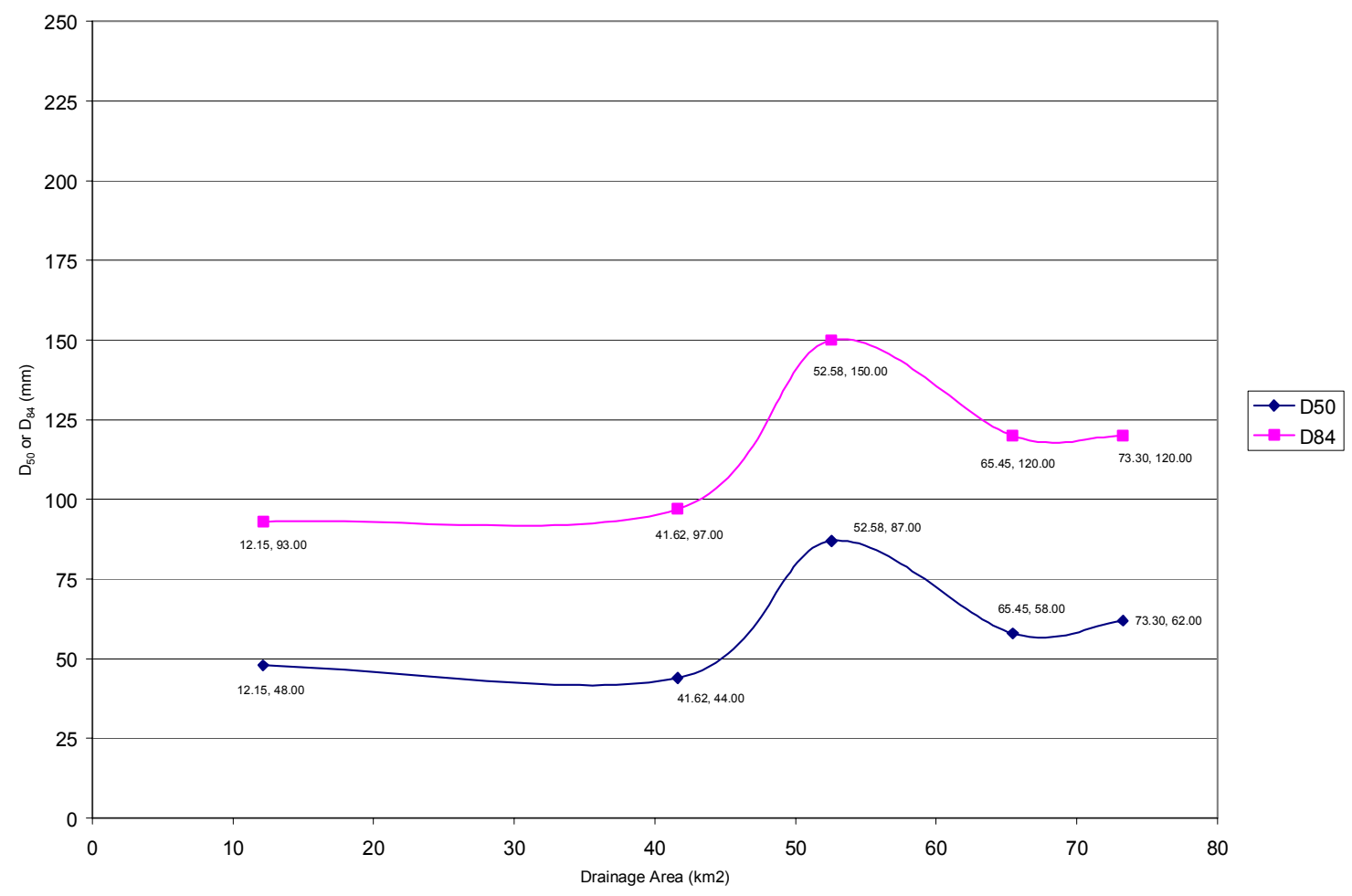




\section{Laurel Run}

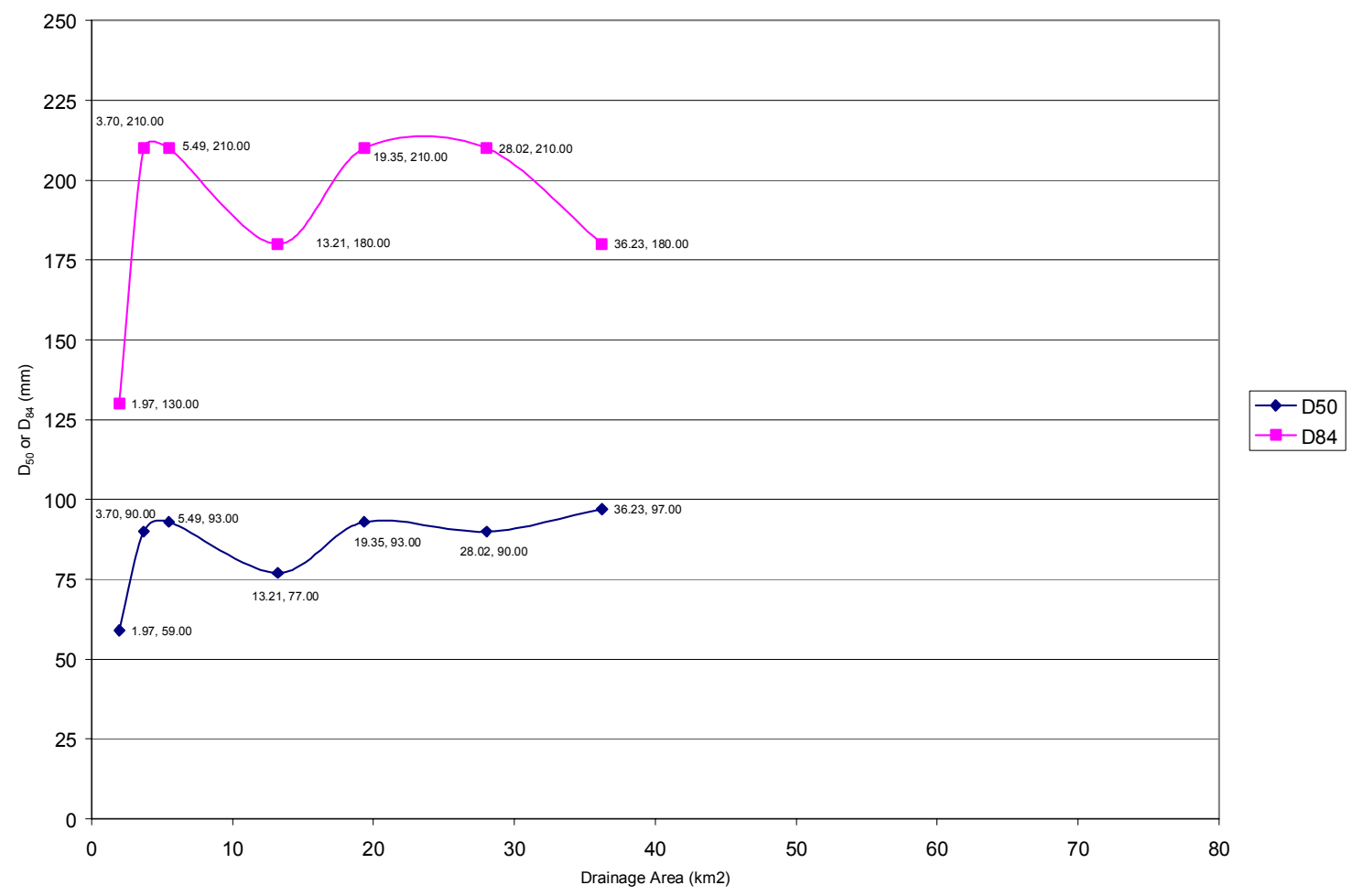




\section{Sherman Creek including Big Spring Run}

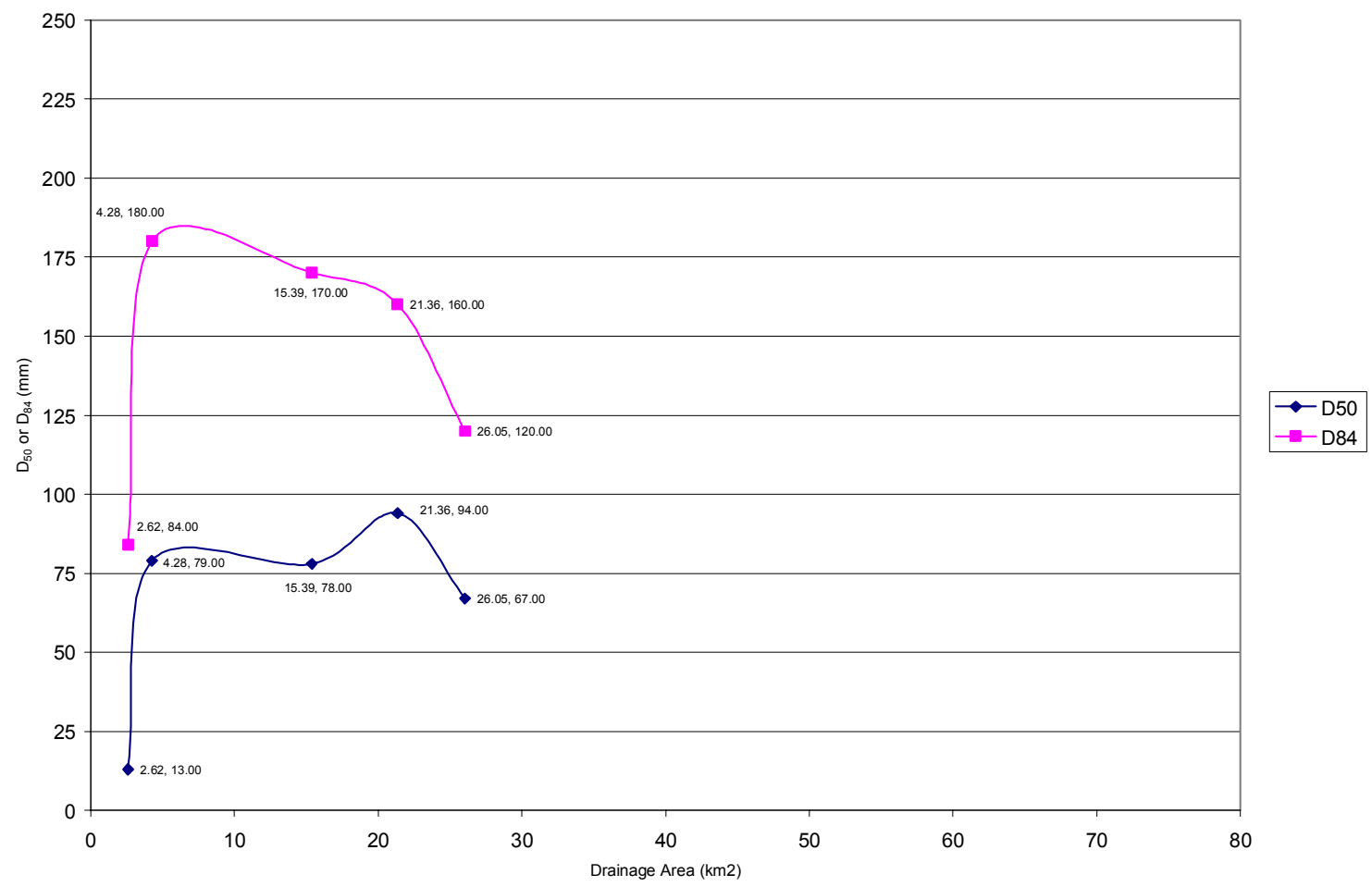




\section{Sherman Creek including Patterson Run}

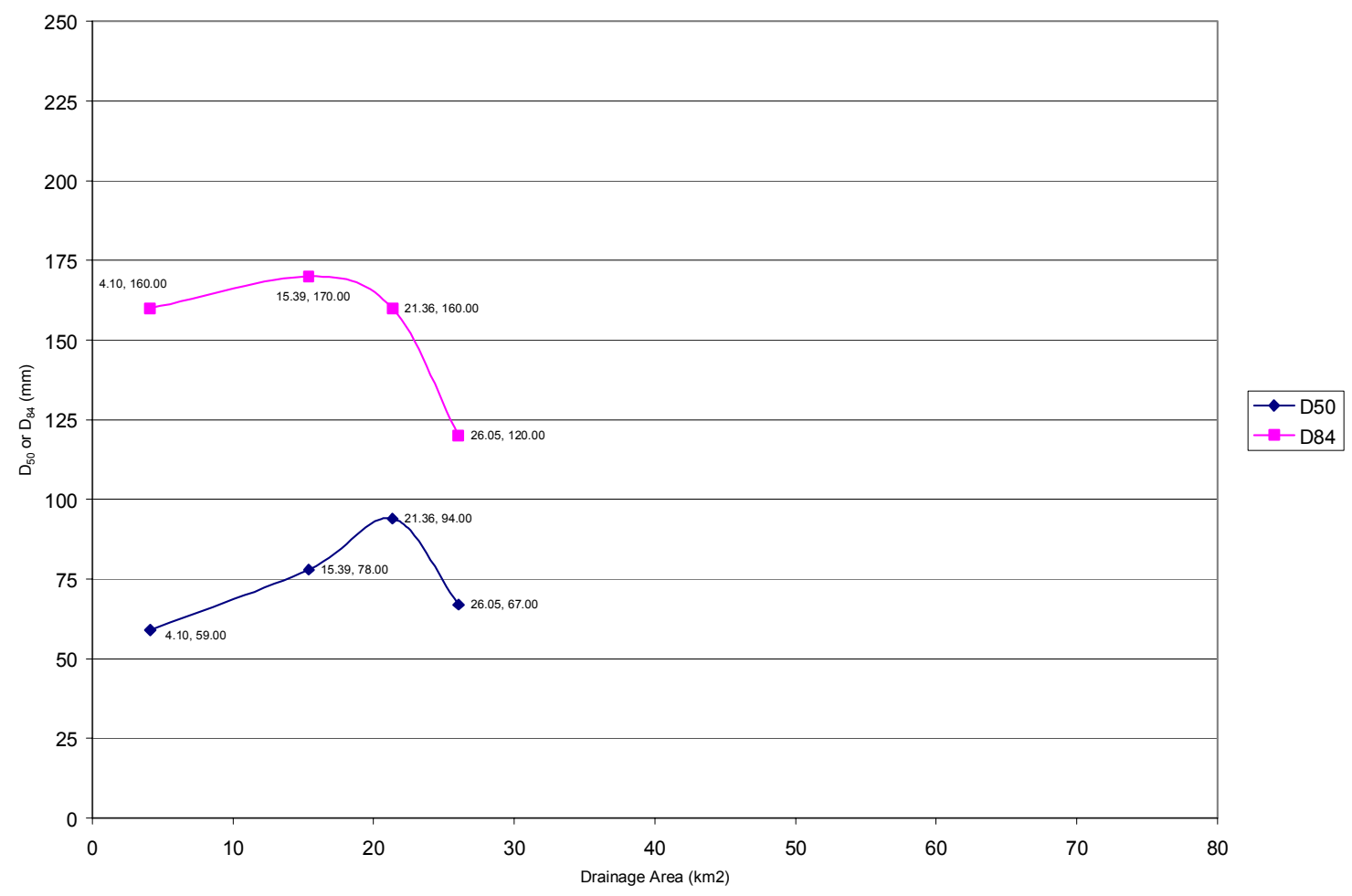




\section{Horse Valley Run}

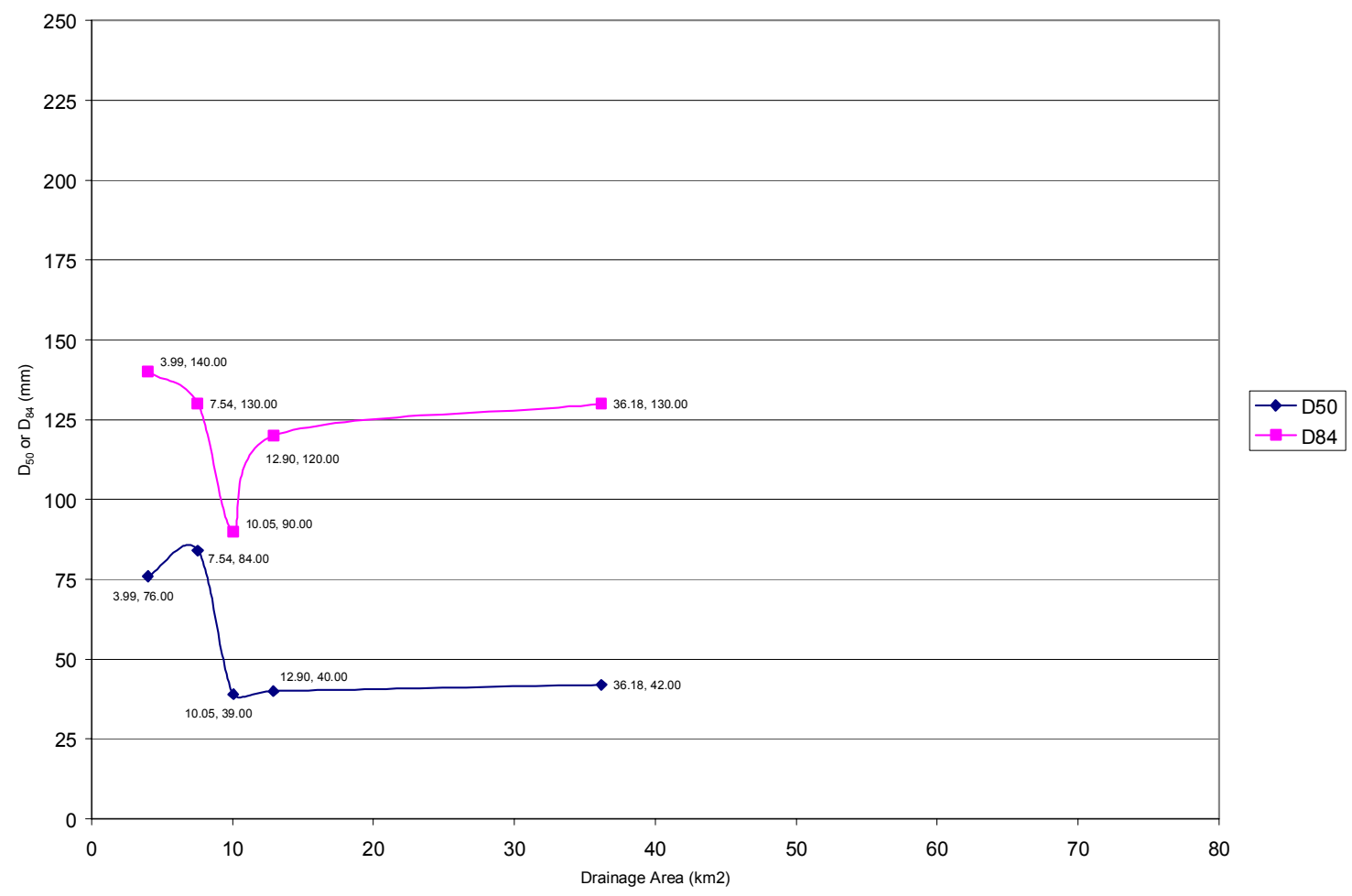

